\title{
ARGONNE NATIONAL LABORATORY-EAST SITE ENVIRONMENTAL REPORT FOR CALENDAR YEAR 1995
}

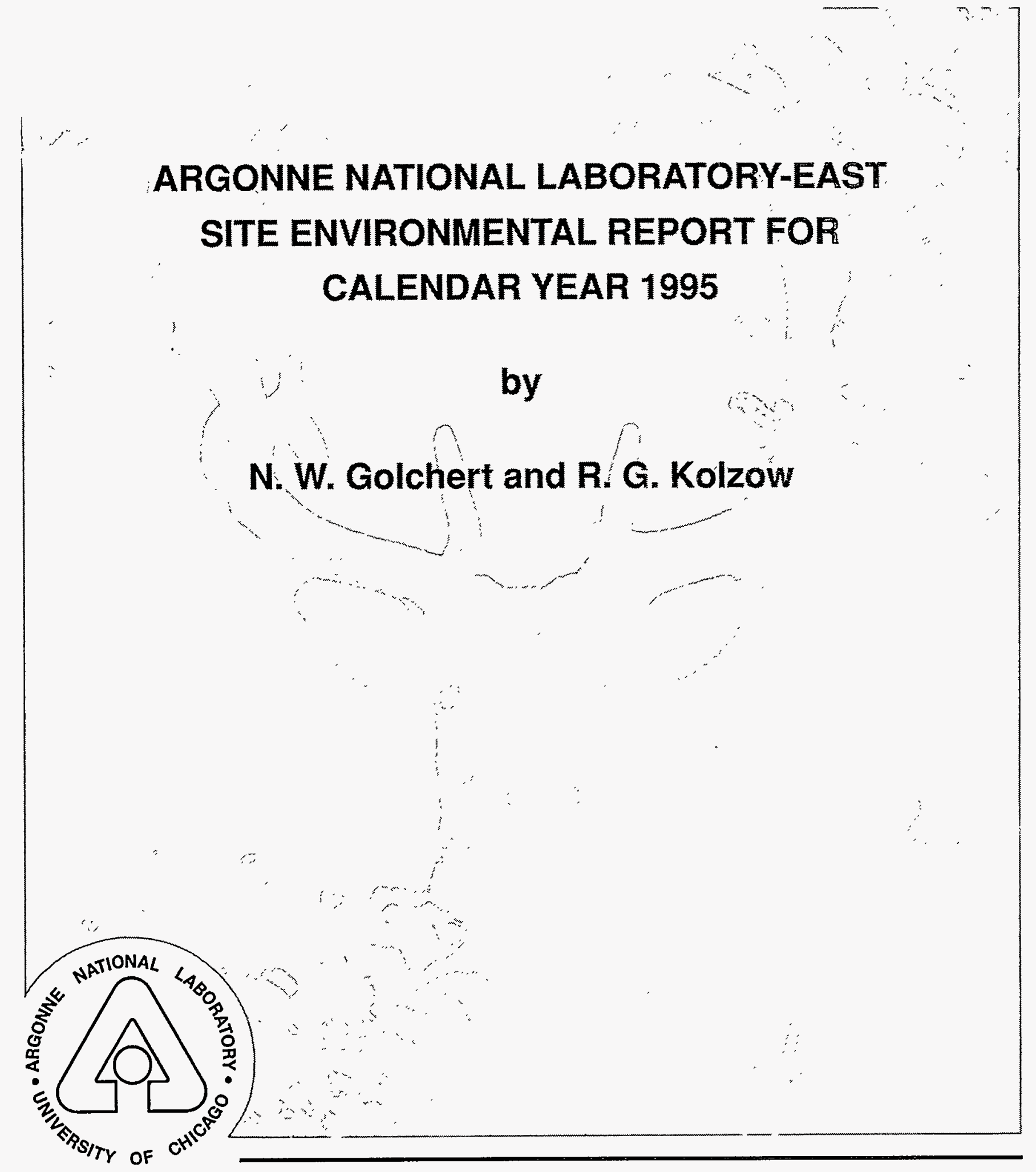

ARGONNE NATIONAL LABORATORY, ARGONNE, ILLINOIS

Operated by THE UNIVERSITY OF CHICAGO

for the U.S. DEPARTMENT OF ENERGY

under Contract W-31-109-Eng-38 
Argonne National Laboratory, with facilities in the states of Illinois and Idaho, is owned by the United States government, and operated by The University of Chicago under the provisions of a contract with the Department of Energy.

\section{DISCLAIMER}

This report was prepared as an account of work sponsored by an agency of the United States Government. Neither the United States Government nor any agency thereof, nor any of their employees, makes any warranty, express or implied, or assumes any legal liability or responsibility for the accuracy, completeness, or usefulness of any information, apparatus, product, or process disclosed, or represents that its use would not infringe privately owned rights. Reference herein to any specific commercial product, process, or service by trade name, trademark, manufacturer, or otherwise, does not necessarily constitute or imply its endorsement, recommendation, or favoring by the United States Government or any agency thereof. The views and opinions of authors expressed herein do not necessarily state or reflect those of the United States Government or any agency thereof.

Reproduced from the best available copy.

Available to DOE and DOE contractors from the Office of Scientific and Technical Information P.O. Box 62

Oak Ridge, TN 37831

Prices available from (423) 576-8401

Available to the public from the National Technical Information Service

U.S. Department of Commerce 5285 Port Royal Road Springfield, VA 22161 


\title{
ARGONNE NATIONAL LABORATORY-EAST SITE ENVIRONMENTAL REPORT FOR CALENDAR YEAR 1995
}

\author{
by \\ N.W. Golchert and R.G. Kolzow \\ Environmental Management Operations
}

September 1996

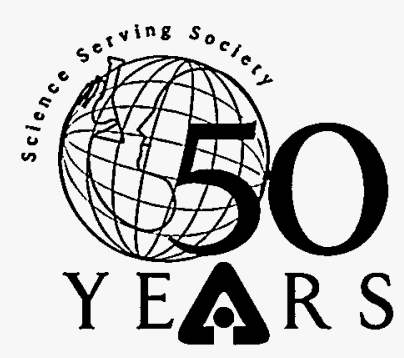
ARGONNE NATIONAL LABORATORY 9700 South Cass Avenue
Argonne, Illinois 60439

Preceding Report in This Series: ANL-95/8 


\section{DISCLAIMER}

Portions of this document may be illegible in electronic image products. Images are produced from the best available original document. 
$\underline{\text { Page }}$

ACRONYMS .............................. xvii

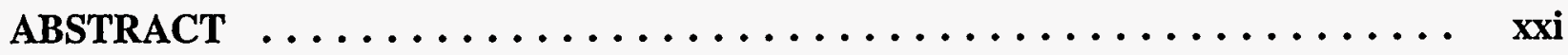

EXECUTIVE SUMMARY $\ldots \ldots \ldots \ldots \ldots \ldots \ldots \ldots \ldots \ldots \ldots \ldots \ldots \ldots$

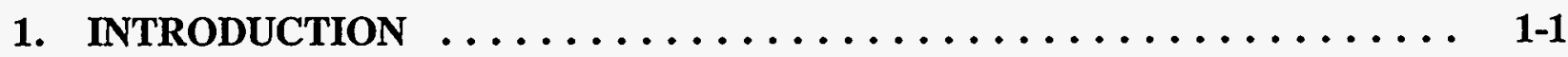

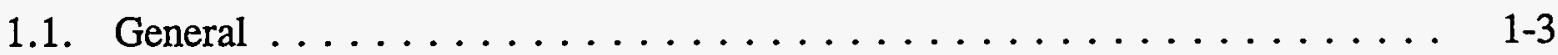

1.2. Description of Site $\ldots \ldots \ldots \ldots \ldots \ldots \ldots \ldots \ldots \ldots \ldots \ldots \ldots \ldots \ldots \ldots \ldots$

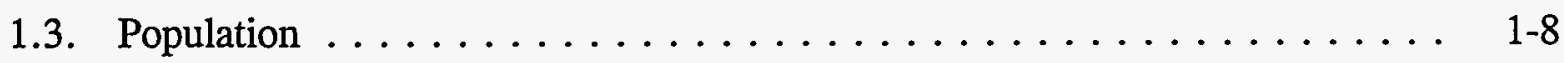

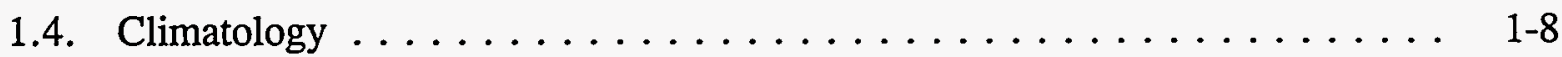

1.5. Geology $\ldots \ldots \ldots \ldots \ldots \ldots \ldots \ldots \ldots \ldots \ldots \ldots \ldots \ldots \ldots \ldots \ldots \ldots$

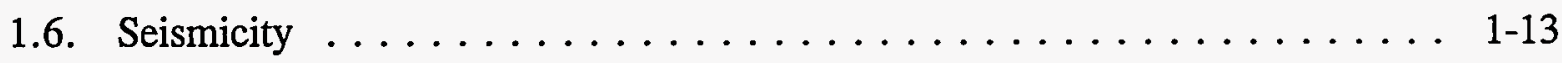

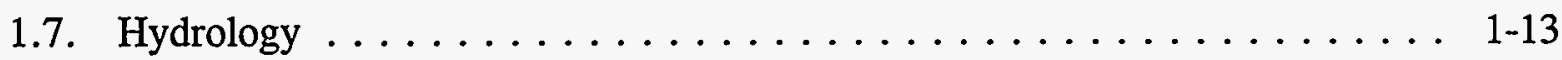

1.8. Water and Land Use $\ldots \ldots \ldots \ldots \ldots \ldots \ldots \ldots \ldots \ldots \ldots \ldots$

1.9. Vegetation $\ldots \ldots \ldots \ldots \ldots \ldots \ldots \ldots \ldots \ldots \ldots \ldots \ldots \ldots \ldots \ldots \ldots$

1.10. Fauna $\ldots \ldots \ldots \ldots \ldots \ldots \ldots \ldots \ldots \ldots \ldots \ldots \ldots \ldots \ldots \ldots \ldots \ldots \ldots \ldots$

1.11. Archaeology . . . . . . . . . . . . . . . . . 1-18

1.12. Endangered Species . . . . . . . . . . . . . . . . 1-19

2. COMPLIANCE SUMMARY $\ldots \ldots \ldots \ldots \ldots \ldots \ldots \ldots \ldots \ldots \ldots$ 2-1

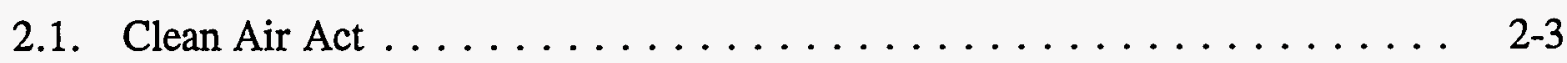

2.1.1. National Emission Standards for Hazardous

Air Pollutants . . . . . . . . . . .

2.1.1.1. Asbestos Emissions $\ldots \ldots \ldots \ldots \ldots \ldots \ldots$ 2-5

2.1.1.2. Radionuclide Emissions $\ldots \ldots \ldots \ldots \ldots \ldots \ldots$ 2-10

2.1.1.3. Halogenated Solvent Cleaner Emissions . . . . . . 2-10

2.1.2. Conventional Air Pollutants $\ldots \ldots \ldots \ldots \ldots \ldots \ldots \ldots .2-11$ 


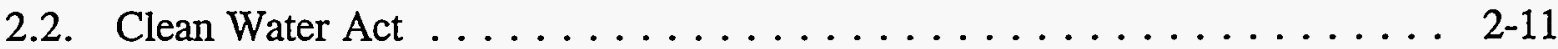

2.2.1. Liquid Effluent Discharge Permit $\ldots \ldots \ldots \ldots \ldots \ldots \ldots .2-12$

2.2.1.1. Effluent Monitoring Results and Compliance Issues $\ldots \ldots \ldots \ldots \ldots \ldots$ 2-14

2.2.1.2. Additional NPDES Monitoring $\ldots \ldots \ldots \ldots \ldots \ldots$ 2-21

2.2.2. Storm-Water Regulations $\ldots \ldots \ldots \ldots \ldots \ldots \ldots \ldots \ldots$ 2-22

2.2.3. NPDES Inspections and Audits $\ldots \ldots \ldots \ldots \ldots \ldots \ldots .2-24$

2.2.4. General Effluent and Stream Quality Standards . . . . . . . 2-24

2.2.5. NPDES Analytical Quality Assurance . . . . . . . . . 2-24

2.2.6. Spill Prevention Control and

Countermeasures Plan $\ldots \ldots \ldots \ldots \ldots \ldots \ldots \ldots \ldots \ldots \ldots \ldots$ 2-25

2.3. Resource Conservation and Recovery Act . . . . . . . . . . 2-25

2.3.1. Hazardous Waste Treatment and Disposal $\ldots \ldots \ldots \ldots \ldots .2-26$

2.3.2. Permit Status . . . . . . . . . . . . . . . . . . 2-29

2.3.3. Hazardous Waste Generation $\ldots \ldots \ldots \ldots \ldots \ldots \ldots$ 2-31

2.3.4. Facility Modifications $\ldots \ldots \ldots \ldots \ldots \ldots \ldots \ldots . \ldots \ldots$

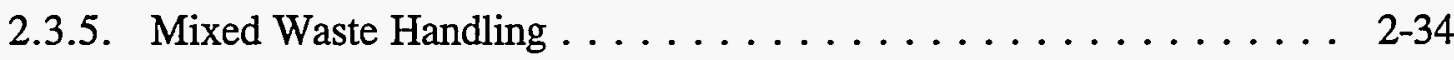

2.3.6. Federal Facility Compliance Act Activities . . . . . . . . 2-35

2.3.7. RCRA Inspections: Hazardous Waste . . . . . . . . . . 2-35

2.3.8. Underground Storage Tanks $\ldots \ldots \ldots \ldots \ldots \ldots \ldots \ldots$ 2-35

2.3.9. Corrective Action for Solid Waste

2.4. Solid Waste Disposal . . . . . . . . . . . . . . . 2-37

2.5. National Environmental Policy Act . . . . . . . . . . . 2-38

2.6. Safe Drinking Water Act . . . . . . . . . . . . . . . . 2-39

2.6.1. Applicability to ANL-E . . . . . . . . . . . . 2-39

2.6.2. Monitoring Requirements . . . . . . . . . . . . 2-40

2.7. Federal Insecticide, Fungicide, and Rodenticide Act . . . . . . . . . . 2-40

2.8. Comprehensive Environmental Response, Compensation

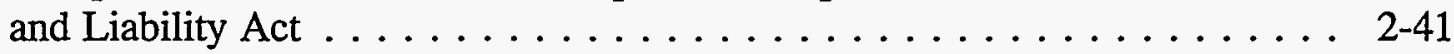


2.8.1. CERCLA Program at ANL-E . . . . . . . . . . . . 2-41

2.8.2. CERCLA Remedial Actions $\ldots \ldots \ldots \ldots \ldots \ldots \ldots \ldots$ 2-42

2.8.3. Emergency Planning and Community Right to Know Act and Superfund Amendments and Reauthorization Act, Title III . . . . . . . . . . 2-43 2.8.3.1. Sections 311 and $312 \ldots \ldots \ldots \ldots \ldots \ldots . \ldots \ldots$

2.8.3.2. Section $313 \ldots \ldots \ldots \ldots \ldots \ldots \ldots \ldots \ldots \ldots \ldots$

2.9. Toxic Substances Control Act $\ldots \ldots \ldots \ldots \ldots \ldots \ldots \ldots \ldots$ 2-46

2.9.1. PCBs in Use at ANL-E . . . . . . . . . . . . . . 2-46

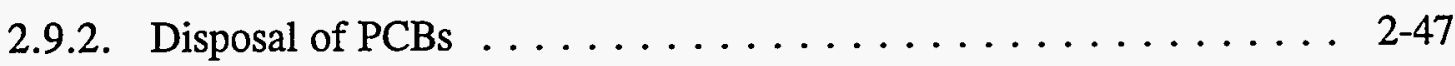

2.9.3. PCB Spills $\ldots \ldots \ldots \ldots \ldots \ldots \ldots \ldots \ldots \ldots \ldots \ldots \ldots \ldots \ldots \ldots$

2.10. Endangered Species Act $\ldots \ldots \ldots \ldots \ldots \ldots \ldots \ldots \ldots \ldots \ldots \ldots \ldots$

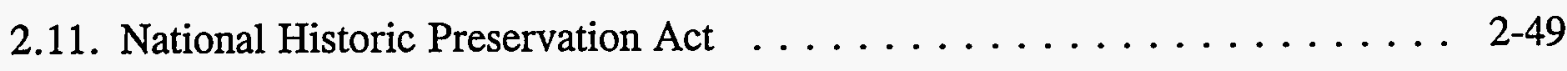

2.12. Floodplain Management $\ldots \ldots \ldots \ldots \ldots \ldots \ldots \ldots \ldots \ldots \ldots \ldots \ldots \ldots$

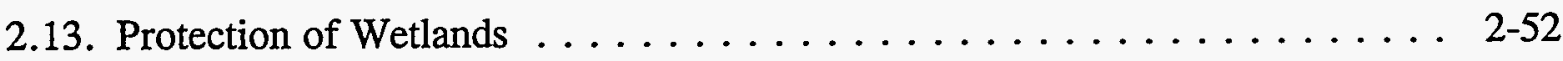

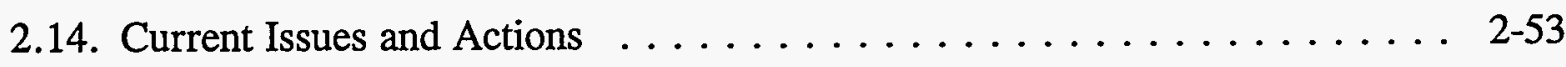

2.14.1. Major Compliance Issues $\ldots \ldots \ldots \ldots \ldots \ldots \ldots \ldots \ldots \ldots \ldots$

2.14.2. Regulatory Agency Interactions $\ldots \ldots \ldots \ldots \ldots \ldots \ldots .2-54$

2.15. Environmental Permits . . . . . . . . . . . . . . 255

3. ENVIRONMENTAL PROGRAM INFORMATION $\ldots \ldots \ldots \ldots \ldots \ldots$ 3-1

3.1. Environmental Management Programs . . . . . . . . . . . 3-3

3.1.1. Environmental Projects . . . . . . . . . . . . .

3.1.2. Waste Management Department . . . . . . . . . . 3-6

3.1.3. Waste Reduction Department . . . . . . . . . . . 3-7

3.1.4. Environmental Protection Department ............ 3-7

3.2. Environmental Support Programs $\ldots \ldots \ldots \ldots \ldots \ldots \ldots \ldots \ldots . \ldots \ldots$ 3-8

3.2.1. Self-Assessment $\ldots \ldots \ldots \ldots \ldots \ldots \ldots \ldots \ldots \ldots \ldots$ 3-8

3.2.2. Environmental Training Programs $\ldots \ldots \ldots \ldots \ldots \ldots . \quad 3-9$ 
3.2.3. Pollution Prevention - Waste Minimization $\ldots \ldots \ldots \ldots \ldots$. 3-10

3.2.4. Site Environmental Performance Measures Program . . . . . . 3-11

3.3. Environmental Monitoring Program Description . . . . . . . . . . 3-12

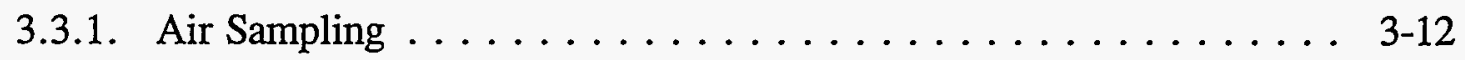

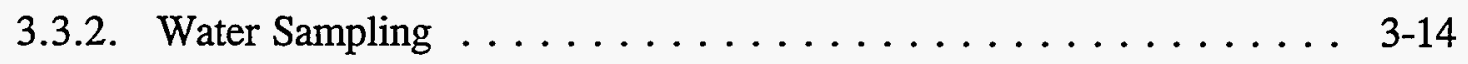

3.3.3. Bottom Sediment $\ldots \ldots \ldots \ldots \ldots \ldots \ldots \ldots \ldots \ldots$ 3-15

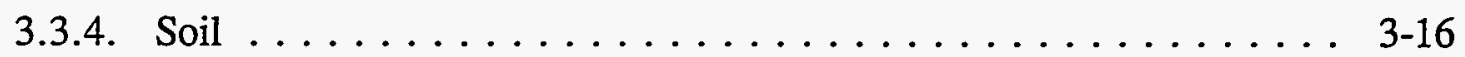

3.3.5. Vegetation $\ldots \ldots \ldots \ldots \ldots \ldots \ldots \ldots \ldots \ldots \ldots \ldots \ldots \ldots \ldots \ldots$ 3-17

3.3.6. External Penetrating Radiation . . . . . . . . . . . 3-18

3.3.7. Data Management . . . . . . . . . . . . . . 3-18

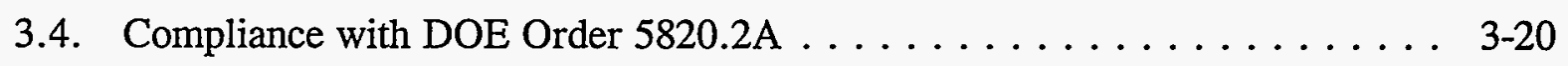

4. ENVIRONMENTAL PROGRAM INFORMATION $\ldots \ldots \ldots \ldots \ldots \ldots$ 4-1

4.1. Description of Monitoring Program $\ldots \ldots \ldots \ldots \ldots \ldots \ldots$ 4-3

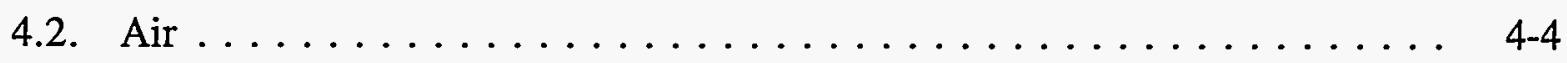

4.3. Surface Water $\ldots \ldots \ldots \ldots \ldots \ldots \ldots \ldots \ldots \ldots \ldots \ldots \ldots \ldots \ldots \ldots$ 4-11

4.4. Soil, Grass, and Bottom Sediment $\ldots \ldots \ldots \ldots \ldots \ldots \ldots \ldots \ldots$ 4 .18

4.5. External Penetrating Radiation $\ldots \ldots \ldots \ldots \ldots \ldots \ldots \ldots \ldots$ 4-22

4.6. Estimates of Potential Radiation Doses . . . . . . . . . . . . . . . . . 4-29

4.6.1. Airborne Pathway . . . . . . . . . . . . . . . . 4 4-29

4.6.2. Water Pathway . . . . . . . . . . . . . . . . . .

4.6.3. External Direct Radiation Pathway . . . . . . . . . . . 4-51

4.6.4. Dose Summary . . . . . . . . . . . . . . 4-52

\section{ENVIRONMENTAL NONRADIOLOGICAL PROGRAM}

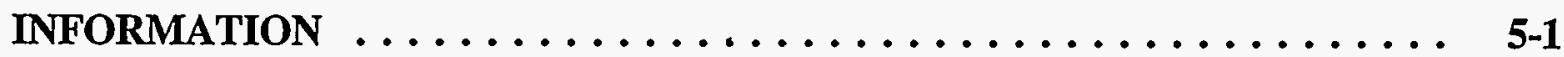

5.1. National Pollutant Discharge Elimination System

Monitoring Results $\ldots \ldots \ldots \ldots \ldots \ldots \ldots \ldots \ldots \ldots \ldots \ldots \ldots$ 5-3

5.1.1. Sewage-Treatment Plant Renovations $\ldots \ldots \ldots \ldots \ldots \ldots$ 5-6 
5.1.2. Effluent Monitoring $\quad \ldots \ldots \ldots \ldots \ldots \ldots \ldots \ldots \ldots \ldots$

5.1.2.1. Sample Collection $\ldots \ldots \ldots \ldots \ldots \ldots \ldots$. $5-7$

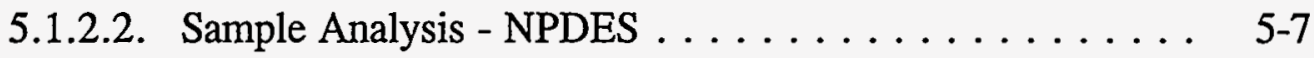

5.1.2.3. Results . . . . . . . . . . . . . .

5.1.2.4. Outfalls $\ldots \ldots \ldots \ldots \ldots \ldots \ldots \ldots \ldots \ldots$ 5-10

5.2. Additional Effluent Monitoring $\ldots \ldots \ldots \ldots \ldots \ldots \ldots \ldots \ldots$ 5-35

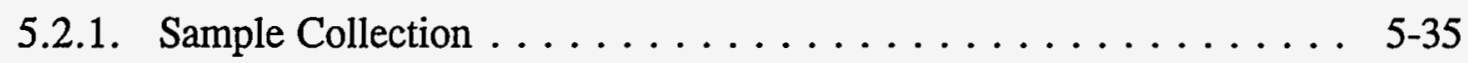

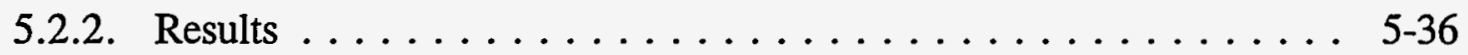

5.3. Sawmill Creek . . . . . . . . . . . . . . . . . 5-37

5.3.1. Sample Collection $\ldots \ldots \ldots \ldots \ldots \ldots \ldots \ldots \ldots \ldots \ldots \ldots \ldots \ldots$

5.3.2. Results . . . . . . . . . . . . 5.38

6. GROUNDWATER PROTECTION $\ldots \ldots \ldots \ldots \ldots \ldots \ldots \ldots \ldots$ 6-1

6.1. Potable Water System . . . . . . . . . . . . . . . . .

6.1.1. Regulatory Required Monitoring $\ldots \ldots \ldots \ldots \ldots \ldots \ldots$ 6-3

6.1.2. Informational Monitoring $\ldots \ldots \ldots \ldots \ldots \ldots \ldots \ldots$ 6-7

6.2. Groundwater Monitoring at Waste Management Sites . . . . . . . 6 6-19

6.2.1. $317 / 319$ Area . . . . . . . . . . . . . . . . . 6-19

6.2.2. Groundwater Monitoring at the $317 / 319$ Area . . . . . . . 6-22

6.2.2.1. Sample Collection . . . . . . . . . . . . . 6-24

6.2.2.2. Sample Analyses $-317 / 319$ Area . . . . . . . . . 6-25

6.2.2.3. Results of Analyses . . . . . . . . . . 6-26

6.3. Sanitary Landfill $\ldots \ldots \ldots \ldots \ldots \ldots \ldots \ldots \ldots \ldots \ldots \ldots .4 \ldots \ldots$

6.3.1. French Drain $\ldots \ldots \ldots \ldots \ldots \ldots \ldots \ldots \ldots \ldots \ldots \ldots$

6.3.2. Monitoring Studies $\ldots \ldots \ldots \ldots \ldots \ldots \ldots \ldots .6 \ldots .46$

6.3.2.1. Sample Collection . . . . . . . . . . . 6-46

6.3.2.2. Sample Analyses - 800 Area . . . . . . . . . . . 6-48

6.3.2.3. Results of Analyses . . . . . . . . . . . . . 6-49 
6.4. CP-5 Reactor Area . . . . . . . . . . . . . . . . . . 6 6-72

6.5. Site Characterization Activities $\ldots \ldots \ldots \ldots \ldots \ldots \ldots \ldots \ldots$ 6-78

6.5.1. 317/319/ENE Area Characterization . . . . . . . . . 6 6

6.5.1.1. RCRA Facility Investigation $\ldots \ldots \ldots \ldots \ldots \ldots$ 6-78

6.5.1.2. Groundwater . . . . . . . . . . . . . . .

6.5.1.3. Soil Borings . . . . . . . 6 . . . . . 6

6.5.1.4. Surface Soil Sampling . . . . . . . . . . . 6 6-81

6.5.1.5. Surface Water and Sediment Sampling . . . . . . . . 6-81

6.5.1.6. South Vaults Decontamination and Demolition ... . . . 6 6-81

6.5.2 800 Area Characterization $\ldots \ldots \ldots \ldots \ldots \ldots \ldots \ldots .6 .82$

6.5.3. Sitewide Hydrogeological Characterization Project . . . . . . . 6-83

7. QUALITY ASSURANCE $\ldots \ldots \ldots \ldots \ldots \ldots \ldots \ldots \ldots \ldots \ldots$ 7-1

7.1. Radiochemical Analysis and Radioactivity

Measurements .................... 7-3

7.2. Chemical Analysis $\ldots \ldots \ldots \ldots \ldots \ldots \ldots \ldots \ldots \ldots \ldots \ldots \ldots$ 7-6

8. APPENDIX $\ldots \ldots \ldots \ldots \ldots \ldots \ldots \ldots \ldots \ldots \ldots \ldots \ldots \ldots$ 8-1

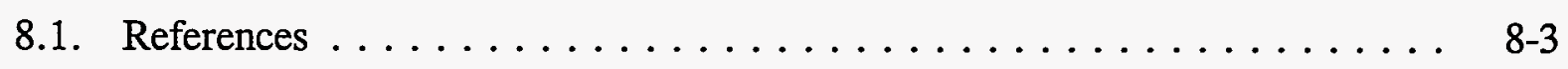

8.2. Acknowledgments $\ldots \ldots \ldots \ldots \ldots \ldots \ldots \ldots \ldots \ldots$ 8.7

8.3. Distribution for $96 / 3 \ldots \ldots \ldots \ldots \ldots \ldots \ldots \ldots \ldots$ 8-8 
1.1 Population Distribution in the Vicinity of ANL-E, $1991 \ldots \ldots \ldots \ldots \ldots \ldots$. . . . . .

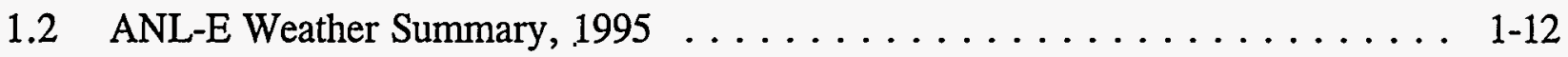

2.1 Asbestos Abatement Projects: IEPA Notification, $1995 \ldots \ldots \ldots \ldots$. . . . . . 2-8

2.2 Disposal of Asbestos-Containing Materials, $1995 \ldots \ldots \ldots \ldots \ldots \ldots$. . . . . . .

2.3 Boiler No. 5: Hours of Operation, $1995 \ldots \ldots \ldots \ldots \ldots \ldots$. . . . . . . . . .

2.41995 Annual Emission Report: Emission Summary . . . . . . . . . . . . . . 2-13

2.5 Characterization of NPDES Outfalls at ANL-E, $1995 \ldots \ldots \ldots \ldots \ldots$. . . . . . .

2.6 Hazardous Waste Treatment and Storage Facilities, $1995 \ldots \ldots \ldots$. . . . . 2-27

2.7 Hazardous Waste Treatment, Storage, and Disposal, 1995 . . . . . . . . . 2-32

2.8 Radioactive Mixed Waste Treatment, Storage, and Disposal, $1995 \ldots \ldots$. . . . 2-33

2.9 Generation and Shipment of Special Waste, $1995 \ldots \ldots \ldots \ldots \ldots \ldots$. . . . . . . .

2.10 List of Inactive Waste Disposal Sites at ANL-E Described in Various CERCLA Reports . . . . . . . . . . . . 2-42

2.11 Compounds Reported under SARA Title III, $1995 \ldots \ldots \ldots \ldots \ldots \ldots$. $\ldots \ldots 44$

2.12 SARA Title III, Section 313, Chemicals, $1994 \ldots \ldots \ldots \ldots \ldots \ldots$. . . . . . . . . .

2.13 ANL-E Environmental Permits in Effect December 31, $1995 \ldots \ldots \ldots$. . . . 2-56

3.1 Environmental Management Projects . . . . . . . . . . . . 3-5

4.1 Total Alpha and Beta Activities in Air Filter

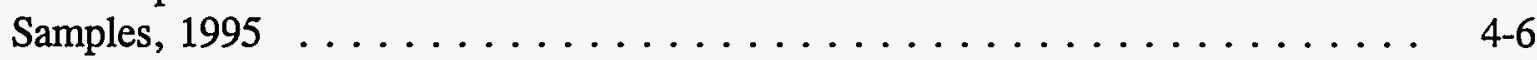

4.2 Gamma-Ray Activity in Air Filter Samples, $1995 \ldots \ldots \ldots \ldots \ldots \ldots$. . . . . . .

4.3 Strontium, Thorium, Uranium, and Plutonium Concentrations in Air Filter Samples, 1995 . . . . . . . . . . . . . . . . . . . 4-10

4.4 Summary of Monitored Airborne Radioactive Emissions from ANL-E Facilities, $1995 \ldots \ldots \ldots \ldots \ldots \ldots \ldots \ldots \ldots \ldots \ldots$. $\ldots \ldots \ldots \ldots$.12

4.5 Radionuclides in Sawmill Creek Water, $1995 \ldots \ldots \ldots$. . . . . . . . 4-14

4.6 Total Radioactivity Released to Sawmill Creek, 1995 . . . . . . . . . . . . 4 4-15

4.7 Radionuclides in Storm-Water Outfalls, 1995 . . . . . . . . . . . . . . . . 4-16

4.8 Radionuclides in Des Plaines River Water, 1995 . . . . . . . . . . 4 4-17

4.9 Radionuclides in Illinois River Water, 1995 . . . . . . . . . . . . . . . . 4-19

4.10 Gamma-Ray-Emitting Radionuclides in Soil, 1995 . . . . . . . . . . . . . 4-21

ANL-E Site Environmental Report 
No.

4.11 Transuranics in Soil $1995 \ldots \ldots \ldots \ldots \ldots \ldots \ldots$. . . . . . . . . . . . . . . . .

4.12 Radionuclides in Grass, 1995 . . . . . . . . . . . . . . . . . . . . 4-24

4.13 Radionuclides in Bottom Sediment, 1995 . . . . . . . . . . . . . . . 4-25

4.14 Environmental Penetrating Radiation at Off-Site Locations, 1995 . . . . . . . . . . . . . . . . . . . 4-26

4.15 Environmental Penetrating Radiation at ANL-E, 1995 . . . . . . . . . . . . 4 4-27

4.16 Radiological Airborne Releases from Building 200, $1995 \ldots \ldots \ldots$. . . . . 4-31

4.17 Maximum Perimeter and Individual Doses from

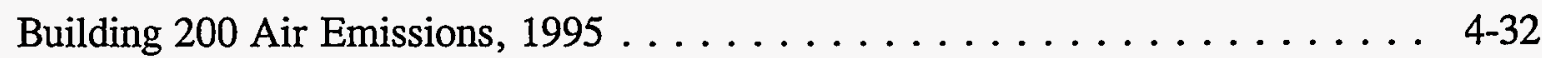

4.18 Radiological Airborne Releases from Building 205, $1995 \ldots \ldots \ldots$. . . . . 4-33

4.19 Maximum Perimeter and Individual Doses from Building 205 Air Emissions, 1995 . . . . . . . . . . . . . . . . . . . . 4-34

4.20 Radiological Airborne Releases from Building 212, $1995 \ldots \ldots \ldots$. . . . . 4-35

4.21 Maximum Perimeter and Individual Doses from Building 212 Air Emissions, $1995 \ldots \ldots$. . . . . . . . . . . . . . . 4-36

4.22 Radiological Airborne Releases from Building 330 (CP-5), $1995 \ldots \ldots \ldots \ldots \ldots \ldots \ldots \ldots \ldots$. . . . . . . . . .

4.23 Maximum Perimeter and Individual Doses from Building 330 (CP-5) Air Emissions, 1995 . . . . . . . . . . . . . . . . 4 4-38

4.24 Radiological Airborne Releases from Building 350, $1995 \ldots \ldots$. . . . . . 4-39

4.25 Maximum Perimeter and Individual Doses from Building 350 Air Emissions, $1995 \ldots \ldots \ldots \ldots$. . . . . . . . . . . 4-40

4.26 Radiological Airborne Releases from Building 375 (IPNS), $1995 \ldots \ldots \ldots \ldots \ldots \ldots$. . . . . . . . . . 4 4 .41

4.27 Maximum Perimeter and Individual Doses from Building 375 (IPNS) Air Emissions, 1995 . . . . . . . . . . . . . . . . 4-42

4.28 Radiological Airborne Releases from Building $411 / 415$ (APS), $1995 \ldots \ldots \ldots \ldots \ldots \ldots \ldots \ldots$. . . . . . . . . . . .

4.29 Maximum Perimeter and Individual Doses from Building 411/415 Air Emissions, 1995 . . . . . . . . . . . . . . . . 4-44

$4.3080 \mathrm{~km}$ Population Dose, 1995 . . . . . . . . . . . . . . . . . . . 4-47

$4.3150-$ Year Committed Effective Dose Equivalent (CEDE) Factors . . . . . . . . 4-49 
No.

$\underline{\text { Title }}$

$\underline{\text { Page }}$

4.32 Radionuclide Concentrations and Dose Estimates

for Sawmill Creek Water, $1995 \ldots \ldots \ldots \ldots$. . . . . . . . . 4-50

4.33 Summary of the Estimated Dose to the Public, 1995 . . . . . . . . . . . 4-53

4.34 Annual Average Dose Equivalent in the U.S. Population . . . . . . . . . 4-54

5.1 NPDES Permit Limit Exceedances, $1995 \ldots \ldots \ldots \ldots \ldots \ldots \ldots$. . . . . . .

5.2 Outfall 001A Effluent Limits and Monitoring Results, $1995 \ldots \ldots \ldots$. . . . 5-11

5.3 Outfall 001B Priority Pollutant Monitoring Results, $1995 \ldots \ldots$. . . . . . . . 5-13

5.4 Volatile Organic Compounds in Laboratory Wastewater, 1995 . . . . . . . . 5 5-14

5.5 Outfall 001 Monitoring Results and Effluent Limits, 1995 . . . . . . . . . 5 5-17

5.6 Outfall 001 Aquatic Toxicity Test Results, $1995 \ldots \ldots \ldots \ldots$. . . . . . . . 5 5-19

5.7 Aquatic Toxicity Test Results, 1991 to $1995 \ldots \ldots \ldots \ldots$. . . . . . . . 5-19

5.8 NPDES Effluent Summary, $1995 \ldots \ldots \ldots \ldots \ldots \ldots \ldots \ldots \ldots \ldots$. $\ldots \ldots \ldots$

5.9 Acute Toxicity Results: Fathead Minnow, $1995 \ldots \ldots \ldots \ldots \ldots$. . . . . . . . .

5.10 Acute Toxicity Results: Ceriodaphnia, $1995 \ldots \ldots \ldots \ldots \ldots \ldots$. . . . . . . . . .

5.11 Chemical Constituents in Effluents from ANL-E Wastewater Treatment Plant, $1995 \ldots \ldots \ldots \ldots \ldots \ldots$. . . . . . . . . . .

5.12 Chemical Constituents in Sawmill Creek: Location 7M, $1995 \ldots \ldots$. . . . . 5-38

6.1 ANL-E Water Supply Wells $\ldots \ldots \ldots \ldots \ldots \ldots \ldots \ldots \ldots$ 6-4

6.2 State of Illinois Required Inorganic Chemicals (900.50), $1995 \ldots \ldots \ldots \ldots$. . . . 6

6.3 State of Illinois Required Pesticides/Herbicides (900.65), $1995 \ldots \ldots \ldots$. . . .6

6.4 Federally Required Phase V Volatile Organic Results, 1995 . . . . . . . . . 6-7

6.5 Copper/Lead Samples Collected March 2 and August 22, $1995 \ldots \ldots \ldots$. . . 6-8

6.6 Radioactivity in ANL-E Domestic Wells, $1995 \ldots \ldots \ldots \ldots$. . . . . . 6-10

6.7 Volatile Organic Compounds in Drinking Water

6.8 Volatile Organic Compounds in Drinking Water Collected May 18, $1995 \ldots \ldots \ldots \ldots \ldots \ldots \ldots \ldots \ldots$. . . . . . . . . . . .

6.9 Volatile Organic Compounds in Drinking Water Collected August 14, $1995 \ldots \ldots \ldots \ldots \ldots \ldots$. . . . . . . . . . . . . . 
No.

Title

$\underline{\text { Page }}$

6.10 Volatile Organic Compounds in Drinking Water

Collected November 20,1995 . . . . . . . . . . . . . . . . . . . . . 6-17

6.11 Groundwater Monitoring Wells: $317 / 319$ Area . . . . . . . . . . . . 6-24

6.12 Groundwater Monitoring Results: 300 Area, Well 317021, 1995 . . . . . . . . . . . . . . . . . . . . . . 6-27

6.13 Groundwater Monitoring Results: 300 Area, Well $317052,1995 \ldots \ldots \ldots \ldots \ldots \ldots \ldots \ldots \ldots \ldots \ldots \ldots$. . . . . . . . . . . . . .

6.14 Groundwater Monitoring Results: 300 Area, Well 317061, 1995 . . . . . . . . . . . . . . . . . . . . . . . . . . 6-29

6.15 Groundwater Monitoring Results: 300 Area, Well 317091, 1995 . . . . . . . . . . . . . . . . . . . . . . . 6-30

6.16 Groundwater Monitoring Results: 300 Area, Well 317101, 1995

6.17 Groundwater Monitoring Results: 300 Area, Well 317111, 1995

6.18 Groundwater Monitoring Results: 300 Area, Well 317121D, 1995 $6-33$

6.19 Groundwater Monitoring Results: 300 Area, Well 319011, 1995 . . . . . . . . . . . . . . . . . . . . . . . . . . 6-34

6.20 Groundwater Monitoring Results: 300 Area, Well 319031, 1995 $6-35$

6.21 Groundwater Monitoring Results: 300 Area, Well 319032, 1995 . . . . . . . . . . . . . . . . . . . . . . . . . . . 6 6-36

6.22 Groundwater Monitoring Results: 300 Area, Well 319131D, 1995 . . . . . . . . . . . . . . . . . . . . . . 6-37

6.23 Illinois Class I Groundwater Quality Standards: Inorganics $\ldots . \ldots \ldots$. . . . 6-39

6.24 Illinois Class I Groundwater Quality Standards: Organics . . . . . . . . . . 6 6-40

6.25 Volatile Organic Compounds in 317 Area: Manholes E-1 and E-2, 1995 . . . . . . . . . . . . . . . . . . . . . . 6-43

6.26 Groundwater Monitoring Wells: 800 Area Landfill . . . . . . . . . . . . 6 6-48

6.27 Groundwater Monitoring Results: Sanitary Landfill, Well $800161,1995 \ldots \ldots \ldots \ldots \ldots \ldots \ldots \ldots \ldots \ldots \ldots \ldots \ldots . \ldots \ldots$. 6 . 50 
No.

$\underline{\text { Title }}$

$\underline{\text { Page }}$

6.28 Groundwater Monitoring Results: Sanitary Landfill,

6.29 Groundwater Monitoring Results: Sanitary Landfill, Well 800163D, 1995

6.30 Groundwater Monitoring Results: Sanitary Landfill, Well 800171, 1995

6.31 Groundwater Monitoring Results: Sanitary Landfill, Well 800173D, 1995

6.32 Groundwater Monitoring Results: Sanitary Landfill, Well 800181, 1995

6.33 Groundwater Monitoring Results: Sanitary Landfill, Well 800183D, 1995 . . . . . . . . . . . . . . . . . . . . . . 6-56

6.34 Groundwater Monitoring Results: Sanitary Landfill, Well 800191, 1995

6.35 Groundwater Monitoring Results: Sanitary Landfill, Well 800192, 1995

6.36 Groundwater Monitoring Results: Sanitary Landfill, Well 800193D, 1995

6.37 Groundwater Monitoring Results: Sanitary Landfill, Well 800201, 1995

6.38 Groundwater Monitoring Results: Sanitary Landfill, Well $800202,1995 \ldots \ldots \ldots \ldots \ldots \ldots \ldots$. . . . . . . . . . . . 61

6.39 Groundwater Monitoring Results: Sanitary Landfill, Well 800203D, 1995 6-62

6.40 Groundwater Monitoring Results: 300 Area, Well 330011, 1995

6.41 Groundwater Monitoring Results: 300 Area, Well 330021, 1995 6-74

6.42 Groundwater Monitoring Results: 300 Area, Well 330031, 1995 6-75

6.43 Groundwater Monitoring Wells: 330 Area/CP-5 . . . . . . . . . . . . 6. 6-76

6.44 Groundwater Chemistry Summary: 317/319 Area, Characterization Wells . . . 6-80

7.1 Detection Limits $\ldots \ldots \ldots \ldots \ldots \ldots \ldots \ldots \ldots \ldots \ldots \ldots \ldots \ldots$ 
No.

7.2 Summary of DOE-EML-QAP Samples, $1995 \ldots \ldots \ldots \ldots \ldots \ldots$ 7-5

7.3 Reference Materials Used for Inorganic Analysis $\ldots \ldots \ldots \ldots \ldots \ldots \ldots$ 7-7

7.4 Limit of Detection for Metal Analysis $\ldots \ldots \ldots \ldots \ldots \ldots \ldots \ldots \ldots$ 7-8

7.5 Quality Check Sample Results: Volatile Analyses, $1995 \ldots \ldots \ldots$. . . . 7-9

7.6 Quality Check Sample Results: Semivolatile Analyses, 1995 . . . . . . . . 7-10 
No.

1.1 Sampling Locations at Argonne National Laboratory-East $\ldots \ldots \ldots \ldots \ldots$ 1-6

1.2 Sampling Locations near Argonne National Laboratory-East . . . . . . . . . . 1-7

1.3 Monthly and Annual Wind Roses at Argonne National Laboratory-East, 1995 . . . . . . . . . . . . . . . . . . . . . . 1-10

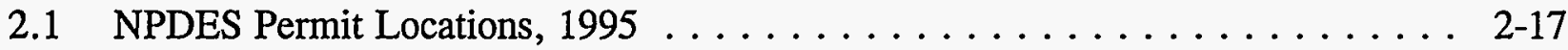

2.2 Distribution of NPDES Permit Exceedances, $1995 \ldots \ldots \ldots \ldots \ldots \ldots$. $2-18$

2.3 Total Number of NPDES Exceedances, $1989-1995 \ldots \ldots \ldots \ldots \ldots \ldots \ldots$. . . . . . . .

2.4 Major Treatment, Storage, and/or Disposal Areas at ANL-E . . . . . . . . . 2-30

4.1 Comparison of Total Alpha and Beta Activities

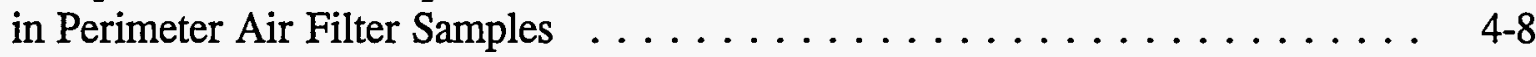

4.2 Comparison of Gamma-Ray Activity in Air Filter Samples . . . . . . . . . . 4 4-9

4.3 Selected Airborne Radionuclide Emissions . . . . . . . . . . . . . . . . 4 4-13

4.4 Penetrating Radiation Measurements at the ANL-E Site, $1995 \ldots \ldots \ldots \ldots$. . . . . .

4.5 Individual and Perimeter Doses from Airborne

Radioactive Emissions . . . . . . . . . . . . . . . . . . . . . . 4 4-46

4.6 Population Dose from Airborne Radioactive Emissions $\ldots \ldots \ldots \ldots$. . . . 4 48

4.7 Comparison of Dose Estimates from Ingestion of Sawmill Creek Water . . . . . . . . . . . . . . . . . 4-51

5.1 ANL-E Sewage Treatment Plant $\ldots \ldots \ldots \ldots \ldots \ldots \ldots \ldots \ldots$ 5-5

5.2 NPDES Outfall Locations $\ldots \ldots \ldots \ldots \ldots \ldots \ldots \ldots \ldots \ldots . \ldots \ldots$. $\ldots \ldots$

5.3 Acetone Levels in Laboratory Wastewater, 1992 to 1995 . . . . . . . . . . . . 5-14

5.4 Methylene Chloride Levels in Laboratory Wastewater, 1992 to 1995 . . . . . 5-15

5.5 Chloroform Levels in Laboratory Wastewater, 1992 to $1995 \ldots \ldots$. . . . . . 5-15

5.6 Total Dissolved Solids and Chloride in Outfall 001 Water, 1995 . . . . . . . . 5-18

6.1 Locations of Components within the 317/319/ENE Area . . . . . . . . . 6-20

6.2 Active Monitoring and Characterization Wells in the 317 and 319 Areas, 1995 . . . . . . . . . . . . . . . . . . . . . . . . . . 6-23

6.3 Concentration of 1,1-Dichloroethane and 1,1,1-Trichloroethane in Well $317021 \ldots \ldots \ldots \ldots$. . . . . . . . . . .

6.4 Trends of Selected Organics in 317 Area Manholes, $1995 \ldots \ldots$. . . . . . 6-44 
No.

6.5 Active Monitoring Wells in the 800 Area Landfill $\ldots \ldots \ldots \ldots \ldots$. . . . . . . .

6.6 Well 800161 Manganese Results . . . . . . . . . . . . . . . . . . . . 6-63

6.7 Well 800162 Manganese Results . . . . . . . . . . . . . . . . . 6-63

6.8 Well 800163D Chloride Results . . . . . . . . . . . . . . . . 6 6-64

6.9 Well 800171 Manganese Results . . . . . . . . . . . . . . . . . 6-64

6.10 Well 800171 TDS Results . . . . . . . . . . . . . . . . . 6-65

6.11 Well 800173D Chloride Results . . . . . . . . . . . . . . . . 6-65

6.12 Well 800173D Manganese Results $\ldots \ldots \ldots \ldots \ldots \ldots \ldots \ldots$ 6.6. . . . . . .

6.13 Well 800181 Manganese Results . . . . . . . . . . . . . . . . . 6-66

6.14 Well 800191 Chloride Results . . . . . . . . . . . . . . . . . . . 6 6-67

6.15 Well 800191 Manganese Results . . . . . . . . . . . . . . . . . . . 6-67

6.16 Well 800192 Manganese Results . . . . . . . . . . . . . . . . . . 6-68

6.17 Well 800193D Chloride Results . . . . . . . . . . . . . . . . . 6 6-68

6.18 Well 800201 Manganese Results . . . . . . . . . . . . . . . . . . . . 6 6-69

6.19 Well 800202 Manganese Results . . . . . . . . . . . . . . . . . . . . . . 6-69

6.20 Well 800203D Chloride Results . . . . . . . . . . . . . . . . . 6-70

6.21 Active Monitoring Wells in the CP-5 Reactor Area . . . . . . . . . . . 6-77 


$\begin{array}{ll}\text { 1,2-DCE } & \text { cis-1,2-Dichloroethene } \\ \text { ACM } & \text { Asbestos-Containing Materials } \\ \text { ADS } & \text { Activity Data Sheets } \\ \text { ALARA } & \text { As Low As Reasonably Achievable } \\ \text { ANL-E } & \text { Argonne National Laboratory-East } \\ \text { AOC } & \text { Area of Concern } \\ \text { APS } & \text { Advanced Photon Source } \\ \text { ASTM } & \text { American Society for Testing and Materials } \\ \text { ATLAS } & \text { Argonne Tandem Linac Accelerating System } \\ \text { BAT } & \text { Best Available Technology } \\ \text { BOD } & \text { Biochemical Oxygen Demand } \\ \text { CAA } & \text { Clean Air Act } \\ \text { CAAPP } & \text { Clean Air Act Permit Program } \\ \text { CEDE } & \text { Committed Effective Dose Equivalent } \\ \text { CERCLA } & \text { Comprehensive Environmental Response, Compensation } \\ & \text { and Liability Act } \\ \text { CFR } & \text { Code of Federal Regulations } \\ \text { CLP } & \text { Contract Laboratory Program } \\ \text { COD } & \text { Chemical Oxygen Demand } \\ \text { CP-5 } & \text { Chicago Pile-Five } \\ \text { CRM } & \text { Cultural Resource Management } \\ \text { CWA } & \text { Clean Water Act } \\ \text { CY } & \text { Calendar Year } \\ \text { D\&D } & \text { Decontamination and Decommissioning } \\ \text { DCG } & \text { Derived Concentration Guides } \\ \text { DMR } & \text { Discharge Monitoring Report } \\ \text { DOE } & \text { U.S. Department of Energy } \\ \text { DOE-CH } & \text { U.S. Department of Energy - Chicago Operations Office } \\ \text { DOT } & \text { U.S. Department of Transportation } \\ \text { EA } & \text { Environmental Assessment } \\ \text { EBWR } & \text { Experimental Boiling Water Reactor } \\ \text { ECR } & \text { Environmental Compliance Representative } \\ \text { EIS } & \text { Environmental Impact Statement } \\ \text { EML } & \text { Environmental Measurements Laboratory } \\ \text { EMO } & \text { Environmental Management Operation } \\ \text { EMS } & \text { Environmental Protection Data Management System } \\ \text { ENE } & \text { East-Northeast } \\ \text { EPA } & \text { U.S. Environmental Protection Agency } \\ \text { EPCRA } & \text { Emergency Planning and Community Right to Know Act } \\ \text { ESA } & \text { Endangered Species Act } \\ \text { ESH } & \text { Environment, Safety and Health } \\ & \end{array}$


ESH-DACH Environment, Safety and Health/Dosimetry and Analytical Services, Chemistry Laboratory

ESH-DACL Environment, Safety and Health/Dosimetry and Analytical Services, Control Laboratory

ESH-DARC Environment, Safety and Health/Dosimetry and Analytical Services, Radiochemistry Laboratory

FFCA

FIFRA

FWS

Federal Facility Compliance Agreement

FY

Federal Insecticide, Fungicide and Rodenticide Act

U.S. Fish and Wildlife Service

Fiscal Year

GOCO

HEPA

Government-Owned Contractor-Operated

HSWA

High-Efficiency Particulate Air

Hazardous and Solid Waste Amendments

IAC

ICRP

IDPH

Illinois Administrative Code

International Commission on Radiological Protection

IIlinois Department of Public Health

IEPA

IHPA

IPCB

IPNS

LEPC

MCL

MCLG

Illinois Environmental Protection Agency

Illinois Historic Preservation Agency

Illinois Pollution Control Board

Intense Pulsed Neutron Source

Local Emergency Planning Committee

Maximum Contaminant Level

Maximum Contaminant Level Goals

MSDS

MSL

NBL

NCRP

NEPA

NESHAP

NHPA

NIST

NPDES

NPL

NRHP

OSHA

PA

PCB

Material Safety Data Sheets

Mean Sea Level

New Brunswick Laboratory

National Commission on Radiation Protection and Measurements

National Environmental Policy Act

National Emission Standards for Hazardous Air Pollutants

National Historic Preservation Act

National Institute of Standards and Technology

National Pollutant Discharge Elimination System

National Priority List

National Register of Historical Places

Occupational Safety and Health Administration

Preliminary Assessment

Polychlorinated Biphenyls

PFS

PSTP

Plant Facilities and Services

QA

QAP

RCRA

RFA

Proposed Site Treatment Plan

Quality Assurance

Quality Assurance Program

Resource Conservation and Recovery Act

RCRA Facility Assessment 


$\begin{array}{ll}\text { RFI } & \text { RCRA Facility Investigation } \\ \text { RMW } & \text { Radioactive Mixed Waste } \\ \text { SARA } & \text { Superfund Amendments and Reauthorization Act } \\ \text { SDWA } & \text { Safe Drinking Water Act } \\ \text { SI } & \text { Site Investigation } \\ \text { SIP } & \text { State Implementation Plan } \\ \text { SOP } & \text { Standard Operating Procedure } \\ \text { SPCC } & \text { Spill Prevention Control and Countermeasures } \\ \text { SRM } & \text { Standard Reference Material } \\ \text { SSI } & \text { Site Screening Investigation } \\ \text { SVOC } & \text { Semivolatile Organic Compounds } \\ \text { SWMU } & \text { Solid Waste Management Unit } \\ \text { TCA } & \text { 1,1,1-Trichloroethane } \\ \text { TCE } & \text { Trichloroethene } \\ \text { TDS } & \text { Total Dissolved Solids } \\ \text { TLD } & \text { Thermoluminescent Dosimeter } \\ \text { TRC } & \text { Total Residual Chlorine } \\ \text { TSCA } & \text { Toxic Substances Control Act } \\ \text { TSS } & \text { Total Suspended Solids } \\ \text { UST } & \text { Underground Storage Tank } \\ \text { VOC } & \text { Volatile Organic Compounds } \\ \text { WM } & \text { Waste Management } \\ \text { WQS } & \text { Water Quality Standards } \\ \text { WTP } & \text { Wastewater Treatment Plant }\end{array}$


This report discusses the results of the environmental protection program at Argonne National Laboratory-East (ANL-E) for 1995. To evaluate the effects of ANL-E operations on the environment, samples of environmental media collected on the site, at the site boundary, and off the ANL-E site were analyzed and compared to applicable guidelines and standards. A variety of radionuclides were measured in air, surface water, on-site groundwater, soil, grass, and bottom sediment samples. In addition, chemical constituents in surface water, groundwater, and ANL-E effluent water were analyzed. External penetrating radiation doses were measured, and the potential for radiation exposure to off-site population groups was estimated. The results of the surveillance program are interpreted in terms of the origin of the radioactive and chemical substances (natural, fallout, ANL-E, and other) and are compared with applicable environmental quality standards. A U.S. Department of Energy dose calculation methodology, based on International Commission on Radiological Protection recommendations and the CAP-88 version of the EPA-AIRDOSE/RADRISK computer code, is used in this report. The status of ANL-E environmental protection activities with respect to the various laws and regulations that govern waste handling and disposal is discussed. This report also discusses progress being made on environmental corrective actions and restoration projects. 
This report summarizes the ongoing environmental protection program conducted by Argonne National Laboratory-East (ANL-E) in 1995. It includes descriptions of the site, the ANL-E missions and programs, the status of compliance with environmental regulations, environmental protection and restoration activities, and the environmental surveillance program. The surveillance program conducts regular monitoring for radiation, radioactive materials, and nonradiological constituents on the ANL-E site and in the surrounding region. These activities document compliance with appropriate standards and permit limits, identify trends, provide information to the public, and contribute to a better understanding of ANL-E's impact on the environment. The surveillance program supports the ANL-E policy of protecting the public, employees, and the environment from harm that could be caused by ANL-E activities and reducing environmental impacts to the greatest degree practicable.

\section{Compliance Summary}

Radionuclide emissions, the disposal of asbestos, and conventional air pollutants from ANL-E facilities are regulated under the Clean Air Act (CAA). A number of airborne radiological emission points at ANL-E are subject to National Emission Standards for Hazardous Air Pollutants (NESHAP) regulations for radionuclide releases from U.S. Department of Energy (DOE) facilities (Code of Federal Regulations, Title 40, Part 61, [40 CFR 61] Subpart H). All such air emission sources were evaluated to ensure that these requirements are being properly addressed. The ANL-E individual off-site dose required to be reported by the U.S. Environmental Protection Agency (EPA) regulations (40 CFR 61, Subpart H) was $0.026 \mathrm{mrem} / \mathrm{yr}$ in 1995 . This is $0.26 \%$ of the $10 \mathrm{mrem} / \mathrm{yr}$ standard.

At ANL-E, asbestos-containing material was frequently encountered during maintenance or renovation of existing facilities and equipment. Asbestos was removed and disposed of in strict accordance with the NESHAP Toxic Substance Control Act (TSCA), Resource Conservation and Recovery Act (RCRA) regulations, and Occupational Safety and Health Administration (OSHA) worker protection standards. All asbestos waste material was disposed of at off-site landfills in Illinois. Approximately $245 \mathrm{~m}^{3}\left(8,600 \mathrm{ft}^{3}\right)$ of asbestos-containing materials was removed and disposed of off site during 1995. 
The ANL-E site contains several sources of conventional air pollutants. The steam plant and fuel dispensing facilities operate continuously and are the only significant sources of such air pollutants. The emergency generators at the Advanced Photon Source are also significant sources, when operational. The operating permit for the steam plant requires continuous opacity and sulfur dioxide monitoring of the smoke stack from Boiler No. 5, the only boiler equipped to burn coal. Only low-sulfur coal was burned six months during 1995, whereas natural gas was used exclusively as a fuel for the other six months of the year. During the period coal was burned, which is in colder weather to supplement the gas-fired boilers, no exceedances were observed. The last of the high-sulfur coal was burned in January 1994.

The principal regulatory mechanism designed to achieve the goals of the Clean Water Act (CWA) is the National Pollutant Discharge Elimination System (NPDES). The authority to implement the NPDES program has been delegated to the State of Illinois. The permit renewal, which became effective October 30,1994, increased the number of monitored discharge points from nine to 28. During 1995, 49 exceedances of the NPDES permit limits were reported out of approximately 1,600 measurements. These all occurred before the permit was modified on August 24, 1995. Since that time, no exceedances have occurred.

ANL-E was granted interim status under RCRA by submitting a Part A permit application in 1980. In 1990, a Part B permit application was submitted to the Illinois Environmental Protection Agency (IEPA). Fifteen hazardous waste treatment and storage facilities have been identified. The Part B permit application is currently under review.

ANL-E has prepared and implemented a sitewide underground storage tank compliance plan. Thirty-three tanks have been removed over the past several years, and 22 tanks were replaced or upgraded in FY 1992 and FY 1993. Of the locations from which tanks were removed or replaced, 17 were found to have some degree of exterior contamination from leaks, spills, or overfills. Four tanks in the 800 Area that are no longer necessary for operation were removed in 1995. ANL-E is still awaiting approval of the cleanup actions for these four tanks. 
In 1986, 10 potential Comprehensive Environmental Response, Compensation and Liability Act (CERCLA) sites were identified. Under the Superfund Amendments and Reauthorization Act (SARA) of 1986, a total of 15 Preliminary Assessment (PA) reports were submitted. In late 1990, Site Screening Investigation (SSI) reports were completed on two individual sites and one composite submittal of three locations (317/319/ENE). At present, characterization studies are conducted on a voluntary basis at various stages for a number of the identified sites. Eventually, the characterization/remediation studies will be regulated through the RCRA Corrective Action process, once ANL-E's RCRA Part B permit has been issued.

The only TSCA compounds in significant quantities at ANL-E are polychlorinated biphenyls (PCBs) contained in electrical capacitors, transformer oil, and PCB-contaminated soil and sludge. All pole-mounted transformers and circuit breakers containing PCBs were replaced or retrofilled with non-PCB oil. All removal and disposal activities were conducted by licensed contractors specializing in such operations. PCB-contaminated sludge from the ANL-E wastewater treatment plant was characterized, containerized, and stored during 1994. Treatability studies conducted at off-site facilities were performed on the contaminated sludge during 1995.

DOE implementation of the National Environmental Policy Act (NEPA) requirements has been undergoing significant changes since 1992. Most NEPA project reviews sent to DOE for review and approval were determined to be categorical exclusions, although Environmental Assessments (EAs) will be required for several projects. Currently, there are no active projects at ANL-E requiring an Environmental Impact Statement (EIS).

The 1995 Environmental Management Plan requests funds for on-site rehabilitation projects, environmental restoration projects, and waste management activities. The rehabilitation projects concentrate on upgrading or replacing existing treatment facilities. Environmental restoration activities consist of projects that assess and clean up inactive waste sites. These include two inactive landfills, three French drains (dry wells used to dispose of liquid chemicals), two inactive wastewater treatment facilities, and a number of areas that may have been contaminated with small amounts of hazardous chemicals. A number of decontamination and decommissioning (D\&D) projects for on-site nuclear facilities have been identified, including cleanup at the Experimental 
Boiling Water Reactor (EBWR) and Chicago Pile-Five (CP-5) research reactors. The majority of the Waste Management projects involve improvements to existing treatment or storage facilities.

The major compliance issue at ANL-E in 1995 was the result of the new NPDES limits for total dissolved solids (TDS), copper, ammonia nitrogen, and total residual chlorine. Another significant issue involved the resolution of the inadvertent shipment, through an independent contractor, of waste oil contaminated with PCBs to an off-site recycling facility in 1994 . Other compliance issues included exceedance of the action levels for copper in drinking water, elevated levels of some routine indicator parameters in the groundwater at the sanitary landfill, and cleanup of environmental contamination caused by previous activities on the ANL-E site.

\section{Environmental Surveillance Program}

Airborne emissions of gaseous radioactive materials from ANL-E were monitored. The effective dose equivalents were estimated at the site perimeter and to the maximally exposed member of the public with the CAP-88 version of the EPA/AIRDOSE-RADRISK code. The estimated maximum perimeter dose was $0.32 \mathrm{mrem} / \mathrm{yr}$ in the north direction, while the estimated maximum dose to a member of the public was $0.12 \mathrm{mrem} / \mathrm{yr}$. This is $0.12 \%$ of the DOE radiation protection standard of $100 \mathrm{mrem} / \mathrm{yr}$ for all pathways. Approximately $80 \%$ of this estimated dose is due to the release of $1,033 \mathrm{Ci}$ of radon-220 in 1995. If the radon-220 impact is excluded from reporting, as required in $40 \mathrm{CFR} 61$, Subpart $\mathrm{H}$, the estimated dose to the maximally exposed individual would be $0.026 \mathrm{mrem} / \mathrm{yr}$. The estimated population dose from all releases to the approximately eight million people living within $80 \mathrm{~km}(50 \mathrm{mi})$ of the site was 8.4 man-rem.

Air monitoring was also conducted at ANL-E for total alpha activity, total beta activity, strontium-90, isotopic thorium, isotopic uranium, and plutonium-239. No statistically significant difference was identified between samples collected at the ANL-E perimeter and samples collected off the site. Monitoring for hazardous chemical constituents in ambient air was not conducted. 
The only source of radionuclides and chemical pollutants in surface water due to ANL-E releases was in Sawmill Creek below the wastewater discharge point. At various times, measurable levels of hydrogen-3, strontium-90, cesium-137, plutonium-239, and americium-241 were detected. Of these radionuclides, the maximum annual release was $0.50 \mathrm{Ci}$ of hydrogen-3. The hydrogen- 3 was added to the wastewater as part of normal Laboratory operations. The dose to a hypothetical individual using water from Sawmill Creek as his or her sole source of drinking water would be $0.0576 \mathrm{mrem} / \mathrm{yr}$. However, no one uses this water for drinking, and dilution by the Des Plaines River reduces the concentrations of the measured radionuclides to levels below their respective detection limits downstream from ANL at Lemont. Sawmill Creek is also monitored for nonradiological constituents to demonstrate compliance with State of Illinois water quality standards. Iron and copper were occasionally detected above the standard.

Surface soil and grass samples were collected at 10 perimeter and 10 off-site locations during 1995. The purpose of the sampling was to detect the possible buildup of radionuclides from the deposition of airborne emissions. The results indicate no statistically significant difference between the perimeter and off-site concentrations of potassium-40, cesium-137, radium-226, thorium-228, thorium-232, plutonium-238, plutonium-239, and americium-241.

Sediment samples were collected from Sawmill Creek, above, at, and below the point of wastewater discharge. For comparative purposes, samples were also collected from the beds of 10 off-site streams and ponds. The analysis of the off-site samples for selected radionuclides established their current ambient levels. Elevated levels of cesium-137 (up to $2.51 \mathrm{pCi} / \mathrm{g}$ ), plutonium-238 (up to $0.007 \mathrm{pCi} / \mathrm{g}$ ), plutonium-239 (up to $0.745 \mathrm{pCi} / \mathrm{g}$ ), and americium-241 (up to $0.063 \mathrm{pCi} / \mathrm{g}$ ) were found in the sediment below the outfall and are attributed to past ANL-E releases.

Dose rates from penetrating radiation (gamma-rays) were measured at 14 perimeter and on-site locations and at five off-site locations in 1995 using thermoluminescent dosimeters. The off-site results averaged $92 \pm 4 \mathrm{mrem} / \mathrm{yr}$, consistent with the long-term average. Abovebackground doses occurred at one perimeter location and were due to ANL-E operations. At the south fence, radiation from a temporary storage facility for radioactive waste resulted in an 
average dose of $129 \pm 12 \mathrm{mrem} / \mathrm{yr}$ for 1995 . The estimated dose from penetrating radiation to the nearest resident south of the site was $<0.01 \mathrm{mrem} / \mathrm{yr}$.

The potential radiation doses to members of the public from ANL-E operations during 1995 were estimated by combining the exposure from inhalation, ingestion, and direct radiation pathways. The inhalation pathway dominates. The highest estimated dose was about $0.12 \mathrm{mrem} / \mathrm{yr}$ to individuals living $500 \mathrm{~m}(1,640 \mathrm{ft})$ north of the site if they were outdoors at that location during the entire year. Doses from other pathways were calculated and were small at this location. The magnitude of the doses from ANL-E operations are well within all applicable standards and are insignificant when compared to doses received by the public from natural radiation $(\sim 300 \mathrm{mrem} / \mathrm{yr})$ or other sources, for example, medical $\mathrm{x}$-rays and consumer products $(\sim 60 \mathrm{mrem} / \mathrm{yr})$.

Radiological and chemical constituents in the groundwater were monitored in several areas of the ANL-E site in 1995. ANL-E domestic water supply is monitored by collecting quarterly samples from the four wells and a treated water tap. All results were less than the limits established by the Safe Drinking Water Act (SDWA) except for elevated levels of TDS. The action level for copper in drinking water was exceeded during 1995.

Ten monitoring wells screened in the glacial till and two into the dolomite were sampled quarterly at the 317/319 Area and analyzed for radiological, volatile organic, semivolatile, PCB, and pesticide/herbicide constituents. The major organic contaminants detected were trichloroethene, 1,1,1-trichloroethane, 1,1-dichloroethane, carbon tetrachloride, 1,2-dichloroethane, tetrachloroethene, and chloroform. Measurable levels of hydrogen-3, strontium-90, and cesium-137 were present in several of the wells. Remediation was begun in this area. A slurry wall was installed south of the 319 Landfill to contain the off-site movement of any pollutants.

Thirteen monitoring wells at the 800 Area sanitary landfill were sampled on a quarterly basis and analyzed for metals, volatile organic compounds, semivolatiles, PCBs, pesticides/herbicides, and hydrogen-3. Levels above Water Quality Standards (WQS) for 
chloride, iron, manganese, and TDS were found in some wells. Above background levels of hydrogen-3, 1,4-dioxane, chlorodifluoromethane, and tetrahydrofuran were found in several of the wells.

An extensive quality assurance program is maintained to cover all aspects of the environmental surveillance sampling and analysis programs. Approved documents are in place along with the supporting standard operating procedures. Newly collected data were compared both with recent results and historical data to ensure that deviations from previous conditions were identified and promptly evaluated. Samples at all locations were collected using well-established and documented procedures to ensure consistency. Samples were analyzed by documented standard analytical procedures. Data quality was verified by a continuing program of analytical laboratory quality control, participation in interlaboratory cross-checks, and replicate sampling and analysis. Data were managed and tracked by a dedicated computerized data management system that assigns unique sample numbers, schedules collection and analysis, checks status, and prepares tables and information for the annual report. 


\section{INTRODUCTION}

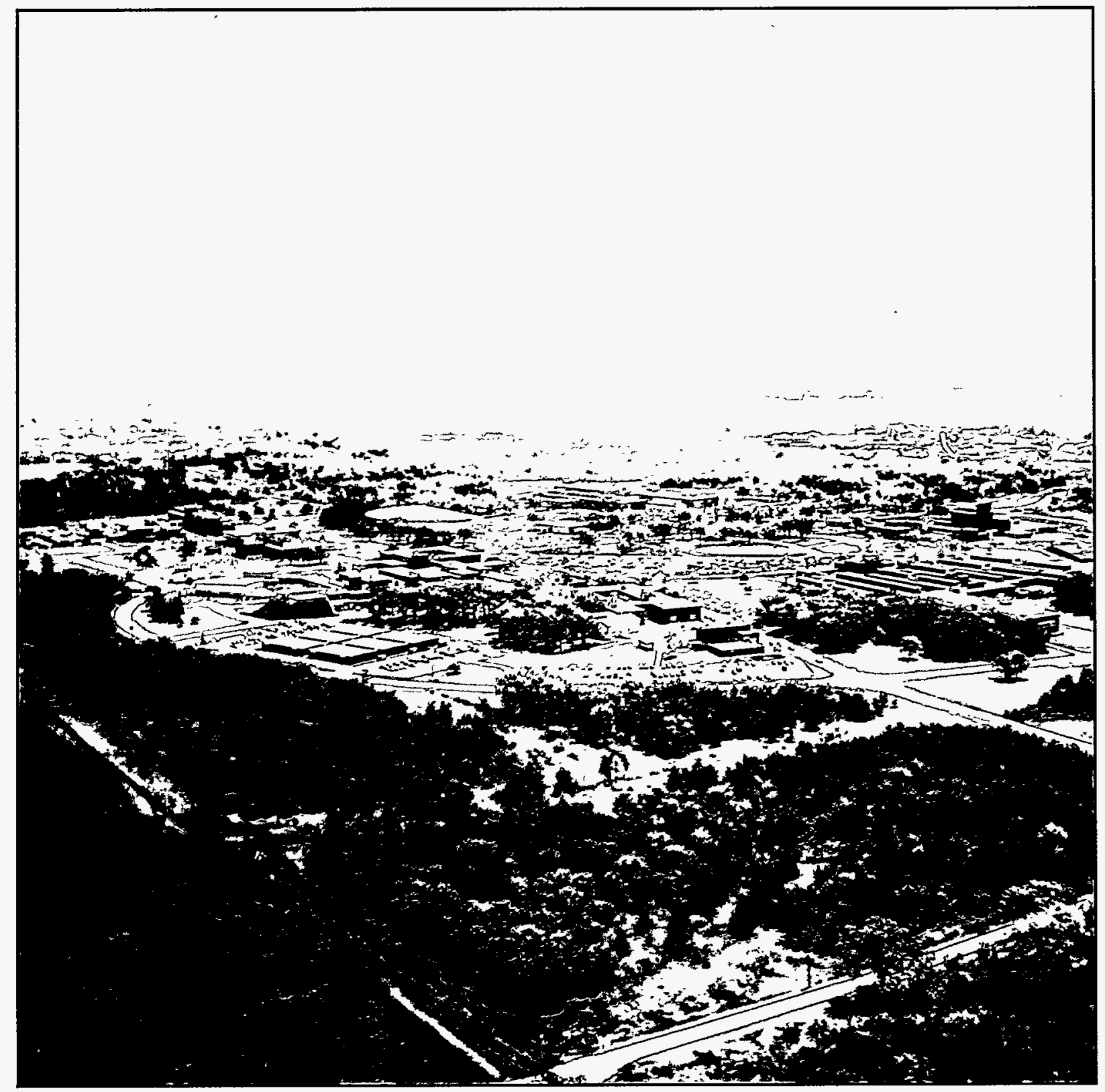




\subsection{General}

This annual report on the Argonne National Laboratory-East (ANL-E) environmental protection program provides the U.S. Department of Energy (DOE), environmental agencies, and the public with information on the levels of radioactive and chemical pollutants in the vicinity of ANL-E and on the amounts, if any, added to the environment by ANL-E operations. It also summarizes the compliance of ANL-E operations with applicable environmental laws and regulations and highlights significant accomplishments and problems related to environmental protection. The report follows the guidelines given in DOE Order 5400.1. ${ }^{1}$

ANL-E conducts a continuing program of environmental surveillance on and near the site to determine the identity, magnitude, and origin of radioactive and chemical substances in the environment. The detection of any such materials released to the environment by ANL-E operations is of special interest. One important function of the program is to verify the adequacy of ANL-E's pollution control systems.

ANL-E is a DOE energy research and development laboratory with several principal objectives. It conducts a broad program of research in the basic energy and related sciences (physical, chemical, material, computer, nuclear, biomedical, and environmental) and serves as an important engineering center for the study of nuclear and nonnuclear energy sources. Energyrelated research projects conducted during 1995 included safety studies for light-water and breeder reactors; superconductivity advances and applications; improvements in the use of coal for power production (particularly high-sulfur coal); synchrotron radiation accelerator design; development of electrochemical energy sources, including fuel cells and batteries for vehicles and for energy storage; and evaluation of heat exchangers for the recovery of waste heat from engines.

Other areas of research are the use of superconducting magnets for improved nuclear particle accelerators, fundamental coal chemistry studies, the immobilization of radioactive waste products for safe disposal, medical radioisotope technology, carcinogenesis, and the biological effects of small amounts of radiation. Environmental research studies include biological activity of energy-related mutagens and carcinogens; characterization and monitoring of energy-related 


\section{INTRODUCTION}

pollutants; and the effects of acid rain on vegetation, soil, and surface water quality. A significant number of these laboratory studies require the controlled use of radioactive and chemically toxic substances.

The principal nuclear facilities at ANL-E are the Advance Photon Source (APS); a superconducting heavy ion linear accelerator (Argonne Tandem Linac Accelerating System [ATLAS]); a 22-MeV pulsed electron Linac; several other charged particle accelerators (principally of the Van de Graaff and Dynamitron types); a large fast neutron source (Intense Pulsed Neutron Source [IPNS]) in which high-energy protons strike a uranium target to produce neutrons; chemical and metallurgical laboratories; and several hot cells and laboratories designed for work with multi-curie quantities of the actinide elements and with irradiated reactor fuel materials. The DOE New Brunswick Laboratory (NBL), a safeguards plutonium and uranium measurements and analytical chemistry laboratory, is located on the ANL-E site.

Two activities continued in 1995 have some potential environmental impact: (1) management of radioactive contamination remaining from the proof-of-breeding in light-water reactors project, which involved the dissolution and analysis of irradiated thorium and uranium-233 dioxide fuel elements and (2) decontamination and decommissioning (D\&D) of various reactor and other nuclear facilities. During 1995, the D\&D of the Experimental Boiling Water Reactor (EBWR) was completed.

The principal nonnuclear activities at ANL-E in 1995 that may have measurable impacts on the environment include the use of a coal-fired boiler (No. 5), studies of the closed-loop heat exchanger for waste heat recovery, and the use of large quantities of chlorine for water treatment. The closed-loop heat exchanger studies involved the use of moderately large quantities of toxic or flammable organic compounds such as toluene, Freon, biphenyl oxides, methyl pyridine, and trifluoroethanol. The major potential for environmental impact from these materials would be associated with any accidental releases caused by equipment malfunction. However, no such releases have occurred. 


\section{INTRODUCTION}

\subsection{Description of Site}

ANL-E occupies the central 688 ha (1,700 acres) of a 1,514-ha (3,740-acre) tract in DuPage County. The site is $43 \mathrm{~km}(27 \mathrm{mi})$ southwest of downtown Chicago and $39 \mathrm{~km}(24 \mathrm{mi})$ west of Lake Michigan. It is north of the Des Plaines River Valley, south of Interstate Highway 55 (I-55) and west of Illinois Highway 83. Figures 1.1 and 1.2 are maps of the site, the surrounding area, and sampling locations of the monitoring program. The 826-hectare (2,040-acre) Waterfall Glen Forest Preserve surrounding the site is mostly former ANL-E property that was deeded to the DuPage County Forest Preserve District in 1973 for use as a public recreational area, nature preserve, and demonstration forest. Figure 1.1 contains numbers on the abscissa and letters on the ordinate. In this report, facilities are identified by the alpha-numeric designations in Figure 1.1 to facilitate their location.

The terrain of ANL-E is gently rolling, partially wooded, former prairie, and farmland. The grounds contain a number of small ponds and streams. The principal stream is Sawmill Creek, which runs through the site in a southerly direction and enters the Des Plaines River about $2.1 \mathrm{~km}(1.3 \mathrm{mi})$ southeast of the center of the site. The land is drained primarily by Sawmill Creek, although the extreme southern portion drains directly into the Des Plaines River, which flows along the southern boundary of the forest preserve. This river flows southwest until it joins the Kankakee River about $48 \mathrm{~km}$ (30 mi) southwest of ANL-E to form the Illinois River.

The largest topographical feature of the area is the Des Plaines River valley, which is about $1.6 \mathrm{~km}(1 \mathrm{mi})$ wide. This valley contains the river, the Chicago Sanitary and Ship Canal, and the Illinois and Michigan Canal. Their presence extends the uninhabited area created by the ANL-E site and surrounding forest preserve about $1.6 \mathrm{~km}(1 \mathrm{mi})$ south of the site. The elevation of the channel surface is $180 \mathrm{~m}$ ( $578 \mathrm{ft}$ ) above sea level. The bluffs that form the southern border of the site rise from the river channel at slope angles of $15^{\circ}$ to $60^{\circ}$, reaching an average elevation of $200 \mathrm{~m}$ ( $650 \mathrm{ft}$ ) above sea level at the top. The land then slopes gradually upward reaching the average site elevation of $220 \mathrm{~m}$ ( $725 \mathrm{ft})$ above sea level at $915 \mathrm{~m}(3,000 \mathrm{ft})$ from the bluffs. Several large ravines oriented in a north-south direction are located in the southern portion of the 


\section{INTRODUCTION}

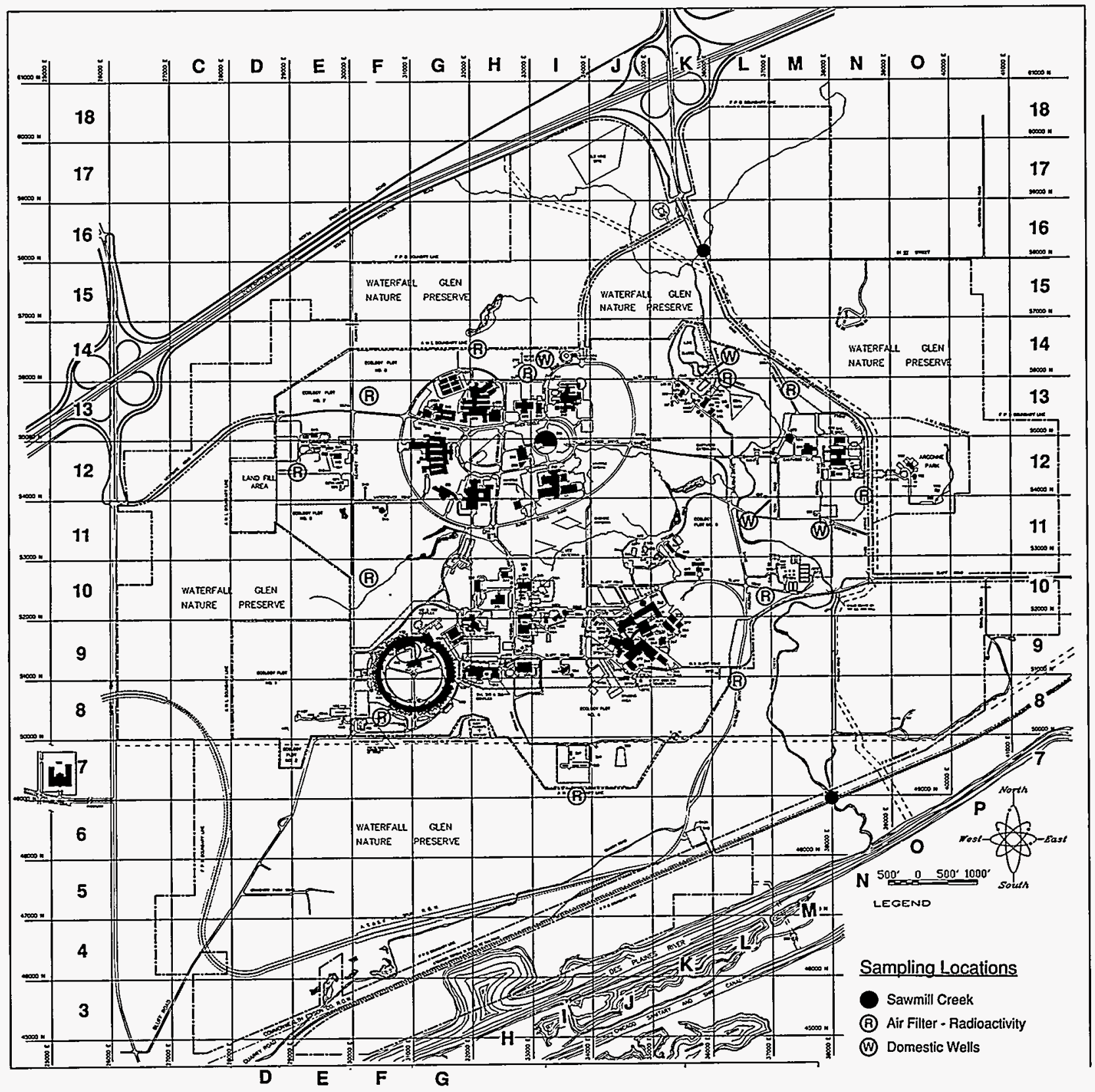

Figure 1.1 Sampling Locations at Argonne National Laboratory-East 


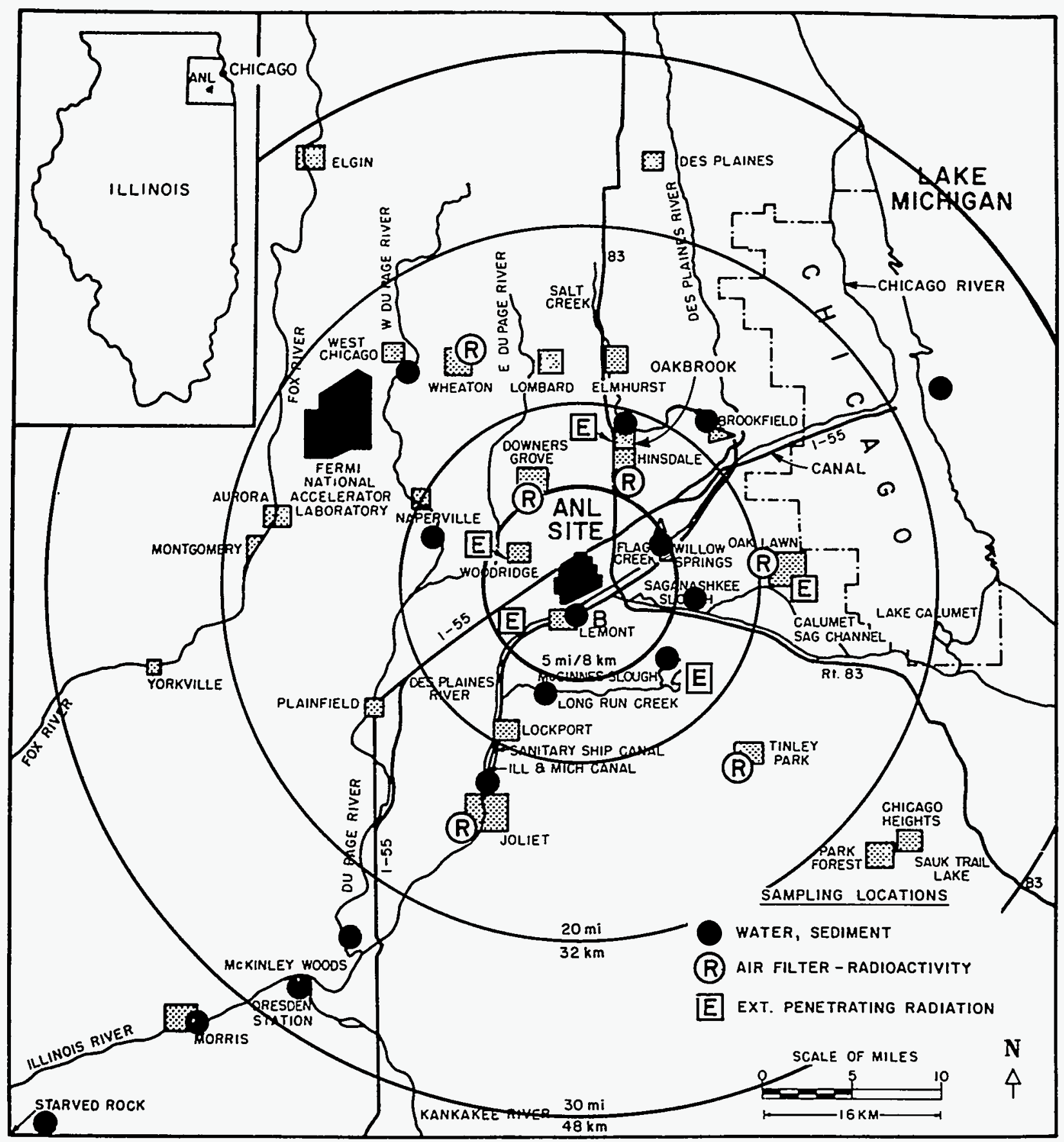

Figure 1.2 Sampling Locations near Argonne National Laboratory-East 
site. The bluffs and ravines generally are forested with mature deciduous trees. The remaining

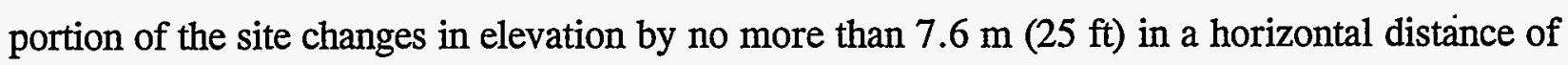
$150 \mathrm{~m}$ (500 ft). The Chicago District Pipe Line Co. and the Burlington Northern Santa Fe Railroad have rights-of-way in the southern portion of the forest preserve.

\subsection{Population}

The area around ANL-E has experienced a large population growth in the past 30 years. Large areas of farmland have been converted into housing. Table 1.1 presents directional and annular $80-\mathrm{km}(50-\mathrm{mi})$ population distribution for the area, which is used for the population dose calculations later in this report. The population distribution, centered on the Chicago Pile-5 (CP-5) reactor (Location 9G in Figure 1.1), was prepared by the Geographic Data Systems Computing and Telecommunications Division at Oak Ridge National Laboratory and represents projections to 1991 based on 1990 census data.

\subsection{Climatology}

The climate of the area is representative of the upper Mississippi Valley, as moderated by Lake Michigan. Summaries of the meteorological data collected on the site from 1949 to 1964 are available $e^{2,3}$ and provide a historical sample of the climatic conditions. The most important meteorological parameters for the purposes of this report are wind direction, wind speed, temperature, and precipitation. The wind data are used to select air sampling locations and distances from sources and to calculate radiation doses from air emissions. Temperature and precipitation data are useful in interpreting some of the monitoring results. The 1995 data were obtained from the on-site ANL-E meteorological station. The 1995 average monthly and annual wind roses are shown in Figure 1.3. The wind roses are polar coordinate plots in which the lengths of the radii represent the percentage frequency of wind speeds in classes of 2.01-6 m/s (4.5-13.4 mph), 6.01-10 m/s (13.4-22.4 mph), and greater than $10.01 \mathrm{~m} / \mathrm{s}(22.4 \mathrm{mph})$. The number in the center of each wind rose represents the percentage of observations of wind speed 
TABLE 1.1

Population Distribution in the Vicinity of ANL-E, 1991

\begin{tabular}{|c|c|c|c|c|c|c|c|c|c|c|}
\hline \multirow[b]{2}{*}{ Direction } & \multicolumn{5}{|c|}{ Population (individuals) at $0-5$ Miles $^{\mathrm{a}}$} & \multicolumn{5}{|c|}{ Population (thousands) at 5-50 Miles $^{\mathrm{a}}$} \\
\hline & $0-1$ & $1-2$ & $2-3$ & $3-4$ & $4-5$ & $5-10$ & $10-20$ & $20-30$ & $30-40$ & $40-50$ \\
\hline $\mathrm{N}$ & 0 & 661 & 4,199 & 5,602 & 8,783 & 44.7 & 172.1 & 336.7 & 187.5 & 221.3 \\
\hline NNE & 0 & 22 & 3,684 & 5,925 & 5,287 & 38.8 & 302.3 & 485.8 & 86.7 & 0 \\
\hline $\mathrm{NE}$ & 0 & 737 & 2,293 & 2,431 & 1,689 & 40.9 & 674.4 & 866.3 & 0 & 0 \\
\hline ENE & 0 & 1,117 & 2,495 & 1,460 & 1,482 & 33.5 & 598.7 & 178.9 & 0 & 0 \\
\hline $\mathrm{E}$ & 0 & 16 & 10 & 1 & 42 & 40.8 & 467.0 & 199.8 & 13.0 & 25.8 \\
\hline ESE & 0 & 0 & 55 & 331 & 306 & 22.4 & 186.1 & 282.0 & 245.0 & 80.9 \\
\hline SE & 0 & 2 & 219 & 425 & 198 & 19.8 & 103.2 & 114.2 & 28.6 & 12.2 \\
\hline SSE & 0 & 72 & 401 & 221 & 1,800 & 12.0 & 22.1 & 7.7 & 11.0 & 16.8 \\
\hline$S$ & 0 & 105 & 2,298 & 921 & 860 & 3.7 & 23.4 & 2.0 & 35.3 & 35.0 \\
\hline SSW & 0 & 33 & 3,504 & 1,229 & 759 & 14.7 & 89.8 & 10.8 & 17.6 & 7.1 \\
\hline SW & 0 & 80 & 20 & 87 & 79 & 11.6 & 36.7 & 9.4 & 16.2 & 9.1 \\
\hline WSW & 0 & 215 & 86 & 620 & 1,646 & 4.8 & 7.6 & 3.7 & 8.0 & 7.2 \\
\hline W & 0 & 779 & 1,237 & 8,338 & 9,056 & 26.2 & 67.2 & 19.0 & 14.8 & 6.7 \\
\hline WNW & 0 & 254 & 224 & 5,867 & 4,433 & 44.3 & 104.6 & 20.7 & 6.6 & 52.9 \\
\hline NW & 0 & 552 & 2,602 & 6,979 & 6,779 & 41.6 & 69.1 & 95.5 & 18.2 & 16.7 \\
\hline NNW & 0 & 492 & 2,774 & 4,521 & 9,390 & 33.4 & 108.5 & 225.2 & 130.6 & 96.5 \\
\hline Total & 0 & 5,137 & 26,101 & 44,958 & 52,589 & 433.2 & $3,112.8$ & $2,857.7$ & 819.1 & 588.4 \\
\hline Cumulative total $^{\mathrm{b}}$ & 0 & 5,137 & 31,238 & 76,196 & 128,785 & 561.9 & $3,674.7$ & $6,532.4$ & $7,351.5$ & $7,939.9$ \\
\hline
\end{tabular}

a To convert from miles to kilometers, multiply by 1.6.

b Cumulative total $=$ total of this sector plus totals of all previous sectors. 

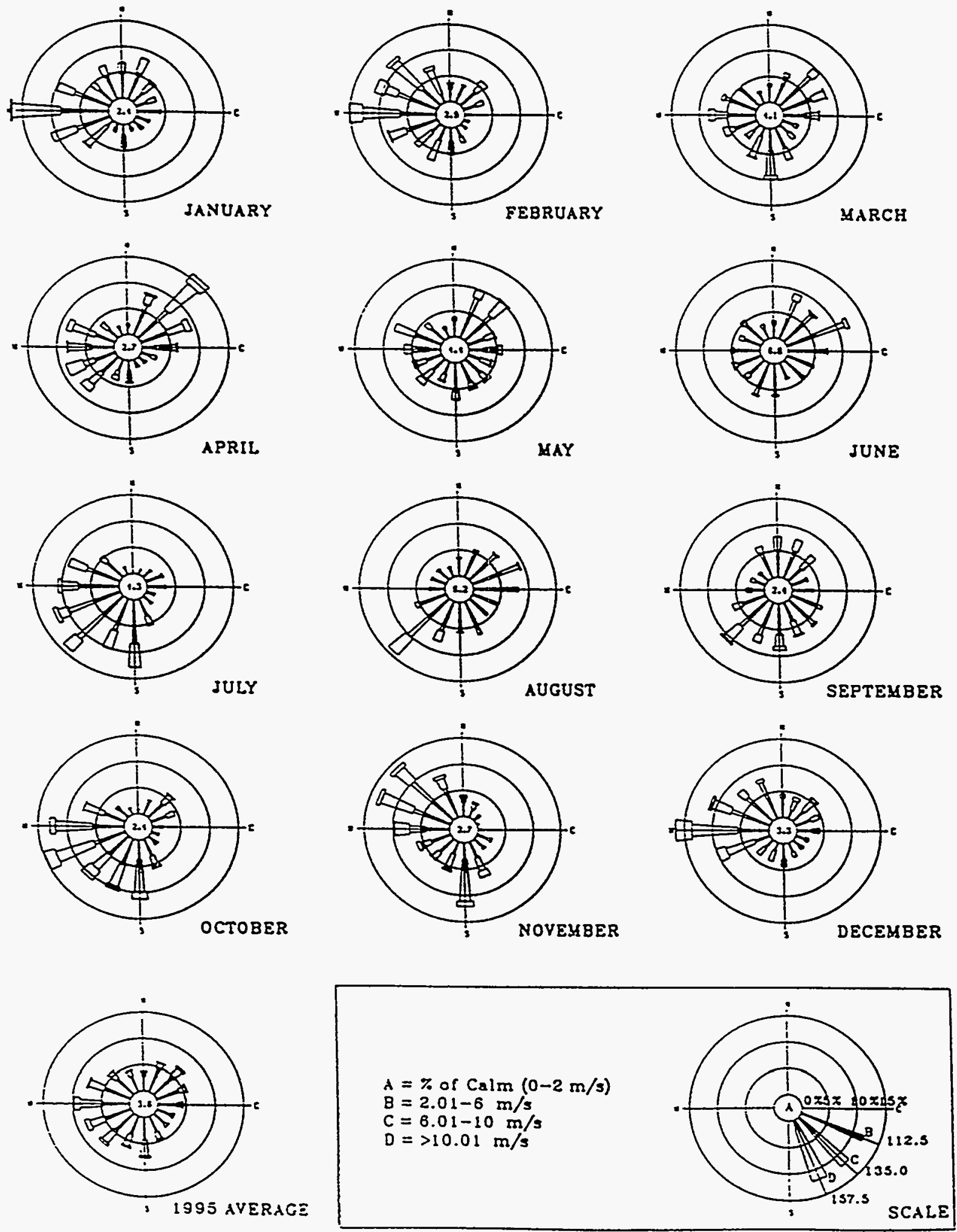

Figure 1.3 Monthly and Annual Wind Roses at Argonne National Laboratory-East, 1995 
less than $2 \mathrm{~m} / \mathrm{s}(4.5 \mathrm{mph})$ in all directions. The direction of the radii from the center represents the direction from which the wind blows. Sixteen radii are shown on each plot at $22.5^{\circ}$ intervals; each radius represents the average wind speed for the direction covering $11.25^{\circ}$ on either side of the radius.

The monthly wind roses indicate that the winds are variable, so that monitoring for airborne releases must be carried out in all directions from the site. For example, the dominant wind direction in January is from the west while in April it is northeast. The annual average wind rose for 1995 is consistent with the long-term average wind direction, which usually varies from the west to south, but with a significant northeast component. Precipitation and temperature data for 1995 are shown in Table 1.2. The monthly precipitation data for 1995 showed some differences from the average. For example, January, October, and November are above the average, while August, September, and December are below the average. The annual total is very similar to the long-term average. The temperatures are similar to the long-term averages, except during the summer when the temperatures were above normal.

\subsection{Geology}

The geology of the ANL-E area consists of about $30 \mathrm{~m}$ (100 ft) of glacial till on top of bedrock, which is Niagaran and Alexandrian dolomite, underlain by shale and older dolomites and sandstones of Ordovician and Cambrian age. The beds are nearly horizontal. Niagaran and Alexandrian dolomite is about $60 \mathrm{~m}$ (200 ft) thick and widely used in DuPage County as a source of groundwater. The shale separating the upper dolomite aquifer from the underlying sandstone and dolomite aquifers retards hydraulic connection between them. The lower aquifer has a much lower piezometric level and does not appear to be affected by pumpage from the overlying bedrock.

The southern boundary of ANL-E follows the escarpment of a broad valley, now occupied by the Des Plaines River and the Chicago Sanitary and Ship Canal. This valley was carved by waters flowing out of the glacial Lake Michigan about 11,000 to 14,000 years ago. The soils on 
TABLE 1.2

ANL-E Weather Summary, 1995

\begin{tabular}{lcccccc}
\hline \multicolumn{1}{c}{ Month } & $\begin{array}{c}\text { ANL-E } \\
1995\end{array}$ & $\begin{array}{c}\text { Precipitation (cm) } \\
\text { ANL-E Historical } \\
\text { Average }^{\mathrm{a}}\end{array}$ & $\begin{array}{c}\text { Historical } \\
\text { Average }^{\mathrm{b}}\end{array}$ & $\begin{array}{c}\text { ANL-E 1995 } \\
\text { Monthly } \\
\text { Average }\end{array}$ & $\begin{array}{c}\text { Temperature (०C) } \\
\text { ANL-E Historical } \\
\text { Average }^{\mathrm{a}}\end{array}$ & $\begin{array}{c}\text { Historical } \\
\text { Average }^{\mathrm{b}}\end{array}$ \\
\hline January & 8.36 & 3.61 & 4.06 & -5.0 & -5.9 & -5.9 \\
February & 2.08 & 3.38 & 3.33 & -3.8 & -3.7 & -3.3 \\
March & 4.75 & 5.56 & 6.58 & 4.2 & 0.6 & 2.2 \\
April & 11.89 & 9.14 & 9.30 & 7.2 & 8.3 & 9.3 \\
May & 11.78 & 7.82 & 8.00 & 14.6 & 14.5 & 15.1 \\
June & 6.25 & 9.47 & 10.36 & 21.9 & 19.7 & 20.3 \\
July & 7.70 & 10.97 & 9.22 & 24.6 & 21.7 & 22.8 \\
August & 3.16 & 8.71 & 8.97 & 25.2 & 20.9 & 22.2 \\
September & 1.74 & 7.14 & 8.51 & 17.4 & 16.8 & 18.2 \\
October & 10.24 & 6.58 & 5.79 & 11.9 & 11.4 & 11.9 \\
November & 10.80 & 4.37 & 5.23 & 0.2 & 2.9 & 4.3 \\
December & $\mathbf{0 . 4 4}$ & $\underline{3.20}$ & $\underline{5.33}$ & -3.6 & -4.2 & -2.4 \\
Total & 79.19 & 80.01 & 79.95 & & & \\
\hline
\end{tabular}

a ANL-E data obtained from Reference 2.

b Data obtained from the National Oceanic and Atmospheric Administration (NOAA) for the weather station at O'Hare International Airport. The average is for the years 1951-1980.

the site were derived from glacial till over the past 12,000 years and are primarily of the Morley series; moderately well-drained upland soils with a slope ranging from $2 \%$ to $20 \%$. The surface layer is a dark grayish-brown silt loam, the subsoil is a brown silty clay, and the underlying material is a silty clay loam glacial till. Morley soils have a relatively low organic content in the surface layer, moderately slow subsoil permeability, and a large water capacity. These soils are well suited to growing crops if good erosion control practices are used. The remaining soils along creeks, intermittent streams, bottomlands, and a few small upland areas are of the Sawmill, Ashkum, Peotone, and Beecher series, which are generally poorly drained. They have a black to dark gray or brown silty clay loam surface layer, high organic-matter content, and a large water capacity. 


\subsection{Seismicity}

No tectonic features within $135 \mathrm{~km}$ (62 mi) of ANL-E are known to be seismically active. The longest of these features is the Sandwich Fault. Smaller local features are the Des Plaines disturbance, a few faults in the Chicago area, and a fault of apparently Cambrian age.

Although a few minor earthquakes have occurred in northern Illinois, none has been positively associated with particular tectonic features. Most of the recent local seismic activity is believed to be caused by isostatic adjustments of the earth's crust in response to glacial loading and unloading, rather than by motion along crustal plate boundaries.

Several areas of considerable seismic activity are located at moderate distances (hundreds of kilometers) from ANL-E. These areas include the New Madrid Fault zone (southeast Missouri) in the St. Louis area, the Wabash Valley Fault zone along the southern Illinois-Indiana border, and the Anna region of western Ohio. Although high-intensity earthquakes have occurred along the New Madrid Fault zone, their relationship to plate motions remains speculative at this time.

According to estimates, ground motions induced by near and distant seismic sources in northern Illinois are expected to be minimal. However, peak accelerations in the ANL-E area may exceed $10 \%$ of gravity (approximate threshold of major damage) once in about 600 years, with an error range of -250 to +450 years.

\subsection{Hydrology}

Most groundwater supplies in the ANL-E area are derived from the Niagaran, and to some extent, the Alexandrian dolomite bedrock. Dolomite well yields are variable, but many are near $800 \mathrm{gal} / \mathrm{min}$. In DuPage County, groundwater pumpage over the past 100 years has led to severe overdraft; in northeastern Illinois, the piezometric surface has been lowered in areas of heavy pumping. Delivery of Lake Michigan water to the major suburban areas is expected to relieve 
this problem. Because the cones of depression of ANL-E wells do not extend beyond the site and adjacent forest preserve, ANL-E water use does not affect neighboring communities.

Two principal aquifers are used as water supplies in the vicinity of ANL-E. The upper aquifer is the Niagaran and Alexandrian dolomite, which is about $60 \mathrm{~m}(200 \mathrm{ft})$ thick in the ANL-E area and has a piezometric surface between 15 and $30 \mathrm{~m}(50$ and $100 \mathrm{ft})$ below the ground surface for much of the site. The lower aquifer is Galesville sandstone, which lies between 150 and $450 \mathrm{~m}$ (500 and 1,500 ft) below the surface. Maquoketa shale separates the upper dolomite aquifer from the underlying sandstone aquifer. This shale retards hydraulic connection between the two aquifers.

The four domestic water supply wells now in use on the ANL-E site (see Figure 1.1) are drilled about $90 \mathrm{~m}$ ( $300 \mathrm{ft}$ ) deep, terminating in the Niagaran dolomite. A well drilled in the Galesville sandstone $490 \mathrm{~m}(1,600 \mathrm{ft})$ deep has been taken out of service. The water level in the Niagaran dolomite has decreased under ANL-E pumping and dropped about $11 \mathrm{~m}(35 \mathrm{ft})$ between 1948 and 1995. The aquifer appears to be adequate for future ANL-E use, but this groundwater source is used throughout the area. Several small capacity water wells used for laboratory experiments, fire protection, and sanitary facilities also exist on the site, primarily in the 800 Area and the meteorology complex.

\subsection{Water and Land Use}

Sawmill Creek flows through the eastern portion of the site. This stream originates north of the site, flows through the property in a southerly direction, and discharges into the Des Plaines River. Two small streams originate on site and combine to form Freund Brook, which discharges into Sawmill Creek. Along the southern margin of the property, the terrain slopes abruptly downward forming forested bluffs. These bluffs are dissected by ravines containing intermittent streams that discharge some site drainage into the Des Plaines River. In addition to the streams, various ponds and cattail marshes are present on the site. There is also a network of ditches and culverts that transport surface runoff toward the smaller streams. 
The greater portion of the ANL-E site is drained by Freund Brook. Two intermittent branches of Freund Brook flow from west to east, draining the interior portion of the site and ultimately discharging into Sawmill Creek. The larger, south branch originates in a marsh adjacent to the western boundary line of the site. It traverses wooded terrain for a distance of about $2 \mathrm{~km}(1.5 \mathrm{mi})$ before discharging into the south branch at Lower Freund Pond.

Sawmill Creek carried effluent water continuously from a sewage treatment plant (Marion Brook Treatment Plant) located a few kilometers north of the site until October 27, 1986, when the plant was closed. Residential and commercial development in the area has resulted in the collection and channeling of runoff water into Sawmill Creek. Treated sanitary and laboratory wastewater from ANL-E are combined and discharged into Sawmill Creek at location 7M in Figure 1.1. This effluent averaged 2.7 million L ( 0.71 million gal) per day. The effluent flow is similar to that in 1994, but a reduction from the 3.9 million $\mathrm{L}$ discharged in 1993, and is attributed to the completion of a sewer replacement project that eliminated infiltration. The combined ANL-E effluent consisted of $46 \%$ laboratory wastewater and $54 \%$ sanitary wastewater. The water flow in Sawmill Creek upstream of the wastewater outfall averaged about 19 million L (5.2 million gal) per day during 1995.

Sawmill Creek and the Des Plaines River above Joliet, about $21 \mathrm{~km}(13 \mathrm{mi})$ southwest of ANL-E, receive very little recreational or industrial use. A few people fish in these waters downstream of ANL-E, and some duck hunting takes place on the Des Plaines River. Water from the Chicago Sanitary and Ship Canal is used by ANL-E for cooling towers and by others for industrial purposes, such as hydroelectric generators and condensers, and for irrigation at the state prison near Joliet. ANL-E usage is about 1.1 million L (290,000 gal) per day. The canal, which receives Chicago Metropolitan Sanitary District effluent water, is used for industrial transportation and some recreational boating. Near Joliet, the river and canal combine into one waterway, which continues until it joins the Kankakee River to form the Illinois River about $48 \mathrm{~km}$ (30 mi) southwest of ANL-E. The Dresden Nuclear Power Station complex is located at the confluence of the Kankakee, Des Plaines, and Illinois rivers. This station uses water from the Kankakee River for cooling and discharges the water into the Illinois River. The first downstream location where water is used for drinking is at Alton, on the Mississippi River about $710 \mathrm{~km}$ (370 mi) 
downstream from ANL-E. At that location, water is used indirectly to replenish groundwater supplies by infiltration. In the vicinity of ANL-E, only subsurface water (from both shallow and deep aquifers) and Lake Michigan water are used for drinking purposes.

The principal recreational area near ANL-E is Waterfall Glen Forest Preserve, which surrounds the site (see Section 1.2 and Figure 1.1). The area is used for hiking, skiing, and equestrian sports. Sawmill Creek flows south through the eastern portion of the preserve on its way to the Des Plaines River. Several large forest preserves of the Forest Preserve District of Cook County are located east and southeast of ANL-E and the Des Plaines River. The preserves include the McGinnis and Saganashkee Sloughs (shown in Figure 1.2), as well as other, smaller lakes. These areas are used for picnicking, boating, fishing, and hiking. A small park located in the eastern portion of the ANL-E site (Location 12-0 in Figure 1.1) is for the use of ANL-E and DOE employees. Recently, use of this park has also been provided to DuPage County.

\subsection{Vegetation}

ANL-E lies within the Prairie Peninsula of the Oak-Hickory Forest Region. The Prairie Peninsula is a mosaic of oak forest, oak openings, and tall-grass prairie occurring in glaciated portions of Illinois, northwest Indiana, southern Wisconsin, and sections of other states. Much of the natural vegetation of this area has been modified by clearing and tillage. Forests in the ANL-E region, which are predominantly oak-hickory forests, are somewhat limited to slopes of shallow, ill-defined ravines or low morainal ridges. Gently rolling to flat intervening areas between ridges and ravines were predominantly occupied by prairie before their use for agriculture. The prevailing successional trend on these areas, in the absence of cultivation, is toward oak-hickory forest. Forest dominated by sugar maple, red oak, and basswood may occupy more pronounced slopes. Poorly drained areas, streamside communities, and floodplains may support forests dominated by silver maple, elm, and cottonwood.

From early photographs of the site, it appears that most of the land that ANL-E now occupies was actively farmed. About $75 \%$ was plowed field and $25 \%$ was pasture, open oak woodlots, and oak forests. Starting in 1953 and continuing for three seasons, some of the 
formerly cultivated fields were planted with jack, white, and red pine trees. Other fields are dominated by bluegrass.

Crown vetch has been planted on much of the developed area since 1954, to help control soil erosion and provide low-maintenance ground cover. Other open space in developed areas has been sown to grass, which is mowed regularly.

The deciduous forests on the remainder of the site are dominated by various species of oak, generally as large, old, widely spaced trees, often not forming a complete canopy. Their large low branches indicate that they probably matured in the open, rather than in a dense forest. Other upland tree species include hickory, hawthorn, cherry, and ash.

\subsection{Fauna}

Terrestrial vertebrates that are commonly observed or likely to occur on the site include about 5 species of amphibians, 7 of reptiles, 40 of summer resident birds, and 25 of mammals. More than a hundred other bird species occur in the area during migration or winter but do not nest on the site or in the surrounding region. An unusual species on the ANL-E site is the fallow deer, a European species that was introduced to the area by a private landowner prior to government acquisition of the property in 1947 and which subsequently increased to about 400 individuals. In November 1988, about 200 of the deer were removed for population control. A significant population of native white-tailed deer also occur on the ANL-E reservation. Invertebrate species, as well as plants and other animals, were also observed on the ANL-E site.

Freund Brook crosses the center of the site but is impounded by a beaver dam in this area. The gradient of the stream is relatively steep, and riffle habitat predominates. The substrate is coarse rock and gravel on a firm mud base. Primary production in the stream is limited by shading, but diatoms and some filamentous algae are common. Aquatic macrophytes include common arrowhead, pondweed, duckweed, and bulrush. Invertebrate fauna consist primarily of dipteran larvae, crayfish, caddisfly larvae, and midge larvae. Few fish are present because of low 
summer flows and high temperatures. Other aquatic habitats on the ANL-E site include additional beaver ponds, artificial ponds, ditches, and Sawmill Creek.

The biotic community of Sawmill Creek is relatively depauperate, reflecting the creek's high silt load, steep gradient, and historic release of sewage effluent from the Marion Brook sewagetreatment plant north of the site. The fauna consists primarily of blackflies, midges, isopods, flatworms, segmented worms, and creek chubs. A few other species of minnows, sunfishes, and catfish are also present. Clean water invertebrates, such as mayflies and stoneflies, are rare or absent. The fish species that have been recorded in ANL-E aquatic habitats include black bullhead, bluegill, creek shub, golden shiner, goldfish, green sunfish, largemouth bass, stoneroller, and orange-spotted sunfish.

The Des Plaines River system, including ANL-E streams, has been rated as "poor" in terms of the fish species present, as determined by the U.S. Fish and Wildlife Service (FWS), a result of domestic and industrial pollution and stream modification.

\subsection{Archaeology}

ANL-E, located in the Illinois and Michigan Canal National Heritage Corridor, is situated in an area known to have a long and complex cultural history. All periods listed in the cultural chronology of Illinois, with the exception of the earliest period (Paleo-Indian), have been documented in the ANL-E area by either professional cultural resource investigation or by interviews of ANL-E staff with local collectors. A variety of site types, including mounds, quarries, lithis workshops, and habitation sites have been reported by amateurs within a $25-\mathrm{km}$ (16-mi) radius.

The 26 recorded sites include prehistoric chert quarries, special purpose camps, base camps, and historical farmsteads. The range of human occupation spans several time periods (Early Archaic through Mississipian Prehistoric to Historical). To date, 20 sites may be eligible for the National Register of Historic Places (NRHP); the remainder have not been formally evaluated for NRHP eligibility. 


\subsection{Endangered Species}

Although the geographic ranges of several federally listed animal species include the northern Illinois region, no suitable habitat for these species is present on the site, with the possible exception of the Indiana bat (Myotis sodalis). An unconfirmed capture of an Indiana bat in nearby Waterfall Glen Forest Preserve indicates that the bat may occur in the ANL-E region. Consultation with the FWS determined that suitable habitat for this species does not exist in the area. The bald eagle, peregrine falcon, piping plover, interior least tern, and Kirtland's warbler could occur in the ANL-E area as extremely rare nonbreeders during migration or winter.

Neither federal nor state-listed threatened or endangered species are known to reside on the ANL-E site. The federally listed endangered Indiana Bat, Myotis sodalis, and the federally threatened Hine's Emerald Dragonfly, Somatochlora hineana, reside in the area and may possibly reside on the ANL-E site. Two state-endangered species, River Otter, Lutra canadensis, and White Lady's Slipper, Cypripededium candidum, and two state-threatened species, Kirtland's Snake, Clonophis kirtlandi, and sedge, Carex crawei, reside in the area and may possibly reside on the ANL-E site. 


\section{COMPLIANCE SUMMARY}

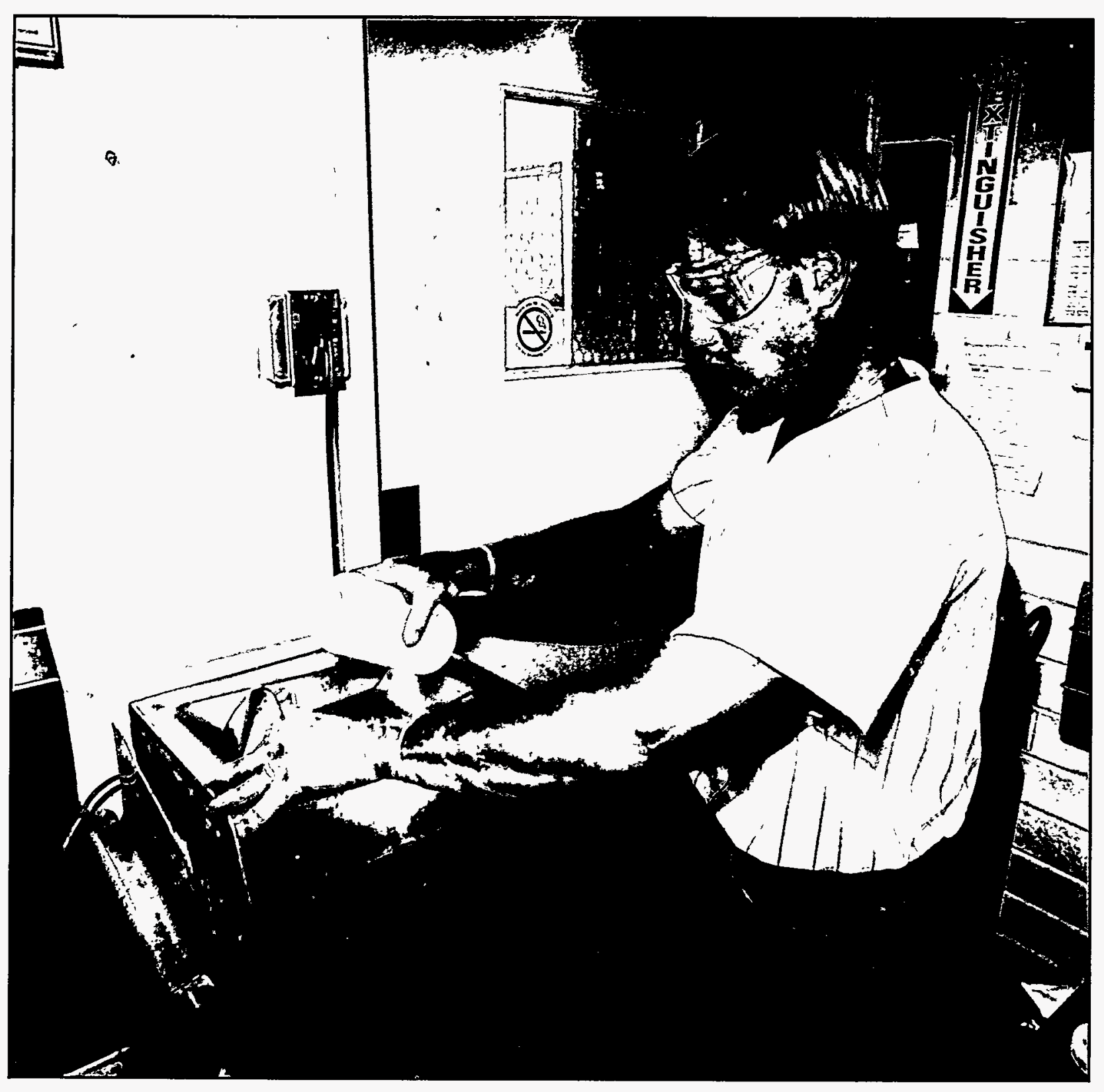


ANL-E is a government-owned, contractor-operated (GOCO) nonproduction facility that is subject to environmental statutes and regulations administered by the U.S. Environmental Protection Agency (EPA), the Illinois Environmental Protection Agency (IEPA), the Illinois Department of Public Health (IDPH), and the State Fire Marshal, as well as numerous DOE Orders and Executive Orders. A detailed listing of applicable regulations is contained in DOE Order 5400.1, ${ }^{1}$ which establishes DOE's policy. concerning environmental compliance. The status of ANL-E during 1995 with regard to these authorities is discussed in this chapter.

To ensure compliance with both the letter and spirit of these requirements, ANL-E has made a commitment to comply with all applicable environmental requirements, as described in the following policy statement revised during 1995:

It is the policy of Argonne National Laboratory that its activities will be conducted in such a manner that worker and public safety, including protection of the environment, is given the highest priority. The Laboratory will comply with all applicable federal and state environmental laws, regulations, and orders.

\subsection{Clean Air Act}

The Clean Air Act (CAA) is a federal statute that specifies National Ambient Air Quality Standards, sets emission limits for air pollutants, and determines emission limits and operating criteria for a number of hazardous air pollutants. The program is implemented by individual states through a State Implementation Plan (SIP), which describes how that state will ensure compliance with the air quality standards for stationary sources.

A number of major changes to the CAA were made with the passage of the Clean Air Act Amendments of 1990. Under Title V of the Clean Air Act Amendments of 1990, ANL-E was required to submit to the IEPA a Clean Air Act Permit Program (CAAPP) application for a sitewide, federally-enforceable air permit to cover emissions of all regulated air pollutants at the facility. This would supersede the state air permits that are currently in effect. All facilities that are designated as major emission sources for regulated air pollutants are subject to this 


\section{COMPLIANCE SUMMARY}

requirement. ANL-E meets the definition of a major source due to potential emissions of oxides of nitrogen $\left(\mathrm{NO}_{\mathrm{x}}\right)$ in excess of 25 tons per year and sulfur dioxide $\left(\mathrm{SO}_{2}\right)$ in excess of 100 tons per year at the Building 108 Central Heating Plant.

Facilities subject to Title V must characterize emissions of all regulated air pollutants, not only those that make them qualify as major sources. For ANL-E, in addition to $\mathrm{NO}_{\mathrm{X}}$ and $\mathrm{SO}_{2}$, emissions of carbon monoxide, particulates, volatile organic compounds (VOCs), hazardous air pollutants (a list of 189 chemicals, including radionuclides), and ozone-depleting substances must also be evaluated. The permit program requires that facilities pay annual fees based upon the total amount of regulated air pollutants (except carbon monoxide) they will be allowed to emit.

Upon acknowledgment of the application by the IEPA as timely and complete, ANL-E would receive an application shield and remain in compliance with the CAA. The statutory deadline for receiving this shield was November 15, 1995; however, because the Illinois Title V program did not receive approval from the EPA until March 7, 1995, the ANL-E deadline to submit its application was designated to be December 7, 1995.

The ANL-E CAAPP application was submitted to the IEPA on September 19, 1995, and the Notice of Completeness was issued by the IEPA on October 26, 1995. The Notice of Completeness also means that current air permits under which operations remain unchanged do not need to be renewed. An exception to this is the ANL-E Fire Department's open burning permit (used for fire training), which must be renewed on an annual basis.

The CAAPP application submitted to the IEPA will need to be revised in 1996 to reflect operational changes in the air sources at ANL-E, including the addition of new sources and the deletion of sources no longer in operation. The schedule for technical review of ANL-E's CAAPP application has not been established but is expected to begin sometime in 1996. Any additional requests for information by the IEPA will be addressed, as well as necessary revisions already described. 
The ANL-E site contains a large number of air emission point sources. The vast majority are laboratory ventilation systems that are exempt from state permitting requirements, except for those systems emitting radionuclides. By the end of 1995 , a total of 40 air permits were in place covering all known emission points. Section 2.15 contains a list (Table 2.13) of the permits in effect at ANL-E. An air emissions inspection was conducted by the IEPA on May 19, 1995. No significant issues were identified.

\subsubsection{National Emission Standards for Hazardous Air Pollutants}

The National Emission Standards for Hazardous Air Pollutants (NESHAP) constitute a body of federal regulations that set forth emission limits and other requirements, such as monitoring, record keeping, and operational requirements, for activities generating emissions of certain hazardous air pollutants. The standards for asbestos, radionuclides, and halogenated solvent cleaning are the only standards affecting ANL-E operations. A total of 23 permits for NESHAP sources have been issued by IEPA to ANL-E. Six new permits for NESHAP sources were issued by the IEPA, three permits were renewed, and one permit was withdrawn in 1995.

\subsubsection{Asbestos Emissions}

Many buildings on the ANL-E site contain large amounts of asbestos-containing materials (ACM) such as thermal system insulation around pipes and tanks, spray-applied surfacing material for fireproofing, floor tile, and asbestos-cement panels. This material is removed as necessary during renovations or maintenance of equipment and facilities. The removal and disposal of this material is governed by the asbestos NESHAP.

The standards for asbestos specify detailed requirements for removal and disposal of certain types of ACM. Until the November 1990 revisions, only friable (easily crushed) ACM was regulated. Now, however, many other types of ACM are regulated, including nonfriable materials that have been, or could be reduced to a crumbly, pulverized or powder state through the process of removal or disposal. This change greatly increases the amount of material regulated by the NESHAP. 
The standard describes accepted procedures for removal of ACM, including notification of the IEPA prior to removal of greater than certain amounts, work practices and procedures to be used, and emission control procedures to be used. The use of specially trained individuals for removal of ACM is mandated.

ANL-E maintains an asbestos abatement program designed to assure compliance with these and other regulatory requirements. ACM are removed from the Laboratory by either a speciallytrained Waste Management (WM) crew (for "small-scale" short-duration projects as defined by the NESHAP-Asbestos Title 40, Part 61 of the Code of Federal Regulations [40 CFR 61], Subpart $\mathrm{M}$ ) or by outside contractors specializing in ACM removal work (for large-scale insulation removal projects lasting a day or longer). All removal work is done in strict compliance with both NESHAP and Occupational Safety and Health Administration (OSHA) requirements governing worker safety at $\mathrm{ACM}$ removal sites. When $\mathrm{ACM}$ is encountered during a renovation or demolition project, it is carefully wetted or otherwise encapsulated and completely removed. The work area is sealed off using disposable glove bags or temporary plastic sheeting barriers, and high-efficiency particulate air (HEPA) filtration equipment is used to control emissions. Air is monitored in the vicinity of such work by ANL-E Industrial Hygiene personnel both during the removal work and after the work is completed, in order to verify that adequate precautions have been taken to prevent the release of significant amounts of asbestos. Personal exposure air samples are collected. Asbestos fiber counts are analyzed using Phase Contrast Microscopy, and selected samples are analyzed by Transmission Electron Microscopy.

Approximately $245 \mathrm{~m}^{3}\left(8,600 \mathrm{ft}^{3}\right)$ of ACM were removed from ANL-E buildings during 1995. These materials included various structural or facility components such as surfacing materials, thermal system insulation, floor tile and mastic, and transite wallboard. Also included are items that were part of the removal activity and became contaminated with asbestos, such as Tyvek coveralls, gloves, and polyethylene sheets. Asbestos-containing laboratory equipment such as the laboratory furnace, heating coil, and transite tabletop were also removed and included in the annual estimate. The primary types of asbestos identified in these materials were chrysotile and amosite. 
Most of the ANL-E asbestos removal activities are small nonscheduled renovation operations as defined by the NESHAP-Asbestos ( 40 CFR 61, Subpart M). The duration of these projects is usually not more than eight hours, and glovebag removal techniques are normally used. A total of 142 small removal projects were completed and generated $77 \mathrm{~m}^{3}\left(2,700 \mathrm{ft}^{3}\right)$ of ACM waste. Projects performed by outside contractors accounted for $28 \mathrm{~m}^{3}\left(980 \mathrm{ft}^{3}\right)$ of the ACM waste from small projects.

The asbestos NESHAP standards require that the IEPA be notified before beginning large asbestos removal projects involving more than $80 \mathrm{~m}$ (260 ft) of pipe insulation or $15 \mathrm{~m}^{2}\left(160 \mathrm{ft}^{2}\right)$ of other materials or $1 \mathrm{~m}^{3}\left(35 \mathrm{ft}^{3}\right)$ of ACM where the length or area cannot be measured. The Notification of Demolition and Renovation Form must be forwarded to the IEPA within a prescribed time limit. Eight Notification of Demolition and Renovation forms were provided to the IEPA during 1995. Project information is provided in Table 2.1.

The NESHAP requires estimation of the total amount of ACM to be removed during renovation or demolition activities during each upcoming calendar year. If this amount exceeds the regulatory levels given above, the IEPA must be notified. ANL-E made such a notification during December 1995 for activities planned for 1996. It is estimated that no more than $128 \mathrm{~m}^{3}$ $\left(4,500 \mathrm{ft}^{3}\right)$ of ACM waste will be generated during 1996.

A separate portion of the standard contains requirements for waste disposal sites used for disposal of ACM. The acceptable disposal practice involves placing wetted waste materials into labeled, leakproof plastic bags for disposal in landfills. Off-site shipments are to be accompanied by completed shipping manifests. The principal requirements applicable to landfill disposal of $\mathrm{ACM}$ relate to covering the $\mathrm{ACM}$ daily with at least six inches of non-asbestos-containing materials and maintenance of disposal records. Asbestos disposal information is provided in Table 2.2. 
TABLE 2.1

Asbestos Abatement Projects: IEPA Notification, 1995

\begin{tabular}{|c|c|c|c|c|c|c|}
\hline $\begin{array}{l}\text { Completion } \\
\text { Date }\end{array}$ & $\begin{array}{l}\text { Noti } \\
(\mathrm{ft})\end{array}$ & $\begin{array}{l}\text { Uantity } \\
\left(\mathrm{ft}^{2}\right)\end{array}$ & Material & Building & $\begin{array}{c}\text { Disposal } \\
\text { Quantity } \\
\left(\mathrm{ft}^{3}\right)\end{array}$ & Landfill \\
\hline \multirow[t]{4}{*}{ January 31,1995} & 300 & 188 & Chiller and Pipe Insulation & 200 & 300 & Community $^{\mathrm{a}}$ \\
\hline & 200 & $N A^{b}$ & Generator Pipe Insulation & 202 & 100 & Community \\
\hline & 75 & 2,000 & Pipe Insulation and Cooling & 203 & 500 & Community \\
\hline & & & Tower Panels & 203 & 350 & County ${ }^{c}$ \\
\hline May 5, 1995 & 165 & 600 & $\begin{array}{l}\text { Pipe Insulation, Floor Tile, } \\
\text { and Mastic }\end{array}$ & 202 & 180 & County \\
\hline May 24, 1995 & 350 & 245 & Pipe and Tank Insulation & 108 & 473 & County \\
\hline \multirow[t]{3}{*}{ July 14, 1995} & 650 & 5,200 & $\begin{array}{l}\text { Pipe Insulation, Floor Tile, } \\
\text { and Mastic }\end{array}$ & 25 & 585 & County \\
\hline & 80 & NA & Air Handling Unit Insulation & 223 & 190 & County \\
\hline & NA & 360 & Exterior Siding & 605 & 80 & County \\
\hline September 15, 1995 & 340 & 100 & Pipe Insulation & 223 & 125 & County \\
\hline December 6, 1995 & $\mathrm{NA}$ & 840 & Floor Tile & 362 & 48 & Liberty $^{d}$ \\
\hline December 23, 1995 & $\mathrm{NA}$ & 20,300 & $\begin{array}{l}\text { Carpet and Floor Tile Mastic, } \\
\text { Spray-on Insulation }\end{array}$ & 213 & 2,430 & County \\
\hline January $29,1996^{\mathrm{e}}$ & $\mathrm{NA}$ & 7,760 & Floor Tile and Mastic & 212 & 544 & Hanford $^{f}$ \\
\hline
\end{tabular}

a Community Landfill Company, Morris, Ill.

b $\mathrm{NA}=$ not applicable.

c County Environmental Livingston Landfill, Pontiac, Ill.

d Chambers Liberty Landfill, Monticello, Ind.

e Majority of project completed in 1995.

f Disposed of as low-level radioactive waste at Westinghouse Hanford Corporation, Richland, Wash. 
TABLE 2.2

Disposal of Asbestos-Containing Materials, 1995

\begin{tabular}{llrr}
\hline Project Size & Landfill & Quantity $\left(\mathrm{ft}^{3}\right)$ & ${\text { Total Quantity }\left(\mathrm{ft}^{3}\right)}^{3}$ \\
Small-Scale & County Environmental $^{\mathrm{a}}$ & 2,069 & \\
& Chambers Liberty $^{\mathrm{b}}$ & 521 & \\
& Pekin Metro $^{\mathrm{c}}$ & 137 & 2,727 \\
& & & \\
Large & County Environmental $_{\text {(IEPA Notification) }}$ & 4,461 & \\
& Community $^{\mathrm{d}}$ & 900 & 5,905 \\
& Hanford $^{\mathrm{e}}$ & 544 & Total 8,632 \\
\hline
\end{tabular}

a County Environmental Livingston Landfill, Pontiac, Ill.

b Chambers Liberty Landfill, Monticello, Ind.

c Central Illinois Landfill Service Corporation Peking Metro Landfill, Peking, Ill.

d Community Landfill Company, Morris, Ill.

e Disposed of as low-level radioactive waste at Westinghouse Hanford Corporation, Richland, Wash.

Until closure of the ANL-E landfill in September 1992, asbestos from small-scale projects was disposed of on site in a designated area of the landfill. The IEPA conducted an asbestos disposal inspection on April 28, 1994. Noncompliance with 40 CFR 61.154(g) - failure to modify deed to reflect the presence of asbestos material - was cited. On June 17, 1994, the IEPA transmitted a Compliance Inquiry Letter that stated that ANL-E was in apparent noncompliance with 40 CFR $61.154(\mathrm{~g})$ in that it failed to modify its property deed to reflect the fact that the landfill had been used for the disposal of ACM, thus making said disposal part of the public record and subject to discovery during a title search of the property.

DOE is responsible for any required modifications to the property deed and provided a response to IEPA on July 8, 1994, indicating the steps that would be taken to modify the deed. However, the deed was not modified during 1995. DOE must address some issues associated with the ANL-E boundary prior to modifying the property deed. 


\subsubsection{Radionuclide Emissions}

The NESHAP standard for radionuclide emissions from DOE facilities (40 CFR 61, Subpart $\mathrm{H}$ ) establishes the emission limits for release of radionuclides other than radon to the air and the requirements for monitoring, reporting, and record keeping. A number of emission points at ANL-E are subject to these requirements. These points include ventilation systems for hot cell facilities for storage and handling of radioactive materials (Buildings 200, 205, and 212), ventilation systems for inactive reactors (Building 330, inactive reactor CP-5), ventilation systems for particle accelerators (Building 375, IPNS facility, and the Building 411 APS Linac), and several ventilation systems associated with the New Brunswick Laboratory (Building 350). In addition, many small ventilation systems and fume hoods are occasionally used for processing of small quantities of radioactive materials.

The amount of radioactive material released to the atmosphere from ANL-E emission sources is extremely small. The maximum off-site dose to a member of the general public for 1995 was 0.026 mrem which, excluding radon-220, is $0.26 \%$ of the 10 mrem per year EPA standard. Section 4.6.1. contains a more detailed discussion of these emission points and compliance with the standard.

\subsubsection{Halogenated Solvent Cleaner Emissions}

The NESHAP standard for halogenated solvent cleaner emissions (40 CFR 63, Subpart T) became effective on December 2, 1994, and establishes emission limits on a variety of cleaning and degreasing activities utilizing a number of halogenated solvents. The Central Shops (Building 363) vapor degreaser is subject to this regulation since a listed solvent (perchloroethylene) is used in cleaning small metal parts on a batch basis. The NESHAP required notification to the IEPA by August 29, 1995, of the presence of the vapor degreaser and the applicability of the rule to its operations. The requisite notification was accomplished in that month. 


\subsubsection{Conventional Air Pollutants}

The ANL-E site contains a number of sources of conventional air pollutants, including a steam plant; oil-fired boilers; gasoline, methanol/gasoline blend, and ethanol/gasoline blend fueldispensing facilities; two alkali metal reaction booths; a number of bulk chemical tanks; a dust collection system; a medical equipment sterilization unit; and fire training activities. The emission sources that have been granted operating permits by the IEPA are provided in Section 2.14. During 1995, nine new air permits were issued by the IEPA, one air permit was withdrawn, and four air permits were renewed.

The operating permit for the steam plant requires continuous opacity and sulfur dioxide monitoring of the smoke stack from Boiler No. 5, the only one of the five boilers equipped to burn coal. The permit requires submission of a quarterly report listing any exceedances beyond emission limits for this boiler [30\% opacity averaged over six minutes and $1.8 \mathrm{lb} \mathrm{SO}_{2}$ per million Btu averaged over a one-hour period]. Table 2.3 gives the hours that Boiler No. 5 operated on low-sulfur coal during 1995. No exceedances occurred at Boiler No. 5 during 1995. The IEPA conducted an air emission compliance inspection of the steam plant on March 19, 1995.

Fuel-dispensing facilities include a commercial service station and Building 46 Grounds and Transportation facility. Except for methanol and ethanol vapors from alternate fuel usage, these facilities have VOC emissions typical of any commercial gasoline service station. Stage II vapor recovery systems were installed at both facilities by November 1, 1994. Pursuant to Illinois Administrative Code, Title 35, Part 254 (35 IAC 254), ANL-E reports an emission summary to the IEPA each May 1 for the previous calendar year. The summary from 1995 is presented in Table 2.4.

\subsection{Clean Water Act}

The Clean Water Act (CWA) was established in 1977 as a major amendment to the Federal Water Pollution Control Act of 1972 and was substantially modified by the Water Quality Act of 1987. Section 101 of the CWA provides for the restoration and maintenance of water quality in 
all waters throughout the country, with the ultimate goal of "fishable and swimmable" water quality. The act established the National Pollutant Discharge Elimination System (NPDES) permitting system, which is the regulatory mechanism designed to achieve this goal. The authority to implement the NPDES program has been delegated to those states, including Illinois, that have developed a program substantially the same and at least as stringent as the federal NPDES program.

The 1987 amendments to the CWA significantly changed the thrust of enforcement activities. Greater emphasis is now placed on monitoring and control of toxic constituents in wastewater, the permitting of outfalls composed entirely of storm water, and the imposition of regulations governing sewage sludge disposal. These changes in the NPDES program resulted in much stricter discharge limits and greatly expanded the number of chemical constituents monitored in the effluent. The wastewater treatment facilities on the ANL-E site are currently being upgraded to improve treatment capabilities.

\subsubsection{Liquid Effluent Discharge Permit}

The NPDES permitting process administered by the IEPA is the primary tool for enforcing the requirements of the NPDES program. Before wastewater can be discharged to any receiving stream, each wastewater discharge point (outfall) must be characterized and described in a permit application. The IEPA then issues a permit that contains numeric limits on certain pollutants 
TABLE 2.4

1995 Annual Emission Report: Emission Summary

\begin{tabular}{|c|c|c|c|c|c|}
\hline Source & $\mathrm{CO}$ & $\mathrm{NO}_{\mathrm{x}}$ & Particulate & $\mathrm{SO}_{2}$ & VOC \\
\hline Boiler 1 - Building 108 & 1,753 & 78,007 & 797 & 478 & 398 \\
\hline Boiler 2 - Building 108 & 12 & 38,438 & 380 & 296 & 169 \\
\hline Boiler 3 - Building 108 & 49 & 48,233 & 487 & 682 & 244 \\
\hline Boiler 4 - Building 108 & 175 & 36,266 & 350 & 105 & 175 \\
\hline Boiler 5 - Building 108 & 47,626 & 257,294 & 726 & 242,157 & 348 \\
\hline APS Generator - Caterpillar (1) & 352 & 1,835 & 65 & 152 & 50 \\
\hline APS Generator - Kohler (2) & .773 & 1,043 & 41 & 214 & 37 \\
\hline Boiler - Building 814 & 57 & 228 & $\mathrm{NA}^{\mathrm{a}}$ & 453 & NA \\
\hline Boiler - Building 825 & 83 & 332 & NA & 660 & NA \\
\hline 308 Alkali Reaction Booth & NA & NA & 1 & NA & NA \\
\hline Central Shops Degreaser & NA & NA & NA & NA & 116 \\
\hline Central Shops Dust Collector & NA & $\mathrm{NA}$ & $<1$ & NA & NA \\
\hline Building 201 - EtO Sterilizer & NA & NA & NA & NA & 24 \\
\hline Building 212 Exhausts & NA & NA & $<1$ & NA & NA \\
\hline Waste Mgmt. HEPA System - Sitewide & NA & NA & $<1$ & NA & NA \\
\hline Building 809 Woodshop Dust Collector & NA & NA & 8 & NA & NA \\
\hline Building 306 Bulking Sheds & NA & NA & 5 & NA & 520 \\
\hline Building 306 Building Vents & NA & NA & $<1$ & NA & NA \\
\hline Building 46 - Methanol/Gasoline & NA & NA & NA & NA & 40 \\
\hline Building 46 - Ethanol/Gasoline & NA & NA & NA & NA & 15 \\
\hline Building 46 - 10,000 Gal Gasoline & NA & NA & NA & NA & 449 \\
\hline Building 108 Sulfuric Acid Tank & NA & NA & 44 & NA & NA \\
\hline Building $300-10,000$ Gal Gasoline & NA & NA & NA & NA & 1,346 \\
\hline Building $300-8,000 \mathrm{Gal}$ Gasoline & $\mathrm{NA}$ & NA & NA & NA & 364 \\
\hline Building $300-6,000$ Gal Gasoline & NA & NA & NA & NA & 303 \\
\hline APS Facility - Accelerator & NA & 4 & NA & NA & NA \\
\hline Torch Cut Lead-Based Paint - Sitewide & NA & NA & 18 & NA & NA \\
\hline PCB Tank Cleanout - Sitewide & NA & NA & NA & NA & 197 \\
\hline Total (lb/yr) & 50,880 & 461,680 & 2,922 & 245,197 & 4,795 \\
\hline Total (ton/yr) & 25.44 & 230.84 & 1.46 & 122.60 & 2.40 \\
\hline
\end{tabular}

a $\mathrm{NA}=$ not applicable. 
likely to be present and sets forth a number of specific and general requirements, including sampling and analysis schedules and reporting and record keeping requirements. Wastewater generation activities at ANL-E are covered by NPDES Permit IL 0034592. This permit was renewed during 1994 and became effective October 30, 1994. For reasons discussed below, the permit was modified during 1995 and became effective August 24, 1995. The modification incorporates interim limits and a compliance schedule for achieving final effluent limits at outfall 001.

Wastewater at ANL-E is generated by a number of activities and consists of sanitary wastewater (from restrooms, cafeteria sinks and sinks in certain buildings and laboratories, steam boiler blowdown, and drinking water filter backwash), laboratory wastewater (from laboratory sinks and floor drains in most buildings), and storm water. Water softener regenerant is discharged to the DuPage County sewer system. Cooling water and cooling tower blowdown are currently discharged into storm-water ditches that are monitored as part of the NPDES permit. The current permit authorizes the release and monitoring of wastewater from 40 separate outfalls, most of which discharge directly or indirectly into Sawmill Creek. Two of the outfalls are internal sampling points that combine to form the main wastewater outfall, outfall 001 . Table 2.5 characterizes these outfalls; Figure 2.1 shows their locations. Outfall 010 is used for emergency overflow discharge from the coal pile.

\subsubsection{Effluent Monitoring Results and Compliance Issues}

Results of the routine monitoring required by the NPDES permit are submitted monthly to the IEPA in a Discharge Monitoring Report (DMR). As required by the permit, any exceedance of permit limits or conditions is reported by telephone to the IEPA within 24 hours, and a written explanation of the exceedance is submitted with each DMR. During 1995, there were 49 exceedances of NPDES permit limits out of approximately 1,600 measurements. This represents a 97\% compliance rate, similar to the 1994 compliance rate. The majority of these exceedances occurred regularly at certain outfalls and for certain parameters, that is total dissolved solids (TDS), copper, and ammonia-nitrogen. The frequency of measurement increased during 1995 because of the revised (October 30, 1994) permit requirements; lower discharge limits were 
TABLE 2.5

Characterization of NPDES Outfalls at ANL-E, 1995

\begin{tabular}{|c|c|c|}
\hline Outfall & Description & Flow $^{\mathrm{a}}$ \\
\hline $001 \mathrm{~A}$ & Sanitary Treatment Plant & 0.6 \\
\hline 001B & Laboratory Treatment Plant & 0.4 \\
\hline 001 & Combined Outfall & 1.0 \\
\hline $003 \mathrm{~A}$ & Swimming Pool & 0.004 \\
\hline 003B & 300 Area (Condensate) & 0.070 \\
\hline $003 \mathrm{C}$ & Building 205 Footing Tile Drainage & 0.075 \\
\hline 003D\&E & Steam Trench Drainage (Condensate) & 0.022 \\
\hline 003F & Building 201 Fire Pond & 0.016 \\
\hline $003 G$ & North Building 201 Storm Sewer (Condensate) & 0.115 \\
\hline $003 \mathrm{H}$ & Building 212 Cooling Tower Blowdown & 0.018 \\
\hline $003 I$ & Buildings 200 and 211 Cooling Tower Blowdown & 0.020 \\
\hline $003 \mathrm{~J}$ & $\begin{array}{l}\text { Building } 213 \text { and Building } 213 \text { Parking Lot } \\
\text { Storm Water }\end{array}$ & 0.023 \\
\hline 004 & $\begin{array}{l}\text { Building } 203 \text { Cooling Tower and Building } 221 \\
\text { Footing Drainage }\end{array}$ & 0.037 \\
\hline $005 \mathrm{~A}$ & Westgate Road Storm Water & Storm Water Only \\
\hline 005B & 800 Area East Storm Water & Storm Water Only \\
\hline $005 \mathrm{C}$ & Building 200 West & 0.016 \\
\hline 005D & Storm Water & Storm Water Only \\
\hline 005E & Building 203 West Footing Drainage and Condensate & 0.036 \\
\hline 006 & Cooling Tower Blowdown & 0.012 \\
\hline 007 & Domestic Cooling Water for Compressor & 0.019 \\
\hline 008 & Transportation and Grounds Storm Water & 0.004 \\
\hline 010 & Coal Pile Runoff Emergency Overflow & Storm Water Only \\
\hline 101 & North Fenceline Marsh Storm Discharge & Storm Water Only \\
\hline 102 & 100 Area Storm-Water Discharge & Storm Water Only \\
\hline 103 & Southeast 100 Area Storm Water & Storm Water Only \\
\hline 104 & Northern East Area Storm-Water Discharge & Storm Water Only \\
\hline $105 \mathrm{~A} \& \mathrm{~B}$ & Building 40 Storm-Water Discharge & Storm Water Only \\
\hline $106 \mathrm{~A} \& \mathrm{~B}$ & Southern East Area Storm-Water Discharge & Storm Water Only \\
\hline 108 & Eastern 300 Area Storm Water and Cooling Water & 0.027 \\
\hline 110 & Shooting Range Storm-Water Discharge & Storm Water Only \\
\hline 111 & 319 Landfill and Northeast 317 Area & Storm Water Only \\
\hline $112 \mathrm{~A} \& \mathrm{~B}$ & Southern and Western 317 Area & Storm Water Only \\
\hline 113 & Southern and Eastern 800 Area Landfill & 0.013 \\
\hline
\end{tabular}


TABLE 2.5 (Cont.)

\begin{tabular}{llc}
\hline Outfall & Description & Flow \\
\hline \multirow{2}{*}{114} & Northern and Western 800 Area Landfill & Storm Water Only \\
115 & $\begin{array}{l}314,315, \text { and 316 Cooling Water, Eastern and } \\
\text { Southern APS Construction Area }\end{array}$ & 0.019 \\
116 & Water Treatment Plant and Storm Water & 0.020 \\
\hline
\end{tabular}

a Flow is measured in million gallons per day except for storm water only.

placed on certain parameters, that is, TDS, copper, and ammonia-nitrogen. Figure 2.2 gives a statistical breakdown.

During March 1995, ANL-E submitted a request for a permit modification to include a compliance schedule that would address bringing the ammonia-nitrogen, copper, and TDS discharges under the respective limits. In addition, ANL-E requested a provisional variance from the existing limits for ammonia-nitrogen, copper, and TDS. ANL-E was subsequently granted the provisional variance by the Illinois Pollution Control Board (IPCB), effective March 28, 1995. The provisional variance allowed ANL-E to continue operating its wastewater treatment plants (WTPs) while the IEPA reviewed ANL-E's request to modify the NPDES permit. The permit modification was granted by the IEPA effective August 24, 1995. The ANL-E wastewater treatment facilities are currently being upgraded to improve treatment capabilities to meet applicable limits by July 1, 1998.

Twenty exceedances of the TDS limit at outfall 001 were noted. At the beginning of 1995 , the NPDES permit limit for TDS was $1,000 \mathrm{mg} / \mathrm{L}$. Supply-water TDS concentrations in the range of $750 \mathrm{mg} / \mathrm{L}$ (well head) to $950 \mathrm{mg} / \mathrm{L}$ (treated water) allow limited capacity for the addition of dissolved solids to the site wastewater. Additions of TDS to the wastewater come from many sources. Discharge of effluents from boiler operations can be a major active source. The modified NPDES permit, effective August 24, 1995, incorporates an interim TDS limit $(1,500 \mathrm{mg} / \mathrm{L})$ and a compliance schedule for achieving final TDS effluent limits (by July 1,1998$)$ 


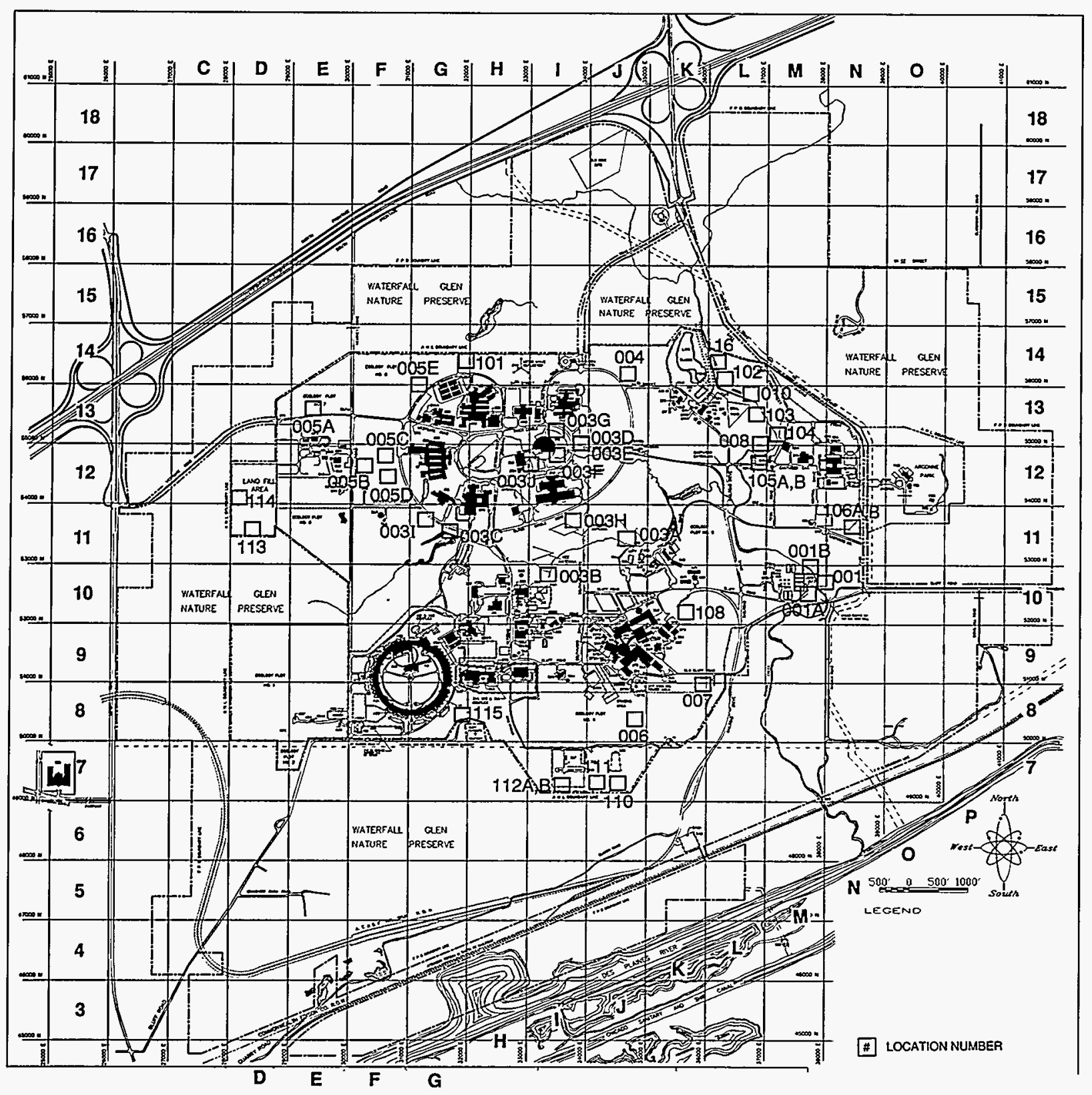

Figure 2.1 NPDES Permit Locations, 1995 




at outfall 001. Lake Michigan water, which has a much lower TDS concentration than ANL-E's current supply-water, will be incorporated as the ANL-E source water by November 1996.

The well water obtained by ANL-E from the Niagaran dolomite has very low copper concentrations. However, after treatment and distribution through copper pipe, which is used for the domestic water distribution within ANL-E buildings, a copper concentration range of $0.5 \mathrm{mg} / \mathrm{L}$ to $1.0 \mathrm{mg} / \mathrm{L}$ is typical at drinking fountains. This range has been determined by the copper/lead monitoring program required by the EPA (Section 6.1.1.). The acceptable copper level for human consumption is significantly above the NPDES Permit limit $(0.051 \mathrm{mg} / \mathrm{L})$ at outfall 001. The WTP does not include a process to remove copper. Past samples collected from the WTP effluent have been below the state effluent limit of $0.5 \mathrm{mg} / \mathrm{L}$. Concentrations in Sawmill Creek, below the point where the treated wastewater has been discharged, however, have consistently exceeded the state stream standard for copper $(0.02 \mathrm{mg} / \mathrm{L})$ for the past 10 years. This trend may be indicative of the current ambient levels of copper in surface water because of the increased use of copper pipe. The corrective action currently being taken by ANL-E to control 


\section{COMPLIANCE SUMMARY}

copper levels in the domestic water supply includes injecting polyphosphate and zinc to coat the copper piping. The addition of zinc has a synergistic effect on the coating of the pipes. Lake Michigan water is less aggressive on the copper pipes than ANL-E's current source of water. It is expected that copper levels will decrease once ANL-E incorporates Lake Michigan as its source of water in late 1996. On August 24, 1995, the IEPA modified ANL-E's NPDES permit to, among other things, incorporate interim copper limits and a compliance schedule for achieving final copper effluent limits at outfall 001. The final limits are effective July 1, 1998.

Four exceedances of the ammonia-nitrogen limit at outfall 001 were noted. The ANL-E WTPs provide minimal treatment for ammonia-nitrogen. The modified NPDES permit, effective August 24, 1995, incorporates an interim ammonia-nitrogen limit and a compliance schedule for achieving a final (by July 1, 1998) ammonia-nitrogen limit at outfall 001.

Total suspended solids (TSS) exceedances accounted for only $4 \%$ of the total. TSS were related to carryover pipe material into the discharge at outfall 003A and excessive surface runoff from rapid snow thaw at outfall 004.

The discharge of total residual chlorine (TRC) at outfalls 003A, 007, and 116 is regulated by Special Condition 8 of the NPDES Permit. Special Condition 8 states that the discharge from outfalls $003 \mathrm{~A}, 007$, and 116 must not exceed $0.05 \mathrm{mg} / \mathrm{L}$ TRC as a daily maximum concentration limit. Compliance with this limit is required as soon as possible, but no later than two years after the effective date of the permit, which is October 30, 1996. Compliance may be achieved by construction of dechlorination equipment or by alternative means. Alternative means of compliance are preferred, because the source of the residual chlorine is presumed to be primarily from improper domestic water connections that may be removed from the storm system. A residual chlorine level of $0.5 \mathrm{mg} / \mathrm{L}$ is maintained throughout the system and, as a result, the discharge of domestic water may result in an exceedance. ANL-E intends to locate and identify sources of chlorine on these systems and eliminate or move the source to a more appropriate drain system. 
The discharge of chlorinated water from outfall 003A has been completely eliminated by the installation of a collection system consisting of a collection tank, piping, and a sump pump. This system captures all the flow and discharges into the sanitary drain system, thereby eliminating the discharge from this outfall and the potential for a permit exceedance. Seventeen drain lines were removed from the storm system at outfall 007, and the frequency and amount of discharge has been significantly reduced. Efforts to identify, locate, and remove sources on 007 will continue in 1996. Four sources of chlorinated water were located and removed from outfall 116. The discharge from this outfall was at or below the permit limit during the last two months of 1995 .

Data regarding the total number of each type of exceedance over the past seven years are presented in Figure 2.3. From 1989 to 1994, the total number of exceedances has been reduced; 50 exceedances in 1989, 86 exceedances in 1990, 44 exceedances in 1991, 19 exceedances during

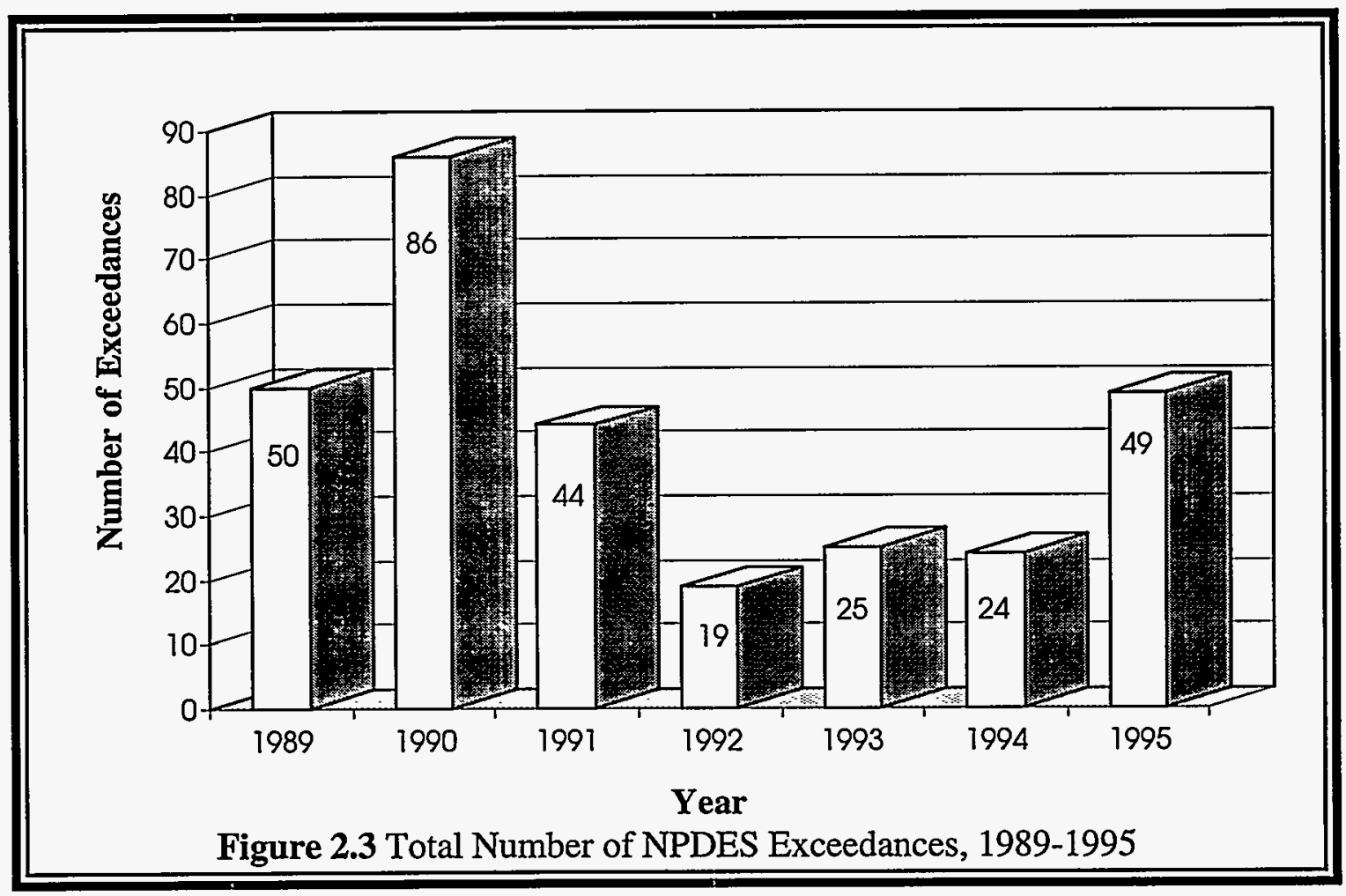




\section{COMPLIANCE SUMMARY}

1992, 25 exceedances during 1993, and 24 exceedances in 1994. Although the number of exceedances is greater (49) in 1995, the NPDES Permit, effective October 30, 1994, placed more restrictive limits on ANL-E discharges and increased the number of analyses required each year by about 600 analyses.

For reasons stated above, copper, TDS, and ammonia-nitrogen limits resulted in a substantial increase of exceedances prior to the issuance of the modified permit. Since the effective date of the modified permit (August 24, 1995), no NPDES exceedances have occurred.

To improve the level of compliance with permit limits, ANL-E is in the fifth year of an intensive effort to build additional wastewater-treatment facilities or upgrade existing facilities. Projects to upgrade and refurbish the Laboratory and sanitary WTPs are scheduled through 1996. These and other corrective action projects are described in the Environmental Management Plan for ANL-E and identified in Chapter 3.

\subsubsection{Additional NPDES Monitoring}

The current permit requires semiannual testing of outfall 001B, the Laboratory WTP outfall, for all the priority pollutants (a list of 126 metals and organic compounds identified by the IEPA as being of particular concern). During 1995, this sampling was conducted in June and December. Chloroform ( $9 \mu \mathrm{g} / \mathrm{L}$ and $5 \mu \mathrm{g} / \mathrm{L}$ ), bromoform ( $3 \mu \mathrm{g} / \mathrm{L}$ and $5 \mu \mathrm{g} / \mathrm{L}$ ), dibromochloromethane (11 $\mu \mathrm{g} / \mathrm{L}$ and $4 \mu \mathrm{g} / \mathrm{L})$, bromodichloromethane $(5 \mu \mathrm{g} / \mathrm{L}$ and $3 \mu \mathrm{g} / \mathrm{L})$, and methylene chloride $(5 \mu \mathrm{g} / \mathrm{L}$ and $29 \mu \mathrm{g} / \mathrm{L})$ were detected in both the June and December samples at low concentrations resulting from normal ANL-E operations. The source of most of these materials is suspected to be from the contact of chlorinated water-with organic chemicals in the Laboratory, as well as the discharge of small amounts of chemicals from various research and support operations. All semivolatile concentrations were below the detection limits. Low concentrations of zinc $(0.370 \mathrm{mg} / \mathrm{L})$, copper $(0.106 \mathrm{mg} / \mathrm{L})$, cadmium $(0.0001 \mathrm{mg} / \mathrm{L})$, lead $(0.0026 \mathrm{mg} / \mathrm{L})$, and nickel $(0.025 \mathrm{mg} / \mathrm{L})$ were detected. No chrysotile asbestos greater than $10 \mathrm{~m} \mu \mathrm{m}$ in length was detected in the June sample. The August 24, 1995, modified NPDES Permit excluded asbestos 
and dioxin from future priority pollutant monitoring at outfall 001B. These findings are discussed further in Chapter 5.

In addition to the priority pollutant analysis, the permit requires annual biological toxicity testing of the combined effluent stream, outfall 001 . This was conducted between June 21 and June 22, 1995. The data indicate that a small amount of toxicity was observed with the fathead minnow, but the effluent was not toxic to the water flea. The 1994 and 1995 data, compared with previous years' data, seem to indicate that cessation of chlorination of ANL-E's effluent correlated with a beneficial effect on aquatic life in the receiving streams.

The new requirements of the revised NPDES Permit require acute toxicity testing at outfalls 003H, 0031, 003J, 004, 006, and 115 twice a year during the months of July and August, as well as the annual acute toxicity testing during June at outfall 001. Samples were collected July 31 through August 4, 1995, and August 23, 1995. The samples were tested on the fathead minnow and the water flea. Three of the outfalls, 003I, 003J, and 004 showed no toxicity.

During July, acute toxicity was noted for both the fathead minnow and the water flea at outfall $003 \mathrm{H}$. Review of outfall $003 \mathrm{H}$ water chemistry data indicated elevated residual chlorine levels, possibly contributing to the toxicity detected. Acute toxicity was noted for the water flea at outfalls 006 and 115. The source of this toxicity is unknown. During August, no toxicity was detected at the outfalls for fathead minnows. The results for the water flea were similar to July's results.

\subsubsection{Storm-Water Regulations}

In November 1990, the EPA promulgated new regulations governing the permitting and discharge of storm water from industrial sites. The ANL-E site contains a large number of small scale operations that are considered industrial activities by the regulation, and thus, are subject to these requirements. An extensive storm-water characterization program began in 1991, and a storm-water permit application was sent to the IEPA during 1992. 
Special Condition 10 of the NPDES Permit identifies 15 additional storm-water outfalls that require characterization and submission of a permit application. ANL-E has since identified three additional outfall locations that will also require characterization. Storm-water characterization was completed at the 18 outfalls, and preparation of the permit application forms was initiated. The characterization data that ANL-E is required to submit to the IEPA includes quantitative data, flow measurements, analyses for certain specified pollutants, and dates, durations, and precipitation volumes of the monitored storm event. Preparation and submission of the permit application will be completed in 1996.

The NPDES Permit contains two special conditions requiring and defining Storm-Water Pollution Prevention Plans for both the APS construction site (No.12) and the rest of the ANL-E site (No.11). Both of these plans were completed according to the requirements of the individual special condition by the mandated date, May 1, 1995, which was 180 days after the effective date of the permit. The special conditions also require implementation of the plans by 365 days after the effective date of the permit; this was accomplished on November 1, 1995.

The same special conditions require that the facility inspect and report on the effectiveness of the Storm-Water Pollution Prevention Plans. Accordingly, the inspection covering the two plans was completed on November 11, 1995. The report arising from the inspection is required by the permit to be submitted to the IEPA 60 days after the one-year period following the final date of the issuances of the NPDES final permit; this was accomplished December 29, 1995. All requirements of Special Conditions Nos. 11 and 12 covering the Storm-Water Pollution Prevention Plans have been fulfilled within the required dates.

The requirements in both special conditions are effective for the life of the permit (October 30, 1999). Changes to the plans will be required throughout this time and are presently in the planning stages from the first inspection and report. This will be accomplished by the summer of 1996. The Storm-Water Pollution Prevention Committee will conduct a yearly inspection as required in Special Condition No. 11. This inspection will be completed in fall 1996, with the resultant report completed by December 1996. 
During 1995, construction was completed on four flumes at NPDES outfalls 004, 006, 007, and 108. These permanent flumes give ANL-E the capability of monitoring flow accurately at these four critical discharge locations. Construction at outfall 003I was initiated but cannot be completed until 1996 because of an installation problem.

\subsubsection{NPDES Inspections and Audits}

On October 24 and 25, 1995, the IEPA conducted a Compliance Sampling Inspection of NPDES outfalls and related facilities, as well as associated sampling and analysis and record keeping requirements. The inspection report has not been issued. Although no significant issues were identified, the IEPA emphasized the need to comply with the various compliance schedules in the modified NPDES Permit and to follow the requirements of the Storm-Water Pollution Prevention Plan. Some erosion control issues at the APS site were also noted.

\subsubsection{General Effluent and Stream Quality Standards}

In addition to specific permit conditions, ANL-E discharges are required to comply with general effluent limits contained in 35 IAC, Subtitle C, Chapter I, Part 304. Also, wastewater discharges must be of sufficient quality to ensure that Sawmill Creek complies with the IEPA General Use Water Quality Standards found in 35 IAC, Subtitle C, Chapter I, Part 302, Subpart B. Chapter 5 of this report, which presents the results of the routine environmental monitoring program, also describes the general effluent limits and water quality standards applicable to the outfalls and discusses compliance with these standards.

\subsubsection{NPDES Analytical Quality Assurance}

ANL-E conducts the majority of the analyses required for inclusion in the DMR. These analyses are conducted with EPA-approved methods in 40 CFR 136. To demonstrate the capabilities of the ANL-E Laboratory for these analyses, the IEPA requires the Laboratory to participate in the DMR Quality Assurance program. The IEPA sends a series of control samples to ANL-E annually, and the analytical results of these samples are submitted to the IEPA and the 
the EPA for review. The proficiency of the Laboratory is determined by how close the analytical results for the submitted samples come to the actual values. The ANL-E Laboratory has consistently performed very well on these tests.

\subsubsection{Spill Prevention Control and Countermeasures Plan}

ANL-E maintains a Spill Prevention Control and Countermeasures (SPCC) plan as required by the CWA and EPA regulations in 40 CFR 112. This plan describes the actions to be taken in case of oil or oil product releases to waterways in the environment. Persons with specific duties and responsibilities in such situations are identified, as are reporting and record-keeping requirements mandated by the regulations. Effective use of this plan is ensured by regular training. This plan was updated in 1995. No reportable spills occurred during 1995.

\subsection{Resource Conservation and Recovery Act}

The Resource Conservation and Recovery Act (RCRA) and its implementing regulations are intended to ensure that hazardous waste is disposed of in an environmentally safe manner and that facilities that treat, store, or dispose of hazardous waste do so in a way that protects human health and the environment. The Hazardous and Solid Waste Amendments of 1984 (HSWA) created a set of restrictions on land disposal of hazardous waste. In addition, HSWA also requires that releases of hazardous waste or hazardous constituents from any solid waste management unit located on the site of a RCRA-permitted facility be cleaned up, regardless of when the waste was placed in the unit or whether the unit was originally intended as a waste disposal unit. As discussed below, these RCRA corrective action provisions will have a far-reaching impact on ANL-E. The RCRA program includes regulations governing management of underground storage tanks containing hazardous materials or petroleum products. The IEPA has been authorized to administer most aspects of the RCRA program in Illinois. 


\subsubsection{Hazardous Waste Treatment and Disposal}

Because of the nature of the research activities conducted at ANL-E, small quantities of a large number of waste chemicals are generated. Many of these materials are classified as hazardous waste under RCRA. A small amount of these wastes also exhibit radioactivity, making them "mixed waste." The hazardous components of mixed waste are subject to RCRA regulations by the IEPA, while the radioactive component is subject to DOE regulation under the Atomic Energy Act of 1954. Hazardous waste is collected by the ANL-E WM Department from individual on-site generators and shipped off-site for treatment and disposal at an approved hazardous waste treatment and disposal facility. Small quantities of reactive hazardous waste are treated on site. To provide for on-site management of hazardous and mixed waste before off-site shipment or on-site treatment, ANL-E operates several RCRA-permitted storage and treatment facilities. These facilities, designed and operated in compliance with RCRA requirements, allow for accumulation and storage of waste pending identification of an off-site disposal site. Off-site treatment options for mixed waste are extremely limited (see Section 2.3.5)

ANL-E has 15 Hazardous Waste Management Units (HWMUs), 11 container storage units, two miscellaneous thermal treatment units, one tank storage unit, and one tank chemical treatment unit. Table 2.6 provides descriptions of all of the units.

Five treatability studies were conducted at ANL-E during 1995. A RCRA Metal Precipitation and Filtration for Non-Transuranic Mixed Aqueous Waste Study consisted of a precipitation process to concentrate hazardous heavy metals separated from low-level mixed aqueous waste generated at ANL-E. A total of $113 \mathrm{~kg}(51 \mathrm{lb})$ of acidic waste with heavy metal waste was treated. This study will continue through 1996.

The Vitrification Study utilized a vitrification process to convert mixed waste into low-level radioactive waste. The mixed waste includes ANL-E-generated evaporator bottoms, HEPA filter media, storage tank sludge, and aqueous treatment sludge. A total of $2.4 \mathrm{~kg}(1.0 \mathrm{lb})$ of waste was treated. 
Hazardous Waste Treatment and Storage Facilities, 1995

Current Interim Status Facilities

Waste and Storage

Tank Storage

Portable Storage Units

Container Storage Area

Dry Mixed Waste Storage Area
Building 325C, East

Building 325C, West

Building 306 - Storage Room A-142

Building 306 - Storage Room A-150

Building 306 - Storage Room C-131

Building 306 - Storage Room C-157 Building 306 - Storage Room D-001

Building 306

Building 306

Building 374A
Storage of ignitable radioactive mixed waste (RMW)

Storage of solid and liquid RMW

Drum storage and lab packing solid and liquid hazardous waste

Drum storage and lab packing of hazardous waste Storage of solid RMW containing toxic metal constituents

Storage of corrosive and toxic mixed waste and radiological liquid wastes $(4,000 \mathrm{gal})$

Storage of hazardous, radiological, or mixed waste (3 units)

Bulking operations to consolidate and reduce the volume of lab-packed waste in containers (1 unit) Storage of liquid and solid bulk or lab-packed flammable and reactive hazardous waste and solid and liquid bulk PCBs and miscellaneous PCB units Storage of bulk and lab-packed liquid flammable hazardous waste

Storage of solid RMW and radioactively contaminated lead bricks. 


\begin{tabular}{lll}
\hline Description & Location & Purpose \\
\hline Mixed Waste Container Storage & Building 329 & $\begin{array}{l}\text { Storage of containers of bulk and lab-packed } \\
\text { ignitable mixed waste or compatible waste } \\
\text { Storage of solid radioactive waste and solid } \\
\text { RMW in the form of steel-encased lead } \\
\text { shielding containers and containerized solid } \\
\text { mixed waste }\end{array}$ \\
Alkali Metal Passivation Booth & B17 Area & Building 308 \\
Alkali Metal Passivation Booth & Building 206 & $\begin{array}{l}\text { Destruction of water reactive alkali metals } \\
\text { Destruction of water reactive alkali metals, } \\
\text { possibly contaminated with radionuclides } \\
\text { Treatment of liquid mixed wastes containing } \\
\text { hazardous metals and/or acids and bases. }\end{array}$ \\
\hline
\end{tabular}


The Recycling of Waste Metals by Solvent Extraction Study was conducted to develop a generic waste recycling process that specifically targets the metals recycling problems. Experiments were conducted on $1.5 \mathrm{~g}$ of aqueous process waste supplied by an off-site facility.

The Soil Flushing and Solidification Study evaluated the technologies of soil washing/flushing and solidification/stabilization of soil samples contaminated with hazardous heavy metals collected from the Aberdeen Proving Grounds, Maryland. A total of $1.0 \mathrm{~kg}(0.5 \mathrm{lb})$ of soil was treated.

Finally, the Solvent Recovery Study included the distillation and filtration of various solvents. About $3.6 \mathrm{~L}$ (1 gal) have been treated. The total quantity of solvents remaining in storage is about $3.0 \mathrm{~L}$ ( $0.8 \mathrm{gal})$. This study is expected to continue in 1996.

Figure 2.4 shows the locations of the major hazardous and nonhazardous waste treatment, storage, and disposal areas at ANL-E.

\subsubsection{Permit Status}

ANL-E was granted interim status under RCRA on April 30, 1982, after submitting a notification of Waste Handling Activities and a Part A application on November 3, 1980. On December 20, 1990, a new Part B permit application (one had been sent to the EPA on December 19, 1985, but not acted upon) was submitted to the IEPA, which had been granted authority to administer most of the RCRA program. The application was submitted to the IEPA and EPA on December 20, 1990. Revisions to the permit application were submitted on June 17, 1991, and September 24, 1991, in response to IEPA and EPA comments.

The RCRA Part B Permit application was revised and updated in 1993. Revision I was submitted to the IEPA November 11, 1993, and includes information on four new portable hazardous waste storage units and a mixed waste storage tank. ANL-E responded to EPA notice of deficiency comments regarding the alkali metal passivation booths in Buildings 308 and 206 and incorporated the response into the revised application. Revision II of the Part B application 

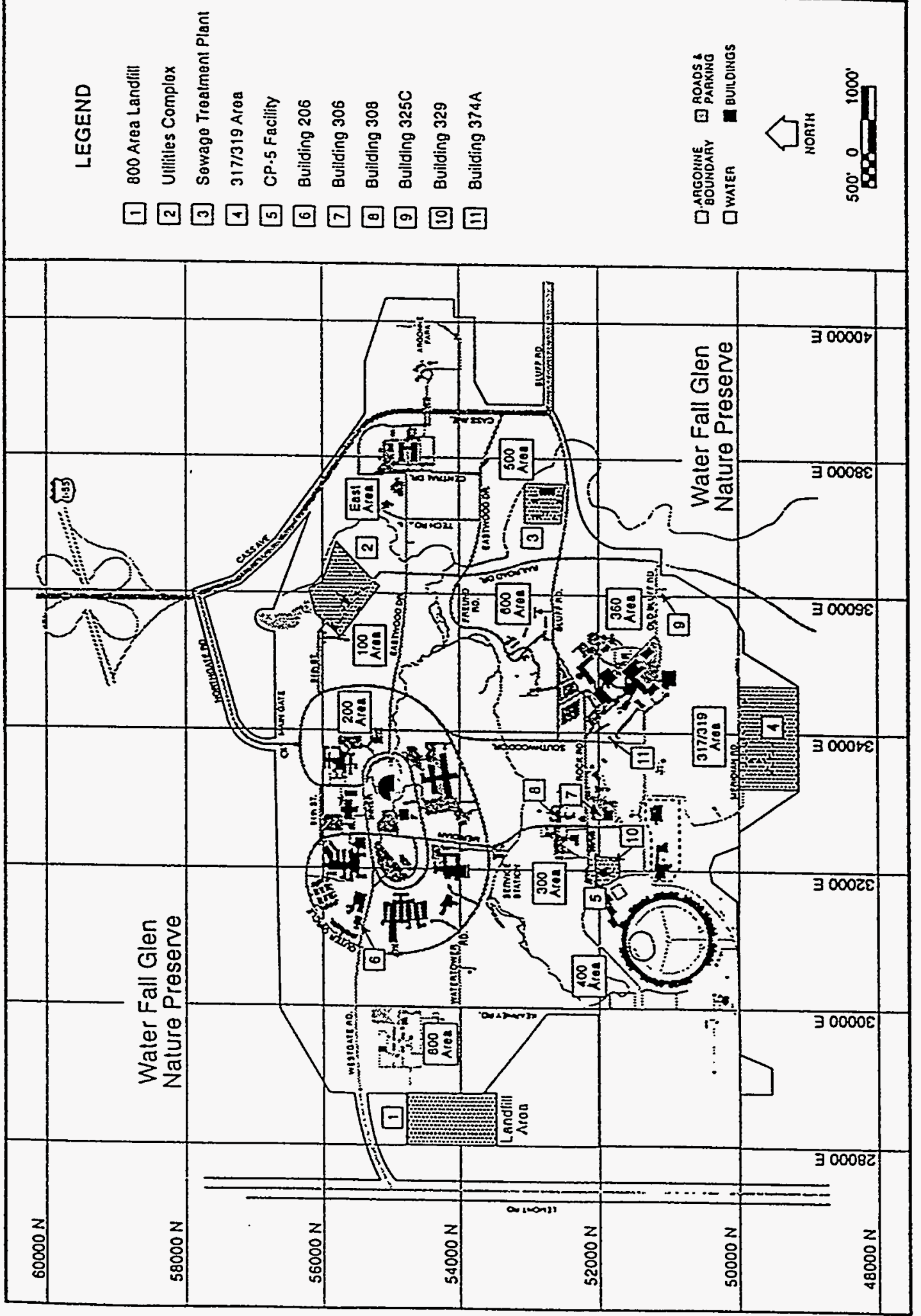

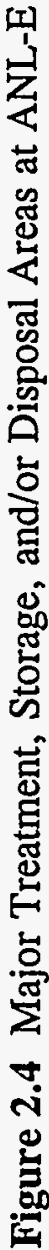


was submitted on May 26, 1995, and included a new hazardous waste storage facility, a new mixed waste storage facility, and a new radioactive waste storage facility. The IEPA is conducting a technical review of the Part B permit application and may issue a draft RCRA Part B Permit by the end of 1996. The RCRA Part B Permit will contain corrective action requirements (see Section 2.3.9).

\subsubsection{Hazardous Waste Generation}

ANL-E typically generates a wide variety of hazardous waste and mixed waste each year. Hazardous and radioactive mixed wastes generated, treated, and stored during 1995 are described in Tables 2.7 and 2.8, respectively. All but one shipment of mixed waste was sent to the DOE Hanford site for storage. One shipment of radioactive contaminated sodium was sent to Argonne National Laboratory-West. All hazardous waste shipped off site went to an IEPA-permitted hazardous waste disposal facility. The reactive hazardous waste (sodium potassium alloy) was treated on the site in the Building 308 alkali metal reaction booth. This unit renders the waste nonhazardous. During 1995, mixed waste consisting of acidic solutions was neutralized in the Building 306 low-level aqueous mixed waste neutralization/precipitation system under a treatability study.

\subsubsection{Facility Modifications}

During 1995, the Building 306 north dock area was extensively rehabilitated with modification, replacement, and upgrading of existing equipment, appurtenances, and fire protection and detection systems. The baler building in the 317 Area was modified to house a carbon dioxide pellet cleaning system. The electrical system was upgraded, and a new HEPAfiltered ventilation system was added to control dust generated from the blasting operation.

During 1996, rooms in Building 306 will be modified to accommodate new mixed waste treatment systems. Room C-139 will house the Aqueous Transuranic Waste Treatment System and Advanced Oxidation Treatment System. The bermed room will be modified so as to have sufficient HEPA-filtered ventilation and other utilities such as potable water and electricity. 
TABLE 2.7

Hazardous Waste Treatment, Storage, and Disposal, 1995

\begin{tabular}{|c|c|c|}
\hline & Gallons & Pounds \\
\hline \multicolumn{3}{|l|}{ Hazardous Waste Generated and Disposed of } \\
\hline Aerosol Cans & 195 & 536 \\
\hline $\begin{array}{l}\text { Gasoline Contaminated Water ( } 800 \text { Area } \\
\text { Leaking Underground Storage Tanks) }\end{array}$ & 3,000 & 25,035 \\
\hline Hazardous Debris & 195 & 780 \\
\hline Hazardous Epoxy & 55 & 330 \\
\hline Hazardous Solutions/Water & 525 & 4,358 \\
\hline Hazardous Paint Wastes & 390 & 2,730 \\
\hline Hazardous Waste Oils & 1,275 & 9,180 \\
\hline Hydrogen Bromide Gas Cylinder & 5 & 15 \\
\hline Labpacks of Liquid Chemicals & 2,951 & 24,045 \\
\hline Labpacks of Solid Chemicals & 295 & 5,254 \\
\hline Lead Acid Batteries & 60 & 728 \\
\hline Lead Dross & 385 & 10,942 \\
\hline Mercury Switches and Gauges & 25 & 100 \\
\hline Mercury Vapor Light Bulbs & 2,010 & 2,010 \\
\hline Petroleum Naphtha with Solvents & 107 & 717 \\
\hline Waste Acidic Solutions & 55 & 500 \\
\hline Waste Caustic Solutions & 220 & 2,288 \\
\hline Waste Diesel Fuel/Water & 295 & 2,360 \\
\hline Wood Pallets with Lead & 2,055 & 13,707 \\
\hline \multicolumn{3}{|l|}{ Hazardous Waste - Treated } \\
\hline Alkali Metals & 2 & 16 \\
\hline
\end{tabular}


TABLE 2.8

Radioactive Mixed Waste Treatment, Storage, and Disposal, 1995

\begin{tabular}{|c|c|c|}
\hline & Gallons & Pounds \\
\hline \multicolumn{3}{|c|}{ Radioactive Mixed Waste - Generated } \\
\hline Acidic Solutions & 120 & 1,080 \\
\hline Alkali Metals & 220 & 2,200 \\
\hline Chromium (Firebrick) & 275 & 6,875 \\
\hline Cyanide Solutions & 11 & 92 \\
\hline Elemental Mercury & 5 & 250 \\
\hline Flammable Liquids & 800 & 5,600 \\
\hline Hazardous Metal Scrap & 901 & 18,020 \\
\hline RMW Debris & 1,270 & 5,080 \\
\hline RMW Sludges & 55 & 550 \\
\hline RMW Lead Articles & 1,875 & 168,750 \\
\hline RMW Soil & 1,320 & 12,144 \\
\hline Uranyl Nitrate & 120 & 2,400 \\
\hline \multicolumn{3}{|c|}{ Radioactive Mixed Waste - Treated } \\
\hline $\begin{array}{l}\text { RMW Acidic Solutions } \\
\text { (Neutralized) }\end{array}$ & 120 & 1,080 \\
\hline \multicolumn{3}{|c|}{ Radioactive Mixed Waste - Shipped } \\
\hline Alkali Metals & 220 & 2,200 \\
\hline Lead Articles & 935 & 84,150 \\
\hline RMW Soil & 1,150 & 10,580 \\
\hline RMW Debris & 2,640 & 10,560 \\
\hline RMW Sludges & 1,045 & 10,450 \\
\hline \multicolumn{3}{|c|}{ Radioactive Mixed Waste - In Storage } \\
\hline Acidic Solutions & 2,077 & 18,693 \\
\hline Alkali Metals & 140 & 1,400 \\
\hline Chromium (Firebrick) & 275 & 6,875 \\
\hline Cyanide Solution & 11 & 92 \\
\hline Elemental Mercury & 5 & 250 \\
\hline
\end{tabular}


TABLE 2.8 (Cont.)

\begin{tabular}{lrr}
\hline & Gallons & Pounds \\
\hline Elemental Cadmium & 55 & 1,375 \\
Hazardous Metal Scrap & 1,089 & 21,780 \\
Lead Articles & 1,057 & 95,130 \\
RMW Debris & 213 & 852 \\
RMW Sludges & 110 & 1,100 \\
RMW Aqueous Solutions & 24 & 199 \\
RMW Glass & 13 & 195 \\
RMW Soil & 165 & 1,518 \\
Uranyl Nitrate & 120 & 2,400 \\
\hline
\end{tabular}

Room D-033 will house the Solidification/Microencapsulation Treatment System. The bermed room will be modified to install a $210 \mathrm{~L}$ (55-gal) in-line drum mixer. The RCRA Part B Permit Application for these processes will be submitted to the IEPA in 1996.

Construction of a new 632- $\mathrm{m}^{2}\left(6,800-\mathrm{ft}^{2}\right)$ Mixed Waste Storage Facility located southwest of Building 306 is planned for 1996 . The facility will be subdivided into storage areas for different types of mixed waste. Each storage area is designed with a separate concrete holding basin for retaining fire suppression fluids in the event of a fire. Each basin is isolated to preverit cross-contamination of waste types.

\subsubsection{Mixed Waste Handling}

The hazardous component of mixed waste is governed by RCRA regulations, while the radioactive component is subject to regulation under the Atomic Energy Act as implemented by DOE Orders. Accordingly, facilities storing or disposing of mixed waste must comply with both DOE requirements and RCRA permitting and facility standards. ANL-E generates several types of mixed waste, including acids, solvents, and sludges contaminated with radionuclides. Corrosive mixed waste is undergoing a treatability study to remove the hazardous characteristics. Some mixed waste was sent to Hanford prior to August 1995 for storage and eventual treatment 
and disposal. The Part B permit application addresses mixed waste management procedures. A number of mixed waste treatment processes will be operational during 1995 and 1996. All of these processes will be incorporated into a Part B Permit revision to the IEPA.

\subsubsection{Federal Facility Compliance Act Activities}

The Federal Facility Compliance Act (FFCA) of 1992 amended RCRA to clarify the application of requirements and sanctions to federal facilities. The FFCA also required the DOE to prepare mixed waste treatment plans for DOE facilities that store or generate mixed waste. This Proposed Site Treatment Plan (PSTP) for mixed waste generated at ANL-E was submitted to the IEPA and the Illinois Department of Nuclear Safety in March 1995. The plan provides for on-site treatment of nearly all of the low-level radioactive mixed waste generated at ANL-E. A small amount of low-level radioactive mixed waste would be shipped to a DOE incinerator in Oak Ridge, Tennessee. Other types of mixed waste (i.e., transuranic mixed waste) would be shipped to DOE's Waste Isolation Pilot Plant in New Mexico for disposal. Mixed waste at ANL-E has been managed in accordance with the PSTP as of October 1995.

\subsubsection{RCRA Inspections: Hazardous Waste}

A RCRA Compliance Inspection was conducted by the IEPA on January 27, 1995. No significant issues were identified. The IEPA, EPA, and the Illinois Department of Nuclear Safety conducted a site visit on October 12, 1995, to discuss RCRA permitting and FFCA issues. No significant issues were identified. A RCRA solid waste management unit (SWMU) inspection was conducted on November 7, 1995. ANL-E is awaiting approval by the IEPA of the cleanup actions taken for four underground storage tanks (USTs) removed from the 800 area during 1995.

\subsubsection{Underground Storage Tanks}

In response to UST regulations, ANL-E prepared a Site-Wide Underground Tank Compliance Plan. The ANL-E site currently contains 25 existing, upgraded, replaced, or new USTs; 33 tanks have been removed over the last several years. The majority of these tanks are 
being used, or were used in the past, for storage of fuel oil for emergency generators or space heaters. The on-site vehicle maintenance facilities use underground gasoline and methanol/ gasoline blend tanks. The ethanol/gasoline bleñd is stored in an aboveground tank. The Compliance Plan establishes a program for replacing or upgrading tanks that must remain in use. Currently, all tanks remaining in use are being monitored under a new record keeping program initiated by ANL-E.

During 1993, nine regulated USTs were upgraded to current technical requirements (secondary containment, corrosion protection, leak detection, double-walled piping, spill and overfill protection) and 10 in-use USTs were replaced with new double-wall fiberglass tanks and required monitoring equipment. In 1994, three new tanks to store vehicle fuel were installed at the new Grounds and Transportation Center. The tanks they replaced, located in the 800 Area, were removed and corrective action completion reports were submitted to the IEPA in 1995.

\subsubsection{Corrective Action for Solid Waste Management Units}

As mentioned previously, the HSWA amendments to RCRA require that any Part B permit issued must include provisions for corrective actions for all releases of hazardous materials from any SWMU at the site, regardless of when the waste was placed in the unit. When issued, the Part B permit will contain a compliance schedule that will govern the corrective action of such units. The Part $B$ permit application submitted to the IEPA identified and provided information on 56 SWMUs, both active and inactive. A RCRA Facility Assessment (RFA) was completed by the IEPA during summer 1991. The RFA report from the IEPA was received in December 1993 and identified 740 units (735 SWMUs and five Areas of Concern [AOCs]). The report identified 432 units (427 SWMUs and five AOCs) for further investigation or other work. ANL-E prepared a report entitled "Proposed Revisions to the RCRA Facility Assessment Report for Argonne National Laboratory-East." This report included recommendations to reduce the number of units that the IEPA identified in the RFA Report for further investigation or other work from 432 units to 71 units (69 SWMUs and two AOCs). ANL-E is working proactively to characterize and investigate these SWMUs with emphasis in the 800 and 317 areas. The majority of these sites are believed to contain little or no residual contamination; however, a number may 


\section{COMPLIANCE SUMMARY}

be required to undergo some type of corrective action. The process of conducting detailed characterization studies to determine if hazardous materials have been released from a number of these units was begun in 1989. A summary of the preliminary results of these investigations can be found in Chapter 6. More extensive characterization is currently underway at a number of the SWMUs in accordance with the IEPA-approved corrective action work plans for the 800 Area and the 317/319 areas. As a result of the interim action that was conducted on SWMU No. 147 (Building 810 Paint and Solvent Disposal Area), the IEPA determined that no further action is necessary for this SWMU.

\subsection{Solid Waste Disposal}

During September 1992, ANL-E closed the operation of its sanitary landfill. This facility began operation in 1966. The original operating permit was issued by the IEPA in 1981 in accordance with 35 IAC 807. A supplemental permit addressing final elevations, a groundwater monitoring program, and closure/post-closure costs was issued by the IEPA on April 24, 1992, and revised on September 15, 1992, and October 22, 1992. The IEPA conducted a closure inspection of this landfill on January 27, 1995, and DuPage County conducted a landfill inspection on June 26,1995 . No significant issues were identified.

The April 24, 1992, supplemental landfill permit required ANL-E to implement a specific groundwater monitoring program at the sanitary landfill. The program is designed to identify any releases from the landfill and demonstrate compliance with the applicable groundwater quality standards. Quarterly monitoring of 11 locations began during July 1992. Exceedances of the groundwater quality standards for chloride, iron, TDS, and manganese were noted at monitoring locations where these levels have been historically reported. One exceedance of the groundwater quality standard for phenols was noted at one location only during the first quarter of 1993 . On January 11,1995 , the IEPA issued a supplemental permit which, among other things, revised the monitoring program to add 13 new well locations, delete the previous 11 well locations, and increase the number and types of contaminants monitored. 
The IEPA began requiring annual nonhazardous special waste reporting in 1991. The report is submitted by February 1 of each year and describes the activity of the previous year. It is a summation of all manifested nonhazardous and polychlorinated biphenyl (PCB) wastes. Table 2.9 describes the nonhazardous special wastes generated and disposed of during 1995.

\subsection{National Environmental Policy Act}

The National Environmental Policy Act of 1969 (NEPA) established a national environmental policy that promotes consideration of environmental factors in federal or federallysponsored projects. NEPA requires that the environmental impacts of proposed actions with potentially significant impacts be considered in an Environmental Assessment (EA) or

\section{TABLE 2.9}

Generation and Shipment of Special Waste, 1995

\begin{tabular}{|c|c|c|}
\hline \multirow[b]{2}{*}{ Waste } & \multicolumn{2}{|c|}{ Amount } \\
\hline & Generated & Disposed of \\
\hline Antifreeze & $100 \mathrm{gal}$ & $930 \mathrm{lb}$ \\
\hline Contaminated Sand (Treatment Plant) & $2,679 \mathrm{yd}^{3}$ & $7,300,000 \mathrm{lb}$ \\
\hline $\begin{array}{l}\text { Contaminated Water ( } 800 \text { Area Leaking } \\
\text { Underground Storage Tanks) }\end{array}$ & $27,600 \mathrm{gal}$ & $229,080 \mathrm{lb}$ \\
\hline $\begin{array}{l}\text { Contaminated Soil ( } 800 \text { Area Leaking } \\
\text { Underground Storage Tanks) }\end{array}$ & $1,140 \mathrm{yd}^{3}$ & $2,280,000 \mathrm{lb}$ \\
\hline Investigation Derived Waste (317 Area) & $3,190 \mathrm{gal}$ & $31,500 \mathrm{lb}$ \\
\hline Medical Waste & $408 \mathrm{~kg}$ & $900 \mathrm{lb}$ \\
\hline Mineral Spirits & $815 \mathrm{gal}$ & $5,542 \mathrm{lb}$ \\
\hline Nonhazardous Liquid Chemicals & 2,300 gal & $9,617 \mathrm{lb}$ \\
\hline Nonhazardous Solid Chemicals & $4,320 \mathrm{gal}$ & $11,488 \mathrm{lb}$ \\
\hline Petroleum Naphtha & $38 \mathrm{gal}$ & $260 \mathrm{lb}$ \\
\hline Sanitary Sewage Sludge & $295 \mathrm{yd}^{3}$ & $590,000 \mathrm{lb}$ \\
\hline Used Oil & $3,025 \mathrm{gal}$ & $21,780 \mathrm{lb}$ \\
\hline Asbestos & $395 \mathrm{yd}^{3}$ & $395,000 \mathrm{lb}$ \\
\hline PCBs & 4,140 gal & $14,510 \mathrm{lb}$ \\
\hline PCB-Contaminated Oil & 587,849 gal & $4,363,022 \mathrm{lb}$ \\
\hline PCB-Contaminated Water & $236,480 \mathrm{gal}$ & $1,950,480 \mathrm{lb}$ \\
\hline PCB-Contaminated Sludge & $3,465 \mathrm{yd}^{3}$ & $7,208,811 \mathrm{lb}$ \\
\hline
\end{tabular}


Environmental Impact Statement (EIS). DOE has promulgated regulations at 10 CFR 1021 that list classes of actions that are categorically excluded from further NEPA review. DOE completed one EA for the Proposed Upgrade of Waste Storage Facilities at Argonne National LaboratoryEast in 1995. ${ }^{4}$ DOE also adopted an EA for Management of Wildlife Causing Damage at Argonne National Laboratory-East (DOE/EA-1128) ${ }^{5}$ that was prepared by the U.S. Department of Agriculture. Two EAs are planned for 1996. One will address all site remediation activities conducted as part of RCRA corrective action/voluntary cleanup action. The second EA will address the disassembly of the JANUS Biological Irradiation Facility located in Building 202. No actions are planned for 1996 that are expected to require an EIS.

\subsection{Safe Drinking Water Act}

The Safe Drinking Water Act of 1974 (SDWA) established a program to ensure that public drinking water supplies are free of potentially harmful materials. This mandate is carried out through the institution of national drinking water quality standards, such as Maximum Contaminant Levels (MCL) and Maximum Contaminant Level Goals (MCLG), as well as through imposition of wellhead protection requirements, monitoring requirements, treatment standards, and regulation of underground injection activities. The regulations implementing the SDWA at 40 CFR 141-143, established Primary and Secondary National Drinking Water Regulations, which set forth requirements to protect human health (primary standards) and provide aesthetically acceptable water (secondary standards).

\subsubsection{Applicability to ANL-E}

The drinking water supply at ANL-E consists of four on-site wells that supply raw water to the water treatment plant. The treatment plant removes iron, softens the water by ionexchange, and adds chlorine before pumping it to the sitewide distribution system. Because of the nature of the ANL-E drinking water system and the persons served by it, the system is classified as a nontransient, noncommunity water supply, and as such is subject to the regulations applicable to such systems. The Laboratory is subject to regulations under the State of Illinois program administered by the IDPH. The IDPH adopted the Illinois Pollution Control Board 
regulations at 35 IAC 605, 607, and 611. These regulations are incorporated by reference into 77 IAC 900 . These regulatory programs establish a monitoring program, design, operation, and maintenance requirements, and secondary water quality standards.

\subsubsection{Monitoring Requirements}

The primary drinking water standards establish certain monitoring and analytical requirements. Both federal and state regulations apply to the ANL-E drinking water monitoring program. ANL-E routinely samples each of the four wells and the treated water quarterly for compliance with applicable regulations. Treated water is also sampled annually for radiological analyses. Chapter 6 of this report presents a detailed discussion of the results of the drinking water program. During 1995, samples continued to be collected, and all state and federally required analyses were conducted. EPA-approved procedures were employed by a certified laboratory. The 1995 results were sent to the IDPH on January 22, 1996. In 1995, ANL-E was required to report nitrate/nitrite, inorganics (metals and fluoride), and pesticide/herbicide/PCB parameters.

The action level for copper was exceeded during 1995, and ANL-E is required to continue semiannual sampling of 40 locations during 1996. Corrosion control measures were implemented by ANL-E to reduce the leaching of lead and copper into the water supply. Polyphosphate was added to the drinking water supply since 1993. To maintain a more consistent level of polyphosphate throughout the water supply system, bubblers were installed at selected locations to maintain flow. The controlled addition of zinc to the drinking water was begun in March 1995 to reduce copper dissolution. Also, ANL-E has identified and replaced several drinking water fountains that were known to contain lead-based components and high levels of copper.

\subsection{Federal Insecticide, Fungicide, and Rodenticide Act}

The Federal Insecticide, Fungicide, and Rodenticide Act (FIFRA) establishes a program to register pesticides, regulate their transportation and disposal, and determine standards for their use. Within ANL-E, all pesticides are applied by licensed contractors who provide any pesticides 
used and remove any unused portions. Herbicides are rarely used, but when they are needed, a licensed contractor is brought in to apply them. In these situations, ANL-E ensures that the herbicide is EPA-approved, that it is used properly, and that any residue is disposed of in accordance with applicable regulations. This is carried out by oversight inspections and maintenance of records.

\subsection{Comprehensive Environmental Response, Compensation and Liability Act}

The Comprehensive Environmental Response, Compensation and Liability Act (CERCLA) addresses cleanup of hazardous waste disposal sites and response to hazardous substance spills. Under CERCLA, the EPA collects data regarding sites subject to CERCLA action through generation of a Preliminary Assessment (PA) report, followed up by a Site Investigation (SI). Sites are then ranked, on the basis of the data collected, according to their potential to cause human health impacts or environmental damage. The sites with the highest rankings are placed on the National Priority List (NPL) and are subject to mandatory cleanup actions. ANL-E is not included in the NPL.

\subsubsection{CERCLA Program at ANL-E}

In early 1990, the EPA requested that DOE submit Site Screening Investigation (SSI) reports for 6 of 13 ANL-E sites for which PA reports had previously been submitted. Upon further discussions between the EPA and DOE, one of the six sites was eliminated from consideration, and three adjacent units (317/319/ENE) were treated as a single site. As a result, three SSI reports were submitted to the EPA in January 1991. Table 2.10 lists those sites for which an SSI was submitted.

Inquiries into waste disposal practices during the 1950s and 1960s have identified a number of smaller waste disposal sites, some of which could contain hazardous materials. These sites are under investigation; however, their potential to impact groundwater is thought to be minimal. 
TABLE 2.10

List of Inactive Waste Disposal Sites at ANL-E

Described in Various CERCLA Reports

Site Name

DOE/CERCLA EPA/SARA EPA/SSI

Waste Sites on Current ANL-E Property

800 Area Landfill and French Drain

319 Area Landfill and French Drain

Landfill East-Northeast of the 319 Area

Compressed Gas Cylinder Disposal Area, 318 Area

French Drain, 317 Area

Mixed Waste Storage Vaults, 317 Area

Shock Treatment Facility, 317 Area

Wastewater Holding Basin, Sewage

Treatment Plant

Liquid Waste Treatment Facility, Building 34

Decommissioned Reactor CP-5, Building 330

Gasoline Spill, Gasoline Station

810 Area Paint Shop

$\begin{array}{ccc}X & X & X \\ X & X & X^{a} \\ X & X & X^{a} \\ X & X & X^{a} \\ X & X & X^{a} \\ & X & X^{a} \\ X & X & X^{a} \\ & X & X\end{array}$

X $\quad \mathrm{X} \quad \mathrm{X}$

$\mathrm{X} \quad \mathrm{X} \quad \mathrm{X}$

$X \quad X \quad X$

$\mathrm{X} \quad \mathrm{X} \quad \mathrm{X}$

Waste Sites on Old ANL-E Property

Currently Waterfall Glen Forest Preserve

Reactive Waste Disposal, Underwriters Pond

$\mathrm{X}$

$\mathrm{X}$

a All units located in the 317,319 , and ENE areas were described in a single SSI report.

\subsubsection{CERCLA Remedial Actions}

Remedial actions to clean up any release of hazardous materials from these sites could occur in a number of different ways. All but one of the CERCLA sites are on the ANL-E site and are included as SWMUs in the RCRA Part B permit application. These may be subject to RCRA corrective action. However, several of the sites contain radiological contamination that is not regulated under RCRA. Those sites could be cleaned up under RCRA and other authorities. 
Regardless of which regulatory vehicle is used to conduct the cleanup of these sites, DOE has committed to clean up all such sites within the next 30 years. Funding has been requested for all but two of these sites. The two remaining sites are the off-site unit, which is no longer under the control of DOE, and a small gasoline spill that was completely cleaned up immediately after the spill occurred. Several of the characterization projects have already begun and will continue over the next few years.

\subsubsection{Emergency Planning and Community Right to Know Act and Superfund Amendments and Reauthorization Act, Title III}

\subsubsection{Sections 311 and 312}

Title III of the 1986 Superfund Amendments and Reauthorization (SARA) amendments to CERCLA created the Emergency Planning and Community Right to Know Act (EPCRA) as a freestanding provision for response to emergency situations involving hazardous materials and for making known to federal, state, and local emergency planning authorities information regarding the presence and storage of hazardous substances and their planned and unplanned environmental releases. Under EPCRA, ANL-E is required to provide to applicable emergency response agencies an inventory of hazardous substances stored on the site, Material Safety Data Sheets (MSDSs), and completed SARA data sheets (Tier I or II forms) for each hazardous substance stored in quantities above a certain threshold planning quantity (typically 10,000 lb; but as low as one pound for certain compounds). However, chemicals used in research laboratories under the direct supervision of a technically qualified individual are exempt from reporting. In November 1987, an inventory and MSDS forms for nine chemicals were submitted to the Local Emergency Planning Committee (LEPC); in March 1988, Tier I reports providing additional information on these chemicals were submitted. Updated Tier II forms were submitted to the LEPC by the required March 1 deadline for the years 1989 through 1995. The Tier II forms updated the previous listings and provided more information regarding the amount of material stored and the location of the material. Table 2.11 lists hazardous compounds reported under SARA Title III for 1995. 
TABLE 2.11

Compounds Reported under SARA Title III, 1995

\begin{tabular}{|c|c|c|c|c|c|}
\hline \multirow[b]{2}{*}{ Compound } & \multicolumn{5}{|c|}{ Hazard Class } \\
\hline & Fire & $\begin{array}{c}\text { Sudden } \\
\text { Release of } \\
\text { Pressure }\end{array}$ & Reactive & $\begin{array}{c}\text { Acute } \\
\text { Health } \\
\text { Hazard }\end{array}$ & $\begin{array}{c}\text { Chronic } \\
\text { Health } \\
\text { Hazard } \\
\end{array}$ \\
\hline Diesel Fuel/Heating Oil & $\mathrm{X}$ & & & & \\
\hline Gasoline & $\mathrm{X}$ & & & & \\
\hline Methanol/Gasoline & $\mathrm{X}$ & & & & \\
\hline Chlorine & & $\mathrm{X}$ & & $\mathrm{X}$ & \\
\hline Chlorofluorocarbon 11 & & $\mathrm{X}$ & & & \\
\hline Sulfuric Acid & & & & $X$ & \\
\hline Calcium Oxide & & & & $\mathrm{X}$ & \\
\hline Oils containing PCBs & & & & & $\mathrm{X}$ \\
\hline Lubricating Oils & $\mathrm{X}$ & & & & \\
\hline $\begin{array}{l}\text { NALCO } 356 \text { Amine } \\
\text { Corrosion Inhibitor }\end{array}$ & $\mathrm{X}$ & & & $\mathrm{X}$ & \\
\hline Pyrofoam & & & & & $\mathrm{X}$ \\
\hline
\end{tabular}

Section 304 of SARA Title III requires that the LEPC and state emergency planning agencies be notified of accidental or unplanned releases of certain hazardous substances to the environment. The procedures for notification are described in the Argonne Comprehensive Emergency Management Plan. No incidents occurred during 1995 that required notification of the LEPC and Illinois Emergency Management Agency.

\subsubsection{Section 313}

Section 313 of the EPCRA was enacted as a free-standing provision of the SARA in 1986. It requires facilities to prepare an annual report entitled "Toxic Chemical Release Inventory, Form R" if annual usage quantities of listed toxic chemicals exceed certain thresholds. In 1995, threshold chemical usage quantities were $10,000 \mathrm{lb}$ for listed chemicals either manufactured or processed. 
Seven Form R reports for 1994 were transmitted to DOE on June 28, 1995, for chemicals where use exceeded the $10,000 \mathrm{lb} / \mathrm{yr}$ reporting threshold. Table 2.12 lists chemicals reported under SARA Title III, Section 313 for 1994. The principal chemical uses for ANL-E are sulfuric acid at the boiler house, methanol for alternate fueled vehicles, and additives to gasoline. The vehicle fuels are all used on site, and consumption cannot be delineated between mobile sources and other uses. Future reporting for constituents in fuel will not be required. Subsequent to filing the report, the EPA amended SARA 313 reporting and eliminated the need for sulfuric acid reporting.

ANL-E data reflect operations and maintenance activities; they do not reflect exempt research and development. Air emissions data reflect full year use of air emissions control equipment installed in vehicle fueling operations during 1994.

On November 30, 1994, the EPA included an additional 286 chemicals and chemical categories to the Section 313 toxic chemical list. Reporting on these additional chemicals will be required beginning in calendar year 1995 (due July 1, 1996). ANL-E is currently reviewing material use to identify and implement source reduction techniques.

TABLE 2.12

SARA Title III, Section 313, Chemicals, 1994

\begin{tabular}{lcc}
\hline Chemicals $^{\mathrm{a}}$ & Off-site Transfer (lb) & Air Releases (lb) \\
\hline Methanol & 103.5 & 22.6 \\
Benzene & 0.91 & 4.67 \\
Toluene & 2 & 9.59 \\
Xylene (mixed isomers) & 1.9 & 19.59 \\
Methyl tert-Butyl ether & 0 & 5.14 \\
Cyclohexane & 6.86 & 0 \\
Naphthalene & 0 & 0 \\
\hline
\end{tabular}

a Range; 11-449 lb released to air. 


\subsection{Toxic Substances Control Act}

The Toxic Substances Control Act of 1976 (TSCA) provides for testing of manufactured substances to determine toxic or otherwise harmful characteristics and regulation of the manufacture, distribution, use, and disposal of regulated substances. The only TSCA-regulated compounds (other than training requirements for asbestos handling activities) in significant quantities at ANL-E are PCBs contained in electrical capacitors and transformer oil and PCBcontaminated sludge. Regulations governing PCB management, such as use and disposal and remediation of spills, are set forth in $40 \mathrm{CFR} 761$. These regulations provide detailed requirements for use and disposal of materials containing concentrations of PCBs above $50 \mathrm{ppm}$. Most of these regulations relate to PCBs contained in dielectric fluids within electrical equipment, such as transformers and capacitors.

\subsubsection{PCBs in Use at ANL-E}

The majority of PCBs at ANL-E were contained in a number of transformers, capacitors, and switches throughout the site. Starting in 1987, ANL-E began removing and disposing of all PCB and PCB-contaminated electrical equipment. All indoor and outdoor transformers, with the exception of one unit in Building 211, have been removed and transported off the site for proper disposal. During 1990, all pole-mounted transformers and circuit breakers containing PCBs were replaced or retrofilled with non-PCB oil. All removal and disposal activities were conducted by licensed contractors specializing in such activities. Accordingly, the equipment has been labeled to reflect its non-PCB status. Operation, removal, storage, and disposal of PCB-containing articles were conducted in compliance with applicable TSCA regulations.

During 1995, most of the ANL-E site was inspected and physically inventoried for suspect PCB materials and equipment. The physical inventory process was completed by the end of 1995 . To date, 1,750 suspect PCB materials and equipment have been identified. Most of the equipment identified and included within the inventory as potential PCB items are capacitors, either alone or in electrical equipment, generally older, out of service, experimental equipment, used for high 
voltage generation or control. All equipment with positive field tests will be laboratory tested to determine the exact PCB status.

ANL-E uses a computerized PCB inventory database for tracking PCB-containing articles. The database assists in the preparation of the PCB Annual Report, which was prepared during June 1995 for CY 1994. All articles originally on the PCB inventory are tagged with a PCB label. All suspect PCB materials and equipment are tagged according to their final status. Tags are provided to include demonstrated PCB-positive equipment and materials, equipment containing PCB capacitors, continued suspect PCB (if status cannot be determined), and proven non-PCB units, including the date of determination. Positive PCB materials are included in the PCB inventory database.

\subsubsection{Disposal of PCBs}

Disposal of PCBs from ANL-E operations includes materials lab-packed and bulked through WM and bulk solids shipped off site through WM. During 1995, large quantities of PCBcontaminated oil, water, and sludge were disposed of by ANL-E as the result of a PCBcontaminated waste oil cleanúp project conducted off site. Table 2.9 gives the amounts of PCBs and PCB-contaminated mạteriáls shipped by ANL-E during 1995.

\subsubsection{PCB Spills}

During 1995 , two treatability studies were conducted at off-site facilities with existing R\&D permits. The studies were to assess the effectiveness of technologies for treating PCB- and radionuclide-contaminated sludge from the Laboratory's WTP. The PCB-contaminated sludge was removed, containerized, and stored on site during 1994. Removal of the drying beds and closure of the area will also be recommended to DOE. The area has been identified as a SWMU subject to the corrective action provisions of RCRA. The schedule for closure of the drying beds will be decided as part of the RCRA corrective action process. 
A secondary issue, finding the source of the PCBs contaminating the Laboratory's WTP, has been a subject of concern. To address it, ANL-E initiated a project in FY 1994 to characterize the contents of all retention tanks across the Laboratory. The retention tanks serve as collection vessels for ANL-E buildings that handle radioactive materials. The purpose of the tanks is to ensure that laboratory wastewater containing unacceptable quantities of radioactive materials does not have a direct link to the Laboratory WTP sewer. When full, ANL-E analyzes the tanks' contents for radioactivity, and if results are below the release limits, the water is released to the WTP.

Sampling during 1995 identified retention tanks in six buildings with PCB concentrations greater than 50 ppm. The buildings include Building 203 (4620 ppm), Building 211 (91 ppm), Building 223 (170 ppm), Building 315 (62 ppm), Building 350 (78 ppm), and Building 375 (51 ppm). The retention tanks in Building 203 were decontaminated during late 1995. The tanks were cleaned according to regulatory requirements. A cleaned tank will no longer be classified as a "PCB container." Clean out of the remaining PCB-contaminated tanks will be scheduled as funds become available. The purpose of the sampling and clean out is to isolate the sources of PCB contamination across the ANL-E site and to clean out the system from the "headwaters" to the WTP.

The EPA conducted two follow-up investigations on November 10, 1994, and January 13, 1995, regarding the inadvertent shipment of PCB-contaminated oil. No subsequent investigation results were received from the EPA during 1995.

\subsection{Endangered Species Act}

The Endangered Species Act of 1973 (ESA) is designed to protect plant and animal resources from the adverse effects of development. Under the Act, the Secretaries of the Interior and Commerce are directed to establish programs to ensure the conservation of endangered or threatened species or critical habitat of such species. For ANL-E, the FWS has been delegated authority to conduct these consultations and enforce the ESA. 


\section{COMPLIANCE SUMMARY}

To comply with the ESA, federal agencies are required to assess the proposed project area to determine if any threatened or endangered species or critical habitat of these species exist. If no such species or habitat are present, this fact is to be documented in a letter to the FWS. If such species or habitat are found to exist, the FWS is to be notified, and a series of consultations and studies are then carried out to determine the extent of impact and any special actions that must be taken to minimize this impact.

At ANL-E, the provisions of the ESA are implemented through the NEPA project review process. All proposed projects must provide a statement describing the potential impact to threatened or endangered species and critical habitat. This statement is included in the general Project Environmental Evaluation Form. If there is the potential for adverse impact, this impact will be further assessed and evaluated through the preparation of a more detailed NEPA document, such as an EA or EIS.

Neither federal nor state-listed threatened or endangered species are known to reside on the ANL-E site. The federally listed endangered Indiana Bat, Myotis sodalis, and the federally threatened Hine's Emerald Dragonfly, Somatochlora hineana, reside in the area and may possibly reside on the ANL-E site. Two state-endangered species - River Otter, Lutra canadensis, and White Lady's Slipper, Cypripedium candidum - and two state-threatened species - Kirtland's Snake, Clonophis kirtlandi, and sedge, Carex crawei - reside in the area and may possibly reside on the ANL-E site. Impacts to these species are also assessed during the NEPA process. No project at ANL-E has ever had to be stopped, delayed, or modified as a result of potential impact to endangered species.

\subsection{National Historic Preservation Act}

The National Historic Preservation Act (NHPA) requires federal agencies to assess the impact of proposed projects on historic or culturally important sites, structures, or objects within the site of the proposed projects. It further requires federal agencies to assess all sites, buildings, and objects on the site to determine if any qualify for inclusion in the NRHP. The act also 


\section{COMPLIANCE SUMMARY}

establishes a procedure for archaeological activities and a system of civil and criminal penalties for unlawfully damaging or removing such artifacts.

The NHPA is implemented at ANL-E through the NEPA review process, as well as through the internal digging permit process. All proposed actions must consider the potential impact to historic or culturally important artifacts and document this consideration in the Project Environmental Evaluation Form. If the proposed site has not been surveyed for the presence of such artifacts, a cultural resources survey is conducted, and any artifacts found are carefully documented and removed. Prior to disturbing the soil, an ANL-E digging permit must be obtained from the Plant Facilities and Services Division. This permit must be signed by an individual who is familiar with the location of archaeological sites at ANL-E prior to digging, to document the fact that no significant cultural resources will be impacted.

During 1993, fieldwork was completed on the archaeological survey of the ANL-E site. Phase I archaeological surveys were conducted to identify the location of potential historic and prehistoric sites at ANL-E. The results of the Phase I surveys were documented in reports that were subsequently submitted to the Illinois Historic Preservation Agency (IHPA) for review. Upon completion of the review, the IHPA makes a determination as to whether or not the sites are eligible for nomination to the NRHP. If the sites are deemed not eligible, the area is considered "cleared," and no further archaeological review is required. If however, the IHPA believes that a site is significant and potentially eligible for nomination to the NRHP, a Phase II survey is recommended. The Phase II survey intensively characterizes the site, and the reported findings are again reviewed by the IHPA to determine the site's eligibility to the NRHP.

Preparation of the Cultural Resource Management (CRM) plan, which included the final site map, was completed in September 1995. The plan, which is currently undergoing review, summarizes the results of the ANL-E site survey and includes additional information from surveys of smaller projects. Three of the archaeological sites identified have been determined by the IHPA to be historically significant and eligible for listing on the NRHP. ANL-E has chosen to leave the sites undisturbed but does not plan to list them on the NRHP. 


\section{COMPLIANCE SUMMARY}

Approximately 20 of the sites identified have been determined to be potentially eligible for NRHP listing. If the sites are to be disturbed, further testing is required before doing so. Another 20 sites (approximately) have been determined to be NRHP ineligible. All sites are identified on the map and described in detail in the CRM Plan.

The survey conducted for the preparation of the CRM Plan did not include an evaluation of on-site historic structures. Three structures may have historical significance: the former CP-5 Reactor; the EBWR; and the Argonne Thermal Source Reactor. A formal evaluation of those structures is planned for 1996.

\subsection{Floodplain Management}

Federal policy on managing flood plains is contained in Executive Order 11988 (May 24, 1977). In addition, 10 CFR 1022 describes DOE's implementation of this Executive Order. This Executive Order requires federal facilities to avoid, to the extent possible, adverse impacts associated with the occupancy and modifications of floodplains. A project proposed for construction in a floodplain must demonstrate that there is no reasonable alternative to the floodplain location.

The ANL-E site is located approximately $46 \mathrm{~m}(150 \mathrm{ft})$ above the nearest large body of water (Des Plaines River) and thus is not subject to major flooding. A number of small areas, associated with Sawmill Creek and other small streams or low-lying areas, are subject to local flood conditions following extremely heavy precipitation. To ensure that these areas are not adversely impacted, ANL-E has maintained a practice of not permitting new facility construction within these areas, unless there is no practical alternative. Any impact to floodplains are fully assessed in a floodplain assessment, and, as appropriate, documented in the NEPA documents prepared for a proposed project. 


\section{COMPLIANCE SUMMARY}

\subsection{Protection of Wetlands}

Federal policy on wetland protection is contained in Executive Order 11990. In addition, 10 CFR 1022 describes DOE's implementation of this Executive Order. This Order requires federal agencies to identify potential impacts to wetlands resulting from proposed activities and to minimize these impacts. Where impacts cannot be avoided, action must be taken to mitigate the damage by repairing the damage or replacing the wetlands with an equal or greater amount of a man-made wetland as much like the original wetland as possible. The current DOE policy is for no net decrease in the amount of wetland as a result of DOE activities.

Because of its topography and the nature of the soil at ANL-E, the site contains a significant number of natural and man-made wetlands. These range from small storm water ditches overgrown with cattails to natural depressions, beaver ponds, and man-made ponds. Potential impacts to those areas from proposed actions are assessed in wetlands assessments and NEPA documentation as appropriate. The APS project, currently nearing completion, required a U.S. Army Corps of Engineers Section 404 permit and extensive wetland mitigation activities, since several small natural wetlands occupied the construction site and had to be replaced elsewhere. These actions were documented in the EA that was approved in early 1990.

During 1993, a sitewide wetlands delineation was completed of the ANL-E site. A survey was conducted to identify and delineate all jurisdictional wetlands present on-site in accordance with the 1987 U.S. Army Corps of Engineers Wetlands Delineation Manual. ${ }^{6}$ The results of the survey were delineated on a site map indicating the aerial extent of all wetlands present at ANL-E down to $500 \mathrm{~m}^{2}$ (1/8th acre). The findings are documented in an accompanying report that describes in detail the soil, vegetation, and hydrology of each wetlands area delineated on the map. Thirty-five individual wetland areas were identified totaling approximately 18 ha (45 acres). The wetlands areas were also digitized onto a computer-aided design file in order to provide ANL-E engineers with scale maps for planning and designing projects. The delineation will also be useful for determining project impacts under NEPA review. 
Activities in 1995 were limited to the dissemination of the sitewide wetlands map to ANL-E and DOE personnel requiring wetlands information. Delineations were also performed for several specific projects to be conducted in close proximity to wetlands identified on the sitewide map. The purpose of these delineations was to specifically identify wetlands boundaries in order to assess project impacts. In 1996, wetlands maps will continue to be disseminated as necessary, and specific delineations will continue to be performed for projects occurring near wetlands identified on the sitewide map. No significant activities are planned for 1996.

\subsection{Current Issues and Actions}

The purpose of this section is to summarize the most important issues related to environmental protection encountered during 1995. Since preceding sections of this chapter contain detailed discussions of specific issues related to each major piece of environmental regulation, discussions of specific issues will not be repeated in this section. These details can be found in the appropriate section of this chapter.

\subsubsection{Major Compliance Issues}

The most significant ongoing issue encountered at ANL-E during 1995 involves wastewater discharges, which affect compliance with existing NPDES wastewater discharge permit requirements. ANL-E was issued a new NPDES permit, effective October 30, 1994. The new permit included a number of changes to sampling parameters and frequency for various outfalls. Since the permit became effective, ANL-E has not been able to consistently meet the permit limits for TDS, copper, ammonia-nitrogen, and TRC. The modified NPDES Permit (August 24, 1995) provides for identifying and implementing actions needed to ensure compliance with ANL-E's NPDES permit by July 1998. Plans to upgrade or construct the necessary wastewater treatment facilities are underway. Plans are also underway to provide ANL-E with Lake Michigan water late in 1996.

Another significant issue at ANL-E during 1995 involves the inadvertent shipment during 1994, through an independent contractor, of waste oil contaminated with PCBs to an off-site 
recycling facility. The EPA and the IEPA were informed of the incident, and both agencies conducted investigations at ANL-E relating to the incident. The IEPA issued a Compliance Inquiry Letter on November 14, 1994, stating that ANL-E was in apparent violation of certain special waste regulations in 35 IAC Parts 808 and 809. ANL-E formally responded through DOE on December 14, 1994. On January 10, 1995, the IEPA formally notified ANL-E that it had been returned to compliance for the apparent violations. During 1995, there had been no correspondence from the EPA following that agency's investigations. In May 1995, DOE sent a letter to ANL-E expressing concern that the events leading to the misidentification and release of the PCB-contaminated oil were in accordance with established policies and procedures. DOE requested that ANL-E evaluate and modify relevant policies and procedures to improve operations and minimize the risk of future incidents. This will be a continuing compliance action for 1996.

During 1995, ANL-E exceeded the action level for copper in drinking water samples. As a result, a number of follow-up actions must be performed. These actions include additional sampling for copper, lead, and water quality parameters during 1996 and maintenance of corrosion control measures.

The IEPA-approved sanitary landfill groundwater monitoring program continues to indicate that the Ground Water Quality Standards of some routine indicator parameters are consistently being exceeded. Contamination in this area will be addressed under the RCRA Corrective Action Program (see Section 2.3.9).

\subsubsection{Regulatory Agency Interactions}

The regulatory agency interactions with ANL-E during 1995 related primarily to site inspections regarding permit requirements and a PCB-contaminated oil issue. One outstanding compliance issue that has been formally identified by regulatory agencies relates to the closed ANL-E solid waste landfill. DOE's failure to modify its property deed to reflect the fact that the landfill had been used for the disposal of ACM, thus making said disposal part of the public record and subject to discovery during a title search of the property, resulted in a formal notice of noncompliance from the IEPA. DOE provided a response to IEPA on July 8, 1994, indicating 
that steps would be taken to modify the deed. DOE has conducted a survey to obtain an accurate legal description of the ANL-E boundary. The survey revealed inaccuracies in the assumed property boundary. DOE is undertaking discussions with the adjacent property owner to resolve these issues.

\subsection{Environmental Permits}

Table 2.13 lists all environmental permits in effect at the end of 1995. Other portions of this chapter discuss special requirements of these permits and compliance with those requirements. The results of monitoring required by these permits are discussed in those sections, as well as in Chapters 5 and 6. 
TABLE 2.13

\begin{tabular}{|c|c|c|c|c|}
\hline $\begin{array}{l}\text { Permit } \\
\text { Requirement }\end{array}$ & Source Name & Building & $\begin{array}{l}\text { Date } \\
\text { Issued }\end{array}$ & $\begin{array}{c}\text { Expiration } \\
\text { Date }\end{array}$ \\
\hline $\operatorname{Air}^{\mathrm{a}}$ & ALEX Alkali Metal Scrubber & 370 & $12 / 5 / 91$ & $12 / 3 / 96$ \\
\hline Air & Alkali Booth & 308 & $2 / 15 / 89$ & $11 / 18 / 98$ \\
\hline NESHAP & Alkali Booth & 206 & $6 / 9 / 93$ & $6 / 9 / 97$ \\
\hline Air & Argonne Service Station & 300 & $1 / 9 / 91$ & $10 / 4 / 00$ \\
\hline Air & Central Shops Rotoclone Dust Collection System & 363 & $3 / 12 / 91$ & $1 / 8 / 01$ \\
\hline Air & Gasoline Dispensing Facility (Modified) ${ }^{b}$ & 46 & $2 / 1 / 93$ & $5 / 2 / 00$ \\
\hline Air & Medical Department Steri-Vac Sterilizer & 201 & $3 / 27 / 91$ & $3 / 22 / 96$ \\
\hline Air & Methanol/Gasoline Storage Tank & 46 & $9 / 24 / 91$ & $9 / 23 / 96$ \\
\hline Air & Oil Fired Boilers & 800 Area & $11 / 1 / 91$ & $10 / 29 / 96$ \\
\hline Air & Open-Burning - Fire Training & Sitewide & $2 / 4 / 94$ & $4 / 17 / 96$ \\
\hline Air & Proton Decay Project Grieve Oven & 366 & $8 / 8 / 91$ & $8 / 6 / 96$ \\
\hline Air & Boiler House & 108 & $12 / 28 / 93$ & $12 / 28 / 98$ \\
\hline Air & Sulfuric Acid Storage Tank & 108 & $1 / 17 / 91$ & $12 / 1 / 99$ \\
\hline NESHAP & Vapor Degreaser ${ }^{c}$ & 363 & $3 / 13 / 90$ & $12 / 1 / 99$ \\
\hline Air & Wood Shop Dust Collection System - Operate & 809 & $12 / 16 / 93$ & $10 / 17 / 96$ \\
\hline NESHAP & Advanced Photon Source - Operating Permit - IEPA & 400 & $12 / 21 / 93$ & $7 / 26 / 98$ \\
\hline NESHAP & Alpha-Gamma Hot Cell Facility & 212 & $3 / 25 / 91$ & $8 / 9 / 00$ \\
\hline NESHAP & Building 212 Exhausts ${ }^{d}$ & 212 & $7 / 30 / 91$ & $7 / 23 / 96$ \\
\hline NESHAP & Building 306 Vents and 317 Area & 306 & $8 / 6 / 91$ & $7 / 25 / 96$ \\
\hline NESHAP & Continuous Wave Deuterium Detector (CWDD) & 369 & $5 / 9 / 91$ & $12 / 28 / 99$ \\
\hline NESHAP & $\mathrm{CP}-5$ & 330 & $5 / 10 / 91$ & $12 / 8 / 96$ \\
\hline NESHAP & Cyclotron & 211 & $5 / 10 / 91$ & $12 / 1 / 99$ \\
\hline
\end{tabular}


TABLE 2.13 (Cont.)

\begin{tabular}{|c|c|c|c|c|}
\hline $\begin{array}{l}\text { Permit } \\
\text { Requirement }\end{array}$ & Source Name & Building & $\begin{array}{l}\text { Date } \\
\text { Issued }\end{array}$ & $\begin{array}{l}\text { Expiration } \\
\text { Date }\end{array}$ \\
\hline NESHAP & EBWR HEPA Filtration System & 331 & $3 / 25 / 91$ & $12 / 5 / 99$ \\
\hline NESHAP & Intense Pulsed Neutron Source & 375 & $3 / 25 / 91$ & $8 / 9 / 00$ \\
\hline NESHAP & M-Wing Hot Cells & 200 & $3 / 25 / 91$ & $8 / 9 / 00$ \\
\hline NESHAP & NBL Plutonium and Uranium Hoods & 350 & $4 / 25 / 91$ & $4 / 19 / 96$ \\
\hline NESHAP & Rad Hoods & Sitewide & $7 / 9 / 92$ & $7 / 9 / 97$ \\
\hline NESHAP & Map Tube Facility & 317 & $5 / 10 / 94$ & $5 / 10 / 99$ \\
\hline Air & APS Emergency Generators & 400 & $5 / 16 / 94$ & $3 / 15 / 99$ \\
\hline Air & Waste Bulking Sheds ${ }^{\mathrm{e}}$ & 306 & $6 / 14 / 94$ & $7 / 25 / 96$ \\
\hline NESHAP & WM HEPA Filter System & Sitewide & $9 / 28 / 94$ & 9/28/99 \\
\hline NESHAP & Rehabilitation - Phase $\mathrm{I}^{\mathrm{f}}$ & 306 & $3 / 13 / 95$ & $7 / 25 / 96$ \\
\hline Air & Hazardous Waste Storage Facility & 307 & $5 / 24 / 95$ & $4 / 26 / 00$ \\
\hline NESHAP & Mixed Waste Storage Facility & 303 & $5 / 18 / 95$ & $4 / 26 / 00$ \\
\hline NESHAP & Rad Waste Storage Facility & 331 & $5 / 18 / 95$ & $4 / 26 / 00$ \\
\hline NESHAP & Lead Brick Cleaning & $200 / 317$ & $6 / 20 / 95$ & $6 / 19 / 00$ \\
\hline Air & Paint Spray Booth & 815 & $7 / 3 / 95$ & $6 / 27 / 00$ \\
\hline Air & Torch Cutting Fumes & Sitewide & $7 / 20 / 95$ & $7 / 20 / 00$ \\
\hline NESHAP & PCB Tank Cleanout ${ }^{g}$ & Sitewide & $8 / 16 / 95$ & 9/28/99 \\
\hline NESHAP & Laboratory Wastewater Plant & 575 & $8 / 29 / 95$ & $8 / 29 / 00$ \\
\hline Hazardous Waste & RCRA Part A Permit & Sitewide & $4 / 30 / 82$ & h \\
\hline Hazardous Waste & RCRA Part A Modification - Storage Units & Sitewide & $2 / 18 / 93$ & - \\
\hline Hazardous Waste & RCRA Part A Modification - Scintillation Vials & Sitewide & $9 / 22 / 93$ & - \\
\hline Hazardous Waste & RCRA Part A Modification - Storage & $303 / 307 / 331$ & $10 / 12 / 95$ & - \\
\hline
\end{tabular}


TABLE 2.13 (Cont.)

\begin{tabular}{|c|c|c|c|c|}
\hline $\begin{array}{l}\text { Permit } \\
\text { Requirement }\end{array}$ & Source Name & Building & $\begin{array}{c}\text { Date } \\
\text { Issued }\end{array}$ & $\begin{array}{c}\text { Expiration } \\
\text { Date }\end{array}$ \\
\hline Miscellaneous & Nuisance Wildlife Control & Sitewide & $1 / 31 / 95$ & $12 / 31 / 95$ \\
\hline Solid Waste & Landfill & 800 Area & $3 / 31 / 82$ & - \\
\hline Şolid Waste & Landfill & 800 Area & $3 / 30 / 89$ & - \\
\hline Solid Waste & Landfill & 800 Area & $4 / 12 / 89$ & - \\
\hline Solid Waste & Landfill Leachate Test Wells & 800 Area & $8 / 31 / 90$ & - \\
\hline Solid Waste & Landfill Groundwater Assessment & 800 Area & $9 / 30 / 91$ & - \\
\hline Solid Waste & Landfill Leachate Characterization & 800 Area & 9/30/91 & - \\
\hline Solid Waste & Landfill Revised Closure Plan & 800 Area & $4 / 24 / 92^{i}$ & - \\
\hline Solid Waste & Landfill Supplemental Closure Plan & 800 Area & $9 / 15 / 92$ & - \\
\hline Water & APS Wetland & Sitewide & $11 / 22 / 88$ & - \\
\hline Water & Landfill Wetlands & 800 Area & $5 / 20 / 81$ & - \\
\hline Water & Lime Sludge Application - Land Application & Sitewide & $1 / 12 / 94$ & $12 / 31 / 98$ \\
\hline Water & NPDES Permitted Outfalls & Sitewide & $10 / 31 / 94$ & $7 / 1 / 99$ \\
\hline Water & NPDES Storm Water Outfalls & Sitewide & $10 / 31 / 94$ & $7 / 1 / 99$ \\
\hline Water & Canal Water Treatment Plant Overflow & Sitewide & $3 / 5 / 93$ & - \\
\hline
\end{tabular}


TABLE 2.13 (Cont.)

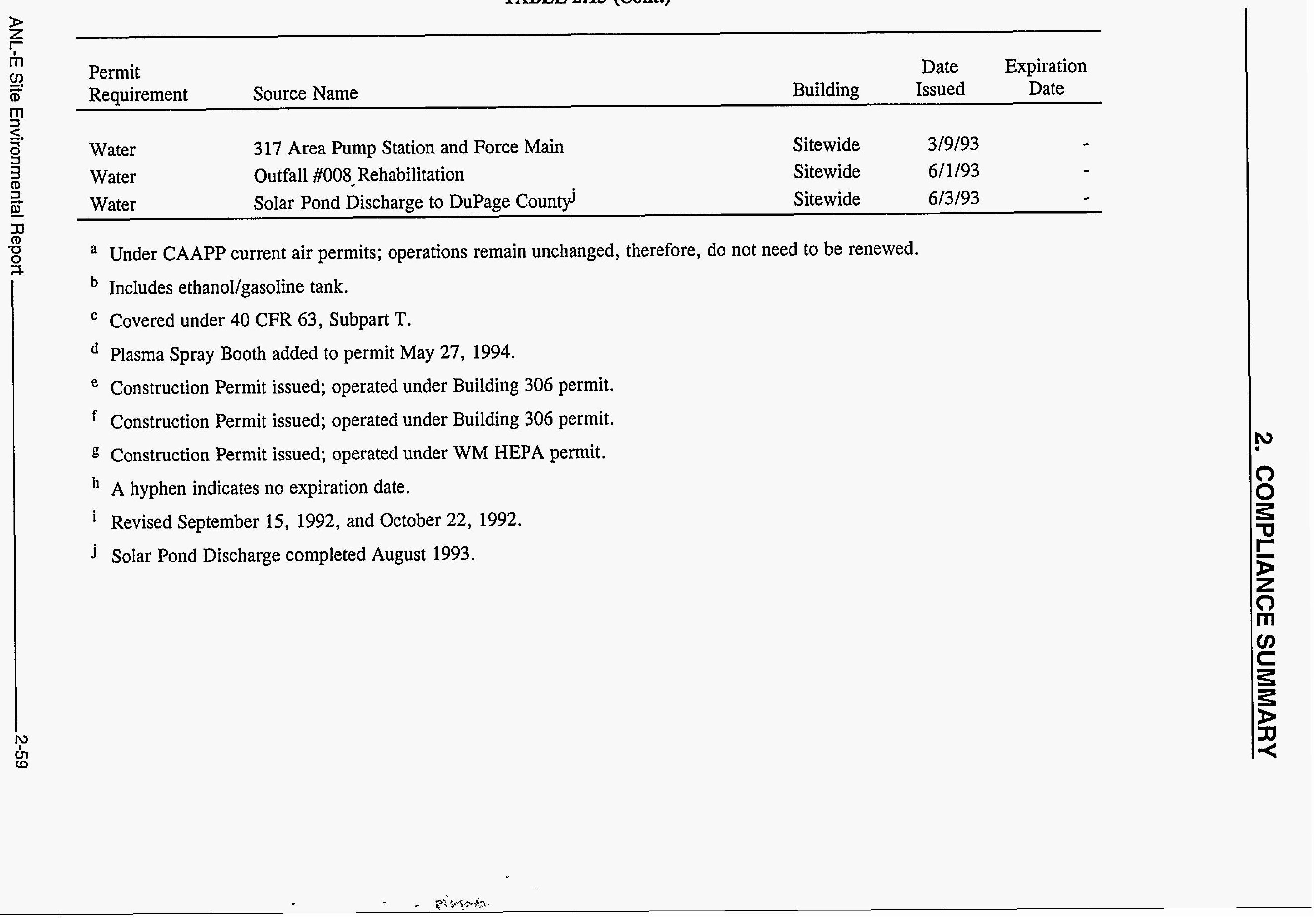




\section{ENVIRONMENTAL PROGRAM INFORMATION}

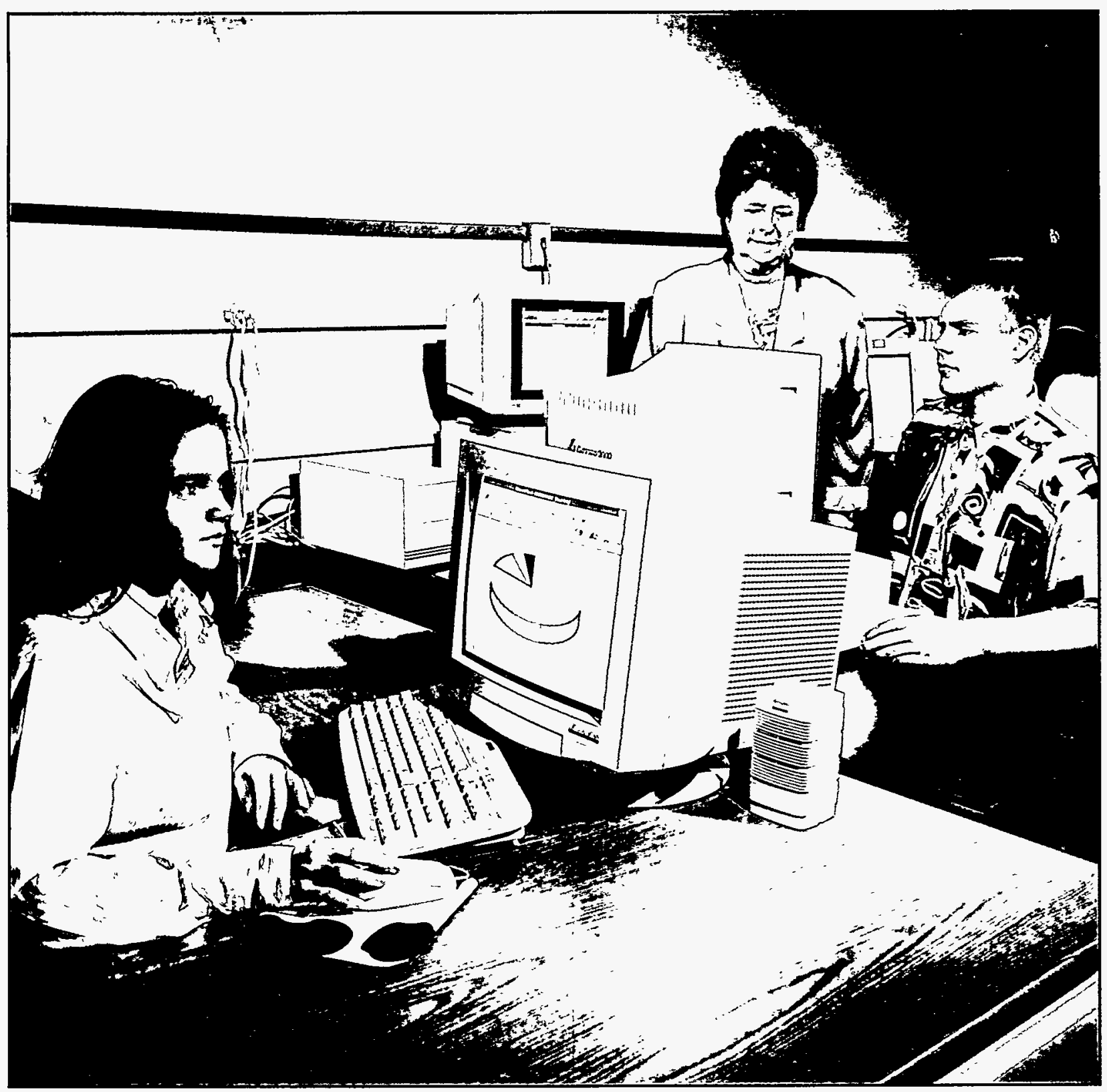


DOE and ANL-E policies require that all operations be conducted in compliance with applicable environmental statutes, regulations, and standards and that environmental obligations be carried out consistently across all operations and organizations. Protection of the environment and human health and safety are given the highest priority. A number of programs and organizations exist at ANL-E to ensure compliance with these regulations and to monitor and minimize the impact of Laboratory operations on the environment.

\subsection{Environmental Management Programs}

ANL-E management has designated Environmental Management Operations (EMO) as the lead environmental organization. EMO's mission is to proactively support ANL-E operations by conducting those activities that ensure compliance with applicable environmental statutes, regulations, DOE Orders, and ANL-E policies and procedures. These activities include technical support in the preparation of permits and compliance documents, consideration of applicable regulatory requirements, and liaison with oversight and compliance organizations; proper collection, treatment, and disposal of radioactive, hazardous, and nonhazardous waste materials; and the conduct of the ANL-E environmental monitoring and surveillance program. These activities are carried out to minimize the potential adverse effects to the health and safety of personnel at the ANL-E site and the general public, to property, and to the environment.

EMO is divided into four major operational departments: Environmental Projects; Waste Management; Waste Reduction; and Environmental Protection. The principal function of EMO is to serve as the ANL-E focal point for implementation of the DOE Office of Environmental Management program.

In 1989, DOE established the goal of achieving compliance with applicable regulations, assessing and cleaning up releases of hazardous materials from inactive waste sites, and returning all such sites to unrestricted use within 30 years. To increase the likelihood of achieving this goal, DOE established the Environmental Restoration and Waste Management Program, now designated as the Environmental Management Program. This program identifies specific needs and establishes a system for allocating funds to support ongoing activities and resolve the various 


\section{ENVIRONMENTAL PROGRAM INFORMATION}

deficiencies. Each of the DOE facilities has prepared a set of planning documents (Activity Data Sheets [ADSs]) describing the activities necessary to bring that specific site into compliance and to identify and clean up inactive waste sites. These planning documents are contained in a report that is updated and published annually, the Environmental Management Plan. The plan projects and activities are subdivided into three categories, namely, corrective activities (those actions necessary in the short term to bring a facility into compliance with environmental regulations), environmental restoration activities (those activities necessary to identify and clean up inactive waste sites and other sites potentially contaminated as a result of DOE activities), and waste management activities (designed to ensure that hazardous and radioactive wastes are stored and disposed of safely and the volume of waste is minimized). The $1995 \mathrm{Plan}$ contained information on 19 separate projects. Table 3.1 lists the on-site activities. The plan is a public document available upon request from DOE.

\subsubsection{Environmental Projects}

The role of the Environmental Projects Department is to support ANL-E operations, organizations, and DOE environmental missions by managing environmental projects in accordance with applicable DOE Orders and environmental authorities. The department provides project management and engineering support for environmental remediation projects. Project management functions include the development of work scopes, project budgets, and schedules. The projects implemented by this department are designed to minimize any current or future impact to the environment or human health.

The corrective activity projects at ANL-E involve the construction of new or upgraded wastewater treatment facilities used for disposal of wastewater from ANL-E. As discussed in Chapters 2 and 5, the site has violated its NPDES wastewater discharge permit a number of times in recent years. Many of these violations can be attributed to the lack of appropriate treatment technology to comply with current effluent limits. These deficiencies will be resolved as these corrective action projects are completed. During 1995, design was completed on the WTP upgrade, and construction was started on the sanitary plant upgrade. 


\section{ENVIRONMENTAL PROGRAM INFORMATION}

\section{TABLE 3.1}

Environmental Management Projects

\begin{tabular}{|c|c|}
\hline $\begin{array}{l}\text { ADS } \\
\text { Number }\end{array}$ & Title \\
\hline CH 1300 & Facility Operations and Maintenance - Defense Programs \\
\hline CH 1301A & Waste Management Projects - Nondefense Programs \\
\hline $\mathrm{CH} 1301 \mathrm{~B}$ & Facility Operations and Maintenance - Nondefense Programs \\
\hline CH 1303 & Rehabilitation of Waste Management Building \\
\hline CH 1304 & Hazardous, Radioactive, and Mixed Waste Storage Facility \\
\hline CH 1306 & Sanitary Wastewater Treatment Plant Improvements \\
\hline CH 1308 & Laboratory and Sanitary Sewage Collection System Rehabilitation \\
\hline CH 1309 & Laboratory Wastewater Treatment Plant Improvements \\
\hline CH 1310 & Treatment of Boiler House Area Wastewater \\
\hline CH 1311 & Canal Water Treatment Plant Rehabilitation \\
\hline $\mathrm{CH} 1313$ & Cooling Tower Blowdown Water Diversion \\
\hline CH 1432 & Remedial Support Activities \\
\hline CH 1433 & Solid Waste Storage/Disposal \\
\hline CH 1434 & Mixed Waste Storage/Disposal Facilities \\
\hline CH 1435 & Treatment Sites \\
\hline CH 1436 & Facility Conversion D\&D Projects \\
\hline CH 1437 & Reactor Facilities D\&D Projects \\
\hline CH 1438 & Support Facilities D\&D Projects \\
\hline CH 1439 & Program Management \\
\hline
\end{tabular}

Environmental Restoration activities represent the projects designed to carry out the objective of assessing and cleaning up inactive waste sites. ANL-E contains a number of inactive waste sites that were used for the disposal of waste during the early years of Laboratory operations. These sites include two inactive landfills, three French drains (which consisted of shallow pits used for disposal of liquid wastes), two inactive wastewater treatment facilities, and a number of areas that may have been contaminated through the discharge of small amounts of hazardous chemicals. Several sites used from the 1940s through the 1970s for open burning of combustible waste and construction debris also exist. A series of ongoing and planned activities has been designed to foster the cleanup of these sites. 


\section{ENVIRONMENTAL PROGRAM INFORMATION}

Environmental Restoration projects at ANL-E are typically broken down into two phases: the characterization phase and the remediation phase. Several of the characterization projects were started in 1989 and 1990. Additional chäracterization is required before significant remediation can be undertaken. The results of some of this early characterization work is presented in Chapter 6. Following the characterization phase, projects designed to clean up and dispose of residual contamination found during characterization will commence.

In addition to the inactive waste site cleanup projects, the plan also contains a number of D\&D projects for on-site nuclear facilities. These D\&D projects are managed within the Technology Development Division. The ANL-E site contains several inactive nuclear reactors and hot cells used in the past for processing radioactive materials. These facilities are either currently undergoing D\&D or are scheduled for D\&D in the next few years. The D\&D operations will remove residual radiological contamination, dispose of radiologically contaminated materials, and return the facilities to unrestricted use status. The largest of such activities, the D\&D of the EBWR and the cleanup of the hot cells in Building 200, were completed by the end of the year.

\subsubsection{Waste Management Department}

The Waste Management Department's missions are to provide treatment, storage, and disposal of all regulated waste generated at ANL-E in compliance with state and federal regulations at minimal cost, and to supply skilled craftspeople uniquely trained to safely provide decontamination and operational support activities for facilities that generate radioactive, hazardous, and other specialized wastes.

The projects included in this section of the plan represent activities necessary to ensure that waste materials currently being generated are properly stored, treated and disposed of. A primary motivation for the improvement in waste handling and disposal operation is the need to upgrade such facilities to comply with increasingly stringent RCRA requirements as well as other state and federal regulations and DOE Orders. The majority of the Waste Management projects involve improvements to existing treatment or storage facilities. Much of the ANL-E waste is a mixture 


\section{ENVIRONMENTAL PROGRAM INFORMATION}

of radioactive and chemically hazardous materials. This waste will be treated in accordance with the FFCA Site Treatment Plan.

\subsubsection{Waste Reduction Department}

The role of the Waste Reduction Department is to develop, promote, and implement waste reduction technologies, practices, policies, and environmental quality through training, review, culture change, and operational activities at ANL-E in support of DOE missions.

\subsubsection{Environmental Protection Department}

The Environmental Protection Department is composed of the Environmental Compliance Section and the Monitoring and Surveillance Section. Environmental protection activities are those sets of actions conducted at ANL-E to ensure the safety of the public, protection of the environment, and compliance with applicable federal, state, and local environmental regulations and with DOE Orders.

The mission of the department is to define the applicable compliance requirements with assistance from ANL-E's Legal Department. The department helps to ensure that ANL-E is in compliance with these standards. Department activities include defining applicable federal, state, and local regulations; defining applicable DOE Orders; developing sitewide regulatory programs; providing technical support in the preparation of permits and NEPA documents; providing technical support and guidance to the ANL-E programs through the Environmental Compliance Representative (ECR) and the Environment, Safety and Health (ESH) representative; conducting reviews of construction projects and experiments; and acting as the liaison to external regulatory agencies and coordinating with internal research and support groups.

Monitoring and surveillance are conducted to determine the effects, if any, of ANL-E activities on the public and on the on-site and off-site environment. Effluent monitoring consists of collecting and analyzing samples or measurements of liquid and gaseous effluents for the purpose of characterizing and quantifying contaminants, assessing radiation exposures to members 


\section{ENVIRONMENTAL PROGRAM INFORMATION}

of the public, providing a means to control effluents at or near the point of discharge, and demonstrating compliance with applicable standards and permit requirements. Environmental surveillance consists of collecting and analyzing samples or direct measurements of air, water, soil, foodstuffs, biota, and other media from the ANL-E site and its environs for the purpose of determining compliance with applicable standards and permit requirements, assessing radiation exposure of the public, and assessing the effects, if any, of ANL-E operations on the local environment. The information generated by this program is compiled each year in the ANL-E Site Environmental Report, which is distributed to ANL-E and DOE personnel and to federal, state, and local regulators.

\subsection{Environmental Support Programs}

\subsubsection{Self-Assessment}

In preparation for the 1990 Tiger Team visit, ANL-E conducted a formal top-down environmental self-assessment. This was followed in the next two years with self-assessments on Tiger Team findings, root causes, and action plans. For 1995, the self-assessment was expanded and formalized to document accomplishments and to develop short- and long-term goals and plans for improvement. All ANL-E organizational units were required to participate in the 1995 assessment.

A guidance document was prepared to standardize the self-assessment process, and organizational assignments were made to coordinate the effort. The following nine topics were selected for the 1995 self-assessment:

- Job or facility-specific training,

- Documentation and records,

- Implementation of building emergency plans,

- Risk management and occupational injuries,

- Egress management (life safety),

- Implementation of chemical hygiene plans, 


\section{ENVIRONMENTAL PROGRAM INFORMATION}

- Implementation of the as low as reasonably achievable (ALARA) process for radiological exposure,

- Environmental protection, and

- Waste minimization.

The product of the assessment was a report that briefly described the mission of the organization and the assessment process; provided a summary of the overall results of the assessment against the nine topics; and established goals, timelines, and milestones. Organizational unit reports were rolled up into higher level reports.

\subsubsection{Environmental Training Programs}

ANL-E has a comprehensive environmental protection training program that includes mechanisms to identify, track, and document requirements for every employee. Environmental protection training for ANL-E personnel is primarily provided by the ESH Training Section, although ancillary training may be delivered by subject matter experts from other organizations. Personnel training requirements are mandated by DOE Orders, the U.S. Department of Transportation (DOT), EPA, and OSHA regulations and are identified by a Job Hazards Checklist form that is completed by every employee and reviewed by the employee's supervisor. A positive answer to any one of a battery of specific questions triggers the training requirements specific to that question. Options also exist for division-required training, recommended training, and elective training.

The system for ensuring that the training (1) meets compliance, (2) is completed, and (3) is documented and managed through the Training Management System, is an on-line main frame computer-based system. Environmental protection training courses and course descriptions are listed in the Training Course Catalog available from divisional representatives, the ESH Training System, or from Human Resources. 


\section{ENVIRONMENTAL PROGRAM INFORMATION}

\subsubsection{Pollution Prevention - Waste Minimization}

Waste minimization is a policy specifically mandated by the Congress in the 1984 Hazardous and Solid Waste Amendments to RCRA. RCRA requires hazardous waste generators to establish a program to reduce the volume or toxicity of waste to the degree determined by the generator to be "economically practicable." Hazardous waste generators, such as ANL-E, must certify in their waste manifest that this requirement has been fulfilled. Generators must also identify in their annual reports to the IEPA the efforts undertaken during the year to reduce the volume and toxicity of waste generated and the changes in volume and toxicity actually achieved.

Pollution is to be prevented at the source wherever and whenever possible. Those potential waste materials that cannot be eliminated or minimized by source reduction are to be recycled, that is, used, reused, or reclaimed. All waste that is nevertheless generated is to be treated to reduce volume, toxicity, or mobility before storage or disposal. Reducing or eliminating the generation of waste should be given prime consideration in research, process design, and plant operations.

DOE Orders $5400.1^{1}$ and $5820.2 \mathrm{~A}^{7}$ and their successors mandate that the management of radioactive waste and other pollutants shall be accomplished in a manner that minimizes the generation of such wastes.

ANL-E has a long-standing history of pollution prevention and waste minimization dating back to the founding of the Laboratory 50 years ago. The first activities included recycling of metals, rare earths, and radionuclides. Efforts to coordinate and expand Pollution Prevention and Waste Minimization Activities were formalized in 1992 with the development of the Waste Prevention Program.

The program has achieved a number of successes. ANL-E established a Waste Minimization Advisory Committee consisting of representatives from divergent areas of Laboratory responsibility. The group reports to the Chief Operations Officer. The committee recently assisted in developing a laboratory Pollution Prevention Policy Statement. ANL-E also 


\section{ENVIRONMENTAL PROGRAM INFORMATION}

developed a Waste Minimization and Pollution Prevention Strategy and implementation plan during 1995.

Contaminated metal and shielding have been a troublesome waste stream for D\&D programs. ANL-E has been successful at recycling large quantities of activated metal and shielding to other DOE programs and projects. In recent years, 1 million pounds of slightly activated steel shielding was transferred to Fermi National Accelerator Laboratory for use as shielding. This avoids procurement of new material for shielding and avoids disposal of the ANL-E material. Approximately $1,000 \mathrm{~m}^{3}\left(1,100 \mathrm{yd}^{3}\right)$ of shielding concrete was recycled to Fermi and other ANL-E projects. In addition, lead bricks were recycled to other ANL-E projects, thus avoiding the treatment and disposal costs associated with this material.

Historic recycling programs, including recycling of paper and printer cartridges, are expanding with additional effort by staff. ANL-E has conducted "dumpster dives" of nonhazardous waste streams and used the results to expand paper recycling. The program has increased paper recycling efforts $75 \%$ since 1993. The ANL-E Central Shops group has added a filter to its cutting oil stream, thereby decreasing the waste release by $80 \%$. It has purchased and is installing a new degreasing machine that will eliminate the use of hazardous cleaning solvents and the requirement for an air permit at its location. Construction and maintenance efforts on site generate large quantities of debris and waste. During 1995, the Central Shops were able to recycle or reuse almost $80 \%$ of this material. The on-site Chemical Management System was expanded to include bar codes for an additional 20,000 items. Reporting capability was added to the system to provide procurement documentation and information about excess materials. ANL-E developed a highly successful effort to transfer microchemistry techniques to local areas schools. The effort has received high praise by the participants, DOE, and the IEPA.

\subsubsection{Site Environmental Performance Measures Program}

Since January 1991, ANL-E has participated in the DOE Performance Indicators Program and has reported information on a quarterly basis to DOE. Of the 32 performance indicators, 14 are environmental. The indicators are used to track air and liquid releases of radiological and 
hazardous effluent, environmental incidents, and waste generation and disposal. A more detailed discussion can be found in Chapter 2 .

In May 1995, the ANL-E operating contract with the University of Chicago was renegotiated. The new contract includes a performance fee based on performance of research and operations, including ES\&H performance. Performance objectives and supporting metrics have been developed to administer the contract and performance fee. While the new contract is a model for nonprofit organizations, a year or more of operation under the new provisions will be required in order for at least one cycle of data and evaluation to emerge.

\subsection{Environmental Monitoring Program Description}

As required by DOE Order $5400.1,{ }^{1}$ ANL-E conducts a routine environmental monitoring program. This program is designed to determine the effect the operation of ANL-E is having on the environment surrounding the site. This section describes this monitoring program. A general description of the techniques used to sample each environmental medium is provided. This is followed by the collection procedures, the sampling schedule, and the analytical techniques used. Greater detail is provided in the Environmental Monitoring Plan.

\subsubsection{Air Sampling}

Continuously operating air samplers are used at ANL-E to measure the concentrations of airborne particulate radioactivity. Currently, nonradiological air contaminants in ambient air are not monitored. Particulate samplers are placed at 14 locations around the ANL-E perimeter and at six off-site locations, approximately five miles from ANL-E to determine the ambient or background concentrations.

Airborne particulate samples for direct radiation measurement are collected continuously at 12 perimeter locations and at five off-site locations on glass fiber filter media. Average flow rates on the air samplers are about $70 \mathrm{~m}^{3} / \mathrm{h}$. Filters are changed weekly. The filters on perimeter samplers are changed by ANL-E staff, and the filters on off-site samplers are changed and mailed 


\section{ENVIRONMENTAL PROGRAM INFORMATION}

to ANL-E by cooperating local agencies. The sampling units are serviced every six months, and the flow meters are recalibrated annually

Additional air samples, used for radiochemical analysis of plutonium and other radionuclides, are collected at two perimeter locations and one off-site location. These samples are collected on special filter media that are changed every 10 days by ANL-E staff. The flow rate calibration and servicing schedule is the same as discussed above.

At the time of sample collection, the date and time when sample collection began, the initial flow rate, the date and time when the sample was collected, and the final flow rate are recorded on a label attached to the sample container. The samples are then transported to ANL-E where this information is then transferred to the Environmental Protection Data Management System (EMS).

Each air filter sample collected for direct measurement is cut in half. Half of each sample for any calendar week is combined with all the other perimeter samples from that week and packaged for gamma-ray spectrometry. A similar package is prepared for the off-site filters for each week. A 2-in. circle is cut from the other half of the filter, mounted in a 2-in. low-lip stainless steel planchet, and counted for alpha and for beta activity. The balance of the filter is saved.

The air filter samples collected for radiochemical analysis are composited by location for each month. After addition of the appropriate tracers, the samples are ashed, and then sequentially analyzed for plutonium, thorium, uranium, and strontium.

Stack monitoring is conducted continuously at those emission points that have a probability of releasing measurable radioactive effluents. The results of these measurements are used for calculating the theoretical annual off-site dose using the required CAP-88 version ${ }^{8}$ of the EPAAIRDOSE atmospheric dispersion computer code and dose conversion. 


\subsubsection{Water Sampling}

Water samples are collected to determine what, if any, radioactive materials or selected hazardous chemicals used or generated at ANL-E enter the environment by the water pathway. The samples are collected from Sawmill Creek below the point at which ANL-E discharges its treated wastewater and storm water. The results of radiological analysis of water collecting at this location are compared to upstream and off-site results to determine the ANL-E contribution. The results of the chemical analysis are compared to the applicable IEPA stream quality standards to determine if the site is degrading the quality of the creek. These results are discussed in more detail in Chapters 4 and 5.

In addition to surface water, subsurface water samples are also collected at approximately 34 locations. These samples are collected from monitoring wells located near sites that have the potential for adversely impacting groundwater. These sites are the 800 Area landfill, the 317/319 waste management area, and the site of the inactive CP-5 reactor. Samples of the domestic water, which comes from four on-site wells, are also collected and analyzed for hazardous or radioactive constituents.

Surface water samples are collected from Sawmill Creek and composited into a single weekly composite sample. A continuous sampling device has been installed at this location to improve sample collection efficiency. To provide control samples, Sawmill Creek is sampled upstream of ANL-E once a month. The Des Plaines River is sampled twice a month below, and monthly above, the mouth of Sawmill Creek to determine if the radioactivity in the creek had any effect on the activity in the river. Water samples are collected from remote locations in the spring and fall to serve as additional control samples.

Subsurface water samples are collected quarterly from the monitoring wells located in the 317/319 Area, 330 (CP-5), and the 800 Area Sanitary Landfill. The monitoring wells are purged, and samples are collected from the recharged well water. These samples are analyzed for both chemical and radiological constituents, as discussed in Chapter 6 . Samples are collected quarterly from the wellheads of the four ANL-E wells that provide the Laboratory domestic water supply. 
The water is pumped to the surface and collected in appropriate containers, depending on the required analysis.

At the time of sample collection for radiological analysis, the sampling location, time, date, and collector identification number are recorded on a label attached to the sample container. Upon return to the Laboratory, the information is transferred to the EMS system. Each sample is assigned a unique number that accompanies it through all analyses.

After the sample has been logged in, an aliquot is removed for tritium analysis, $20 \mathrm{~mL}$ of concentrated nitric acid $\left(\mathrm{HNO}_{3}\right)$ is added per gallon of water as a preservative, and the sample is filtered through Whatman No. 2 filter paper to remove sediment present in the sample. Appropriate aliquots are then taken, depending on the analysis.

For nonradiological analysis, samples are collected and preserved using EPA-prescribed procedures. Cooling is used for organic analysis, and nitric acid is used to preserve samples to be analyzed for metals. Specific collection procedures are used for other components, and EPA methods are used. All samples are analyzed within the required holding period or noncompliance is documented. The quality control requirements of either $S W-846^{9}$ and/or the Contract Laboratory Program (CLP) are met or deviations are documented. All samples are assigned a unique number that serves as a reference source for each sample. When duplicate samples are obtained, unique numbers are assigned, and an indication that duplicates exist is entered in the data management system.

\subsubsection{Bottom Sediment}

Bottom sediment accumulates small amounts of radioactive materials that may be present from time to time in a stream and, as a result, acts as an integrator of the radioactive material that was present in the water. The sediment provides a historical record of radioactive materials in the surface water system. These samples are not routinely analyzed for chemical constituents. 


\section{ENVIRONMENTAL PROGRAM INFORMATION}

Bottom sediment samples are collected annually from Sawmill Creek above, at, and several locations below the point at which ANL-E discharges its treated wastewater. Periodically, sediment samples are collected from several on-site ponds and lagoons. Ten off-site bottom sediment samples are collected each year, five in the spring and five in the fall, from remote locations to serve as controls. One gallon of sediment is collected from each location with a stainless steel scoop and is transferred to a glass bottle.

At the time of sample collection, the date, time, and sample collector identification are recorded on sample labels affixed to the sample container. Upon return to the Laboratory, the information is transferred to the EMS system. Each sample is assigned a unique number that accompanies it through the process.

Each sample is dried for several days at $110^{\circ} \mathrm{C}\left(230^{\circ} \mathrm{F}\right)$, ball milled, and sieved through a No. 70 mesh screen. The material that does not pass the No. 70 screen is discarded. A 100-g portion is taken for gamma-ray spectrometric measurement and other appropriate aliquots are used for specific radiochemical analyses.

\subsubsection{Soil}

Soil accumulates small amounts of particulate matter and serves as an integrator of the deposition of airborne releases of radioactive materials. Although it should not be used as the primary measurement system for air monitoring, in many cases, 'it may be the only available avenue if insufficient air sampling occurred at the time of an incident. The ANL-E program is designed to provide samples for analysis to determine if any changes in concentrations have occurred over the year. No analysis for chemical constituents is carried out on these samples.

Each year soil from 10 locations is collected at the site perimeter (five spring and five fall) and 10 at remote locations (five spring and five fall). Sampling sites are selected in reasonably level areas that represent undisturbed soil. Two 1-m (3-ft) squares are marked off, and soil samples are collected from the corners and center of each square. Samples are collected with a 10.4-cm (4-in.) diameter coring tool to a depth of $5 \mathrm{~cm}$ (2 in.). All 10 cores are composited as 
a single sample. This procedure follows the American Society for Testing and Materials (ASTM) Standard Method for Sampling Surface Soil for Radionuclides, C-998.

At the time of sample collection, the date, time, and sample collector identification number are recorded on a preprinted sample label affixed to the sample container. Upon return to the laboratory, the information is transferred to the EMS system. Each sample is assigned a unique number that accompanies it through the process.

The entire sample is dried at $110^{\circ} \mathrm{C}\left(230^{\circ} \mathrm{F}\right)$ for several days, ball milled, and sieved through a No. 70 mesh screen. The material that does not pass the No. 70 mesh screen is discarded. A 100-g portion is taken for gamma-ray spectrometric measurement and appropriate aliquots taken for radiochemical analysis. Because a known area of surface soil was collected, results are calculated in terms of concentration and deposition.

\subsubsection{Vegetation}

Grass samples are collected to determine the uptake of radionuclides from the soil by vegetation. This is performed to monitor the vegetation part of the food chain pathway.

Grass samples are collected each year from 10 perimeter and 10 off-site locations at the same places as the soil samples. All the grass within one of the 1-m plots used for soil sampling is cut just above the soil surface and collected.

At the time of sample collection, the date, time, and sample collector identification number are recorded on a preprinted sample label affixed to the sample container. Upon return to the Laboratory, the information is transferred to the EMS system. Each sample is assigned a unique number that accompanies it through the process.

Grass samples are washed in water to remove surface dirt, dried at $110^{\circ} \mathrm{C}\left(230^{\circ} \mathrm{F}\right)$ for several days, and ground. A 100-g aliquot is measured by gamma-ray spectrometry, and appropriate aliquots taken for radiochemical analysis. 


\section{ENVIRONMENTAL PROGRAM INFORMATION}

\subsubsection{External Penetrating Radiation}

Measurements of direct penetrating radiation emanating from several sources within ANL-E are taken by using calcium fluoride thermoluminescent dosimeter (TLD) chips. Each measurement is the average of four chips exposed in the same packet. All calcium fluoride packets are shielded with $1 / 16$ in. copper foil to reduce or eliminate the beta and low-energy $\mathrm{x}$-ray components. The response of the chips is determined with a U.S. National Institute of Standards and Technology (NIST) standard radium-226 source.

Dosimeters are exposed at 14 locations at the site perimeter and on the site and at five locations off the site. All dosimeters are changed quarterly.

At the time of dosimeter collection, the date, time, and collector identification number are recorded on a preprinted label affixed to the container. Upon return to the Laboratory, the information is transferred to the EMS system. Each sample is assigned a unique number that accompanies it through the process.

The individual chips are read on an Eberline Model TLR- 6 TLD reader. Control chips are read and their contribution subtracted from the values of the field chips. A set of chips irradiated with a radium-226 standard source is also read, and these values are used to convert the individual field readings to dose.

\subsubsection{Data Management}

The management of the large amount of data assembled in the environmental monitoring program is handled by ANL-E in a very structured manner that allows a number of reports to be generated. Basic radiological data management, including sample record keeping, is implemented with the EMS computerized record-keeping program. All sample and analytical data are kept in the EMS for eventual output in formats required for either regulatory compliance reports or for the annual reports. In addition, reports are provided for trend analysis, statistical analysis, and tracking. 


\section{ENVIRONMENTAL PROGRAM INFORMATION}

The ANL-E-developed EMS program is the basic data management tool; it generates sampling schedules, all other tracking and calculation routines, and the final analytical result tabulations. The EMS program is set up for the radiological portion of the monitoring program and nonradiological monitoring for groundwater and NPDES surface water effluents. For purposes of this plan, the procedures for nonradiological sampling follow the same basic protocol as shown below.

The starting point for effluent monitoring and environmental surveillance is establishing a set of sampling locations and a sample schedule. On the basis of regulatory parameters, pathway analysis, or professional judgment, sample locations for the various media are identified and entered into the EMS. For each sample location, nine categories of data are entered into the EMS: geographic code, location description, sampling frequency, sample type (water, soil, plant, etc.), exact sampling position, last date sampled, sampling priority (same location with multiple samples), size of sample to collect, and analytes.

Once the data are entered, the EMS program is used to generate a sampling schedule. Every week a schedule for the next week is printed out, along with uniquely numbered, preprinted labels for the sample containers. These items are provided to the staff who are doing the sampling in the field. Field data are entered into the EMS system. At the time when the samples are submitted to the analytical laboratory, chain-of-custody documents are generated. In addition, the same information is provided electronically to assist the Laboratory in data entry. All necessary information required by the Laboratory is provided.

As the Laboratory results are compiled, the data are entered into the EMS program. This permits up-to-date tracking of all samples currently in process. When the analysis is completed on each sample and the results electronically entered into the EMS, the completed final results sample card is retained in a file as an additional quality assurance measure.

Complete data sets for all samples are maintained by the EMS program. When all results have been completed and entered into the EMS, a final result card is generated listing all data related to each sample. The electronic files are backed up by the EMO computer network server. 


\section{ENVIRONMENTAL PROGRAM INFORMATION}

The printed final result card is filed after review, then ultimately put in DOE's archives in Chicago. EMO staff annually print and bind the complete results for reference, by sample type, for the past calendar year. Final results are thus available both on-line via the network and in hard copy.

\subsection{Compliance with DOE Order 5820.2A}

DOE Order 5820.2A, "Radioactive Waste Management," Section III-3 (k) ${ }^{7}$ requires that an environmental monitoring and surveillance program be conducted, to determine any releases or migration from low-level treatment, storage, or disposal sites. Compliance with these requirements is an integral part of the ANL-E sitewide monitoring and surveillance program. To cover the waste management operations in general, the perimeter air monitoring network and the monitoring of the liquid effluent streams and the Sawmill Creek are relied on. The analytical results are collected in Chapter 4 of this report.

Of particular interest is monitoring of the waste management activities conducted in the 317 Area. This includes air monitoring for total alpha, total beta, and gamma-ray emitters and radiochemical determinations of plutonium, uranium, thorium, and strontium-90; direct radiation measurements with TLDs; surface water discharges for tritium and gamma-ray emitters; perimeter soil and plant samples analyzed for gamma-ray emitters, plutonium, and americium; and subsurface water samples at 15 monitoring wells with analyses for tritium, strontium-90, and gamma-ray emitters, plus selected monitoring for VOCs. The results are presented in Chapters 4 and 6 of this report. 


\section{ENVIRONMENTAL PROGRAM INFORMATION}

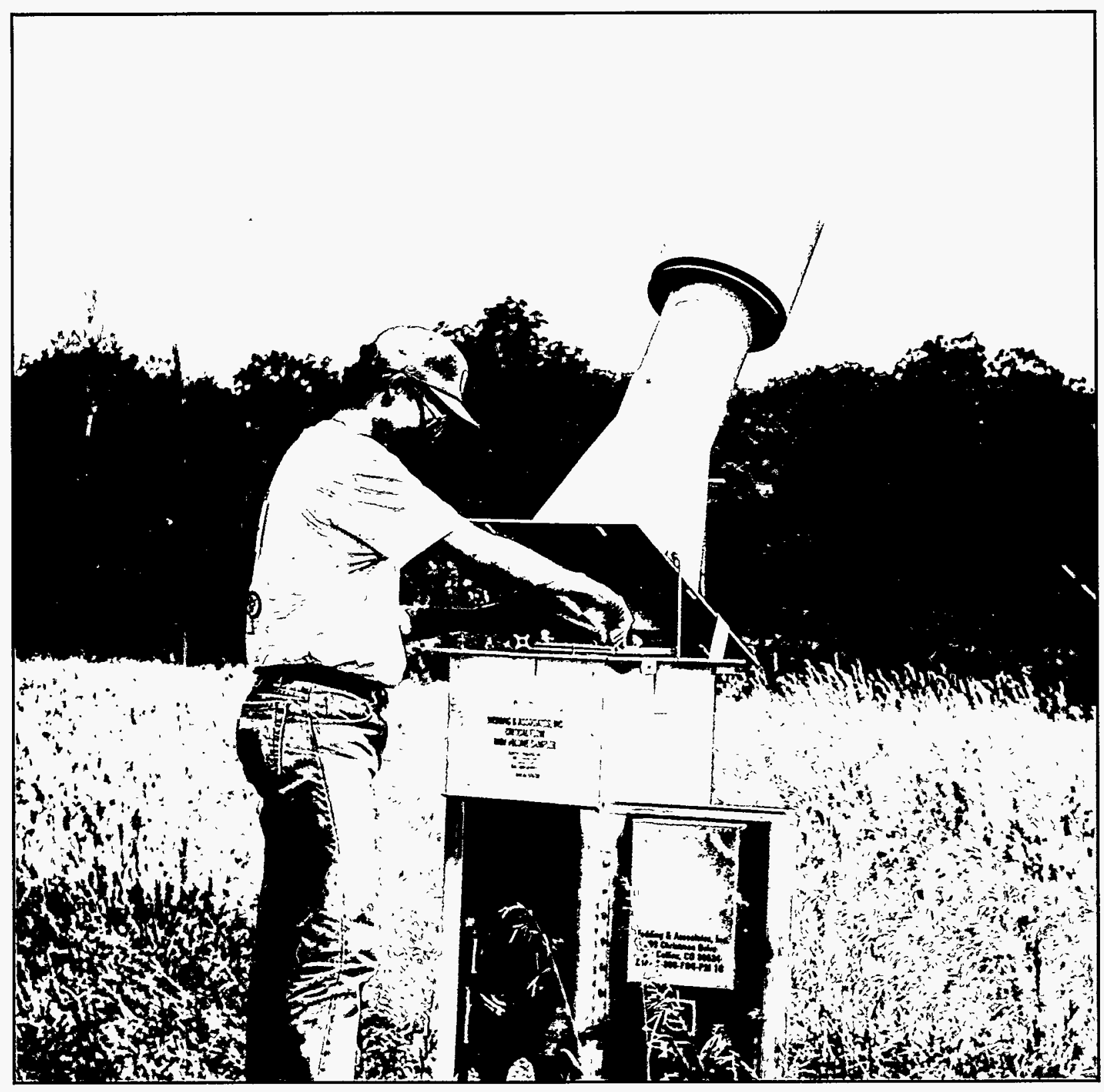




\section{ENVIRONMENTAL RADIOLOGICAL PROGRAM INFORMATION}

\subsection{Description of Monitoring Program}

The radioactivity of the environment around ANL-E was determined by measuring the concentrations of radioactive nuclides in naturally occurring materials and by measuring the external penetrating radiation dose. Sample collections and measurements were made at the site perimeter and off the site for comparative purposes. Some on-site results are also reported when they are useful in interpreting perimeter and off-site results.

Because radioactivity is primarily transported by air and water, the sample collection program concentrated on these media. In addition, samples of soil, plants, and materials from the beds of lakes and streams also were analyzed. The program followed the guidance provided in the DOE Environmental Regulatory Guide. ${ }^{10}$ About 1,422 samples were collected, and approximately 4,770 radiological analyses were performed. The results of radioactivity measurements are expressed in terms of $\mathrm{pCi} / \mathrm{L}$ for water; $\mathrm{fCi} / \mathrm{m}^{3}$ and $\mathrm{aCi} / \mathrm{m}^{3}$ for air; and $\mathrm{pCi} / \mathrm{g}$, $\mathrm{fCi} / \mathrm{g}$, and $/$ or $\mathrm{nCi} / \mathrm{m}^{2}$ for soil, bottom sediment, and vegetation. Penetrating radiation measurements are reported in units of $\mathrm{mrem} / \mathrm{yr}$ and population dose in man-rem.

DOE has provided guidance ${ }^{11}$ for effective dose equivalent calculations for members of the public based on International Commission on Radiological Protection (ICRP) Publications 26 and $30{ }^{12,13}$ Those procedures have been used in preparing this report. The methodology requires three components to be calculated: (1) the committed effective dose equivalent (CEDE) from all sources of ingestion, (2) the CEDE from inhalation, and (3) direct effective dose equivalent from external radiation. These three components are summed for comparison with the DOE effective dose equivalent limits for environmental exposure. The guidance requires that sufficient data on exposure to radionuclide sources be available to assure that at least $90 \%$ of the total CEDE is accounted for. The primary radiation dose limit for members of the public is $100 \mathrm{mrem} / \mathrm{yr}$. The effective dose equivalents for members of the public from all routine DOE operations, natural background and medical exposures excluded, shall not exceed $100 \mathrm{mrem} / \mathrm{yr}$ and adhere to the ALARA process or be as far below the limits as is practical taking into account social, economic, technical, practical, and public policy considerations. Routine DOE operations are normally planned operations, which exclude actual or potential accidental or unplanned releases. 
The measured or calculated environmental radionuclide concentrations are converted to a 50-year committed effective dose equivalent with the use of the CEDE factors ${ }^{14}$ and compared to the annual dose limits for uncontrolled areas. "The CEDEs are calculated from the DOE Derived Concentration Guides (DCGs) ${ }^{11}$ for members of the public on the basis of a radiation dose of $100 \mathrm{mrem} / \mathrm{yr}$. The numerical values of the CEDE factors used in this report are provided later in this chapter. Although the CEDE factors apply only to concentrations above natural levels, for comparative purposes, the calculated dose is sometimes given in this report for radioactivities that are primarily of natural origin. Such values are enclosed in parentheses. Occasionally, other standards are used, and their sources are identified in the text.

\subsection{Air}

The radioactive content of particulate matter in the air was determined by collecting and analyzing air-filter samples. The sampling locations are shown in Figures 1.1 and 1.2. Separate collections were made for specific radiochemical analyses and for gross alpha, gross beta, and gamma-ray spectrometry. The latter measurements were taken from samples collected continuously on laminated glass fiber filters (changed weekly) at 12 locations at the ANL-E site perimeter by using $\mathrm{PM}_{10}$ units (particulate matter less than 10 micrometers) and at five off-site locations.

Samples were collected at the site perimeter to determine if a statistically significant difference exists between perimeter measurements and measurements taken from samples collected at various off-site locations. The off-site samples establish the local background concentrations of naturally occurring or ubiquitous man-made radionuclides, such as from nuclear weapons testing fallout. Higher levels of radioactivity in the air measured at the site perimeter may indicate radioactivity releases from ANL-E, providing that the perimeter samples are greater than the background samples by an amount greater than the relative error of the measurement. The relative error is a result of natural variation in background concentrations as well as sampling and measurement error. This relative error is typically 5 to $20 \%$ of the measurement value for most of the analyses, but approaches $100 \%$ at values near the detection limit of the instrument. 


\section{ENVIRONMENTAL RADIOLOGICAL PROGRAM INFORMATION}

Table 4.1 summarizes the total alpha and beta activities in the individual weekly samples. These measurements were made in low-background gas-flow proportional counters, and the counting efficiencies used to convert counting rates to disintegration rates were those measured for a $0.05-\mathrm{MeV}$ beta and a $5.5-\mathrm{MeV}$ alpha on filter paper. The average concentrations of gammaray emitters, as determined by gamma-ray spectrometry performed on composite weekly samples, are given in Table 4.2. The gamma-ray detector is a shielded germanium diode calibrated for each gamma-ray-emitting nuclide measured.

The alpha activity, principally due to naturally occurring nuclides, averaged the same as in the past several years and was in its normal range. The perimeter beta activity averaged $30 \mathrm{fCi} / \mathrm{m}^{3}$, which is slightly higher than the average value for the past five years but similar to the average value of 1994. The gamma-ray emitters listed in Table 4.2 are those that have been present in the air for the past few years and are of natural origin. The beryllium-7 exhibits an increase in concentration in the spring, indicating its stratospheric origin. The concentration of lead-210 in the air is due to the radioactive decay of gaseous radon-222 and is similar to the concentration last year.

The annual average alpha and beta activities since 1985 are displayed in Figure 4.1. The elevated beta activity in 1986 was due to fallout from the Chernobyl incident. If the radionuclides attributed to the Chernobyl incident are subtracted from the annual beta average of $40 \mathrm{fCi} / \mathrm{m}^{3}$, the net would be $27 \mathrm{fCi} / \mathrm{m}^{3}$, very similar to the averages of the other years. Figure 4.2 presents the annual average concentrations of the two major gamma-ray-emitting radionuclides in air. The annual average beryllium-7 concentrations decreased regularly since 1987, reached a minimum in 1991, and are now increasing. The increase in the beryllium-7 air concentrations has been observed worldwide by the DOE Environmental Laboratory's Surface Air Sampling Program and is attributed to an increase in solar activity. ${ }^{15}$

Samples for radiochemical analyses were collected at perimeter locations $12 \mathrm{~N}$ and $7 \mathrm{I}$ (Figure 1.1) and off the site in Downers Grove (Figure 1.2). Collections were made on polystyrene filters. The total air volume filtered for the monthly samples was about $20,000 \mathrm{~m}^{3}$ 


\section{TABLE 4.1}

Total Alpha and Beta Activities in Air Filter Samples, $1995^{\mathrm{a}}$ (concentrations in $\mathrm{fCi} / \mathrm{m}^{3}$ )

\begin{tabular}{|c|c|c|c|c|c|c|c|c|}
\hline \multirow[b]{2}{*}{ Month } & \multirow[b]{2}{*}{ Location } & \multirow{2}{*}{$\begin{array}{l}\text { No. of } \\
\text { Samples }\end{array}$} & \multicolumn{3}{|c|}{ Alpha Activity } & \multicolumn{3}{|c|}{ Beta Activity } \\
\hline & & & Avg. & Min. & Max. & Avg. & Min. & Max. \\
\hline \multirow[t]{2}{*}{ January } & Perimeter & 35 & 1.5 & 0.8 & 2.6 & 30.9 & 15.3 & 46.1 \\
\hline & Off-Site & 18 & 1.7 & 0.5 & 3.6 & 32.3 & 20.0 & 58.0 \\
\hline \multirow[t]{2}{*}{ February } & Perimeter & 47 & 1.9 & 1.2 & 2.5 & 36.7 & 22.9 & 43.2 \\
\hline & Off-Site & 20 & 1.8 & 0.6 & 3.2 & 32.6 & 15.2 & 50.8 \\
\hline \multirow[t]{2}{*}{ March } & Perimeter & 58 & 1.6 & 0.7 & 2.6 & 26.1 & 18.2 & 39.3 \\
\hline & Off-Site & 23 & 1.4 & 0.6 & 3.3 & 22.7 & 15.4 & 34.6 \\
\hline \multirow[t]{2}{*}{ April } & Perimeter & 47 & 1.4 & 0.9 & 2.1 & 22.1 & 16.4 & 32.2 \\
\hline & Off-Site & 17 & 1.2 & 0.5 & 1.8 & 19.0 & 11.2 & 29.8 \\
\hline \multirow[t]{2}{*}{ May } & Perimeter & 58 & 1.1 & 0.1 & 2.3 & 19.0 & 11.1 & 26.2 \\
\hline & Off-Site & 24 & 1.0 & 0.3 & 1.5 & 16.3 & 10.6 & 23.3 \\
\hline \multirow[t]{2}{*}{ June } & Perimeter & 46 & 2.0 & 0.8 & 3.7 & 28.4 & 17.6 & 48.3 \\
\hline & Off-Site & 17 & 1.7 & 1.1 & 3.0 & 23.8 & 16.0 & 42.3 \\
\hline \multirow[t]{2}{*}{ July } & Perimeter & 48 & 2.4 & 1.1 & 3.9 & 30.5 & 15.5 & 40.9 \\
\hline & Off-Site & 20 & 2.1 & 0.5 & 4.6 & 26.2 & 16.4 & 38.1 \\
\hline \multirow[t]{2}{*}{ August } & Perimeter & 59 & 1.6 & 0.7 & 2.8 & 32.0 & 20.0 & 56.9 \\
\hline & Off-Site & 23 & 1.4 & 0.2 & 3.7 & 28.1 & 16.9 & 54.9 \\
\hline \multirow[t]{2}{*}{ September } & Perimeter & 44 & 1.6 & 0.6 & 3.0 & 34.7 & 15.4 & 57.2 \\
\hline & Off-Site & 15 & 1.2 & 0.4 & 3.3 & 28.4 & 16.4 & 53.2 \\
\hline \multirow[t]{2}{*}{ October } & Perimeter & 39 & 1.6 & 0.6 & 2.4 & 32.9 & 16.1 & 46.4 \\
\hline & Off-Site & 15 & 1.5 & 0.8 & 2.8 & 28.7 & 16.1 & 45.0 \\
\hline \multirow[t]{2}{*}{ November } & Perimeter & 54 & 1.6 & 0.4 & 3.0 & 31.7 & 13.3 & 49.0 \\
\hline & Off-Site & 20 & 1.9 & 0.5 & 4.3 & 35.8 & 17.6 & 69.3 \\
\hline \multirow[t]{2}{*}{ December } & Perimeter & 34 & 2.2 & 1.2 & 3.0 & 42.9 & 26.0 & 57.2 \\
\hline & Off-Site & 19 & 2.4 & 0.1 & 5.1 & 38.6 & 1.4 & 72.9 \\
\hline Annual & Perimeter & 569 & $1.7 \pm 0.2$ & 0.1 & 3.9 & $30.7 \pm 4.0$ & 11.1 & 57.2 \\
\hline Summary & Off-Site & 231 & $1.6 \pm 0.3$ & 0.1 & 5.1 & $27.7 \pm 4.2$ & 1.4 & 72.9 \\
\hline
\end{tabular}

a These results were obtained by measuring the samples four days after they were collected to avoid counting the natural activity due to short-lived radon and thorium decay products. This activity is normally present in the air and disappears within four days by radioactive decay. 


\section{TABLE 4.2}

Gamma-Ray Activity in Air Filter Samples, 1995 (concentrations in $\mathrm{fCi} / \mathrm{m}^{3}$ )

\begin{tabular}{|c|c|c|c|}
\hline Month & Location & Beryllium-7 & Lead-210 \\
\hline January & $\begin{array}{l}\text { Perimeter } \\
\text { Off-Site }\end{array}$ & $\begin{array}{l}72 \\
74\end{array}$ & $\begin{array}{l}26 \\
26\end{array}$ \\
\hline February & $\begin{array}{l}\text { Perimeter } \\
\text { Off-Site }\end{array}$ & $\begin{array}{r}116 \\
85\end{array}$ & $\begin{array}{l}28 \\
29\end{array}$ \\
\hline March & $\begin{array}{l}\text { Perimeter } \\
\text { Off-Site }\end{array}$ & $\begin{array}{l}136 \\
115\end{array}$ & $\begin{array}{l}18 \\
17\end{array}$ \\
\hline April & $\begin{array}{l}\text { Perimeter } \\
\text { Off-Site }\end{array}$ & $\begin{array}{l}146 \\
105\end{array}$ & $\begin{array}{l}14 \\
12\end{array}$ \\
\hline May & $\begin{array}{l}\text { Perimeter } \\
\text { Off-Site }\end{array}$ & $\begin{array}{l}149 \\
103\end{array}$ & $\begin{array}{r}11 \\
9\end{array}$ \\
\hline June & $\begin{array}{l}\text { Perimeter } \\
\text { Off-Site }\end{array}$ & $\begin{array}{l}192 \\
136\end{array}$ & $\begin{array}{l}19 \\
16\end{array}$ \\
\hline July & $\begin{array}{l}\text { Perimeter } \\
\text { Off-Site }\end{array}$ & $\begin{array}{l}163 \\
132\end{array}$ & $\begin{array}{l}21 \\
19\end{array}$ \\
\hline August & $\begin{array}{l}\text { Perimeter } \\
\text { Off-Site }\end{array}$ & $\begin{array}{l}134 \\
105\end{array}$ & $\begin{array}{l}23 \\
21\end{array}$ \\
\hline September & $\begin{array}{l}\text { Perimeter } \\
\text { Off-Site }\end{array}$ & $\begin{array}{l}158 \\
125\end{array}$ & $\begin{array}{l}24 \\
20\end{array}$ \\
\hline October & $\begin{array}{l}\text { Perimeter } \\
\text { Off-Site }\end{array}$ & $\begin{array}{l}99 \\
77\end{array}$ & $\begin{array}{l}24 \\
24\end{array}$ \\
\hline November & $\begin{array}{l}\text { Perimeter } \\
\text { Off-Site }\end{array}$ & $\begin{array}{r}88 \\
100\end{array}$ & $\begin{array}{l}24 \\
24\end{array}$ \\
\hline December & $\begin{array}{l}\text { Perimeter } \\
\text { Off-Site }\end{array}$ & $\begin{array}{r}104 \\
82\end{array}$ & $\begin{array}{l}32 \\
27\end{array}$ \\
\hline $\begin{array}{l}\text { Annual } \\
\text { Summary }\end{array}$ & $\begin{array}{l}\text { Perimeter } \\
\text { Off-Site }\end{array}$ & $\begin{array}{l}130 \pm 22 \\
103 \pm 13\end{array}$ & $\begin{array}{l}22 \pm 3 \\
20 \pm 3\end{array}$ \\
\hline Dose (mrem) & $\begin{array}{l}\text { Perimeter } \\
\text { Off-Site }\end{array}$ & $\begin{array}{l}(0.00033) \\
(0.00026)\end{array}$ & $\begin{array}{l}(2.48) \\
(2.31)\end{array}$ \\
\hline
\end{tabular}




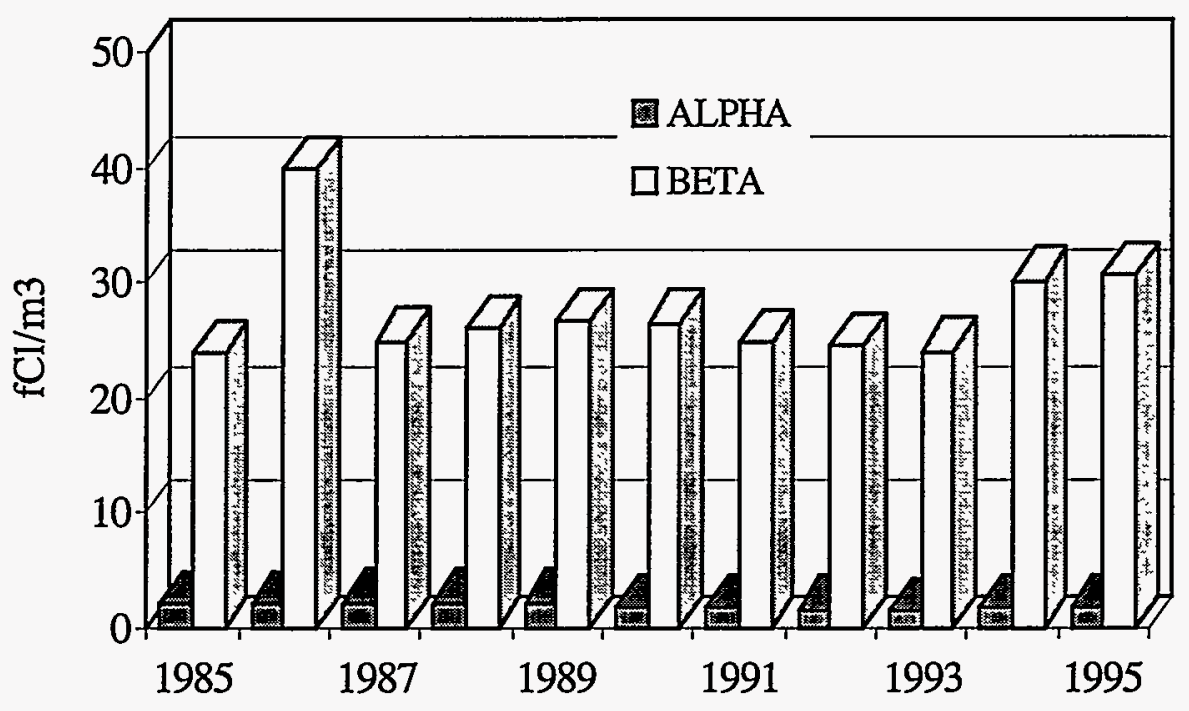

YEAR

Figure 4.1 Comparison of Total Alpha and Beta Activities in Perimeter Air-Filter Samples

$\left(700,000 \mathrm{ft}^{3}\right)$. Samples were ignited at $600^{\circ} \mathrm{C}\left(1,112^{\circ} \mathrm{F}\right)$ to remove organic matter and were prepared for analysis by vigorous treatment with hot hydrochloric, hydrofluoric, and nitric acids.

Plutonium and thorium were separated on an anion exchange column, and the uranium was extracted from the column effluent. Following the extraction, the aqueous phase was analyzed for radiostrontium by a standard radiochemical procedure. The separated plutonium, thorium, and uranium fractions were electrodeposited and measured by alpha spectrometry. The chemical recoveries were monitored by adding known amounts of plutonium-242, thorium-229, and uranium-236 tracers prior to ignition. Because spectrometry cannot distinguish between plutonium-239 and plutonium-240, it should be understood that when plutonium-239 is mentioned in this report, the alpha activity due to the plutonium-240 isotope is also included. The results are given in Table 4.3. 


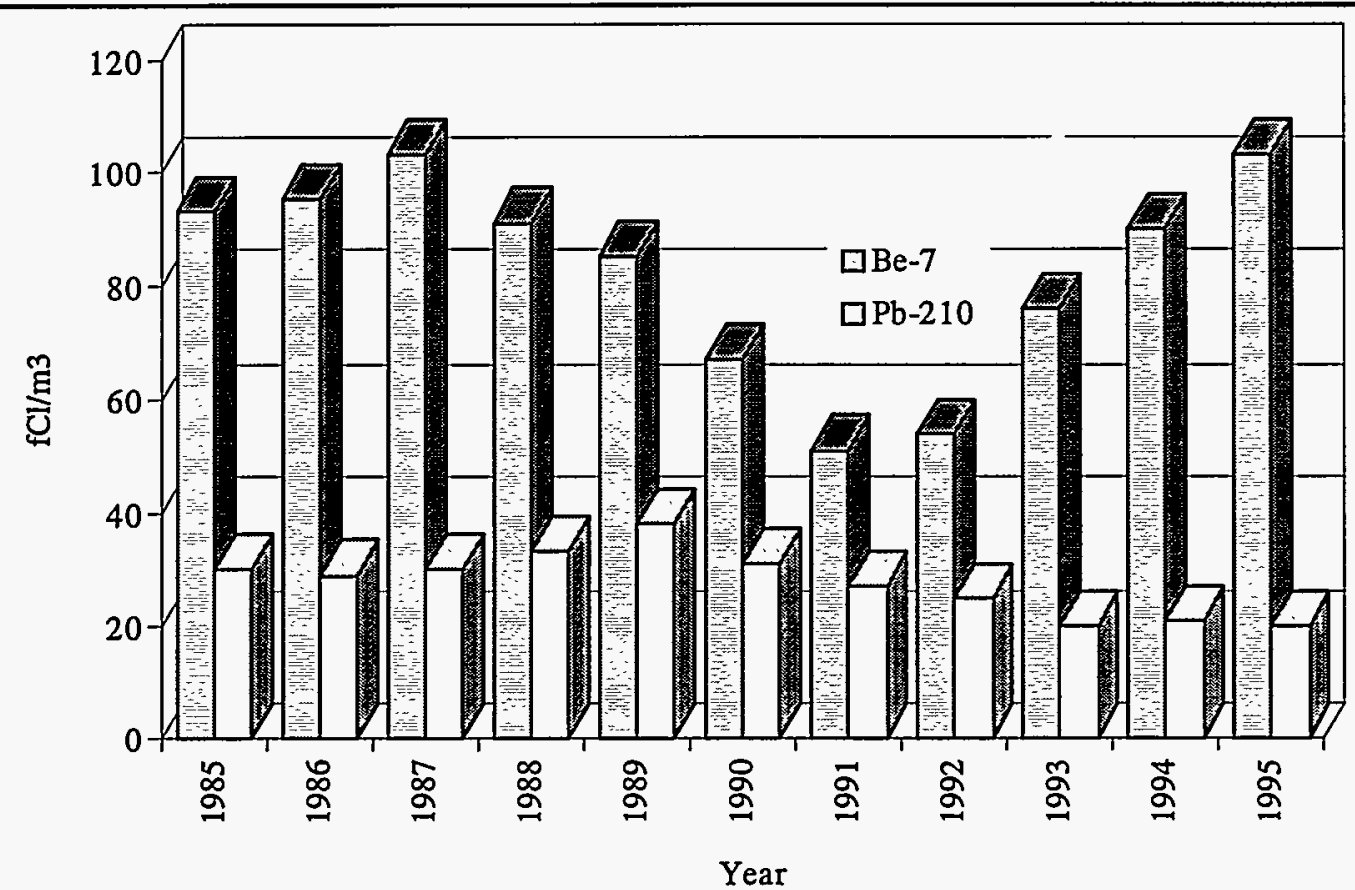

Figure 4.2 Comparison of Gamma-Ray Activity in Air-Filter Samples

The strontium-90 concentrations have decreased over the past several years so that during 1995 most of the results were less than the detection limit of $10 \mathrm{aCi} / \mathrm{m}^{3}$. Strontium- 89 was not observed above the detection limit of $100 \mathrm{aCi} / \mathrm{m}^{3}$. The plutonium-239 concentrations are similar to last year at Location 7I, Location $12 \mathrm{~N}$, and at the off-site sampling location.

The thorium and uranium concentrations are in the same range as in the past and are considered to be of natural origin. The amounts of thorium and uranium in a sample were proportional to the mass of inorganic material collected on the filter paper. The bulk of these elements in the air was due to resuspension of soil.

The major airborne effluents released at ANL-E during 1995 are listed by location in Table 4.4, and the annual releases of the major sources since 1985 are illustrated in Figure 4.3. The radon-220 released from Building 200 is due to radioactive contamination from the "proof-ofbreeding" program and from nuclear medicine studies. Even though the CP-5 reactor ceased operations in 1979, hydrogen-3 continues to be emitted from Building 330 . The hydrogen-3 
TABLE 4.3

Strontium, Thorium, Uranium, and Plutonium Concentrations

in Air Filter Samples, 1995

(Concentrations in $\mathrm{aCi} / \mathrm{m}^{3}$ )

\begin{tabular}{|c|c|c|c|c|c|c|c|c|}
\hline Month & Location $^{2}$ & Strontium-90 & Thorium-228 & Thorium-230 & Thorium-232 & Uranium-234 & Uranium-238 & Plutonium-239 \\
\hline \multirow[t]{3}{*}{ January } & 71 & $<10$ & $20 \pm 2$ & $26 \pm 2$ & $15 \pm 1$ & $24 \pm 2$ & $25 \pm 2$ & $2.4 \pm 0.9$ \\
\hline & $12 \mathrm{~N}$ & $<10$ & $9 \pm 2$ & $10 \pm 1$ & $6 \pm 1$ & $11 \pm 1$ & $11 \pm 1$ & $0.5 \pm 0.4$ \\
\hline & Off-Site & $<10$ & $3 \pm 2$ & $6 \pm 1$ & $4 \pm 1$ & $7 \pm 1$ & $7 \pm 1$ & $0.4 \pm 0.3$ \\
\hline \multirow[t]{3}{*}{ February } & 71 & $<10$ & $9 \pm 2$ & $10 \pm 2$ & $6 \pm 1$ & $12 \pm 1$ & $10 \pm 1$ & $0.7 \pm 0.6$ \\
\hline & $12 \mathrm{~N}$ & $<10$ & $6 \pm 1$ & $8 \pm 1$ & $4 \pm 1$ & $10 \pm 1$ & $8 \pm 1$ & $<0.1$ \\
\hline & Off-Site & $<10$ & $2 \pm 1$ & $2 \pm 1$ & $1 \pm 1$ & $5 \pm 1$ & $3 \pm 1$ & $1.5 \pm 0.5$ \\
\hline \multirow[t]{3}{*}{ March } & $7 \mathrm{I}$ & $<10$ & $8 \pm 1$ & $8 \pm 1$ & $5 \pm 1$ & $10 \pm 2$ & $10 \pm 2$ & $0.5 \pm 0.3$ \\
\hline & $12 \mathrm{~N}$ & $<10$ & $7 \pm 1$ & $8 \pm 1$ & $5 \pm 1$ & $10 \pm 2$ & $9 \pm 1$ & $0.4 \pm 0.3$ \\
\hline & Off-Site & $<10$ & $2 \pm 5$ & $3 \pm 1$ & $1 \pm 1$ & $4 \pm 1$ & $4 \pm 1$ & $0.3 \pm 0.2$ \\
\hline \multirow[t]{3}{*}{ April } & 71 & $<10$ & $10 \pm 1$ & $9 \pm 2$ & $5 \pm 1$ & $10 \pm 2$ & $11 \pm 2$ & $0.2 \pm 0.4$ \\
\hline & $12 \mathrm{~N}$ & $<10$ & $9 \pm 2$ & $8 \pm 1$ & $5 \pm 1$ & $7 \pm 1$ & $9 \pm 2$ & $0.2 \pm 0.3$ \\
\hline & Off-Site & $<10$ & $2 \pm 1$ & $2 \pm 1$ & $<1$ & $3 \pm 1$ & $2 \pm 1$ & $1.7 \pm 0.7$ \\
\hline \multirow[t]{3}{*}{ May } & $7 I$ & $<10$ & $8 \pm 1$ & $9 \pm 1$ & $6 \pm 1$ & $10 \pm 2$ & $9 \pm 2$ & $0.2 \pm 0.2$ \\
\hline & $12 \mathrm{~N}$ & $<10$ & $9 \pm 2$ & $8 \pm 1$ & $6 \pm 1$ & $8 \pm 1$ & $9 \pm 1$ & $1.2 \pm 0.6$ \\
\hline & Off-Site & $<10$ & $2 \pm 1$ & $2 \pm 1$ & $1 \pm 1$ & $4 \pm 1$ & $3 \pm 1$ & $0.8 \pm 0.4$ \\
\hline \multirow[t]{3}{*}{ June } & 71 & $<10$ & $11 \pm 1$ & $13 \pm 1$ & $8 \pm 1$ & $12 \pm 2$ & $14 \pm 2$ & $<0.1$ \\
\hline & $12 \mathrm{~N}$ & $<10$ & $7 \pm 1$ & $6 \pm 1$ & $4 \pm 1$ & $5 \pm 1$ & $6 \pm 1$ & $0.3 \pm 0.2$ \\
\hline & Off-Site & $<10$ & $4 \pm 1$ & $3 \pm 1$ & $2 \pm 1$ & $3 \pm 1$ & $2 \pm 1$ & $0.2 \pm 0.3$ \\
\hline \multirow[t]{3}{*}{ July } & 71 & $15 \pm 2$ & $16 \pm 2$ & $12 \pm 1$ & $6 \pm 1$ & $12 \pm 2$ & $11 \pm 2$ & $0.6 \pm 0.6$ \\
\hline & $12 \mathrm{~N}$ & $<10$ & $8 \pm 1$ & $9 \pm 1$ & $5 \pm 1$ & $7 \pm 2$ & $8 \pm 2$ & $<0.1$ \\
\hline & Off-Site & $<10$ & $5 \pm 1$ & $4 \pm 1$ & $2 \pm 1$ & $4 \pm 1$ & $3 \pm 1$ & $1.6 \pm 0.9$ \\
\hline \multirow[t]{3}{*}{ August } & 71 & $<10$ & $10 \pm 1$ & $11 \pm 1$ & $8 \pm 1$ & $10 \pm 1$ & $10 \pm 1$ & $0.3 \pm 0.2$ \\
\hline & $12 \mathrm{~N}$ & $-b$ & - & - & - & - & - & - \\
\hline & Off-Site & $<10$ & $11 \pm 1$ & $7 \pm 1$ & $5 \pm 1$ & $7 \pm 1$ & $8 \pm 1$ & $0.8 \pm 0.5$ \\
\hline \multirow[t]{3}{*}{ September } & $7 I$ & $<10$ & $7 \pm 1$ & $7 \pm 1$ & $4 \pm 1$ & $6 \pm 1$ & $6 \pm 1$ & $<0.1$ \\
\hline & $12 \mathrm{~N}$ & - & - & - & - & - & - & - \\
\hline & Off-Site & $<10$ & $3 \pm 1$ & $2 \pm 1$ & $2 \pm 1$ & $3 \pm 1$ & $3 \pm 1$ & $<0.1$ \\
\hline \multirow[t]{3}{*}{ October } & $7 I$ & $17 \pm 3$ & $16 \pm 3$ & $20 \pm 2$ & $13 \pm 2$ & $20 \pm 2$ & $22 \pm 2$ & $0.7 \pm 0.3$ \\
\hline & $12 \mathrm{~N}$ & $<10$ & $12 \pm 4$ & $17 \pm 3$ & $10 \pm 2$ & $16 \pm 3$ & $16 \pm 3$ & $1.4 \pm 0.6$ \\
\hline & Off-Site & $<10$ & $2 \pm 1$ & $2 \pm 1$ & $<1$ & $2 \pm 1$ & $3 \pm 1$ & $<0.1$ \\
\hline \multirow[t]{3}{*}{ November } & 71 & $<10$ & $16 \pm 2$ & $19 \pm 2$ & $12 \pm 1$ & $17 \pm 1$ & $18 \pm 1$ & $0.4 \pm 0.2$ \\
\hline & $12 \mathrm{~N}$ & $<10$ & $17 \pm 5$ & $21 \pm 3$ & $14 \pm 3$ & $26 \pm 4$ & $25 \pm 4$ & $1.3 \pm 0.8$ \\
\hline & Off-Site & $<10$ & $4 \pm 1$ & $5 \pm 1$ & $3 \pm 1$ & $5 \pm 1$ & $6 \pm 1$ & $0.2 \pm 0.1$ \\
\hline \multirow[t]{3}{*}{ December } & $7 I$ & $<10$ & $22 \pm 3$ & $30 \pm 3$ & $19 \pm 2$ & $24 \pm 2$ & $27 \pm 2$ & $0.6 \pm 0.4$ \\
\hline & $12 \mathrm{~N}$ & $<10$ & $14 \pm 3$ & $19 \pm 2$ & $13 \pm 2$ & $16 \pm 2$ & $17 \pm 2$ & $0.3 \pm 0.2$ \\
\hline & Off-Site & $<10$ & $5 \pm 1$ & $8 \pm 1$ & $4 \pm 1$ & $7 \pm 1$ & $8 \pm 1$ & $0.3 \pm 0.2$ \\
\hline Annual & $7 I$ & $<10$ & $13 \pm 11$ & $14 \pm 16$ & $9 \pm 10$ & $14 \pm 13$ & $14 \pm 15$ & $0.6 \pm 1.4$ \\
\hline \multirow[t]{2}{*}{ Summary } & $12 N$ & $<10$ & $10 \pm 8$ & $11 \pm 12$ & $7 \pm 8$ & $12 \pm 14$ & $12 \pm 13$ & $0.2 \pm 3.2$ \\
\hline & Off-Site & $<10$ & $4 \pm 6$ & $4 \pm 4$ & $2 \pm 3$ & $4 \pm 4$ & $4 \pm 5$ & $0.7 \pm 1.4$ \\
\hline \multirow[t]{3}{*}{ Dose (mrem) } & 71 & $<(0.00011)$ & $(0.0316)$ & $(0.0287)$ & $(0.089)$ & $(0.00069)$ & $(0.00072)$ & $(0.0014)$ \\
\hline & $12 \mathrm{~N}$ & $<(0.00011)$ & $(0.0241)$ & $(0.0227)$ & $(0.070)$ & $(0.00059)$ & $(0.00058)$ & $(0.0005)$ \\
\hline & Off-Site & $<(0.00011)$ & $(0.0091)$ & $(0.0073)$ & $(0.022)$ & $(0.00022)$ & $(0.00021)$ & $(0.0017)$ \\
\hline
\end{tabular}

a Perimeter locations are given in terms of the grid coordinates in Figure 1.1.

b A hyphen indicates that data are unavailable. 


\section{ENVIRONMENTAL RADIOLOGICAL PROGRAM INFORMATION}

emitted from Building 212 is from tritium recovery studies. In addition to the nuclides listed in Table 4.4, several other fission products also were released in millicurie or smaller amounts. The quantities listed in Table 4.4 were measured by on-line stack monitors in the exhaust systems of the buildings, except for Building 350 .

\subsection{Surface Water}

All surface water samples collected in the monitoring program were acidified to $0.1 \mathrm{~N}$ with $\mathrm{HNO}_{3}$ and filtered immediately after collection. Total nonvolatile alpha and beta activities were determined by counting the residue remaining after evaporation of the water and then applying counting efficiency corrections determined for plutonium-239 (for alpha activity) and thallium-204 (for beta activity) to obtain disintegration rates. Hydrogen-3 was measured from a separate aliquot, and this activity does not appear in the results for total nonvolatile beta activity. Analyses for the radionuclides were performed by specific radiochemical separations followed by appropriate counting. One-liter aliquots were used for all analyses except for hydrogen-3 and the transuranium nuclides. Hydrogen-3 analyses were performed by liquid scintillation counting of $9 \mathrm{~mL}$ of a distilled sample in a nonhazardous cocktail. Analyses for transuranium nuclides were performed on 10-L samples with chemical separation methods followed by alpha spectrometry. Plutonium-236 was used to determine the yields of plutonium and neptunium, which were separated from the sample together. A group separation of a fraction containing the transplutonium elements was monitored for recovery with an americium-243 tracer. Isotopic uranium concentrations were determined by alpha spectrometry by using uranium-236 as an isotopic tracer.

ANL-E wastewater is discharged into Sawmill Creek, which runs through the ANL-E grounds, drains surface water from much of the site, and flows into the Des Plaines River about $500 \mathrm{~m}(0.3 \mathrm{mi})$ downstream from the ANL-E wastewater outfall. Sawmill Creek was sampled upstream from the ANL-E site and downstream from the wastewater outfall to determine if radioactivity was added to the stream by ANL-E wastewater or surface drainage. The sampling locations are shown in Figure 1.1. Below the wastewater outfall, daily samples were collected. Equal portions of the daily samples collected each week were combined and analyzed to obtain 


\section{ENVIRONMENTAL RADIOLOGICAL PROGRAM INFORMATION}

TABLE 4.4

Summary of Monitored Airborne Radioactive Emissions from ANL-E Facilities, 1995

\begin{tabular}{|c|c|c|c|c|}
\hline Building & Nuclide & Half-Life & $\begin{array}{l}\text { Amount } \\
\text { Released } \\
\text { (CI) }\end{array}$ & $\begin{array}{c}\text { Amount } \\
\text { Released } \\
\text { (Bq) }\end{array}$ \\
\hline 200 & Radon-220 & $56 \mathrm{~s}$ & 1033.2 & $3.8 \times 10^{13}$ \\
\hline 205 & Hydrogen-3 (HTO) & $12.3 \mathrm{yr}$ & 0.43 & $1.6 \times 10^{10}$ \\
\hline \multirow[t]{5}{*}{212} & Hydrogen-3 (HTO) & $12.3 \mathrm{yr}$ & 58.3 & $2.2 \times 10^{12}$ \\
\hline & Hydrogen-3 (HT) & $12.3 \mathrm{yr}$ & 388.1 & $1.4 \times 10^{13}$ \\
\hline & Krypton-85 & $10.7 \mathrm{yr}$ & 29.8 & $1.1 \times 10^{13}$ \\
\hline & Antimony-125 & $2.71 \mathrm{yr}$ & 0.000033 & $1.2 \times 10^{6}$ \\
\hline & Radon-220 & $56 \mathrm{~s}$ & 1.2 & $4.4 \times 10^{10}$ \\
\hline $330(\mathrm{CP}-5)$ & Hydrogen-3 (HTO) & $12.3 \mathrm{yr}$ & 5.88 & $2.2 \times 10^{11}$ \\
\hline \multirow[t]{7}{*}{350 (NBL) } & Uranium-234 & $2.4 \times 10^{5} \mathrm{yr}$ & $2.2 \times 10^{-7}$ & $8.1 \times 10^{3}$ \\
\hline & Uranium-238 & $4.5 \times 10^{9} \mathrm{yr}$ & $2.2 \times 10^{-7}$ & $8.1 \times 10^{3}$ \\
\hline & Plutonium-238 & $87.7 \mathrm{yr}$ & $9.6 \times 10^{-9}$ & $3.6 \times 10^{2}$ \\
\hline & Plutonium-239 & $2.4 \times 10^{4} \mathrm{yr}$ & $1.8 \times 10^{-8}$ & $6.7 \times 10^{2}$ \\
\hline & Plutonium-240 & $6.6 \times 10^{4} \mathrm{yr}$ & $1.8 \times 10^{-8}$ & $6.7 \times 10^{2}$ \\
\hline & Plutonium-241 & $14.4 \mathrm{yr}$ & $5.6 \times 10^{-7}$ & $1.8 \times 10^{4}$ \\
\hline & Plutonium-242 & $3.76 \times 10^{5} \mathrm{yr}$ & $3.8 \times 10^{-9}$ & $1.4 \times 10^{2}$ \\
\hline \multirow[t]{2}{*}{375 (IPNS) } & Carbon-11 & $20 \mathrm{~m}$ & 430.0 & $1.6 \times 10^{13}$ \\
\hline & Argon-41 & $1.8 \mathrm{~h}$ & 5.3 & $2.0 \times 10^{11}$ \\
\hline \multirow[t]{3}{*}{ 411/415 (APS) } & Carbon-11 & $20 \mathrm{~m}$ & 1.2 & $4.4 \times 10^{10}$ \\
\hline & Nitrogen-13 & $10 \mathrm{~m}$ & 54.4 & $2.0 \times 10^{12}$ \\
\hline & Oxygen-15 & $122 \mathrm{~s}$ & 5.8 & $2.1 \times 10^{11}$ \\
\hline
\end{tabular}




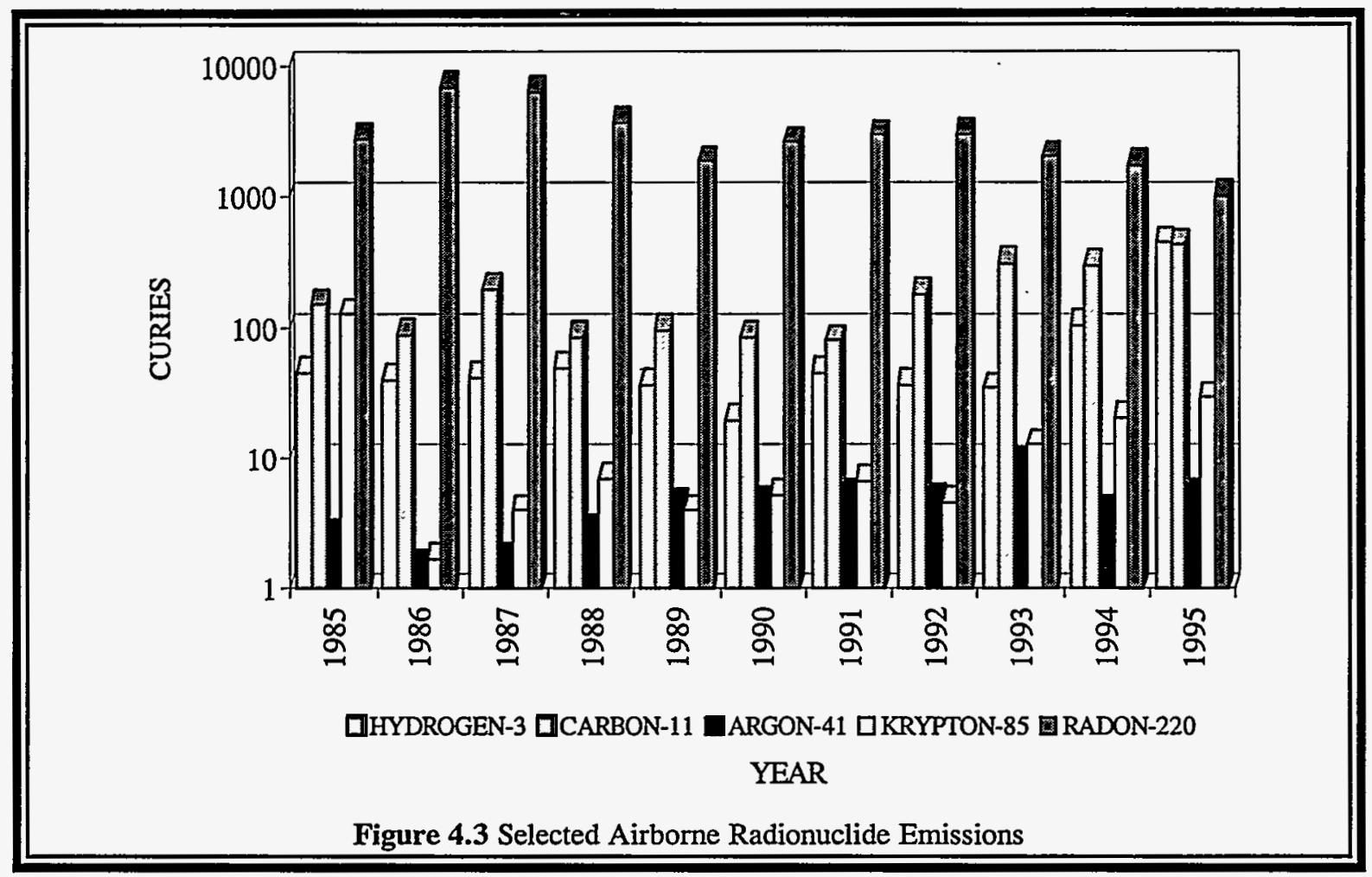

an average weekly concentration. Upstream of the site, samples were collected once a month and were analyzed for the same radionuclides measured in the below-outfall samples.

Table 4.5 gives the annual summaries of the results obtained for Sawmill Creek. Comparison of the results and $95 \%$ confidence levels of the averages for the two sampling locations shows that the nuclides found in the creek water that can be attributed to ANL-E operations are hydrogen-3, strontium-90, cesium-137, plutonium-239, americium-241, and occasionally neptunium-237, plutonium-238, curium-242 and/or californium-252, and curium-244 and/or californium-249. The percentage of individual samples containing activity attributable to ANL-E was $22 \%$ for hydrogen-3, $88 \%$ for strontium- $90,12 \%$ for cesium-137, $73 \%$ for plutonium-239, and $61 \%$ for americium-241. The concentrations of all these nuclides are low and a small fraction of the allowed DOE limits. If the concentrations of the radionuclides listed in Table 4.5 were increased by a factor of five, which approximates the effect of the dilution by Sawmill Creek on the ANL-E effluent water, the concentrations would still be below the DOE limits. This demonstrates compliance with DOE Order $5400.5^{11}$ for use of Best Available Technology (BAT) for release of liquid effluents. 
TABLE 4.5

Radionuclides in Sawmill Creek Water, 1995

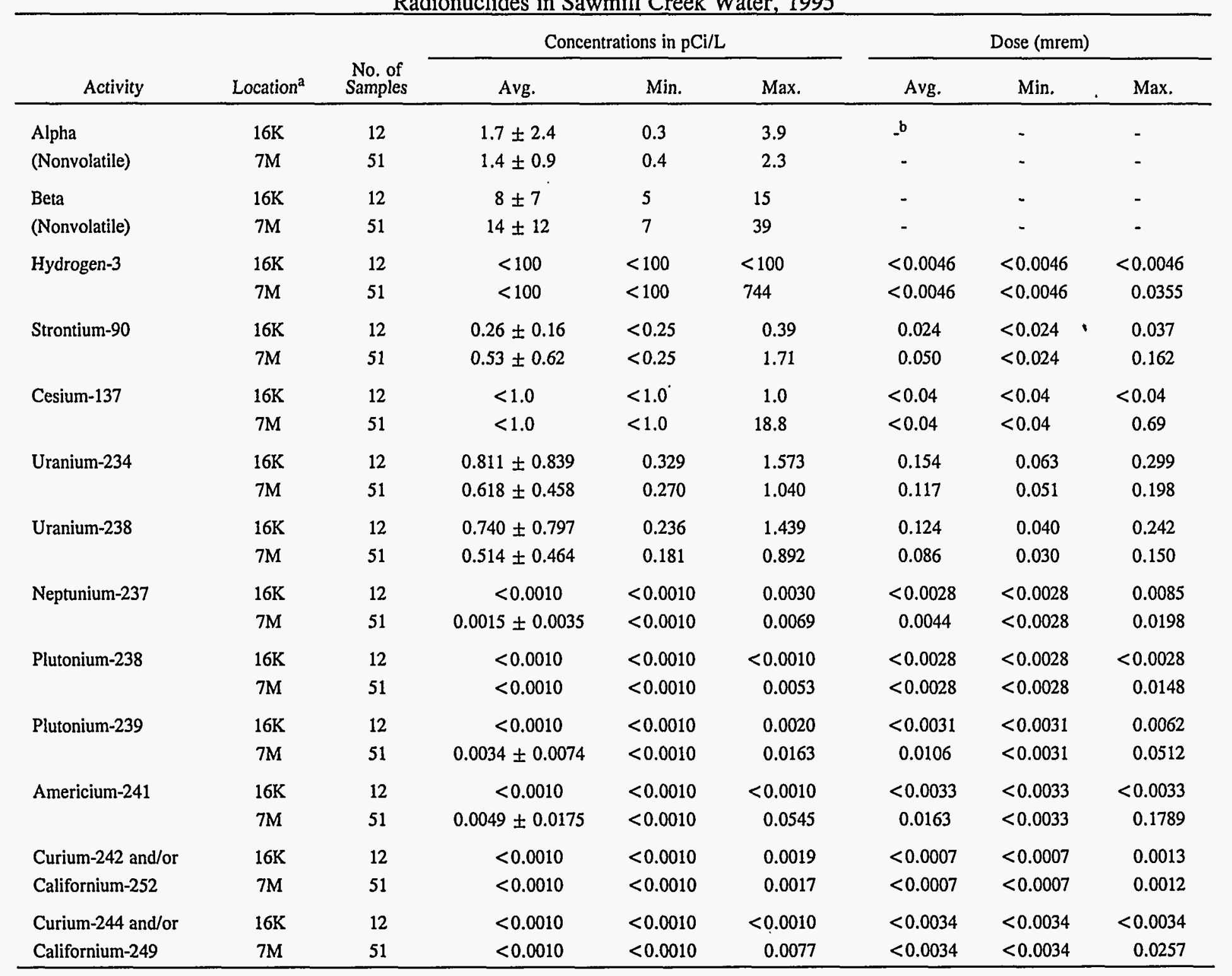

a Location 16K is upstream from the ANL-E site, and location 7M is downstream from the ANL-E wastewater outfall.

$b$ A hyphen indicates no CEDES for alpha and beta. 


\section{ENVIRONMENTAL RADIOLOGICAL PROGRAM INFORMATION}

Liquid wastewater from buildings or facilities that use or process radioactive materials are collected in retention tanks. When a tank is full, it is sampled and analyzed for alpha and beta radioactivity. If the radioactivity exceeds the release limits, the tank is processed by evaporation and the residue disposed of as solid low-level radioactive waste. If the radioactivity is below the release limits, the wastewater is conveyed to the Laboratory WTP in dedicated pipes to waste storage tanks. These tanks are again sampled and analyzed for radioactivity and if below the release limits, discharged to the environment. The release limits are based on the DCGs of plutonium-239 (0.03 pCi/mL) for alpha activity and for strontium-90 $(1.0 \mathrm{pCi} / \mathrm{mL})$ for beta activity. These radionuclides were selected because of their potential for release and their conservative allowable limits in the environment. This effluent monitoring program documents that no liquid releases above the DCGs have occurred and reinforces the demonstration of compliance with the use of BAT as required by DOE Order 5400.5.11

At location 7M, below the ANL-E outfall, the annual average concentrations of most measured radionuclides were similar to recent annual averages. All the annual averages were well below the applicable standards. The annual total radioactive effluent discharged to the creek in ANL-E wastewater can be estimated from the average net concentrations and the volume of water carried by the creek. These totals are presented in Table 4.6.

TABLE 4.6

Total Radioactivity Released to Sawmill Creek, 1995

\begin{tabular}{llr}
\multicolumn{3}{c}{ Sawmill Creek, 1995 } \\
\hline Radionuclide & Released (Ci) & Percent \\
\hline Hydrogen-3 & 0.50 & 98.4 \\
Strontium-90 & 0.0022 & 0.4 \\
Cesium-137 & 0.0059 & 1.2 \\
Plutonium-239 & 0.000026 & $<0.1$ \\
Americium-241 & 0.000039 & $<0.1$ \\
Total & 0.51 & \\
\hline
\end{tabular}


On the basis of the results of the Storm-Water Characterization Study (see Section 2.2.2), two perimeter surface water locations were identified that contained measurable levels of radionuclides. They were south of the 319 Area, Location 7J, and south of the 800 Area Landfill, Location 11D in Figure 1.1. Samples were scheduled to be collected quarterly and analyzed for hydrogen- 3 and strontium- 90 and by gamma-ray spectrometry. The results are presented in Table 4.7.

The source of the radionuclides at Location $7 \mathrm{~J}$ appears to be leachate from the 319 Area Landfill. The hydrogen-3 at Location 11D is probably also from the leachate and the decrease in the concentration from earlier years is due to the completion of the clay cap on the Landfill in the fall of 1993. A leachate collection system was constructed south of the 319 Landfill in late 1995 and became operational in 1996.

Because Sawmill Creek empties into the Des Plaines River, which in turn flows into the Illinois River, data on the radioactivity in the two rivers are important in assessing the contribution of ANL-E wastewater to environmental radioactivity. The Des Plaines River was sampled twice a month below, and once a month above, the mouth of Sawmill Creek to determine if the radioactivity in the creek had any effect on the radioactivity in the river.

Table 4.8 presents annual summaries of the results obtained for these two locations. The average nonvolatile alpha, beta, and uranium concentrations in the river were very similar to past

\section{TABLE 4.7}

Radionuclides in Storm-Water Outfalls, 1995

(Concentrations in $\mathrm{pCi} / \mathrm{L}$ )

\begin{tabular}{lcccc}
\hline \multicolumn{1}{c}{ Date Collected } & $\begin{array}{c}\text { Location 7J } \\
\text { Hydrogen-3 }\end{array}$ & $\begin{array}{c}\text { Location 7J } \\
\text { Strontium-90 }\end{array}$ & $\begin{array}{c}\text { Location 7J } \\
\text { Cesium-137 }\end{array}$ & $\begin{array}{c}\text { Location 11D } \\
\text { Hydrogen-3 }\end{array}$ \\
\hline January 12, 1995 & 224 & 1.1 & $<1$ & 164 \\
April 18, 1995 & 16,360 & 2.2 & $<1$ & 8,366 \\
August 3, 1995 & 1252 & 1.7 & $<1$ & 1,270 \\
October 20, 1995 & 1905 & 3.2 & $<1$ & 302 \\
\hline
\end{tabular}


TABLE 4.8

Radionuclides in Des Plaines River Water, 1995

\begin{tabular}{|c|c|c|c|c|c|c|c|c|}
\hline \multirow[b]{2}{*}{ Activity } & \multirow[b]{2}{*}{ Location $^{\mathrm{a}}$} & \multirow{2}{*}{$\begin{array}{l}\text { No. of } \\
\text { Samples }\end{array}$} & \multicolumn{3}{|c|}{ Concentrations in $\mathrm{pCi} / \mathrm{L}$} & \multicolumn{3}{|c|}{ Dose (mrem) } \\
\hline & & & Avg. & Min. & Max. & Avg. & Min. & Max. \\
\hline Alpha & A & 12 & $1.1 \pm 1.0$ & 0.4 & 1.8 & b & - & - \\
\hline (Nonvolatile) & B & 24 & $1.1 \pm 0.8$ & 0.5 & 1.9 & - & - & - \\
\hline Beta & A & 12 & $12 \pm 9$ & 4 & 18 & - & - & - \\
\hline (Nonvolatile) & B & 24 & $13 \pm 10$ & 4 & 22 & - & - & - \\
\hline \multirow[t]{2}{*}{ Hydrogen-3 } & A & 12 & $<100$ & $<100$ & $<100$ & $<0.0046$ & $<0.0046$ & $<0.0046$ \\
\hline & B & 24 & $<100$ & $<100$ & 941 & $<0.0046$ & $<0.0046$ & 0.0432 \\
\hline \multirow[t]{2}{*}{ Strontium-90 } & A & 12 & $0.29 \pm 14$ & $<0.25$ & 0.41 & 0.027 & $<0.024$ & 0.039 \\
\hline & B & 24 & $0.33 \pm 0.22$ & $<0.25$ & 0.57 & 0.032 & $<0.024$ & 0.054 \\
\hline \multirow[t]{2}{*}{ Uranium-234 } & A & 12 & $0.538 \pm 0.453$ & 0.184 & 0.839 & 0.102 & 0.035 & 0.159 \\
\hline & B & 24 & $0.571 \pm 0.385$ & 0.203 & 0.811 & 0.108 & 0.038 & 0.154 \\
\hline \multirow[t]{2}{*}{ Uranium-238 } & A & 12 & $0.463 \pm 0.418$ & 0.182 & 0.788 & 0.078 & 0.031 & 0.132 \\
\hline & B & 24 & $0.491 \pm 0.359$ & 0.154 & 0.730 & 0.082 & 0.026 & 0.123 \\
\hline \multirow[t]{2}{*}{ Neptunium-237 } & A & 12 & $<0.0010$ & $<0.0010$ & $<0.0010$ & $<0.0028$ & $<0.0028$ & $<0.0028$ \\
\hline & B & 12 & $<0.0010$ & $<0.0010$ & 0.0013 & $<0.0028$ & $<0.0028$ & 0.0036 \\
\hline \multirow[t]{2}{*}{ Plutonium-238 } & A & 12 & $<0.0010$ & $<0.0010$ & $<0.0010$ & $<0.0028$ & $<0.0028$ & $<0.0028$ \\
\hline & B & 12 & $<0.0010$ & $<0.0010$ & $<0.0010$ & $<0.0028$ & $<0.0028$ & $<0.0028$ \\
\hline \multirow[t]{2}{*}{ Plutonium-239 } & A & 12 & $<0.0010$ & $<0.0010$ & 0.0011 & $<0.0031$ & $<0.0031$ & 0.0034 \\
\hline & B & 12 & $<0.0010$ & $<0.0010$ & $<0.0010$ & $<0.0031$ & $<0.0031$ & $<0.0031$ \\
\hline \multirow[t]{2}{*}{ Americium-241 } & A & 12 & $<0.0010$ & $<0.0010$ & 0.0013 & $<0.0033$ & $<0.0033$ & 0.0043 \\
\hline & B & 12 & $<0.0010$ & $<0.0010$ & $<0.0010$ & $<0.0033$ & $<0.0033$ & $<0.0033$ \\
\hline Curium-242 and/or & A & 12 & $<0.0010$ & $<0.0010$ & $<0.0010$ & $<0.0007$ & $<0.0007$ & $<0.0007$ \\
\hline Californium-252 & B & 12 & $<0.0010$ & $<0.0010$ & $<0.0010$ & $<0.0007$ & $<0.0007$ & $<0.0007$ \\
\hline Curium-244 and/or & A & 12 & $<0.0010$ & $<0.0010$ & $<0.0010$ & $<0.0034$ & $<0.0034$ & $<0.0034$ \\
\hline Californium-249 & B & 12 & $<0.0010$ & $<0.0010$ & $<0.0010$ & $<0.0034$ & $<0.0034$ & $<0.0034$ \\
\hline
\end{tabular}

a Location A near Willow Springs is upstream, and location B near Lemont is downstream from the mouth of Sawmill Creek. See Figure 1.2.

b A hyphen indicates no CEDEs for alpha and beta. 
averages and remained in the normal range. Results were quite similar above and below the creek for all radionuclides because the activity in Sawmill Creek was reduced by dilution to the point that it was not detectable in the Des Plaines River. The average nonvolatile alpha and beta activities, $0.8 \mathrm{pCi} / \mathrm{L}$ and $7.3 \mathrm{pCi} / \mathrm{L}$, respectively, of 25 off-site surface water samples collected in 1995 are similar to the levels found in previous years. The hydrogen-3 concentration in these surface water samples averaged $64 \mathrm{pCi} / \mathrm{L}$.

The radioactivity levels in samples of Illinois River water, shown in Table 4.9, were similar to those found previously at these same locations. No radioactivity originating at ANL-E could be detected in the Des Plaines or Illinois rivers. The elevated hydrogen-3 levels appear to be due to discharges from the Dresden nuclear power station complex.

\subsection{Soil, Grass, and Bottom Sediment}

The radioactive content of soil, grass, and bottom sediment was measured at the site perimeter and off the site. The purpose of the off-site sampling was to measure deposition for comparison with perimeter samples and with results obtained by other organizations for samples collected at large distances from nuclear installations. Such comparisons are useful in determining if the radioactivity of soil near ANL-E is normal. For this purpose, site-selection criteria and

sample collection and sample preparation techniques recommended by the ASTM were used. ${ }^{16,17}$ Sites were selected in several directions and at various distances from ANL-E. Each site was selected on the basis that the soil appeared, or was known to have been, undisturbed for a number of years. Attempts were made to select open, level, grassy areas that were mowed at reasonable intervals. Public parks were selected when available.

As part of the quality assurance program, replicate samples were taken from $10 \%$ of the locations. The EMS data management system has been programmed to schedule the replicate samples on a rotating basis. The following tables will show paired results from the same location. 


\section{TABLE 4.9}

Radionuclides in Illinois River Water, 1995

Concentrations in $\mathrm{pCi} / \mathrm{L}$

\begin{tabular}{llcccccc}
\hline $\begin{array}{c}\text { Date } \\
\text { Collected }\end{array}$ & \multicolumn{1}{c}{ Location } & Alpha $^{\mathrm{a}}$ & Beta $^{\mathrm{a}}$ & Hydrogen-3 & Uranium-234 & Uranium-238 & Plutonium-239 \\
\hline May 3 & McKinley Woods Park, Ill. & $0.8 \pm 0.3$ & $7.3 \pm 0.3$ & $<100$ & $0.53 \pm 0.09$ & $0.51 \pm 0.09$ & $<0.001$ \\
May 3 & Dresden Lock \& Dam, Ill. & $0.5 \pm 0.2$ & $4.0 \pm 0.2$ & $1163 \pm 60$ & $0.53 \pm 0.09$ & $0.52 \pm 0.08$ & $<0.001$ \\
May 3 & Morris, Ill. & $0.7 \pm 0.3$ & $5.6 \pm 0.3$ & $213 \pm 46$ & $0.53 \pm 0.10$ & $0.50 \pm 0.09$ & $-\mathrm{b}$ \\
May 3 & Starved Rock State Park, Ill. & $0.7 \pm 0.2$ & $5.1 \pm 0.2$ & $178 \pm 45$ & $0.48 \pm 0.09$ & $0.52 \pm 0.09$ & - \\
May 3 & Starved Rock State Park, Ill. & $0.7 \pm 0.2$ & $4.8 \pm 0.2$ & $156 \pm 45$ & $0.51 \pm 0.09$ & $0.43 \pm 0.08$ & - \\
October 4 & McKinley Woods Park. Ill. & $0.5 \pm 0.2$ & $10.4 \pm 0.3$ & $<100$ & $0.15 \pm 0.06$ & $0.15 \pm 0.05$ & $<0.001$ \\
October 4 & McKinley Woods Park, Ill. & $1.8 \pm 0.3$ & $10.0 \pm 0.3$ & $<100$ & $0.18 \pm 0.04$ & $0.12 \pm 0.03$ & $<0.001$ \\
October 4 & Dresden Lock \& Dam, Ill. & $0.3 \pm 0.2$ & $5.6 \pm 0.2$ & $<100$ & $0.24 \pm 0.07$ & $0.22 \pm 0.06$ & $<0.001$ \\
October 4 & Morris, Ill. & $1.1 \pm 0.3$ & $8.6 \pm 0.3$ & $165 \pm 45$ & $0.31 \pm 0.08$ & $0.24 \pm 0.06$ & - \\
October 4 & Starved Rock State Park, Ill. & $0.7 \pm 0.3$ & $10.0 \pm 0.3$ & $114 \pm 44$ & $0.34 \pm 0.05$ & $0.22 \pm 0.04$ & - \\
\hline
\end{tabular}

a Nonvolatile activity.

b A hyphen indicates that no analysis was performed. 
Comparison of the analytical data in these tables of pairs of samples collected at the same location will provide a measure of the heterogeneity of the media, that is, soil, grass, or bottom sediment.

Each soil sample consisted of 10 cores, totaling $864 \mathrm{~cm}^{2}\left(134 \mathrm{in}^{2}\right)$ in area by $5 \mathrm{~cm}(2 \mathrm{in}$.) deep. Through.1976, samples were collected down to $30 \mathrm{~cm}$ (12 in.) to measure total deposition. The results of five years of sample collection at this depth have established the total deposition in the ANL-E environment. Reducing the sampling depth to $5 \mathrm{~cm}$ (2 in.) will make the analysis more sensitive to changes in current deposition. The grass samples were obtained by collecting the grass from a $1-\mathrm{m}^{2}\left(10-\mathrm{ft}^{2}\right)$ area in the immediate vicinity of a soil sample. A grab sample technique was used to obtain bottom sediments from water bodies. After drying, grinding, and mixing $100-\mathrm{g}$ portions of each soil, bottom sediment and grass samples were analyzed by the same methods described in Section 4.2 for air filter residues. The plutonium and americium were separated from the same 10-g aliquot of soil. Results are given in terms of the oven-dried $\left(110^{\circ} \mathrm{C} ; 230^{\circ} \mathrm{F}\right)$ weight.

The results for the gamma-ray emitting nuclides in soil are presented in Table 4.10. Intermediate half-life fission products reported in 1986 have decayed to below their detection limits, and no evidence of Chernobyl fallout is apparent. The cesium-137 levels are similar to those found over the past several years and represent an accumulation from nuclear tests over a period of many years. The annual average concentrations for the perimeter and off-site samples were similar. The plutonium and americium concentrations are given in Table 4.11. The range and average concentrations of plutonium and americium in soil were similar at both perimeter and off-site sampling points. For fallout americium-241 in soil, about $10 \%$ is due to direct deposition, while about $90 \%$ is due to the decay of the previously deposited plutonium-241. The americium-241/plutonium-239 ratio is consistent with the current estimated value for this ratio of 0.43 in fallout derived material. ${ }^{18}$ 
TABLE 4.10

Gamma-Ray-Emitting Radionuclides in Soil, 1995 (Concentrations in $\mathrm{pCi} / \mathrm{g}$ )

\begin{tabular}{|c|c|c|c|c|c|c|}
\hline $\begin{array}{l}\text { Date } \\
\text { Collected }\end{array}$ & Location & Potassium-40 & Cesium-137 & Radium-226 & Thorium-228 & Thorium-232 \\
\hline & Perimeter $^{\mathrm{a}}$ & & & & & \\
\hline May 2 & $10 \mathrm{P}$ & $22.23 \pm 0.74$ & $0.86 \pm 0.04$ & $1.08 \pm 0.06$ & $1.08 \pm 0.04$ & $0.79 \pm 0.09$ \\
\hline May 2 & $14 \mathrm{E}$ & $20.70 \pm 0.62$ & $0.59 \pm 0.03$ & $1.30 \pm 0.06$ & $1.24 \pm 0.04$ & $0.90 \pm 0.08$ \\
\hline May 2 & $14 \mathrm{~N}$ & $17.06 \pm 0.57$ & $0.75 \pm 0.03$ & $0.93 \pm 0.05$ & $1.09 \pm 0.04$ & $0.81 \pm 0.08$ \\
\hline May 2 & $4 \mathrm{EF}$ & $17.19 \pm 0.57$ & $0.65 \pm 0.03$ & $0.73 \pm 0.05$ & $0.89 \pm 0.04$ & $0.74 \pm 0.08$ \\
\hline May 2 & $7 \mathrm{EF}$ & $20.61 \pm 0.64$ & $0.65 \pm 0.03$ & $1.18 \pm 0.06$ & $1.14 \pm 0.04$ & $0.77 \pm 0.08$ \\
\hline May 2 & $14 \mathrm{~N}$ & $17.33 \pm 0.57$ & $0.73 \pm 0.03$ & $1.04 \pm 0.06$ & $1.15 \pm 0.04$ & $0.88 \pm 0.08$ \\
\hline October 16 & $13 D$ & $18.54 \pm 0.68$ & $0.70 \pm 0.04$ & $0.94 \pm 0.06$ & $1.14 \pm 0.04$ & $0.94 \pm 0.09$ \\
\hline October 16 & $13 \mathrm{~N}$ & $19.62 \pm 0.61$ & $0.58 \pm 0.03$ & $1.22 \pm 0.06$ & $1.12 \pm 0.04$ & $0.79 \pm 0.08$ \\
\hline October 16 & $15 \mathrm{H}$ & $16.83 \pm 0.65$ & $0.21 \pm 0.02$ & $1.01 \pm 0.06$ & $1.14 \pm 0.04$ & $0.87 \pm 0.09$ \\
\hline October 16 & $7 \mathrm{M}$ & $13.46 \pm 0.59$ & $0.44 \pm 0.03$ & $0.68 \pm 0.05$ & $0.57 \pm 0.03$ & $0.50 \pm 0.07$ \\
\hline October 16 & $8 G$ & $17.10 \pm 0.57$ & $0.72 \pm 0.03$ & $1.00 \pm 0.06$ & $1.26 \pm 0.04$ & $0.87 \pm 0.08$ \\
\hline \multirow[t]{3}{*}{ October 16} & $15 \mathrm{H}$ & $21.15 \pm 0.72$ & $0.50 \pm 0.03$ & $1.10 \pm 0.06$ & $1.14 \pm 0.04$ & $0.86 \pm 0.09$ \\
\hline & Average & $18.49 \pm 5.42$ & $0.62 \pm 0.37$ & $1.02 \pm 0.41$ & $1.08 \pm 0.41$ & $0.81 \pm 0.25$ \\
\hline & Off-site & & & & & \\
\hline May 3 & 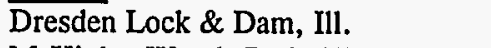 & $12.38 \pm 0.50$ & $0.73 \pm 0.03$ & $0.69 \pm 0.05$ & $0.59 \pm 0.03$ & $0.46 \pm 0.07$ \\
\hline May 3 & McKinley Woods Park, Ill. & $18.09 \pm 0.58$ & $1.58 \pm 0.05$ & $0.77 \pm 0.05$ & $0.81 \pm 0.04$ & $0.59 \pm 0.08$ \\
\hline May 3 & Morris, Ill. & $15.35 \pm 0.55$ & $0.47 \pm 0.03$ & $0.94 \pm 0.05$ & $0.98 \pm 0.04$ & $0.75 \pm 0.08$ \\
\hline May 3 & Dresden Lock \& Dam, Ill. & $19.35 \pm 0.69$ & $1.25 \pm 0.04$ & $0.96 \pm 0.06$ & $0.84 \pm 0.04$ & $0.63 \pm 0.08$ \\
\hline May 4 & Romeoville, Ill. & $14.99 \pm 0.62$ & $0.49 \pm 0.03$ & $0.96 \pm 0.06$ & $1.15 \pm 0.04$ & $0.93 \pm 0.09$ \\
\hline May 4 & Lemont. Ill. & $20.48 \pm 0.62$ & $0.53 \pm 0.03$ & $1.08 \pm 0.06$ & $1.11 \pm 0.04$ & $0.83 \pm 0.08$ \\
\hline May 4 & Lemont, Ill. & $18.68 \pm 0.59$ & $0.36 \pm 0.03$ & $0.94 \pm 0.05$ & $1.03 \pm 0.04$ & $0.91 \pm 0.08$ \\
\hline May 5 & Pioneer Park, Naperville, Ill. & $14.22 \pm 0.53$ & $0.24 \pm 0.03$ & $1.22 \pm 0.06$ & $1.97 \pm 0.05$ & $1.61 \pm 0.10$ \\
\hline October 4 & Channahon, Ill. & $15.21 \pm 0.54$ & $0.17 \pm 0.02$ & $1.04 \pm 0.06$ & $1.36 \pm 0.04$ & $1.16 \pm 0.09$ \\
\hline October 4 & Starved Rock State Park, Ill. & $13.23 \pm 0.51$ & $0.46 \pm 0.03$ & $0.86 \pm 0.05$ & $0.80 \pm 0.04$ & $0.68 \pm 0.07$ \\
\hline October 4 & Starved Rock State Park. Ill. & $13.59 \pm 0.52$ & $0.47 \pm 0.03$ & $0.89 \pm 0.05$ & $0.85 \pm 0.04$ & $0.62 \pm 0.08$ \\
\hline October 6 & McCormick Woods, Brookfield, Ill. & $19.31 \pm 0.69$ & $0.20 \pm 0.02$ & $1.23 \pm 0.06$ & $0.97 \pm 0.04$ & $0.80 \pm 0.09$ \\
\hline October 6 & Bemis Woods, Western Springs, IIl. & $18.72 \pm 0.68$ & $0.21 \pm 0.02$ & $1.44 \pm 0.07$ & $1.13 \pm 0.04$ & $0.76 \pm 0.09$ \\
\hline \multirow[t]{2}{*}{ October 6} & Bemis Woods, Western Springs, Ill. & $18.14 \pm 0.67$ & $0.20 \pm 0.03$ & $1.49 \pm 0.07$ & $1.07 \pm 0.04$ & $0.91 \pm 0.09$ \\
\hline & Average & $16.55+5.79$ & $0.53 \pm 0.90$ & $1.04 \pm 0.51$ & $1.05+0.71$ & $0.83 \pm 0.62$ \\
\hline
\end{tabular}

a The perimeter locations are given in terms of the grid coordinates in Figure 1.1 


\section{ENVIRONMENTAL RADIOLOGICAL PROGRAM INFORMATION}

The radionuclide concentrations measured in grass are listed in Table 4.12. The annual averages and concentration ranges were similar at the perimeter and off-site locations and were similar to those of previous years, indicating no cóntribution from ANL-E operations. In terms of deposition, the plutonium-239 concentration was a factor of about $10^{4}$ less in the grass than in the soil from the same location.

Table 4.13 gives the results of analyses of bottom sediment samples for gamma-ray emitters and transuranics. The annual off-site averages were in the same range found in off-site samples collected in previous years. Plutonium results varied widely among locations and were strongly dependent on the retentiveness of the bottom material. A set of sediment samples was collected on July 26, 1995, from the Sawmill Creek bed, above, at the outfall, and at several locations below the point at which ANL-E discharges its treated wastewater (location 7M in Figure 1.1). The results, as listed in Table 4.13, show that the concentrations in the sample above the $7 \mathrm{M}$ outfall are similar to those of the off-site samples. The plutonium, americium, and cesium-137 concentrations are elevated below the outfall, indicating that their origin is in ANL-E wastewater. The changes in concentrations of these nuclides with time and location indicate the dynamic nature of the sediment material in this area.

\subsection{External Penetrating Radiation}

Levels of external penetrating radiation at and in the vicinity of the ANL-E site were measured with calcium fluoride TLD chips. Each measurement reported represents the average of four chips exposed in the same packet. All calcium fluoride packets were shielded with $1.6 \mathrm{~mm}$ (1/16 in.) copper foil to reduce or eliminate the beta and low-energy x-ray components. The response of the chips was determined with a NIST standard radium-226 source, and the results were calculated in terms of the air dose. Commercial dosimeters were placed next to the calcium fluoride dosimeters and after the end of the exposure period, were read by the vendor. The results were very similar to the in-house readings; beginning in 1996, only the commercial TLDs will be deployed. Dosimeters were exposed at 14 locations at the site boundary and on the 
TABLE 4.11

Transuranics in Soil, 1995

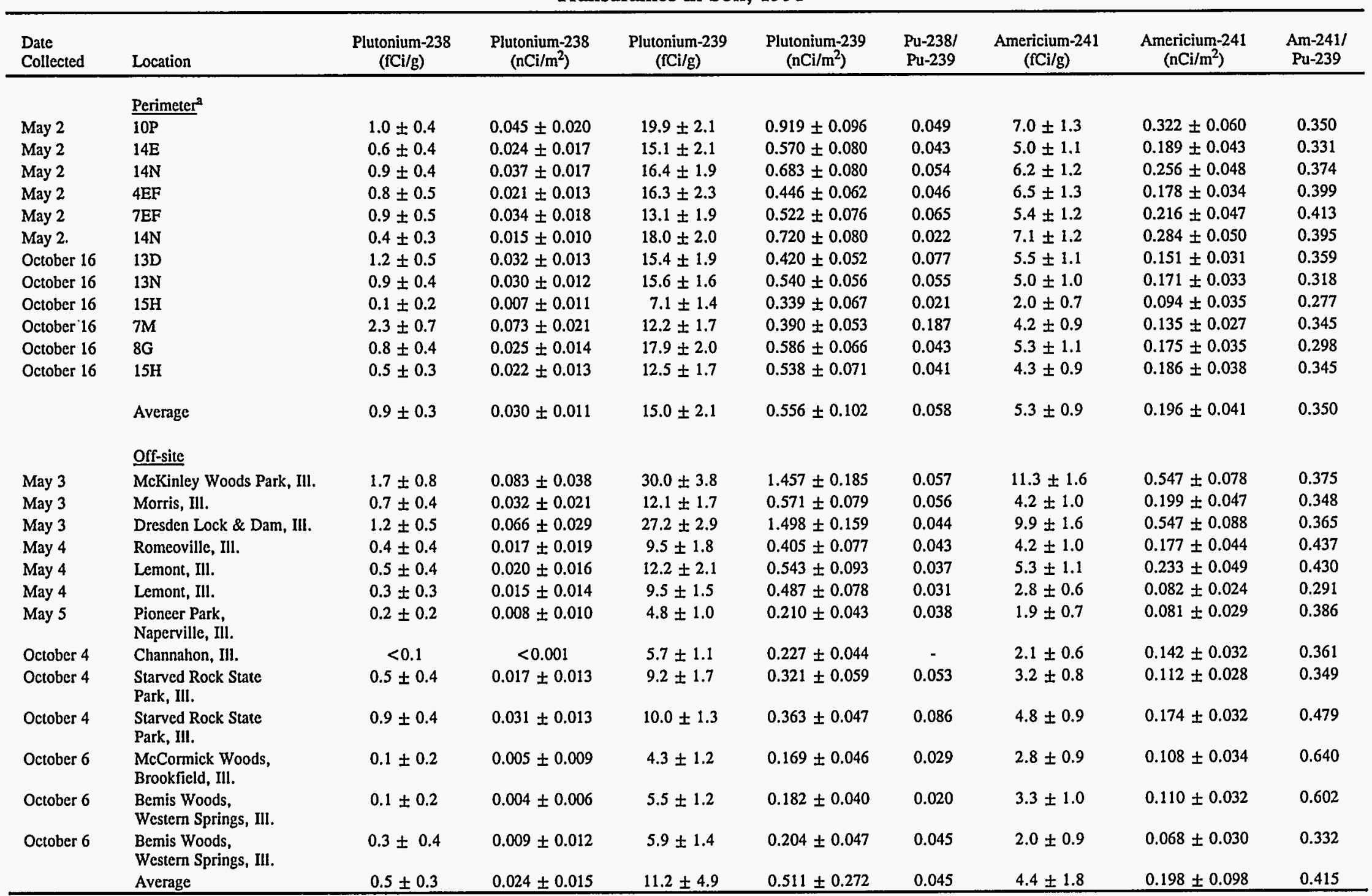

\footnotetext{
${ }^{a}$ The perimeter locations are given in terms of the grid coordinates in Figure 1.1.
} 
TABLE 4.12

Radionuclides in Grass, 1995

\begin{tabular}{|c|c|c|c|c|c|}
\hline $\begin{array}{l}\text { Date } \\
\text { Collected }\end{array}$ & Location & $\begin{array}{l}\text { Potassium-40 } \\
(\mathrm{pCi} / \mathrm{g})\end{array}$ & $\begin{array}{l}\text { Cesium-137 } \\
\text { (fCi/g) }\end{array}$ & $\begin{array}{c}\text { Plutonium-239 } \\
\text { (fCi/g) }\end{array}$ & $\begin{array}{c}\text { Deposited } \\
\text { Plutoniu239 } \\
\left(\mathrm{pCi} / \mathrm{m}^{2}\right)\end{array}$ \\
\hline & Perimeter $^{\mathrm{a}}$ & & & & \\
\hline May 2 & $10 \mathrm{P}$ & $10.85 \pm 0.40$ & $19 \pm 15$ & $0.5 \pm 0.1$ & $0.09 \pm 0.02$ \\
\hline May 2 & $14 \mathrm{E}$ & $11.61 \pm 0.44$ & $16 \pm 14$ & $0.5 \pm 0.1$ & $0.10 \pm 0.02$ \\
\hline May 2 & $14 \mathrm{~N}$ & $13.91 \pm 0.44$ & $<10$ & $0.2 \pm 0.1$ & $0.02 \pm 0.01$ \\
\hline May 2 & $4 \mathrm{EF}$ & $19.40 \pm 0.52$ & $12 \pm 13$ & $<0.1$ & $<0.01$ \\
\hline May 2 & 7EF & $20.57 \pm 0.53$ & $15 \pm 13$ & $0.6 \pm 0.1$ & $0.08 \pm 0.01$ \\
\hline May 2 & $14 \mathrm{~N}$ & $14.99 \pm 0.49$ & $10 \pm 14$ & $0.1 \pm 0.1$ & $0.02 \pm 0.01$ \\
\hline October 16 & $13 \mathrm{D}$ & $9.45 \pm 0.39$ & $<10$ & $<0.1$ & 0.01 \\
\hline October 16 & $15 \mathrm{H}$ & $9.72 \pm 0.34$ & $<10$ & $0.3 \pm 0.1$ & $0.04 \pm 0.02$ \\
\hline October 16 & $7 \mathrm{M}$ & $17.87 \pm 0.43$ & $<10$ & $0.2 \pm 0.1$ & $0.03 \pm 0.01$ \\
\hline October 16 & $8 \mathrm{G}$ & $6.48 \pm 0.32$ & $<10$ & $<0.1$ & $<0.01$ \\
\hline \multirow[t]{3}{*}{ October 16} & $15 \mathrm{H}$ & $7.38 \pm 0.28$ & $<10$ & $0.2 \pm 0.1$ & $0.03 \pm 0.01$ \\
\hline & Average & $12.93 \pm 1.02$ & $<10$ & $0.3 \pm 0.1$ & $0.04 \pm 0.01$ \\
\hline & $\underline{\text { Off-Site }}$ & & & & \\
\hline May 3 & Dresden Lock \& Dam, Ill. & $22.37 \pm 0.68$ & $<10$ & $0.3 \pm 0.1$ & $0.02 \pm 0.01$ \\
\hline May 3 & McKinley Woods Park, Ill. & $15.48 \pm 0.48$ & $<10$ & $0.3 \pm 0.1$ & $0.02 \pm 0.01$ \\
\hline May 3 & Morris, Ill. & $32.04 \pm 0.57$ & $<10$ & $0.1 \pm 0.1$ & $0.02 \pm 0.01$ \\
\hline May 3 & Dresden Lock \& Dam, Ill. & $18.50 \pm 0.62$ & $15 \pm 17$ & $0.1 \pm 0.1$ & $<0.01$ \\
\hline May 4 & Romeoville, Ill. & $30.78 \pm 0.75$ & $<10$ & $<0.1$ & $<0.01$ \\
\hline May 4 & Lemont, Ill. & $29.39 \pm 0.66$ & $10 \pm 15$ & $<0.1$ & $0.01 \pm 0.01$ \\
\hline May 4 & Lemont, Ill. & $23.27 \pm 0.53$ & $<10$ & $0.2 \pm 0.1$ & $0.02 \pm 0.01$ \\
\hline May 5 & Pioneer Park, Naperville, Ill. & $33.30 \pm 0.64$ & $15 \pm 13$ & $0.5 \pm 0.2$ & $0.04 \pm 0.01$ \\
\hline October 4 & Channahon, Ill. & $15.75 \pm 0.50$ & $<10$ & $<0.1$ & $<0.01$ \\
\hline October 4 & Starved Rock State Park, Ill. & $6.89 \pm 0.32$ & $21 \pm 14$ & $0.6 \pm 0.1$ & $0.07 \pm 0.02$ \\
\hline October 4 & Starved Rock State Park, Ill. & $8.69 \pm 0.33$ & $13 \pm 11$ & $0.3 \pm 0.1$ & $0.04 \pm 0.01$ \\
\hline October 6 & $\begin{array}{l}\text { McCormick Woods, } \\
\text { Brookfield, Ill. }\end{array}$ & $16.20 \pm 0.58$ & $<10$ & $<0.1$ & $<0.01$ \\
\hline October 6 & $\begin{array}{l}\text { Bemis Woods, Western } \\
\text { Springs, IIl. }\end{array}$ & $19.67 \pm 0.47$ & $<10$ & $<0.1$ & $<0.01$ \\
\hline \multirow[t]{2}{*}{ October 6} & $\begin{array}{l}\text { Bemis Woods, Western } \\
\text { Springs, IIl. }\end{array}$ & $34.47 \pm 0.81$ & $<10$ & $0.1 \pm 0.1$ & $0.01 \pm 0.01$ \\
\hline & Average & $21.91 \pm 1.44$ & $<10$ & $0.2 \pm 0.1$ & $0.02 \pm 0.01$ \\
\hline
\end{tabular}

${ }^{2}$ The perimeter locations are given in terms of the grid coordinates in Figure 1.1. 


\section{TABLE 4.13}

Radionuclides in Bottom Sediment, 1995

\begin{tabular}{|c|c|c|c|c|c|c|c|c|c|}
\hline \multirow{2}{*}{$\begin{array}{l}\text { Date } \\
\text { Collected }\end{array}$} & \multirow[b]{2}{*}{ Location } & \multicolumn{5}{|c|}{ Concentrations in $\mathrm{Ci} / \mathrm{g}$} & \multicolumn{3}{|c|}{ Concentrations in $\mathrm{fCi} / \mathrm{g}$} \\
\hline & & Potassium -40 & Cesium-137 & Radium-226 & Thorium-228 & Thorium-232 & Plutonium-238 & Plutonium-239 & Americium-241 \\
\hline & Perimeter $^{\mathrm{a}}$ & & & & & & & & \\
\hline July 26 & $\begin{array}{l}\text { Sawmill Creek } 25 \mathrm{~m} \\
\text { Above Outfall }\end{array}$ & $8.83 \pm 0.49$ & $0.03 \pm 0.02$ & $0.61 \pm 0.05$ & $0.41 \pm 0.03$ & $0.39 \pm 0.07$ & $0.1 \pm 0.2$ & $1.2 \pm 0.6$ & $0.5 \pm 0.3$ \\
\hline July 26 & Sawmill Creek At Outfall & $9.28 \pm 0.50$ & $0.95 \pm 0.04$ & $0.59 \pm 0.05$ & $0.45 \pm 0.04$ & $0.34 \pm 0.07$ & $2.7 \pm 0.9$ & $33.2 \pm 3.8$ & $15.3 \pm 2.0$ \\
\hline July 26 & $\begin{array}{l}\text { Sawmill Creek } 50 \mathrm{~m} \\
\text { Below Outfall }\end{array}$ & $7.83 \pm 0.47$ & $0.42 \pm 0.03$ & $0.48 \pm 0.05$ & $0.36 \pm 0.03$ & $0.31 \pm 0.07$ & $0.1 \pm 0.2$ & $3.0 \pm 1.0$ & $1.3 \pm 0.5$ \\
\hline July 26 & $\begin{array}{l}\text { Sawmill Creek } 100 \mathrm{~m} \\
\text { Below Outfall }\end{array}$ & $16.88 \pm 0.65$ & $2.51 \pm 0.06$ & $0.89 \pm 0.06$ & $0.87 \pm 0.04$ & $0.63 \pm 0.09$ & $7.4 \pm 1.4$ & $745.2 \pm 45.1$ & $63.1 \pm 4.6$ \\
\hline \multirow[t]{2}{*}{ July 26} & $\begin{array}{l}\text { Sawmill Creek At } \\
\text { Des Plaines River }\end{array}$ & $18.32 \pm 0.68$ & $0.41 \pm 0.03$ & $1.10 \pm 0.07$ & $1.03 \pm 0.05$ & $0.81 \pm 0.10$ & $0.9 \pm 0.6$ & $14.5 \pm 2.2$ & $3.8 \pm 1.0$ \\
\hline & Off-site & & & & & & & & \\
\hline May 3 & $\begin{array}{l}\text { Illinois River Dresden } \\
\text { Lock \& Dam, Ill. }\end{array}$ & $24.71 \pm 0.91$ & $0.04 \pm 0.03$ & $1.49 \pm 0.09$ & $1.49 \pm 0.06$ & $1.07 \pm 0.13$ & $0.1 \pm 0.2$ & $3.4 \pm 0.9$ & $<0.1$ \\
\hline May 3 & $\begin{array}{l}\text { Illinois River McKinley } \\
\text { Woods Park, Ill. }\end{array}$ & $14.19 \pm 0.60$ & $0.02 \pm 0.02$ & $0.62 \pm 0.05$ & $0.64 \pm 0.04$ & $0.54 \pm 0.08$ & $1.6 \pm 0.7$ & $4.3 \pm 1.2$ & $5.2 \pm 1.2$ \\
\hline May 3 & Illinois River Morris, Ill. & $8.83 \pm 0.43$ & $0.02 \pm 0.02$ & $0.35 \pm 0.04$ & $0.40 \pm 0.03$ & $0.34 \pm 0.06$ & $<0.1$ & $0.4 \pm 0.4$ & $0.5 \pm 0.4$ \\
\hline May 3 & $\begin{array}{l}\text { Illinois River Dresden } \\
\text { Lock \& Dam, III. }\end{array}$ & $21.96 \pm 0.74$ & $0.05 \pm 0.03$ & $1.48 \pm 0.07$ & $1.28 \pm 0.05$ & $1.03 \pm 0.10$ & $0.1 \pm 0.2$ & $5.3 \pm 1.2$ & - \\
\hline May 4 & $\begin{array}{l}\text { Des Plaines River } \\
\text { Romeoville, Ill. }\end{array}$ & $15.45 \pm 0.63$ & $0.86 \pm 0.04$ & $1.18 \pm 0.07$ & $1.00 \pm 0.05$ & $0.84 \pm 0.09$ & $1.5 \pm 0.6$ & $42.3 \pm 3.8$ & $11.8 \pm 2.1$ \\
\hline May 4 & $\begin{array}{l}\text { Long Run Creek } \\
\text { Lemont. Ill. }\end{array}$ & $20.79 \pm 0.72$ & $0.02 \pm 0.02$ & $1.60 \pm 0.07$ & $1.30 \pm 0.05$ & $0.95 \pm 0.10$ & $<0.1$ & $<0.1$ & $0.1 \pm 0.4$ \\
\hline May 5 & $\begin{array}{l}\text { DuPage River, Pioneer } \\
\text { Park, Naperville, Ill. }\end{array}$ & $14.59 \pm 0.62$ & $0.11 \pm 0.03$ & $0.85 \pm 0.07$ & $4.34 \pm 0.08$ & $3.98 \pm 0.16$ & $0.2 \pm 0.3$ & $4.0 \pm 1.1$ & $1.3 \pm 0.5$ \\
\hline October 4 & $\begin{array}{l}\text { DuPage River } \\
\text { Channahon, Ill. }\end{array}$ & $6.93 \pm 0.45$ & $0.04 \pm 0.02$ & $0.69 \pm 0.06$ & $0.58 \pm 0.04$ & $0.47 \pm 0.08$ & $0.1 \pm 0.2$ & $1.3 \pm 0.6$ & $0.8 \pm 0.4$ \\
\hline October 4 & $\begin{array}{l}\text { Illinois River, Starved } \\
\text { Rock State Park, Ill. }\end{array}$ & $5.54 \pm 0.40$ & $0.03 \pm 0.02$ & $0.45 \pm 0.05$ & $0.29 \pm 0.03$ & $0.21 \pm 0.07$ & $0.1 \pm 0.2$ & $0.6 \pm 0.4$ & $0.5 \pm 0.2$ \\
\hline October 4 & $\begin{array}{l}\text { DuPage River } \\
\text { Channahon. Ill. }\end{array}$ & $6.58 \pm 0.40$ & $0.04 \pm 0.02$ & $0.77 \pm 0.05$ & $0.65 \pm 0.04$ & $0.47 \pm 0.07$ & $0.1 \pm 0.3$ & $1.9 \pm 0.8$ & $1.2 \pm 0.5$ \\
\hline October 6 & $\begin{array}{l}\text { Des Plaines River, } \\
\text { McCormick Woods, } \\
\text { Brookfield, Ill. }\end{array}$ & $20.43 \pm 0.71$ & $0.36 \pm 0.03$ & $1.32 \pm 0.07$ & $1.13 \pm 0.05$ & $0.84 \pm 0.09$ & $0.2 \pm 0.3$ & $7.2 \pm 1.5$ & $3.4 \pm 0.7$ \\
\hline \multirow[t]{2}{*}{ October 6} & $\begin{array}{l}\text { Salt Creek, Bemis Woods, } \\
\text { Western Springs, IL }\end{array}$ & $14.01 \pm 0.60$ & $0.09 \pm 0.03$ & $1.04 \pm 0.06$ & $0.74 \pm 0.04$ & $0.59 \pm 0.08$ & $0.1 \pm 0.2$ & $3.5 \pm 1.0$ & $1.2 \pm 0.4$ \\
\hline & Average & $14.50 \pm 14.37$ & $0.14 \pm 0.55$ & $0.99 \pm 0.94$ & $1.15 \pm 2.37$ & $0.94 \pm 2.19$ & $0.3 \pm 1.3$ & $6.2 \pm 25.5$ & $2.4 \pm 7.8$ \\
\hline
\end{tabular}

a The perimeter locations are given in terms of the grid coordinates in Figure 1.1. 


\section{ENVIRONMENTAL RADIOLOGICAL PROGRAM INFORMATION}

site. Readings were also taken at five off-site locations for comparative purposes. These locations are shown in Figure 1.2.

The results are summarized in Tables 4.14 and 4.15 , and the site boundary and on-site readings are shown in Figure 4.4. Measurements were taken during the four successive exposure periods shown in the tables, and the results were calculated in terms of annual dose for ease in comparing measurements made for different elapsed times. The uncertainty given in the tables for an average is the $95 \%$ confidence limit calculated from the standard deviation of the average.

The off-site results averaged $92 \pm 4 \mathrm{mrem} / \mathrm{y}$ and were higher than last year's off-site average of $82 \pm 10 \mathrm{mrem} / \mathrm{yr} .{ }^{19}$ Elevated third quarter results may be related to a lack of precipitation during the summer, which allows higher levels of radon to emanate from the soil. To compare boundary results for individual sampling periods, the standard deviation of the 20 individual off-site results is useful. This value is $9 \mathrm{mrem} / \mathrm{yr}$, so individual results in the range of $92 \pm 18 \mathrm{mrem} / \mathrm{yr}$ may be considered to be the average natural background with a $95 \%$ probability.

TABLE 4.14

Environmental Penetrating Radiation at Off-Site Locations, 1995

\begin{tabular}{lccccc}
\hline & \multicolumn{5}{c}{ Dose Rate (mrem/yr) } \\
\cline { 2 - 6 } \multicolumn{1}{c}{ Location } & $1 / 5-4 / 6$ & $4 / 6-7 / 6$ & $7 / 6-10 / 10$ & $10 / 10-1 / 4$ & Average \\
\hline & 88 & 91 & 103 & 95 & $94 \pm 6$ \\
Lemont & 96 & 98 & 114 & 96 & $101 \pm 9$ \\
Oak Brook & 81 & 92 & 95 & 88 & $89 \pm 6$ \\
Orland Park & 86 & 99 & 103 & 98 & $97 \pm 7$ \\
Woodridge & 76 & 81 & 85 & 75 & $79 \pm 5$ \\
Willow Springs & $85 \pm 7$ & $92 \pm 6$ & $100 \pm 9$ & $90 \pm 8$ & $92 \pm 4$ \\
Average & \multicolumn{5}{c}{}
\end{tabular}


TABLE 4.15

Environmental Penetrating Radiation at ANL-E, 1995

\begin{tabular}{|c|c|c|c|c|c|c|}
\hline \multirow{3}{*}{\multicolumn{2}{|c|}{ Location $^{\mathrm{a}}$}} & \multicolumn{5}{|c|}{ Dose Rate (mrem/yr) } \\
\hline & & \multicolumn{5}{|c|}{ Period of Measurement } \\
\hline & & $1 / 5-4 / 6$ & $4 / 6-7 / 6$ & $7 / 6-10 / 10$ & $10 / 10-1 / 4$ & Average \\
\hline $14 G$ & Boundary & 91 & 100 & 105 & - & $99 \pm 8$ \\
\hline 141 & Boundary & 91 & 99 & 108 & 93 & $98 \pm 7$ \\
\hline $14 \mathrm{~L}$ & Boundary & 85 & 85 & 97 & 90 & $89 \pm 6$ \\
\hline 61 & $200 \mathrm{~m} \mathrm{~N}$ of Quarry Road & 89 & 94 & 105 & 98 & $97 \pm 7$ \\
\hline $7 I$ & $\begin{array}{l}\text { Center, Waste Storage } \\
\text { Area Facility } 317\end{array}$ & 2,333 & 5,078 & 7,328 & 7,328 & $5,516 \pm 2,324$ \\
\hline $7 \mathrm{I}$ & Boundary & 121 & 122 & 147 & 126 & $129 \pm 12$ \\
\hline $8 \mathrm{H}$ & Boundary & 88 & 94 & 110 & 94 & $97 \pm 9$ \\
\hline $8 \mathrm{H}$ & $65 \mathrm{~m} \mathrm{~S}$ of Building 316 & 86 & 96 & 101 & 94 & $94 \pm 6$ \\
\hline $8 \mathrm{H}$ & $\begin{array}{l}200 \mathrm{~m} \text { NW of Waste } \\
\text { Storage Area (Heliport) }\end{array}$ & 91 & 103 & 104 & 96 & $99 \pm 6$ \\
\hline $8 \mathrm{H}$ & $\begin{array}{l}\text { Boundary, Center, } \\
\text { St. Patrick Cemetery }\end{array}$ & 94 & 98 & 118 & 103 & $103 \pm 10$ \\
\hline $9 \mathrm{H}$ & $50 \mathrm{~m} \mathrm{SE}$ of $\mathrm{CP}-5$ & 111 & 128 & 121 & 123 & $121 \pm 7$ \\
\hline $9 I$ & $\begin{array}{l}65 \mathrm{~m} \mathrm{NE} \text { of Building } 350 \\
230 \mathrm{~m} \text { NE of Building } 316\end{array}$ & 81 & 82 & 89 & 82 & $84 \pm 4$ \\
\hline $9 / 10$ & EF - Boundary & 95 & 111 & 111 & 96 & $103 \pm 9$ \\
\hline $10 / 11$ & $\mathrm{~K}$ - Lodging Facilities & 74 & 89 & 97 & 90 & $88 \pm 9$ \\
\hline
\end{tabular}

a See Figure 4.4.

In the past, two site boundary locations, 7I (south) and 14I (north), had dose rates consistently above the average background. At 7I, this was due to radiation from ANL-E's Radioactive Waste Storage Facility (317 Area) in the northern half of grid 7I. Waste is packaged and temporarily kept in this area before removal for permanent disposal off-site. The dose at this perimeter fence location was about $129 \pm 12 \mathrm{mrem} / \mathrm{yr}$. In previous years, this value has ranged up to $941 \mathrm{mrem} / \mathrm{yr}$, which was in 1985 . About $300 \mathrm{~m}(0.2 \mathrm{mi})$ south of the fence in grid 6I, the measured dose dropped to $97 \pm 7 \mathrm{mrem} / \mathrm{yr}$, within the normal background range. The recent increase in dose in the 317 Area has been due to a concerted effort to transport radioactive historic waste off the site and to conduct environmental restoration activities in the 317 Area. 


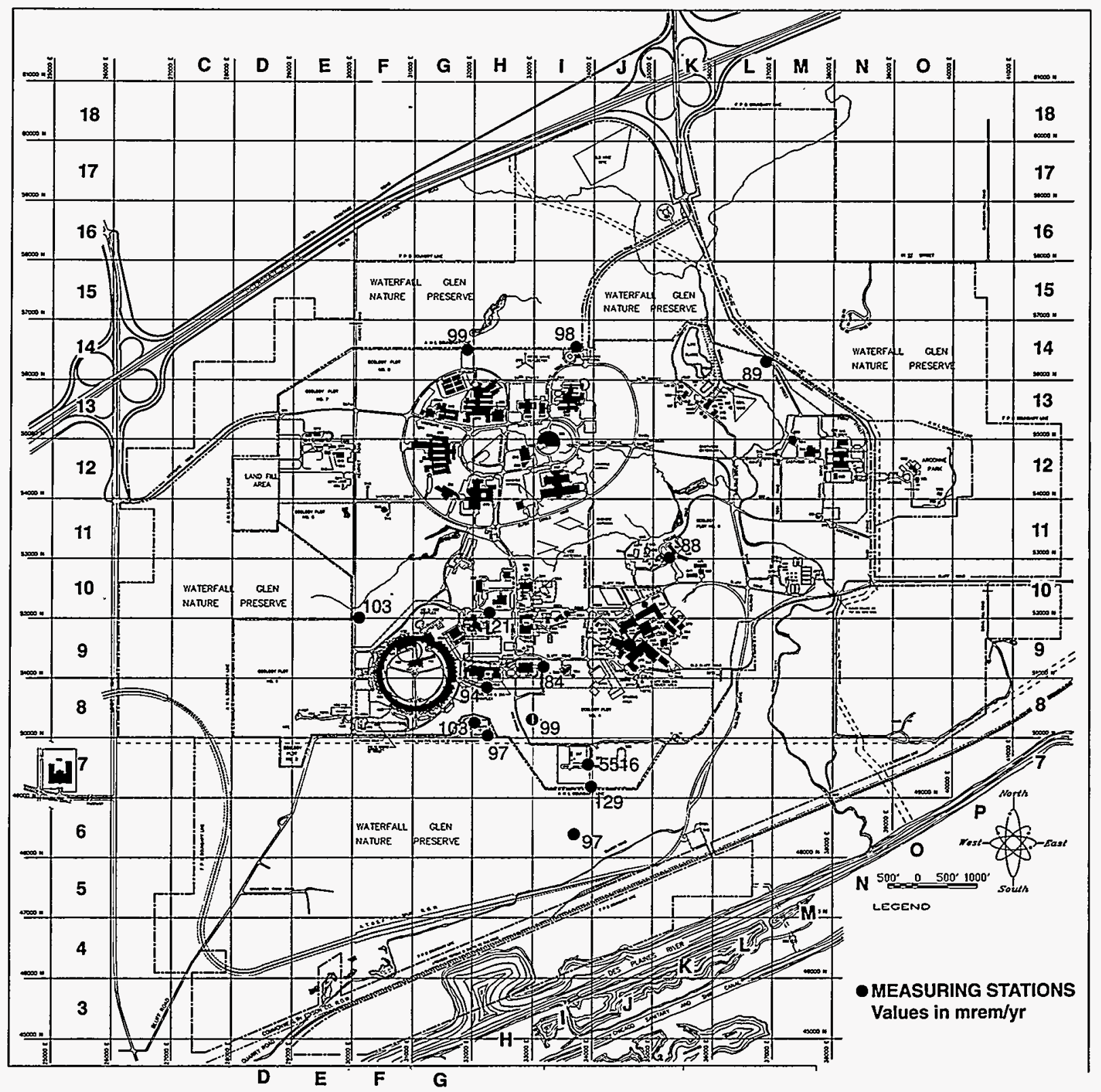

Figure 4.4. Penetrating Radiation Measurements at the ANL-E Site, 1995 


\section{ENVIRONMENTAL RADIOLOGICAL PROGRAM INFORMATION}

In the past, an elevated perimeter area was at Location 14I, at the north boundary. This dose was attributed to the use of cobalt-60 irradiation sources in Building 202. However, the irradiation program using the cobalt-60 source was terminated at the end of FY 1990 and not used at all since then. The perimeter dose at Location 14I, $98 \pm 7 \mathrm{mrem} / \mathrm{yr}$, was within the normal background range.

An elevated on-site dose was measured in the past at Location $9 \mathrm{H}$, next to the CP-5 facility, where irradiated hardware from $\mathrm{CP}-5$ was stored. During the past few years, considerable cleanup of the CP-5 yard occurred as part of the CP-5 D\&D project. The dose at Location $9 \mathrm{H}$ decreased from about $1,200 \mathrm{mrem} / \mathrm{yr}$ in 1989 to $121 \mathrm{mrem} / \mathrm{yr}$ in 1995 . The cleanup was completed in 1994; the residual dose is from sources in the building.

\subsection{Estimates of Potential Radiation Doses}

The radiation doses at the site boundary and off the site that could have been received by the public from radioactive materials and radiation leaving the site were calculated. Calculations were performed for three exposure pathways; airborne, water, and direct radiation from external sources.

\subsubsection{Airborne Pathway}

Guidance issued by the $\mathrm{DOE}^{11}$ stipulates that DOE facilities with airborne releases of radioactive materials are subject to $40 \mathrm{CFR}$ Part 61 , Subpart $\mathrm{H},{ }^{20}$ which requires the use of the CAP-88 version ${ }^{8}$ of the EPA-AIRDOSE/RADRISK code to calculate the dose for radionuclides released to the air and to demonstrate compliance with the regulation. The dose limit applicable for 1995 for the air pathway is $10 \mathrm{mrem} / \mathrm{yr}$ effective dose equivalent. The EPA-AIRDOSE/ RADRISK computer code uses a modified Gaussian plume equation to estimate both horizontal and vertical dispersion of radionuclides released to the air from stacks or area sources. For 1995, doses were calculated for hydrogen-3, carbon-11, nitrogen-13, oxygen-15, argon-41, krypton-85, radon-220 plus daughters, and a number of actinide radionuclides. The annual release rates are those listed in Table 4.4; separate calculations were performed for each of the seven release 
points. The wind speed and direction data shown in Figure 1.3 were used for these calculations. Doses were calculated for an area extending out to $80 \mathrm{~km}(50 \mathrm{mi})$ from ANL-E. The population distribution of the 16 compass segments and 10 distance increments given in Table 1.1 was used. The dose rate was calculated at the midpoint of each interval and integrated over the entire area to give the annual population cumulative dose.

Distances from the specific facilities that exhaust radiological airborne emissions (see Table 4.4) to the fenceline (perimeter) and nearest resident were determined in the 16 compass segments. Calculations also were performed to evaluate the major airborne pathways: ingestion, inhalation, and immersion, both at the point of maximum perimeter exposure and to the maximally exposed resident. The perimeter and resident doses and the maximum doses are listed, respectively, for releases from Buildings 200 (Tables 4.16 and 4.17), Building 205 (Tables 4.18 and 4.19), Building 212 (Tables 4.20 and 4.21), Building 330 (Tables 4.22 and 4.23), Building 350 (Tables 4.24 and 4.25), Building 375 (Tables 4.26 and 4.27) and Building 411 (Tables 4.28 and 4.29). The doses given in these tables are the committed whole body effective dose equivalents.

The dominant contributors to the calculated doses were the radon-220 and daughters released from Building 200. This accounted for $80 \%$ of the off-site dose in 1995. The highest perimeter dose rates were in the north-northwest sector with a maximum dose of $0.32 \mathrm{mrem} / \mathrm{yr}$ at a fenceline location north of Building 203 (location 14H in Figure 1.1). The major contributor to this dose was inhalation of lead-212 $(0.19 \mathrm{mrem} / \mathrm{yr})$, and the organs receiving the greatest dose were the lung and the bone. The releases from the other facilities are very minor contributors to the total dose.

During 1995, a significant D\&D program was completed for the M-wing hot cells in Building 200, which were the source of the radon-220 emissions. Cleanup of the major source of the radon-220, cell M-1, was completed in 1995. This has resulted in a decrease of radon-220 emissions; $2,023 \mathrm{Ci}$ in 1993 to $1,750 \mathrm{Ci}$ in 1994 to $1,033 \mathrm{Ci}$ in 1995 . However, some radon-220 


\section{TABLE 4.16}

Radiological Airborne Releases from Building 200, 1995

Source Term: Radon-220 $=1,033.2 \mathrm{Ci}$ (plus daughters)

\begin{tabular}{lcccc}
\hline Direction & $\begin{array}{c}\text { Distance to } \\
\text { Perimeter }(\mathrm{m})\end{array}$ & $\begin{array}{c}\text { Dose } \\
(\mathrm{mrem} / \mathrm{yr})\end{array}$ & $\begin{array}{c}\text { Distance to Nearest } \\
\text { Resident }(\mathrm{m})\end{array}$ & $\begin{array}{c}\text { Dose } \\
(\mathrm{mrem} / \mathrm{yr})\end{array}$ \\
\hline N & 500 & 0.320 & 1,000 & 0.092 \\
NNE & 600 & 0.220 & 1,100 & 0.076 \\
NE & 750 & 0.150 & 2,600 & 0.019 \\
ENE & 1,700 & 0.042 & 3,100 & 0.016 \\
E & 2,400 & 0.026 & 3,500 & 0.015 \\
ESE & 2,200 & 0.027 & 3,600 & 0.013 \\
SE & 2,100 & 0.025 & 4,000 & 0.009 \\
SSE & 2,000 & 0.028 & 4,000 & 0.009 \\
S & 1,500 & 0.017 & 4,000 & 0.004 \\
SSW & 1,000 & 0.075 & 2,500 & 0.016 \\
SW & 800 & 0.220 & 2,200 & 0.045 \\
WSW & 1,100 & 0.066 & 1,500 & 0.039 \\
W & 750 & 0.120 & 1,500 & 0.037 \\
WNW & 800 & 0.096 & 1,300 & 0.043 \\
NW & 600 & 0.120 & 1,100 & 0.044 \\
NNW & 600 & 0.160 & 800 & 0.095 \\
\hline
\end{tabular}


TABLE 4.17

Maximum Perimeter and Individual Doses from Building 200 Air Emissions, 1995

Dose (mrem/yr)

\begin{tabular}{lll}
\hline Pathway & $\begin{array}{c}\text { Perimeter } \\
(500 \mathrm{~m} \mathrm{NNE})\end{array}$ & $\begin{array}{c}\text { Individual } \\
(800 \mathrm{~m} \mathrm{NNW})\end{array}$ \\
\hline Ingestion & $4.3 \times 10^{-13}$ & $1.5 \times 10^{-13}$ \\
Inhalation & $3.2 \times 10^{-1}$ & $9.4 \times 10^{-2}$ \\
Air Immersion & $2.3 \times 10^{-3}$ & $6.0 \times 10^{-4}$ \\
Ground Surface & $1.5 \times 10^{-4}$ & $5.1 \times 10^{-5}$ \\
Total & & \\
& 0.320 & 0.095 \\
Radionuclide & & \\
Thallium-208 & $2.0 \times 10^{-3}$ & $5.1 \times 10^{-4}$ \\
Bismuth-212 & $3.8 \times 10^{-2}$ & $1.3 \times 10^{-2}$ \\
Lead-212 & $1.9 \times 10^{-1}$ & $6.7 \times 10^{-2}$ \\
Radon-220 & $9.2 \times 10^{-1}$ & $1.4 \times 10^{-2}$ \\
& & \\
Total & 0.320 & 0.095 \\
\hline
\end{tabular}




\section{TABLE 4.18}

Radiological Airborne Releases from Building 205, 1995

Source Term: Hydrogen $-3=0.43 \mathrm{Ci}$

\begin{tabular}{lrccc}
\hline Direction & $\begin{array}{c}\text { Distance to } \\
\text { Perimeter }(\mathrm{m})\end{array}$ & $\begin{array}{c}\text { Dose } \\
(\mathrm{mrem} / \mathrm{yr})\end{array}$ & $\begin{array}{c}\text { Distance to } \\
\text { Nearest Resident }(\mathrm{m})\end{array}$ & $\begin{array}{c}\text { Dose } \\
\text { (mrem/yr) }\end{array}$ \\
\hline N & 850 & $2 \times 10^{-5}$ & 1,300 & $1 \times 10^{-5}$ \\
NNE & 1,000 & $2 \times 10^{-5}$ & 2,100 & $6 \times 10^{-6}$ \\
NE & 1,200 & $1 \times 10^{-5}$ & 2,700 & $4 \times 10^{-6}$ \\
ENE & 2,400 & $6 \times 10^{-6}$ & 3,000 & $4 \times 10^{-6}$ \\
E & 2,200 & $7 \times 10^{-6}$ & 2,400 & $4 \times 10^{-6}$ \\
ESE & 2,000 & $7 \times 10^{-6}$ & 3,500 & $3 \times 10^{-6}$ \\
SE & 1,800 & $7 \times 10^{-6}$ & 3,900 & $2 \times 10^{-6}$ \\
SSE & 1,500 & $1 \times 10^{-5}$ & 4,000 & $2 \times 10^{-6}$ \\
S & 1,300 & $5 \times 10^{-6}$ & 3,900 & $1 \times 10^{-6}$ \\
SSW & 1,100 & $1 \times 10^{-5}$ & 2,400 & $4 \times 10^{-6}$ \\
SW & 900 & $4 \times 10^{-5}$ & 2,100 & $1 \times 10^{-5}$ \\
WSW & 1,100 & $1 \times 10^{-5}$ & 1,800 & $7 \times 10^{-6}$ \\
W & 1,300 & $8 \times 10^{-6}$ & 1,800 & $6 \times 10^{-6}$ \\
WNW & 1,100 & $1 \times 10^{-5}$ & 1,700 & $7 \times 10^{-6}$ \\
NW & 1,100 & $1 \times 10^{-5}$ & 1,500 & $6 \times 10^{-6}$ \\
NNW & 900 & $2 \times 10^{-5}$ & 1,500 & $8 \times 10^{-6}$ \\
\hline
\end{tabular}


TABLE 4.19

Maximum Perimeter and Individual Doses from

Building 205 Air Emissions, 1995

Dose (mrem/yr)

\begin{tabular}{|c|c|c|}
\hline Pathway & $\begin{array}{c}\text { Perimeter } \\
\text { (900 m SW) }\end{array}$ & $\begin{array}{c}\text { Individual } \\
(1,300 \mathrm{~m} \mathrm{~N})\end{array}$ \\
\hline Ingestion & $9 \times 10^{-6}$ & $3 \times 10^{-6}$ \\
\hline Inhalation & $3 \times \cdot 10^{-5}$ & $1 \times 10^{-5}$ \\
\hline Air Immersion & $-^{\mathrm{a}}$ & - \\
\hline Ground Surface & - & - \\
\hline Total & $4 \times 10^{-5}$ & $1 \times 10^{-5}$ \\
\hline \multicolumn{3}{|l|}{ Radionuclide } \\
\hline Hydrogen-3 & $4 \times 10^{-5}$ & $1 \times 10^{-5}$ \\
\hline
\end{tabular}

a A hyphen indicates no exposure by this pathway. 
TABLE 4.20

Radiological Airborne Releases from Building 212, 1995

\begin{tabular}{|c|c|c|c|c|}
\hline Source Term: & \multicolumn{2}{|c|}{$\begin{array}{l}\text { Hydrogen-3 (HT) } \\
\text { Hydrogen-3 (HTO) } \\
\text { Krypton-85 } \\
\text { Antimony-125 } \\
\text { Radon-220 }\end{array}$} & $\begin{array}{l}=58.3 \mathrm{Ci} \\
=388.1 \mathrm{Ci} \\
=29.8 \mathrm{Ci} \\
=3.3 \times 10^{-5} \mathrm{Ci} \\
=1.2 \mathrm{Ci}\end{array}$ & \multirow[b]{2}{*}{$\begin{array}{c}\text { Dose } \\
\text { (mrem/yr) }\end{array}$} \\
\hline Direction & $\begin{array}{c}\text { Distance to } \\
\text { Perimeter (m) }\end{array}$ & $\begin{array}{c}\text { Dose } \\
\text { (mrem/yr) }\end{array}$ & $\begin{array}{l}\text { Distance to Nearest } \\
\text { Resident (m) }\end{array}$ & \\
\hline $\mathrm{N}$ & 800 & $2.8 \times 10^{-2}$ & 2,000 & $7.2 \times 10^{-3}$ \\
\hline NNE & 1,000 & $1.9 \times 10^{-2}$ & 2,500 & $5.3 \times 10^{-3}$ \\
\hline $\mathrm{NE}$ & 1,300 & $1.3 \times 10^{-2}$ & 2,000 & $7.0 \times 10^{-3}$ \\
\hline ENE & 1,500 & $1.2 \times 10^{-2}$ & 2,500 & $5.5 \times 10^{-3}$ \\
\hline $\mathrm{E}$ & 1,600 & $1.2 \times 10^{-2}$ & 2,800 & $5.0 \times 10^{-3}$ \\
\hline ESE & 1,200 & $1.6 \times 10^{-2}$ & 2,500 & $5.4 \times 10^{-3}$ \\
\hline SE & 1,400 & $1.1 \times 10^{-2}$ & 3,500 & $2.8 \times 10^{-3}$ \\
\hline SSE & 1,400 & $1.2 \times 10^{-2}$ & 4,500 & $2.0 \times 10^{-3}$ \\
\hline$S$ & 1,500 & $4.0 \times 10^{-3}$ & 5,000 & $7.0 \times 10^{-4}$ \\
\hline SSW & 1,600 & $8.2 \times 10^{-3}$ & 5,000 & $1.4 \times 10^{-3}$ \\
\hline SW & 1,400 & $2.1 \times 10^{-2}$ & 2,400 & $9.9 \times 10^{-3}$ \\
\hline WSW & 1,300 & $1.1 \times 10^{-2}$ & 2,300 & $4.7 \times 10^{-3}$ \\
\hline W & 1,700 & $7.2 \times 10^{-3}$ & 2,200 & $4.8 \times 10^{-3}$ \\
\hline WNW & 1,500 & $8.2 \times 10^{-3}$ & 2,000 & $5.4 \times 10^{-3}$ \\
\hline NW & 1,300 & $7.8 \times 10^{-3}$ & 2,000 & $4.3 \times 10^{-3}$ \\
\hline NNW & 1,000 & $1.4 \times 10^{-2}$ & 2,000 & $5.3 \times 10^{-3}$ \\
\hline
\end{tabular}


TABLE 4.21

Maximum Perimeter and

Individual Doses from

Building 212 Air Emissions, 1995

Dose (mrem/yr)

\begin{tabular}{lcc}
\hline Pathway & $\begin{array}{c}\text { Perimeter } \\
(800 \mathrm{~m} \mathrm{~N})\end{array}$ & $\begin{array}{c}\text { Individual } \\
(2,400 \mathrm{~m} \mathrm{SW})\end{array}$ \\
\hline Ingestion & $6.7 \times 10^{-3}$ & $2.4 \times 10^{-3}$ \\
Inhalation & $2.2 \times 10^{-2}$ & $7.6 \times 10^{-3}$ \\
Air Immersion & $1.6 \times 10^{-5}$ & $6.0 \times 10^{-6}$ \\
Ground Surface & $8.3 \times 10^{-6}$ & $3.1 \times 10^{-6}$ \\
Total & $2.8 \times 10^{-2}$ & $9.0 \times 10^{-3}$ \\
Radionuclide & & \\
Hydrogen-3 & $2.8 \times 10^{-2}$ & $9.9 \times 10^{-3}$ \\
Krypton-85 & $2.4 \times 10^{-5}$ & $8.9 \times 10^{-6}$ \\
Antimony- 125 & $8.5 \times 10^{-6}$ & $3.2 \times 10^{-6}$ \\
Radon-220 & $2.7 \times 10^{-5}$ & $2.6 \times 10^{-7}$ \\
Total & & \\
\hline
\end{tabular}




\section{ENVIRONMENTAL RADIOLOGICAL PROGRAM INFORMATION}

TABLE 4.22

Radiological Airborne Releases from Building 330 (CP-5), 1995

Source Term: Hydrogen-3 $($ HTO $)=5.88 \mathrm{Ci}$

\begin{tabular}{lcccc}
\hline Direction & $\begin{array}{c}\text { Distance to } \\
\text { Perimeter }(\mathrm{m})\end{array}$ & $\begin{array}{c}\text { Dose } \\
(\mathrm{mrem} / \mathrm{yr})\end{array}$ & $\begin{array}{c}\text { Distance to Nearest } \\
\text { Resident }(\mathrm{m})\end{array}$ & $\begin{array}{c}\text { Dose } \\
(\mathrm{mrem} / \mathrm{yr})\end{array}$ \\
\hline N & 1,500 & $1.5 \times 10^{-4}$ & 2,000 & $9.5 \times 10^{-5}$ \\
NNE & 1,800 & $1.1 \times 10^{-4}$ & 3,300 & $4.6 \times 10^{-5}$ \\
NE & 2,100 & $8.6 \times 10^{-5}$ & 2,800 & $5.6 \times 10^{-5}$ \\
ENE & 2,200 & $8.9 \times 10^{-5}$ & 3,300 & $4.8 \times 10^{-5}$ \\
E & 1,500 & $1.7 \times 10^{-4}$ & 3,100 & $5.6 \times 10^{-5}$ \\
ESE & 1,300 & $1.9 \times 10^{-4}$ & 3,500 & $4.3 \times 10^{-5}$ \\
SE & 1,200 & $1.8 \times 10^{-4}$ & 3,500 & $3.7 \times 10^{-5}$ \\
SSE & 1,000 & $2.6 \times 10^{-4}$ & 3,500 & $3.8 \times 10^{-5}$ \\
S & 500 & $2.5 \times 10^{-4}$ & 3,000 & $1.9 \times 10^{-5}$ \\
SSW & 700 & $3.9 \times 10^{-4}$ & 3,500 & $3.2 \times 10^{-5}$ \\
SW & 900 & $5.2 \times 10^{-4}$ & 2,400 & $1.3 \times 10^{-4}$ \\
WSW & 1,400 & $1.3 \times 10^{-4}$ & 2,000 & $7.7 \times 10^{-5}$ \\
W & 700 & $3.7 \times 10^{-4}$ & 2,000 & $7.3 \times 10^{-5}$ \\
WNW & 700 & $3.2 \times 10^{-4}$ & 1,900 & $7.7 \times 10^{-5}$ \\
NW & 1,500 & $8.5 \times 10^{-5}$ & 2,000 & $5.7 \times 10^{-5}$ \\
NNW & 1,600 & $9.5 \times 10^{-5}$ & 1,900 & $7.5 \times 10^{-5}$ \\
\hline
\end{tabular}




\section{ENVIRONMENTAL RADIOLOGICAL PROGRAM INFORMATION}

TABLE 4.23

Maximum Perimeter and Individual Doses from Building 330 (CP-5) Air Emissions, 1995

Dose (mrem/yr)

\begin{tabular}{lcc}
\hline Pathway & $\begin{array}{c}\text { Perimeter } \\
(900 \mathrm{~m} \mathrm{SW})\end{array}$ & $\begin{array}{c}\text { Individual } \\
(2,400 \mathrm{~m} \mathrm{SW})\end{array}$ \\
\hline Ingestion & $1.2 \times 10^{-4}$ & $3.1 \times 10^{-5}$ \\
Inhalation & $4.0 \times 10^{-4}$ & $1.0 \times 10^{-4}$ \\
Air Immersion & $\mathrm{-}^{\mathrm{a}}$ & - \\
Ground Surface & - & - \\
Total & $5.2 \times 10^{-4}$ & $1.3 \times 10^{-4}$ \\
Radionuclide & & \\
& & \\
Hydrogen-3 & $5.2 \times 10^{-4}$ & $1.3 \times 10^{-4}$ \\
\hline
\end{tabular}

a A hyphen indicates no exposure by this pathway. 


\section{TABLE 4.24}

Radiological Airborne Releases from Building 350, 1995

$$
\text { Source Term: } \begin{aligned}
& \text { Uranium-234 }=2.2 \times 10^{-7} \mathrm{Ci} \\
& \text { Uranium-238 }=2.2 \times 10^{-7} \mathrm{Ci} \\
& \text { Plutonium-238 }=9.6 \times 10^{-9} \mathrm{Ci} \\
& \text { Plutonium-239 }=1.8 \times 10^{-8} \mathrm{Ci} \\
& \text { Plutonium-240 }=1.8 \times 10^{-8} \mathrm{Ci} \\
& \text { Plutonium-241 }=5.6 \times 10^{-7} \mathrm{Ci} \\
& \text { Plutonium-242 }=3.8 \times 10^{-9} \mathrm{Ci}
\end{aligned}
$$

\begin{tabular}{lcccc}
\hline Direction & $\begin{array}{c}\text { Distance to } \\
\text { Perimeter }(\mathrm{m})\end{array}$ & $\begin{array}{c}\text { Dose } \\
(\mathrm{mrem} / \mathrm{yr})\end{array}$ & $\begin{array}{c}\text { Distance to Nearest } \\
\text { Resident }(\mathrm{m})\end{array}$ & $\begin{array}{c}\text { Dose } \\
\text { (mrem/yr) }\end{array}$ \\
\hline N & 1,700 & $6 \times 10^{-6}$ & 2,200 & $5 \times 10^{-6}$ \\
NNE & 1,800 & $5 \times 10^{-6}$ & 3,200 & $3 \times 10^{-6}$ \\
NE & 2,200 & $4 \times 10^{-6}$ & 3,100 & $3 \times 10^{-6}$ \\
ENE & 2,000 & $6 \times 10^{-6}$ & 3,100 & $3 \times 10^{-6}$ \\
E & 1,700 & $8 \times 10^{-6}$ & 2,500 & $5 \times 10^{-6}$ \\
ESE & 900 & $1 \times 10^{-5}$ & 3,000 & $3 \times 10^{-6}$ \\
SE & 900 & $1 \times 10^{-5}$ & 3,000 & $3 \times 10^{-6}$ \\
SSE & 700 & $2 \times 10^{-5}$ & 2,700 & $4 \times 10^{-6}$ \\
S & 600 & $5 \times 10^{-6}$ & 2,700 & $1 \times 10^{-6}$ \\
SSW & 400 & $9 \times 10^{-6}$ & 2,500 & $3 \times 10^{-6}$ \\
SW & 600 & $2 \times 10^{-5}$ & 2,700 & $6 \times 10^{-6}$ \\
WSW & 800 & $1 \times 10^{-5}$ & 2,100 & $4 \times 10^{-6}$ \\
W & 900 & $8 \times 10^{-6}$ & 2,200 & $4 \times 10^{-6}$ \\
WNW & 1,000 & $6 \times 10^{-6}$ & 2,100 & $3 \times 10^{-6}$ \\
NW & 1,900 & $3 \times 10^{-6}$ & 2,400 & $2 \times 10^{-6}$ \\
NNW & 1,900 & $4 \times 10^{-6}$ & 2,200 & $3 \times 10^{-6}$ \\
\hline
\end{tabular}


TABLE 4.25

Maximum Perimeter and Individual Doses from

Building 350 Air Emissions, 1995

Dose (mrem/yr)

\begin{tabular}{|c|c|c|}
\hline Pathway & $\begin{array}{c}\text { Perimeter } \\
\text { (700 m SSE) }\end{array}$ & $\begin{array}{c}\text { Individual } \\
(2,700 \mathrm{~m} \mathrm{SW})\end{array}$ \\
\hline Ingestion & $1 \times 10^{-7}$ & $4 \times 10^{-8}$ \\
\hline Inhalation & $2 \times 10^{-5}$ & $5 \times 10^{-6}$ \\
\hline Air Immersion & $7 \times 10^{-15}$ & $2 \times 10^{-15}$ \\
\hline Ground Surface & $1 \times 10^{-9}$ & $4 \times 10^{-10}$ \\
\hline Total & $2 \times 10^{-5}$ & $6 \times 10^{-6}$ \\
\hline \multicolumn{3}{|l|}{ Radionuclide } \\
\hline Uranium-234 & $6 \times 10^{-6}$ & $2 \times 10^{-6}$ \\
\hline Uranium-238 & $5 \times 10^{-6}$ & $2 \times 10^{-6}$ \\
\hline Plutonium-238 & $7 \times 10^{-7}$ & $2 \times 10^{-7}$ \\
\hline Plutonium-239 & $1 \times 10^{-6}$ & $5 \times 10^{-6}$ \\
\hline Plutonium-240 & $1 \times 10^{-6}$ & $5 \times 10^{-7}$ \\
\hline Plutonium-241 & $8 \times 10^{-7}$ & $3 \times 10^{-7}$ \\
\hline Plutonium-242 & $3 \times 10^{-7}$ & $1 \times 10^{-7}$ \\
\hline Total & $2 \times 10^{-5}$ & $6 \times 10^{-6}$ \\
\hline
\end{tabular}


TABLE 4.26

Radiological Airborne Releases from Building 375 (IPNS), 1995

Source Term Carbon-11 $=430.0 \mathrm{Ci}$

Argon $-41=5.3 \mathrm{Ci}$

\begin{tabular}{lcccc}
\hline Direction & $\begin{array}{c}\text { Distance to } \\
\text { Perimeter }(\mathrm{m})\end{array}$ & $\begin{array}{c}\text { Dose } \\
(\mathrm{mrem} / \mathrm{yr})\end{array}$ & $\begin{array}{c}\text { Distance to Nearest } \\
\text { Resident }(\mathrm{m})\end{array}$ & $\begin{array}{c}\text { Dose } \\
(\mathrm{mrem} / \mathrm{yr})\end{array}$ \\
\hline N & 1,600 & $3.4 \times 10^{-2}$ & 3,200 & $1.0 \times 10^{-2}$ \\
NNE & 1,700 & $3.0 \times 10^{-2}$ & 3,100 & $1.1 \times 10^{-2}$ \\
NE & 1,700 & $3.0 \times 10^{-2}$ & 2,700 & $1.4 \times 10^{-2}$ \\
ENE & 1,500 & $4.1 \times 10^{-2}$ & 2,500 & $1.7 \times 10^{-2}$ \\
E & 600 & $2.0 \times 10^{-1}$ & 2,500 & $2.0 \times 10^{-2}$ \\
ESE & 600 & $1.7 \times 10^{-1}$ & 2,500 & $1.7 \times 10^{-2}$ \\
SE & 600 & $1.5 \times 10^{-1}$ & 2,500 & $1.4 \times 10^{-2}$ \\
SSE & 600 & $1.7 \times 10^{-1}$ & 3,000 & $1.0 \times 10^{-2}$ \\
S & 800 & $3.5 \times 10^{-2}$ & 3,000 & $3.6 \times 10^{-3}$ \\
SSW & 800 & $8.5 \times 10^{-2}$ & 3,500 & $5.9 \times 10^{-3}$ \\
SW & 800 & $1.6 \times 10^{-1}$ & 4,000 & $8.4 \times 10^{-3}$ \\
WSW & 1,500 & $3.0 \times 10^{-2}$ & 2,700 & $1.1 \times 10^{-2}$ \\
W & 2,200 & $1.6 \times 10^{-2}$ & 2,700 & $1.0 \times 10^{-2}$ \\
WNW & 1,500 & $2.6 \times 10^{-2}$ & 2,600 & $9.9 \times 10^{-3}$ \\
NW & 2,200 & $1.1 \times 10^{-2}$ & 2,500 & $8.8 \times 10^{-3}$ \\
NNW & 1,800 & $2.0 \times 10^{-2}$ & 2,200 & $1.4 \times 10^{-2}$ \\
\hline
\end{tabular}




\section{TABLE 4.27}

Maximum Perimeter and Individual Doses from

Building 375 (IPNS) Air Emissions, 1995

Dose (mrem/yr)

\begin{tabular}{lcc}
\hline Pathway & $\begin{array}{c}\text { Perimeter } \\
(600 \mathrm{~m} \mathrm{E})\end{array}$ & $\begin{array}{c}\text { Individual } \\
(2,200 \mathrm{~m} \mathrm{NNW})\end{array}$ \\
\hline Ingestion & \multicolumn{1}{c}{${ }^{\mathrm{a}}$} & - \\
Inhalation & $8.7 \times 10^{-3}$ & $8.7 \times 10^{-4}$ \\
Air Immersion & $1.8 \times 10^{-1}$ & $1.8 \times 10^{-2}$ \\
Ground Surface & $6.7 \times 10^{-3}$ & $7.5 \times 10^{-4}$ \\
& & \\
Total & $2.0 \times 10^{-1}$ & $2.0 \times 10^{-2}$ \\
Radionuclide & & \\
& & \\
Carbon-11 & $2.0 \times 10^{-1}$ & $2.0 \times 10^{-2}$ \\
Argon-41 & $3.1 \times 10^{-3}$ & $3.7 \times 10^{-4}$ \\
Total & & \\
\hline
\end{tabular}

a A hyphen indicates no exposure by this pathway. 


\section{TABLE 4.28}

Radiological Airborne Releases from Building 411/415 (APS), 1995

\begin{tabular}{|c|c|c|c|c|}
\hline \multirow{2}{*}{$\begin{array}{l}\text { Source Term } \\
\text { Direction }\end{array}$} & \multicolumn{4}{|c|}{$\begin{array}{l}\text { Carbon- } 11=1.2 \mathrm{Ci} \\
\text { Nitrogen-13 }=54.4 \mathrm{Ci} \\
\text { Oxygen-15 }=5.8 \mathrm{Ci}\end{array}$} \\
\hline & $\begin{array}{c}\text { Distance to } \\
\text { Perimeter (m) }\end{array}$ & $\begin{array}{c}\text { Dose } \\
\text { (mrem/yr) }\end{array}$ & $\begin{array}{c}\text { Distance to } \\
\text { Nearest Resident (m) }\end{array}$ & $\begin{array}{c}\text { Dose } \\
\text { (mrem/yr) }\end{array}$ \\
\hline $\mathrm{N}$ & 1,500 & $4.1 \times 10^{-3}$ & 2,000 & $2.3 \times 10^{-3}$ \\
\hline NNE & 1,600 & $3.5 \times 10^{-3}$ & 2,100 & $2.1 \times 10^{-3}$ \\
\hline $\mathrm{NE}$ & 2,200 & $1.9 \times 10^{-3}$ & 3,100 & $9.3 \times 10^{-4}$ \\
\hline ENE & 2,500 & $1.7 \times 10^{-3}$ & 3,300 & $9.3 \times 10^{-4}$ \\
\hline $\mathrm{E}$ & 1,600 & $4.3 \times 10^{-3}$ & 3,400 & $9.4 \times 10^{-4}$ \\
\hline ESE & 1,500 & $4.2 \times 10^{-3}$ & 3,500 & $7.7 \times 10^{-4}$ \\
\hline SE & 400 & $3.3 \times 10^{-2}$ & 3,000 & $8.9 \times 10^{-4}$ \\
\hline SSE & 400 & $3.9 \times 10^{-2}$ & 3,000 & $8.9 \times 10^{-4}$ \\
\hline$S$ & 350 & $1.5 \times 10^{-2}$ & 2,500 & $4.6 \times 10^{-4}$ \\
\hline SSW & 400 & $3.0 \times 10^{-2}$ & 2,800 & $7.7 \times 10^{-4}$ \\
\hline SW & 550 & $3.2 \times 10^{-2}$ & 3,000 & $1.2 \times 10^{-3}$ \\
\hline WSW & 800 & $1.0 \times 10^{-2}$ & 1,400 & $3.7 \times 10^{-3}$ \\
\hline $\mathrm{W}$ & 800 . & $9.7 \times 10^{-3}$ & 1,500 & $3.0 \times 10^{-3}$ \\
\hline WNW & 500 & $1.7 \times 10^{-2}$ & 1,400 & $3.0 \times 10^{-3}$ \\
\hline NW & 350 & $2.1 \times 10^{-2}$ & 1,600 & $1.9 \times 10^{-3}$ \\
\hline NNW & 1,500 & $2.8 \times 10^{-3}$ & 2,000 & $1.6 \times 10^{-3}$ \\
\hline
\end{tabular}


TABLE 4.29

Maximum Perimeter and Individual Doses from Building 411/415 Air Emissions, 1995

Dose (mrem/yr)

\begin{tabular}{lcc}
\hline Pathway & $\begin{array}{c}\text { Perimeter } \\
(400 \mathrm{~m} \mathrm{SSE})\end{array}$ & $\begin{array}{c}\text { Individual } \\
(1,400 \mathrm{~m} \mathrm{SW})\end{array}$ \\
\hline Ingestion & \multicolumn{1}{c}{$-^{\mathrm{a}}$} & - \\
Inhalation & $1.1 \times 10^{-3}$ & $1.1 \times 10^{-4}$ \\
Air Immersion & $3.7 \times 10^{-2}$ & $3.5 \times 10^{-3}$ \\
Ground Surface & $6.4 \times 10^{-4}$ & $6.8 \times 10^{-5}$ \\
Total & $3.9 \times 10^{-2}$ & $3.7 \times 10^{-3}$ \\
& & \\
Radionuclide & & \\
Carbon-11 & $8.6 \times 10^{-4}$ & $9.4 \times 10^{-5}$ \\
Nitrogen-13 & $3.5 \times 10^{-2}$ & $3.4 \times 10^{-3}$ \\
Oxygen-15 & $2.5 \times 10^{-3}$ & $1.1 \times 10^{-4}$ \\
Total & & \\
\hline
\end{tabular}

a A hyphen indicates no exposure by this pathway. 


\section{ENVIRONMENTAL RADIOLOGICAL PROGRAM INFORMATION}

emissions will continue because of the ongoing nuclear medical program that separates radium-224 from the thorium-228 parent.

In August of 1992, operation of the JANUS reactor (Building 202) was terminated because of a lack of programmatic support. In early 1993, the fuel was removed and shipped to the Savannah River Plant for reprocessing. Likewise, the cyclotron in Building 211 ceased operation at the end of 1992 because of the lack of use. The facility was placed in standby status awaiting future D\&D. Neither facility will produce radiological airborne emissions in the future.

The full-time resident who would receive the largest annual dose $(0.12 \mathrm{mrem} / \mathrm{yr})$ is located approximately $0.8 \mathrm{~km}(0.5 \mathrm{mi})$ north-northwest of the site boundary. The major contributor to the whole body dose is the inhalation dose from lead-212 (0.06 mrem/yr). If radon-220 and daughters were excluded from the calculation, as required by $\mathrm{NESHAP}^{20}$ the maximally exposed resident would receive a dose of $0.026 \mathrm{mrem} / \mathrm{yr}$, primarily carbon-11 from the IPNS facility (Building 375).

The individual doses to the maximally exposed member of the public and the maximum fenceline dose are shown in Figure 4.5. The decrease in individual and population doses since 1988 are due in part to the decrease of the radon-220 emissions that resulted from the cleanup of the Building $200 \mathrm{M}$-Wing hot cells.

The population data in Table 1.1 were used to calculate the cumulative population dose from gaseous radioactive effluents from ANL-E operations. The results are given in Table 4.30, together with the natural external radiation dose. The natural radiation dose listed is the product of the $80-\mathrm{km}(50-\mathrm{mi})$ population and the natural radiation dose of $300 \mathrm{mrem} / \mathrm{yr} .{ }^{21}$ It is assumed that this dose is representative of the entire area within an $80-\mathrm{km}(50-\mathrm{mi})$ radius. The population dose since 1987, due to ANL-E operations, is shown in Figure 4.6.

The potential radiation exposures by the inhalation pathways also were calculated by the methodology specified in DOE Order 5400.5. ${ }^{11}$ The total quantity for each radionuclide inhaled, in microcuries $(\mu \mathrm{Ci})$, is calculated by multiplying the annual average air concentrations by the 


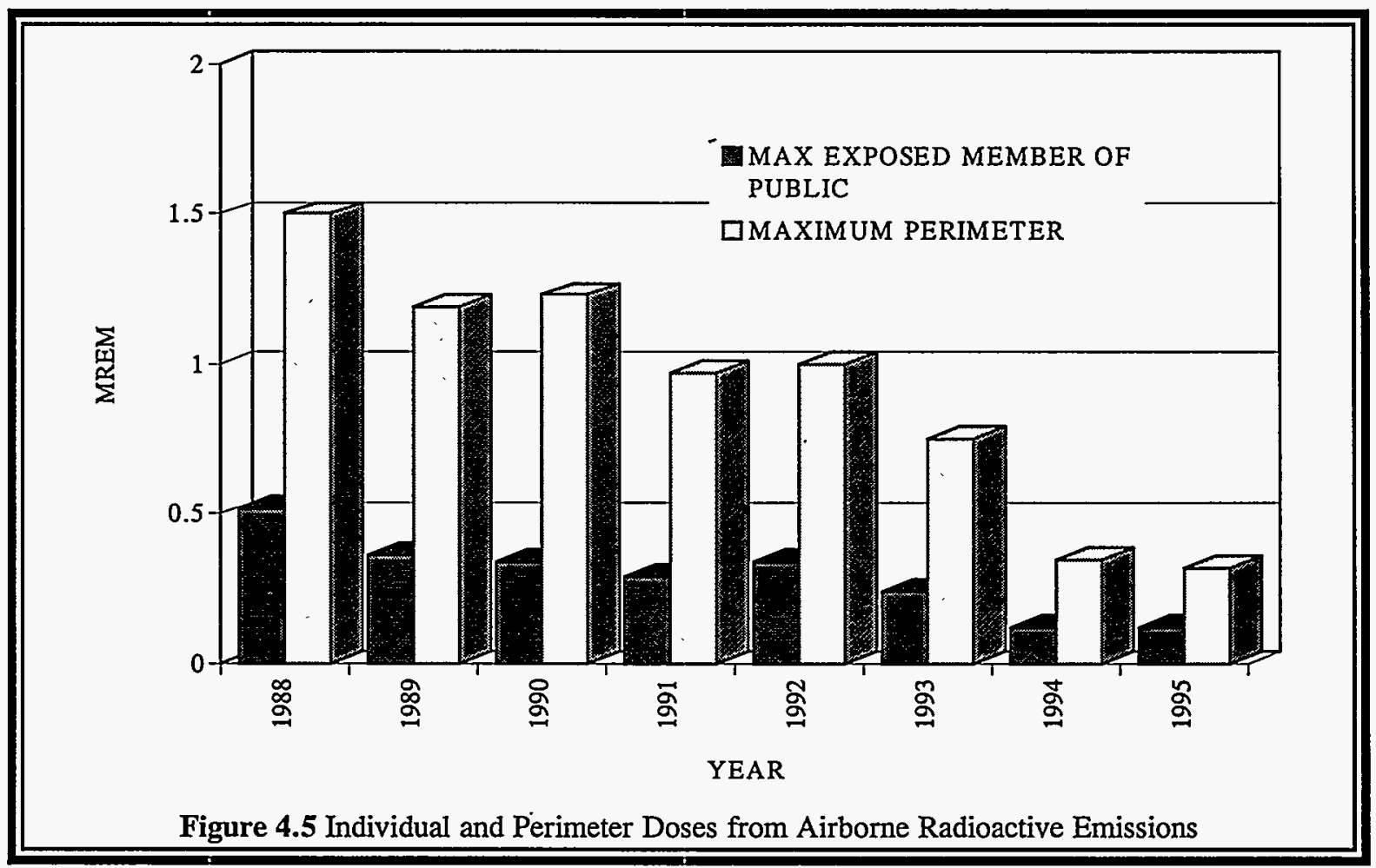

general public breathing rate of $8,400 \mathrm{~m}^{3} / \mathrm{yr}^{22}$ This annual intake is then multiplied by the CEDE for the appropriate lung retention class. ${ }^{7}$ Because the CEDE factors are in units of $\mathrm{rem} / \mu \mathrm{Ci}$, this calculation gives the 50-year CEDE. The applicable CEDE factors are listed in Table 4.31.

The calculated doses in Tables 4.2 and 4.3 were obtained using this procedure. Because they are all essentially at perimeter locations, these doses represent the fenceline values for those radionuclides measured. In most cases, these doses also are the same as the off-site measurements and represent the ambient dose for the area from these nuclides. No doses were calculated for the total alpha and total beta measurements since the guidance does not provide CEDE factors for such measurements.

\subsubsection{Water Pathway}

Following the methodology outlined in DOE Order 5400.5, ${ }^{11}$ the annual intake of radionuclides (in $\mu \mathrm{Ci}$ ) ingested with water is obtained by multiplying the concentration of 
TABLE 4.30

80 km Population Dose, 1995

\begin{tabular}{lc}
\hline Radionuclide & Man-rem \\
\hline Hydrogen-3 & 1.59 \\
Carbon-11 & 1.12 \\
Nitrogen-13 & 0.05 \\
Oxygen-15 & $<0.01$ \\
Argon-41 & 0.07 \\
Krypton-85 & $<0.01$ \\
Antimony-125 & $<0.01$ \\
Thallium-208 & $<0.01$ \\
Lead-212 & 5.09 \\
Bismuth-212 & 0.53 \\
Radon-220 & $<0.01$ \\
Uranium-234 & $<0.01$ \\
Uranium-238 & $<0.01$ \\
Plutonium-238 & $<0.01$ \\
Plutonium-239 & $<0.01$ \\
Plutonium-240 & $<0.01$ \\
Plutonium-241 & $<0.01$ \\
Plutonium-242 & $<0.01$ \\
Total & 8.45 \\
Natural & $2.4 \times 10^{6}$ \\
\hline &
\end{tabular}

radionuclides in microcuries per milliliter $(\mu \mathrm{Ci} / \mathrm{mL})$ by the average annual water consumption of a member of the general public $\left(7.3 \times 10^{5} \mathrm{~mL}\right)$. This annual intake is then multiplied by the CEDE factor for ingestion (Table 4.31) to obtain the dose received in that year. This procedure is carried out for all radionuclides and the individual results are summed to obtain the total ingestion dose.

The only location where radionuclides attributable to ANL-E operations could be found in off-site water was Sawmill Creek below the wastewater outfall (see Table 4.5). Although this water is not used for drinking purposes, the 50-year effective dose equivalent was calculated for 


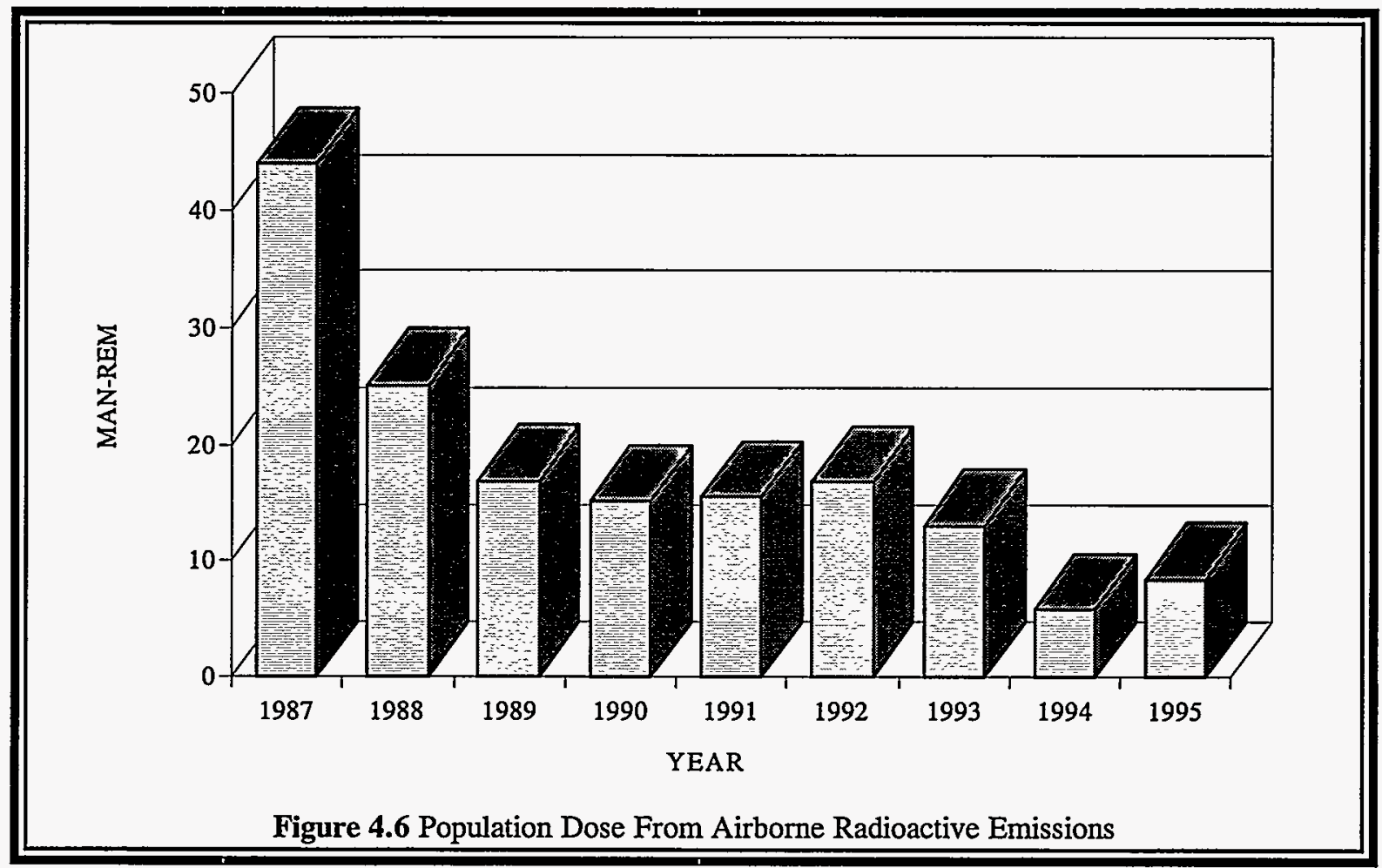

a hypothetical individual ingesting water at the radionuclide concentrations measured at that location. Those radionuclides added to Sawmill Creek by ANL-E wastewater, their net concentrations in the creek, and the corresponding dose rates (if water at these concentrations were used as the sole water supply by an individual) are given in Table 4.32. The dose rates were all well below the standards for the general population. It should be emphasized that Sawmill Creek is not used for drinking, swimming, or boating. Inspection of the area shows that there are fish in the stream, but they do not constitute a significant source of food for any individual. Figure 4.7 is a plot of the estimated dose an individual would receive if ingesting Sawmill Creek water.

As indicated in Table 4.5, occasional Sawmill Creek samples (fewer than 10\%) contained traces of neptunium-237, plutonium-238, curium-242,244, or californium-249,252, but the averages were only slightly greater than the detection limit. The annual dose to an individual consuming water at these concentrations can be calculated with the same method used for those radionuclides more commonly found in creek water; this method of averaging, however, probably 
TABLE 4.31

50-Year Committed Effective Dose Equivalent (CEDE) Factors

$(\mathrm{Rem} / \mu \mathrm{Ci})$

\begin{tabular}{lcc}
\hline Nuclide & Ingestion & Inhalation \\
\hline Hydrogen-3 & $6.3 \times 10^{-5}$ & $9.6 \times 10^{-5}$ \\
Beryllium-7 & $-^{\mathrm{a}}$ & $2.7 \times 10^{-4}$ \\
Carbon-11 & - & $8.0 \times 10^{-6}$ \\
Strontium-90 & 0.13 & 1.32 \\
Cesium-137 & 0.05 & 0.032 \\
Lead-210 & - & 13.2 \\
Radium-226 & 1.1 & - \\
Thorium-228 & - & 310 \\
Thorium-230 & - & 260 \\
Thorium-232 & - & 1100 \\
Uranium-234 & 0.26 & 130 \\
Uranium-235 & 0.25 & 120 \\
Uranium-238 & 0.23 & 120 \\
Neptunium-237 & 3.90 & - \\
Plutonium-238 & 3.80 & - \\
Plutonium-239 & 4.30 & 330 \\
Americium-241 & 4.50 & - \\
Curium-242 & 0.11 & - \\
Curium-244 & 2.30 & - \\
Californium-249 & 4.60 & - \\
Californium-252 & 0.94 & - \\
\hline
\end{tabular}

a A hyphen indicates value not required. 
TABLE 4.32

Radionuclide Concentrations and Dose Estimates for Sawmill Creek Water, 1995

\begin{tabular}{lcrr}
\hline Radionuclide & $\begin{array}{c}\text { Total Released } \\
\text { (Ci) }\end{array}$ & $\begin{array}{c}\text { Net Avg. } \\
\text { Conc. (pCi/L) }\end{array}$ & $\begin{array}{c}\text { Dose } \\
(\mathrm{mrem})\end{array}$ \\
\hline Hydrogen-3 & 0.50 & 62 & 0.0028 \\
Strontium-90 & 0.0022 & 0.27 & 0.0256 \\
Cesium-137 & 0.0059 & 0.73 & 0.0266 \\
Plutonium-239 & 0.000026 & 0.0033 & 0.0010 \\
Americium-241 & 0.000039 & 0.0048 & 0.0016 \\
& & & \\
Sum & 0.51 & & .0 .0576 \\
\hline
\end{tabular}

overestimates the true concentration. Annual doses range from $3 \times 10^{-3}$ to $6 \times 10^{-5} \mathrm{mrem} / \mathrm{yr}$ for these radionuclides.

DOE Order $5400.5^{11}$ requires that an evaluation be made of the dose to aquatic organisms from liquid effluents. The dose limit is one $\mathrm{rad} /$ day or $365 \mathrm{rad} / \mathrm{yr}$. The location that could result in the highest dose to aquatic organisms is in Sawmill Creek downstream of the point where ANL-E discharges its treated wastewater. Inspection of the creek at this location indicates the presence of small bluegill and carp (about $100 \mathrm{~g}$ each). Using the annual average concentrations of the radionuclides listed in Table 4.5, a dose can be estimated. The sum of the exposure from these radionuclides is estimated to be about $5 \times 10^{-6} \mathrm{rad} / \mathrm{yr}$, well within the DOE standard, and therefore demonstrating compliance with that portion of the order.

The EPA has established drinking water standards based on a maximum dose of $4 \mathrm{mrem} / \mathrm{yr}$ for man-made beta particle and photon-emitting radionuclides. ${ }^{23}$ The EPA standard is $2 \times 10^{4}$ $\mathrm{pCi} / \mathrm{L}$ for hydrogen- 3 and $8 \mathrm{pCi} / \mathrm{L}$ for strontium- 90 . The net concentrations in Table 4.32 correspond to $0.31 \%$ (hydrogen-3) and $3.4 \%$ (strontium-90) of the EPA standards. No specific EPA standards exist for the transuranic nuclides. 


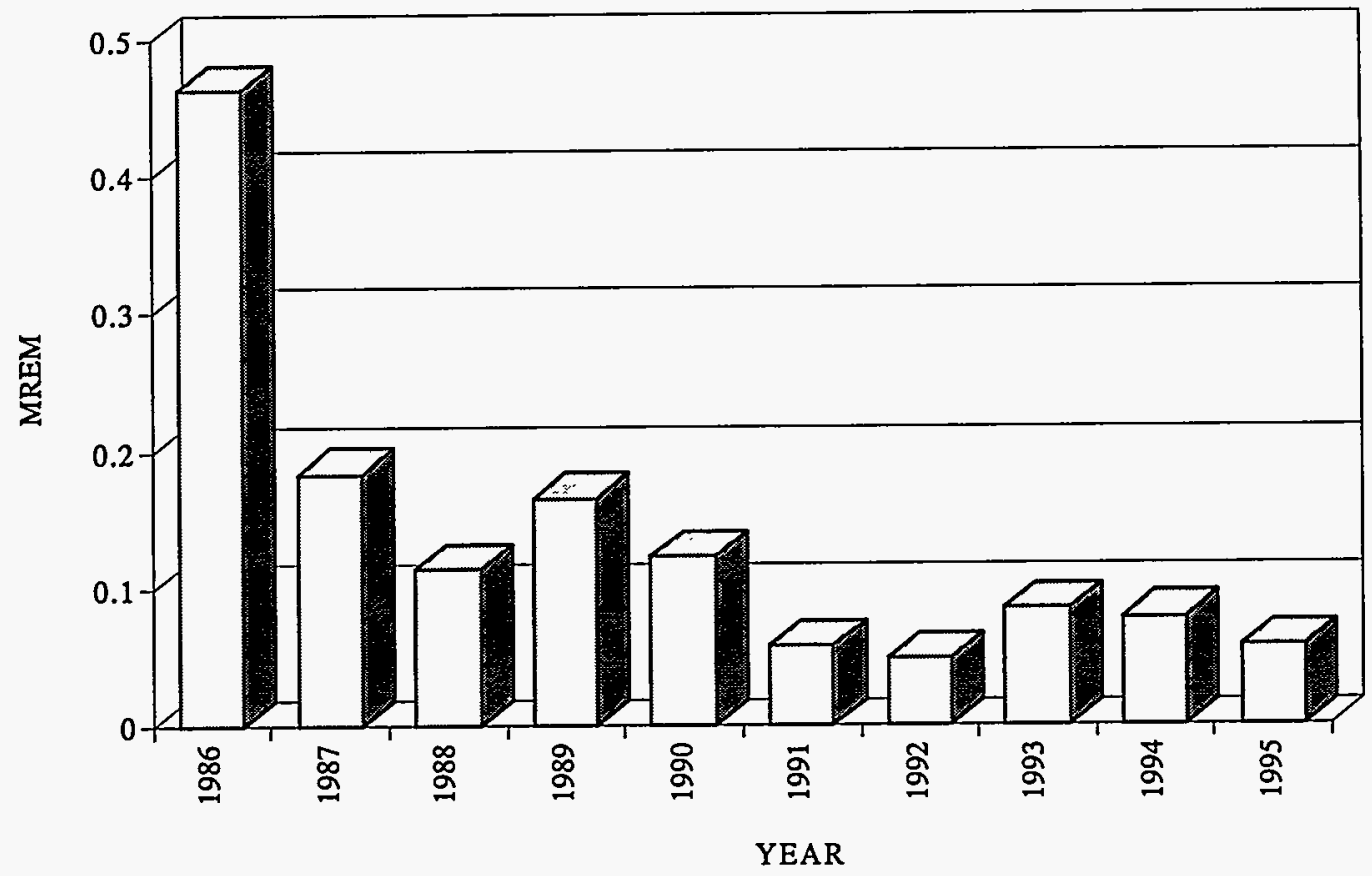

Figure 4.7 Comparison of Dose Estimates from Ingestion of Sawmill Creek Water

Sawmill Creek flows into the Des Plaines River. The flow rate of Sawmill Creek (see Section 1.6) is about $10 \mathrm{ft}^{3} / \mathrm{s}$, while the flow rate of the Des Plaines River in the vicinity of ANL-E is about $900 \mathrm{ft}^{3} / \mathrm{s}$. Applying this ratio to the concentration of radionuclides in Sawmill Creek listed in Table 4.32, the dose to a hypothetical individual ingesting water from the Des Plaines River at Lemont would be about $0.0006 \mathrm{mrem} / \mathrm{yr}$. Significant additional dilution occurs further downstream. Very few people, either directly or indirectly, use the Des Plaines River as a source of drinking water. If 100 people used Des Plaines River water at the hypothetical concentration at Lemont, the estimated population dose would be about $10^{-4}$ man-rem.

\subsubsection{External Direct Radiation Pathway}

The TLD measurements given in Section 4.5 were used to calculate the radiation dose from external sources. Above-normal fenceline doses attributable to ANL-E operations were found at the southern boundary near the Waste Storage Facility (Location 7I). 
At Location 7l, the fenceline dose from ANL-E was about $129 \pm 12 \mathrm{mrem} / \mathrm{yr}$. Approximately $300 \mathrm{~m}(0.3 \mathrm{mi})$ south of the fenceline (grid 61$)$, the measured dose was $97 \pm 7 \mathrm{mrem} / \mathrm{yr}$, the same as the normal range of the off-site average ( $92 \pm 4 \mathrm{mrem} / \mathrm{yr}$ ). No individuals live in this area. The closest residents are about $1.6 \mathrm{~km}(1 \mathrm{mi})$ south of the fenceline. At this distance, the calculated dose rate from the Waste Storage Facility was $0.006 \mathrm{mrem} / \mathrm{yr}$, if the energy of the radiation were that of a $0.66-\mathrm{MeV}$ cesium- 137 gamma-ray, and about $0.018 \mathrm{mrem} / \mathrm{yr}$ if the energy were that of a $1.33-\mathrm{MeV}$ cobalt- 60 gamma-ray.

At the fenceline, where higher doses were measured, the land is wooded and unoccupied. All of these dose calculations are based on full-time, outdoor exposure. Actual exposures to individuals would be substantially less, since some of the individuals are indoors (which provides shielding) or away from their dwellings for part of the time.

In addition to the permanent residences in the area, occasionally visitors may conduct activities around ANL-E that could result in exposure to radiation from this site. Examples of these activities could be cross-country skiing, horseback riding, or running in the fire lane next to the perimeter fence. If the individual spent 10 minutes per week adjacent to the 317 Area, the dose would be $0.03 \mathrm{mrem} / \mathrm{yr}$ at the 317 Area fence (location 7I).

\subsubsection{Dose Summary}

The total effective dose equivalent received by off-site residents during 1995 was a combination of the individual doses received through the separate pathways that contributed to exposure: hydrogen-3, carbon-11, nitrogen-13, oxygen-15, argon-41, krypton-85, radon-220 (plus daughters), and actinides through the airborne pathway. The highest dose was about $0.12 \mathrm{mrem} / \mathrm{yr}$ to individuals living north of the site if they were outdoors at that location during the entire year. The total annual population dose to the entire area within an $80-\mathrm{km}$ (50-mi) radius is 8.4 man-rem. The dose pathways are collected in Table 4.33 and compared to the applicable standards. 
TABLE 4.33

Summary of the Estimated Dose to the Public, 1995

(mrem/yr)

\begin{tabular}{lcc}
\hline Pathway & ANL-E Estimate & Applicable Standard \\
\hline & & \\
Air (less radon) & 0.026 & 10 (EPA) \\
Air Total & 0.12 & $100(\mathrm{DOE})$ \\
Water & 0.058 & $100(\mathrm{DOE})$ \\
Direct Radiation & 0.01 & $100(\mathrm{DOE})$ \\
Maximum Public & 0.12 & $100(\mathrm{DOE})$ \\
\hline
\end{tabular}

To put the maximum individual dose of $0.12 \mathrm{mrem} / \mathrm{yr}$ attributable to ANL-E operations into perspective, comparisons can be made to annual average doses received by the public from natural or accepted sources of radiation. These values are listed in Table 4.34. It is obvious that the magnitude of the doses received from ANL-E operations is insignificant compared with these sources. Therefore, the monitoring program results establish that the radioactive emissions from ANL-E are very low and do not endanger the health or safety of those living in the vicinity of the site. 
TABLE 4.34

Annual Average Dose Equivalent in the U.S. Population ${ }^{\mathrm{a}}$

\begin{tabular}{lr}
\hline Source & $\begin{array}{c}\text { Dose } \\
\text { (mrem) }\end{array}$ \\
\hline Natural Sources & \\
$\quad$ Radon & 200 \\
Internal (Potassium-40 and Radium-226) & 39 \\
Cosmic & 28 \\
Terrestrial & 28 \\
Medical & \\
Diagnostic X-rays & 39 \\
Nuclear Medicine & 14 \\
Consumer Products & \\
Domestic Water Supplies, & 10 \\
$\quad$ Building Materials, etc. & \\
Occupational (Medical Radiology, & 1 \\
Industrial Radiography, Research, etc.) & \\
& \\
Nuclear Fuel Cycle & $<1$ \\
Fallout & 360 \\
Other Miscellaneous Sources & $<1$ \\
& \\
\hline
\end{tabular}

a National Council on Radiological Protection Report No. $93 .{ }^{21}$ 


\section{ENVIRONMENTAL NONRADIOLOGICAL PROGRAM INFORMATION}

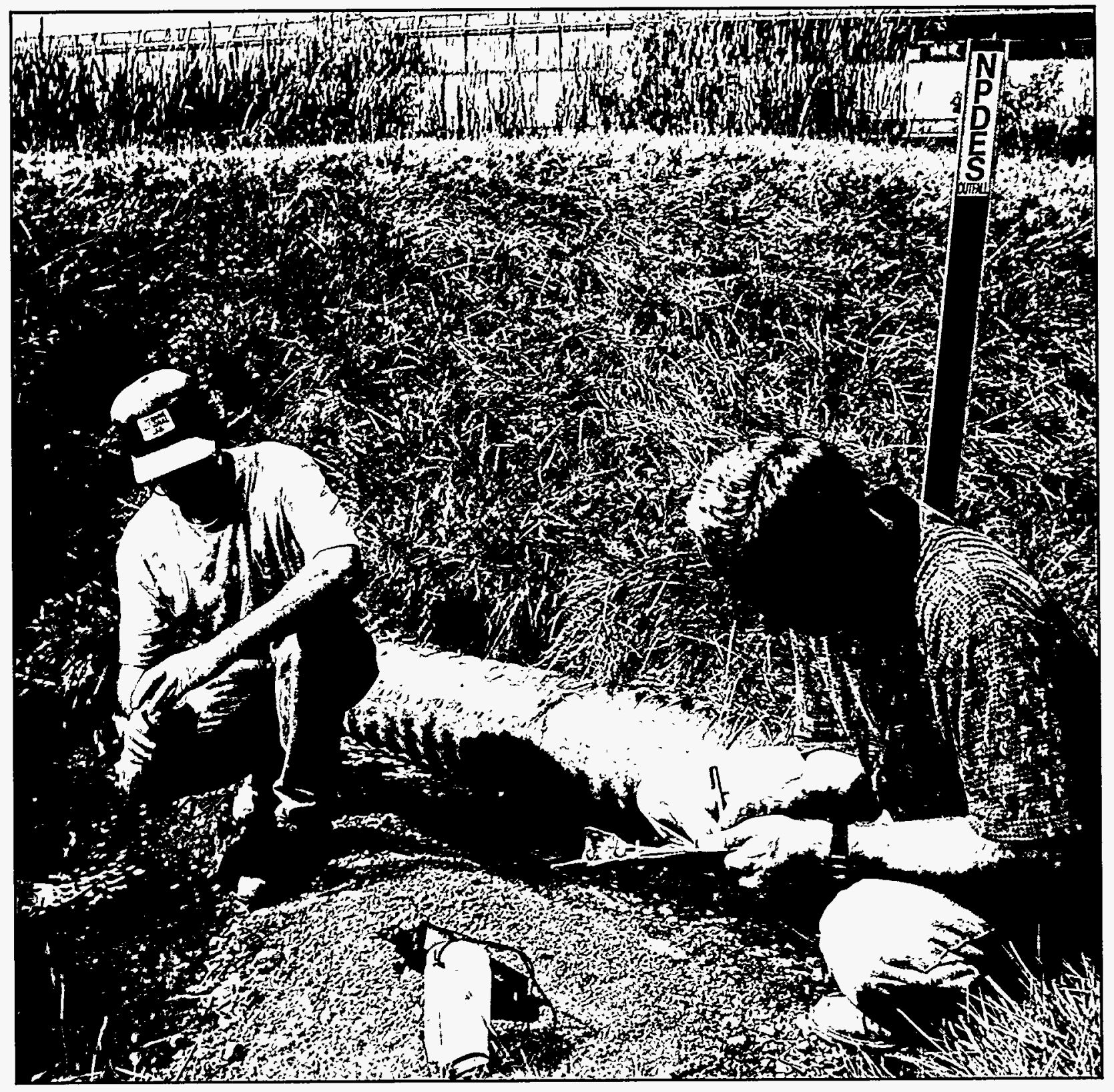




\section{ENVIRONMENTAL NONRADIOLOGICAL PROGRAM INFORMATION}

The nonradiological monitoring program involves the collection and analysis of surface water and groundwater samples from numerous locations throughout the site. The release of nonradiological pollutants to the air from ANL-E is extremely small, except for the boiler house, which is equipped with dedicated monitoring equipment for $\mathrm{SO}_{2}$ and opacity. No exceedances for opacity or $\mathrm{SO}_{2}$ were noted during 1995 over a period of 2,867 hours of operation of Boiler No. 5, the coal-burning boiler. Chapter 3 provides a detailed discussion of the environmental monitoring program.

Surface water samples for nonradiological chemical analyses are collected from NPDES permitted outfalls and Sawmill Creek. Analyses conducted on the samples from the NPDES outfalls vary, depending on the permit-mandated monitoring requirements for each outfall. The results of the analyses are compared with the permit limits for each outfall to determine whether they comply with the permit. Besides being published in this report, the NPDES monitoring results are transmitted monthly to the IEPA in an official DMR. Table 5.1 summarizes the exceedances of permit limits during 1995.

In addition to the permit-required monitoring, other analyses are conducted on samples collected from the combined wastewater outfall (NPDES outfall 001) to provide a more complete evaluation of the impact of the wastewater on the environment. Samples of water from Sawmill Creek are also collected and analyzed for a number of inorganic constituents. The results of these additional analyses of the main outfall and receiving streams are then compared with IEPA General Effluent Standards and Stream Quality Standards listed in the IAC, Title 35, Subtitle C, Chapter I. ${ }^{24}$

\subsection{National Pollutant Discharge Elimination System Monitoring Results}

Wastewater is processed at ANL-E in two independent treatment systems, the sanitary system and the laboratory system. The sanitary wastewater collection and treatment system collects wastewater from lavatories, the cafeteria, office buildings, and other portions of the site that do not contain radioactive or hazardous materials. This wastewater is treated in a biological wastewater treatment system consisting of primary clarifiers, trickling filters, final clarifiers, and 
TABLE 5.1

NPDES Permit Limit Exceedances, 1995

\begin{tabular}{llc}
\hline Outfall & \multicolumn{1}{c}{ Parameter } & $\begin{array}{c}\text { Number of } \\
\text { Exceedances }\end{array}$ \\
\hline \multirow{2}{*}{001} & Total Dissolved Solids & 20 \\
& Copper & 23 \\
& Ammonia-nitrogen & 4 \\
\multirow{2}{*}{$003 \mathrm{~A}$} & Total Suspended Solids & 1 \\
& & \\
004 & Total Suspended Solids & 1 \\
\hline
\end{tabular}

slow sand filters. Wastewater generated by research-related activities, such as laboratories and experimental equipment, flows to a series of retention tanks located in each building. When a retention tank is full, a sample is collected and analyzed for radioactivity. If the wastewater is found to be below the release limits for discharge, it is pumped to the laboratory wastewater collection system, which directs the flow to the laboratory wastewater treatment system. This system consists of a series of concrete holding tanks that collect the wastewater prior to discharge. As with the retention tanks, once a holding tank is full, it is sampled and analyzed for radioactivity. If the level of radioactivity is below ANL-E discharge criteria, which were selected to ensure compliance with DOE Orders, it is pumped to a lined equalization basin, slowly combined with the sanitary waste stream, and discharged to Sawmill Creek. If either a retention tank or holding tank is found to contain unacceptable levels of radioactivity, the wastewater is pumped into portable tanks, treated by evaporation in Building 306 , and the residue is disposed of as radioactive waste. Figure 5.1 shows the two wastewater treatment systems that are located adjacent to each other. The volume of wastewater discharged from these facilities averaged 1.46 million L/day ( 0.38 million gal/day) sanitary wastewater and 1.24 million L/day ( 0.33 million gal/day) laboratory process wastewater. 


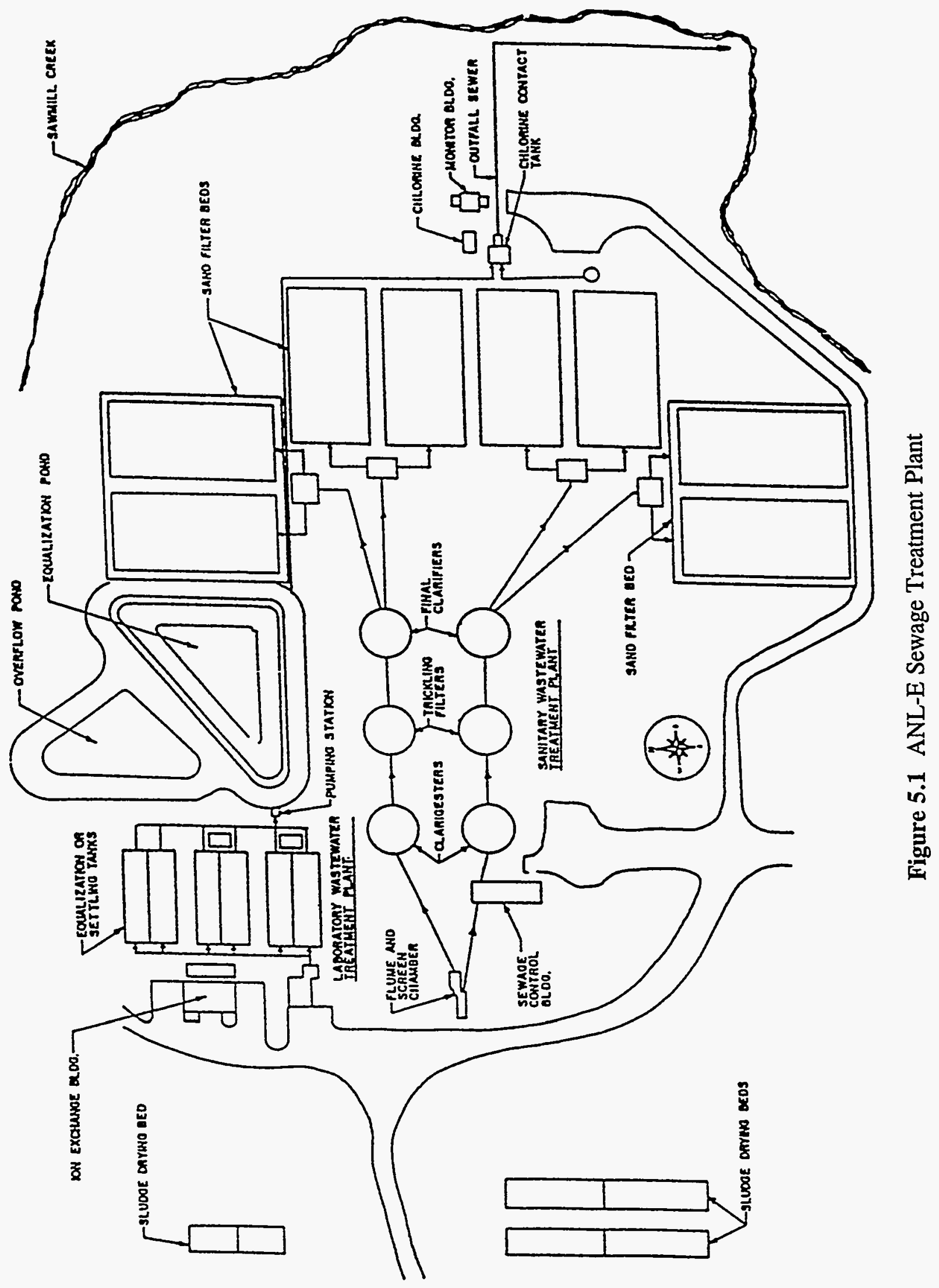




\section{ENVIRONMENTAL NONRADIOLOGICAL PROGRAM INFORMATION}

\subsubsection{Sewage Treatment Plant Renovations}

Two projects to renovate the existing laboratory and sanitary WTP facilities were in various phases of design and construction during 1995. The existing Laboratory treatment facilities are being renovated, and additional treatment capability will be provided. New facilities will provide additional treatment capability for heavy metals, suspended solids, and volatile organics. Major treatment process equipment areas to be provided in the renovation include oil and grease removal, grit removal, metals precipitation, suspended solids filtering, air stripping, carbon adsorption, sludge handling, flow monitoring, and process control instrumentation. Also, the hydraulic capacity of the laboratory plant will be expanded to enable treatment of the existing flow rate and anticipated future loadings. This project is currently under construction.

The sanitary WTP is being upgraded to replace equipment that has reached its design life and to add equipment where a more efficient or environmentally sound process applies. The equipment to be rehabilitated includes the headworks, the clarigesters, the existing trickling filters, the final clarifiers, and the intermittent sand filters. The disinfection system will not be upgraded or replaced as it is no longer used or required. The final design was completed during early 1995, and construction commenced in July 1995. The project is scheduled for completion during 1996.

\subsubsection{Effluent Monitoring}

The two treatment plant systems process the vast majority of wastewater generated by ANL-E. However, a small amount of process wastewater, primarily cooling tower blowdown and cooling water, is discharged directly to a number of small streams and ditches throughout the site. This wastewater does not contain significant amounts of contaminants and does not require treatment before discharge. However, these discharge points are included in the site NPDES permit as separate regulated outfalls.

ANL-E-processed wastewater discharges are regulated by NPDES Permit No. IL 0034592 (effective October 30, 1994, and modified August 24, 1995). ${ }^{25}$ Discharge limits for 26 surface water discharge points (outfalls) and two internal monitoring points are included in this permit. 


\section{ENVIRONMENTAL NONRADIOLOGICAL PROGRAM INFORMATION}

The analyses required and the frequency of analysis for each point are specified in the permit.

The analytical methods required for NPDES monitoring are listed in Table 1B of 40 CFR $136 .{ }^{26}$ Sample collection, preservation, and holding times are also mandated by requirements stipulated in Table 2 of 40 CFR $136 .^{26}$

The NPDES outfall locations are shown in Figure 5.2. Outfalls 001A and 001B, the two internal monitoring points representing the effluent from the sanitary system and laboratory system, respectively, are both located at the WTP. Their flows combine to form outfall 001, which is also located at the treatment facility. The combined stream flows through an outfall pipe that discharges into Sawmill Creek approximately $1,100 \mathrm{~m}(3,500 \mathrm{ft})$ south of the treatment plant.

\subsubsection{Sample Collection}

NPDES samples are collected by ANL-E's EMO personnel, with the exception of samples from locations 001, 001A, and 001B, which are collected by Plant Facilities and Services Division (PFS) personnel. All samples are collected using specially cleaned and labeled bottles with appropriate preservatives added. Custody seals and chain-of-custody sheets are also used. All samples are analyzed within the required holding time. Samples are collected at locations 001A, 001B, and 001 on a weekly basis. Samples are collected at the other locations in accordance with the NPDES permit.

\subsubsection{Sample Analysis - NPDES}

NPDES sample analyses were performed using standard operating procedures (SOPs) and written, reviewed, and issued as controlled documents by members of the Environment, Safety, and Health Division, Analytical Services, Radiochemistry Laboratory (ESH-DARC), Chemistry Laboratory (ESH-DACH), and Control Laboratory (ESH-DACL). These SOPs reference protocols found in 40 CFR 136, "Test Procedures for the Analysis of Pollutants Under the Clean Water Act." Six metal analyses were performed using flame atomic absorption spectroscopy. Mercury was determined by cold vapor atomic absorption spectroscopy. Hexavalent chromium 


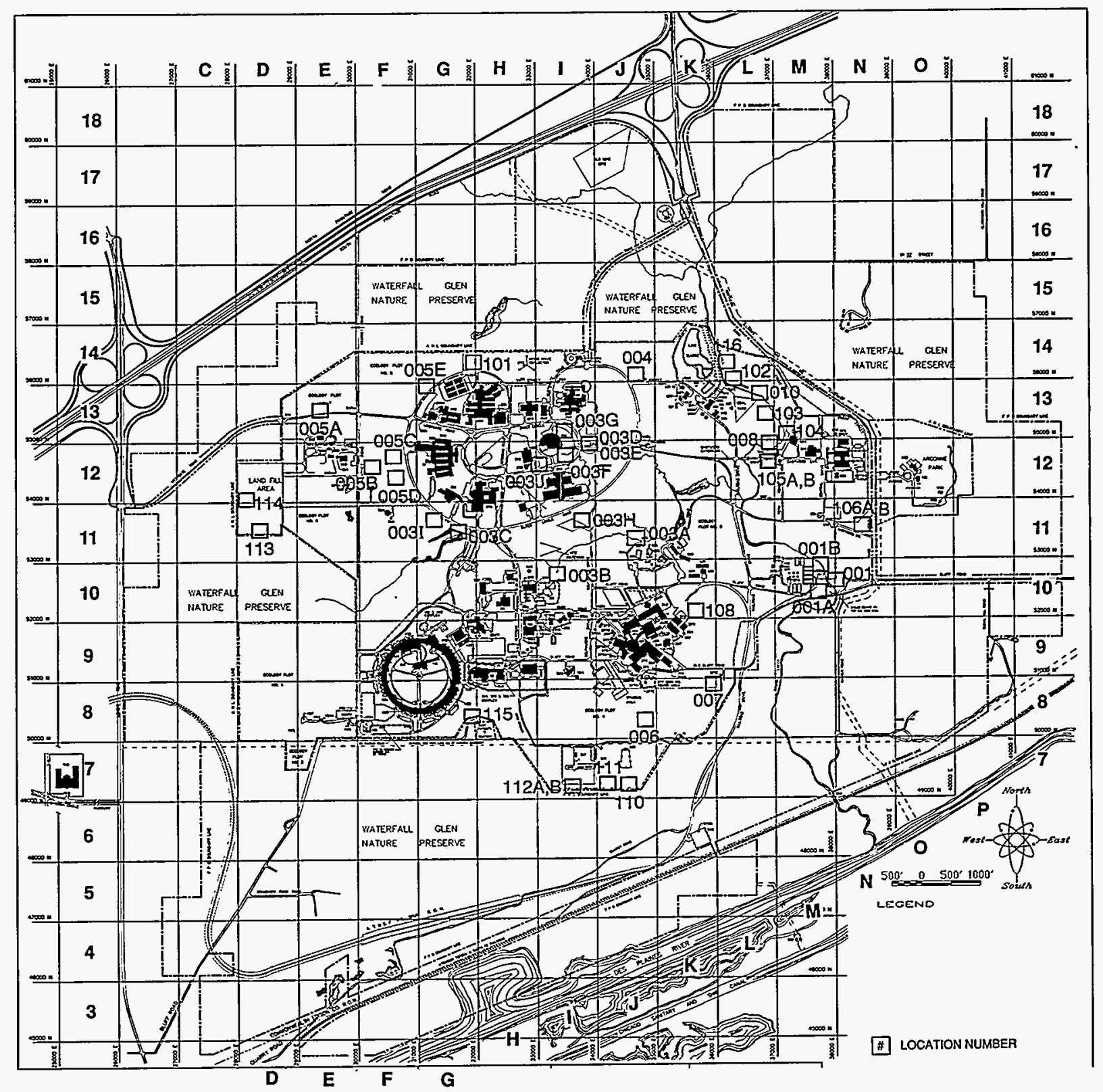

Figure 5.2 NPDES Outfall Locations 


\section{ENVIRONMENTAL NONRADIOLOGICAL PROGRAM INFORMATION}

determination and chemical oxygen demand (COD) were performed using a colorimetric technique. Five-day biochemical oxygen demand $\left(\mathrm{BOD}_{5}\right)$ was determined using a dissolved oxygen probe. TSS, TDS, and fats, oils, and grease were determined gravimetrically. Sulfate determination was performed using a turbidimetric technique; chloride was determined by titrimetry. Ammonia was determined by distillation followed by an ion selective electrode finish. Five VOCs were determined by using a purge and trap sample pretreatment followed by gas chromatography-mass spectroscopy detection. Beta radioactivity was performed using a gas flow proportional counting technique. Hydrogen- 3 was determined by distillation followed by a beta liquid scintillation counting technique.

Semiannually, NPDES outfall 001B is sampled and analyzed for priority pollutant compounds. VOCs were determined using a purge and trap sample pretreatment followed by gas chromatography-mass spectroscopy detection. Semivolatile organic compounds (SVOCs) and 2,3,7,8-tetrachlorodibenzo-p-dioxin were determined by solvent extraction followed by gas chromatography-mass spectroscopy detection. $\mathrm{PCB} /$ pesticides were determined by solvent extraction followed by gas chromatography-electron capture detection. Thirteen metals were determined by graphite furnace atomic absorption and flame atomic absorption spectroscopy. Asbestos analysis was performed using transmission electron microscopy. Cyanide and phenol were determined by distillation followed by a spectrophotometric finish. Asbestos and 2,3,7,8-tetrachlorodibenzo-p-dioxin were removed from the permit effective August 24, 1995.

NPDES outfall 001 is sampled and analyzed annually for acute aquatic toxicity parameters. NPDES outfalls $003 \mathrm{H}, 003 \mathrm{I}, 003 \mathrm{~J}, 004,006$, and 115 are tested biannually. An off-site contracted laboratory performed both the sample collection and analyses. The testing is performed by using ANL-E effluent with Sawmill Creek receiving water, introducing species of fish and invertebrates, and measuring survival over two to seven days. Statistically significant mortality is reported as a function of effluent concentration. 


\section{ENVIRONMENTAL NONRADIOLOGICAL PROGRAM INFORMATION}

\subsubsection{Results}

During 1995, approximately $97 \%$ of all NPDES analyses were in compliance with their applicable permit limits as compared to 1994, 1993, 1992, and 1991 rates of $97.5 \%, 97.5 \%$, $98 \%$, and 96\%, respectively. Specific limit exceedances are discussed later in this section as well as in Chapter 2. A discussion of the analytical results for each outfall follows.

\subsubsection{Outfalls}

Outfall 001A. This outfall is composed of treated sanitary wastewater and various wastewater streams from the boiler house area, including coal pile storm-water runoff. The effectiveness of the sanitary wastewater treatment systems is evaluated by weekly monitoring for $\mathrm{BOD}, \mathrm{pH}$, and TSS. The limits for five-day BOD are a monthly average of $10 \mathrm{mg} / \mathrm{L}$ with a maximum value of $20 \mathrm{mg} / \mathrm{L}$. The permit limits for TSS are a maximum concentration of $24 \mathrm{mg} / \mathrm{L}$ and a monthly average of $12 \mathrm{mg} / \mathrm{L}$. The $\mathrm{pH}$ must range between values of 6 and 9 . All samples collected and analyzed for these parameters were within the permit limits during 1995 .

The permit requires weekly monitoring for total chromium, copper, iron, lead, manganese, zinc, and oil and grease. The effluent limits for these parameters and results are shown in Table 5.2. There are two limits listed, one is a maximum limit for any single sample and the other is for the average of all samples collected during the month. The constituents presented in Table 5.2 are present in the coal pile runoff that may discharge to the sanitary sewage system. All samples collected and analyzed for these parameters were within the permit limits during 1995. The averages shown in Table 5.2 are the annual averages for each constituent.

Outfall 001B. This outfall consists of processed wastewater from the laboratory wastewater system. The permit requires that weekly samples be collected and analyzed for BOD, TSS, mercury, $\mathrm{pH}$, and COD. 


\section{ENVIRONMENTAL NONRADIOLOGICAL PROGRAM INFORMATION}

\section{TABLE 5.2}

Outfall 001A Effluent Limits and Monitoring Results, 1995

(Concentrations in $\mathrm{mg} / \mathrm{L}$ )

\begin{tabular}{lccccc}
\hline Constituent & Minimum & Average & $\begin{array}{c}\text { Average } \\
\text { Limit }\end{array}$ & Maximum & $\begin{array}{c}\text { Maximum } \\
\text { Limit }\end{array}$ \\
\hline Chromium & $-^{\mathrm{a}}$ & $<0.02$ & 1.00 & $<0.02$ & 2.00 \\
Copper & 0.018 & 0.055 & 0.50 & 0.106 & 1.00 \\
Iron & 0.08 & 0.314 & 2.00 & 1.21 & 4.00 \\
Lead & - & $<0.10$ & 0.20 & $<0.10$ & 0.40 \\
Manganese & $<0.015$ & 0.049 & 1.00 & 1.09 & 2.00 \\
Zinc & 0.04 & 0.123 & 1.00 & 0.254 & 2.00 \\
Oil \& Grease & - & $<5.0$ & 15.0 & $<5.0$ & 30.0 \\
\hline
\end{tabular}

a A hyphen indicates no minimum values.

The limits established for BOD are a daily maximum of $20 \mathrm{mg} / \mathrm{L}$ with a 30-day average of $10 \mathrm{mg} / \mathrm{L}$. The permit also contains BOD mass loading limits of $114 \mathrm{lb} /$ day as a daily maximum and $57 \mathrm{lb} /$ day as a 30-day average. The mass loading represents the weight of material discharged per day and is a function of concentration and flow. The daily maximum limit for TSS is $24 \mathrm{mg} / \mathrm{L}$ with a 30-day average of $12 \mathrm{mg} / \mathrm{L}$. The TSS mass loading limits are 136 and $68 \mathrm{lb} /$ day, respectively. There were no exceedances of the BOD or TSS concentration limits in 1995.

The daily maximum concentration limit for mercury is $6 \mu \mathrm{g} / \mathrm{L}$; the 30-day average is $3 \mu \mathrm{g} / \mathrm{L}$. The corresponding loading values are $0.034 \mathrm{lb} /$ day and $0.017 \mathrm{lb} /$ day. No exceedances of the mercury concentration limit were noted.

No concentration limits have been established for COD. The once-per-week grab samples give a rough indication of the organic content of this stream. The values obtained in 1995 ranged from less than $10 \mathrm{mg} / \mathrm{L}$ to $29 \mathrm{mg} / \mathrm{L}$.

A special condition at location $001 \mathrm{~B}$ requires monitoring for the 126 priority pollutants listed in the permit during the months of June and December. The June sampling is to be 


\section{ENVIRONMENTAL NONRADIOLOGICAL PROGRAM INFORMATION}

conducted at the same time that aquatic toxicity testing of outfall 001 is conducted. Fibrous asbestos and 2,3,7,8-tetrachlorodibenzo-p-dioxin (commonly called dioxin) are also tested. The modified August 24, 1995, NPDES permit removed the requirement for asbestos and dioxin monitoring. Samples were collected on June 19, 1995, and December 5, 1995, and analyzed within the required holding times.

Analysis of these samples indicated that very small amounts of a few chemicals were present. The results for SVOCs, PCBs, and pesticides were all less than the detection limits. The results for metals were similar to concentrations found in ANL-E treated drinking water. The samples contained several VOCs at very low levels. The majority of compounds found are halomethanes. The concentrations of volatile organics identified in these samples are contained in Table 5.3. While there are currently no permit limits or effluent standards for these compounds with which to compare these results, the concentrations found are believed to be of little concern because they are below acceptable standards for drinking water supplies, where such standards exist. No chrysotile asbestos fibers greater than $10 \mu \mathrm{m}$ in length were detected in the June sample, and there were no detectable levels of dioxin.

The laboratory wastewater treatment system consists of six 69,000 -gal equalization or settling (holding) tanks (see Figure 5.1) that are pumped to a lined equalization pond before being discharged to Sawmill Creek. During 1989, a study was performed to determine the levels of VOCs in the influent to these tanks and to determine the variability of this concentration. A number of different volatile organics were found to be present from time to time, with the concentration varying greatly throughout the day. Maximum levels were found to occur in the late afternoon. As a follow-up to this study, each month one influent sample is obtained at about 1300 hours and analyzed for VOCs. During August 1993, the discharge of water from Manhole 2E (refer to Section 6.2.2.3.) in the 317 Area began on a regular basis. This water is known to contain volatile organics at consistent levels. A modified NPDES permit was issued by the IEPA to reflect this discharge. 


\section{TABLE 5.3}

Outfall 001B Priority Pollutant Monitoring Results, 1995 (Concentrations in $\mu \mathrm{g} / \mathrm{L}$ )

\begin{tabular}{lcc}
\hline Compound & $\begin{array}{c}\text { Concentration in } \\
\text { June Sample }\end{array}$ & $\begin{array}{c}\text { Concentration in } \\
\text { December Sample }\end{array}$ \\
\hline Bromodichloromethane & 5 & 3 \\
Bromoform & 10 & 3 \\
Chloroform & 9 & 5 \\
Dibromochloromethane & 11 & 4 \\
Methylene Chloride & 5 & 29 \\
\hline
\end{tabular}

Overall, the 1995 results are quite similar to the 1994 results. Table 5.4 shows the 1995 results for the most common compounds found. In addition to these compounds, most samples contained very low concentrations of 4-methyl-2-pentanone (levels range to $3 \mu \mathrm{g} / \mathrm{L}$ ), a commonly used ketone for chemical extraction processes. Bromoform, bromodichloromethane, chloroform, and dibromochloromethane are halomethanes that are produced due to contact of the chlorinated water supply with organic chemicals. Chloroform levels above $10 \mu \mathrm{g} / \mathrm{L}$ are probably due to other causes.

Unlike 1992, 1993, and 1994, the more persistent VOCs were noted at greater frequency but at lower ranges of concentration. Acetone was found in all samples, and levels ranged to $769 \mu \mathrm{g} / \mathrm{L}$. Methylene chloride was found in all samples and ranged to $407 \mu \mathrm{g} / \mathrm{L}$. Infrequent trace levels of other chemicals, that is, 2-butanone, ethylbenzene, ethyl ether, and tetrahydrofuran, were also noted.

Figures 5.3, 5.4, and 5.5 present comparisons of the 1992 through 1995 Laboratory wastewater results for the more persistent VOCs. ANL-E's waste generator education program regarding disposal of chemicals down laboratory drains continues to be a contributing factor to the reduction of volatile organics in laboratory wastewater. 


\section{TABLE 5.4}

Volatile Organic Compounds in Laboratory Wastewater, 1995

(Concentrations in $\mu \mathrm{g} / \mathrm{L}$ )

\begin{tabular}{lcccccc}
\hline Month & Acetone & Chloroform & $\begin{array}{c}\text { Methylene } \\
\text { Chloride }\end{array}$ & $\begin{array}{c}\text { Bromodi- } \\
\text { chloroethane }\end{array}$ & $\begin{array}{c}\text { Dibromo- } \\
\text { chloromethane }\end{array}$ & Bromoform \\
\hline January & 12 & 2 & 4 & 4 & 6 & 2 \\
February & 23 & 4 & 11 & 4 & 5 & 2 \\
March & 769 & 8 & 115 & 4 & 5 & 1 \\
April & 10 & 7 & 3 & 6 & 3 & $<1$ \\
May & 17 & 5 & 7 & 3 & 5 & 2 \\
June & 33 & 3 & 4 & 6 & 11 & 9 \\
July & 70 & 8 & 3 & 10 & 12 & 7 \\
August & 9 & 6 & 1 & 4 & 6 & 8 \\
September & 80 & 12 & 17 & 7 & 10 & 8 \\
October & 65 & 84 & 407 & 7 & 9 & 8 \\
November & 29 & 3 & 13 & 5 & 8 & 5 \\
December & 6 & 3 & 4 & 4 & 6 & 3 \\
\hline
\end{tabular}

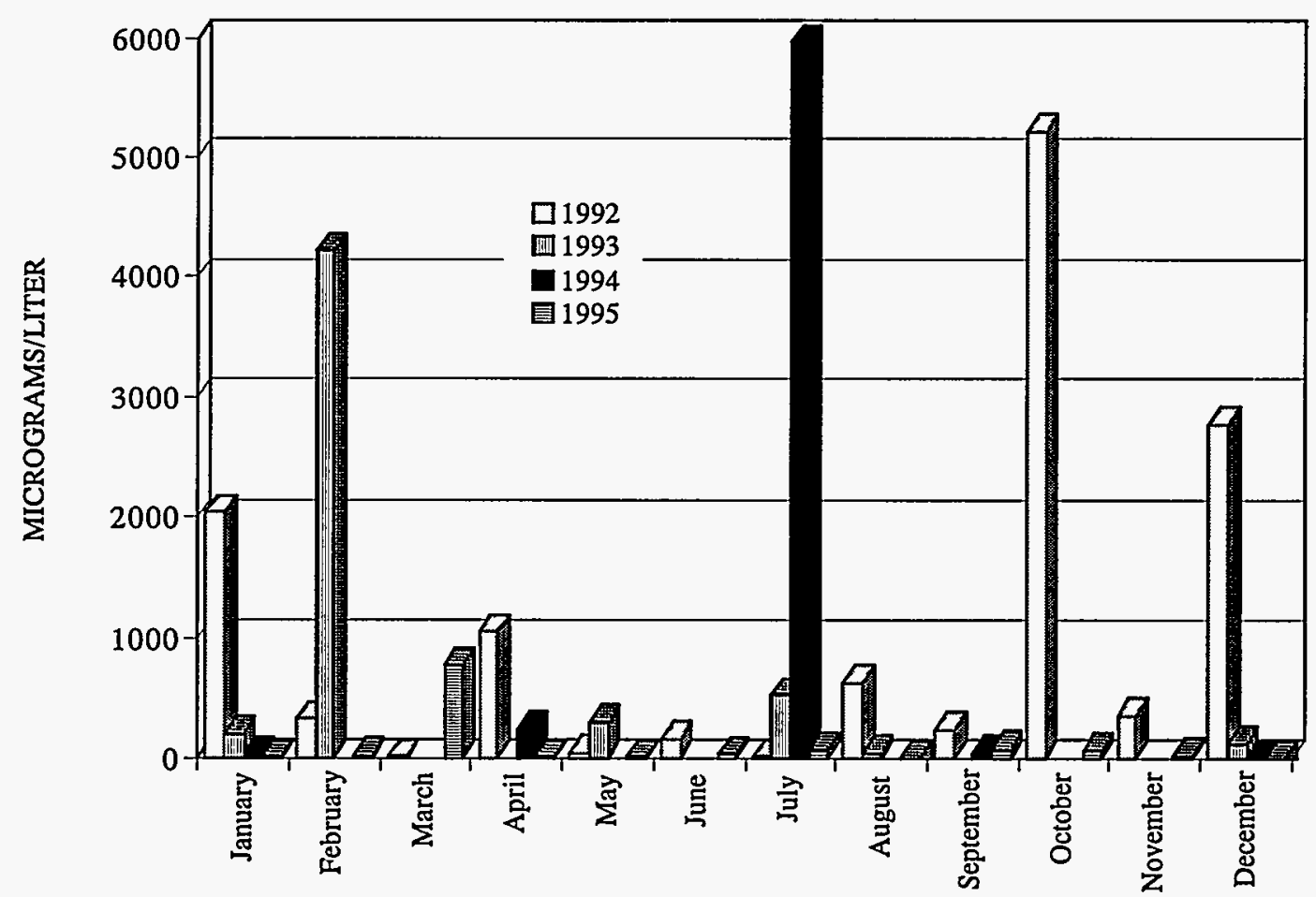

Figure 5.3 Acetone Levels in Laboratory Wastewater, 1992 to 1995 


\section{ENVIRONMENTAL NONRADIOLOGICAL PROGRAM INFORMATION}

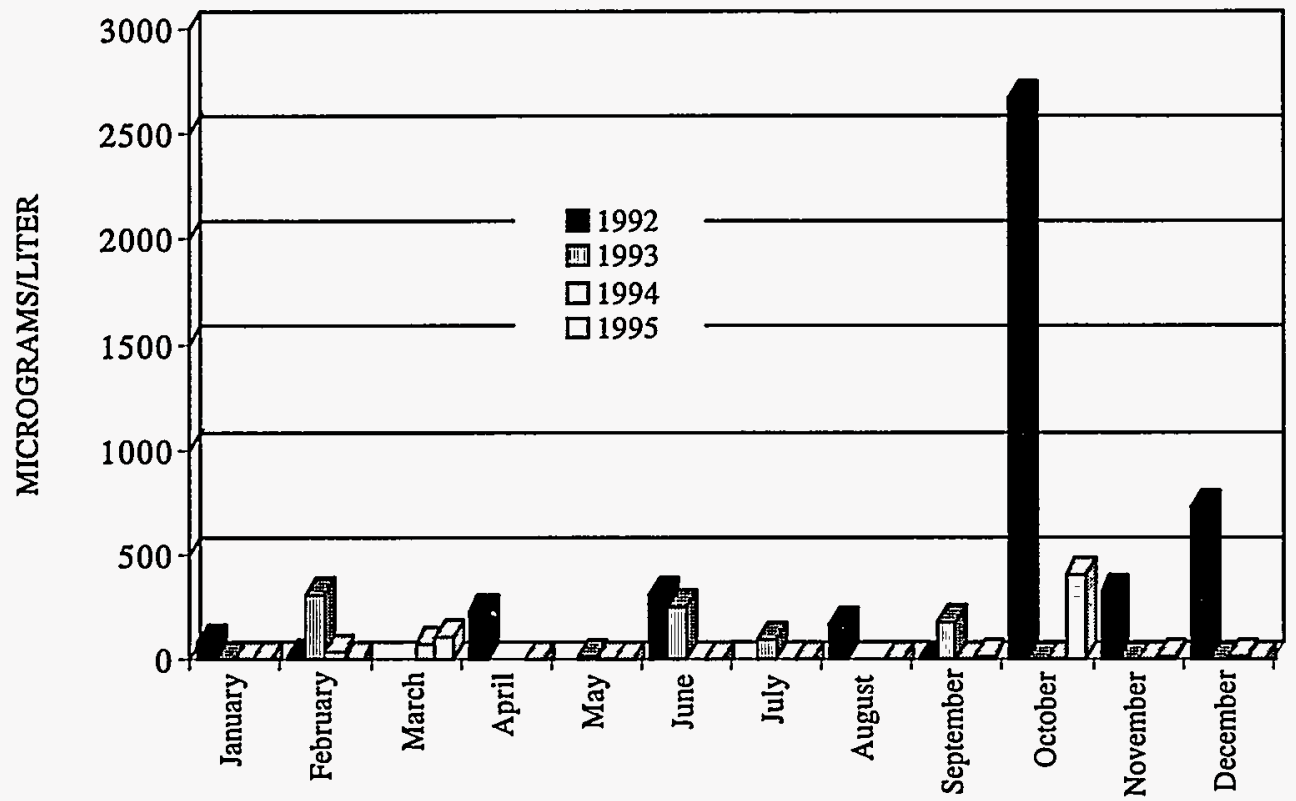

Figure 5.4 Methylene Chloride Levels in Laboratory Wastewater, 1992 to 1995

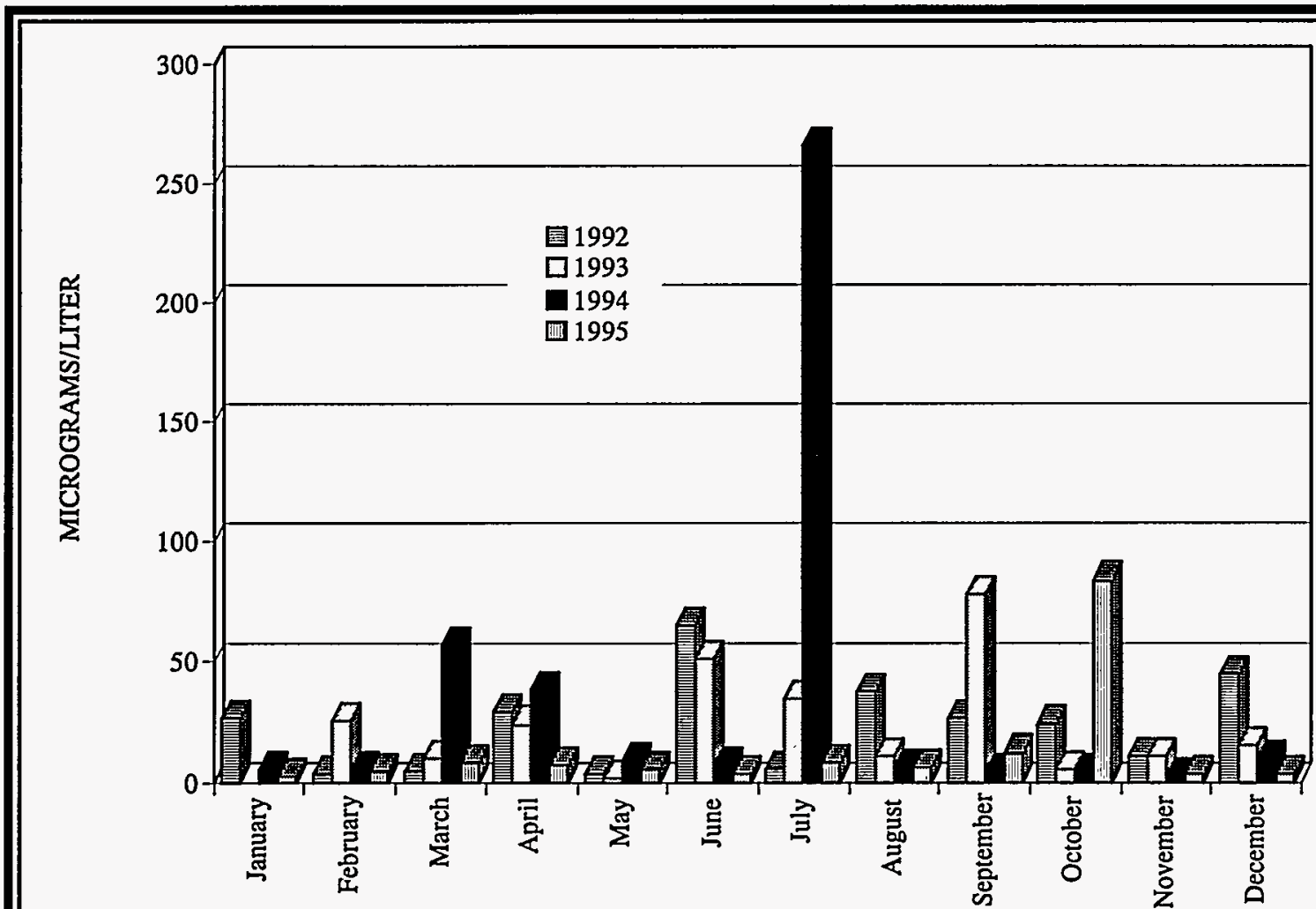

Figure 5.5 Chloroform Levels in Laboratory Wastewater, 1992 to 1995 


\section{ENVIRONMENTAL NONRADIOLOGICAL PROGRAM INFORMATION}

Outfall 001. The treated wastewater streams from the two treatment systems are combined and samples for analysis of most of the permit parameters are collected from a manhole downstream of the former chlorine contact chamber. This combined effluent then flows through the outfall sewer to Sawmill Creek. The effluent travels through this sewer for approximately $1,300 \mathrm{~m}(0.8 \mathrm{mi})$ before being discharged.

The permit requires analysis of the combined effluent once a week for TDS, chloride, and sulfate. The results, limits, and number of exceedances are presented in Table 5.5. An interim limit of $1,500 \mathrm{mg} / \mathrm{L}$ became effective August 24, 1995. The limit is effective up to June 30, 1998.

The 1,000 $\mu \mathrm{g} / \mathrm{L}$ limit for TDS was exceeded 20 times between January and August 1995. Frequent TDS exceedances (5-January, 4-February, 3-March) occurred early in 1995. TDS exceedances were believed to be related to discharges from boiler operations, that is, boiler blowdown, which is known to contain high levels of TDS, and domestic water treatment. Chemical analysis for chloride shows a close relationship between TDS levels and chloride levels. Figure 5.6 shows the results of TDS and chloride analyses for 1995. The groundwater at ANL-E is characterized by high TDS levels, that is, approximately $800 \mathrm{ppm}$. This elevated concentration allows only a narrow margin of added TDS (about $200 \mathrm{ppm}$ ) to the wastewater to remain below the NPDES effluent standard of 1,000 ppm (modified August 24, 1995). The modified NPDES Permit incorporates an interim TDS limit $(1,500 \mathrm{mg} / \mathrm{L})$ and a compliance schedule for achieving final TDS effluent limits at outfall 001. The final limits will be effective July 1, 1998. Levels for sulfate and chloride were not exceeded during 1995.

During the period of January to August, ANL-E exceeded the copper limit $(0.051 \mathrm{mg} / \mathrm{L}$ daily maximum) in 23 of 34 samples. The well water obtained by ANL-E from the Niagaran dolomite has very low copper concentrations. However, after treatment and distribution through domestic water distribution copper piping, a copper concentration range of $0.5 \mathrm{mg} / \mathrm{L}$ to $1.0 \mathrm{mg} / \mathrm{L}$ 


\section{ENVIRONMENTAL NONRADIOLOGICAL PROGRAM INFORMATION}

TABLE 5.5

Outfall 001 Monitoring Results and Effluent Limits, 1995

(Concentrations in $\mathrm{mg} / \mathrm{L}$ )

\begin{tabular}{lccccc}
\hline Constituent & Minimum & Average & Maximum & Limit & Exceedances \\
\hline Copper & 0.30 & 0.062 & 0.090 & 0.051 & 23 \\
& & & & $1.0^{\mathrm{a}}$ & 0 \\
Total Dissolved & 881 & 1,101 & 1,388 & 1,000 & 20 \\
Solids & & & & $1,500^{\mathrm{a}}$ & 0 \\
Ammonia-Nitrogen & 0.2 & 3.3 & 8.0 & $3.0^{\mathrm{b}}$ & 4 \\
& & & & Monitor only $^{\mathrm{a}}$ & 0 \\
\hline
\end{tabular}

a Interim limit effective August 24, 1995.

b April-October.

is typical at drinking fountains. The range has been determined by the lead/copper monitoring program (refer to Chapter 6) required by the EPA. The action level for copper in drinking water has been established at $1.3 \mathrm{mg} / \mathrm{L}$. Essentially all the ANL-E monitoring locations are below this action level. These acceptable levels for human consumption are significantly above the NPDES permit limit at outfall 001. There is no process in the WTP to remove copper. Past samples collected from the WTP effluent have been below the IEPA effluent limit of $0.5 \mathrm{mg} / \mathrm{L}$, but concentrations measured in Sawmill Creek, below the point where the treated wastewater has been discharged, have consistently exceeded the IEPA stream standard for copper $(0.02 \mathrm{mg} / \mathrm{L})$ for several years. This is indicative of the current ambient levels of copper in surface water as a result of the increased use of copper pipe for domestic water distribution. The modified NPDES Permit (effective August 24, 1995) incorporates an interim upper limit (1.0 mg/L daily maximum) and a compliance schedule for achieving final copper effluent limits at outfall 001 . The final limits will be effective July 1, 1998.

ANL-E exceeded the ammonia-nitrogen limit $(3.0 \mathrm{mg} / \mathrm{L})$ twice during June and twice in July. The ANL-E WTPs provide minimal treatment for ammonia-nitrogen. The modified NPDES Permit (effective August 24, 1995) incorporates interim ammonia-nitrogen limits (monitor 


\section{ENVIRONMENTAL NONRADIOLOGICAL PROGRAM INFORMATION}

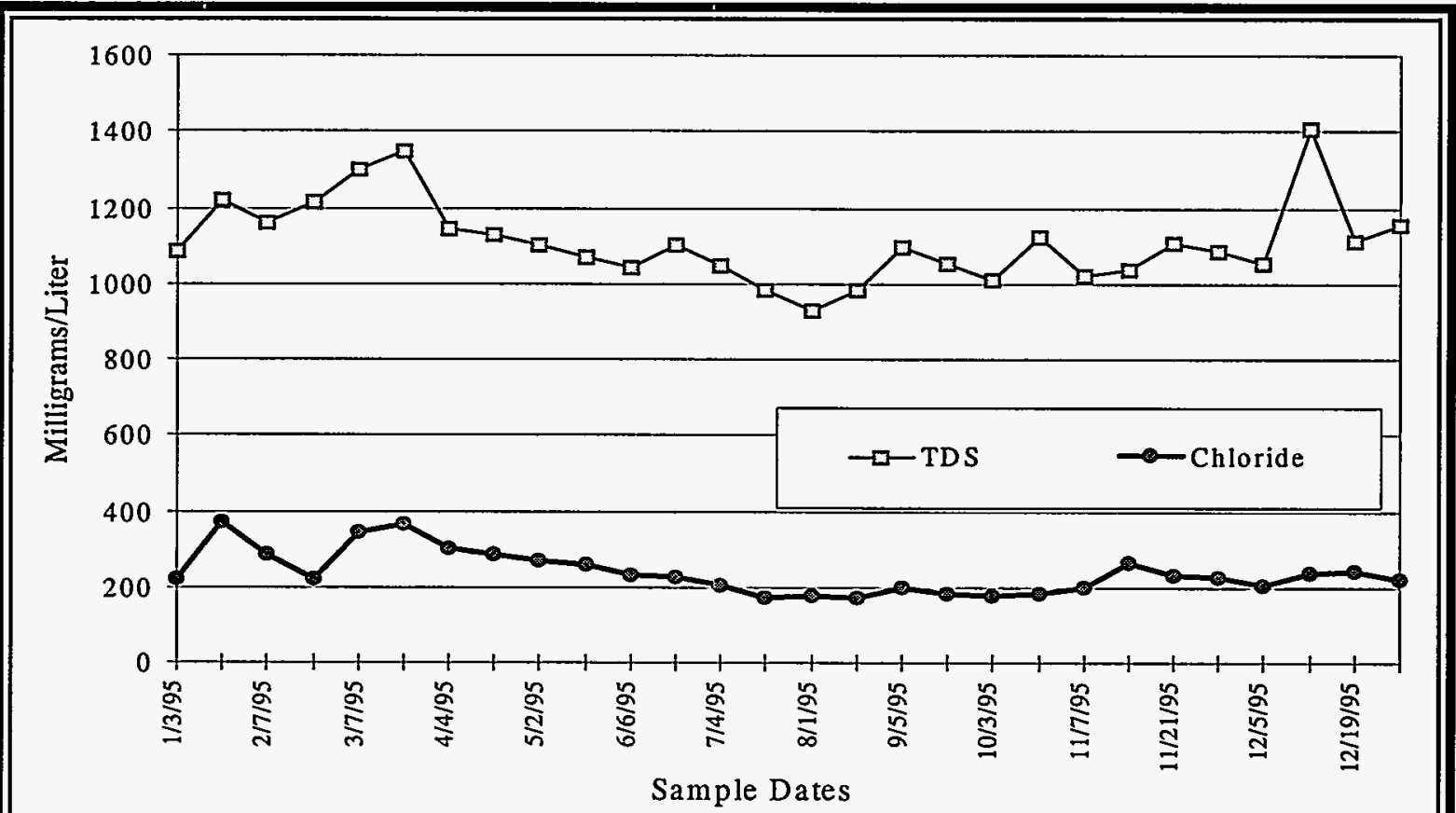

Figure 5.6 Total Dissolved Solids and Chloride in Outfall 001 Water, 1995

only) and a compliance schedule for achieving final ammonia-nitrogen effluent limits at outfall 001. The final limits will be effective July 1, 1998.

The permit requires that a biological toxicity screening test be performed on wastewater from outfall 001 in June of each year. The toxicity testing is run on at least three trophic levels of aquatic species for acute toxicity. The 1995 testing was conducted on samples collected during June 21 to June 22, 1995, using the water flea, Ceriodaphnia dubia, and the fathead minnow, Pimephales promelas.

A small amount of toxicity was observed with fathead minnows, but the effluent was not toxic to the water flea. The $\mathrm{LC}_{50}$ for both species is greater than $100 \%$. Table 5.6 summarizes the results from the various toxicity tests for 1995 . Table 5.7 summarizes the test results from 1991 to 1995. 


\section{ENVIRONMENTAL NONRADIOLOGICAL PROGRAM INFORMATION}

TABLE 5.6

Outfall 001 Aquatic Toxicity Test Results, 1995

\begin{tabular}{|c|c|c|c|c|}
\hline Test & Endpoint & $\begin{array}{c}96 / 48-\text { Hour } \\
\mathrm{LC}_{50}{ }^{\mathrm{a}} \\
(\%)\end{array}$ & $\begin{array}{l}\text { NOEC } \\
(\%)\end{array}$ & $\begin{array}{c}\text { LOEC }^{C} \\
(\%)\end{array}$ \\
\hline $\begin{array}{l}\text { 96-Hour Fathead Minnow } \\
\text { Acute Toxicity }\end{array}$ & Survival & $>100.0$ & 50 & 100 \\
\hline $\begin{array}{l}\text { 48-Hour Ceriodaphnia } \\
\text { Acute Toxicity }\end{array}$ & Survival & $>100.0$ & $>100$ & $>100$ \\
\hline
\end{tabular}

a $\mathrm{LC}_{50}=$ Concentration of wastewater that produces $50 \%$ mortality in the test population.

b NOEC $=$ No Observable Effect Concentration is the highest concentration of the effluent at which no adverse effect is observed.

c LOEC $=$ Lowest Observable Effect Concentration is the lowest concentration of the effluent at which an adverse effect is observed.

TABLE 5.7

Aquatic Toxicity Test Results, 1991 to 1995

\begin{tabular}{lrrrrr}
\hline & $\begin{array}{c}1991 \\
\text { Test }\end{array}$ & $\begin{array}{c}1992 \\
(\%)\end{array}$ & $\begin{array}{c}1993 \\
(\%)\end{array}$ & $\begin{array}{c}1994 \\
(\%)\end{array}$ & $\begin{array}{c}1995 \\
(\%)\end{array}$ \\
\hline Minnow, Acute, LC 50 & & & & & \\
Ceriodaphnia, Acute, LC 50 & 61.6 & $<6.2$ & 100.0 & 100.0 & $>100$ \\
Minnow, Chronic, Survival, NOEC & 50.0 & 100.0 & 50.0 & 100.0 & a $^{\text {a }}$ \\
Minnow, Chronic, Survival, LOEC & 100.0 & 100.0 & 100.0 & 100.0 & - \\
Minnow, Chronic, Growth, NOEC & 50.0 & 100.0 & 50.0 & 100.0 & - \\
Ceriodaphnia, Chronic, Survival, & 50.0 & 50.0 & 50.0 & 100.0 & - \\
NOEC & & & & & \\
Ceriodaphnia, Chronic, Survival, & 100.0 & 100.0 & 100.0 & 100.0 & - \\
LOEC & & & & & \\
Ceriodaphnia, Chronic, Reproduction, & 50.0 & 50.0 & 25.0 & 100.0 & - \\
NOEC & & & & & \\
Algal Growth, LOEC & 6.2 & 6.2 & 100.0 & 100.0 & - \\
Algal Growth, NOEC & 3.1 & $<6.25$ & 100.0 & 100.0 & - \\
\hline
\end{tabular}

a A hyphen indicates that no analysis was performed. 


\section{ENVIRONMENTAL NONRADIOLOGICAL PROGRAM INFORMATION}

The permit also requires that weekly $\mathrm{pH}$, ammonia nitrogen, dissolved iron, manganese, and zinc measurements be made. No results exceeded NPDES limits during 1995 . Monthly monitoring for lead, hexavalent and trivalent chromium, and beta radioactivity is required.

Outfall 003A. This discharge is located approximately $25 \mathrm{~m} \mathrm{(75} \mathrm{ft)} \mathrm{north} \mathrm{of} \mathrm{the} \mathrm{swimming}$ pool and is a vitrified clay pipe that was originally used as the discharge point for all the swimming pool activities (filter backwash, draining, and overflow). Table 5.8 presents the sampling requirements and effluent limits. One exceedance of the TSS limit was noted in 1995. The effluent discharging directly from the pipe contains noticeable solids. The solids appear to be pipe material that is sloughing off the outfall pipe.

TRC levels exceeded the $0.05 \mathrm{mg} / \mathrm{L}$ TRC NPDES permit limit in 14 of 23 samples. Special Condition 8 of the NPDES permit allows ANL-E two years to achieve compliance with the $0.05 \mathrm{mg} / \mathrm{L}$ TRC limit. Therefore, the IEPA does not consider an exceedance of the TRC limit to be "reportable" until October 30, 1996. By July 1995, discharge of chlorinated water from outfall 003A had been completely eliminated by installation of a sump collection system that captures all the flow and discharges into the sanitary drain system.

Outfall 003B. The outfall is located approximately $150 \mathrm{~m}(500 \mathrm{ft})$ northeast of Building 308 and is composed of storm-water runoff and condensate from the buildings in the watershed of the outfall. The discharge point is a 1-m (36-in.) concrete pipe to a tributary brook flowing north to the Freund Brook. Table 5.8 gives the sampling requirements and effluent limits. No exceedances occurred during 1995.

Outfall 003C. The discharge from this outfall is made up of footing tile drainage and storm-water runoff. The discharge point is a $0.65-\mathrm{m}$ (24-in.) concrete pipe discharging into Freund Brook approximately $50 \mathrm{~m}$ (150 ft) upstream of the gas station, south of Building 205. The sampling requirements and effluent limits are given in Table 5.8. No exceedances occurred during 1995. 


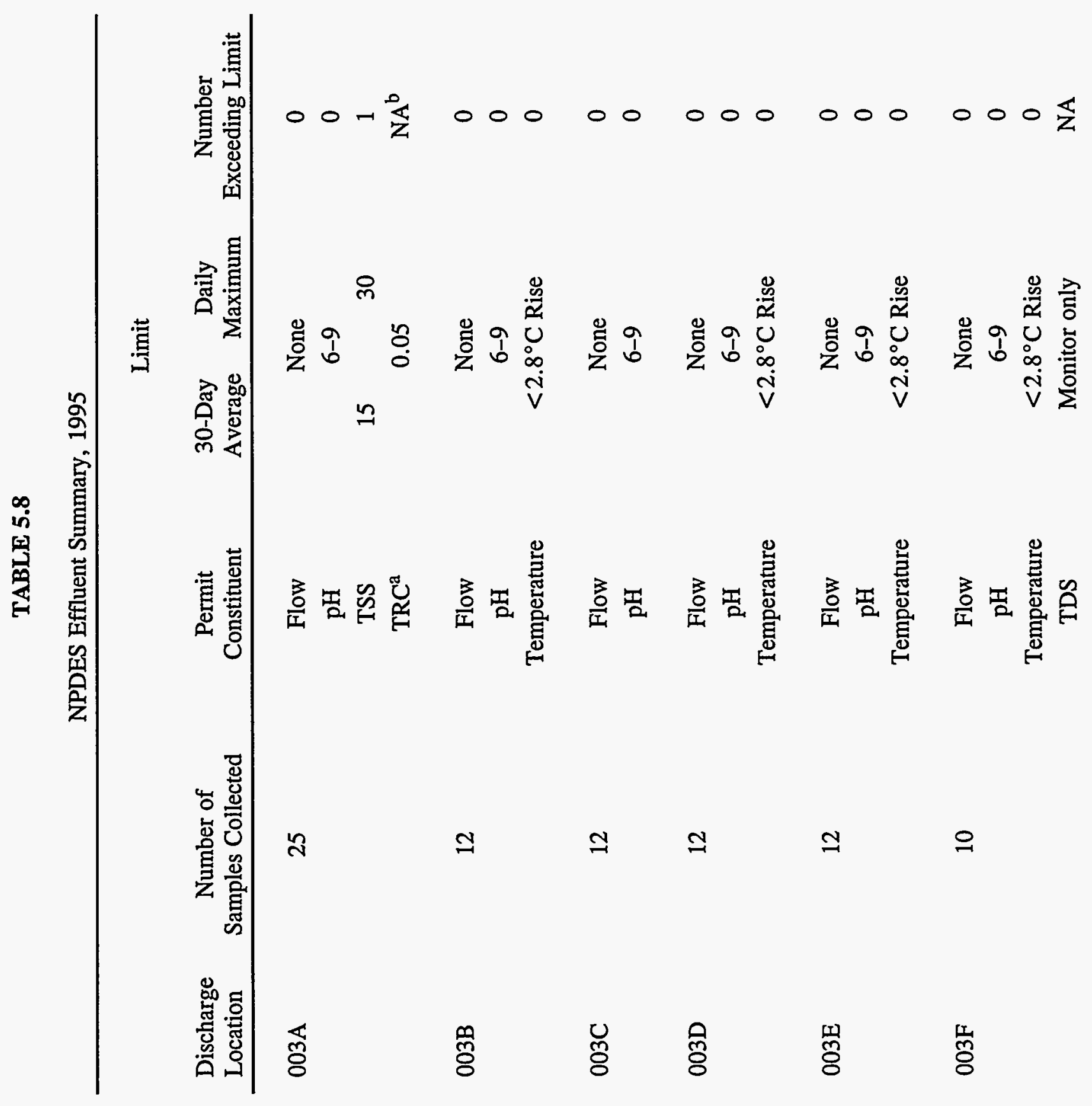


TABLE 5.8 (Cont.)

\begin{tabular}{|c|c|c|c|c|}
\hline \multirow[b]{2}{*}{$\begin{array}{l}\text { Discharge } \\
\text { Location }\end{array}$} & \multirow[b]{2}{*}{$\begin{array}{c}\text { Number of } \\
\text { Samples Collected }\end{array}$} & \multirow[b]{2}{*}{$\begin{array}{c}\text { Permit } \\
\text { Constituent }\end{array}$} & Limit & \multirow[b]{2}{*}{$\begin{array}{c}\text { Number } \\
\text { Exceeding Limit }\end{array}$} \\
\hline & & & $\begin{array}{cc}\text { 30-Day } & \text { Daily } \\
\text { Average } & \text { Maximum }\end{array}$ & \\
\hline \multirow[t]{3}{*}{$003 \mathrm{G}$} & 12 & Flow & None & 0 \\
\hline & & $\mathrm{pH}$ & $6-9$ & 0 \\
\hline & & Temperature & $<2.8^{\circ} \mathrm{C}$ Rise & 0 \\
\hline \multirow[t]{4}{*}{$003 \mathrm{H}$} & 12 & Flow. & None & 0 \\
\hline & & $\mathrm{pH}$ & $6-9$ & 0 \\
\hline & & Temperature & $<2.8^{\circ} \mathrm{C}$ Rise & 0 \\
\hline & & TDS & Monitor only & NA \\
\hline \multirow[t]{5}{*}{$003 I$} & 12 & Flow & None & 0 \\
\hline & & $\mathrm{pH}$ & $6-9$ & 0 \\
\hline & & Temperature & $<2.8^{\circ} \mathrm{C}$ Rise & 0 \\
\hline & & TDS & Monitor only & NA \\
\hline & & Oil \& Grease & Monitor only & NA \\
\hline \multirow[t]{4}{*}{$003 \mathrm{~J}$} & 12 & Flow & None & 0 \\
\hline & & $\mathrm{pH}$ & $6-9$ & 0 \\
\hline & & Temperature & $<2.8^{\circ} \mathrm{C}$ Rise & 0 \\
\hline & & TDS & Monitor only & NA \\
\hline \multirow[t]{3}{*}{004} & 12 & Flow & None & 0 \\
\hline & & $\mathrm{pH}$ & $6-9$ & 0 \\
\hline & & TSS & 30 & 1 \\
\hline
\end{tabular}


TABLE 5.8 (Cont.)

\begin{tabular}{|c|c|c|c|c|c|}
\hline \multirow[b]{2}{*}{$\begin{array}{l}\text { Discharge } \\
\text { Location }\end{array}$} & \multirow[b]{2}{*}{$\begin{array}{c}\text { Number of } \\
\text { Samples Collected }\end{array}$} & \multirow[b]{2}{*}{$\begin{array}{c}\text { Permit } \\
\text { Constituent }\end{array}$} & \multicolumn{2}{|c|}{ Limit } & \multirow[b]{2}{*}{$\begin{array}{c}\text { Number } \\
\text { Exceeding Limit }\end{array}$} \\
\hline & & & $\begin{array}{l}\text { 30-Day } \\
\text { Average }\end{array}$ & $\begin{array}{c}\text { Daily } \\
\text { Maximum }\end{array}$ & \\
\hline \multirow[t]{4}{*}{$005 \mathrm{C}$} & 12 & Flow & \multicolumn{2}{|c|}{ None } & 0 \\
\hline & & $\mathrm{pH}$ & \multicolumn{2}{|c|}{$6-9$} & 0 \\
\hline & & Temperature & \multicolumn{2}{|c|}{$<2.8^{\circ} \mathrm{C}$ Rise } & 0 \\
\hline & & Oil \& Grease & \multicolumn{2}{|c|}{ Monitor only } & $\mathrm{NA}$ \\
\hline \multirow[t]{2}{*}{$005 \mathrm{E}$} & 12 & Flow & \multicolumn{2}{|c|}{ None } & 0 \\
\hline & & $\mathrm{pH}$ & \multicolumn{2}{|c|}{$6-9$} & 0 \\
\hline \multirow[t]{5}{*}{006} & 12 & Flow & \multicolumn{2}{|c|}{ None } & 0 \\
\hline & & $\mathrm{pH}$ & \multicolumn{2}{|c|}{$6-9$} & 0 \\
\hline & & TSS & 15 & 30 & 0 \\
\hline & & TDS & \multicolumn{2}{|c|}{ Monitor only } & NA \\
\hline & & Temperature & \multicolumn{2}{|c|}{$<2.8^{\circ} \mathrm{C}$ Rise } & 0 \\
\hline \multirow[t]{5}{*}{007} & 47 & Flow & \multicolumn{2}{|c|}{ None } & 0 \\
\hline & & $\mathrm{pH}$ & \multicolumn{2}{|c|}{$6-9$} & 0 \\
\hline & & Temperature & \multicolumn{2}{|c|}{$<2.8^{\circ} \mathrm{C}$ Rise } & 0 \\
\hline & & TRC & \multicolumn{2}{|c|}{0.05} & NA \\
\hline & & Oil \& Grease & \multicolumn{2}{|c|}{ Monitor only } & NA \\
\hline \multirow[t]{3}{*}{008} & 12 & Flow & \multicolumn{2}{|c|}{ None } & 0 \\
\hline & & $\mathrm{pH}$ & \multicolumn{2}{|c|}{ 6-9 } & 0 \\
\hline & & VOC & \multicolumn{2}{|c|}{ Monitor only } & NA \\
\hline
\end{tabular}


TABLE 5.8 (Cont.)

\begin{tabular}{|c|c|c|c|c|c|}
\hline \multirow[b]{2}{*}{$\begin{array}{l}\text { Discharge } \\
\text { Location }\end{array}$} & \multirow[b]{2}{*}{$\begin{array}{c}\text { Number of } \\
\text { Samples Collected }\end{array}$} & \multirow[b]{2}{*}{$\begin{array}{c}\text { Permit } \\
\text { Constituent }\end{array}$} & \multicolumn{2}{|c|}{ Limit } & \multirow[b]{2}{*}{$\begin{array}{l}\text { Number } \\
\text { Exceeding Limit }\end{array}$} \\
\hline & & & $\begin{array}{l}\text { 30-Day } \\
\text { Average }\end{array}$ & $\begin{array}{c}\text { Daily } \\
\text { Maximum }\end{array}$ & \\
\hline \multirow[t]{12}{*}{010} & 0 & Flow & \multicolumn{2}{|c|}{ None } & NA \\
\hline & & $\mathrm{pH}$ & \multicolumn{2}{|c|}{$6-9$} & NA \\
\hline & & TSS & 15 & 30 & NA \\
\hline & & Total Iron & 2 & 4 & $\mathrm{NA}$ \\
\hline & & Dissolved Iron & & 1.0 & NA \\
\hline & & Lead & & 0.1 & NA \\
\hline & & Zinc & & 1.0 & $\mathrm{NA}$ \\
\hline & & Manganese & & 1.0 & NA \\
\hline & & Hexavalent Chromium & 0.011 & 0.016 & NA \\
\hline & & Trivalent Chromium & 0.519 & 2.0 & $\mathrm{NA}$ \\
\hline & & Copper & 0.031 & 0.051 & $\mathrm{NA}$ \\
\hline & & Oil \& Grease & 15 & 30 & NA \\
\hline \multirow[t]{3}{*}{108} & 12 & Flow & \multicolumn{2}{|c|}{ None } & 0 \\
\hline & & $\mathrm{pH}$ & \multicolumn{2}{|c|}{$6-9$} & 0 \\
\hline & & Temperature & \multicolumn{2}{|c|}{$<2.8^{\circ} \mathrm{C}$ Rise } & 0 \\
\hline \multirow[t]{2}{*}{111} & 2 & Flow & \multicolumn{2}{|c|}{ None } & $\mathrm{NA}$ \\
\hline & & Tritium & \multicolumn{2}{|c|}{ Monitor Only } & NA \\
\hline \multirow[t]{2}{*}{$112 \mathrm{~A}$} & 2 & Flow & \multicolumn{2}{|c|}{ None } & $\mathrm{NA}$ \\
\hline & & Tritium & \multicolumn{2}{|c|}{ Monitor Only } & $\mathrm{NA}$ \\
\hline
\end{tabular}


TABLE 5.8 (Cont.)

Limit

\begin{tabular}{|c|c|c|c|c|}
\hline $\begin{array}{l}\text { Discharge } \\
\text { Location }\end{array}$ & $\begin{array}{c}\text { Number of } \\
\text { Samples Collected }\end{array}$ & $\begin{array}{l}\text { Permit } \\
\text { Constituent }\end{array}$ & $\begin{array}{c}\text { Daily } \\
\text { Maximum }\end{array}$ & $\begin{array}{l}\text { Number } \\
\text { Exceeding Limit }\end{array}$ \\
\hline \multirow[t]{2}{*}{ 112B } & \multirow[t]{2}{*}{2} & Flow & None & NA \\
\hline & & Tritium & Monitor Only & $\mathrm{NA}$ \\
\hline \multirow[t]{4}{*}{113} & \multirow[t]{4}{*}{5} & Flow & None & 0 \\
\hline & & Tritium & Monitor Only & NA \\
\hline & & PCB 1260 & Monitor Only & NA \\
\hline & & $\begin{array}{c}\text { Lead, Copper, Nickel, } \\
\text { Zinc }\end{array}$ & Monitor Only & NA \\
\hline \multirow[t]{4}{*}{114} & \multirow[t]{4}{*}{5} & Flow & None & 0 \\
\hline & & Tritium & Monitor Only & NA \\
\hline & & PCB 1260 & Monitor Only & NA \\
\hline & & $\begin{array}{c}\text { Lead, Copper, Nickel, } \\
\text { Zinc }\end{array}$ & Monitor Only & NA \\
\hline \multirow[t]{4}{*}{115} & \multirow[t]{4}{*}{12} & Flow & None & 0 \\
\hline & & $\mathrm{pH}$ & $6-9$ & 0 \\
\hline & & Temperature & $<2.8^{\circ} \mathrm{C}$ Rise & 0 \\
\hline & & TDS & Monitor only & NA \\
\hline \multirow[t]{3}{*}{116} & \multirow[t]{3}{*}{26} & Flow & None & 0 \\
\hline & & $\mathrm{pH}$ & $6-9$ & 0 \\
\hline & & $\mathrm{TRC}^{1}$ & 0.05 & NA \\
\hline
\end{tabular}

a NPDES Special Condition gives ANL-E two years to comply with the TRC limit.

b $\mathrm{NA}=$ not applicable. 


\section{ENVIRONMENTAL NONRADIOLOGICAL PROGRAM INFORMATION}

Outfalls 003D and 003E. These two discharge points are from the steam trench around Inner Circle Drive and discharge into the north fork of Freund Brook approximately $150 \mathrm{~m}$ (500 ft) east of the intersection of Inner Circle Drive and Eastwood Extension. Table 5.8 gives the sampling requirements and effluent limits. No exceedances occurred during 1995.

Outfall 003F. This outfall is intended to discharge excess water from the fire pond during storm events. The building discharges cooling tower water to the fire pond, and the rate is.low enough to generally not discharge without rain water to attain flow. The discharge is through a cement raceway to the south fork of the north branch of Freund Brook. Table 5.8 gives the sampling requirements and effluent limits. No exceedances occurred during 1995.

Outfall 003G. Footing tile drainage from the Inner Circle steam trench is pumped to the storm sewer passing around the northeast portion of Building 201 and discharges into the northern fork of the southern branch of Freund Brook. Condensate leaks in the steam trench produce discharge on a regular basis to the storm sewer. Table 5.8 gives the sampling requirements and effluent limits. No exceedances occurred during 1995.

Outfall $003 \mathrm{H}$. This discharge originates from the footing tile drainage around Building 212 and storm water collected from around Buildings 212 and 214 and their associated parking lots. The cooling tower located on the south roof of Building 212 discharges into the tile drainage system and is the source of the industrial discharge. Table 5.8 gives the sampling requirements and effluent limits. No exceedances occurred during 1995.

Special Condition 9 of the NPDES Permit requires acute toxicity testing on the effluent from outfalls $003 \mathrm{H}, 003 \mathrm{I}, 003 \mathrm{~J}, 004,006$, and 115 . The testing is performed on the fathead minnow (Pimephales promelas) and daphnids (Ceriodaphnia dubia). The testing is performed on a biannual basis during the months of July and August. These outfalls were sampled during the periods of July 31 to August 4, 1995, and August 21 to August 25, 1995. Outfall 003H was acutely toxic to the fathead minnow and daphnids. The $\mathrm{LC}_{50}$ value for Ceriodaphnia was higher in the August 21, 1995, test set. Water chemistry data indicated residual chlorine levels of 


\section{ENVIRONMENTAL NONRADIOLOGICAL PROGRAM INFORMATION}

$0.6 \mathrm{mg} / \mathrm{L}$ to greater than $2.0 \mathrm{mg} / \mathrm{L}$, which possibly contributed to the toxicity detected. The results are summarized in Tables 5.9 and 5.10.

Outfall 003I. This outfall collects storm water from the Building 200, 211, and the western portion of Building 205 areas and also gets cooling tower discharge from the cooling tower located behind Building 200. Table 5.8 gives the sampling requirements and effluent limits. No exceedances were noted during 1995. Results of acute toxicity tests for outfall 003I are presented in Tables 5.9 and 5.10. Outfall 003I was not acutely toxic to the fathead minnow or daphnids.

Outfall 003J. This outfall collects storm water from the Building 213 area and parking lot, which passes through a storm sewer around the Building 201. Cooling tower blowdown is the industrial discharge to this system. The sampling requirements and effluent limits are given in Table 5.8. No exceedances were noted during 1995. Results of acute toxicity tests for outfall 003J are presented in Tables 5.9 and 5.10. Outfall 003J was not acutely toxic to the fathead minnow or daphnids.

Outfall 004. This outfall discharges storm water from the Building 203 and 221 areas and cooling water from Building 221 . The discharge is to a drainage ditch and sewer system that pass around the northeastern portion of Outer Circle Drive and to a ditch leading north to the fenceline, east of the Visitor's Center. Table 5.8 gives the sampling requirements and effluent limits. One exceedance of TSS limits occurred in 1995, most likely due to surface runoff from the surrounding area during periods of heavy precipitation. Results of acute toxicity tests for outfall 004 are presented in Tables 5.9 and 5.10. Outfall 004 was not acutely toxic to the fathead minnow or daphnids.

Outfall 005A. This outfall discharges runoff from the northwestern portion of the 800 Area. The flow passes under Westgate Road, east of the west gate, and flows toward the northwestern fenceline. This is a storm-water only outfall. 
TABLE 5.9

Acute Toxicity Results: Fathead Minnow, 1995

\begin{tabular}{lccc}
\hline & $\begin{array}{c}\text { 96-Hour } \mathrm{LC}_{50} \\
\text { N. promelas }\end{array}$ & $\begin{array}{c}\text { 96-Hour } \mathrm{LC}_{50} \\
P \text {. promelas }\end{array}$ & \\
Outfall & $\begin{array}{c}\text { Aug. 2-6, 1995 } \\
\text { Aug. 23-27, 1995 }\end{array}$ & Comments \\
\hline & & & \\
$003 \mathrm{H}$ & $<50 \%$ & $>100 \%$ & Variable toxicity \\
$003 \mathrm{I}$ & $>100 \%$ & $>100 \%$ & Not acutely toxic \\
$003 \mathrm{~J}$ & $>100 \%$ & $>100 \%$ & Not acutely toxic \\
004 & $>100 \%$ & $>100 \%$ & Not acutely toxic \\
006 & $>100 \%$ & $>100 \%$ & Not acutely toxic \\
115 & $>100 \%$ & $>100 \%$ & Not acutely toxic \\
\hline
\end{tabular}

TABLE 5.10

Acute Toxicity Results: Ceriodaphnia, 1995

\begin{tabular}{|c|c|c|c|c|}
\hline $\begin{array}{l}\text { NPDES } \\
\text { Outfall }\end{array}$ & $\begin{array}{l}\text { 48-Hour } \mathrm{LC}_{50} \\
\text { C. dubia } \\
\text { Aug. 2-4, } 1995\end{array}$ & $\begin{array}{l}\text { 48-Hour } \mathrm{LC}_{50} \\
\text { C. dubia } \\
\text { Aug. } 4-6,1995\end{array}$ & $\begin{array}{c}\text { 48-Hour } \mathrm{LC}_{50} \\
\text { C. dubia } \\
\text { Aug. 23-25, } 1995\end{array}$ & Comments \\
\hline $003 \mathrm{H}$ & $<50 \%$ & $<50 \%$ & $91 \%$ & Variable toxicity \\
\hline $003 I$ & $>100 \%$ & $>100 \%$ & $>100 \%$ & $\begin{array}{l}\text { Not acutely } \\
\text { toxic to } \\
\text { daphnids }\end{array}$ \\
\hline 003J & $>100 \%$ & $>100 \%$ & $>100 \%$ & $\begin{array}{l}\text { Not acutely } \\
\text { toxic to } \\
\text { daphnids }\end{array}$ \\
\hline 004 & $>100 \%$ & $>100 \%$ & $>100 \%$ & $\begin{array}{l}\text { Not acutely } \\
\text { toxic to } \\
\text { daphnids }\end{array}$ \\
\hline 006 & $<50 \%$ & $<50 \%$ & $<50 \%$ & $\begin{array}{l}\text { Acutely toxic to } \\
\text { daphnids }\end{array}$ \\
\hline 115 & $<50 \%$ & $<50 \%$ & $<50 \%$ & $\begin{array}{l}\text { Acutely toxic to } \\
\text { daphnids }\end{array}$ \\
\hline
\end{tabular}

a Dilution water proved to be acutely toxic to Ceriodaphnia and made it necessary to reset tests on August 4, 1995. 


\section{ENVIRONMENTAL NONRADIOLOGICAL PROGRAM INFORMATION}

Outfall 005B. The outfall for this watershed discharges runoff collected from the major portion of the 800 Area. The flow is collected from the parking lots and roadways and flows by storm sewers to the east, where it is discharged to the marsh located on the eastern side of Kearney Road. This is a storm-water only outfall.

Outfall 005C. This outfall collects storm water from the northern side and the loading dock area of Building 200. The Building 200 clear water system discharges to this outfall, which passes through sewers to the west of the loading dock, and to the beaver pond west of Building 200. The sampling requirements and effluent limits are given in Table 5.8. No exceedances occurred during 1995.

Outfall 005D. The Building $200 \mathrm{M}$-Wing loading dock area storm-water runoff is collected in a storm sewer and passes west to the Beaver pond located west of Building 200. The discharge is through a 1-m (36-in.) corrugated pipe into the pond. This is a storm-water only discharge.

Outfall 005E. This outfall discharges footing tile drainage from the west side of Building 203 and Building 208. The outfall also discharges storm water collected from the same area. The industrial discharge arises from cup drains and compressors discharging into the footing tile sumps. The sampling requirements and effluent limits are given in Table 5.8. No exceedances occurred during 1995.

Outfall 006. Cooling towers at Building 350 and the 377 Area discharge into the drainage ditch that flows south of the Canal Water Treatment Plant, bends south, and flows to the south fenceline. The permit requires monthly sampling for $\mathrm{pH}$, TSS, and temperature. The limits are given in Table 5.8. No exceedances of NPDES limits occurred in 1995. Results of acute toxicity tests for outfall 006 are presented in Tables 5.9 and 5.10. Outfall 006 was acutely toxic to Ceriodaphnia. The source of the acute toxicity is unknown.

Outfall 007. The watershed for outfall 007 includes the southeastern section of the 300 Area, extending from Building 370 east to Building 366, and north to Building 367. Water is collected in catchment basins and conveyed toward the southeast to a point approximately $30 \mathrm{~m}$ 


\section{ENVIRONMENTAL NONRADIOLOGICAL PROGRAM INFORMATION}

(100 ft) southeast of Building 366, where it is discharged into a ditch on the south side of Old Bluff Road. This ditch runs along the roadside for $15 \mathrm{~m} \mathrm{(50} \mathrm{ft),} \mathrm{at} \mathrm{which} \mathrm{point} \mathrm{it} \mathrm{turns} \mathrm{south} \mathrm{and}$ runs to the fenceline where it is discharged to the forest preserve. The once-through cooling water of compressors is the industrial component of this outfall.

Table 5.8 gives the sampling requirements and effluent limits. TRC levels exceeded the NPDES permit limit of $0.05 \mathrm{mg} / \mathrm{L}$ in 41 out of 47 samples collected during 1995 . For reasons explained above for outfall 003A, these are not "reportable" exceedances to the IEPA. Apparently, some discharge of potable water from the 300 Area flows through this outfall. Seventeen drain lines were removed from the storm system on outfall 007 , and the frequency and amount of discharge have been significantly reduced.

Outfall 008. The watershed for this outfall includes the area around the new Vehicle Maintenance and Grounds Building 46. Runoff is collected in storm-water grates and catchments and conveyed through sewers to the discharge point in Sawmill Creek, located directly west of Building 24. Industrial activity in this small watershed involves the activities associated with maintenance of all facility vehicles, grounds, maintenance, the storage of the equipment associated with these activities, and fueling for the vehicles.

Five VOCs are monitored once a month. The only NPDES limit that applies at this point is $\mathrm{pH}$. No exceedances were noted during 1995.

Outfall 010. This outfall is the outfall for the coal pile storage area runoff collection system overflow line. The collection system consists of a trench on the north and west sides of the coal pile; a sump is located at the extreme southern end of the western trenchline. The overflow line comes into use only when the runoff reaches the level at which the trench system would overflow; the line was put into place to ensure against overflow conditions. During normal operations, the water is pumped to the equalization basin located in the western area of the 100 Area. The industrial activity associated with this outfall is solely the coal pile operation. The berm and trench system in place to collect runoff has been improved to eliminate discharge from the outfall. 


\section{ENVIRONMENTAL NONRADIOLOGICAL PROGRAM INFORMATION}

This outfall is sampled once per day when flow occurs. Analyses are performed for $\mathrm{pH}$, TSS, TDS, iron, lead, zinc, manganese, trivalent and hexavalent chromium, copper, and oil and grease. No flow occurred at this site during 1995.

Outfall 101. The drainage to the outfall is through ditches along the streets and sewer conduits from the parking lot to a marsh located between Outer Circle Drive and the fenceline to the outfall; the conduits consist of a $0.65-\mathrm{m}$ (24-in.) corrugated metal pipe with a Palmer-Bowlus flume. The drainage then discharges on the other side of the fenceline into the forest preserve. The sources of storm-water runoff to the outfall are the Building 203 parking lot with loading dock and the excess equipment storage area on the north side of Outer Circle Drive. This is a storm-water only discharge.

Outfall 102. This watershed includes portions of the 100 Area. Large amounts of paved areas are associated with the industrial activities for the production of steam such as those areas associated with the WTP, the lime sludge pond, and the tarmac around the boiler house. The contributing runoff flows are collected from storm-water inlet grates and catch basins, through storm sewers to a discharge point of a $0.30-\mathrm{m}$ (12-in.) corrugated metal pipe extending out of the bank of Sawmill Creek. This is a storm-water only discharge.

Outfall 103. The watershed for outfall 103 includes the southern and southeastern extreme of the 100 Area and the area south of the coal pile. These areas drain into a storm sewer that runs due east of the coal pile toward Sawmill Creek. The outfall is located at the outlet of a $0.35-\mathrm{m}$ (15-in.) corrugated metal pipe culvert located approximately $50 \mathrm{~m}(150 \mathrm{ft})$ from the creek. Activities that are industrial in nature take place in and around the Utilities area and consist of boiler house steam generation, storage of plastic and metal, loading dock activities, a flue gas scrubber and cooling pond (no longer in use), steam condensate return storage (two tanks), and the southern access road to the coal pile storage area. This is a storm-water only discharge.

Outfall 104. This outfall includes the buildings and parking areas remaining in the East Area, excluding Buildings 40 and 46 . Buildings 4,5 , and 6 and their smaller attendant buildings are included, as well as Buildings 24 and 25 . The area is served by a number of roadways leading 


\section{ENVIRONMENTAL NONRADIOLOGICAL PROGRAM INFORMATION}

to and from these buildings, with contributing storm grate inlets on the roadways and parking areas. This is a storm-water only discharge.

Outfalls 105A and 105B. Two discharge points are located within this watershed. The contributing sources of storm water for this watershed receive runoff from areas around Building 40, and elevated water tower tanks for potable water distribution, and scrub vegetation areas on the west side of Tech Road. Industrial activity within this watershed includes receiving, loading, parking and storage areas, and oil-containing transformers. These are storm-water only discharges.

Outfalls 106A and 106B. The watershed for these outfalls encompasses the largest portion of the East Area, most of which is now demolished and the buildings razed. A portion of the eastern end of the Shipping and Receiving Area is part of this watershed, Building 33, which has electrical transformers located outside of it, and a portion of Argonne Park. As with outfall 105 above, this watershed is served by two distinct outfalls. The industrial activities within this watershed are the receiving and shipping areas with loading docks and the transformer area. These are storm-water only discharges.

Outfall 108. This watershed encompasses a portion of the 300 Area. The drainage area includes the parking areas north of Building 360, the buildings in and around Building 360 , excluding Buildings 370 and 390 and the southern and western end of the 300 Area, and the paved parking and loading dock areas in and around the eastern portions of the 300 Area (surrounding Building 363). The industrial activities ongoing in this watershed are shipping and receiving, a metals reclaim dumpster (Building 363), loading dock activities, and numerous outdoor equipment storage areas. Table 5.8 gives the sampling requirements and effluent limits. No exceedances occurred during 1995.

Outfall 110. The watershed for this outfall includes the shooting range (inactive since March 1993) and the area just south of the range. No other industrial activities take place within this watershed at present. Past industrial activity involved use of the shooting range for practice by the security force. This is a storm-water only discharge. 


\section{ENVIRONMENTAL NONRADIOLOGICAL PROGRAM INFORMATION}

Outfall 111. This outfall is located on the south fenceline of the site due south of the old, closed 319 Area Landfill, between the watershed for outfall 110 and the watershed for outfalls 112A and 112B. This watershed encompasses the 319 Landfill, the 318 Area (landfill area for compressed gases), and portions of the 317 Area, primarily the paved area. In addition, the roadways for access to these areas drain to this outfall through a small ditch running along the southern extreme of the 319 Landfill, turning south to the fenceline, and then to the outfall location, which is a $0.65-\mathrm{m}$ (24-in.) corrugated metal pipe culvert that passes under the fence and discharges into the forest preserve. Industrial activities within this watershed consist of the 317 Area radioactive waste storage and remediation activities, the 319 Landfill Area, and the associated roadways for access. This outfall is sampled semiannually for flow and hydrogen-3 (tritium) and has no permit limits. Tritium results were $246 \mathrm{pCi} / \mathrm{L}$ (January) and 1,270 pCi/L (August).

Outfalls $112 \mathrm{~A}$ and 112B. The contributing sources of storm water within this watershed receive runoff from the southern and western sections of the 317 Area radioactive waste storage. Runoff flow is generally toward the south in sheet flow from the source areas; the eastern portions consolidate at the fenceline at the southeastern corner of the 317 Area and pass under the fence through rough concrete fill. The western and central portions of the drainage area sheet flow consolidate in the same manner and pass under the fence through the same material approximately $50 \mathrm{~m}(150 \mathrm{ft})$ to the west. Both flows discharge into large gullies in the forest preserve and conjoin into one flow approximately $100 \mathrm{~m}$ (328 ft) south of the ANL-E fenceline. Industrial activity within this watershed consists of the 317 Area radioactive waste storage and remediation activities, loading activities at Building 350, and the associated roadways for access. These outfalls are sampled semiannually for flow and hydrogen- 3 and have no permit limits. Tritium results were less than 100 pCi/L during January and November 1995.

Outfall 113. This outfall is the discharge point for runoff from the eastern, southern, and southwestern sections of the closed 800 Area Landfill. The outfall is located in a ditch on the extreme southern end of the landfill, approximately $50 \mathrm{~m}(150 \mathrm{ft})$ from the southwestern corner of the landfill fenceline. This discharge flows under the fence in the ditch and empties into the creek that flows south from the wetland marsh west of the site. The marsh is the headwaters of 


\section{ENVIRONMENTAL NONRADIOLOGICAL PROGRAM INFORMATION}

one leg of the Freund Brook system that runs through the middle of the ANL-E site and discharges into Sawmill Creek. Industrial activity within this watershed is limited to the landfill. This outfall was sampled monthly when discharging and has no permit limits. Flow occurred during five months in 1995.

Outfall 114. This outfall is the discharge point for runoff coming from the northern and northwestern sections of the closed 800 Area Landfill. The outfall is located in a ditch on the extreme western side of the landfill, approximately halfway between the northern and southern boundaries of the landfill. The flow proceeds along the western edge of the landfill where water is added from the marsh. The flow eventually combines with the ditch from the outfall 113 flow and then passes into the creek that flows south from the wetland marsh west of the ANL-E site. Industrial activity within this watershed is limited to the landfill. This outfall was sampled monthly when discharging and has no permit limits. Flow occurred during five months in 1995.

Outfall 115. The watershed encompasses the APS site and the southern areas around the Building 314, 315, and 316 complex. . The APS flow drains into ditches that discharge through a cement culvert into a collection pond located on the southeastern portion of the APS site. The 0.65-m (24-in.) sewer conduit from the Building 314, 315, and 316 complex discharges into the same collection pond approximately $10 \mathrm{~m}$ (30 ft) east of the ditch culvert. The flow from this pond discharges south through a culvert into another pond, flows through this pond, and discharges through a 1-m (36-in.) corrugated metal pipe culvert under the south fenceline into the forest preserve. Industrial activities within the watershed are the APS construction, all roadways associated with APS construction, loading docks in the APS buildings, and the Building 314, 315, and 316 complex storage, loading areas, and cooling water discharges. Table 5.8 gives the sampling requirements and effluent limits. No exceedances occurred during 1995.

Results of acute toxicity tests for outfall 115 are presented in Tables 5.9 and Table 5.10. Outfall 115 was acutely toxic to Ceriodaphnia. The source of the acute toxicity is unknown.

Outfall 116. This outfall was originally intended as a storm-water discharge point only; however, it also contains nonstorm-water discharge as well. The source of the discharge was 


\section{ENVIRONMENTAL NONRADIOLOGICAL PROGRAM INFORMATION}

traced back and found to be potable water from the domestic water treatment plant located uphill from the rest of the main Utilities area. This source was investigated for corrective action and the flow stopped. The watershed for this outfall contains sections of the domestic water treatment plant, including the garage and storage area, the area around well 5, and the associated access roads for the domestic water treatment plant. Flow is conducted through storm-water sewers and discharged at the outfall, which is a $0.25-\mathrm{m}$ (10-in.) vitrified clay pipe with a cement raceway into Sawmill Creek. Industrial activities for this watershed include parking, loading, and materials storage around the domestic water treatment plant; domestic water treatment plant operation, including bulk chemical storage (brine tank) and transformers (Building 129); outdoor equipment storage area and four flammable materials storage cabinets (Building 130); outdoor materials storage (Buildings 107 and 163); well operation and maintenance (Building 160); and the associated roadways for these activities.

Table 5.8 gives the sampling requirements and effluent limits. TRC levels exceeded the NPDES permit limit of $0.05 \mathrm{mg} / \mathrm{L}$ in 15 out of 26 samples collected during 1995. For reasons explained above under outfall 003A, no reportable exceedance occurred. Four sources of chlorinated water were located and removed from outfall 116. The discharge from outfall 116 was at or below the NPDES Permit limit during the last two months of 1995.

\subsection{Additional Effluent Monitoring}

To characterize the wastewater from the ANL-E site more fully, composite samples of the combined effluent were collected each week and analyzed for the constituents shown in Table 5.11. The results are then compared to the IEPA General Effluent Limits found in 35 IAC, Subtitle C, Part $304 .^{27}$

\subsubsection{Sample Collection}

Samples for analysis of inorganic constituents are collected daily from outfall 001 located at the WTP using a refrigerated time proportional sampler. A portion of the sample is transferred to a specially cleaned bottle, a security seal is affixed, and chain-of-custody is maintained. Five 
TABLE 5.11

Chemical Constituents in Effluents from ANL-E Wastewater Treatment

Plant, 1995

(Concentrations in $\mathrm{mg} / \mathrm{L}$ )

\begin{tabular}{|c|c|c|c|c|c|}
\hline \multirow[b]{2}{*}{ Constituent } & \multirow{2}{*}{$\begin{array}{c}\text { No. of } \\
\text { Samples }\end{array}$} & \multicolumn{3}{|c|}{ Concentrations } & \multirow[b]{2}{*}{ Limit } \\
\hline & & Avg. & Min. & Max. & \\
\hline Arsenic & 52 & 0.0025 & $<0.0025$ & 0.0035 & 0.25 \\
\hline Barium & 51 & 0.0204 & 0.0150 & 0.0253 & 2.0 \\
\hline Beryllium & 52 & - & - & $<0.0001$ & - \\
\hline Cadmium & 52 & 0.0001 & $<0.0001$ & 0.0005 & 0.15 \\
\hline Chromium & 51 & - & - & $<0.0600$ & 1.0 \\
\hline Cobalt & 51 & - & - & $<0.0250$ & - \\
\hline Copper & 52 & 0.0549 & 0.0340 & 0.0900 & 0.5 \\
\hline Fluoride & 52 & 0.4264 & 0.2780 & 0.6060 & 15.0 \\
\hline Iron & 51 & 0.2377 & 0.1111 & 0.6869 & 2.0 \\
\hline Lead & 52 & 0.0020 & $<0.0005$ & 0.0038 & 0.2 \\
\hline Manganese & 51 & 0.0356 & $<0.0025$ & 0.1214 & 1.0 \\
\hline Mercury & 52 & 0.0004 & $<0.0001$ & 0.0051 & 0.5 \\
\hline Nickel & 51 & 0.0401 & $<0.0400$ & 0.0497 & 1.0 \\
\hline Silver & 52 & 0.0011 & $<0.0010$ & 0.0022 & 0.1 \\
\hline Thallium & 52 & - & - & $<0.0015$ & - \\
\hline Vanadium & 51 & - & - & $<0.0550$ & - \\
\hline Zinc & 51 & 0.1664 & 0.0150 & 0.3210 & 1.0 \\
\hline $\mathrm{pH}$ (units) & 45 & - & 7.70 & 8.29 & $6.0-9.0$ \\
\hline
\end{tabular}

daily samples are composited on an equal volume basis to produce a weekly sample that is then analyzed.

\subsubsection{Results}

Fifteen metals were determined by inductively coupled plasma emission spectroscopy, flame atomic absorption spectroscopy, and graphite furnace atomic absorption spectroscopy. Mercury was analyzed using cold vapor atomic absorption spectroscopy, and fluoride was determined by a specific ion electrode. Table 5.11 gives the results for 1995 . None of the annual average results or maximum results exceeded General Effluent Limits. Higher maximum concentrations 


\section{ENVIRONMENTAL NONRADIOLOGICAL PROGRAM INFORMATION}

were noted for iron, manganese, and zinc than in previous years, but within the General Effluent Limits. ${ }^{30}$

\subsection{Sawmill Creek}

Sawmill Creek is a small natural stream that is fed primarily by storm-water runoff. During periods of low precipitation, the creek above ANL-E has a very low flow. At these times, a major portion of the water in Sawmill Creek south of the site consists of ANL-E wastewater and discharges to assorted storm drains. To determine the impact ANL-E wastewaters have on Sawmill Creek, samples of the creek downstream of all ANL-E discharge points were collected and analyzed. The results were then compared to the IEPA General Use Water Quality Standards found in 35 IAC, Subtitle C, Part $302 .{ }^{30}$

\subsubsection{Sample Collection}

A proportional sampler is used to collect a daily sample at a point well downstream of the combined wastewater discharge point where thorough mixing of the ANL-E effluent and Sawmill Creek water is assured. Samples are collected in precleaned, labeled bottles and security seals are used. After $\mathrm{pH}$ measurement, the daily samples are acidified and then combined into equal volume weekly composites and analyzed for the same set of inorganic constituents in Table 5.12.

Fifteen metals were determined by inductively coupled plasma emission spectroscopy, flame atomic absorption spectroscopy, and graphite furnace atomic absorption spectroscopy. Mercury was analyzed using cold vapor atomic absorption spectroscopy. Fluoride was determined by a specific ion electrode. 


\subsubsection{Results}

The results obtained are shown in Table 5.12. As in previous years, the annual average concentration for copper was above the Water Quality Standards (WQS). The maximum concentrations for copper and iron exceeded the WQS. Elevated levels of copper are probably due to leaching of copper from the domestic water distribution system (refer to Section 6.1.1). The cause of elevated iron levels is unknown.

TABLE 5.12

Chemical Constituents in Sawmill Creek: Location 7M, 1995

(Concentrations in $\mathrm{mg} / \mathrm{L}$ )

\begin{tabular}{lccccc}
\hline & & \multicolumn{3}{c}{ Concentrations } \\
Constituent & $\begin{array}{c}\text { No. of } \\
\text { Samples }\end{array}$ & Avg. & Min. & Max. & Limit \\
\cline { 3 - 5 } Arsenic & 51 & 0.0025 & $<0.0025$ & 0.0037 & 1.0 \\
Barium & 50 & 0.0397 & 0.0184 & 0.0664 & 5.0 \\
Beryllium & 51 & - & - & $<0.0001$ & - \\
Cadmium & 51 & 0.0006 & $<0.0001$ & 0.0152 & 0.05 \\
Chromium & 50 & - & - & $<0.0600$ & 1.0 \\
Cobalt & 50 & - & - & $<0.0150$ & - \\
Copper & 51 & 0.0386 & $<0.0100$ & 0.1540 & 0.02 \\
Fluoride & 50 & 0.3248 & 0.1680 & 0.5700 & 1.4 \\
Iron & 50 & 0.4278 & 0.1387 & 1.9140 & 1.0 \\
Lead & 51 & 0.0039 & 0.0008 & 0.0231 & 0.1 \\
Manganese & 50 & 0.0793 & $<0.0150$ & 0.5200 & 1.0 \\
Mercury & 51 & $<0.0001$ & $<0.0001$ & 0.0019 & 0.5 \\
Nickel & 50 & $<0.0400$ & $<0.0400$ & 0.0405 & 1.0 \\
Silver & 51 & $<0.0010$ & $<0.0010$ & 0.0011 & 0.005 \\
Thallium & 51 & - & - & $<0.0015$ & - \\
Vanadium & 50 & - & - & $<0.0550$ & - \\
Zinc & 50 & 0.1420 & $<0.0150$ & 0.6154 & 1.0 \\
pH (Units) & 50 & - & 7.51 & 8.47 & $6.5-9.0$ \\
\hline & & & & & \\
\hline
\end{tabular}

a Location $7 \mathrm{M}$ is $15 \mathrm{~m}(50 \mathrm{ft})$ downstream from the ANL-E wastewater outfall. 


\section{GROUNDWATER PROTECTION}

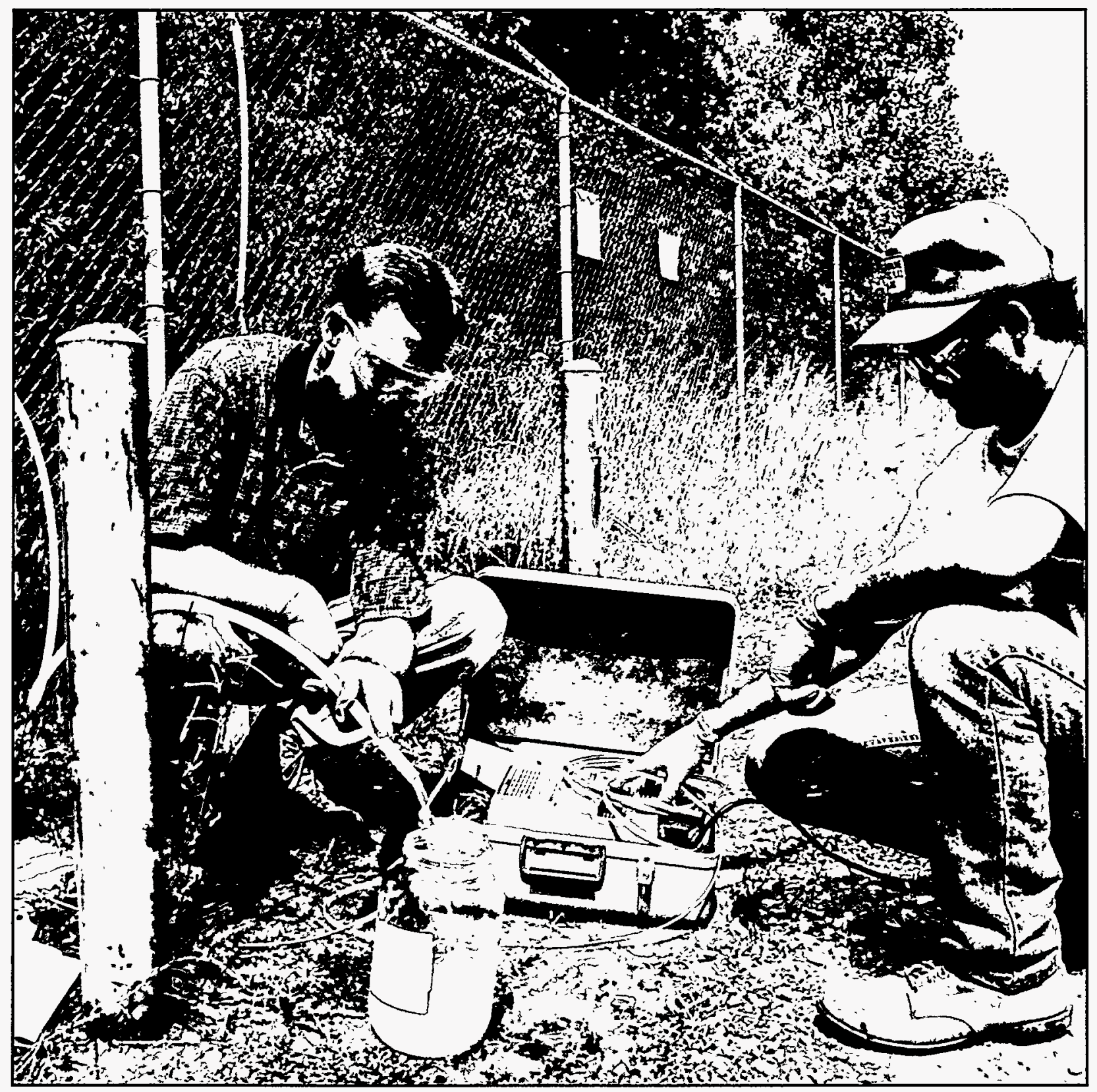




\section{GROUNDWATER PROTECTION}

The groundwater below the ANL-E site is monitored through the collection and analysis of samples obtained from the on-site water supply wells and from a series of groundwater monitoring wells located near several sites that have the potential for causing groundwater impact. Federal and state drinking water regulations are used to evaluate the quality of groundwater used for human consumption at ANL-E. Regulations establishing comprehensive water quality standards for the protection of groundwater have been enacted - IEPA Groundwater Quality Standards, 35 IAC, Subtitle F, Part $620 .^{31}$ In addition, demonstration of compliance with the groundwater protection requirements in DOE Order 5400.1, as related to sitewide characterization studies and monitoring well requirements, is presented in this chapter. The permit for the 800 Area landfill requires a groundwater monitoring program; the program was initiated in July 1992.

\subsection{Potable Water System}

The ANL-E domestic water is supplied by four wells that are described in Section 1.7 and Table 6.1. Their locations are shown in Figure 1.1. According to the National Primary Drinking Water Regulations, ${ }^{23}$ the ANL-E system is classified as a nontransient, noncommunity public water system, since it regularly serves at least 25 of the same persons over six months of the year. This designation determines the parameters to be monitored and the frequency of monitoring. Monitoring of the ANL-E domestic water supply is conducted to demonstrate compliance with applicable regulations and to obtain information on the concentrations of other constituents.

\subsubsection{Regulatory Required Monitoring}

The primary regulations that apply to ANL-E are the Illinois Pollution Control Board Rules, 35 IAC 611. These rules identify the inorganic (Section 611.301), organic (Section 611.311), copper, lead, and water quality parameter (Section 611.356 through 611.359) constituents and monitoring requirements.

All chemical analyses were performed by a commercial laboratory that is certified by the State of Illinois to conduct SDWA analyses. Lead was determined by graphite furnace atomic absorption spectroscopy. Copper was determined by inductively coupled plasma atomic emission 
TABLE 6.1

ANL-E Water Supply Wells

\begin{tabular}{llcccccc}
\hline $\begin{array}{l}\text { Well } \\
\text { No. }\end{array}$ & Location & $\begin{array}{c}\text { Well } \\
\text { Elevation }^{\mathrm{a}}\end{array}$ & $\begin{array}{c}\text { Static Water } \\
\text { Level }\end{array}$ & $\begin{array}{c}\text { Bedrock } \\
\text { Elevation }^{\text {Well }}\end{array}$ & $\begin{array}{c}\text { Well } \\
\text { Depth }^{\mathrm{b}}\end{array}$ & Diameter $^{\mathrm{c}}$ & Year $^{\mathrm{d}}$ \\
\hline & Building 31 & 671 & $\sim 613$ & 605 & 284 & 12 & 1948 \\
1 & Building 32 & 664 & $\sim 612$ & 601 & 300 & 12 & 1948 \\
3 & Building 163 & 689 & $\sim 609$ & 600 & 318 & 12 & 1955 \\
4 & Building 264 & 716 & $\sim 608$ & 595 & 340 & 14 & 1959 \\
\hline
\end{tabular}

a Feet mean sea level.

b Feet below ground.

c Inner diameter (in.).

d Year drilled.

spectroscopy. VOCs were determined by using a purge and trap sample pretreatment followed by gas chromatography-mass spectroscopy detection. Nitrate and fluoride were analyzed using ion chromatography. Samples were collected quarterly from each of the four ANL-E domestic wells and a treated tap water sample in Building 200. The tap water was analyzed for nitrate, metals, VOCs, pesticides, and herbicides. Mercury was determined by cold vapor atomic absorption spectroscopy. Selenium was analyzed by graphite furnace atomic absorption spectroscopy, while barium, cadmium, and chromium were determined by inductively coupled plasma atomic emission spectroscopy. Extraction, followed by gas chromatography-electron capture detection was used to determine 1,2-dibromo-3-chloropropane, ethylene dibromide, hexachlorocyclopentadiene, chlorinated pesticides, and herbicides. Carbamate pesticides were measured by liquid chromatography and fluorescence detection. Alkalinity was measured by titration, calcium by flame atomic absorption spectroscopy, and orthophosphate by a colormetric technique. The samples were analyzed for the constituents specified in the regulations by approved methods that allowed the minimum detectable limit of $0.0005 \mathrm{mg} / \mathrm{L}$ to be met for the organic chemicals. The results were provided to the DuPage County Health Department and the IDPH. 


\section{GROUNDWATER PROTECTION}

On March 17, 1993, the IDPH granted ANL-E a permanent waiver for sampling of asbestos and an extension to November 24, 1995, for the testing of inorganics/metals. On July 22, 1993, ANL-E submitted seven quarters of organic data and petitioned the IDPH for sampling/analysis waivers from the requirements. On August 6, 1993, the IDPH approved a waiver for the 18 Phase II Volatile Organic Compounds to November 24, 1998, a waiver for Synthetic Organic Chemicals/Herbicides-Pesticides to November 24, 1995, and a permanent waiver for all future sampling for unregulated chemicals. Future sampling is only required at a representative tap; however, well head sampling will be continued for informational monitoring of radionuclides and VOCs.

Based on the requirements and direction from the IDPH, the following required analyses were conducted in 1995. Nitrate/nitrite analyses were conducted on tap water samples collected February 28, 1995, and the tap water samples collected on May 18, 1995, were analyzed for inorganic parameters (fluoride, mercury, selenium, barium, cadmium, and chromium). The results are presented in Table 6.2. All concentrations were less than the State of Illinois MCL. The state also required that the one set of pesticide/herbicide compounds listed in 35 IAC $900.65^{32}$ be analyzed. The tap water sample collected May 18, 1995, was analyzed for these compounds, and the results are listed in Table 6.3. All parameters were less than their respective detection limits and the state limits. Quarterly results of three VOCs (dichloromethane, 1,2,4-trichlorobenzene, and 1,1,2-trichloroethane) are part of the 1995 Phase $V$ federally required analysis. These results are presented in Table 6.4. All results were below the detection limits except dichloromethane $(0.0012 \mathrm{mg} / \mathrm{L})$ in the November 20,1995 , tap water sample, but this result was below the MCL of $0.005 \mathrm{mg} / \mathrm{L}$.

Title 35, Part 611.356, of the IAC requires collection of finished water samples for lead and copper analyses at selected sites to determine if the concentrations of more than $10 \%$ of the samples are above the action level of $0.015 \mathrm{mg} / \mathrm{L}$ for lead and $1.3 \mathrm{mg} / \mathrm{L}$ for copper. The required sampling protocols maximize the opportunity for having lead and copper present. Sampling locations are determined after a water piping materials survey. Priority sampling locations are those that have lead pipes, are served by lead service lines, or have copper pipes with lead solder joints. Samples must be drawn from where the water has stood motionless in the 
TABLE 6.2

State of Illinois Required Inorganic Chemicals (900.50), 1995

(Concentrations in $\mathrm{mg} / \mathrm{L}$ )

\begin{tabular}{llcc}
\hline Chemical & Date Collected & State Limit & ANL-E Result \\
\hline Nitrate & February 28 & 10 & 0.59 \\
Nitrite & February 28 & 1 & $<0.02$ \\
Fluoride & May 18 & 4 & 0.31 \\
Mercury & May 18 & 0.002 & $<0.0002$ \\
Barium & May 18 & 5 & $<0.02$ \\
Cadmium & May 18 & 0.005 & $<0.005$ \\
Chromium & May 18 & 0.1 & $<0.01$ \\
Selenium & May 18 & 0.05 & $<0.005$ \\
\hline
\end{tabular}

TABLE 6.3

State of Illinois Required Pesticides/Herbicides (900.65), 1995 (Concentrations in $\mathrm{mg} / \mathrm{L}$ )

\begin{tabular}{lll}
\hline Chemical & State Limit & ANL-E Result \\
\hline Alachlor & 0.002 & $<0.0002$ \\
Aldicarb & 0.01 & $<0.0005$ \\
Aldicarb Sulfone & 0.04 & $<0.0008$ \\
Aldicarb Sulfoxide & 0.01 & $<0.0005$ \\
Atrazine & 0.003 & $<0.0001$ \\
Carbofuran & 0.04 & $<0.0009$ \\
Chlordane & 0.002 & $<0.0002$ \\
Eythylene Dibromide & 0.00005 & $<0.00001$ \\
Heptachlor & 0.0004 & $<0.00004$ \\
Heptachlor Epoxide & 0.0002 & $<0.00002$ \\
Lindane & 0.0002 & $<0.00002$ \\
Methoxychlor & 0.4 & $<0.0001$ \\
Pentachlorophenol & 0.2 & $<0.00004$ \\
Polychlorinated Biphenyl & 0.0005 & $<0.0001$ \\
Toxaphene & 0.005 & $<0.001$ \\
1,2-Dibromochloropropane & 0.0002 & $<0.00002$ \\
2,4-D & 0.07 & $<0.0001$ \\
2,4,5-TP (Silvex) & 0.05 & $<0.00005$ \\
\hline
\end{tabular}


TABLE 6.4

Federally Required Phase V Volatile Organic Results, 1995 (Concentrations in $\mathrm{mg} / \mathrm{L}$ )

\begin{tabular}{lrrrr}
\hline & \multicolumn{4}{c}{ Date Collected } \\
\cline { 2 - 5 } $\begin{array}{l}\text { Phase V } \\
\text { Chemical }\end{array}$ & March 1 & May 18 & August 14 & November 20 \\
\hline & & & & \\
Dichloromethane & $<0.0005$ & $<0.0005$ & $<0.0005$ & 0.0012 \\
1,2,4-Trichlorobenzene & $<0.0005$ & $<0.0005$ & $<0.0005$ & $<0.0005$ \\
1,1,2-Trichloroethane & $<0.0005$ & $<0.0005$ & $<0.0005$ & $<0.0005$ \\
\hline
\end{tabular}

piping for at least six hours. Because of exceedance of the lead and copper action level in 1994, semiannual sampling was required in 1995 at 40 sites.

Samples were collected, following the above protocols, on March 2, 1995, and August 22, 1995 , analyzed by a laboratory certified to conduct SDWA analyses, and the results transmitted to the IDPH through DOE, on June 27, 1995, and December 13, 1995. The results indicated that seven of the 40 copper results exceeded the action level for each sampling period, while the lead results did not exceed the action level. The results are presented in Table 6.5. On the basis of direction received from the IDPH on December 19, 1995, semiannual sampling at 40 sites must be continued during 1996.

\subsubsection{Informational Monitoring}

Samples were collected quarterly at the wellhead. These samples were analyzed for several types of radioactive constituents and VOCs to determine their presence in ANL-E drinking water. Samples from each well were tested for total alpha, total beta, hydrogen-3, and strontium-90. Alpha and beta radioactivity were determined by a gas flow proportional counting technique. Hydrogen-3 was determined by distillation followed by a beta liquid scintillation counting technique. Strontium-90 was determined by ion-exchange separations followed by proportional counting. The results are presented in Table 6.6. Because ANL-E is a nontransient, 
TABLE 6.5

Copper/Lead Samples Collected March 2 and August 22, 1995 (Concentrations in $\mathrm{mg} / \mathrm{L}$ )

\begin{tabular}{|c|c|c|c|c|}
\hline \multirow[b]{2}{*}{ Sample No. } & \multicolumn{2}{|c|}{ March 2} & \multicolumn{2}{|c|}{ August 22} \\
\hline & Copper & Lead & Copper & Lead \\
\hline 1 & 0.05 & $<0.005$ & 0.04 & $<0.005$ \\
\hline 2 & 0.16 & $<0.005$ & 0.12 & $<0.005$ \\
\hline 3 & 0.20 & $<0.005$ & 0.15 & $<0.005$ \\
\hline 4 & 0.27 & $<0.005$ & 0.15 & $<0.005$ \\
\hline 5 & 0.28 & $<0.005$ & 0.28 & $<0.005$ \\
\hline 6 & 0.37 & $<0.005$ & 0.31 & $<0.005$ \\
\hline 7 & 0.44 & $<0.005$ & 0.37 & $<0.005$ \\
\hline 8 & 0.53 & $<0.005$ & 0.39 & $<0.005$ \\
\hline 9 & 0.53 & $<0.005$ & 0.41 & $<0.005$ \\
\hline 10 & 0.57 & $<0.005$ & 0.48 & $<0.005$ \\
\hline 11 & 0.57 & $<0.005$ & 0.53 & $<0.005$ \\
\hline 12 & 0.61 & $<0.005$ & 0.54 & $<0.005$ \\
\hline 13 & 0.62 & $<0.005$ & 0.54 & $<0.005$ \\
\hline 14 & 0.62 & $<0.005$ & 0.55 & $<0.005$ \\
\hline 15 & 0.66 & $<0.005$ & 0.59 & $<0.005$ \\
\hline 16 & 0.75 & $<0.005$ & 0.67 & $<0.005$ \\
\hline 17 & 0.76 & $<0.005$ & 0.67 & $<0.005$ \\
\hline 18 & 0.83 & $<0.005$ & 0.70 & $<0.005$ \\
\hline 19 & 0.84 & $<0.005$ & 0.77 & $<0.005$ \\
\hline 20 & 0.86 & $<0.005$ & 0.77 & $<0.005$ \\
\hline 21 & 0.90 & $<0.005$ & 0.79 & $<0.005$ \\
\hline 22 & 0.92 & $<0.005$ & 0.79 & $<0.005$ \\
\hline 23 & 0.97 & $<0.005$ & 0.81 & $<0.005$ \\
\hline 24 & 1.0 & $<0.005$ & 0.87 & $<0.005$ \\
\hline 25 & 1.0 & $<0.005$ & 0.94 & $<0.005$ \\
\hline 26 & 1.1 & $<0.005$ & 1.0 & $<0.005$ \\
\hline 27 & 1.1 & $<0.005$ & 1.0 & $<0.005$ \\
\hline 28 & 1.2 & $<0.005$ & 1.0 & $<0.005$ \\
\hline 29 & 1.2 & $<0.005$ & 1.1 & $<0.005$ \\
\hline 30 & 1.2 & $<0.005$ & 1.1 & $<0.005$ \\
\hline 31 & 1.2 & $<0.005$ & 1.1 & $<0.005$ \\
\hline 32 & 1.3 & $<0.005$ & 1.2 & $<0.005$ \\
\hline 33 & 1.3 & 0.005 & 1.3 & $<0.005$ \\
\hline 34 & 1.8 & 0.006 & 1.4 & $<0.005$ \\
\hline 35 & 1.8 & 0.006 & 1.4 & $<0.005$ \\
\hline \multirow[t]{2}{*}{36} & 2.0 & 0.007 & 2.0 & $<0.005$ \\
\hline & (90th Percentile) & (90th Percentile) & (90th Percentile) & (90th Percentile) \\
\hline 37 & 2.1 & 0.008 & 2.1 & 0.005 \\
\hline 38 & 2.2 & 0.009 & 2.5 & 0.008 \\
\hline 39 & 2.4 & 0.012 & 2.8 & 0.015 \\
\hline 40 & 2.6 & 0.016 & 2.8 & 0.023 \\
\hline Action Level & 1.3 & 0.015 & 1.3 & 0.015 \\
\hline
\end{tabular}


noncommunity water system, the following EPA limits are established for the nuclides measured in Table 6.6:

$\begin{array}{ll}\text { Gross Alpha Particle Activity } & =15 \mathrm{pCi} / \mathrm{L} \\ \text { Gross Beta Particle Activity } & =50 \mathrm{pCi} / \mathrm{L} \\ \text { Hydrogen-3 } & =2 \times 10^{4} \mathrm{pCi} / \mathrm{L} \\ \text { Strontium-90 } & =8 \mathrm{pCi} / \mathrm{L}\end{array}$

Well 1 was removed from service in 1990, and the system was not operated during 1995; however, samples were collected for monitoring. All the radiological results are in the normal range of concentrations for the various constituents except for strontium-90 in well 1 . The concentration of strontium-90 in well 1 was $3 \%$ of the EPA drinking water standard. Since hydrogen-3 had been identified in well 1 in the past, these constitutes may be indicators of continued migration from the same source.

Although VOCs were not required to demonstrate compliance with the Drinking Water Regulations for 1995, the results are included in the informational monitoring section to determine if any past disposal practices have resulted in groundwater contamination and to support the environmental restoration program. Samples were collected quarterly, and the results are presented in Tables 6.7 through 6.10. Samples were analyzed for the SDWA volatile compounds and quantified by EPA Method 524.2. The limit of detection reported in the tables is the practical quantification limit, which is defined as 10 times the method detection limit.

Trichloroethylene was found in well 1 in the first and fourth quarter samples while dichloromethane was found in all the wells and tap water in the fourth quarter sample. The tap water samples showed five VOCs (dichlorobromomethane, bromoform, chlorodibromomethane, chloroform, and dibromomethane) present. These compounds are known to be associated with chlorination of drinking water, that is, trihalomethanes. 


\section{TABLE 6.6}

Radioactivity in ANL-E Domestic Wells, 1995

(Concentrations in $\mathrm{pCi} / \mathrm{L}$ )

\begin{tabular}{llrrrr}
\hline $\begin{array}{l}\text { Type of } \\
\text { Activity }\end{array}$ & Location & $\begin{array}{c}\text { No. of } \\
\text { Samples }\end{array}$ & Avg. & Min. & Max. \\
\hline \multirow{3}{*}{ Alpha } & Well 1 & 4 & 9.4 & 8.1 & 11.1 \\
(Nonvolatile) & Well 2 & 4 & 4.1 & 3.1 & 6.0 \\
& Well 3 & 4 & 3.3 & 1.8 & 4.7 \\
& Well 4 & 4 & 2.5 & 1.4 & 4.4 \\
& Tap & 4 & 1.0 & 0.7 & 1.5 \\
Beta & Well 1 & 4 & 16.1 & 12.9 & 19.3 \\
(Nonvolatile) & Well 2 & 4 & 9.1 & 8.4 & 10.1 \\
& Well 3 & 4 & 10.2 & 9.2 & 11.3 \\
& Well 4 & 4 & 10.3 & 9.1 & 12.8 \\
& Tap & 4 & 4.7 & 4.3 & 5.2 \\
Hydrogen-3 & Well 1 & 4 & 124 & $<100$ & 176 \\
& Well 2 & 4 & $<100$ & $<100$ & $<100$ \\
& Well 3 & 4 & $<100$ & $<100$ & $<100$ \\
& Well 4 & 4 & $<100$ & $<100$ & $<100$ \\
& Tap & 4 & $<100$ & $<100$ & $<100$ \\
& & & & & $<0.25$ \\
& Well 1 & 4 & $<0.25$ & $<0.25$ & 0.27 \\
& Well 2 & 4 & $<0.25$ & $<0.25$ & $<0.25$ \\
& Well 3 & 4 & $<0.25$ & $<0.25$ & $<0.25$ \\
& Well 4 & 4 & $<0.25$ & $<0.25$ & $<0.25$ \\
& Tap & 4 & $<0.25$ & $<0.25$ & $<0.25$ \\
\hline \multirow{5}{*}{ Strontium-90 } & 4 & & &
\end{tabular}




\section{TABLE 6.7}

Volatile Organic Compounds in Drinking Water Collected February 28, 1995

(Concentrations in $\mathrm{mg} / \mathrm{L}$ )

\begin{tabular}{|c|c|c|c|c|c|}
\hline Parameter & Well 1 & Well 2 & Well 3 & Well 4 & Tap \\
\hline Benzene & $<0.0005$ & $<0.0005$ & $<0.0005$ & $<0.0005$ & $<0.0005$ \\
\hline Vinyl Chloride & $<0.0005$ & $<0.0005$ & $<0.0005$ & $<0.0005$ & $<0.0005$ \\
\hline Carbon Tetrachloride & $<0.0005$ & $<0.0005$ & $<0.0005$ & $<0.0005$ & $<0.0005$ \\
\hline 1,2-Dichloroethane & $<0.0005$ & $<0.0005$ & $<0.0005$ & $<0.0005$ & $<0.0005$ \\
\hline Trichloroethylene & 0.0013 & $<0.0005$ & $<0.0005$ & $<0.0005$ & $<0.0005$ \\
\hline 1,1-Dichloroethylene & $<0.0005$ & $<0.0005$ & $<0.0005$ & $<0.0005$ & $<0.0005$ \\
\hline 1,1,1-Trichloroethylene & $<0.0005$ & $<0.0005$ & $<0.0005$ & $<0.0005$ & $<0.0005$ \\
\hline p-Dichlorobenzene & $<0.0005$ & $<0.0005$ & $<0.0005$ & $<0.0005$ & $<0.0005$ \\
\hline Bromobenzene & $<0.001$ & $<0.001$ & $<0.001$ & $<0.001$ & $<0.001$ \\
\hline Dichlorobromomethane & $<0.0005$ & $<0.0005$ & $<0.0005$ & $<0.0005$ & 0.0119 \\
\hline Bromoform & $<0.0005$ & $<0.0005$ & $<0.0005$ & $<0.0005$ & 0.0012 \\
\hline Bromomethane & $<0.002$ & $<0.002$ & $<0.002$ & $<0.002$ & $<0.002$ \\
\hline Chlorobenzene & $<0.0005$ & $<0.0005$ & $<0.0005$ & $<0.0005$ & $<0.0005$ \\
\hline Chlorodibromomethane & $<0.0005$ & $<0.0005$ & $<0.0005$ & $<0.0005$ & 0.0091 \\
\hline Chloroethane & $<0.002$ & $<0.002$ & $<0.002$ & $<0.002$ & $<0.002$ \\
\hline Chloroform & $<0.0005$ & $<0.0005$ & $<0.0005$ & $<0.0005$ & 0.0095 \\
\hline Chloromethane & $<0.002$ & $<0.002$ & $<0.002$ & $<0.002$ & $<0.002$ \\
\hline o-Chlorotoluene & $<0.001$ & $<0.001$ & $<0.001$ & $<0.001$ & $<0.001$ \\
\hline p-Chlorotoluene & $<0.001$ & $<0.001$ & $<0.001$ & $<0.001$ & $<0.001$ \\
\hline Dibromomethane & $<0.001$ & $<0.001$ & $<0.001$ & $<0.001$ & $<0.001$ \\
\hline m-Dichlorobenzene & $<0.001$ & $<0.001$ & $<0.001$ & $<0.001$ & $<0.001$ \\
\hline o-Dichlorobenzene & $<0.0005$ & $<0.0005$ & $<0.0005$ & $<0.0005$ & $<0.0005$ \\
\hline 1,1-Dichloroethane & $<0.001$ & $<0.001$ & $<0.001$ & $<0.001$ & $<0.001$ \\
\hline cis-1,2-Dichloroethylene & $<0.0005$ & $<0.0005$ & $<0.0005$ & $<0.0005$ & $<0.0005$ \\
\hline trans-1,2-Dichloroethylene & $<0.0005$ & $<0.0005$ & $<0.0005$ & $<0.0005$ & $<0.0005$ \\
\hline Dichloromethane & $<0.0005$ & $<0.0005$ & $<0.0005$ & $<0.0005$ & $<0.0005$ \\
\hline 1,2-Dichloropropane & $<0.0005$ & $<0.0005$ & $<0.0005$ & $<0.0005$ & $<0.0005$ \\
\hline 1,3-Dichloropropane & $<0.001$ & $<0.001$ & $<0.001$ & $<0.001$ & $<0.001$ \\
\hline 2,2-Dichloropropane & $<0.001$ & $<0.001$ & $<0.001$ & $<0.001$ & $<0.001$ \\
\hline 1,1-Dichloropropene & $<0.001$ & $<0.001$ & $<0.001$ & $<0.001$ & $<0.001$ \\
\hline 1,3-Dichloropropene & $<0.001$ & $<0.001$ & $<0.001$ & $<0.001$ & $<0.001$ \\
\hline Ethylbenzene & $<0.0005$ & $<0.0005$ & $<0.0005$ & $<0.0005$ & 0.0008 \\
\hline Styrene & $<0.0005$ & $<0.0005$ & $<0.0005$ & $<0.0005$ & $<0.0005$ \\
\hline 1,1,1,2-Tetrachloroethane & $<0.001$ & $<0.001$ & $<0.001$ & $<0.001$ & $<0.001$ \\
\hline 1,1,2,2-Tetrachloroethane & $<0.001$ & $<0.001$ & $<0.001$ & $<0.001$ & $<0.001$ \\
\hline
\end{tabular}


TABLE 6.7 (Cont.)

\begin{tabular}{|c|c|c|c|c|c|}
\hline Parameter & Well 1 & Well 2 & Well 3 & Well 4 & 'Tap \\
\hline Tetrachloroethylene & $<0.0005$ & $<0.0005$ & $<0.0005$ & $<0.0005$ & $<0.0005$ \\
\hline Toluene & $<0.0005$ & $<0.0005$ & $<0.0005$ & $<0.0005$ & $<0.0005$ \\
\hline 1,1,2-Trichloroethane & $<0.0005$ & $<0.0005$ & $<0.0005$ & $<0.0005$ & $<0.0005$ \\
\hline 1,2,3-Trichloropropane & $<0.001$ & $<0.001$ & $<0.001$ & $<0.001$ & $<0.001$ \\
\hline m\&p-Xylene & $<0.0005$ & $<0.0005$ & $<0.0005$ & $<0.0005$ & 0.0021 \\
\hline o-Xylene & $<0.0005$ & $<0.0005$ & $<0.0005$ & $<0.0005$ & 0.0005 \\
\hline 1,2-Dibromo-3-Chloropropane & $<0.010$ & $<0.010$ & $<0.010$ & $<0.010$ & $<0.010$ \\
\hline Ethylenedibromide (EDB) & $<0.010$ & $<0.010$ & $<0.010$ & $<0.010$ & $<0.010$ \\
\hline Bromochloromethane & $<0.001$ & $<0.001$ & $<0.001$ & $<0.001$ & $<0.001$ \\
\hline n-Butylbenzene & $<0.001$ & $<0.001$ & $<0.001$ & $<0.001$ & $<0.001$ \\
\hline sec-Butylbenzene & $<0.001$ & $<0.001$ & $<0.001$ & $<0.001$ & $<0.001$ \\
\hline tert-Butylbenzene & $<0.001$ & $<0.001$ & $<0.001$ & $<0.001$ & $<0.001$ \\
\hline Dichlorodifluoromethane & $<0.001$ & $<0.001$ & $<0.001$ & $<0.001$ & $<0.001$ \\
\hline Fluorotrichloromethane & $<0.001$ & $<0.001$ & $<0.001$ & $<0.001$ & $<0.001$ \\
\hline Hexachlorobutadiene & $<0.001$ & $<0.001$ & $<0.001$ & $<0.001$ & $<0.001$ \\
\hline Isopropylbenzene & $<0.001$ & $<0.001$ & $<0.001$ & $<0.001$ & $<0.001$ \\
\hline p-Isopropyltoluene & $<0.001$ & $<0.001$ & $<0.001$ & $<0.001$ & $<0.001$ \\
\hline Naphthalene & $<0.001$ & $<0.001$ & $<0.001$ & $<0.001$ & $<0.001$ \\
\hline n-Propylbenzene & $<0.001$ & $<0.001$ & $<0.001$ & $<0.001$ & $<0.001$ \\
\hline 1,2,3-Trichlorobenzene & $<0.001$ & $<0.001$ & $<0.001$ & $<0.001$ & $<0.001$ \\
\hline 1,2,4-Trichlorobenzene & $<0.0005$ & $<0.0005$ & $<0.0005$ & $<0.0005$ & $<0.0005$ \\
\hline 1,2,4-Trimethylbenzene & $<0.001$ & $<0.001$ & $<0.001$ & $<0.001$ & $<0.001$ \\
\hline 1,3,5-Trimethylbenzene & $<0.001$ & $<0.001$ & $<0.001$ & $<0.001$ & $<0.001$ \\
\hline
\end{tabular}




\section{TABLE 6.8}

Volatile Organic Compounds in Drinking Water Collected May 18, 1995

(Concentrations in $\mathrm{mg} / \mathrm{L}$ )

\begin{tabular}{|c|c|c|c|c|c|}
\hline Parameter & Well 1 & Well 2 & Well 3 & Well 4 & Tap \\
\hline Benzene & $<0.0005$ & $<0.0005$ & $<0.0005$ & $<0.0005$ & $<0.0005$ \\
\hline Vinyl Chloride & $<0.0005$ & $<0.0005$ & $<0.0005$ & $<0.0005$ & $<0.0005$ \\
\hline Carbon Tetrachloride & $<0.0005$ & $<0.0005$ & $<0.0005$ & $<0.0005$ & $<0.0005$ \\
\hline 1,2-Dichloroethane & $<0.0005$ & $<0.0005$ & $<0.0005$ & $<0.0005$ & $<0.0005$ \\
\hline Trichloroethylene & $<0.0005$ & $<0.0005$ & $<0.0005$ & $<0.0005$ & $<0.0005$ \\
\hline 1,1-Dichloroethylene & $<0.0005$ & $<0.0005$ & $<0.0005$ & $<0.0005$ & $<0.0005$ \\
\hline $1,1,1$-Trichloroethylene & $<0.0005$ & $<0.0005$ & $<0.0005$ & $<0.0005$ & $<0.0005$ \\
\hline p-Dichlorobenzene & $<0.0005$ & $<0.0005$ & $<0.0005$ & $<0.0005$ & $<0.0005$ \\
\hline Bromobenzene & $<0.001$ & $<0.001$ & $<0.001$ & $<0.001$ & $<0.001$ \\
\hline Dichlorobromomethane & $<0.0005$ & $<0.0005$ & $<0.0005$ & $<0.0005$ & 0.0121 \\
\hline Bromoform & $<0.0005$ & $<0.0005$ & $<0.0005$ & $<0.0005$ & 0.0057 \\
\hline Bromomethane & $<0.002$ & $<0.002$ & $<0.002$ & $<0.002$ & $<0.002$ \\
\hline Chlorobenzene & $<0.0005$ & $<0.0005$ & $<0.0005$ & $<0.0005$ & $<0.0005$ \\
\hline Chlorodibromomethane & $<0.0005$ & $<0.0005$ & $<0.0005$ & $<0.0005$ & 0.0157 \\
\hline Chloroethane & $<0.002$ & $<0.002$ & $<0.002$ & $<0.002$ & $<0.002$ \\
\hline Chloroform & $<0.0005$ & $<0.0005$ & $<0.0005$ & $<0.0005$ & 0.0062 \\
\hline Chloromethane & $<0.002$ & $<0.002$ & $<0.002$ & $<0.002$ & $<0.002$ \\
\hline o-Chlorotoluene & $<0.001$ & $<0.001$ & $<0.001$ & $<0.001$ & $<0.001$ \\
\hline $\mathrm{p}$-Chlorotoluene & $<0.001$ & $<0.001$ & $<0.001$ & $<0.001$ & $<0.001$ \\
\hline Dibromomethane & $<0.001$ & $<0.001$ & $<0.001$ & $<0.001$ & 0.0012 \\
\hline m-Dichlorobenzene & $<0.001$ & $<0.001$ & $<0.001$ & $<0.001$ & $<0.001$ \\
\hline o-Dichlorobenzene & $<0.0005$ & $<0.0005$ & $<0.0005$ & $<0.0005$ & $<0.0005$ \\
\hline 1,1-Dichloroethane & $<0.001$ & $<0.001$ & $<0.001$ & $<0.001$ & $<0.001$ \\
\hline cis-1,2-Dichloroethylene & $<0.0005$ & $<0.0005$ & $<0.0005$ & $<0.0005$ & $<0.0005$ \\
\hline trans-1,2-Dichloroethylene & $<0.0005$ & $<0.0005$ & $<0.0005$ & $<0.0005$ & $<0.0005$ \\
\hline Dichloromethane & $<0.0005$ & $<0.0005$ & $<0.0005$ & $<0.0005$ & $<0.0005$ \\
\hline 1,2-Dichloropropane & $<0.0005$ & $<0.0005$ & $<0.0005$ & $<0.0005$ & $<0.0005$ \\
\hline 1,3-Dichloropropane & $<0.001$ & $<0.001$ & $<0.001$ & $<0.001$ & $<0.001$ \\
\hline 2,2-Dichloropropane & $<0.001$ & $<0.001$ & $<0.001$ & $<0.001$ & $<0.001$ \\
\hline 1,1-Dichloropropene & $<0.001$ & $<0.001$ & $<0.001$ & $<0.001$ & $<0.001$ \\
\hline 1,3-Dichloropropene & $<0.001$ & $<0.001$ & $<0.001$ & $<0.001$ & $<0.001$ \\
\hline Ethylbenzene & $<0.0005$ & $<0.0005$ & $<0.0005$ & $<0.0005$ & 0.0006 \\
\hline Styrene & $<0.0005$ & $<0.0005$ & $<0.0005$ & $<0.0005$ & $<0.0005$ \\
\hline 1,1,1,2-Tetrachloroethane & $<0.001$ & $<0.001$ & $<0.001$ & $<0.001$ & $<0.001$ \\
\hline 1,1,2,2-Tetrachloroethane & $<0.001$ & $<0.001$ & $<0.001$ & $<0.001$ & $<0.001$ \\
\hline
\end{tabular}


TABLE 6.8 (Cont.)

\begin{tabular}{|c|c|c|c|c|c|}
\hline Parameter & Well 1 & Weill 2 & Well 3 & Well 4 & Tap \\
\hline Tetrachloroethylene & $<0.0005$ & $<0.0005$ & $<0.0005$ & $<0.0005$ & $<0.0005$ \\
\hline Toluene & $<0.0005$ & $<0.0005$ & $<0.0005$ & $<0.0005$ & $<0.0005$ \\
\hline 1,1,2-Trichloroethane & $<0.0005$ & $<0.0005$ & $<0.0005$ & $<0.0005$ & $<0.0005$ \\
\hline 1,2,3-Trichloropropane & $<0.001$ & $<0.001$ & $<0.001$ & $<0.001$ & $<0.001$ \\
\hline m\&p-Xylene & $<0.0005$ & $<0.0005$ & $<0.0005$ & $<0.0005$ & 0.0025 \\
\hline o-Xylene & $<0.0005$ & $<0.0005$ & $<0.0005$ & $<0.0005$ & 0.0006 \\
\hline 1,2-Dibromo-3-Chloropropane & $<0.010$ & $<0.010$ & $<0.010$ & $<0.010$ & $<0.010$ \\
\hline Ethylenedibromide (EDB) & $<0.010$ & $<0.010$ & $<0.010$ & $<0.010$ & $<0.010$ \\
\hline Bromochloromethane & $<0.001$ & $<0.001$ & $<0.001$ & $<0.001$ & $<0.001$ \\
\hline n-Butylbenzene & $<0.001$ & $<0.001$ & $<0.001$ & $<0.001$ & $<0.001$ \\
\hline sec-Butylbenzene & $<0.001$ & $<0.001$ & $<0.001$ & $<0.001$ & $<0.001$ \\
\hline tert-Butylbenzene & $<0.001$ & $<0.001$ & $<0.001$ & $<0.001$ & $<0.001$ \\
\hline Dichlorodifluoromethane & $<0.001$ & $<0.001$ & $<0.001$ & $<0.001$ & $<0.001$ \\
\hline Fluorotrichloromethane & $<0.001$ & $<0.001$ & $<0.001$ & $<0.001$ & $<0.001$ \\
\hline Hexachlorobutadiene & $<0.001$ & $<0.001$ & $<0.001$ & $<0.001$ & $<0.001$ \\
\hline Isopropylbenzene & $<0.001$ & $<0.001$ & $<0.001$ & $<0.001$ & $<0.001$ \\
\hline p-Isopropyltoluene & $<0.001$ & $<0.001$ & $<0.001$ & $<0.001$ & $<0.001$ \\
\hline Naphthalene & $<0.001$ & $<0.001$ & $<0.001$ & $<0.001$ & $<0.001$ \\
\hline n-Propylbenzene & $<0.001$ & $<0.001$ & $<0.001$ & $<0.001$ & $<0.001$ \\
\hline 1,2,3-Trichlorobenzene & $<0.001$ & $<0.001$ & $<0.001$ & $<0.001$ & $<0.001$ \\
\hline 1,2,4-Trichlorobenzene & $<0.0005$ & $<0.0005$ & $<0.0005$ & $<0.0005$ & $<0.0005$ \\
\hline 1,2,4-Trimethylbenzene & $<0.001$ & $<0.001$ & $<0.001$ & $<0.001$ & $<0.001$ \\
\hline 1,3,5-Trimethylbenzene & $<0.001$ & $<0.001$ & $<0.001$ & $<0.001$ & $<0.001$ \\
\hline
\end{tabular}




\section{TABLE 6.9}

Volatile Organic Compounds in Drinking Water Collected August 14, 1995 (Concentrations in $\mathrm{mg} / \mathrm{L}$ )

\begin{tabular}{|c|c|c|c|c|c|}
\hline Parameter & Well 1 & Well 2 & Well 3 & Well 4 & Tap \\
\hline Benzene & $<0.0005$ & $<0.0005$ & $<0.0005$ & $<0.0005$ & $<0.0005$ \\
\hline Vinyl Chloride & $<0.0005$ & $<0.0005$ & $<0.0005$ & $<0.0005$ & $<0.0005$ \\
\hline Carbon Tetrachloride & $<0.0005$ & $<0.0005$ & $<0.0005$ & $<0.0005$ & $<0.0005$ \\
\hline 1,2-Dichloroethane & $<0.0005$ & $<0.0005$ & $<0.0005$ & $<0.0005$ & $<0.0005$ \\
\hline Trichloroethylene & $<0.0005$ & $<0.0005$ & $<0.0005$ & $<0.0005$ & $<0.0005$ \\
\hline 1,1-Dichloroethylene & $<0.0005$ & $<0.0005$ & $<0.0005$ & $<0.0005$ & $<0.0005$ \\
\hline 1,1,1-Trichloroethylene & $<0.0005$ & $<0.0005$ & $<0.0005$ & $<0.0005$ & $<0.0005$ \\
\hline p-Dichlorobenzene & $<0.0005$ & $<0.0005$ & $<0.0005$ & $<0.0005$ & $<0.0005$ \\
\hline Bromobenzene & $<0.001$ & $<0.001$ & $<0.001$ & $<0.001$ & $<0.001$ \\
\hline Dichlorobromomethane & $<0.0005$ & $<0.0005$ & $<0.0005$ & $<0.0005$ & 0.0108 \\
\hline Bromoform & $<0.0005$ & $<0.0005$ & $<0.0005$ & $<0.0005$ & 0.0044 \\
\hline Bromomethane & $<0.002$ & $<0.002$ & $<0.002$ & $<0.002$ & $<0.002$ \\
\hline Chlorobenzene & $<0.0005$ & $<0.0005$ & $<0.0005$ & $<0.0005$ & $<0.0005$ \\
\hline Chlorodibromomethane & $<0.0005$ & $<0.0005$ & $<0.0005$ & $<0.0005$ & 0.0145 \\
\hline Chloroethane & $<0.002$ & $<0.002$ & $<0.002$ & $<0.002$ & $<0.002$ \\
\hline Chloroform & $<0.0005$ & $<0.0005$ & $<0.0005$ & $<0.0005$ & 0.0053 \\
\hline Chloromethane & $<0.002$ & $<0.002$ & $<0.002$ & $<0.002$ & $<0.002$ \\
\hline o-Chlorotoluene & $<0.001$ & $<0.001$ & $<0.001$ & $<0.001$ & $<0.001$ \\
\hline p-Chlorotoluene & $<0.001$ & $<0.001$ & $<0.001$ & $<0.001$ & $<0.001$ \\
\hline Dibromomethane & $<0.001$ & $<0.001$ & $<0.001$ & $<0.001$ & $<0.001$ \\
\hline m-Dichlorobenzene & $<0.001$ & $<0.001$ & $<0.001$ & $<0.001$ & $<0.001$ \\
\hline o-Dichlorobenzene & $<0.0005$ & $<0.0005$ & $<0.0005$ & $<0.0005$ & $<0.0005$ \\
\hline 1,1-Dichloroethane & $<0.001$ & $<0.001$ & $<0.001$ & $<0.001$ & $<0.001$ \\
\hline cis-1,2-Dichloroethylene & $<0.0005$ & $<0.0005$ & $<0.0005$ & $<0.0005$ & $<0.0005$ \\
\hline trans-1,2-Dichloroethylene & $<0.0005$ & $<0.0005$ & $<0.0005$ & $<0.0005$ & $<0.0005$ \\
\hline Dichloromethane & $<0.0005$ & $<0.0005$ & $<0.0005$ & $<0.0005$ & $<0.0005$ \\
\hline 1,2-Dichloropropane & $<0.0005$ & $<0.0005$ & $<0.0005$ & $<0.0005$ & $<0.0005$ \\
\hline 1,3-Dichloropropane & $<0.001$ & $<0.001$ & $<0.001$ & $<0.001$ & $<0.001$ \\
\hline 2,2-Dichloropropane & $<0.001$ & $<0.001$ & $<0.001$ & $<0.001$ & $<0.001$ \\
\hline 1,1-Dichloropropene & $<0.001$ & $<0.001$ & $<0.001$ & $<0.001$ & $<0.001$ \\
\hline 1,3-Dichloropropene & $<0.001$ & $<0.001$ & $<0.001$ & $<0.001$ & $<0.001$ \\
\hline Ethylbenzene & $<0.0005$ & $<0.0005$ & $<0.0005$ & $<0.0005$ & 0.0005 \\
\hline Styrene & $<0.0005$ & $<0.0005$ & $<0.0005$ & $<0.0005$ & $<0.0005$ \\
\hline $1,1,1,2$-Tetrachloroethane & $<0.001$ & $<0.001$ & $<0.001$ & $<0.001$ & $<0.001$ \\
\hline 1,1,2,2-Tetrachloroethane & $<0.001$ & $<0.001$ & $<0.001$ & $<0.001$ & $<0.001$ \\
\hline
\end{tabular}


TABLE 6.9 (Cont.)

\begin{tabular}{|c|c|c|c|c|c|}
\hline Parameter & Well 1 & Well 2 & Well 3 & Well 4 & Tap \\
\hline Tetrachloroethylene & $<0.0005$ & $<0.0005$ & $<0.0005$ & $<0.0005$ & $<0.0005$ \\
\hline Toluene & $<0.0005$ & $<0.0005$ & $<0.0005$ & $<0.0005$ & $<0.0005$ \\
\hline 1,1,2-Trichloroethane & $<0.0005$ & $<0.0005$ & $<0.0005$ & $<0.0005$ & $<0.0005$ \\
\hline 1,2,3-Trichloropropane & $<0.001$ & $<0.001$ & $<0.001$ & $<0.001$ & $<0.001$ \\
\hline m\&p-Xylene & $<0.0005$ & $<0.0005$ & $<0.0005$ & $<0.0005$ & 0.0022 \\
\hline o-Xylene & $<0.0005$ & $<0.0005$ & $<0.0005$ & $<0.0005$ & 0.0006 \\
\hline 1,2-Dibromo-3-Chloropropane & $<0.010$ & $<0.010$ & $<0.010$ & $<0.010$ & $<0.010$ \\
\hline Ethylenedibromide (EDB) & $<0.010$ & $<0.010$ & $<0.010$ & $<0.010$ & $<0.010$ \\
\hline Bromochloromethane & $<0.001$ & $<0.001$ & $<0.001$ & $<0.001$ & $<0.001$ \\
\hline n-Butylbenzene & $<0.001$ & $<0.001$ & $<0.001$ & $<0.001$ & $<0.001$ \\
\hline sec-Butylbenzene & $<0.001$ & $<0.001$ & $<0.001$ & $<0.001$ & $<0.001$ \\
\hline tert-Butylbenzene & $<0.001$ & $<0.001$ & $<0.001$ & $<0.001$ & $<0.001$ \\
\hline Dichlorodifluoromethane & $<0.001$ & $<0.001$ & $<0.001$ & $<0.001$ & $<0.001$ \\
\hline Fluorotrichloromethane & $<0.001$ & $<0.001$ & $<0.001$ & $<0.001$ & $<0.001$ \\
\hline Hexachlorobutadiene & $<0.001$ & $<0.001$ & $<0.001$ & $<0.001$ & $<0.001$ \\
\hline Isopropylbenzene & $<0.001$ & $<0.001$ & $<0.001$ & $<0.001$ & $<0.001$ \\
\hline p-Isopropyltoluene & $<0.001$ & $<0.001$ & $<0.001$ & $<0.001$ & $<0.001$ \\
\hline Naphthalene & $<0.001$ & $<0.001$ & $<0.001$ & $<0.001$ & $<0.001$ \\
\hline n-Propylbenzene & $<0.001$ & $<0.001$ & $<0.001$ & $<0.001$ & $<0.001$ \\
\hline 1,2,3-Trichlorobenzene & $<0.001$ & $<0.001$ & $<0.001$ & $<0.001$ & $<0.001$ \\
\hline 1,2,4-Trichlorobenzene & $<0.0005$ & $<0.0005$ & $<0.0005$ & $<0.0005$ & $<0.0005$ \\
\hline 1,2,4-Trimethylbenzene & $<0.001$ & $<0.001$ & $<0.001$ & $<0.001$ & $<0.001$ \\
\hline 1,3,5-Trimethylbenzene & $<0.001$ & $<0.001$ & $<0.001$ & $<0.001$ & $<0.001$ \\
\hline
\end{tabular}




\section{TABLE 6.10}

Volatile Organic Compounds in Drinking Water Collected November 20, 1995

(Concentrations in $\mathrm{mg} / \mathrm{L}$ )

\begin{tabular}{|c|c|c|c|c|c|}
\hline Parameter & Well 1 & Well 2 & Well 3 & Well 4 & Tap \\
\hline Benzene & $<0.0005$ & $<0.0005$ & $<0.0005$ & $<0.0005$ & $<0.0005$ \\
\hline Vinyl Chloride & $<0.0005$ &.$<0.0005$ & $<0.0005$ & $<0.0005$ & $<0.0005$ \\
\hline Carbon Tetrachloride & $<0.0005$ & $<0.0005$ & $<0.0005$ & $<0.0005$ & $<0.0005$ \\
\hline 1,2-Dichloroethane & $<0.0005$ & $<0.0005$ & $<0.0005$ & $<0.0005$ & $<0.0005$ \\
\hline Trichloroethylene & 0.0007 & $<0.0005$ & $<0.0005$ & $<0.0005$ & $<0.0005$ \\
\hline 1,1-Dichloroethylene & $<0.0005$ & $<0.0005$ & $<0.0005$ & $<0.0005$ & $<0.0005$ \\
\hline $1,1,1$-Trichloroethylene & $<0.0005$ & $<0.0005$ & $<0.0005$ & $<0.0005$ & $<0.0005$ \\
\hline p-Dichlorobenzene & $<0.0005$ & $<0.0005$ & $<0.0005$ & $<0.0005$ & $<0.0005$ \\
\hline Bromobenzene & $<0.001$ & $<0.001$ & $<0.001$ & $<0.001$ & $<0.001$ \\
\hline Dichlorobromomethane & $<0.0005$ & $<0.0005$ & $<0.0005$ & $<0.0005$ & 0.0053 \\
\hline Bromoform & $<0.0005$ & $<0.0005$ & $<0.0005$ & $<0.0005$ & 0.0062 \\
\hline Bromomethane & $<0.002$ & $<0.002$ & $<0.002$ & $<0.002$ & $<0.002$ \\
\hline Chlorobenzene & $<0.0005$ & $<0.0005$ & $<0.0005$ & $<0.0005$ & $<0.0005$ \\
\hline Chlorodibromomethane & $<0.0005$ & $<0.0005$ & $<0.0005$ & $<0.0005$ & 0.0110 \\
\hline Chloroethane & $<0.002$ & $<0.002$ & $<0.002$ & $<0.002$ & $<0.002$ \\
\hline Chloroform & $<0.0005$ & $<0.0005$ & $<0.0005$ & $<0.0005$ & 0.0016 \\
\hline Chloromethane & $<0.002$ & $<0.002$ & $<0.002$ & $<0.002$ & $<0.002$ \\
\hline o-Chlorotoluene & $<0.001$ & $<0.001$ & $<0.001$ & $<0.001$ & $<0.001$ \\
\hline p-Chlorotoluene & $<0.001$ & $<0.001$ & $<0.001$ & $<0.001$ & $<0.001$ \\
\hline Dibromomethane & $<0.001$ & $<0.001$ & $<0.001$ & $<0.001$ & $<0.001$ \\
\hline m-Dichlorobenzene & $<0.001$ & $<0.001$ & $<0.001$ & $<0.001$ & $<0.001$ \\
\hline o-Dichlorobenzene & $<0.0005$ & $<0.0005$ & $<0.0005$ & $<0.0005$ & $<0.0005$ \\
\hline 1,1-Dichloroethane & $<0.001$ & $<0.001$ & $<0.001$ & $<0.001$ & $<0.001$ \\
\hline cis-1,2-Dichloroethylene & $<0.0005$ & $<0.0005$ & $<0.0005$ & $<0.0005$ & $<0.0005$ \\
\hline trans-1,2-Dichloroethylene & $<0.0005$ & $<0.0005$ & $<0.0005$ & $<0.0005$ & $<0.0005$ \\
\hline Dichloromethane & 0.0027 & 0.0014 & 0.0018 & 0.0010 & 0.0012 \\
\hline 1,2-Dichloropropane & $<0.0005$ & $<0.0005$ & $<0.0005$ & $<0.0005$ & $<0.0005$ \\
\hline 1,3-Dichloropropane & $<0.001$ & $<0.001$ & $<0.001$ & $<0.001$ & $<0.001$ \\
\hline 2,2-Dichloropropane & $<0.001$ & $<0.001$ & $<0.001$ & $<0.001$ & $<0.001$ \\
\hline 1,1-Dichloropropene & $<0.001$ & $<0.001$ & $<0.001$ & $<0.001$ & $<0.001$ \\
\hline 1,3-Dichloropropene & $<0.001$ & $<0.001$ & $<0.001$ & $<0.001$ & $<0.001$ \\
\hline Ethylbenzene & $<0.0005$ & $<0.0005$ & $<0.0005$ & $<0.0005$ & $<0.0005$ \\
\hline Styrene & $<0.0005$ & $<0.0005$ & $<0.0005$ & $<0.0005$ & $<0.0005$ \\
\hline 1,1,1,2-Tetrachloroethane & $<0.001$ & $<0.001$ & $<0.001$ & $<0.001$ & $<0.001$ \\
\hline
\end{tabular}


TABLE 6.10 (Cont.)

\begin{tabular}{|c|c|c|c|c|c|}
\hline Parameter & Well 1 & Well 2 & Well 3 & Well 4 & Tap \\
\hline 1,1,2,2-Tetrachloroethane & $<0.001$ & $<0.001$ & $<0.001$ & $<0.001$ & $<0.001$ \\
\hline Tetrachloroethylene & $<0.0005$ & $<0.0005$ & $<0.0005$ & $<0.0005$ & $<0.0005$ \\
\hline Toluene & $<0.0005$ & $<0.0005$ & $<0.0005$ & $<0.0005$ & $<0.0005$ \\
\hline 1,1,2-Trichloroethane & $<0.0005$ & $<0.0005$ & $<0.0005$ & $<0.0005$ & $<0.0005$ \\
\hline 1,2,3-Trichloropropane & $<0.001$ & $<0.001$ & $<0.001$ & $<0.001$ & $<0.001$ \\
\hline m\&p-Xylene & $<0.0005$ & $<0.0005$ & $<0.0005$ & $<0.0005$ & 0.0006 \\
\hline o-Xylene & $<0.0005$ & $<0.0005$ & $<0.0005$ & $<0.0005$ & $<0.0005$ \\
\hline 1,2-Dibromo-3-Chloropropane & $<0.010$ & $<0.010$ & $<0.010$ & $<0.010$ & $<0.010$ \\
\hline Ethylenedibromide (EDB) & $<0.010$ & $<0.010$ & $<0.010$ & $<0.010$ & $<0.010$ \\
\hline Bromochloromethane & $<0.001$ & $<0.001$ & $<0.001$ & $<0.001$ & $<0.001$ \\
\hline n-Butylbenzene & $<0.001$ & $<0.001$ & $<0.001$ & $<0.001$ & $<0.001$ \\
\hline sec-Butylbenzene & $<0.001$ & $<0.001$ & $<0.001$ & $<0.001$ & $<0.001$ \\
\hline tert-Butylbenzene & $<0.001$ & $<0.001$ & $<0.001$ & $<0.001$ & $<0.001$ \\
\hline Dichlorodifluoromethane & $<0.001$ & $<0.001$ & $<0.001$ & $<0.001$ & $<0.001$ \\
\hline Fluorotrichloromethane & $<0.001$ & $<0.001$ & $<0.001$ & $<0.001$ & $<0.001$ \\
\hline Hexachlorobutadiene & $<0.001$ & $<0.001$ & $<0.001$ & $<0.001$ & $<0.001$ \\
\hline Isopropylbenzene & $<0.001$ & $<0.001$ & $<0.001$ & $<0.001$ & $<0.001$ \\
\hline p-Isopropyltoluene & $<0.001$ & $<0.001$ & $<0.001$ & $<0.001$ & $<0.001$ \\
\hline Naphthalene & $<0.001$ & $<0.001$ & $<0.001$ & $<0.001$ & $<0.001$ \\
\hline n-Propylbenzene & $<0.001$ & $<0.001$ & $<0.001$ & $<0.001$ & $<0.001$ \\
\hline 1,2,3-Trichlorobenzene & $<0.001$ & $<0.001$ & $<0.001$ & $<0.001$ & $<0.001$ \\
\hline 1,2,4-Trichlorobenzene & $<0.0005$ & $<0.0005$ & $<0.0005$ & $<0.0005$ & $<0.0005$ \\
\hline 1,2,4-Trimethylbenzene & $<0.001$ & $<0.001$ & $<0.001$ & $<0.001$ & $<0.001$ \\
\hline 1,3,5-Trimethylbenzene & $<0.001$ & $<0.001$ & $<0.001$ & $<0.001$ & $<0.001$ \\
\hline
\end{tabular}




\subsection{Groundwater Monitoring at Waste Management Sites}

ANL-E has occupied its current site since 1948. Since that time, waste generated by ANL-E was placed in a number of on-site disposal units ranging from ditches filled with construction and demolition debris during the 1950s to a modern sanitary landfill used for nonhazardous solid waste disposal until September 1992. Several of these units contain significant amounts of hazardous materials and, therefore, represent a potential threat to the environment. Groundwater below these sites is monitored routinely to assess the amount and nature of hazardous chemical releases from these units. The sites that are routinely monitored are the sanitary landfill in the 800 Area and the 317/319 Area, which consists of eight separate waste management units located within a small geographical area. The site of an inactive experimental reactor, CP-5, is also monitored periodically to determine if any releases of radionuclides occurred from this unit.

\subsubsection{7/319 Area}

Management of waste has been conducted in eight separate units within the 317 and 319 areas. The 317 Area is currently used as a temporary storage area for radioactive waste before it is shipped off site for disposal. The area also contained two RCRA-permitted units that were formally closed during 1994 and one permitted area that is still active. The 319 Area is an inactive landfill adjacent to the 317 Area. In addition to these units, a second landfill site, the East-Northeast (ENE) landfill, is located to the east-northeast of the 319 Area. This unit was used in the late 1940s and early 1950s primarily for the disposal of construction debris from several sites, including the University of Chicago's Manhattan Project. Figure 6.1 is a sketch of the 317/319 Area.

The most significant units in this area in terms of groundwater impact are an inactive French drain (dry well) in the 317 area and the landfill and French drain in the 319 Area. The 317 Area French drain operated until the mid 1950s and was used for disposal of unknown amounts of liquid chemical wastes. The landfill at 319 was operated from the mid-1950s until 1968. The French drain, similar to the one in the 317 Area, was operated until 1968. Quantities of a wide 


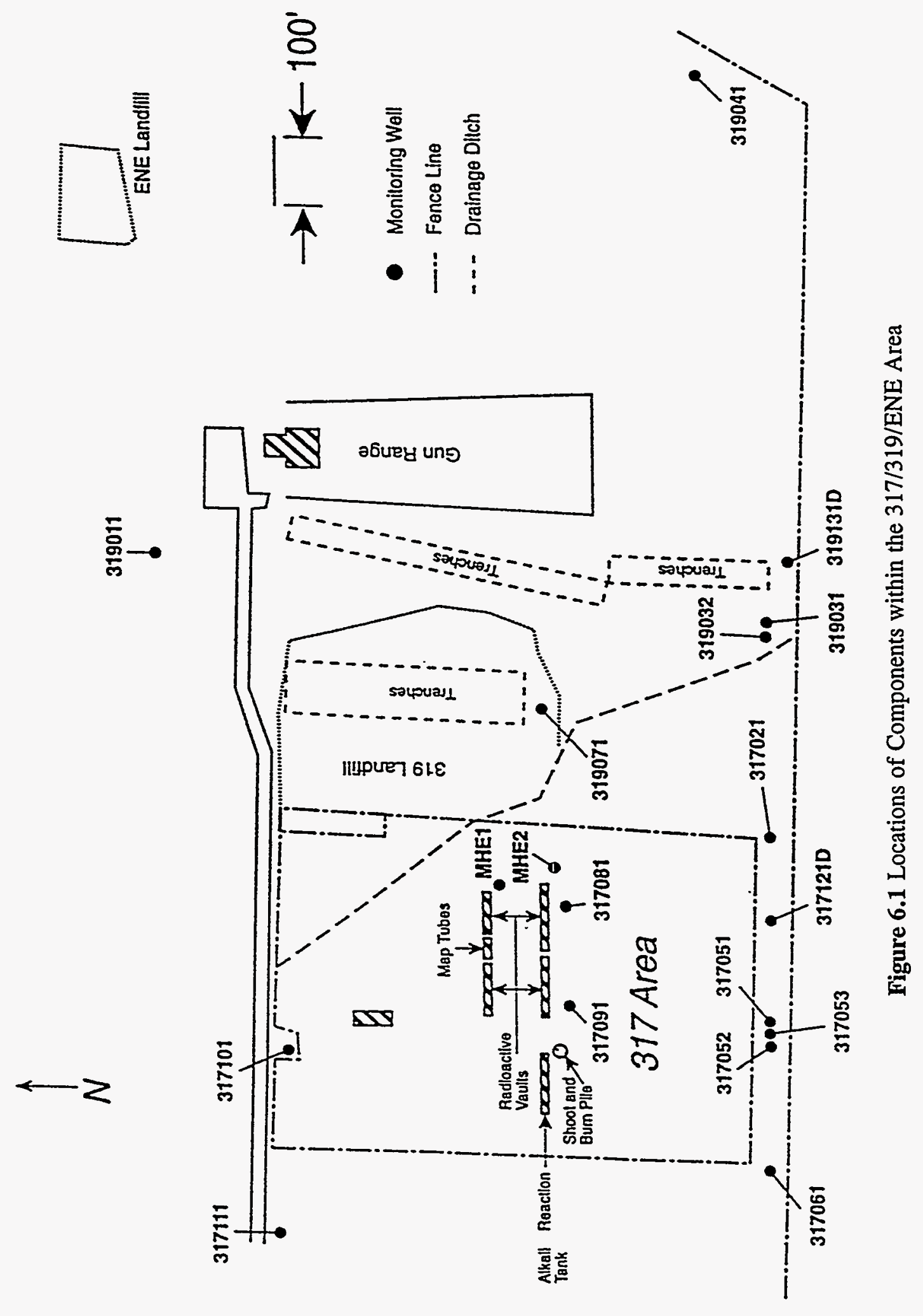


variety of liquid wastes, including heavy metals, solvents, and waste oil, some containing PCBs, were poured into this drain.

The 317 Area contained six vaults used for temporary storage of solid radioactive waste. Water from footing drains and/or sumps was collected and discharged into a sewer system. This sewer system, which was designed to drain off site, was permanently closed in 1986 after it was discovered that the water contained very small amounts of several radionuclides. Water collecting in the sewer system was periodically pumped out from manholes into portable tanks, transported to the Waste Management Building, and analyzed for radioactivity before release to the laboratory wastewater collection system. During August 1993, the discharge of water from these manholes to the laboratory sewer system began. Monthly samples from two manholes associated with this system were analyzed for VOCS. The results are presented in Section 6.2.2.3. During 1995, decontamination and demolition of three unused concrete waste storage vaults was begun (see Section 6.5.1).

The 319 Area currently consists of a mound created by waste fill activities. The waste consisted of noncombustible refuse and demolition and construction debris. In addition, suspect waste (material that was not known to be contaminated but that had the potential for hidden radioactive contamination that could not be confirmed by direct measurement, such as the inside of long pipes or ductwork, was also placed in this unit. The landfill consisted of a number of trenches, 3 to $5 \mathrm{~m}$ (10 to $15 \mathrm{ft}$ ) deep, which were filled with waste material. When the trenches were filled with waste, they were covered with soil. A recent geophysical survey has identified at least three of these trenches. Recently, five test pits were dug into the waste; the waste was inspected, photographed, and surveyed for the presence of radioactive or VOC contamination; then placed back into the excavation. Field measurements of radioactivity levels and organic vapor concentrations indicated that this material is not significantly contaminated.

The French drain in the 319 Area was constructed in the late 1950s in an area of the fill material by placing a corrugated steel pipe vertically into a gravel-filled excavation and backfilling around the pipe. Waste liquids were poured into the pit and flowed into the pipe. 


\section{GROUNDWATER PROTECTION}

The ENE landfill is believed to consist primarily of construction debris and other noncombustible rubbish such as metal turnings and empty steel drums. The waste was placed in a natural ravine and covered with soil.

\subsubsection{Groundwater Monitoring at the $317 / 319$ Area}

Eleven active monitoring wells (some of which are clustered or nested) are installed at the locations shown in Figure 6.2. Well data are listed in Table 6.11. The wide range in water level elevations shown in Table 6.11 is not unusual and is due to the fact that some of the wells are screened at different depths in different saturated zones. This variation in water level also may be indicative of "perched" (i.e., discontinuous) groundwater conditions within the glacial till. Samples are collected quarterly following EPA sampling protocols listed in the RCRA GroundWater Monitoring Technical Enforcement Guidance Document (September 1986). ${ }^{33}$

Groundwater monitoring in the 317/319 Area has been conducted since 1986 . Wells 319011, 317021, and 319031, were installed in September 1986; 317061 in August 1987; 317091 in July 1988; 317101 and 317111 in September 1988; and wells 319032 and 317052 were installed in June 1989. These wells were all completed in the glacial till. In addition, wells 317121D and 319131D were installed in November 1989 and reach the dolomite aquifer at about $25 \mathrm{~m}$ ( $80 \mathrm{ft}$ ) below the surface. Well 319071, which was dry, was sealed in September 1995 in accordance with state and county well code regulations. Well 317081 was damaged and removed during 1995.

Wells 317101 and 317111 are upgradient of the 317 storage area, and well 319011 is upgradient of the 319 landfill area. A sand lens present at 5 to $8 \mathrm{~m}$ (15 to $25 \mathrm{ft}$ ) was recently discovered and wells 317052 and 319032 were placed at this depth. This layer is also intercepted by wells 317091 and 317101 .

In addition to wells in this area, two manholes associated with the vault sewer system were monitored on a monthly basis. The location of the manholes is shown in Figure 6.1. 


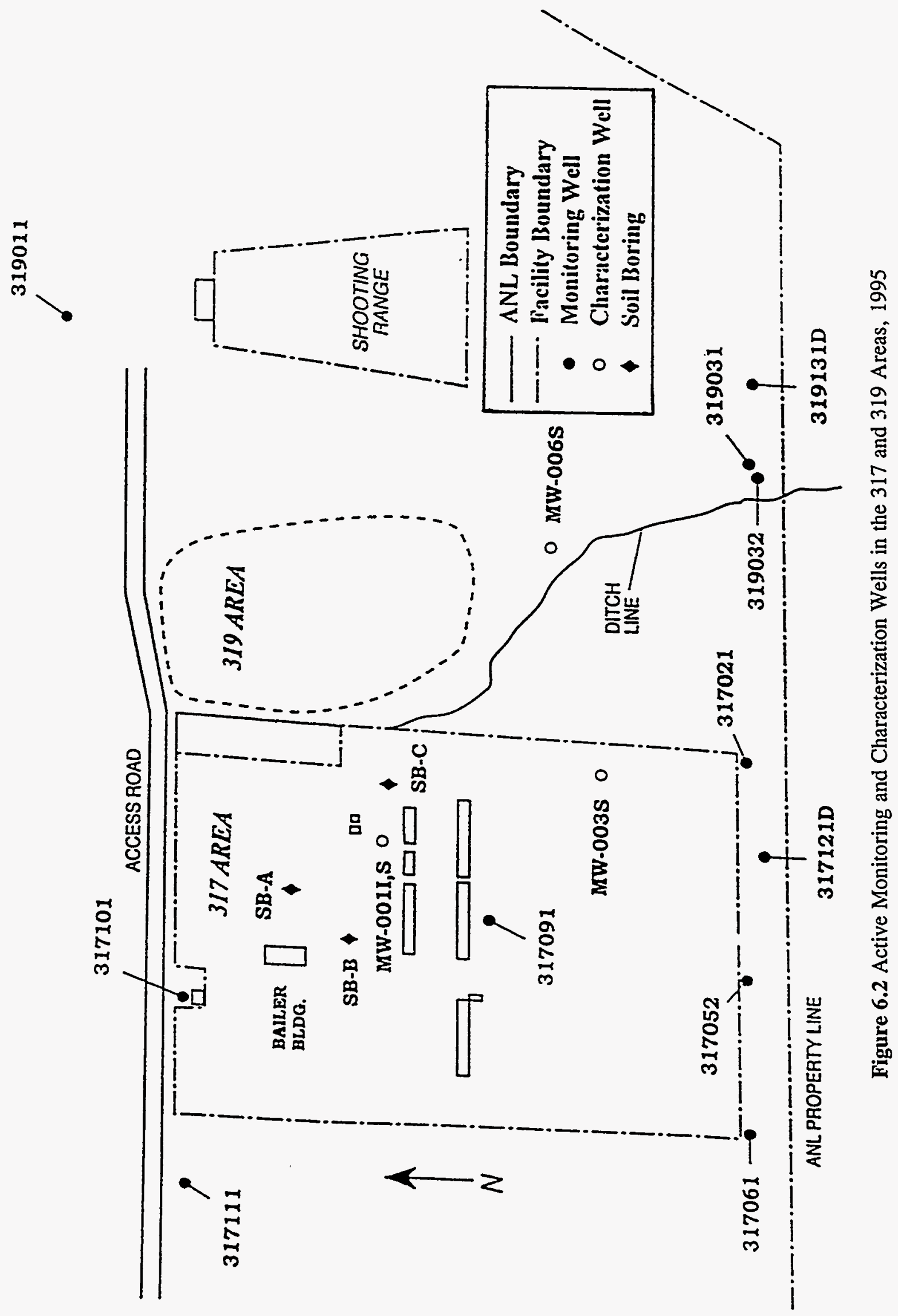


TABLE 6.11

Groundwater Monitoring Wells: 317/319 Area

\begin{tabular}{lcccccc}
\hline $\begin{array}{l}\text { ID } \\
\text { Number }\end{array}$ & $\begin{array}{c}\text { Well } \\
\text { Depth }^{\mathrm{a}}\end{array}$ & $\begin{array}{c}\text { Ground } \\
\text { Elevation }^{\mathrm{b}}\end{array}$ & $\begin{array}{c}\text { Monitoring } \\
\text { Zone }^{\mathrm{c}}\end{array}$ & $\begin{array}{c}\text { Well } \\
\text { Type }^{\mathrm{d}}\end{array}$ & $\begin{array}{c}\text { Date } \\
\text { Drilled }\end{array}$ & $\begin{array}{c}\text { Water } \\
\text { Elevation }^{-}\end{array}$ \\
\hline 319011 & 40 & 688.3 & $35-40 / 653-648$ & $2 / \mathrm{PVC}$ & $9 / 86$ & 655.8 \\
317021 & 40 & 686.2 & $35-40 / 651-646$ & $2 / \mathrm{PVC}$ & $9 / 86$ & 664.2 \\
319031 & 41 & 670.2 & $36-41 / 634-629$ & $2 / \mathrm{PVC}$ & $9 / 86$ & 633.0 \\
319032 & 25 & 670.2 & $20-25 / 650-645$ & $2 / \mathrm{PVC}$ & $8 / 89$ & 650.5 \\
317051 & 20 & 683.4 & $15-20 / 668-663$ & $2 / \mathrm{PVC}$ & $7 / 87$ & Not Measured \\
317053 & 22 & 683.4 & $17-22 / 666-661$ & $2 / \mathrm{PVC}$ & $8 / 89$ & Dry \\
317052 & 14 & 683.4 & $9-14 / 674-669$ & $2 / \mathrm{PVC}$ & $8 / 89$ & 676.0 \\
317061 & 40 & 680.9 & $35-40 / 646-641$ & $2 / \mathrm{PVC}$ & $7 / 87$ & 659.4 \\
317091 & 30 & 684.0 & $20-30 / 663-653$ & $2 / \mathrm{PVC}$ & $7 / 88$ & 674.4 \\
317101 & 39 & 692.3 & $29-39 / 663 / 653$ & $2 / \mathrm{PVC}$ & $8 / 89$ & 670.2 \\
317111 & 39 & 689.8 & $29-39 / 670-660$ & $2 / \mathrm{PVC}$ & $8 / 89$ & 682.8 \\
$317121 \mathrm{D}$ & 79 & 681.0 & $69-79 / 612-602$ & $6 / \mathrm{CS}$ & $9 / 88$ & 612.4 \\
$319131 \mathrm{D}$ & 69 & 667.8 & $59-69 / 609-599$ & $6 / \mathrm{CS}$ & $9 / 88$ & 607.1 \\
\hline
\end{tabular}

Note: Wells identified by a " $D$ " are deeper wells monitoring the dolomite bedrock aquifer.

${ }^{\text {a }}$ Feet below ground.

b Feet mean sea level.

c Depth/elevation.

${ }^{\mathrm{d}}$ Inner diameter (in.)/well material (PVC = polyvinyl chloride, $\mathrm{CS}=$ carbon steel).

\subsubsection{Sample Collection}

The monitoring wells are sampled using the protocol listed in the RCRA Ground-Water Monitoring Technical Enforcement Guidance Document. ${ }^{33}$ The volume of the water in the casing is determined by measuring the water depth from the surface and the depth to the bottom of the well. This latter measurement also determines whether siltation has occurred that might restrict water movement in the screen area. For those wells in the glacial till that do not recharge rapidly, the well is emptied and the volume of water removed is compared to the calculated volume. In most cases, these volumes are nearly identical. The well is then sampled by bailing with a dedicated Teflon bailer. The field parameters for these samples $(\mathrm{pH}$, specific conductance, redox 


\section{GROUNDWATER PROTECTION}

potential, and temperature) are measured statically. For those samples in the porous, saturated zone that recharges rapidly, three well volumes are purged using dedicated submersible pumps while the field parameters are measured continuously. These parameters stabilize quickly in these wells. In the case of the dolomite wells, samples are collected as soon as these readings stabilize. Samples for VOCs, SVOCs, PCB/pesticides, metals, and radioactivity are collected in that order. The samples are placed in precleaned bottles, labeled, and preserved.

During each sampling event, one well is selected for replicate sampling. An effort is made to vary this selection so that replicates are obtained at every well over the course of time. In addition, a field blank is also obtained.

\subsubsection{Sample Analyses - 317/319 Area}

The 317/319 groundwater chemical analyses were performed using SOPs written, reviewed, and issued as controlled documents by members of the ESH-DACH. These SOPs reference protocols found in SW-846, 3rd edition, "Test Methods for Evaluating Solid Waste." ${ }^{9}$ Sixteen metals were routinely determined. Ten were measured using inductively coupled plasma atomic emission spectroscopy and five by graphite furnace atomic absorption spectroscopy. Mercury was determined by cold vapor atomic absorption spectroscopy. Chloride was determined by titrimetry. VOCs were determined by using a purge and trap sample pretreatment followed by gas chromatography-mass spectroscopy detection. SVOCs were determined by solvent extraction followed by gas chromatography-mass spectroscopy detection. $\mathrm{PCB} /$ pesticides were determined by solvent extraction followed by gas chromatography-electron capture detection. In the case of organic compound analyses, efforts were made to identify compounds that were present but not included on the method list. This was accomplished and standard solutions of these compounds were prepared and analyzed.

The 317/319 groundwater radiological analyses were performed using SOPs written, reviewed, and issued as controlled documents by members of the ESH-DARC. Cesium-137 was determined by gamma-ray spectrometry. Hydrogen- 3 was determined by distillation followed 


\section{GROUNDWATER PROTECTION}

by a beta liquid scintillation counting technique. Strontium-90 was determined by an ionexchange separation followed by a proportional counting technique.

\subsubsection{Results of Analyses}

The description of each well, a listing of field parameters measured during sample collection, and the results of chemical and radiological analyses of samples from the wells in the 317/319 Area are contained in Tables 6.12 through 6.22. All radiological and inorganic analytical results are shown in these tables. The analysis methods used for organic compounds will identify and quantify all the compounds contained in the CLP Target Compound List. However, the vast majority of these compounds were not detected in the samples. To simplify the format of these tables, those results less than the detection limit are not included. Only those constituents that were present in amounts great enough to quantify are shown. The detection limits for the organic compounds listed were typically 1 to $5 \mu \mathrm{g} / \mathrm{L}$.

Field Results. The purging of wells to produce water representative of the groundwater being studied is followed by measuring the field parameters. For the wells reported in this study, temperature, $\mathrm{pH}$, and specific conductance remain fairly constant after two well volumes were removed. The redox potential stabilizes after two well volumes are removed. On the basis of this information, sampling is conducted after the removal of three well volumes. The field parameters listed in the tables are the final readings obtained at the time of sampling. Wells 319011, 317021, 317061,317111 , and 319031 usually dry up after one well volume is removed. Therefore, field parameters are measured on one well volume. Well 319031 was dry during the first, third, and fourth quarters. Well 317081 was damaged, and no samples were collected in 1995. Well 317091 was sampled only during the first and second quarters. During the third quarter, the well was considered within the D\&D area for the south vaults (see Section 6.5.1) and could not be sampled. The well was abandoned during the fourth quarter and sealed in accordance with state and county well code requirements. 
TABLE 6.12

Groundwater Monitoring Results: 300 Area Well, 317021, 1995

\begin{tabular}{|c|c|c|c|c|c|}
\hline \multirow[b]{2}{*}{ Constituent } & \multirow[b]{2}{*}{ Units } & \multirow[b]{2}{*}{ March 3} & \multicolumn{2}{|c|}{$\begin{array}{l}\text { Well Point Elevation } \\
\text { Ground Surface Elevation } \\
\text { Casing Material: }\end{array}$} & \multirow{2}{*}{$\begin{array}{l}\mathrm{m}(\mathrm{MSL}) \\
196.90 \\
209.17 \\
\text { PVC } \\
\\
\text { Nov. } 95 \\
\end{array}$} \\
\hline & & & May 26 & Aug. 29 & \\
\hline Water Elevation & $\mathrm{m}$ & 199.87 & 202.25 & 200.54 & 199.48 \\
\hline Temperature & ${ }^{\circ} \mathrm{C}$ & 10.5 & 11.3 & 10.5 & 9.8 \\
\hline $\mathrm{pH}$ & $\mathrm{pH}$ & 7.46 & 7.50 & 7.25 & 7.31 \\
\hline Redox & $\mathrm{mV}$ & 346 & 215 & 166 & 158 \\
\hline Conductivity & $\mu \mathrm{mho} / \mathrm{cm}$ & 578 & 566 & 566 & 553 \\
\hline Chloride - Filtered & $\mathrm{mg} / \mathrm{L}$ & 15 & 14 & 16 & 18 \\
\hline Arsenic - Filtered & $\mathrm{mg} / \mathrm{L}$ & $<0.0025$ & $<0.0025$ & $<0.0025$ & $<0.0025$ \\
\hline Barium - Filtered & $\mathrm{mg} / \mathrm{L}$ & 0.0312 & 0.0308 & 0.0319 & 0.0316 \\
\hline Beryllium - Filtered & $\mathrm{mg} / \mathrm{L}$ & $<0.0001$ & $<0.0001$ & $<0.0001$ & $<0.0001$ \\
\hline Cadmium - Filtered & $\mathrm{mg} / \mathrm{L}$ & $<0.0001$ & $<0.0001$ & $<0.0001$ & $<0.0001$ \\
\hline Chromium - Filtered & $\mathrm{mg} / \mathrm{L}$ & $<0.060$ & $<0.060$ & $<0.060$ & $<0.060$ \\
\hline Cobalt - Filtered & $\mathrm{mg} / \mathrm{L}$ & $<0.025$ & $<0.025$ & $<0.025$ & $<0.025$ \\
\hline Copper - Filtered & $\mathrm{mg} / \mathrm{L}$ & $<0.045$ & $<0.045$ & $<0.045$ & $<0.045$ \\
\hline Iron - Filtered & $\mathrm{mg} / \mathrm{L}$ & $<0.025$ & $<0.025$ & $<0.025$ & $<0.025$ \\
\hline Lead - Filtered & $\mathrm{mg} / \mathrm{L}$ & $<0.0005$ & $<0.0005$ & $<0.0005$ & $<0.0005$ \\
\hline Manganese - Filtered & $\mathrm{mg} / \mathrm{L}$ & $<0.020$ & $<0.020$ & $<0.020$ & $<0.020$ \\
\hline Mercury - Filtered & $\mathrm{mg} / \mathrm{L}$ & 0.0001 & $<0.0001$ & $<0.0001$ & $<0.0001$ \\
\hline Nickel - Filtered & $\mathrm{mg} / \mathrm{L}$ & $<0.040$ & $<0.040$ & $<0.040$ & $<0.040$ \\
\hline Silver - Filtered & $\mathrm{mg} / \mathrm{L}$ & $<0.001$ & $<0.001$ & $<0.001$ & $<0.001$ \\
\hline Thallium - Filtered & $\mathrm{mg} / \mathrm{L}$ & $<0.0015$ & $<0.0015$ & $<0.0015$ & $<0.0015$ \\
\hline Vanadium - Filtered & $\mathrm{mg} / \mathrm{L}$ & $<0.055$ & $<0.055$ & $<0.055$ & $<0.055$ \\
\hline Zinc - Filtered & $\mathrm{mg} / \mathrm{L}$ & $<0.0150$ & $<0.0150$ & $<0.0150$ & 0.0625 \\
\hline Cesium-137 & $\mathrm{pCi} / \mathrm{L}$ & $<1.0$ & $<1.0$ & $<1.0$ & 1.9 \\
\hline Hydrogen-3 & $\mathrm{nCi} / \mathrm{L}$ & $<0.1$ & $<0.1$ & $<0.1$ & $<0.1$ \\
\hline Strontium-90 & $\mathrm{pCi} / \mathrm{L}$ & $<0.25$ & $<0.25$ & 0.27 & $<0.25$ \\
\hline 1,1,1-Trichloroethane & $\mu \mathrm{g} / \mathrm{L}$ & 162 & 147 & 124 & 111 \\
\hline 1,1-Dichloroethane & $\mu \mathrm{g} / \mathrm{L}$ & 75 & 54 & 59 & 68 \\
\hline 1,1-Dichloroethene & $\mu \mathrm{g} / \mathrm{L}$ & 2 & 2 & 1 & 1 \\
\hline 1,2-Dichloroethane & $\mu \mathrm{g} / \mathrm{L}$ & 8 & 6 & 9 & $-{ }^{a}$ \\
\hline Acetone & $\mu \mathrm{g} / \mathrm{L}$ & - & - & - & 3 \\
\hline Carbon tetrachloride & $\mu \mathrm{g} / \mathrm{L}$ & 6 & 8 & 7 & 6 \\
\hline Chloroform & $\mu \mathrm{g} / \mathrm{L}$ & - & 3 & 3 & 3 \\
\hline Methylene Chloride & $\mu \mathrm{g} / \mathrm{L}$ & - & 2 & - & 1 \\
\hline Tetrachloroethene & $\mu \mathrm{g} / \mathrm{L}$ & 1 & 1 & 1 & 1 \\
\hline Trichloroethene & $\mu \mathrm{g} / \mathrm{L}$ & 4 & 6 & 6 & 5 \\
\hline Vinyl Chloride & $\mu \mathrm{g} / \mathrm{L}$ & - & - & - & 2 \\
\hline
\end{tabular}

a A hyphen indicates that the concentration is below the detection limit. 
TABLE 6.13

Groundwater Monitoring Results: 300 Area, Well 317052, 1995

\begin{tabular}{|c|c|c|c|c|c|c|}
\hline \multirow[b]{2}{*}{ Constituent } & \multirow[b]{2}{*}{ Units } & \multirow[b]{2}{*}{ March 8} & \multirow[b]{2}{*}{ May 26} & \multicolumn{2}{|c|}{$\begin{array}{l}\text { Well Point Elevation } \\
\text { Ground Surface Elevation } \\
\text { Casing Material: }\end{array}$} & \multirow{2}{*}{$\begin{array}{l}\text { m(MSL) } \\
203.70 \\
208.32 \\
\text { PVC } \\
\text { Nov. } 9 \\
\end{array}$} \\
\hline & & & & Aug. 29 & Nov. 9 & \\
\hline Water Elevation & $\mathrm{m}$ & 205.00 & 205.36 & 204.52 & 204.45 & 204.4500 \\
\hline Temperature & ${ }^{\circ} \mathrm{C}$ & 7.5 & 8.2 & 13.3 & 13.0 & 13.0000 \\
\hline $\mathrm{pH}$ & $\mathrm{pH}$ & 7.47 & 7.61 & 7.27 & 7.68 & 7.6800 \\
\hline Redox & $\mathrm{mV}$ & 341 & 272 & 185 & 112 & 112.0000 \\
\hline Conductivity & $\mu \mathrm{mho} / \mathrm{cm}$ & 466 & 482 & 571 & 559 & 559.0000 \\
\hline Chloride - Filtered & $\mathrm{mg} / \mathrm{L}$ & 2 & 1 & 2 & 3 & 3.0000 \\
\hline Arsenic - Filtered & $\mathrm{mg} / \mathrm{L}$ & $<0.0025$ & $<0.0025$ & $<0.0025$ & $<0.0025$ & $<0.0025$ \\
\hline Barium - Filtered & $\mathrm{mg} / \mathrm{L}$ & 0.0025 & 0.0205 & 0.0261 & 0.0274 & 0.0285 \\
\hline Beryllium - Filtered & $\mathrm{mg} / \mathrm{L}$ & $<0.0001$ & $<0.0001$ & $<0.0001$ & $<0.0001$ & $<0.0001$ \\
\hline Cadmium - Filtered & $\mathrm{mg} / \mathrm{L}$ & $<0.0001$ & $<0.0001$ & $<0.0001$ & $<0.0001$ & $<0.0001$ \\
\hline Chromium - Filtered & $\mathrm{mg} / \mathrm{L}$ & $<0.060$ & $<0.060$ & $<0.060$ & $<0.060$ & $<0.060$ \\
\hline Cobalt - Filtered & $\mathrm{mg} / \mathrm{L}$ & $<0.025$ & $<0.025$ & $<0.025$ & $<0.025$ & $<0.025$ \\
\hline Copper - Filtered & $\mathrm{mg} / \mathrm{L}$ & $<0.045$ & $<0.045$ & $<0.045$ & $<0.045$ & $<0.045$ \\
\hline Iron - Filtered & $\mathrm{mg} / \mathrm{L}$ & $<0.0250$ & $<0.0250$ & 0.3304 & $<0.0250$ & $<0.0250$ \\
\hline Lead - Filtered & $\mathrm{mg} / \mathrm{L}$ & $<0.0005$ & 0.0009 & 0.0006 & $<0.0005$ & $<0.0005$ \\
\hline Manganese - Filtered & $\mathrm{mg} / \mathrm{L}$ & $<0.0200$ & $<0.0200$ & 0.0367 & $<0.0200$ & $<0.0200$ \\
\hline Mercury - Filtered & $\mathrm{mg} / \mathrm{L}$ & $<0.0001$ & $<0.0001$ & $<0.0001$ & $<0.0001$ & $<0.0001$ \\
\hline Nickel - Filtered & $\mathrm{mg} / \mathrm{L}$ & $<0.0400$ & $<0.0400$ & 0.2405 & $<0.0400$ & $<0.0400$ \\
\hline Silver - Filtered & $\mathrm{mg} / \mathrm{L}$ & $<0.001$ & $<0.001$ & $<0.001$ & $<0.001$ & $<0.001$ \\
\hline Thallium - Filtered & $\mathrm{mg} / \mathrm{L}$ & $<0.0015$ & $<0.0015$ & $<0.0015$ & $<0.0015$ & $<0.0015$ \\
\hline Vanadium - Filtered & $\mathrm{mg} / \mathrm{L}$ & $<0.055$ & $<0.055$ & $<0.055$ & $<0.055$ & $<0.055$ \\
\hline Zinc - Filtered & $\mathrm{mg} / \mathrm{L}$ & $<0.015$ & $<0.015$ & $<0.015$ & $<0.015$ & $<0.015$ \\
\hline Cesium-137 & $\mathrm{pCi} / \mathrm{L}$ & $<1.0$ & $<1.0$ & $<1.0$ & $<1.0$ & $<1.0$ \\
\hline Hydrogen-3 & $\mathrm{nCi} / \mathrm{L}$ & $<0.1$ & $<0.1$ & $<0.1$ & $<0.1$ & $<0.1$ \\
\hline Strontium-90 & $\mathrm{pCi} / \mathrm{L}$ & $<0.25$ & $<0.25$ & $<0.25$ & $<0.25$ & $<0.25$ \\
\hline Acetone & $\mu \mathrm{g} / \mathrm{L}$ & $-^{a}$ & - & - & 4 & 3 \\
\hline Methylene Chloride & $\mu \mathrm{g} / \mathrm{L}$ & - & - & 2 & 2 & 3. \\
\hline
\end{tabular}

a A hyphen indicates that the concentration is below the detection limit. 
TABLE 6.14

Groundwater Monitoring Results: 300 Area, Well 317061, 1995

\begin{tabular}{|c|c|c|c|c|c|}
\hline \multirow[b]{2}{*}{ Constituent } & \multirow[b]{2}{*}{ Units } & \multirow[b]{2}{*}{ March 8} & \multicolumn{2}{|c|}{$\begin{array}{l}\text { Well Point Elevation } \\
\text { Ground Surface Elevation } \\
\text { Casing Material: }\end{array}$} & \multirow{2}{*}{$\begin{array}{l}\mathrm{m}(\mathrm{MSL}) \\
194.93 \\
207.54 \\
\text { PVC } \\
\text { Nov. } 9 \\
\end{array}$} \\
\hline & & & May 26 & Aug. 29 & \\
\hline Water Elevation & $\mathrm{m}$ & 198.72 & 200.71 & 198.85 & 198.61 \\
\hline Temperature & ${ }^{\circ} \mathrm{C}$ & 10.4 & 10.7 & 10.7 & 10.2 \\
\hline $\mathrm{pH}$ & $\mathrm{pH}$ & 7.17 & 7.42 & 7.15 & 7.26 \\
\hline Redox & $\mathrm{mV}$ & 357 & 301 & 111 & 78 \\
\hline Conductivity & $\mu \mathrm{mho} / \mathrm{cm}$ & 788 & 795 & 800 & 782 \\
\hline Chloride - Filtered & $\mathrm{mg} / \mathrm{L}$ & 60 & 64 & 62 & 57 \\
\hline Arsenic-Filtered & $\mathrm{mg} / \mathrm{L}$ & $<0.0025$ & $<0.0025$ & $<0.0025$ & $<0.0025$ \\
\hline Barium - Filtered & $\mathrm{mg} / \mathrm{L}$ & 0.0542 & 0.0531 & 0.0516 & 0.0542 \\
\hline Beryllium- Filtered & $\mathrm{mg} / \mathrm{L}$ & $<0.0001$ & $<0.0001$ & $<0.0001$ & $<0.0001$ \\
\hline Cadmium - Filtered & $\mathrm{mg} / \mathrm{L}$ & $<0.0001$ & $<0.0001$ & $<0.0001$ & $<0.0001$ \\
\hline Chromium - Filtered & $\mathrm{mg} / \mathrm{L}$ & $<0.060$ & $<0.060$ & $<0.060$ & $<0.060$ \\
\hline Cobalt - Filtered & $\mathrm{mg} / \mathrm{L}$ & $<0.025$ & $<0.025$ & $<0.025$ & $<0.025$ \\
\hline Copper - Filtered & $\mathrm{mg} / \mathrm{L}$ & $<0.045$ & $<0.045$ & $<0.045$ & $<0.045$ \\
\hline Iron - Filtered & $\mathrm{mg} / \mathrm{L}$ & $<0.025$ & $<0.025$ & $<0.025$ & $<0.025$ \\
\hline Lead - Filtered & $\mathrm{mg} / \mathrm{L}$ & $<0.0005$ & $<0.0005$ & $<0.0005$ & 0.0005 \\
\hline Manganese - Filtered & $\mathrm{mg} / \mathrm{L}$ & $<0.02$ & $<0.02$ & $<0.02$ & 0.0202 \\
\hline Mercury - Filtered & $\mathrm{mg} / \mathrm{L}$ & $<0.0001$ & $<0.0001$ & $<0.0001$ & $<0.0001$ \\
\hline Nickel - Filtered & $\mathrm{mg} / \mathrm{L}$ & $<0.040$ & $<0.040$ & $<0.040$ & $<0.040$ \\
\hline Silver - Filtered & $\mathrm{mg} / \mathrm{L}$ & $<0.001$ & $<0.001$ & $<0.001$ & $<0.001$ \\
\hline Thallium - Filtered & $\mathrm{mg} / \mathrm{L}$ & $<0.0015$ & $<0.0015$ & $<0.0015$ & $<0.0015$ \\
\hline Vanadium - Filtered & $\mathrm{mg} / \mathrm{L}$ & $<0.055$ & $<0.055$ & $<0.055$ & $<0.055$ \\
\hline Zinc - Filtered & $\mathrm{mg} / \mathrm{L}$ & $<0.015$ & $<0.015$ & $<0.015$ & 0.0319 \\
\hline Cesium-137 & $\mathrm{pCi} / \mathrm{L}$ & $<1.0$ & $<1.0$ & $<1.0$ & $<1.0$ \\
\hline Hydrogen-3 & $\mathrm{nCi} / \mathrm{L}$ & $<0.1$ & $<0.1$ & $<0.1$ & $<0.1$ \\
\hline Strontium-90 & $\mathrm{pCi} / \mathrm{L}$ & $<0.25$ & $<0.25$ & $<0.25$ & $<0.25$ \\
\hline Acetone & $\mu \mathrm{g} / \mathrm{L}$ & 4 & 5 & $-^{\mathrm{a}}$ & 3 \\
\hline Methylene chloride & $\mu \mathrm{g} / \mathrm{L}$ & 3 & - & - & 1 \\
\hline
\end{tabular}

a A hyphen indicates that the concentration is below the detection limit. 


\section{TABLE 6.15}

Groundwater Monitoring Results: 300 Area, Well 317091, 1995

\begin{tabular}{|c|c|c|c|}
\hline & & $\begin{array}{l}\text { Well Point Elevation } \\
\text { Ground Surface Elevation } \\
\text { Casing Material: }\end{array}$ & $\begin{array}{l}\mathrm{m}(\mathrm{MSL}) \\
199.16 \\
208.14 \\
\text { PVC } \\
\end{array}$ \\
\hline Constituent & Units & March 8 & May 31 \\
\hline Water Elevation & $\mathrm{m}$ & 201.86 & 203.96 \\
\hline Temperature & ${ }^{\circ} \mathrm{C}$ & 8.8 & 9.7 \\
\hline $\mathrm{pH}$ & $\mathrm{pH}$ & 7.39 & 7.64 \\
\hline Redox & $\mathrm{mV}$ & 381 & 293 \\
\hline Conductivity & $\mu \mathrm{mho} / \mathrm{cm}$ & 528 & 535 \\
\hline Chloride & $\mathrm{mg} / \mathrm{L}$ & 10 & 6 \\
\hline Arsenic - Filtered & $\mathrm{mg} / \mathrm{L}$ & $<0.0025$ & $<0.0025$ \\
\hline Barium - Filtered & $\mathrm{mg} / \mathrm{L}$ & 0.0243 & 0.0279 \\
\hline Beryllium - Filtered & $\mathrm{mg} / \mathrm{L}$ & $<0.0001$ & $<0.0001$ \\
\hline Cadmium - Filtered & $\mathrm{mg} / \mathrm{L}$ & $<0.0001$ & $<0.0001$ \\
\hline Chromium - Filtered & $\mathrm{mg} / \mathrm{L}$ & $<0.060$ & $<0.060$ \\
\hline Cobalt - Filtered & $\mathrm{mg} / \mathrm{L}$ & $<0.025$ & $<0.025$ \\
\hline Copper - Filtered & $\mathrm{mg} / \mathrm{L}$ & $<0.045$ & $<0.045$ \\
\hline Iron - Filtered & $\mathrm{mg} / \mathrm{L}$ & $<0.025$ & $<0.025$ \\
\hline Lead - Filtered & $\mathrm{mg} / \mathrm{L}$ & $<0.0005$ & $<0.0005$ \\
\hline Manganese - Filtered & $\mathrm{mg} / \mathrm{L}$ & $<0.020$ & $<0.020$ \\
\hline Mercury - Filtered & $\mathrm{mg} / \mathrm{L}$ & $<0.0001$ & $<0.0001$ \\
\hline Nickel - Filtered & $\mathrm{mg} / \mathrm{L}$ & $<0.040$ & $<0.040$ \\
\hline Silver - Filtered & $\mathrm{mg} / \mathrm{L}$ & $<0.0010$ & $<0.0010$ \\
\hline Thallium -Filtered & $\mathrm{mg} / \mathrm{L}$ & $<0.0015$ & $<0.0015$ \\
\hline Vanadium - Filtered & $\mathrm{mg} / \mathrm{L}$ & $<0.055$ & $<0.055$ \\
\hline Zinc - Filtered & $\mathrm{mg} / \mathrm{L}$ & $<0.015$ & $<0.015$ \\
\hline Cesium-137 & $\mathrm{pCi} / \mathrm{L}$ & $<1.0$ & $<1.0$ \\
\hline Hydrogen-3 & $\mathrm{nCi} / \mathrm{L}$ & $<0.1$ & $<0.1$ \\
\hline Strontium-90 & $\mathrm{pCi} / \mathrm{L}$ & $<0.25$ & $<0.25$ \\
\hline
\end{tabular}




\section{GROUNDWATER PROTECTION}

TABLE 6.16

Groundwater Monitoring Results: 300 Area, Well 317101, 1995

\begin{tabular}{|c|c|c|c|c|c|c|}
\hline \multirow[b]{2}{*}{ Constituent } & \multirow[b]{2}{*}{ Units } & \multirow[b]{2}{*}{ March 8} & \multirow[b]{2}{*}{ March 8} & \multicolumn{2}{|c|}{$\begin{array}{l}\text { Well Point Elevation } \\
\text { Ground Surface Elevation } \\
\text { Casing Material: }\end{array}$} & \multirow{2}{*}{$\begin{array}{l}\text { m(MSL) } \\
198.66 \\
211.04 \\
\text { PVC } \\
\\
\text { Nov. } 9 \\
\end{array}$} \\
\hline & & & & May 26 & Aug. 29 & \\
\hline Water Elevation & $\mathrm{m}$ & 202.31 & 202.31 & 204.2 & 202.77 & 202.18 \\
\hline Temperature & ${ }^{\circ} \mathrm{C}$ & 11.6 & 11.6 & 11.4 & 11.5 & 11.5 \\
\hline $\mathrm{pH}$ & $\mathrm{pH}$ & 7.18 & 7.18 & 7.32 & 7.04 & 7.11 \\
\hline Redox & $\mathrm{mV}$ & 371 & 371 & 299 & 164 & 191 \\
\hline Conductivity & $\mu \mathrm{mho} / \mathrm{cm}$ & 1485 & 1485 & 1608 & 1299 & 1042 \\
\hline Chloride - Filtered & $\mathrm{mg} / \mathrm{L}$ & 393 & 406 & 500 & 225 & 169 \\
\hline Arsenic - Filtered & $\mathrm{mg} / \mathrm{L}$ & $<0.0025$ & $<0.0025$ & $<0.0025$ & $<0.0025$ & $<0.0025$ \\
\hline Barium - Filtered & $\mathrm{mg} / \mathrm{L}$ & 0.0683 & 0.0663 & 0.0703 & 0.0391 & 0.0420 \\
\hline Beryllium - Filtered & $\mathrm{mg} / \mathrm{L}$ & $<0.0001$ & $<0.0001$ & $<0.0001$ & $<0.0001$ & $<0.0001$ \\
\hline Cadmium -Filtered & $\mathrm{mg} / \mathrm{L}$ & $<0.0001$ & $<0.0001$ & $<0.0001$ & $<0.0001$ & 0.0005 \\
\hline Chromium - Filtered & $\mathrm{mg} / \mathrm{L}$ & $<0.060$ & $<0.060$ & $<0.060$ & $<0.060$ & $<0.060$ \\
\hline Cobalt - Filtered & $\mathrm{mg} / \mathrm{L}$ & $<0.025$ & $<0.025$ & $<0.025$ & $<0.025$ & $<0.025$ \\
\hline Copper - Filtered & $\mathrm{mg} / \mathrm{L}$ & $<0.045$ & $<0.045$ & $<0.045$ & $<0.045$ & $<0.045$ \\
\hline Iron - Filtered & $\mathrm{mg} / \mathrm{L}$ & $<0.025$ & $<0.025$ & $<0.025$ & $<0.025$ & $<0.025$ \\
\hline Lead - Filtered & $\mathrm{mg} / \mathrm{L}$ & $<0.0005$ & $<0.0005$ & $<0.0005$ & $<0.0005$ & $<0.0005$ \\
\hline Manganese - Filtered & $\mathrm{mg} / \mathrm{L}$ & 0.0542 & 0.0604 & 0.0269 & $<0.0200$ & 0.0849 \\
\hline Mercury - Filtered & $\mathrm{mg} / \mathrm{L}$ & $<0.0001$ & $<0.0001$ & $<0.0001$ & $<0.0001$ & $<0.0001$ \\
\hline Nickel - Filtered & $\mathrm{mg} / \mathrm{L}$ & $<0.04$ & $<0.040$ & $<0.04$ & $<0.04$ & $<0.04$ \\
\hline Silver - Filtered & $\mathrm{mg} / \mathrm{L}$ & $<0.001$ & $<0.001$ & $<0.001$ & $<0.001$ & $<0.001$ \\
\hline Thallium - Filtered & $\mathrm{mg} / \mathrm{L}$ & $<0.0015$ & $<0.0015$ & $<0.0015$ & $<0.0015$ & $<0.0015$ \\
\hline Vanadium - Filtered & $\mathrm{mg} / \mathrm{L}$ & $<0.055$ & $<0.055$ & $<0.055$ & $<0.055$ & $<0.055$ \\
\hline Zinc - Filtered & $\mathrm{mg} / \mathrm{L}$ & $<0.015$ & $<0.0150$ & $<0.0150$ & $<0.015$ & $<0.015$ \\
\hline Cesium-137 & $\mathrm{pCi} / \mathrm{L}$ & $<1.0$ & $<1.0$ & $<1.0$ & $<1.0$ & $<1.0$ \\
\hline Hydrogen-3 & $\mathrm{nCi} / \mathrm{L}$ & $<0.1$ & $<0.1$ & $<0.1$ & $<0.1$ & $<0.1$ \\
\hline Strontium-90 & $\mathrm{pCi} / \mathrm{L}$ & $<0.25$ & $<0.25$ & $<0.25$ & $<0.25$ & $<0.25$ \\
\hline Acetone & $\mu \mathrm{g} / \mathrm{L}$ & 4 & $-^{a}$ & - & - & 2 \\
\hline Methylene chloride & $\mu \mathrm{g} / \mathrm{L}$ & 3 & 2 & - & - & 1 \\
\hline
\end{tabular}

a A hyphen indicates that the concentration is below the detection limit. 
TABLE 6.17

Groundwater Monitoring Results: 300 Area, Well 317111, 1995

\begin{tabular}{|c|c|c|c|c|c|c|}
\hline \multirow[b]{2}{*}{ Constituent } & \multirow[b]{2}{*}{ Units } & \multirow[b]{2}{*}{ March 8} & \multirow[b]{2}{*}{ May 26} & \multicolumn{2}{|c|}{$\begin{array}{l}\text { Well Point Elevation } \\
\text { Ground Surface Elevation } \\
\text { Casing Material: }\end{array}$} & \multirow{2}{*}{$\begin{array}{l}\mathrm{m}(\mathrm{MSL}) \\
200.72 \\
213.02 \\
\text { PVC } \\
\\
\text { Nov. } 9 \\
\end{array}$} \\
\hline & & & & May 26 & Aug. 29 & \\
\hline Water Elevation & $\mathrm{m}$ & 204.34 & 206.79 & 206.79 & 203.51 & 202.62 \\
\hline Temperature & ${ }^{\circ} \mathrm{C}$ & 10.8 & 10.9 & 10.9 & 11.3 & 10.9 \\
\hline $\mathrm{pH}$ & $\mathrm{pH}$ & 7.24 & 7.83 & 7.83 & 7.41 & 7.19 \\
\hline Redox & $\mathrm{mV}$ & 293 & 267 & 267 & 63 & 197 \\
\hline Conductivity & $\mu \mathrm{mho} / \mathrm{cm}$ & 813 & 881 & 881 & 925 & 976 \\
\hline Chloride - Filtered & $\mathrm{mg} / \mathrm{L}$ & 110 & 135 & 135 & 152 & 171 \\
\hline Arsenic - Filtered & $\mathrm{mg} / \mathrm{L}$ & $<0.0025$ & $<0.0025$ & $<0.0025$ & $<0.0025$ & $<0.0025$ \\
\hline Barium - Filtered & $\mathrm{mg} / \mathrm{L}$ & 0.0641 & 0.0641 & 0.0635 & 0.0724 & 0.0812 \\
\hline Beryllium - Filtered & $\mathrm{mg} / \mathrm{L}$ & $<0.0001$ & $<0.0001$ & $<0.0001$ & $<0.0001$ & $<0.0001$ \\
\hline Cadmium - Filtered & $\mathrm{mg} / \mathrm{L}$ & $<0.0001$ & $<0.0001$ & $<0.0001$ & $<0.0001$ & $<0.0001$ \\
\hline Chromium - Filtered & $\mathrm{mg} / \mathrm{L}$ & $<0.060$ & $<0.06$ & $<0.060$ & $<0.060$ & $<0.060$ \\
\hline Cobalt - Filtered & $\mathrm{mg} / \mathrm{L}$ & $<0.025$ & $<0.025$ & $<0.025$ & $<0.025$ & $<0.025$ \\
\hline Copper - Filtered & $\mathrm{mg} / \mathrm{L}$ & $<0.045$ & $<0.045$ & $<0.045$ & $<0.045$ & $<0.045$ \\
\hline Iron - Filtered & $\mathrm{mg} / \mathrm{L}$ & $<0.0250$ & $<0.0250$ & $<0.0250$ & 0.0686 & $<0.0250$ \\
\hline Lead - Filtered & $\mathrm{mg} / \mathrm{L}$ & $<0.0005$ & $<0.0005$ & $<0.0005$ & $<0.0005$ & $<0.0005$ \\
\hline Manganese - Filtered & $\mathrm{mg} / \mathrm{L}$ & 0.0459 & 0.0262 & 0.0255 & 0.0373 & 0.0931 \\
\hline Mercury - Filtered & $\mathrm{mg} / \mathrm{L}$ & $<0.0001$ & $<0.0001$ & $<0.0001$ & $<0.0001$ & $<0.0001$ \\
\hline Nickel - Filtered & $\mathrm{mg} / \mathrm{L}$ & $<0.040$ & $<0.040$ & $<0.040$ & $<0.040$ & $<0.040$ \\
\hline Silver - Filtered & $\mathrm{mg} / \mathrm{L}$ & $<0.001$ & $<0.001$ & $<0.001$ & $<0.001$ & $<0.001$ \\
\hline Thallium - Filtered & $\mathrm{mg} / \mathrm{L}$ & $<0.0015$ & $<0.0015$ & $<0.0015$ & $<0.0015$ & $<0.0015$ \\
\hline Vanadium - Filtered & $\mathrm{mg} / \mathrm{L}$ & $<0.055$ & $<0.055$ & $<0.055$ & $<0.055$ & $<0.055$ \\
\hline Zinc - Filtered & $\mathrm{mg} / \mathrm{L}$ & $<0.015$ & $<0.015$ & $<0.015$ & $<0.015$ & $<0.015$ \\
\hline Cesium-137 & $\mathrm{pCi} / \mathrm{L}$ & $<1.0$ & $<1.0$ & $<1.0$ & $<1.0$ & $<1.0$ \\
\hline Hydrogen-3 & $\mathrm{nCi} / \mathrm{L}$ & $<0.1$ & $<0.1$ & $<0.1$ & $<0.1$ & $<0.1$ \\
\hline Strontium-90 & $\mathrm{pCi} / \mathrm{L}$ & $<0.25$ & $<0.025$ & $<0.25$ & $<0.25$ & $<0.25$ \\
\hline Acetone & $\mu \mathrm{g} / \mathrm{L}$ & $-^{\mathrm{a}}$ & - & 3 & - & 3 \\
\hline Methylene Chloride & $\mu \mathrm{g} / \mathrm{L}$ & - & - & - & & 5 \\
\hline
\end{tabular}

a A hyphen indicates that the concentration is below the detection limit. 


\section{TABLE 6.18}

Groundwater Monitoring Results: 300 Area, Well 317121D, 1995

\begin{tabular}{|c|c|c|c|c|c|}
\hline \multirow[b]{2}{*}{ Constituent } & \multirow[b]{2}{*}{ Units } & \multirow[b]{2}{*}{ March 8} & \multicolumn{2}{|c|}{$\begin{array}{l}\text { Well Point Elevation } \\
\text { Ground Surface Elevation } \\
\text { Casing Material: }\end{array}$} & \multirow{2}{*}{$\begin{array}{l}\mathrm{m}(\mathrm{MSL}) \\
183.17 \\
207.57 \\
\text { STEEL } \\
\\
\text { Nov. } 9 \\
\end{array}$} \\
\hline & & & May 31 & August 30 & \\
\hline Water Elevation & $\mathrm{m}$ & 186.31 & 186.48 & 186.41 & 186.31 \\
\hline Temperature & ${ }^{\circ} \mathrm{C}$ & 11.2 & 11.5 & 11.8 & 10.9 \\
\hline $\mathrm{pH}$ & $\mathrm{pH}$ & 9.72 & 11.09 & 11.06 & 11.18 \\
\hline Redox & $\mathrm{mV}$ & 260 & 117 & 25 & -50 \\
\hline Conductivity & $\mu \mathrm{mho} / \mathrm{cm}$ & 454 & 507 & 537 & 406 \\
\hline Chloride - Filtered & $\mathrm{mg} / \mathrm{L}$ & 42 & 6 & 43 & 54 \\
\hline Arsenic - Filtered & $\mathrm{mg} / \mathrm{L}$ & $<0.0025$ & $<0.0025$ & $<0.0025$ & $<0.0025$ \\
\hline Barium - Filtered & $\mathrm{mg} / \mathrm{L}$ & 0.0260 & 0.1246 & 0.1382 & 0.0461 \\
\hline Beryllium - Filtered & $\mathrm{mg} / \mathrm{L}$ & $<0.0001$ & $<0.0001$ & $<0.0001$ & $<0.0001$ \\
\hline Cadmium - Filtered & $\mathrm{mg} / \mathrm{L}$ & $<0.0001$ & $<0.0001$ & $<0.0001$ & $<0.0001$ \\
\hline Chromium - Filtered & $\mathrm{mg} / \mathrm{L}$ & $<0.060$ & $<0.060$ & $<0.060$ & $<0.060$ \\
\hline Cobalt - Filtered & $\mathrm{mg} / \mathrm{L}$ & $<0.025$ & $<0.025$ & $<0.025$ & $<0.025$ \\
\hline Copper - Filtered & $\mathrm{mg} / \mathrm{L}$ & $<0.045$ & $<0.045$ & $<0.045$ & $<0.045$ \\
\hline Iron - Filtered & $\mathrm{mg} / \mathrm{L}$ & $<0.0250$ & $<0.0250$ & $<0.0250$ & 0.0301 \\
\hline Lead - Filtered & $\mathrm{mg} / \mathrm{L}$ & $<0.0005$ & $<0.0005$ & 0.0005 & $<0.0005$ \\
\hline Manganese - Filtered & $\mathrm{mg} / \mathrm{L}$ & $<0.020$ & $<0.020$ & $<0.020$ & $<0.020$ \\
\hline Mercury - Filtered & $\mathrm{mg} / \mathrm{L}$ & $<0.0001$ & $<0.0001$ & $<0.0001$ & $<0.0001$ \\
\hline Nickel - Filtered & $\mathrm{mg} / \mathrm{L}$ & $<0.040$ & $<0.040$ & $<0.040$ & $<0.040$ \\
\hline Silver - Filtered & $\mathrm{mg} / \mathrm{L}$ & $<0.001$ & $<0.001$ & $<0.001$ & $<0.001$ \\
\hline Thallium - Filtered & $\mathrm{mg} / \mathrm{L}$ & $<0.0015$ & $<0.0015$ & $<0.0015$ & $<0.0015$ \\
\hline Vanadium - Filtered & $\mathrm{mg} / \mathrm{L}$ & $<0.055$ & $<0.055$ & $<0.055$ & $<0.055$ \\
\hline Zinc - Filtered & $\mathrm{mg} / \mathrm{L}$ & $<0.015$ & $<0.015$ & $<0.015$ & $<0.015$ \\
\hline Cesium-137 & $\mathrm{pCi} / \mathrm{L}$ & $<1.0$ & $<1.0$ & $<1.0$ & 1.2 \\
\hline Hydrogen-3 & $\mathrm{nCi} / \mathrm{L}$ & $<0.1$ & $<0.1$ & $<0.1$ & $<0.1$ \\
\hline Strontium-90 & $\mathrm{pCi} / \mathrm{L}$ & $<0.25$ & $<0.25$ & $<0.25$ & $<0.25$ \\
\hline 2-Butanone & $\mu \mathrm{g} / \mathrm{L}$ & $\mathrm{a}^{\mathrm{a}}$ & 1 & 2 & - \\
\hline 2-Heptanone & $\mu \mathrm{g} / \mathrm{L}$ & - & 0.9 & 0.9 & - \\
\hline 2-Hexanone & $\mu \mathrm{g} / \mathrm{L}$ & - & 0.4 & 0.5 & - \\
\hline Acetone & $\mu \mathrm{g} / \mathrm{L}$ & 5 & 6 & 9 & 3 \\
\hline Methylene Chloride & $\mu \mathrm{g} / \mathrm{L}$ & - & - & - & 1 \\
\hline
\end{tabular}

a A hyphen indicates that the concentration is below the detection limit. 
TABLE 6.19

Groundwater Monitoring Results: 300 Area, Well 319011, 1995

\begin{tabular}{|c|c|c|c|c|c|}
\hline \multirow[b]{2}{*}{ Constituent } & \multirow[b]{2}{*}{ Units } & \multirow[b]{2}{*}{ March 8} & \multicolumn{2}{|c|}{$\begin{array}{l}\text { Well Point Elevation } \\
\text { Ground Surface Elevation } \\
\text { Casing Material: }\end{array}$} & \multirow{2}{*}{$\begin{array}{l}\text { m(MSL) } \\
196.95 \\
209.81 \\
\text { PVC } \\
\text { Nov. } 9 \\
\end{array}$} \\
\hline & & & May 26 & Aug. 29 & \\
\hline Water Elevation & $\mathrm{m}$ & 198.67 & 201.32 & 199.56 & 199.22 \\
\hline Temperature & ${ }^{\circ} \mathrm{C}$ & 10.3 & 10.8 & 10.9 & 10.2 \\
\hline $\mathrm{pH}$ & $\mathrm{pH}$ & 7.19 & 7.42 & 7.25 & 7.01 \\
\hline Redox & $\mathrm{mV}$ & 333 & 301 & 138 & 203 \\
\hline Conductivity & $\mu \mathrm{mho} / \mathrm{cm}$ & 806 & 858 & 859 & 826 \\
\hline Chloride - Filtered & $\mathrm{mg} / \mathrm{L}$ & 26 & 34 & 36 & 41 \\
\hline Arsenic - Filtered & $\mathrm{mg} / \mathrm{L}$ & $<0.0025$ & $<0.0025$ & $<0.0025$ & $<0.0025$ \\
\hline Barium - Filtered & $\mathrm{mg} / \mathrm{L}$ & 0.0289 & 0.0303 & 0.0337 & 0.0355 \\
\hline Beryllium - Filtered & $\mathrm{mg} / \mathrm{L}$ & $<0.0001$ & $<0.0001$ & $<0.0001$ & $<0.0001$ \\
\hline Cadmium - Filtered & $\mathrm{mg} / \mathrm{L}$ & $<0.0001$ & $<0.0001$ & $<0.0001$ & $<0.0001$ \\
\hline Chromium - Filtered & $\mathrm{mg} / \mathrm{L}$ & $<0.060$ & $<0.060$ & $<0.060$ & $<0.060$ \\
\hline Cobalt - Filtered & $\mathrm{mg} / \mathrm{L}$ & $<0.025$ & $<0.025$ & $<0.025$ & $<0.025$ \\
\hline Copper - Filtered & $\mathrm{mg} / \mathrm{L}$ & $<0.045$ & $<0.045$ & $<0.045$ & $<0.045$ \\
\hline Iron - Filtered & $\mathrm{mg} / \mathrm{L}$ & $<0.025$ & $<0.025$ & $<0.025$ & $<0.025$ \\
\hline Lead - Filtered & $\mathrm{mg} / \mathrm{L}$ & $<0.0005$ & $<0.0005$ & $<0.0005$ & $<0.0005$ \\
\hline Manganese - Filtered & $\mathrm{mg} / \mathrm{L}$ & $<0.0200$ & 0.0417 & $<0.0200$ & $<0.0200$ \\
\hline Mercury - Filtered & $\mathrm{mg} / \mathrm{L}$ & $<0.0001$ & $<0.0001$ & $<0.0001$ & $<0.0001$ \\
\hline Nickel - Filtered & $\mathrm{mg} / \mathrm{L}$ & $<0.040$ & $<0.040$ & $<0.040$ & $<0.040$ \\
\hline Silver - Filtered & $\mathrm{mg} / \mathrm{L}$ & $<0.001$ & $<0.001$ & $<0.001$ & $<0.001$ \\
\hline Thallium - Filtered & $\mathrm{mg} / \mathrm{L}$ & $<0.0015$ & $<0.0015$ & $<0.0015$ & $<0.0015$ \\
\hline Vanadium - Filtered & $\mathrm{mg} / \mathrm{L}$ & $<0.055$ & $<0.055$ & $<0.055$ & $<0.055$ \\
\hline Zinc - Filtered & $\mathrm{mg} / \mathrm{L}$ & $<0.0150$ & $<0.0150$ & $<0.0150$ & 0.0318 \\
\hline Cesium-137 & $\mathrm{pCi} / \mathrm{L}$ & $<1.0$ & $<1.0$ & $<1.0$ & $<1.0$ \\
\hline Hydrogen-3 & $\mathrm{nCi} / \mathrm{L}$ & $<0.1$ & $<0.1$ & $<0.1$ & $<0.1$ \\
\hline Strontium-90 & $\mathrm{pCi} / \mathrm{L}$ & $<0.25$ & $<0.25$ & $<0.25$ & $<0.25$ \\
\hline Acetone & $\mu \mathrm{g} / \mathrm{L}$ & 6 & $-^{\mathrm{a}}$ & - & 3 \\
\hline Methylene Chloride & $\mu \mathrm{g} / \mathrm{L}$ & 2 & - & - & 3 \\
\hline
\end{tabular}

a A hyphen indicates that the concentration is below the detection limit. 


\section{GROUNDWATER PROTECTION}

TABLE 6.20

Groundwater Monitoring Results: 300 Area,

Well 319031, 1995

\begin{tabular}{|c|c|c|c|}
\hline & & $\begin{array}{l}\text { Well Point Elevation } \\
\text { Ground Surface Elevation } \\
\text { Casing Material: }\end{array}$ & $\begin{array}{l}\text { m(MSL) } \\
192.08 \\
204.28 \\
\text { PVC }\end{array}$ \\
\hline Constituent & Units & May 26 & \\
\hline Water Elevation & $\mathrm{m}$ & 193.14 & \\
\hline Temperature & ${ }^{\circ} \mathrm{C}$ & 10.3 & \\
\hline $\mathrm{pH}$ & $\mathrm{pH}$ & 7.4 & \\
\hline Redox & $\mathrm{mV}$ & 309 & \\
\hline Conductivity & $\mu \mathrm{mho} / \mathrm{cm}$ & 711 & \\
\hline Chloride & $\mathrm{mg} / \mathrm{L}$ & 21 & \\
\hline Arsenic - Filtered & $\mathrm{mg} / \mathrm{L}$ & $<0.0025$ & \\
\hline Barium - Filtered & $\mathrm{mg} / \mathrm{L}$ & 0.0511 & \\
\hline Beryllium - Filtered & $\mathrm{mg} / \mathrm{L}$ & $<0.0001$ & \\
\hline Cadmium - Filtered & $\mathrm{mg} / \mathrm{L}$ & $<0.0001$ & \\
\hline Chromium - Filtered & $\mathrm{mg} / \mathrm{L}$ & $<0.060$ & \\
\hline Cobalt - Filtered & $\mathrm{mg} / \mathrm{L}$ & $<0.025$ & \\
\hline Copper - Filtered & $\mathrm{mg} / \mathrm{L}$ & $<0.045$ & \\
\hline Iron - Filtered & $\mathrm{mg} / \mathrm{L}$ & $<0.025$ & \\
\hline Lead - Filtered & $\mathrm{mg} / \mathrm{L}$ & $<0.0005$ & \\
\hline Manganese - Filtered & $\mathrm{mg} / \mathrm{L}$ & $<0.020$ & \\
\hline Mercury - Filtered & $\mathrm{mg} / \mathrm{L}$ & $<0.0001$ & \\
\hline Nickel - Filtered & $\mathrm{mg} / \mathrm{L}$ & $<0.040$ & \\
\hline Silver - Filtered & $\mathrm{mg} / \mathrm{L}$ & $<0.001$ & \\
\hline Thallium - Filtered & $\mathrm{mg} / \mathrm{L}$ & $<0.0015$ & \\
\hline Vanadium - Filtered & $\mathrm{mg} / \mathrm{L}$ & $<0.055$ & \\
\hline Zinc - Filtered & $\mathrm{mg} / \mathrm{L}$ & $<0.015$ & \\
\hline Cesium-137 & $\mathrm{pCi} / \mathrm{L}$ & $<1.0$ & \\
\hline Hydrogen-3 & $\mathrm{nCi} / \mathrm{L}$ & 1.04 & \\
\hline Strontium-90 & $\mathrm{pCi} / \mathrm{L}$ & 0.37 & \\
\hline 1,1,1-Trichloroethane & $\mu \mathrm{g} / \mathrm{L}$ & 4 & \\
\hline Trichloroethene & $\mu \mathrm{g} / \mathrm{L}$ & 6 & \\
\hline
\end{tabular}


TABLE 6.21

Groundwater Monitoring Results: 300 Area, Well 319032, 1995

\begin{tabular}{|c|c|c|c|c|c|c|}
\hline \multirow[b]{2}{*}{ Constituent } & \multirow[b]{2}{*}{ Units } & \multirow[b]{2}{*}{ March 8} & \multirow[b]{2}{*}{ May 26} & \multicolumn{2}{|c|}{$\begin{array}{l}\text { Nell Point Elevation } \\
\text { Ground Surface Elevation } \\
\text { Casing Material: }\end{array}$} & \multirow{2}{*}{$\begin{array}{l}\text { m(MSL) } \\
195.82 \\
204.28 \\
\text { PVC } \\
\text { Nov. } 9 \\
\end{array}$} \\
\hline & & & & Aug. 29 & Aug. 29 & \\
\hline Water Elevation & $\mathrm{m}$ & 197.35 & 197.73 & 197.65 & 197.65 & 196.98 \\
\hline Temperature & ${ }^{\circ} \mathrm{C}$ & 10.2 & 9.6 & 10.3 & 10.3 & 10.8 \\
\hline $\mathrm{pH}$ & $\mathrm{pH}$ & 7.17 & 7.37 & 7.19 & 7.19 & 7.18 \\
\hline Redox & $\mathrm{mV}$ & 363 & 294 & 165 & 165 & 169 \\
\hline Conductivity & $\mu \mathrm{mho} / \mathrm{cm}$ & 854 & 774 & 755 & 755 & 774 \\
\hline Chloride - Filtered & $\mathrm{mg} / \mathrm{L}$ & 26 & 21 & 19 & 20 & 21 \\
\hline Arsenic - Filtered & $\mathrm{mg} / \mathrm{L}$ & $<0.0025$ & $<0.0025$ & $<0.0025$ & $<0.0025$ & $<0.0025$ \\
\hline Barium - Filtered & $\mathrm{mg} / \mathrm{L}$ & 0.0573 & 0.0529 & 0.0712 & 0.0689 & 0.0674 \\
\hline Beryllium - Filtered & $\mathrm{mg} / \mathrm{L}$ & $<0.0001$ & $<0.0001$ & $<0.0001$ & $<0.0001$ & $<0.0001$ \\
\hline Cadmium - Filtered & $\mathrm{mg} / \mathrm{L}$ & $<0.0001$ & $<0.0001$ & $<0.0001$ & $<0.0001$ & $<0.0001$ \\
\hline Chromium - Filtered & $\mathrm{mg} / \mathrm{L}$ & $<0.060$ & $<0.060$ & $<0.060$ & $<0.060$ & $<0.060$ \\
\hline Cobalt - Filtered & $\mathrm{mg} / \mathrm{L}$ & $<0.025$ & $<0.025$ & $<0.025$ & $<0.025$ & $<0.025$ \\
\hline Copper - Filtered & $\mathrm{mg} / \mathrm{L}$ & $<0.045$ & $<0.045$ & $<0.045$ & $<0.045$ & $<0.045$ \\
\hline Iron - Filtered & $\mathrm{mg} / \mathrm{L}$ & $<0.025$ & $<0.025$ & $<0.025$ & $<0.025$ & $<0.025$ \\
\hline Lead - Filtered & $\mathrm{mg} / \mathrm{L}$ & $<0.0005$ & $<0.0005$ & $<0.0005$ & 0.0007 & $<0.0005$ \\
\hline Manganese - Filtered & $\mathrm{mg} / \mathrm{L}$ & $<0.020$ & $<0.020$ & $<0.020$ & $<0.020$ & $<0.020$ \\
\hline Mercury - Filtered & $\mathrm{mg} / \mathrm{L}$ & $<0.0001$ & $<0.0001$ & $<0.0001$ & $<0.0001$ & $<0.0001$ \\
\hline Nickel - Filtered & $\mathrm{mg} / \mathrm{L}$ & $<0.040$ & $<0.040$ & $<0.040$ & $<0.040$ & $<0.040$ \\
\hline Silver - Filtered & $\mathrm{mg} / \mathrm{L}$ & $<0.001$ & $<0.001$ & $<0.001$ & $<0.001$ & $<0.001$ \\
\hline Thallium - Filtered & $\mathrm{mg} / \mathrm{L}$ & $<0.0015$ & $<0.0015$ & $<0.0015$ & $<0.0015$ & $<0.0015$ \\
\hline Vanadium - Filtered & $\mathrm{mg} / \mathrm{L}$ & $<0.055$ & $<0.055$ & $<0.055$ & $<0.055$ & $<0.055$ \\
\hline Zinc - Filtered & $\mathrm{mg} / \mathrm{L}$ & $<0.015$ & $<0.015$ & $<0.015$ & $<0.015$ & 0.035 \\
\hline Cesium-137 & $\mathrm{pCi} / \mathrm{L}$ & $<1.0$ & 1.0 & $<1.0$ & $<1.0$ & $<1.0$ \\
\hline Hydrogen-3 & $\mathrm{nCi} / \mathrm{L}$ & 0.543 & 0.528 & 0.643 & 0.644 & 0.644 \\
\hline Strontium-90 & $\mathrm{pCi} / \mathrm{L}$ & $<0.25$ & $<0.25$ & $<0.25$ & $<0.25$ & $<0.25$ \\
\hline 1,1,1-Trichloroethane & $\mu \mathrm{g} / \mathrm{L}$ & $-a^{a}$ & - & - & 0.5 & - \\
\hline 1,1-Dichloroethane & $\mu \mathrm{g} / \mathrm{L}$ & - & $\therefore$ & - & 0.4 & - \\
\hline 1,4-Dioxane & $\mu \mathrm{g} / \mathrm{L}$ & - & - & - & 39 & - \\
\hline Acetone & $\mu \mathrm{g} / \mathrm{L}$ & - & - & - & - & 3 \\
\hline Methylene Chloride & $\mu \mathrm{g} / \mathrm{L}$ & 2 & - & - & - & 3 \\
\hline
\end{tabular}

a A hyphen indicates that the concentration is below the detection limit. 
TABLE 6.22

Groundwater Monitoring Results: 300 Area, Well 319131D, 1995

\begin{tabular}{|c|c|c|c|c|c|}
\hline \multirow[b]{2}{*}{ Constituent } & \multirow[b]{2}{*}{ Units } & \multirow[b]{2}{*}{ March 8} & \multicolumn{2}{|c|}{$\begin{array}{l}\text { Well Point Elevation } \\
\text { Ground Surface Elevation } \\
\text { Casing Material: }\end{array}$} & \multirow{2}{*}{$\begin{array}{l}\mathrm{m}(\mathrm{MSL}) \\
182.06 \\
203.56 \\
\text { STEEL } \\
\text { Nov. } 9 \\
\end{array}$} \\
\hline & & & May 31 & Aug. 30 & \\
\hline Water Elevation & $\mathrm{m}$ & 184.40 & 184.89 & 184.35 & 184.29 \\
\hline Temperature & ${ }^{\circ} \mathrm{C}$ & 5.9 & 12.6 & 12.0 & 11.0 \\
\hline $\mathrm{pH}$ & $\mathrm{pH}$ & 7.67 & 7.41 & 7.17 & 7.13 \\
\hline Redox & $\mathrm{mV}$ & 369 & 293 & 160 & 116 \\
\hline Conductivity & $\mu \mathrm{mho} / \mathrm{cm}$ & 810 & 850 & 826 & 819 \\
\hline Chloride - Filtered & $\mathrm{mg} / \mathrm{L}$ & 50 & 44 & 50 & 52 \\
\hline Arsenic - Filtered & $\mathrm{mg} / \mathrm{L}$ & $<0.0025$ & $<0.0025$ & $<0.0025$ & $<0.0025$ \\
\hline Barium - Filtered & $\mathrm{mg} / \mathrm{L}$ & 0.0628 & 0.0755 & 0.0713 & 0.0734 \\
\hline Beryllium - Filtered & $\mathrm{mg} / \mathrm{L}$ & $<0.0001$ & $<0.0001$ & $<0.0001$ & $<0.0001$ \\
\hline Cadmium - Filtered & $\mathrm{mg} / \mathrm{L}$ & $<0.0001$ & $<0.0001$ & $<0.0001$ & $<0.0001$ \\
\hline Chromium - Filtered & $\mathrm{mg} / \mathrm{L}$ & $<0.060$ & $<0.060$ & $<0.060$ & $<0.060$ \\
\hline Cobalt - Filtered & $\mathrm{mg} / \mathrm{L}$ & $<0.025$ & $<0.025$ & $<0.025$ & $<0.025$ \\
\hline Copper - Filtered & $\mathrm{mg} / \mathrm{L}$ & $<0.045$ & $<0.045$ & $<0.045$ & $<0.045$ \\
\hline Iron - Filtered & $\mathrm{mg} / \mathrm{L}$ & $<0.0250$ & $<0.0250$ & 0.0328 & $<0.0250$ \\
\hline Lead - Filtered & $\mathrm{mg} / \mathrm{L}$ & $<0.0005$ & $<0.0005$ & 0.0005 & $<0.0005$ \\
\hline Manganese - Filtered & $\mathrm{mg} / \mathrm{L}$ & 0.0286 & $<0.0200$ & $<0.0200$ & $<0.0200$ \\
\hline Mercury - Filtered & $\mathrm{mg} / \mathrm{L}$ & $<0.0001$ & $<0.0001$ & $<0.0001$ & $<0.0001$ \\
\hline Nickel - Filtered & $\mathrm{mg} / \mathrm{L}$ & $<0.040$ & $<0.040$ & $<0.040$ & $<0.040$ \\
\hline Silver - Filtered & $\mathrm{mg} / \mathrm{L}$ & $<0.001$ & $<0.001$ & $<0.001$ & $<0.001$ \\
\hline Thallium - Filtered & $\mathrm{mg} / \mathrm{L}$ & $<0.0015$ & $<0.0015$ & $<0.0015$ & $<0.0015$ \\
\hline Vanadium - Filtered & $\mathrm{mg} / \mathrm{L}$ & $<0.055$ & $<0.055$ & $<0.055$ & $<0.055$ \\
\hline Zinc - Filtered & $\mathrm{mg} / \mathrm{L}$ & $<0.015$ & $<0.015$ & $<0.015$ & $<0.015$ \\
\hline Cesium-137 & $\mathrm{pCi} / \mathrm{L}$ & $<1.0$ & $<1.0$ & $<1.0$ & $<1.0$ \\
\hline Hydrogen-3 & $\mathrm{nCi} / \mathrm{L}$ & 1.259 & 1.329 & 1.299 & 1.023 \\
\hline Strontium-90 & $\mathrm{pCi} / \mathrm{L}$ & $<0.25$ & $<0.25$ & $<0.25$ & $<0.25$ \\
\hline Acetone & $\mu \mathrm{g} / \mathrm{L}$ & $-^{\mathrm{a}}$ & - & - & 2 \\
\hline Carbon Tetrachloride & $\mu \mathrm{g} / \mathrm{L}$ & - & 2 & - & - \\
\hline Methylene Chloride & $\mu \mathrm{g} / \mathrm{L}$ & - & - & - & 2 \\
\hline
\end{tabular}

a A hyphen indicates that the concentration is below the detection limit. 


\section{GROUNDWATER PROTECTION}

Inorganic Results. ANL-E chose to use a conservative approach for evaluating the monitoring results by selecting as the standard of comparison the Illinois Groundwater Quality Standards for Class I: Potable Resource Groundwater, 31 IAC, Section 620.410. The standards are presented in Tables 6.23 and 6.24. In 1995, all samples for metals analyses were field filtered prior to preservation with acid (IEPA requirement for the IEPA-approved groundwater monitoring program at the 800 Area Landfill, Section 6.3.2.3). As noted in previous years, no elevated levels, with respect to the WQS for the inorganics were noted with the exception of $\mathrm{pH}$ at dolomite well 317121D and chloride at well 317101. The $\mathrm{pH}$ changes drastically between the purging of two to five volumes of water. In each case, the last value obtained was recorded. Several wells had elevated levels of barium and manganese, but well below the WQS. Barium concentrations in these wells ranged from $0.02 \mathrm{mg} / \mathrm{L}$ to $0.14 \mathrm{mg} / \mathrm{L}$, and manganese levels ranged from less than $0.02 \mathrm{mg} / \mathrm{L}$ to $0.9 \mathrm{mg} / \mathrm{L}$. The source of the elevated barium and manganese levels is unknown. Elevated levels of manganese have been reported in previous annual reports. ${ }^{19}$

Organic Results. Each well was sampled quarterly and analyzed for VOCs. The results for 1995 are similar to those reported for 1994. VOCs were detected in wells 317021, 319031, 319032, 317052, 317061, 319011, 317101, 317111, 317121D, and 319131D. The levels of volatile organics are persistent and appear to be indicative of different sources of contamination. Once during the year, the wells were sampled and analyzed for SVOCs, PCBs, and pesticides and herbicides. In 1995, no semivolatiles, PCBs, pesticides, or herbicides were found.

Organic WQSs were exceeded for at least one parameter in wells 317021 and 319031 but at very low concentrations. Figure 6.3 shows the results for well 317021 . The major components are 1,1,1-trichloroethane (TCA) and 1,1-dichloroethane, which can be a decomposition product of TCA. As can be seen, the concentrations roughly parallel each other and the levels found are remarkably constant until 1991, at which time a substantial increase is seen. The previous 
TABLE 6.23

Illinois Class I Groundwater Quality

Standards: Inorganics

(Concentrations in $\mathrm{mg} / \mathrm{L}$, except

radionuclides and $\mathrm{pH}$ )

\begin{tabular}{|c|c|}
\hline Constituent & Standard \\
\hline Antimony & 0.006 \\
\hline Arsenic & 0.05 \\
\hline Barium & 2 \\
\hline Beryllium & 0.004 \\
\hline Boron & 2 \\
\hline Cadmium & 0.005 \\
\hline Chloride & 200 \\
\hline Chromium & 0.1 \\
\hline Cobalt & 1 \\
\hline Copper & 0.65 \\
\hline Cyanide & 0.2 \\
\hline Fluoride & 4 \\
\hline Iron & 5 \\
\hline Lead & 0.0075 \\
\hline Manganese & 0.15 \\
\hline Mercury & 0.002 \\
\hline Nickel & 0.1 \\
\hline Nitrate, as $\mathrm{N}$ & 10 \\
\hline Radium-226 & $20 \mathrm{pCi} / \mathrm{L}$ \\
\hline Radium-228 & $20 \mathrm{pCi} / \mathrm{L}$ \\
\hline Selenium & 0.05 \\
\hline Silver & 0.05 \\
\hline Sulfate & 400 \\
\hline Thallium & 0.002 \\
\hline Total Dissolved Solids & 1,200 \\
\hline Zinc & 5 \\
\hline $\mathrm{pH}$ & 6.5-9.0 units \\
\hline
\end{tabular}


TABLE 6.24

Illinois Class I Groundwater Quality

Standards: Organics

(Concentrations in $\mathrm{mg} / \mathrm{L}$ )

\begin{tabular}{|c|c|}
\hline Constituent & Standard \\
\hline Alachlor & 0.002 \\
\hline Aldicarb & 0.003 \\
\hline Atrazine & 0.003 \\
\hline Benzene & 0.005 \\
\hline Benzo(a)pyrene & 0.0002 \\
\hline Carbofuran & 0.04 \\
\hline Carbon Tetrachloride & 0.005 \\
\hline Chlordane & 0.002 \\
\hline Dalapon & 0.2 \\
\hline Dichloromethane & 0.005 \\
\hline Di(2-ethyhexyl)phthalate & 0.006 \\
\hline Dinoseb & 0.007 \\
\hline Endothall & 0.1 \\
\hline Endrin & 0.002 \\
\hline Ethylene Dibromide & 0.00005 \\
\hline Heptachlor & 0.0004 \\
\hline Heptachlor Epoxide & 0.0002 \\
\hline Hexachlorocyclopentadiene & 0.05 \\
\hline Lindane & 0.0002 \\
\hline $2,4-\mathrm{D}$ & 0.07 \\
\hline o-Dichlorobenzene & 0.6 \\
\hline p-Dichlorobenzene & 0.075 \\
\hline 1,2-Dibromo-3-Chloropropane & 0.0002 \\
\hline 1,2-Dichloroethane & 0.005 \\
\hline 1,1-Dichloroethene & 0.007 \\
\hline cis-1,2-Dichloroethylene & 0.07 \\
\hline trans-1,2-Dichloroethylene & 0.1 \\
\hline 1,2-Dichloropropane & 0.005 \\
\hline Ethylbenzene & 0.7 \\
\hline Methoxychlor & 0.04 \\
\hline Monochlorobenzene & 0.1 \\
\hline Pentachlorophenol & 0.001 \\
\hline
\end{tabular}


TABLE 6.24 (Cont.)

\begin{tabular}{ll}
\hline Constituent & Standard \\
\hline & \\
Phenols & 0.1 \\
Picloram & 0.5 \\
PCBs (decachlorobiphenyl) & 0.0005 \\
Simazine & 0.004 \\
Styrene & 0.1 \\
2,4-5-TP (Silvex) & 0.05 \\
Tetrachloroethylene & 0.005 \\
Toluene & 1 \\
Toxaphene & 0.003 \\
1,1,1-Trichloroethane & 0.2 \\
1,1,2-Trichloroethane & 0.005 \\
1,2,4-Trichlorobenzene & 0.07 \\
Trichloroethylene & 0.005 \\
Vinyl Chloride & 0.002 \\
Xylenes & 10 \\
\hline
\end{tabular}

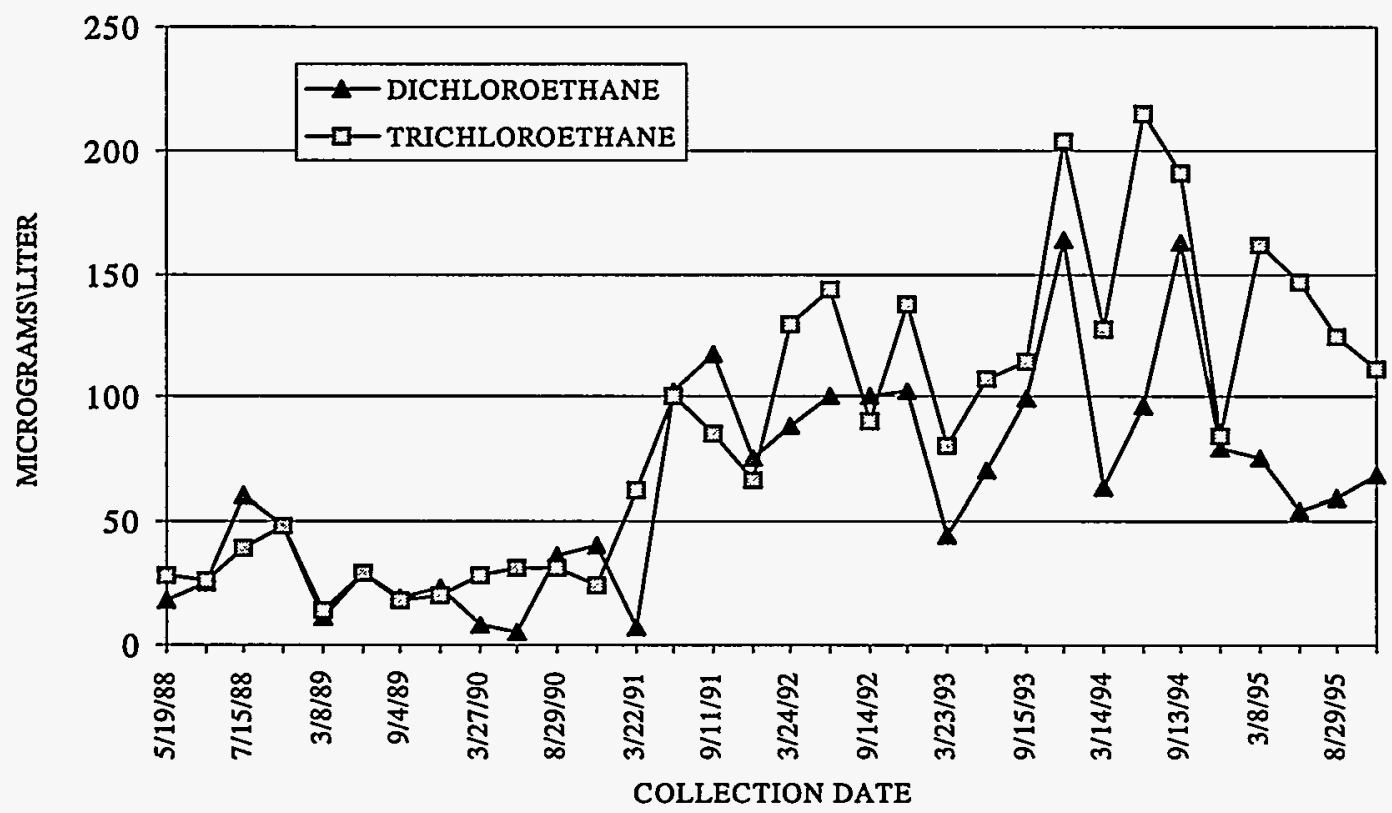

Figure 6.3 Concentration of 1,1-Dichioroethane and 1,1,1-Trichloroethane in Well \#317021 


\section{GROUNDWATER PROTECTION}

consistency would indicate that this well is sampling a large area of contaminated water that is unaffected by seasonal water level changes. The large increase in the summer and fall of 1991 is clearly related to a period of intense drought and could be related to restricted flow of normal dilution water. Carbon tetrachloride, 1,2,-dichloroethane, and trichloroethene (TCE) were found. Trace levels of acetone, chloroform, tetrachloroethene, methylene chloride, vinyl chloride, and 1,1-dichloroethene were also found in this well but at levels well below the WQS; 1,1-dichloroethene can be a decomposition product of TCE. The well is immediately below a former sewer line that was known to be contaminated. The sewer line was permanently closed in 1986.

Wells 317081 and 317091 are adjacent to the storage vaults and are close to one another. Well 317081 was damaged and could not be sampled during 1995. VOCs have been found in past years in well 317081, mainly TCE, 1,2-DCE, and carbon tetrachloride. When TCE breaks down in the presence of soil bacteria, the cis isomer of 1,2-DCE is produced almost exclusively. The fact that they have both been present in past years at relatively stable concentrations indicates that there may be an ongoing release of TCE into the groundwater, such as from highly contaminated soil. The half-life for the conversion indicated is about 30 days. The end product of this conversion is vinyl chloride, which has a half-life of 26,000 days. Vinyl chloride was never detected.

During 1995, well 317091 was sampled only during two quarters because of restricted access related to 317 Area characterization activities. In past years, the levels and variety of volatile organics found in this well have been quite variable with levels appearing to decrease over time. No volatile organics were found in this well during 1995.

Well 319031 is frequently dry but contains organic constituents when water is present. During 1995, this well was sampled one quarter and only TCE was found at a level that exceeded the WQS of $5 \mu \mathrm{g} / \mathrm{L}$. In the past, more VOCs have been found. Dolomite well 317121D had trace levels of a number of VOCs that included 2-butanone, 2-heptanone, 2-hexanone, acetone, and methylene chloride. 
PCB compounds were reported in several of the wells in 1990. These wells were resampled in 1991, 1992, 1993, 1994, and 1995, and no PCBs were indicated. Semivolatile organics and pesticides/herbicides were not detected in any of the wells during 1995.

Manholes E1 and E2, described in Sections 6.2.1 and 6.2.2, in the 317 Area are sampled monthly and analyzed for VOCs. The results are presented in Table 6.25. Existing foundation drains around storage vaults convey groundwater away from the structures and into manholes E1 and E2. Volatile organics are detected at fairly consistent levels in all samples as shown in Figure 6.4. As previously discussed for well 317081, the consistency would indicate that these manholes are collecting an area of contaminated water. The fact that levels are constant and the TCE, 1,2-DCE, and carbon tetrachloride, are present in most of the samples, indicates an ongoing release of these compounds into the groundwater, such as from highly contaminated soils. Trace levels of acetone, benzene, bromodichloromethane, 2-butanone, trans-1,2-dichloroethene, 1,2-dichloroethane, trichlorofluoromethane, 4-methyl-2-pentanone, ethyl ether, and methylene

\section{TABLE 6.25}

Volatile Organic Compounds in 317 Area: Manholes E-1 and E-2, 1995

(Concentrations in $\mu \mathrm{g} / \mathrm{L}$ )

\begin{tabular}{|c|c|c|c|c|c|c|c|c|c|c|}
\hline \multirow[b]{2}{*}{ Date } & \multicolumn{2}{|c|}{ Chloroform } & \multicolumn{2}{|c|}{$\begin{array}{c}\text { Tetra- } \\
\text { chloroethene }\end{array}$} & \multicolumn{2}{|c|}{$\begin{array}{c}\text { Tri- } \\
\text { chloroethene }\end{array}$} & \multicolumn{2}{|c|}{$\begin{array}{c}\text { cis-1,2- } \\
\text { Dichloroethene }\end{array}$} & \multicolumn{2}{|c|}{$\begin{array}{c}\text { Carbon } \\
\text { Tetrachloride }\end{array}$} \\
\hline & E-1 & $\mathrm{E}-2$ & E-1 & $\mathrm{E}-2$ & E-1 & E-2 & E-1 & E-2 & E-1 & E-2 \\
\hline $1 / 9 / 95$ & 219 & 4 & 58 & 7 & 9 & 8 & 19 & 23 & 583 & 18 \\
\hline 2/7/95 & 89 & 8 & 54 & 13 & 15 & 9 & 15 & 17 & 327 & 41 \\
\hline $3 / 6 / 95$ & 111 & 4 & 51 & 6 & 6 & 4 & 10 & 10 & 402 & 17 \\
\hline $4 / 17 / 95$ & 861 & 70 & 93 & 34 & 110 & 21 & 53 & 16 & 765 & 206 \\
\hline $5 / 9 / 95$ & 115 & 52 & 329 & $<1$ & 16 & 8 & 6 & $<1$ & 1405 & 157 \\
\hline $6 / 5 / 95$ & 861 & 19 & 128 & 16 & 177 & 22 & 47 & 19 & 905 & 75 \\
\hline $7 / 7 / 95$ & 133 & 12 & 312 & 87 & 18 & 2 & 10 & $<1$ & 1143 & 335 \\
\hline $8 / 7 / 95$ & 178 & 16 & 154 & 87 & 32 & 5 & 27 & 4 & 576 & 302 \\
\hline $9 / 5 / 95$ & 164 & 28 & 136 & 128 & 14 & 5 & 14 & 3 & 681 & 560 \\
\hline $10 / 3 / 95$ & 805 & 2 & 77 & 9 & 230 & $<1$ & 163 & $<1$ & 490 & 43 \\
\hline $11 / 6 / 95$ & 369 & 2 & 141 & 3 & 66 & 14 & 27 & 4 & 693 & 7 \\
\hline $12 / 4 / 95$ & 130 & 9 & 56 & 5 & 4 & 2 & 3 & 3 & 539 & 16 \\
\hline
\end{tabular}



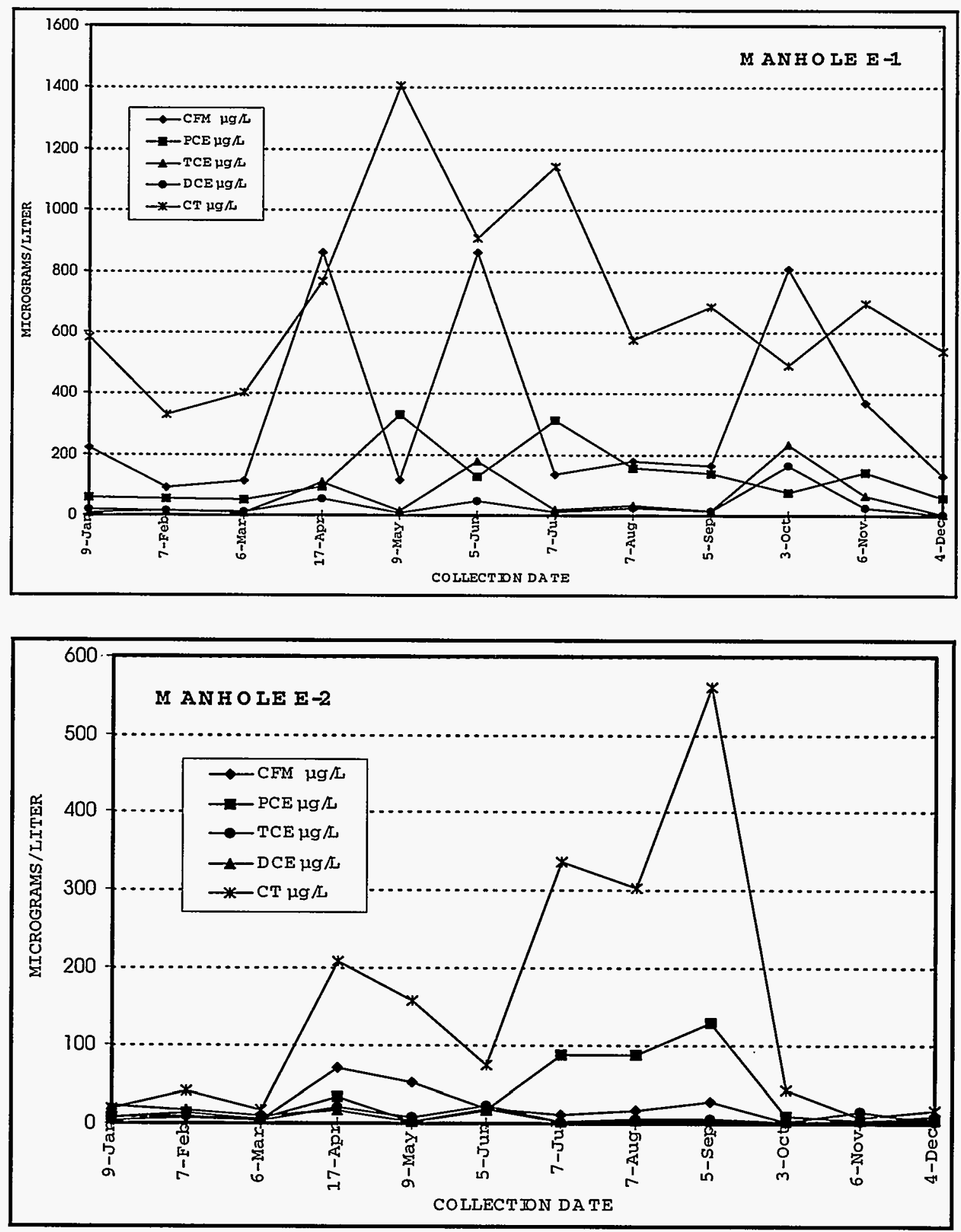

Figure 6.4 Trends of Selected Organics in 317 Area Manholes, 1995 


\section{GROUNDWATER PROTECTION}

chloride, have been found but not on a consistent basis. Carbon tetrachloride was detected in all samples in both manholes. The source of these compounds is believed to be the French drains previously described in Section 6.2.1; however, additional characterization activities described in Section 6.5.2 will better define the nature, rate, and extent of contamination at this location.

Radioactive Constituents. Samples collected quarterly from the monitoring wells in the 317 and 319 Areas were analyzed for hydrogen-3, strontium-90, and gamma-ray emitters. The results are presented in Tables 6.12 to 6.22. Evidence of possible migration of radionuclides off the site is noted by the low concentrations of hydrogen-3 in wells 319031, 319032, and 319131D, which are located near the south perimeter fence. During one quarter, a small amount of cesium137 was detected in wells $317021,317121 \mathrm{D}$, and 319032 . A small amount of strontium-90 was also detected in wells 317021 and 319031 . These monitoring wells are directly below a small drainage swale from the 319 Area that has contained water intermittently with measurable concentrations of hydrogen-3 and strontium-90. All concentrations are well below any applicable standards.

\subsection{Sanitary Landfill}

The 800 Area is the site of ANL-E's sanitary landfill. The 8.8-ha (21.8-acre) landfill is located on the western edge of ANL-E property (Figure 1.1). The landfill has received waste since 1966 and operated under IEPA permit No. 1981-29-OP, which was issued on September 18, 1981. ${ }^{34}$ The landfill received general refuse, construction debris, boiler house ash, and other nonradioactive solid waste until September 1992. The landfill is now being closed pursuant to permit number 1992-002-SP and supplemental permit number 1994-506-SP.

\subsubsection{French Drain}

The landfill area was used for the disposal of certain types of liquid wastes from 1969 to 1978. The wastes were poured into a French drain that consisted of a corrugated steel pipe placed in a gravel-filled pit dug into an area previously filled with waste. The liquid waste was poured into the drain and allowed to permeate into the gravel and thence into the soil and fill material. 
Available documentation indicates that $109,000 \mathrm{~L}$ (29,000 gal) of liquid waste were placed in this drain. Many of the wastes disposed of in this manner are now defined as hazardous wastes. The presence of volatile and other toxic organic compounds has been confirmed by soil gas surveys conducted at the landfill. Measurable amounts of these materials were identified in soil vapors and in shallow groundwater of the landfill.

\subsubsection{Monitoring Studies}

During October 1992, 15 stainless steel wells, wells 800161 through 800203D, were installed around the landfill as part of the IEPA-approved closure plan. These wells are required to be monitored as part of the IEPA-approved groundwater monitoring program, effective January 1995. These wells are set in five clusters, each cluster consisting of a shallow, medium, and deep well (see Figure 6.5 and Table 6.26). Wells 800172 and 800182 are consistently dry.

Prior to 1995, the groundwater monitoring network surrounding the 800 Area Landfill consisted of 16 wells. All results for samples collected from this network have been previously reported in ANL-E Site Environmental Reports. In January 1995, the IEPA deleted the 16 wells from the groundwater monitoring network. During October 1995, each well was abandoned and sealed in accordance with state and county well code requirements.

\subsubsection{Sample Collection}

The same procedure for well water sample collection previously described for the 300 Area was used for this area. Each well is sampled annually for semivolatiles, PCBs, pesticides, and herbicides. Also, during the second quarter, in accordance with the IEPA-approved groundwater monitoring plan, both filtered and unfiltered samples for numerous parameters (e.g., metals, chloride, sulfate) are required. Volatile organics are required to be monitored only during the second quarter. 


\section{GROUNDWATER PROTECTION}

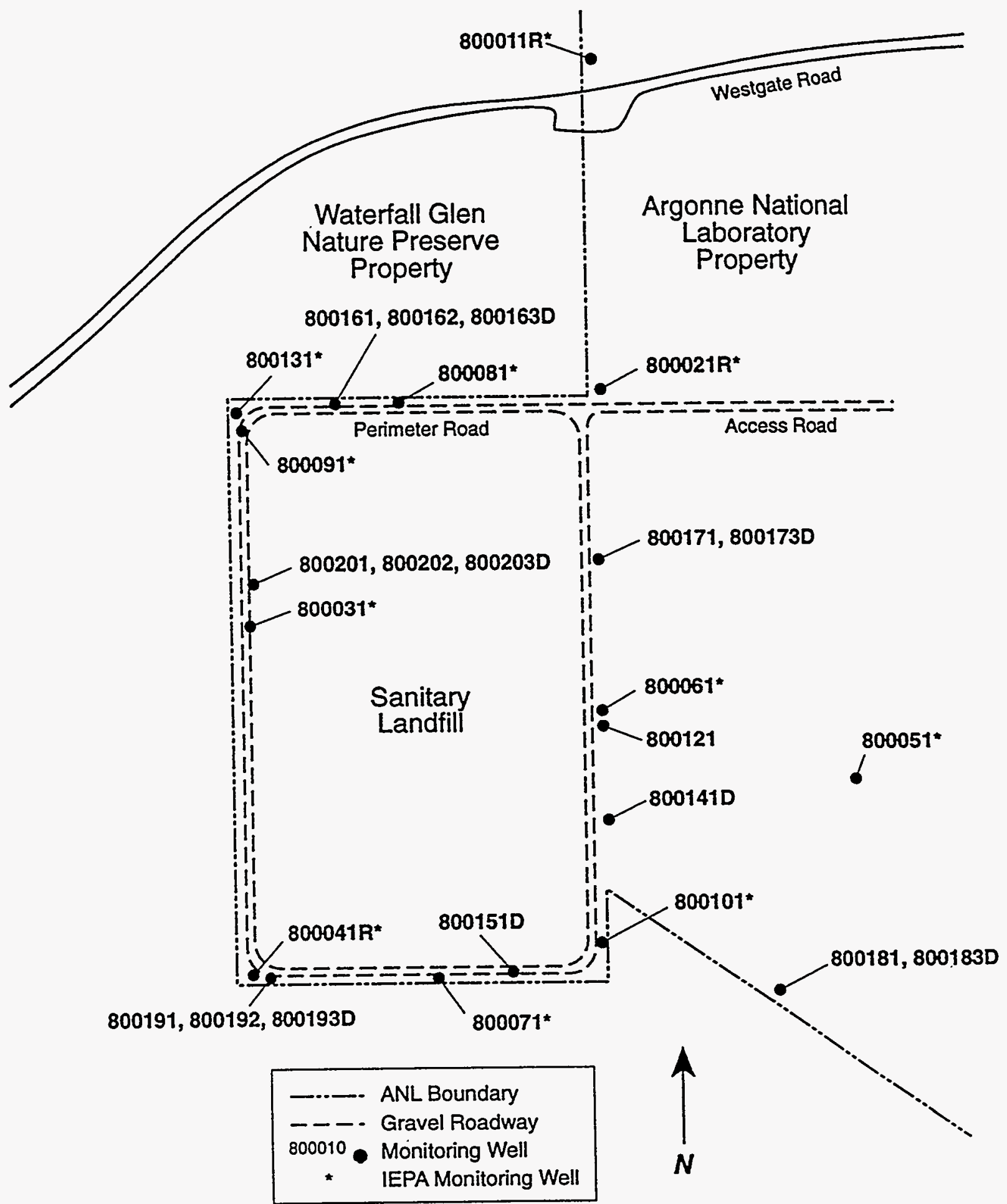

Figure 6.5 Active Monitoring Wells in the 800 Area Landfill (not to scale) 
TABLE 6.26

Groundwater Monitoring Wells: 800 Area Landfill

\begin{tabular}{lrrlrrr}
\hline $\begin{array}{l}\text { ID } \\
\text { Number }\end{array}$ & $\begin{array}{c}\text { Well } \\
\text { Depth }^{\mathrm{a}}\end{array}$ & $\begin{array}{c}\text { Ground } \\
\text { Elevation }^{\mathrm{b}}\end{array}$ & $\begin{array}{c}\text { Monitoring } \\
\text { Zone }^{\mathrm{c}}\end{array}$ & $\begin{array}{c}\text { Well } \\
\text { Type }^{\mathrm{d}}\end{array}$ & $\begin{array}{c}\text { Date } \\
\text { Drilled }\end{array}$ & $\begin{array}{c}\text { Water } \\
\text { Elevation }\end{array}$ \\
\hline 800161 & 25 & 757.1 & $20-25 / 737-732$ & $2 / \mathrm{SS}$ & $10 / 92$ & 754.53 \\
800162 & 70 & 757.0 & $65-70 / 692-687$ & $2 / \mathrm{SS}$ & $10 / 92$ & 718.35 \\
$800163 \mathrm{D}$ & 154 & 757.1 & $144-154 / 613-603$ & $2 / \mathrm{SS}$ & $9 / 92$ & 642.78 \\
800171 & 25 & 749.4 & $20-25 / 729-724$ & $2 / \mathrm{SS}$ & $10 / 92$ & 739.73 \\
$800173 \mathrm{D}$ & 129 & 749.4 & $119-129 / 630-620$ & $2 / \mathrm{SS}$ & $10 / 92$ & 632.84 \\
800181 & 35 & 756.3 & $30-35 / 726-721$ & $2 / \mathrm{SS}$ & $10 / 92$ & 734.65 \\
$800183 \mathrm{D}$ & 164 & 755.8 & $154-164 / 602-592$ & $2 / \mathrm{SS}$ & $10 / 92$ & 632.71 \\
800191 & 15 & 746.0 & $10-15 / 736-731$ & $2 / \mathrm{SS}$ & $10 / 92$ & 743.46 \\
800192 & 60 & 746.0 & $55-60 / 691-686$ & $2 / \mathrm{SS}$ & $10 / 92$ & 733.31 \\
$800193 \mathrm{D}$ & 151 & 746.0 & $141-151 / 605-595$ & $2 / \mathrm{SS}$ & $10 / 92$ & 632.72 \\
800201 & 35 & 747.8 & $30-35 / 718-713$ & $2 / \mathrm{SS}$ & $10 / 92$ & 734.42 \\
800202 & 60 & 747.8 & $55-60 / 693-688$ & $2 / \mathrm{SS}$ & $10 / 92$ & 718.35 \\
$800203 \mathrm{D}$ & 126 & 747.8 & $116-126 / 632-622$ & $2 / \mathrm{SS}$ & $9 / 92$ & 632.64 \\
\hline
\end{tabular}

Note: Wells identified by a " $D$ " are deeper wells monitoring the dolomite bedrock aquifer.
a Feet below ground.
b Feet mean sea level.
c Depth/elevation.
d Inner diameter (in.)/well material (SS = stainless steel).

\subsubsection{Sample Analyses - 800 Area}

The 800 Area sample analyses were performed using SOPs written, reviewed, and issued as controlled documents by members of the ESH-DACH, ESH-DACL, and ESH-DARC. These SOP reference protocols can be found in SW-846, 3rd edition, "Test Methods for Evaluating Solid Waste." 9 Sixteen metals were routinely determined. Ten metals were analyzed using flame atomic absorption spectroscopy and inductively coupled plasma atomic emission spectroscopy, and five metals were analyzed by graphite furnace atomic absorption spectroscopy. Mercury was determined by cold vapor atomic absorption spectroscopy. VOCs were determined by using a 


\section{GROUNDWATER PROTECTION}

purge and trap sample pretreatment followed by gas chromatography-mass spectroscopy detection. SVOCs were determined by solvent extraction followed by gas chromatography-mass spectroscopy detection. $\mathrm{PCB} /$ pesticides were determined by solvent extraction followed by gas chromatography-electron capture detection. In the case of organic compound analyses, efforts were made to identify compounds that were present but not included on the method list. This was accomplished and standard solutions of these compounds were prepared and analyzed. TDS were determined gravimetrically. Sulfate determination was performed using a turbidimetric technique while chloride was determined by titrimetry. Ammonia was determined by using distillation followed by an ion selective electrode technique.

Some analyses were performed at an off-site contracted laboratory. SW- $846^{9}$ procedures were specified and used. Cyanide and phenol were determined by distillation followed by a spectrophotometric finish. Total organic carbon and total organic halide were determined by combustion techniques followed by infrared detection and coulometric titration, respectively.

The 800 Area groundwater radiological analyses were performed using SOPs written, reviewed, and issued as controlled documents by members of the ESH-DARC Section. Hydrogen- 3 was determined by distillation followed by a beta liquid scintillation counting technique. Strontium-90 was determined by an ion-exchange separation followed by a proportional counting technique.

\subsubsection{Results of Analyses}

A description of each well, a list of field parameters measured during sample collection, and the results of chemical and radiological analysis of samples from the wells in the 800 Area are contained in Tables 6.27 to 6.39. All radiological and inorganic analysis results are shown in these tables. The analytical methods used for organic compounds will identify and quantify all the compounds contained in the CLP Target Compound List. However, the vast majority of these compounds were not detected in the samples. Only those constituents that were present in amounts great enough to quantify are shown. The detection limits for the organic compounds listed were typically 1 to $5 \mu \mathrm{g} / \mathrm{L}$. Figures 6.6 to 6.20 show the trends for exceedances of the 
TABLE 6.27

Groundwater Monitoring Results: Sanitary Landfill, Well 800161, 1995

\begin{tabular}{|c|c|c|c|c|c|c|}
\hline \multirow[b]{2}{*}{ Constituent } & \multirow[b]{2}{*}{ Units } & \multirow[b]{2}{*}{ Feb. 14} & \multicolumn{3}{|c|}{$\begin{array}{l}\text { Well Point Elevation } \\
\text { Ground Surface Elevation } \\
\text { Casing Material: }\end{array}$} & \multirow{2}{*}{$\begin{array}{l}\text { m(MSL) } \\
223.11 \\
230.76 \\
\text { S. STEEL } \\
\text { Oct. } 10\end{array}$} \\
\hline & & & April 4 & April 4 & July 12 & \\
\hline Water Elevation & $\mathrm{m}$ & 228.19 & 228.98 & 228.9800 & 227.1300 & 225.8800 \\
\hline Temperature & ${ }^{\circ} \mathrm{C}$ & 10.5 & 10.3 & 10.3 & 11.5 & 11.5 \\
\hline $\mathrm{pH}$ & $\mathrm{pH}$ & 7.21 & 7.32 & 7.32 & 7.33 & 7.12 \\
\hline Redox & $\mathrm{mV}$ & 257 & 326 & 326 & 400 & 26 \\
\hline Conductivity & $\mu \mathrm{mho} / \mathrm{cm}$ & 1008 & 1011 & 1011 & 1065 & 1060 \\
\hline Chloride - Filtered & $\mathrm{mg} / \mathrm{L}$ & 82 & 77 & 79 & 87 & 85 \\
\hline Fluoride - Filtered & $\mathrm{mg} / \mathrm{L}$ & $-{ }^{a}$ & 0.262 & - & - & - \\
\hline Sulfate - Filtered & $\mathrm{mg} / \mathrm{L}$ & 178 & 135 & 136 & 177 & 178 \\
\hline Total Dissolved Solids - Filtered & $\mathrm{mg} / \mathrm{L}$ & 941 & - & 859 & 898 & 949 \\
\hline Cyanide (Total) & $\mathrm{mg} / \mathrm{L}$ & $<0.002$ & - & $<0.002$ & $<0.002$ & $<0.002$ \\
\hline Arsenic & $\mathrm{mg} / \mathrm{L}$ & - & - & $<0.0025$ & - & - \\
\hline Barium & $\mathrm{mg} / \mathrm{L}$ & - & - & 0.1628 & - & - \\
\hline Beryllium & $\mathrm{mg} / \mathrm{L}$ & - & - & $<0.0001$ & - & - \\
\hline Boron & $\mathrm{mg} / \mathrm{L}$ & - & - & 0.1066 & - & - \\
\hline Cadmium & $\mathrm{mg} / \mathrm{L}$ & - & - & 0.0001 & - & - \\
\hline Chromium & $\mathrm{mg} / \mathrm{L}$ & - & - & $<0.060$ & - & - \\
\hline Cobalt & $\mathrm{mg} / \mathrm{L}$ & - & - & $<0.025$ & - & - \\
\hline Copper & $\mathrm{mg} / \mathrm{L}$ & - & - & $<0.045$ & - & - \\
\hline Iron & $\mathrm{mg} / \mathrm{L}$ & - & - & 1.263 & - & - \\
\hline Lead & $\mathrm{mg} / \mathrm{L}$ & - & - & 0.0016 & - & - \\
\hline Manganese & $\mathrm{mg} / \mathrm{L}$ & - & - & 0.6658 & - & - \\
\hline Mercury & $\mathrm{mg} / \mathrm{L}$ & - & - & $<0.0001$ & - & - \\
\hline Nickel & $\mathrm{mg} / \mathrm{L}$ & - & - & $<0.040$ & - & - \\
\hline Silver & $\mathrm{mg} / \mathrm{L}$ & - & - & 0.0026 & - & - \\
\hline Thallium & $\mathrm{mg} / \mathrm{L}$ & - & - & $<0.0015$ & - & - \\
\hline Vanadium & $\mathrm{mg} / \mathrm{L}$ & - & - & $<0.055$ & - & - \\
\hline Zinc & $\mathrm{mg} / \mathrm{L}$ & - & - & $<0.015$ & - & - \\
\hline Ammonia nitrogen - Filtered & $\mathrm{mg} / \mathrm{L}$ & 0.7 & - & 0.3 & 0.3 & 0.1 \\
\hline Arsenic - Filtered & $\mathrm{mg} / \mathrm{L}$ & $<0.0025$ & $<0.0025$ & - & $<0.0025$ & $<0.0025$ \\
\hline Barium - Filtered & $\mathrm{mg} / \mathrm{L}$ & 0.1631 & 0.1573 & - & 0.1553 & 0.1498 \\
\hline Beryllium - Filtered & $\mathrm{mg} / \mathrm{L}$ & $<0.0001$ & $<0.0001$ & - & $<0.0001$ & $<0.0001$ \\
\hline Cadmium - Filtered & $\mathrm{mg} / \mathrm{L}$ & $<0.0001$ & $<0.0001$ & - & 0.0001 & $<0.0001$ \\
\hline Chromium - Filtered & $\mathrm{mg} / \mathrm{L}$ & $<0.060$ & $<0.060$ & - & $<0.060$ & $<0.060$ \\
\hline Cobalt - Filtered & $\mathrm{mg} / \mathrm{L}$ & $<0.025$ & $<0.025$ & - & $<0.025$ & $<0.025$ \\
\hline Copper - Filtered & $\mathrm{mg} / \mathrm{L}$ & $<0.045$ & $<0.045$ & - & $<0.045$ & $<0.045$ \\
\hline Iron - Filtered & $\mathrm{mg} / \mathrm{L}$ & $<0.0200$ & 0.0451 & - & 0.0447 & $<0.0250$ \\
\hline Lead - Filtered & $\mathrm{mg} / \mathrm{L}$ & $<0.0005$ & $<0.0005$ & - & $<0.0005$ & $<0.0005$ \\
\hline Manganese - Filtered & $\mathrm{mg} / \mathrm{L}$ & 0.7610 & 0.6519 & - & 0.5419 & 0.6984 \\
\hline Mercury - Filtered & $\mathrm{mg} / \mathrm{L}$ & $<0.0001$ & $<0.0001$ & - & $<0.0001$ & $<0.0001$ \\
\hline Nickel - Filtered & $\mathrm{mg} / \mathrm{L}$ & $<0.040$ & $<0.040$ & - & $<0.040$ & $<0.040$ \\
\hline Silver - Filtered & $\mathrm{mg} / \mathrm{L}$ & $<0.001$ & $<0.001$ & - & $<0.001$ & $<0.001$ \\
\hline Thallium - Filtered & $\mathrm{mg} / \mathrm{L}$ & $<0.0015$ & $<0.0015$ & - & $<0.0015$ & $<0.0015$ \\
\hline Vanadium - Filtered & $\mathrm{mg} / \mathrm{L}$ & $<0.055$ & $<0.055$ & - & $<0.055$ & $<0.055$ \\
\hline Zinc - Filtered & $\mathrm{mg} / \mathrm{L}$ & $<0.015$ & $<0.015$ & - & $<0.015$ & $<0.015$ \\
\hline Nitrate & $\mathrm{mg} / \mathrm{L}$ & - & $<0.50$ & - & - & - \\
\hline Phenols & $\mathrm{mg} / \mathrm{L}$ & $<0.015$ & - & $<0.020$ & $<0.015$ & $<0.020$ \\
\hline Hydrogen-3 & $\mathrm{nCi} / \mathrm{L}$ & 0.280 & - & 0.290 & 0.277 & 0.215 \\
\hline Total organic carbons & $\mathrm{mg} / \mathrm{L}$ & 2.3 & - & 3.2 & 3.5 & 4.4 \\
\hline Total organic carbons & $\mathrm{mg} / \mathrm{L}$ & 2.3 & - & 3.1 & 3.7 & 5.5 \\
\hline Total organic carbons & $\mathrm{mg} / \mathrm{L}$ & 2.6 & - & 3.1 & 3.7 & 4.5 \\
\hline Total organic carbons & $\mathrm{mg} / \mathrm{L}$ & 2.6 & - & 3.0 & 3.6 & 4.4 \\
\hline Total organic halogens & $\mathrm{mg} / \mathrm{L}$ & 0.014 & - & $<0.010$ & 0.016 & $<0.010$ \\
\hline Total organic halogens & $\mathrm{mg} / \mathrm{L}$ & 0.015 & - & $<0.010$ & 0.016 & $<0.010$ \\
\hline Methylene Chloride & $\mu \mathrm{g} / \mathrm{L}$ & - & - & 3 & 1 & 4 \\
\hline
\end{tabular}

a A hyphen indicates that no analysis was performed. 


\section{TABLE 6.28}

Groundwater Monitoring Results: Sanitary Landfill, Well 800162, 1995

$\begin{array}{ll}\text { Well Point Elevation } & \text { m(MSL) } \\ \text { Ground Surface Elevation } & 209.40 \\ \text { Casing Material: } & \text { S. STEEL }\end{array}$

\begin{tabular}{|c|c|c|c|c|c|c|c|}
\hline Constituent & Units & Feb. 28 & April 6 & April 6 & July 12 & July 12 & Oct. 12 \\
\hline Water Elevation & $\mathrm{m}$ & 218.92 & 219.03 & 219.03 & 219.29 & 219.29 & 218.22 \\
\hline Temperature $\mathrm{pH}$ & ${ }^{\circ} \mathrm{C}$ & 11.2 & 11.1 & 11.1 & 11.7 & 11.7 & 11.3 \\
\hline $\mathrm{pH}$ & $\mathrm{pH}$ & 7.09 & 6.50 & 6.50 & 7.10 & 7.10 & 6.96 \\
\hline Redox & $\mathrm{mV}$ & 269 & 299 & 299 & 412 & 412 & -52 \\
\hline Conductivity & $\mu \mathrm{mho} / \mathrm{cm}$ & 730 & 723 & 723 & 759 & 759 & 760 \\
\hline Chloride - Filtered & $\mathrm{mg} / \mathrm{L}$ & 52 & 49 & 49 & 45 & 44 & 46 \\
\hline Fluoride - Filtered & $\mathrm{mg} / \mathrm{L}$ & $-a^{a}$ & 0.254 & - & - & - & - \\
\hline Sulfate - Filtered & $\mathrm{mg} / \mathrm{L}$ & 60 & 55 & 64 & 64 & 59 & 67 \\
\hline Total Dissolved Solids - Filtered & $\mathrm{mg} / \mathrm{L}$ & 613 & - & 559 & 606 & 619 & 597 \\
\hline Cyanide (Total) & $\mathrm{mg} / \mathrm{L}$ & $<0.002$ & - & $<0.002$ & $<0.002$ & $<0.002$ & $<0.002$ \\
\hline Arsenic & $\mathrm{mg} / \mathrm{L}$ & - & - & 0.0025 & - & - & - \\
\hline Barium & $\mathrm{mg} / \mathrm{L}$ & - & - & 0.0563 & - & - & - \\
\hline Beryllium & $\mathrm{mg} / \mathrm{L}$ & - & - & $<0.0001$ & - & - & - \\
\hline Boron & $\mathrm{mg} / \mathrm{L}$ & - & - & 0.1654 & - & - & - \\
\hline Cadmium & $\mathrm{mg} / \mathrm{L}$ & - & - & $<0.0001$ & - & - & - \\
\hline Chromium & $\mathrm{mg} / \mathrm{L}$ & - & - & $<0.060$ & - & - & - \\
\hline Cobalt & $\mathrm{mg} / \mathrm{L}$ & - & - & $<0.025$ & - & - & - \\
\hline Copper & $\mathrm{mg} / \mathrm{L}$ & - & - & $<0.045$ & - & - & - \\
\hline Iron & $\mathrm{mg} / \mathrm{L}$ & - & - & 1.911 & - & - & - \\
\hline Lead & $\mathrm{mg} / \mathrm{L}$ & - & - & 0.0006 & - & - & - \\
\hline Manganese & $\mathrm{mg} / \mathrm{L}$ & - & - & 0.6945 & - & - & - \\
\hline Mercury & $\mathrm{mg} / \mathrm{L}$ & - & - & $<0.0001$ & - & - & - \\
\hline Nickel & $\mathrm{mg} / \mathrm{L}$ & - & - & $<0.040$ & - & - & - \\
\hline Silver & $\mathrm{mg} / \mathrm{L}$ & - & - & $<0.001$ & - & - & - \\
\hline Thallium & $\mathrm{mg} / \mathrm{L}$ & - & - & $<0.0015$ & - & - & - \\
\hline Vanadium & $\mathrm{mg} / \mathrm{L}$ & - & - & $<0.055$ & - & - & - \\
\hline Zinc & $\mathrm{mg} / \mathrm{L}$ & - & - & $<0.015$ & - & & - \\
\hline Ammonia nitrogen - Filtered & $\mathrm{mg} / \mathrm{L}$ & 0.4 & - & 0.2 & 0.1 & 0.1 & 0.4 \\
\hline Arsenic - Filtered & $\mathrm{mg} / \mathrm{L}$ & $<0.0025$ & $<0.0025$ & - & $<0.0025$ & $<0.0025$ & $<0.0025$ \\
\hline Barium - Filtered & $\mathrm{mg} / \mathrm{L}$ & 0.0376 & 0.0444 & - & 0.0435 & 0.0435 & 0.0400 \\
\hline Beryllium - Filtered & $\mathrm{mg} / \mathrm{L}$ & $<0.0001$ & $<0.0001$ & - & $<0.0001$ & $<0.0001$ & $<0.0001$ \\
\hline Cadmium - Filtered & $\mathrm{mg} / \mathrm{L}$ & $<0.0001$ & $<0.0001$ & - & $<0.0001$ & $<0.0001$ & 0.0001 \\
\hline Chromium - Filtered & $\mathrm{mg} / \mathrm{L}$ & $<0.060$ & $<0.060$ & - & $<0.060$ & $<0.060$ & $<0.060$ \\
\hline Cobalt - Filtered & $\mathrm{mg} / \mathrm{L}$ & $<0.025$ & $<0.025$ & - & $<0.025$ & $<0.025$ & $<0.025$ \\
\hline Copper - Filtered & $\mathrm{mg} / \mathrm{L}$ & $<0.045$ & $<0.045$ & - & $<0.045$ & $<0.045$ & $<0.045$ \\
\hline Iron - Filtered & $\mathrm{mg} / \mathrm{L}$ & 0.4710 & 0.9373 & - & 0.6197 & 0.3844 & 0.4012 \\
\hline Lead - Filtered & $\mathrm{mg} / \mathrm{L}$ & $<0.0005$ & $<0.0005$ & - & $<0.0005$ & $<0.0005$ & 0.0008 \\
\hline Manganese - Filtered & $\mathrm{mg} / \mathrm{L}$ & 0.7220 & 0.5988 & - & 0.5147 & 0.5414 & 0.2987 \\
\hline Mercury - Filtered & $\mathrm{mg} / \mathrm{L}$ & $<0.0001$ & $<0.0001$ & - & $<0.0001$ & $<0.0001$ & $<0.0001$ \\
\hline Nickel - Filtered & $\mathrm{mg} / \mathrm{L}$ & $<0.040$ & $<0.040$ & - & $<0.040$ & $<0.040$ & $<0.040$ \\
\hline Silver - Filtered & $\mathrm{mg} / \mathrm{L}$ & $<0.001$ & $<0.001$ & - & $<0.001$ & $<0.001$ & $<0.001$ \\
\hline Thallium - Filtered & $\mathrm{mg} / \mathrm{L}$ & $<0.0015$ & $<0.0015$ & - & $<0.0015$ & $<0.0015$ & $<0.0015$ \\
\hline Vanadium - Filtered & $\mathrm{mg} / \mathrm{L}$ & $<0.055$ & $<0.055$ & - & $<0.055$ & $<0.055$ & $<0.055$ \\
\hline Zinc - Filtered & $\mathrm{mg} / \mathrm{L}$ & $<0.0150$ & $<0.0150$ & - & $<0.0150$ & $<0.0150$ & 0.0353 \\
\hline Nitrate & $\mathrm{mg} / \mathrm{L}$ & - & 1.46 & - & - & - & - \\
\hline Phenols & $\mathrm{mg} / \mathrm{L}$ & $<0.015$ & - & $<0.020$ & $<0.015$ & $<0.015$ & $<0.020$ \\
\hline Hydrogen-3 & $\mathrm{nCi} / \mathrm{L}$ & $<0.1$ & - & $<0.1$ & $<0.1$ & $<0.1$ & $<0.1$ \\
\hline Total organic carbons & $\mathrm{mg} / \mathrm{L}$ & 4.2 & - & 2.8 & 4.0 & 6.3 & 4.3 \\
\hline Total organic carbons & $\mathrm{mg} / \mathrm{L}$ & 4.5 & - & 3.0 & 4.0 & 6.7 & 4.2 \\
\hline Total organic carbons & $\mathrm{mg} / \mathrm{L}$ & 4.5 & - & 2.7 & 4.3 & 6.5 & 4.1 \\
\hline Total organic carbons & $\mathrm{mg} / \mathrm{L}$ & 4.5 & - & 2.9 & 4.4 & 7.7 & 4.3 \\
\hline Total organic halogens & $\mathrm{mg} / \mathrm{L}$ & 0.013 & - & $<0.010$ & 0.019 & $<0.010$ & $<0.010$ \\
\hline Total organic halogens & $\mathrm{mg} / \mathrm{L}$ & 0.012 & - & $<0.010$ & 0.020 & $<0.010$ & $<0.010$ \\
\hline Acetone & $\mu \mathrm{g} / \mathrm{L}$ & 6 & - & - & - & 2 & - \\
\hline Methylene Chloride & $\mu \mathrm{g} / \mathrm{L}$ & 1 & - & - & 2 & - & 2 \\
\hline Toluene & $\mu \mathrm{g} / \mathrm{L}$ & 1 & . & . & . & $=$ & - \\
\hline
\end{tabular}

2 A hyphen indicates that no analysis was performed. 
TABLE 6.29

Groundwater Monitoring Results: Sanitary Landfill, Well 800163D, 1995

\begin{tabular}{|c|c|c|c|c|c|c|c|}
\hline & & & & & $\begin{array}{l}11 \text { Point Ele } \\
\text { und Surfac } \\
\text { ing Materia }\end{array}$ & ion & $\begin{array}{l}\text { m(MSL) } \\
183.79 \\
230.76 \\
\text { S. STEEL } \\
\end{array}$ \\
\hline Constituent & Units & Feb. 28 & Feb. 28 & April 6 & April 6 & July 12 & Oct. 12 \\
\hline Water Elevation & $\mathrm{m}$ & 193.14 & 193.14 & 193.06 & 193.06 & 192.86 & 192.46 \\
\hline Temperature & ${ }^{\circ} \mathrm{C}$ & 10.9 & 10.9 & 11.1 & 11.1 & 12.2 & 11.7 \\
\hline $\mathrm{pH}$ & $\mathrm{pH}$ & 7.09 & 7.09 & 6.43 & 6.43 & 6.90 & 6.86 \\
\hline Redox & $\mathrm{mV}$ & 103 & 103 & 290 & 290 & 415 & -61 \\
\hline Conductivity & $\mu \mathrm{mho} / \mathrm{cm}$ & 1228 & 1228 & 1496 & 1496 & 1413 & 1100 \\
\hline Chloride - Filtered & $\mathrm{mg} / \mathrm{L}$ & 266 & 278 & 419 & 415 & 387 & 212 \\
\hline Fluoride - Filtered & $\mathrm{mg} / \mathrm{L}$ & $-{ }^{\mathrm{a}}$ & - & 0.310 & - & - & - \\
\hline Sulfate - Filtered & $\mathrm{mg} / \mathrm{L}$ & 134 & 129 & 140 & 136 & 66 & 33 \\
\hline Total Dissolved Solids - Filtered & $\mathrm{mg} / \mathrm{L}$ & 952 & 925 & - & 1147 & 1133 & 909 \\
\hline Cyanide (Total) & $\mathrm{mg} / \mathrm{L}$ & $<0.002$ & $<0.002$ & - & $<0.002$ & $<0.002$ & $<0.002$ \\
\hline Arsenic & $\mathrm{mg} / \mathrm{L}$ & - & - & - & 0.0052 & - & - \\
\hline Barium & $\mathrm{mg} / \mathrm{L}$ & - & - & - & 0.073 & - & - \\
\hline Beryllium & $\mathrm{mg} / \mathrm{L}$ & - & - & - & $<0.0001$ & - & - \\
\hline Boron & $\mathrm{mg} / \mathrm{L}$ & - & - & - & 0.1356 & - & - \\
\hline Cadmium & $\mathrm{mg} / \mathrm{L}$ & - & - & - & $<0.0001$ & - & - \\
\hline Chromium & $\mathrm{mg} / \mathrm{L}$ & - & - & - & $<0.060$ & - & - \\
\hline Cobalt & $\mathrm{mg} / \mathrm{L}$ & - & - & - & $<0.025$ & - & - \\
\hline Copper & $\mathrm{mg} / \mathrm{L}$ & - & - & - & $<0.045$ & - & - \\
\hline Iron & $\mathrm{mg} / \mathrm{L}$ & - & - & - & 3.042 & - & - \\
\hline Lead & $\mathrm{mg} / \mathrm{L}$ & - & - & - & 0.0011 & - & - \\
\hline Manganese & $\mathrm{mg} / \mathrm{L}$ & - & - & - & 0.0732 & - & - \\
\hline Mercury & $\mathrm{mg} / \mathrm{L}$ & - & - & - & $<0.0001$ & - & - \\
\hline Nickel & $\mathrm{mg} / \mathrm{L}$ & - & - & - & $<0.040$ & - & - \\
\hline Silver & $\mathrm{mg} / \mathrm{L}$ & - & - & - & $<0.001$ & - & - \\
\hline Thallium & $\mathrm{mg} / \mathrm{L}$ & - & - & - & $<0.0015$ & - & - \\
\hline Vanadium & $\mathrm{mg} / \mathrm{L}$ & - & - & - & $<0.055$ & - & - \\
\hline Zinc & $\mathrm{mg} / \mathrm{L}$ & - & - & - & $<0.015$ & - & - \\
\hline Ammonia nitrogen - Filtered & $\mathrm{mg} / \mathrm{L}$ & 1.0 & 1.0 & - & 0.4 & 1.0 & 1.0 \\
\hline Arsenic - Filtered & $\mathrm{mg} / \mathrm{L}$ & - & 0.0026 & .0044 & - & 0.0052 & $<0.0025$ \\
\hline Barium - Filtered & $\mathrm{mg} / \mathrm{L}$ & 0.0639 & 0.0612 & 0.0724 & - & 0.0684 & 0.0504 \\
\hline Beryllium - Filtered & $\mathrm{mg} / \mathrm{L}$ & $<0.0001$ & $<0.0001$ & $<0.0001$ & - & $<0.0001$ & $<0.0001$ \\
\hline Cadmium - Filtered & $\mathrm{mg} / \mathrm{L}$ & $<0.0001$ & $<0.0001$ & $<0.0001$ & - & $<0.0001$ & $<0.0001$ \\
\hline Chromium - Filtered & $\mathrm{mg} / \mathrm{L}$ & $<0.060$ & $<0.060$ & $<0.060$ & - & $<0.060$ & $<0.060$ \\
\hline Cobalt- Filtered & $\mathrm{mg} / \mathrm{L}$ & $<0.025$ & $<0.025$ & $<0.025$ & - & $<0.025$ & $<0.025$ \\
\hline Copper - Filtered & $\mathrm{mg} / \mathrm{L}$ & $<0.045$ & $<0.045$ & $<0.045$ & - & $<0.045$ & $<0.045$ \\
\hline Iron - Filtered & $\mathrm{mg} / \mathrm{L}$ & 2.079 & 2.166 & 3.091 & - & 3.832 & $<0.025$ \\
\hline Lead - Filtered & $\mathrm{mg} / \mathrm{L}$ & 0.0006 & 0.0006 & $<0.0005$ & - & $<0.0005$ & 0.0007 \\
\hline Manganese - Filtered & $\mathrm{mg} / \mathrm{L}$ & 0.0730 & 0.0740 & 0.0719 & - & 0.0781 & 0.0650 \\
\hline Mercury - Filtered & $\mathrm{mg} / \mathrm{L}$ & $<0.0001$ & $<0.0001$ & $<0.0001$ & - & $<0.0001$ & $<0.0001$ \\
\hline Nickel - Filtered & $\mathrm{mg} / \mathrm{L}$ & $<0.040$ & $<0.040$ & $<0.040$ & - & $<0.040$ & $<0.040$ \\
\hline Silver- Filtered & $\mathrm{mg} / \mathrm{L}$ & $<0.001$ & $<0.001$ & $<0.001$ & - & $<0.001$ & $<0.001$ \\
\hline Thallium - Filtered & $\mathrm{mg} / \mathrm{L}$ & $<0.0015$ & $<0.0015$ & $<0.0015$ & - & $<0.0015$ & $<0.0015$ \\
\hline Vanadium - Filtered & $\mathrm{mg} / \mathrm{L}$ & $<0.055$ & $<0.055$ & $<0.055$ & - & $<0.055$ & $<0.055$ \\
\hline Zinc - Filtered & $\mathrm{mg} / \mathrm{L}$ & $<0.015$ & $<0.015$ & $<0.015$ & - & $<0.015$ & 0.0234 \\
\hline Arsenic & $\mathrm{mg} / \mathrm{L}$ & 0.0031 & - & - & - & - & - \\
\hline Nitrate & $\mathrm{mg} / \mathrm{L}$ & - & - & 1.12 & - & - & - \\
\hline Phenols & $\mathrm{mg} / \mathrm{L}$ & $<0.015$ & $<0.015$ & - & $<0.020$ & $<0.015$ & $<0.020$ \\
\hline Hydrogen-3 & $\mathrm{nCi} / \mathrm{L}$ & $<0.1$ & $<0.1$ & - & $<0.1$ & $<0.1$ & $<0.1$ \\
\hline Total organic carbons & $\mathrm{mg} / \mathrm{L}$ & 4.9 & 5.3 & - & 5.6 & 6.4 & 3.9 \\
\hline Total organic carbons & $\mathrm{mg} / \mathrm{L}$ & 4.5 & 5.5 & - & 5.4 & 6.8 & 3.7 \\
\hline Total organic carbons & $\mathrm{mg} / \mathrm{L}$ & 4.9 & 4.9 & - & 5.5 & 6.5 & 3.8 \\
\hline Total organic carbons & $\mathrm{mg} / \mathrm{L}$ & 4.4 & 4.7 & - & 5.6 & 6.6 & 3.9 \\
\hline Total organic halogens & $\mathrm{mg} / \mathrm{L}$ & $<0.010$ & 0.016 & - & 0.020 & $<0.001$ & $<0.010$ \\
\hline Total organic halogens & $\mathrm{mg} / \mathrm{L}$ & $<0.010$ & 0.016 & - & 0.020 & $<0.010$ & $<0.010$ \\
\hline 2-Butanone & $\mu \mathrm{g} / \mathrm{L}$ & 0.6 & 0.5 & - & - & 0.5 & - \\
\hline Acetone & $\mu \mathrm{g} / \mathrm{L}$ & 13 & - & - & - & - & - \\
\hline Methylene Chloride & $\mu \mathrm{g} / \mathrm{L}$ & 3 & 2 & - & - & 3 & - \\
\hline Toluene & $\mu \mathrm{g} / \mathrm{L}$ & 0.7 & - & - & - & - & - \\
\hline
\end{tabular}

a A hyphen indicates that no analysis was performed. 
TABLE 6.30

Groundwater Monitoring Results: Sanitary Landfill, Well 800171, 1995

\begin{tabular}{|c|c|c|c|c|c|c|}
\hline \multirow[b]{2}{*}{ Constituent } & \multirow[b]{2}{*}{ Units } & \multirow[b]{2}{*}{ Feb. 14} & \multirow[b]{2}{*}{ April 4} & \multicolumn{2}{|c|}{$\begin{array}{l}\text { Well Point Elevation } \\
\text { Ground Surface Elevation } \\
\text { Casing Material: }\end{array}$} & \multirow{2}{*}{$\begin{array}{l}\mathrm{m}(\mathrm{MSL}) \\
220.68 \\
228.42 \\
\text { S. STEEL } \\
\text { Oct. } 10\end{array}$} \\
\hline & & & & April 4 & July 12 & \\
\hline Water Elevation & $\mathrm{m}$ & 226.20 & 226.55 & 226.55 & 225.90 & 225.26 \\
\hline Temperature & ${ }^{\circ} \mathrm{C}$ & 9.6 & 10.6 & 10.6 & 11.1 & 12.9 \\
\hline $\mathrm{pH}$ & $\mathrm{pH}$ & 6.86 & 6.69 & 6.69 & 6.80 & 7.07 \\
\hline Redox & $\mathrm{mV}$ & 246 & 342 & 342 & 410 & 11 \\
\hline Conductivity & $\mu \mathrm{mho} / \mathrm{cm}$ & 1437 & 1451 & 1451 & 1470 & 1670 \\
\hline Chloride - Filtered & $\mathrm{mg} / \mathrm{L}$ & 105 & 86 & 87 & 90 & 121 \\
\hline Fluoride - Filtered & $\mathrm{mg} / \mathrm{L}$ & $-^{2}$ & 0.154 & - & - & - \\
\hline Sulfate - Filtered & $\mathrm{mg} / \mathrm{L}$ & 225 & 188 & 208 & 212 & 209 \\
\hline Total Dissolved Solids - Filtered & $\mathrm{mg} / \mathrm{L}$ & 1309 & - & 1220 & 1260 & 1409 \\
\hline Cyanide (Total) & $\mathrm{mg} / \mathrm{L}$ & $<0.002$ & - & $<0.002$ & - & $<0.002$ \\
\hline Arsenic & $\mathrm{mg} / \mathrm{L}$ & - & - & $<0.0025$ & - & - \\
\hline Barium & $\mathrm{mg} / \mathrm{L}$ & - & - & 0.1324 & - & - \\
\hline Beryllium & $\mathrm{mg} / \mathrm{L}$ & - & - & 0.0002 & - & - \\
\hline Boron & $\mathrm{mg} / \mathrm{L}$ & - & - & 0.1489 & - & - \\
\hline Cadmium & $\mathrm{mg} / \mathrm{L}$ & - & - & 0.0012 & - & - \\
\hline Chromium & $\mathrm{mg} / \mathrm{L}$ & - & - & $<0.060$ & - & - \\
\hline Cobalt & $\mathrm{mg} / \mathrm{L}$ & - & - & $<0.025$ & - & - \\
\hline Copper & $\mathrm{mg} / \mathrm{L}$ & - & - & $<0.045$ & - & - \\
\hline Iron & $\mathrm{mg} / \mathrm{L}$ & - & - & 4.295 & - & - \\
\hline Lead & $\mathrm{mg} / \mathrm{L}$ & - & - & 0.0065 & - & - \\
\hline Manganese & $\mathrm{mg} / \mathrm{L}$ & - & - & 0.3876 & - & - \\
\hline Mercury & $\mathrm{mg} / \mathrm{L}$ & - & - & $<0.0001$ & - & - \\
\hline Nickel & $\mathrm{mg} / \mathrm{L}$ & - & - & $<0.040$ & - & - \\
\hline Silver & $\mathrm{mg} / \mathrm{L}$ & - & - & $<0.001$ & - & - \\
\hline Thallium & $\mathrm{mg} / \mathrm{L}$ & - & - & $<0.0015$ & - & - \\
\hline Vanadium & $\mathrm{mg} / \mathrm{L}$ & - & - & $<0.055$ & - & - \\
\hline Zinc & $\mathrm{mg} / \mathrm{L}$ & - & - & 0.0178 & - & - \\
\hline Ammonia nitrogen - Filtered & $\mathrm{mg} / \mathrm{L}$ & 0.2 & - & 0.1 & 0.9 & 0.2 \\
\hline Arsenic - Filtered & $\mathrm{mg} / \mathrm{L}$ & $<0.0025$ & $<0.0025$ & - & $<0.0025$ & $<0.0025$ \\
\hline Barium - Filtered & $\mathrm{mg} / \mathrm{L}$ & 0.1120 & 0.1079 & - & 0.1098 & 0.1250 \\
\hline Beryllium - Filtered & $\mathrm{mg} / \mathrm{L}$ & $<0.0001$ & $<0.0001$ & - & $<0.0001$ & $<0.0001$ \\
\hline Cadmium - Filtered & $\mathrm{mg} / \mathrm{L}$ & 0.0004 & 0.0006 & - & 0.0003 & $<0.0001$ \\
\hline Chromium - Filtered & $\mathrm{mg} / \mathrm{L}$ & $<0.060$ & $<0.060$ & - & $<0.060$ & $<0.060$ \\
\hline Cobalt - Filtered & $\mathrm{mg} / \mathrm{L}$ & $<0.025$ & $<0.025$ & - & $<0.025$ & $<0.025$ \\
\hline Copper - Filtered & $\mathrm{mg} / \mathrm{L}$ & $<0.045$ & $<0.045$ & - & $<0.045$ & $<0.045$ \\
\hline Iron - Filtered & $\mathrm{mg} / \mathrm{L}$ & 0.3080 & 0.1843 & - & 0.0404 & $<0.0250$ \\
\hline Lead - Filtered & $\mathrm{mg} / \mathrm{L}$ & 0.0006 & $<0.0005$ & - & $<0.0005$ & 0.0005 \\
\hline Manganese - Filtered & $\mathrm{mg} / \mathrm{L}$ & 0.4030 & 0.3373 & - & 0.3235 & 0.3723 \\
\hline Mercury - Filtered & $\mathrm{mg} / \mathrm{L}$ & $<0.0001$ & $<0.0001$ & - & $<0.0001$ & $<0.0001$ \\
\hline Nickel - Filtered & $\mathrm{mg} / \mathrm{L}$ & $<0.040$ & $<0.040$ & - & $<0.040$ & $<0.040$ \\
\hline Silver - Filtered & $\mathrm{mg} / \mathrm{L}$ & $<0.001$ & $<0.001$ & - & $<0.001$ & $<0.001$ \\
\hline Thallium - Filtered & $\mathrm{mg} / \mathrm{L}$ & $<0.0015$ & $<0.0015$ & - & $<0.0015$ & $<0.0015$ \\
\hline Vanadium - Filtered & $\mathrm{mg} / \mathrm{L}$ & $<0.055$ & $<0.055$ & - & $<0.055$ & $<0.055$ \\
\hline Zinc - Filtered & $\mathrm{mg} / \mathrm{L}$ & $<0.015$ & $<0.015$ & - & $<0.015$ & $<0.015$ \\
\hline Nitrate & $\mathrm{mg} / \mathrm{L}$ & - & 0.76 & - & - & - \\
\hline Phenols & $\mathrm{mg} / \mathrm{L}$ & $<0.015$ & - & $<0.020$ & $<0.015$ & $<0.020$ \\
\hline Hydrogen-3 & $\mathrm{nCi} / \mathrm{L}$ & 0.314 & - & 0.309 & 0.334 & 0.580 \\
\hline Total organic carbons & $\mathrm{mg} / \mathrm{L}$ & 2.8 & - & 2.6 & 3.1 & 5.2 \\
\hline Total organic carbons & $\mathrm{mg} / \mathrm{L}$ & 2.8 & - & 3.1 & 3.5 & 5.3 \\
\hline Total organic carbons & $\mathrm{mg} / \mathrm{L}$ & 3.1 & - & 3.1 & 3.3 & 5.3 \\
\hline Total organic carbons & $\mathrm{mg} / \mathrm{L}$ & 3.0 & - & 3.0 & 3.6 & 4.9 \\
\hline Total organic halogens & $\mathrm{mg} / \mathrm{L}$ & 0.020 & - & 0.020 & 0.036 & $<0.010$ \\
\hline Total organic halogens & $\mathrm{mg} / \mathrm{L}$ & - & - & 0.019 & 0.043 & $<0.010$ \\
\hline Chloroethane & $\mu \mathrm{g} / \mathrm{L}$ & - & - & 2 & - & - \\
\hline Methylene Chloride & $\mu \mathrm{g} / \mathrm{L}$ & 2 & - & 1 & - & - \\
\hline Trichloroethene & $\mu \mathrm{g} / \mathrm{L}$ & 0.6 & - & 0.8 & 2.0 & - \\
\hline cis-1,2-Dichloroethene & $\mu \mathrm{g} / \mathrm{L}$ & - & - & 0.2 & - & - \\
\hline
\end{tabular}

a A hyphen indicates that no analysis was performed. 
TABLE 6.31

Groundwater Monitoring Results: Sanitary Landfill, Well 800173D, 1995

\begin{tabular}{|c|c|c|c|c|c|c|}
\hline \multirow[b]{2}{*}{ Constiment } & \multirow[b]{2}{*}{ Units } & \multirow[b]{2}{*}{ Feb. 28} & \multicolumn{3}{|c|}{$\begin{array}{l}\text { Well Point Elevation } \\
\text { Ground Surface Elevation } \\
\text { Casing Material: }\end{array}$} & $\begin{array}{l}\text { m(MSL) } \\
188.98 \\
228.42 \\
\text { S. STEEL }\end{array}$ \\
\hline & & & April 6 & April 6 & July 12 & Oct. 12 \\
\hline Water Elevation & $\mathbf{m}$ & 193.08 & 192.97 & 193.00 & 192.80 & 192.42 \\
\hline Temperature & ${ }^{\circ} \mathrm{C}$ & 11.4 & 11.4 & 11.4 & 11.6 & 11.5 \\
\hline $\mathrm{pH}$ & $\mathrm{pH}$ & 6.97 & 6.38 & 6.38 & 7.07 & 6.93 \\
\hline Redox & $\mathrm{mV}$ & 279 & 191 & 191 & 417 & -76 \\
\hline Conductivity & $\mu \mathrm{mho} / \mathrm{cm}$ & 1467 & 1693 & 1693 & 1436 & 1233 \\
\hline Chloride - Filtered & $\mathrm{mg} / \mathrm{L}$ & 425 & 547 & 534 & 412 & 231 \\
\hline Fluoride - Filtered & $\mathrm{mg} / \mathrm{L}$ & $-a^{a}$ & 0.295 & - & - & - \\
\hline Sulfate - Filtered & $\mathrm{mg} / \mathrm{L}$ & 67 & 50 & 68. & 16 & 18 \\
\hline Total Dissolved Solids - Filtered & $\mathrm{mg} / \mathrm{L}$ & 1087 & - & 1192 & 1021 & 889 \\
\hline Cyanide (Total) & $\mathrm{mg} / \mathrm{L}$ & $<0.002$ & - & $<0.002$ & $<0.002$ & $<0.002$ \\
\hline Arsenic & $\mathrm{mg} / \mathrm{L}$ & - & - & 0.0112 & - & - \\
\hline Barium & $\mathrm{mg} / \mathrm{L}$ & - & & 0.155 & - & - \\
\hline Beryllium & $\mathrm{mg} / \mathrm{L}$ & - & - & $<0.0003$ & - & - \\
\hline Boron & $\mathrm{mg} / \mathrm{L}$ & - & - & 0.1455 & - & - \\
\hline Cadmium & $\mathrm{mg} / \mathrm{L}$ & - & - & 0.0001 & - & - \\
\hline Chromium & $\mathrm{mg} / \mathrm{L}$ & - & - & 0.1176 & - & - \\
\hline Cobalt & $\mathrm{mg} / \mathrm{L}$ & - & - & $<0.025$ & - & - \\
\hline Copper & $\mathrm{mg} / \mathrm{L}$ & - & - & $<0.045$ & - & - \\
\hline Iron & $\mathrm{mg} / \mathrm{L}$ & - & - & 21.03 & - & - \\
\hline Lead & $\mathrm{mg} / \mathrm{L}$ & - & - & 0.0097 & - & - \\
\hline Manganese & $\mathrm{mg} / \mathrm{L}$ & - & - & 0.583 & - & - \\
\hline Mercury & $\mathrm{mg} / \mathrm{L}$ & - & - & $<0.0001$ & - & - \\
\hline Nickel & $\mathrm{mg} / \mathrm{L}$ & - & - & 0.099 & - & - \\
\hline Silver & $\mathrm{mg} / \mathrm{L}$ & - & - & $<0.001$ & - & - \\
\hline Thallium & $\mathrm{mg} / \mathrm{L}$ & - & - & $<0.0015$ & - & - \\
\hline Vanadium & $\mathrm{mg} / \mathrm{L}$ & - & - & $<0.055$ & - & - \\
\hline Zinc & $\mathrm{mg} / \mathrm{L}$ & - & - & 0.022 & - & - \\
\hline Ammonia nitrogen - Filtered & $\mathrm{mg} / \mathrm{L}$ & 0.90 & - & 0.50 & 1.00 & 0.20 \\
\hline Barium - Filtered & $\mathrm{mg} / \mathrm{L}$ & - & 0.108 & - & - & - \\
\hline Arsenic - Filtered & $\mathrm{mg} / \mathrm{L}$ & 0.0057 & 0.0057 & - & 0.0061 & 0.0026 \\
\hline Barium - Filtered & $\mathrm{mg} / \mathrm{L}$ & 0.0942 & - & - & 0.0918 & 0.0825 \\
\hline Beryllium - Filtered & $\mathrm{mg} / \mathrm{L}$ & $<0.0001$ & $<0.0001$ & - & $<0.0001$ & $<0.0001$ \\
\hline Cadmium - Filtered & $\mathrm{mg} / \mathrm{L}$ & $<0.0001$ & $<0.0001$ & - & $<0.0001$ & $<0.0001$ \\
\hline Chromium - Filtered & $\mathrm{mg} / \mathrm{L}$ & $<0.060$ & $<0.060$ & - & $<0.060$ & $<0.060$ \\
\hline Cobalt - Filtered & $\mathrm{mg} / \mathrm{L}$ & $<0.025$ & $<0.025$ & - & $<0.025$ & $<0.025$ \\
\hline Copper - Filtered & $\mathrm{mg} / \mathrm{L}$ & $<0.045$ & $<0.045$ & - & $<0.045$ & $<0.045$ \\
\hline Iron - Filtered & $\mathrm{mg} / \mathrm{L}$ & 4.9880 & 6.8930 & - & 2.9910 & 0.9421 \\
\hline Lead - Filtered & $\mathrm{mg} / \mathrm{L}$ & 0.0006 & $<0.0005$ & - & $<0.0005$ & 0.0008 \\
\hline Manganese - Filtered & $\mathrm{mg} / \mathrm{L}$ & 0.2080 & 0.2018 & - & 0.2122 & 0.1707 \\
\hline Mercury - Filtered & $\mathrm{mg} / \mathrm{L}$ & $<0.0001$ & $<0.0001$ & - & $<0.0001$ & $<0.0001$ \\
\hline Nickel - Filtered & $\mathrm{mg} / \mathrm{L}$ & $<0.040$ & $<0.040$ & - & $<0.040$ & $<0.040$ \\
\hline Silver - Filtered & $\mathrm{mg} / \mathrm{L}$ & $<0.001$ & $<0.001$ & - & $<0.001$ & $<0.001$ \\
\hline Thallium - Filtered & $\mathrm{mg} / \mathrm{L}$ & $<0.0015$ & $<0.0015$ & - & $<0.0015$ & $<0.0015$ \\
\hline Vanadium - Filtered & $\mathrm{mg} / \mathrm{L}$ & $<0.055$ & $<0.055$ & - & $<0.055$ & $<0.055$ \\
\hline Zinc - Filtered & $\mathrm{mg} / \mathrm{L}$ & $<0.015$ & $<0.015$ & - & $<0.015$ & $<0.015$ \\
\hline Nitrate & $\mathrm{mg} / \mathrm{L}$ & - & 1.15 & - & - & - \\
\hline Phenols & $\mathrm{mg} / \mathrm{L}$ & $<0.015$ & - & $<0.020$ & $<0.015$ & $<0.020$ \\
\hline Hydrogen-3 & $\mathrm{nCi} / \mathrm{L}$ & $<0.1$ & - & $<0.1$ & $<0.1$ & $<0.1$ \\
\hline Total organic carbons & $\mathrm{mg} / \mathrm{L}$ & 7.7 & - & 8.4 & 8.5 & 5.6 \\
\hline Total organic carbons & $\mathrm{mg} / \mathrm{L}$ & 7.9 & - & 8.4 & 8.1 & 5.8 \\
\hline Total organic carbons & $\mathrm{mg} / \mathrm{L}$ & 7.8 & - & 8.6 & 8.6 & 5.5 \\
\hline Total organic carbons & $\mathrm{mg} / \mathrm{L}$ & 7.6 & - & 8.5 & 8.7 & 5.8 \\
\hline Total organic halogens & $\mathrm{mg} / \mathrm{L}$ & $<0.010$ & - & 0.013 & 0.023 & $<0.010$ \\
\hline Total organic halogens & $\mathrm{mg} / \mathrm{L}$ & $<0.010$ & - & 0.012 & 0.023 & 0.010 \\
\hline 2-Butanone & $\mu \mathrm{g} / \mathrm{L}$ & 0.6 & - & - & - & - \\
\hline Acetone & $\mu \mathrm{g} / \mathrm{L}$ & 6 & - & - & - & 8 \\
\hline Methylene Chloride & $\mu \mathrm{g} / \mathrm{L}$ & 1 & - & - & 2 & 12 \\
\hline
\end{tabular}

a A hyphen indicates that no analysis was performed. 
TABLE 6.32

Groundwater Monitoring Results: Sanitary Landfill, Well 800181, 1995

\begin{tabular}{|c|c|c|c|c|c|c|}
\hline \multirow[b]{2}{*}{ Constituent } & \multirow[b]{2}{*}{ Units } & \multirow[b]{2}{*}{ Feb. 14} & \multirow[b]{2}{*}{ April 4} & \multicolumn{2}{|c|}{$\begin{array}{l}\text { Well Point Elevation } \\
\text { Ground Surface Elevation } \\
\text { Casing Material: }\end{array}$} & \multirow{2}{*}{$\begin{array}{l}\text { m(MSL) } \\
219.76 \\
230.52 \\
\text { S. STEEL } \\
\text { Oct. } 10 \\
\end{array}$} \\
\hline & & & & April 4 & July 12 & \\
\hline Water Elevation & $\mathrm{m}$ & 223.27 & 223.46 & 223.46 & 222.96 & 221.66 \\
\hline Temperature & ${ }^{\circ} \mathrm{C}$ & 10.1 & 10.2 & 10.2 & 10.0 & 10.3 \\
\hline $\mathrm{pH}$ & $\mathrm{pH}$ & 7.22 & 7.21 & 7.21 & 7.24 & 7.02 \\
\hline Redox & $\mathrm{mV}$ & 195 & 332 & 332 & 420 & 159 \\
\hline Conductivity & $\mu \mathrm{mho} / \mathrm{cm}$ & 1012 & 987 & 987 & 1023 & 1021 \\
\hline Chloride - Filtered & $\mathrm{mg} / \mathrm{L}$ & 10 & 10 & 11 & 4 & 4 \\
\hline Fluoride - Filtered & $\mathrm{mg} / \mathrm{L}$ & $--^{a}$ & 0.256 & - & - & - \\
\hline Sulfate - Filtered & $\mathrm{mg} / \mathrm{L}$ & 212 & 173 & 198 & 207 & 191 \\
\hline Total Dissolved Solids - Filtered & $\mathrm{mg} / \mathrm{L}$ & 903 & - & 829 & 866 & 922 \\
\hline Cyanide (Total) & $\mathrm{mg} / \mathrm{L}$ & $<0.002$ & - & $<0.002$ & $<0.002$ & $<0.002$ \\
\hline Arsenic & $\mathrm{mg} / \mathrm{L}$ & - & - & 0.0122 & $\cdot$ & - \\
\hline Barium & $\mathrm{mg} / \mathrm{L}$ & - & - & 0.7327 & - & - \\
\hline Beryllium & $\mathrm{mg} / \mathrm{L}$ & - & - & 0.0017 & - & - \\
\hline Boron & $\mathrm{mg} / \mathrm{L}$ & - & - & 0.3143 & - & - \\
\hline Cadmium & $\mathrm{mg} / \mathrm{L}$ & - & - & 0.0005 & - & - \\
\hline Chromium & $\mathrm{mg} / \mathrm{L}$ & - & - & 0.1118 & - & - \\
\hline Cobalt & $\mathrm{mg} / \mathrm{L}$ & - & & 0.0312 & - & - \\
\hline Copper & $\mathrm{mg} / \mathrm{L}$ & - & - & 0.0825 & - & - \\
\hline Iron & $\mathrm{mg} / \mathrm{L}$ & - & - & 95.12 & - & - \\
\hline Lead & $\mathrm{mg} / \mathrm{L}$ & - & - & 0.0310 & - & - \\
\hline Manganese & $\mathrm{mg} / \mathrm{L}$ & - & - & 1.670 & - & - \\
\hline Mercury & $\mathrm{mg} / \mathrm{L}$ & - & - & $<0.0001$ & - & - \\
\hline Nickel & $\mathrm{mg} / \mathrm{L}$ & - & - & 0.1254 & - & - \\
\hline Silver & $\mathrm{mg} / \mathrm{L}$ & - & - & $<0.001$ & - & - \\
\hline Thallium & $\mathrm{mg} / \mathrm{L}$ & - & - & $<0.0015$ & - & - \\
\hline Vanadium & $\mathrm{mg} / \mathrm{L}$ & - & - & 0.1045 & - & - \\
\hline Zinc & $\mathrm{mg} / \mathrm{L}$ & - & - & 0.2099 & - & - \\
\hline Ammonia nitrogen - Filtered & $\mathrm{mg} / \mathrm{L}$ & 0.3 & - & 0.8 & 0.7 & 0.1 \\
\hline Arsenic - Filtered & $\mathrm{mg} / \mathrm{L}$ & $<0.0025$ & $<0.0025$ & - & $<0.0025$ & $<0.0025$ \\
\hline Barium - Filtered & $\mathrm{mg} / \mathrm{L}$ & 0.1555 & 0.1570 & - & 0.1641 & 0.1548 \\
\hline Beryllium - Filtered & $\mathrm{mg} / \mathrm{L}$ & $<0.0001$ & $<0.0001$ & - & $<0.0001$ & $<0.0001$ \\
\hline Cadmium - Filtered & $\mathrm{mg} / \mathrm{L}$ & $<0.0001$ & $<0.0001$ & - & $<0.0001$ & $<0.0001$ \\
\hline Chromium - Filtered & $\mathrm{mg} / \mathrm{L}$ & $<0.060$ & $<0.060$ & - & $<0.060$ & $<0.060$ \\
\hline Cobalt - Filtered & $\mathrm{mg} / \mathrm{L}$ & $<0.025$ & $<0.025$ & - & $<0.025$ & $<0.025$ \\
\hline Copper - Filtered & $\mathrm{mg} / \mathrm{L}$ & $<0.045$ & $<0.045$ & - & $<0.045$ & $<0.045$ \\
\hline Iron - Filtered & $\mathrm{mg} / \mathrm{L}$ & $<0.020$ & $<0.025$ & - & $<0.025$ & $<0.025$ \\
\hline Lead - Filtered & $\mathrm{mg} / \mathrm{L}$ & 0.0007 & $<0.0005$ & - & $<0.0005$ & 0.0006 \\
\hline Manganese - Filtered & $\mathrm{mg} / \mathrm{L}$ & 0.4040 & 0.3446 & - & 0.0496 & 0.0401 \\
\hline Mercury - Filtered & $\mathrm{mg} / \mathrm{L}$ & $<0.0001$ & $<0.0001$ & - & $<0.0001$ & $<0.0001$ \\
\hline Nickel - Filtered & $\mathrm{mg} / \mathrm{L}$ & $<0.040$ & $<0.040$ & - & $<0.040$ & $<0.040$ \\
\hline Silver - Filtered & $\mathrm{mg} / \mathrm{L}$ & $<0.001$ & $<0.001$ & - & $<0.001$ & $<0.001$ \\
\hline Thallium - Filtered & $\mathrm{mg} / \mathrm{L}$ & $<0.0015$ & $<0.0015$ & - & $<0.0015$ & $<0.0015$ \\
\hline Vanadium - Filtered & $\mathrm{mg} / \mathrm{L}$ & $<0.055$ & $<0.055$ & - & $<0.055$ & $<0.055$ \\
\hline Zinc - Filtered & $\mathrm{mg} / \mathrm{L}$ & $<0.015$ & $<0.015$ & - & $<0.015$ & $<0.015$ \\
\hline Nitrate & $\mathrm{mg} / \mathrm{L}$ & - & $<0.50$ & - & - & - \\
\hline Phenols & $\mathrm{mg} / \mathrm{L}$ & $<0.015$ & - & $<0.020$ & $<0.015$ & $<0.020$ \\
\hline Hydrogen-3 & $\mathrm{nCi} / \mathrm{L}$ & $<0.1$ & - & $<0.1$ & $<0.1$ & $<0.1$ \\
\hline Total organic carbons & $\mathrm{mg} / \mathrm{L}$ & 2.1 & - & 1.3 & 2.4 & 3.5 \\
\hline Total organic carbons & $\mathrm{mg} / \mathrm{L}$ & 1.8 & - & 1.4 & 2.0 & 4.0 \\
\hline Total organic carbons & $\mathrm{mg} / \mathrm{L}$ & 1.7 & - & 1.2 & 1.7 & 4.3 \\
\hline Total organic carbons & $\mathrm{mg} / \mathrm{L}$ & 2.6 & - & 1.4 & 1.8 & 2.8 \\
\hline Total organic halogens & $\mathrm{mg} / \mathrm{L}$ & $<0.010$ & - & $<0.010$ & $<0.010$ & 0.020 \\
\hline Total organic halogens & $\mathrm{mg} / \mathrm{L}$ & $<0.010$ & - & $<0.010$ & $<0.010$ & 0.020 \\
\hline Methylene Chloride & $\mu \mathrm{g} / \mathrm{L}$ & - & - & 2 & 2 & 2 \\
\hline
\end{tabular}

a Ayphen indicates that no analysis was performed. 
TABLE 6.33

Groundwater Monitoring Results: Sanitary Landfill, Well 800183D, 1995

\begin{tabular}{|c|c|c|c|c|c|c|}
\hline \multirow[b]{2}{*}{ Constituent } & \multirow[b]{2}{*}{ Units } & \multirow[b]{2}{*}{ Feb. 28} & \multirow[b]{2}{*}{ April 6} & \multicolumn{2}{|c|}{$\begin{array}{l}\text { Well Point Elevation } \\
\text { Ground Surface Elevation } \\
\text { Casing Material: }\end{array}$} & \multirow{2}{*}{$\begin{array}{l}\text { m(MSL) } \\
180.44 \\
230.37 \\
\text { S. STEEL } \\
\text { Oct. } 12\end{array}$} \\
\hline & & & & April 6 & July 12 & \\
\hline Water Elevation & $\mathrm{m}$ & 193.06 & 192.97 & 192.97 & 192.80 & 192.42 \\
\hline Temperature & ${ }^{\circ} \mathrm{C}$ & 11.2 & 11.5 & 11.5 & 12.0 & 12.2 \\
\hline $\mathrm{pH}$ & $\mathrm{pH}$ & 7.12 & 6.64 & 6.64 & 7.11 & 7.53 \\
\hline Redox & $\mathrm{mV}$ & -18 & 320 & 320 & 420 & -84 \\
\hline Conductivity & $\mu \mathrm{mho} / \mathrm{cm}$ & 940 & 955 & 955 & 1051 & 1006 \\
\hline Chloride - Filtered & $\mathrm{mg} / \mathrm{L}$ & 114 & 119 & 122 & 159 & 135 \\
\hline Fluoride - Filtered & $\mathrm{mg} / \mathrm{L}$ & $-{ }^{2}$ & 0.350 & - & - & - \\
\hline Sulfate - Filtered & $\mathrm{mg} / \mathrm{L}$ & 122 & 140 & 143 & 166 & 166 \\
\hline Total Dissolved Solids - Filtered & $\mathrm{mg} / \mathrm{L}$ & 792 & - & 819 & 859 & 790 \\
\hline Cyanide (Total) & $\mathrm{mg} / \mathrm{L}$ & $<0.002$ & - & $<0.002$ & $<0.002$ & $<0.002$ \\
\hline Arsenic & $\mathrm{mg} / \mathrm{L}$ & - & - & 0.0028 & - & - \\
\hline Barium & $\mathrm{mg} / \mathrm{L}$ & - & - & 0.0536 & - & - \\
\hline Beryllium & $\mathrm{mg} / \mathrm{L}$ & - & - & $<0.0001$ & - & - \\
\hline Boron & $\mathrm{mg} / \mathrm{L}$ & - & - & 0.2223 & - & - \\
\hline Cadmium & $\mathrm{mg} / \mathrm{L}$ & - & - & $<0.0001$ & - & - \\
\hline Chromium & $\mathrm{mg} / \mathrm{L}$ & - & - & $<0.060$ & - & - \\
\hline Cobalt & $\mathrm{mg} / \mathrm{L}$ & - & - & $<0.025$ & - & - \\
\hline Copper & $\mathrm{mg} / \mathrm{L}$ & - & - & $<0.045$ & - & - \\
\hline Iron & $\mathrm{mg} / \mathrm{L}$ & - & - & 2.563 & - & - \\
\hline Lead & $\mathrm{mg} / \mathrm{L}$ & - & - & 0.0012 & - & - \\
\hline Manganese & $\mathrm{mg} / \mathrm{L}$ & - & - & 0.0554 & - & - \\
\hline Mercury & $\mathrm{mg} / \mathrm{L}$ & - & - & $<0.0001$ & - & - \\
\hline Nickel & $\mathrm{mg} / \mathrm{L}$ & - & - & $<0.040$ & - & - \\
\hline Silver & $\mathrm{mg} / \mathrm{L}$ & - & - & 0.0012 & - & - \\
\hline Thallium & $\mathrm{mg} / \mathrm{L}$ & - & - & $<0.0015$ & - & - \\
\hline Vanadium & $\mathrm{mg} / \mathrm{L}$ & - & - & $<0.055$ & - & - \\
\hline Zinc & $\mathrm{mg} / \mathrm{L}$ & - & - & $<0.015$ & - & - \\
\hline Ammonia nitrogen - Filtered & $\mathrm{mg} / \mathrm{L}$ & 0.9 & - & 0.6 & 1.5 & 1.0 \\
\hline Arsenic - Filtered & $\mathrm{mg} / \mathrm{L}$ & $<0.0025$ & $<0.0025$ & - & $<0.0025$ & $<0.0025$ \\
\hline Barium - Filtered & $\mathrm{mg} / \mathrm{L}$ & 0.0408 & 0.0445 & - & 0.0447 & 0.0475 \\
\hline Beryllium - Filtered & $\mathrm{mg} / \mathrm{L}$ & $<0.0001$ & $<0.0001$ & - & $<0.0001$ & $<0.0001$ \\
\hline Cadmium - Filtered & $\mathrm{mg} / \mathrm{L}$ & $<0.0001$ & $<0.0001$ & - & $<0.0001$ & $<0.0001$ \\
\hline Chromium - Filtered & $\mathrm{mg} / \mathrm{L}$ & $<0.060$ & $<0.060$ & - & $<0.060$ & $<0.060$ \\
\hline Cobalt - Filtered & $\mathrm{mg} / \mathrm{L}$ & $<0.025$ & $<0.025$ & - & $<0.025$ & $<0.025$ \\
\hline Copper - Filtered & $\mathrm{mg} / \mathrm{L}$ & $<0.045$ & $<0.045$ & - & $<0.045$ & $<0.045$ \\
\hline Iron - Filtered & $\mathrm{mg} / \mathrm{L}$ & 1.0700 & 0.9078 & - & 0.5682 & 0.9492 \\
\hline Lead - Filtered & $\mathrm{mg} / \mathrm{L}$ & 0.0005 & $<0.0005$ & - & $<0.0005$ & 0.0007 \\
\hline Manganese - Filtered & $\mathrm{mg} / \mathrm{L}$ & 0.0150 & $<0.0200$ & - & 0.0389 & $<0.0200$ \\
\hline Mercury - Filtered & $\mathrm{mg} / \mathrm{L}$ & $<0.0001$ & $<0.0001$ & - & $<0.0001$ & $<0.0001$ \\
\hline Nickel - Filtered & $\mathrm{mg} / \mathrm{L}$ & $<0.040$ & $<0.040$ & - & $<0.040$ & $<0.040$ \\
\hline Silver - Filtered & $\mathrm{mg} / \mathrm{L}$ & $<0.001$ & $<0.001$ & - & $<0.001$ & $<0.001$ \\
\hline Thallium - Filtered & $\mathrm{mg} / \mathrm{L}$ & $<0.0015$ & $<0.0015$ & - & $<0.0015$ & $<0.0015$ \\
\hline Vanadium - Filtered & $\mathrm{mg} / \mathrm{L}$ & $<0.055$ & $<0.055$ & - & $<0.055$ & $<0.055$ \\
\hline Zinc - Filtered & $\mathrm{mg} / \mathrm{L}$ & $<0.015$ & $<0.015$ & - & $<0.015$ & $<0.015$ \\
\hline Nitrate & $\mathrm{mg} / \mathrm{L}$ & - & $<0.50$ & - & - & - \\
\hline Phenols & $\mathrm{mg} / \mathrm{L}$ & $<0.015$ & - & $<0.020$ & $<0.015$ & $<0.020$ \\
\hline Hydrogen-3 & $\mathrm{nCi} / \mathrm{L}$ & $<0.1$ & - & $<0.1$ & $<0.1$ & $<0.1$ \\
\hline Total organic carbons & $\mathrm{mg} / \mathrm{L}$ & 2.0 & - & 2.0 & 2.8 & 2.2 \\
\hline Total organic carbons & $\mathrm{mg} / \mathrm{L}$ & 2.0 & - & 2.3 & 2.8 & 2.3 \\
\hline Total organic carbons & $\mathrm{mg} / \mathrm{L}$ & 2.2 & - & 2.1 & 2.9 & 2.2 \\
\hline Total organic carbons & $\mathrm{mg} / \mathrm{L}$ & 2.0 & - & 2.3 & 2.8 & 2.2 \\
\hline Total organic halogens & $\mathrm{mg} / \mathrm{L}$ & $<0.010$ & - & $<0.010$ & 0.011 & $<0.010$ \\
\hline Total organic halogens & $\mathrm{mg} / \mathrm{L}$ & $<0.010$ & - & $<0.010$ & 0.013 & $<0.010$ \\
\hline 2-Butanone & $\mu \mathrm{g} / \mathrm{L}$ & 0.8 & - & - & - & - \\
\hline Acetone & $\mu \mathrm{g} / \mathrm{L}$ & 7 & - & - & 6 & - \\
\hline Methylene Chloride & $\mu \mathrm{g} / \mathrm{L}$ & 4 & - & 3 & 3 & 7 \\
\hline
\end{tabular}

a A hyphen indicates that no analysis was performed. 
TABLE 6.34

Groundwater Monitoring Results: Sanitary Landfill, Well 800191, 1995

\begin{tabular}{|c|c|c|c|c|c|c|c|}
\hline \multirow[b]{2}{*}{ Constituent } & \multirow[b]{2}{*}{ Units } & \multirow[b]{2}{*}{ Feb. 14} & \multirow[b]{2}{*}{ April 4} & \multirow[b]{2}{*}{ April 4} & \multicolumn{2}{|c|}{$\begin{array}{l}\text { Well Point Elevation } \\
\text { Ground Surface Elevation } \\
\text { Casing Material: }\end{array}$} & \multirow{2}{*}{$\begin{array}{l}\text { m(MSL) } \\
222.81 \\
227.38 \\
\text { S. STEEL } \\
\text { Oct. } 10 \\
\end{array}$} \\
\hline & & & & & July 14 & Oct. 10 & \\
\hline Water Elevation & $\mathrm{m}$ & 226.01 & 226.19 & 226.19 & 225.64 & 225.17 & 225.17 \\
\hline Temperature & ${ }^{\circ} \mathrm{C}$ & 8.4 & 7.7 & 7.7 & 11.4 & 13.5 & 13.5 \\
\hline $\mathrm{pH}$ & $\mathrm{pH}$ & 7.02 & 7.00 & 7.00 & 6.93 & 7.24 & 7.24 \\
\hline Redox & $\mathrm{mV}$ & 257 & 337 & 337 & 287 & -35 & -35 \\
\hline Conductivity & $\mu \mathrm{mho} / \mathrm{cm}$ & 1242 & 1214 & 1214 & 1378 & 1333 & 1333 \\
\hline Chloride- Filtered & $\mathrm{mg} / \mathrm{L}$ & 297 & 309 & 309 & 269 & 269 & 281 \\
\hline Fluoride - Filtered & $\mathrm{mg} / \mathrm{L}$ & $-^{2}$ & 0.250 & - & - & - & - \\
\hline Sulfate - Filtered & $\mathrm{mg} / \mathrm{L}$ & 144 & 135 & 151 & 166 & 154 & 148 \\
\hline Total Dissolved Solids - Filtered & $\mathrm{mg} / \mathrm{L}$ & 1076 & - & 1010 & 1031 & 1009 & 1024 \\
\hline Cyanide (Total) & $\mathrm{mg} / \mathrm{L}$ & $<0.002$ & - & $<0.002$ & $<0.002$ & $<0.002$ & $<0.002$ \\
\hline Arsenic & $\mathrm{mg} / \mathrm{L}$ & - & - & $<0.0025$ & - & - & - \\
\hline Barium & $\mathrm{mg} / \mathrm{L}$ & - & - & 0.1133 & - & - & - \\
\hline Beryllium & $\mathrm{mg} / \mathrm{L}$ & - & - & $<0.0001$ & - & - & - \\
\hline Boron & $\mathrm{mg} / \mathrm{L}$ & - & - & 0.1563 & - & - & - \\
\hline Cadmium & $\mathrm{mg} / \mathrm{L}$ & - & - & 0.0004 & - & - & - \\
\hline Chromium & $\mathrm{mg} / \mathrm{L}$ & - & - & $<0.060$ & - & - & - \\
\hline Cobalt & $\mathrm{mg} / \mathrm{L}$ & - & - & $<0.025$ & - & - & - \\
\hline Copper & $\mathrm{mg} / \mathrm{L}$ & - & - & $<0.045$ & - & - & - \\
\hline Iron & $\mathrm{mg} / \mathrm{L}$ & - & - & 5.504 & - & - & - \\
\hline Lead & $\mathrm{mg} / \mathrm{L}$ & - & - & 0.0062 & - & - & - \\
\hline Manganese & $\mathrm{mg} / \mathrm{L}$ & - & - & 1.239 & - & - & - \\
\hline Mercury & $\mathrm{mg} / \mathrm{L}$ & - & - & $<0.0001$ & - & - & - \\
\hline Nickel & $\mathrm{mg} / \mathrm{L}$ & - & $=$ & $<0.040$ & - & - & - \\
\hline Silver & $\mathrm{mg} / \mathrm{L}$ & - & - & $<0.001$ & - & - & - \\
\hline Thallium & $\mathrm{mg} / \mathrm{L}$ & - & - & $<0.0015$ & - & - & - \\
\hline Vanadium & $\mathrm{mg} / \mathrm{L}$ & - & - & $<0.055$ & - & - & - \\
\hline Zinc & $\mathrm{mg} / \mathrm{L}$ & - & - & 0.0188 & - & - & - \\
\hline Ammonia nitrogen - Filtered & $\mathrm{mg} / \mathrm{L}$ & 0.4 & - & 0.7 & 0.4 & 0.6 & 0.5 \\
\hline Arsenic - Filtered & $\mathrm{mg} / \mathrm{L}$ & $<0.0025$ & $<0.0025$ & - & $<0.0025$ & $<0.0025$ & $<0.0025$ \\
\hline Barium - Filtered & $\mathrm{mg} / \mathrm{L}$ & 0.0625 & 0.0682 & - & 0.0694 & 0.0653 & 0.0636 \\
\hline Beryllium - Filtered & $\mathrm{mg} / \mathrm{L}$ & $<0.0001$ & $<0.0001$ & - & $<0.0001$ & $<0.0001$ & $<0.0001$ \\
\hline Cadmium - Filtered & $\mathrm{mg} / \mathrm{L}$ & $<0.0001$ & $<0.0001$ & - & $<0.0001$ & $<0.0001$ & $<0.0001$ \\
\hline Chromium - Filtered & $\mathrm{mg} / \mathrm{L}$ & $<0.060$ & $<0.060$ & - & $<0.060$ & $<0.060$ & $<0.060$ \\
\hline Cobalt - Filtered & $\mathrm{mg} / \mathrm{L}$ & $<0.025$ & $<0.025$ & - & $<0.025$ & $<0.025$ & $<0.025$ \\
\hline Copper - Filtered & $\mathrm{mg} / \mathrm{L}$ & $<0.045$ & $<0.045$ & - & $<0.045$ & $<0.045$ & $<0.045$ \\
\hline Iron - Filtered & $\mathrm{mg} / \mathrm{L}$ & 0.1700 & 0.4145 & - & 0.3688 & 0.5550 & 0.3816 \\
\hline Lead - Filtered & $\mathrm{mg} / \mathrm{L}$ & 0.0005 & $<0.0005$ & - & $<0.0005$ & 0.0007 & 0.0008 \\
\hline Manganese - Filtered & $\mathrm{mg} / \mathrm{L}$ & 1.345 & 1.183 & - & 1.199 & 1.131 & 1.124 \\
\hline Mercury - Filtered & $\mathrm{mg} / \mathrm{L}$ & $<0.0001$ & $<0.0001$ & - & $<0.0001$ & $<0.0001$ & $<0.0001$ \\
\hline Nickel - Filtered & $\mathrm{mg} / \mathrm{L}$ & $<0.040$ & $<0.040$ & - & $<0.040$ & $<0.040$ & $<0.040$ \\
\hline Silver - Filtered & $\mathrm{mg} / \mathrm{L}$ & $<0.001$ & $<0.001$ & - & $<0.001$ & $<0.001$ & $<0.001$ \\
\hline Thallium - Filtered & $\mathrm{mg} / \mathrm{L}$ & $<0.0015$ & $<0.0015$ & - & $<0.0015$ & $<0.0015$ & $<0.0015$ \\
\hline Vanadium - Filtered & $\mathrm{mg} / \mathrm{L}$ & $<0.055$ & $<0.055$ & - & $<0.055$ & $<0.055$ & $<0.055$ \\
\hline Zinc - Filtered & $\mathrm{mg} / \mathrm{L}$ & $<0.0150$ & $<0.0150$ & - & 0.0632 & $<0.0150$ & $<0.0150$ \\
\hline Nitrate & $\mathrm{mg} / \mathrm{L}$ & - & 0.98 & - & - & - & - \\
\hline Phenols & $\mathrm{mg} / \mathrm{L}$ & $<0.015$ & - & $<0.020$ & $<0.015$ & $<0.020$ & 0.047 \\
\hline Hydrogen-3 & $\mathrm{nCi} / \mathrm{L}$ & $<0.1$ & - & $<0.1$ & $<0.1$ & $<0.1$ & $<0.1$ \\
\hline Total organic carbon $s$ & $\mathrm{mg} / \mathrm{L}$ & 6.6 & - & 6.5 & 7.8 & 6.6 & 6.4 \\
\hline Total organic carbons & $\mathrm{mg} / \mathrm{L}$ & 6.6 & - & 6.1 & 6.2 & 6.5 & 6.4 \\
\hline Total organic carbons & $\mathrm{mg} / \mathrm{L}$ & 6.6 & - & 5.9 & 6.3 & 6.0 & 6.3 \\
\hline Total organic carbons & $\mathrm{mg} / \mathrm{L}$ & 7.1 & - & 6.2 & 6.8 & 6.5 & 6.9 \\
\hline Total organic halogens & $\mathrm{mg} / \mathrm{L}$ & 0.023 & - & $<0.010$ & 0.013 & $<0.010$ & $<0.010$ \\
\hline Total organic halogens & $\mathrm{mg} / \mathrm{L}$ & 0.021 & - & $<0.010$ & 0.013 & $<0.010$ & $<0.010$ \\
\hline Methylene Chloride & $\mu \mathrm{g} / \mathrm{L}$ & 1 & - & - & 5 & 8 & 3 \\
\hline
\end{tabular}

a A hyphen indicates that no analysis was performed. 
TABLE 6.35

Groundwater Monitoring Results: Sanitary Landfill, Well 800192, 1995

\begin{tabular}{|c|c|c|c|c|c|c|}
\hline & & & & $\begin{array}{l}\text { Well Point } \\
\text { Ground Sur } \\
\text { Casing Mat }\end{array}$ & $\begin{array}{l}\text { vation } \\
\text { e Elevation } \\
\text { al: }\end{array}$ & $\begin{array}{l}\mathrm{m}(\mathrm{MSL}) \\
209.09 \\
227.38 \\
\text { S. STEEL } \\
\end{array}$ \\
\hline Constituent & Units & Feb. 28 & April 11 & April 11 & July 14 & Oct. 12 \\
\hline Water Elevation & $\mathrm{m}$ & 222.43 & 222.50 & 222.50 & 222.50 & 221.70 \\
\hline Temperature & ${ }^{\circ} \mathrm{C}$ & 10.7 & 10.6 & 10.6 & 11.7 & 11.5 \\
\hline $\mathrm{pH}$ & $\mathrm{pH}$ & 6.87 & 6.91 & 6.91 & 6.72 & 6.81 \\
\hline Redox & $\mathrm{mV}$ & 254 & 133 & 133 & 367 & -54 \\
\hline Conductivity & $\mu \mathrm{mho} / \mathrm{cm}$ & 971 & 991 & 991 & 1026 & 1011 \\
\hline Chloride - Filtered & $\mathrm{mg} / \mathrm{L}$ & 62 & 46 & 49 & 35 & 42 \\
\hline Fluoride - Filtered & $\mathrm{mg} / \mathrm{L}$ & $-a^{a}$ & 0.224 & - & - & - \\
\hline Sulfate - Filtered & $\mathrm{mg} / \mathrm{L}$ & 216 & 216 & 227 & 236 & 263 \\
\hline Total Dissolved Solids - Filtered & $\mathrm{mg} / \mathrm{L}$ & 863 & - & 829 & 907 & 879 \\
\hline Cyanide (Total) & $\mathrm{mg} / \mathrm{L}$ & $<0.002$ & - & $<0.002$ & $<0.002$ & $<0.002$ \\
\hline Arsenic & $\mathrm{mg} / \mathrm{L}$ & - & - & 0.0051 & - & - \\
\hline Barium & $\mathrm{mg} / \mathrm{L}$ & - & - & 0.4132 & - & - \\
\hline Beryllium & $\mathrm{mg} / \mathrm{L}$ & - & - & $<0.0001$ & - & - \\
\hline Boron & $\mathrm{mg} / \mathrm{L}$ & - & - & 0.0982 & - & - \\
\hline Cadmium & $\mathrm{mg} / \mathrm{L}$ & - & - & $<0.0001$ & - & - \\
\hline Chromium & $\mathrm{mg} / \mathrm{L}$ & - & - & $<0.060$ & - & - \\
\hline Cobalt & $\mathrm{mg} / \mathrm{L}$ & - & - & $<0.025$ & - & - \\
\hline Copper & $\mathrm{mg} / \mathrm{L}$ & - & - & $<0.045$ & - & - \\
\hline Iron & $\mathrm{mg} / \mathrm{L}$ & - & - & 9.035 & - & - \\
\hline Lead & $\mathrm{mg} / \mathrm{L}$ & - & - & 0.0006 & - & - \\
\hline Manganese & $\mathrm{mg} / \mathrm{L}$ & - & - & 0.179 & - & - \\
\hline Mercury & $\mathrm{mg} / \mathrm{L}$ & - & - & $<0.0001$ & - & - \\
\hline Nickel & $\mathrm{mg} / \mathrm{L}$ & - & - & $<0.040$ & - & - \\
\hline Silver & $\mathrm{mg} / \mathrm{L}$ & - & - & $<0.001$ & - & - \\
\hline Thallium & $\mathrm{mg} / \mathrm{L}$ & - & - & $<0.0015$ & - & - \\
\hline Vanadium & $\mathrm{mg} / \mathrm{L}$ & - & - & $<0.055$ & - & - \\
\hline Zinc & $\mathrm{mg} / \mathrm{L}$ & - & - & $<0.015$ & - & - \\
\hline Ammonia nitrogen - Filtered & $\mathrm{mg} / \mathrm{L}$ & 1.5 & - & 1.0 & 0.8 & 0.7 \\
\hline Arsenic - Filtered & $\mathrm{mg} / \mathrm{L}$ & $<0.0025$ & $<0.0025$ & - & 0.0031 & $<0.0025$ \\
\hline Barium - Filtered & $\mathrm{mg} / \mathrm{L}$ & 0.3863 & 0.3447 & - & 0.3382 & 0.3273 \\
\hline Beryllium - Filtered & $\mathrm{mg} / \mathrm{L}$ & $<0.0001$ & $<0.0001$ & - & $<0.0001$ & $<0.0001$ \\
\hline Cadmium - Filtered & $\mathrm{mg} / \mathrm{L}$ & $<0.0001$ & $<0.0001$ & - & $<0.0001$ & $<0.0001$ \\
\hline Chromium - Filtered & $\mathrm{mg} / \mathrm{L}$ & $<0.060$ & $<0.060$ & - & $<0.060$ & $<0.060$ \\
\hline Cobalt - Filtered & $\mathrm{mg} / \mathrm{L}$ & $<0.025$ & $<0.025$ & - & $<0.025$ & $<0.025$ \\
\hline Copper - Filtered & $\mathrm{mg} / \mathrm{L}$ & $<0.045$ & $<0.045$ & - & $<0.045$ & $<0.045$ \\
\hline Iron - Filtered & $\mathrm{mg} / \mathrm{L}$ & 1.436 & 5.315 & - & 4.772 & 3.085 \\
\hline Lead - Filtered & $\mathrm{mg} / \mathrm{L}$ & 0.0005 & $<0.0005$ & - & $<0.0005$ & $<0.0005$ \\
\hline Manganese - Filtered & $\mathrm{mg} / \mathrm{L}$ & 0.1580 & 0.1775 & - & 0.1751 & 0.1797 \\
\hline Mercury - Filtered & $\mathrm{mg} / \mathrm{L}$ & $<0.0001$ & $<0.0001$ & - & $<0.0001$ & $<0.0001$ \\
\hline Nickel - Filtered & $\mathrm{mg} / \mathrm{L}$ & $<0.040$ & $<0.040$ & - & $<0.040$ & $<0.040$ \\
\hline Silver - Filtered & $\mathrm{mg} / \mathrm{L}$ & $<0.001$ & $<0.001$ & - & $<0.001$ & $<0.001$ \\
\hline Thallium - Filtered & $\mathrm{mg} / \mathrm{L}$ & $<0.0015$ & $<0.0015$ & - & $<0.0015$ & $<0.0015$ \\
\hline Vanadium - Filtered & $\mathrm{mg} / \mathrm{L}$ & $<0.055$ & $<0.055$ & - & $<0.055$ & $<0.055$ \\
\hline Zinc - Filtered & $\mathrm{mg} / \mathrm{L}$ & $<0.0150$ & $<0.0150$ & - & 0.1652 & $<0.0150$ \\
\hline Nitrate & $\mathrm{mg} / \mathrm{L}$ & - & $<0.50$ & - & - & - \\
\hline Phenols & $\mathrm{mg} / \mathrm{L}$ & $<0.015$ & - & $<0.020$ & $<0.015$ & $<0.020$ \\
\hline Hydrogen-3 & $\mathrm{nCi} / \mathrm{L}$ & 0.157 & - & 0.178 & 0.164 & 0.239 \\
\hline Total organic carbons & $\mathrm{mg} / \mathrm{L}$ & 10.3 & - & 8.1 & 8.4 & 9.9 \\
\hline Total organic carbons & $\mathrm{mg} / \mathrm{L}$ & 10.0 & - & 8.2 & 8.6 & 8.6 \\
\hline Total organic carbons & $\mathrm{mg} / \mathrm{L}$ & 9.8 & - & 8.0 & 8.6 & 8.9 \\
\hline Total organic carbons & $\mathrm{mg} / \mathrm{L}$ & 9.8 & - & 8.5 & 9.0 & 10.0 \\
\hline Total organic halogens & $\mathrm{mg} / \mathrm{L}$ & 0.010 & - & 0.015 & 0.013 & $<0.010$ \\
\hline Total organic halogens & $\mathrm{mg} / \mathrm{L}$ & 0.010 & - & 0.014 & 0.014 & 0.013 \\
\hline Methylene Chloride & $\mu \mathrm{g} / \mathrm{L}$ & 1 & - & - & 2 & 4 \\
\hline
\end{tabular}

a A hyphen indicates that no analysis was performed. 
TABLE 6.36

Groundwater Monitoring Results: Sanitary Landfill, Well 800193D, 1995

\begin{tabular}{|c|c|c|c|c|c|c|c|c|}
\hline \multirow[b]{2}{*}{ Constituent } & \multirow[b]{2}{*}{ Units } & \multirow[b]{2}{*}{ Feb. 28} & \multirow[b]{2}{*}{ April 11} & \multirow[b]{2}{*}{ April 11} & \multicolumn{2}{|c|}{$\begin{array}{l}\text { Well Point Elevation } \\
\text { Ground Surface Elevation } \\
\text { Casing Material: }\end{array}$} & \multicolumn{2}{|c|}{$\begin{array}{l}\text { m(MSL) } \\
181.36 \\
227.38 \\
\text { S. STEEL }\end{array}$} \\
\hline & & & & & April 11 & April 11 & July 14 & Oct. 12 \\
\hline Water Elevation & $\bar{m}$ & 192.98 & 192.92 & 192.92 & 192.92 & 192.92 & 192.80 & 192.41 \\
\hline Temperature & ${ }^{\circ} \mathrm{C}$ & 11.5 & 11.3 & 11.3 & 11.3 & 11.3 & 12.0 & 12.0 \\
\hline $\mathrm{pH}$ & $\mathrm{pH}$ & 7.12 & 7.07 & 7.07 & 7.07 & 7.07 & 6.91 & 7.02 \\
\hline Redox & $\mathrm{mV}$ & 289 & 255 & 255 & 255 & 255 & 270 & -27 \\
\hline Conductivity & $\mu \mathrm{mho} / \mathrm{cm}$ & 1011 & 1080 & 1080 & 1080 & 1080 & 1263 & 1001 \\
\hline Chloride - Filtered & $\mathrm{mg} / \mathrm{L}$ & 156 & 232 & 244 & 256 & 256 & 259 & 125 \\
\hline Fluoride - Filtered & $\mathrm{mg} / \mathrm{L}$ & $-a^{a}$ & 0.304 & 0.310 & - & - & - & - \\
\hline Sulfate - Filtered & $\mathrm{mg} / \mathrm{L}$ & 170 & 149 & 135 & 151 & 151 & 177 & 178 \\
\hline Total Dissolved Solids - Filtered & $\mathrm{mg} / \mathrm{L}$ & 799 & - & - & 813 & 813 & 1013 & 791 \\
\hline Cyanide (Total) & $\mathrm{mg} / \mathrm{L}$ & $<0.002$ & - & - & 0.008 & 0.005 & $<0.002$ & $<0.002$ \\
\hline Arsenic & $\mathrm{mg} / \mathrm{L}$ & - & - & - & 0.0152 & 0.0148 & - & - \\
\hline Barium & $\mathrm{mg} / \mathrm{L}$ & - & - & - & 0.3580 & 0.3444 & - & - \\
\hline Beryllium & $\mathrm{mg} / \mathrm{L}$ & - & - & - & $<0.0001$ & $<0.0001$ & - & - \\
\hline Boron & $\mathrm{mg} / \mathrm{L}$ & - & - & - & 0.2282 & 0.2458 & - & - \\
\hline Cadmium & $\mathrm{mg} / \mathrm{L}$ & - & - & - & $<0.0001$ & $<0.0001$ & - & - \\
\hline Chromium & $\mathrm{mg} / \mathrm{L}$ & - & - & - & $<0.060$ & $<0.060$ & - & - \\
\hline Cobalt & $\mathrm{mg} / \mathrm{L}$ & - & - & - & $<0.025$ & $<0.025$ & - & - \\
\hline Copper & $\mathrm{mg} / \mathrm{L}$ & - & - & - & $<0.045$ & $<0.045$ & - & - \\
\hline Iron & $\mathrm{mg} / \mathrm{L}$ & - & - & - & 24.27 & 23.21 & - & - \\
\hline Lead & $\mathrm{mg} / \mathrm{L}$ & - & - & - & 0.0036 & 0.0035 & - & - \\
\hline Manganese & $\mathrm{mg} / \mathrm{L}$ & - & - & - & 0.1401 & 0.1334 & - & - \\
\hline Mercury & $\mathrm{mg} / \mathrm{L}$ & - & - & - & $<0.0001$ & $<0.0001$ & - & - \\
\hline Nickel & $\mathrm{mg} / \mathrm{L}$ & - & - & - & $<0.040$ & $<0.040$ & - & - \\
\hline Silver & $\mathrm{mg} / \mathrm{L}$ & - & - & - & $<0.001$ & $<0.001$ & - & - \\
\hline Thallium & $\mathrm{mg} / \mathrm{L}$ & - & - & - & $<0.0015$ & $<0.0015$ & - & - \\
\hline Vanadium & $\mathrm{mg} / \mathrm{L}$ & - & - & - & $<0.055$ & $<0.055$ & - & - \\
\hline Zinc & $\mathrm{mg} / \mathrm{L}$ & - & - & - & 0.0153 & $<0.0150$ & - & - \\
\hline Ammonia Nitrogen - Filtered & $\mathrm{mg} / \mathrm{L}$ & 0.9 & - & - & 0.6 & 0.5 & 0.5 & 0.6 \\
\hline Arsenic - Filtered & $\mathrm{mg} / \mathrm{L}$ & $<0.0025$ & $<0.0025$ & $<0.0025$ & - & - & $<0.0025$ & $<0.0025$ \\
\hline Barium - Filtered & $\mathrm{mg} / \mathrm{L}$ & 0.0811 & 0.1002 & 0.0909 & - & - & 0.0848 & 0.0678 \\
\hline Beryllium - Filtered & $\mathrm{mg} / \mathrm{L}$ & $<0.0001$ & $<0.0001$ & $<0.0001$ & - & - & $<0.0001$ & $<0.0001$ \\
\hline Cadmium - Filtered & $\mathrm{mg} / \mathrm{L}$ & $<0.0001$ & $<0.0001$ & $<0.0001$ & - & - & $<0.0001$ & $<0.0001$ \\
\hline Chromium - Filtered & $\mathrm{mg} / \mathrm{L}$ & $<0.060$ & $<0.060$ & $<0.060$ & - & - & $<0.060$ & $<0.060$ \\
\hline Cobalt - Filtered & $\mathrm{mg} / \mathrm{L}$ & $<0.025$ & $<0.025$ & $<0.025$ & - & - & $<0.025$ & $<0.025$ \\
\hline Copper - Filtered & $\mathrm{mg} / \mathrm{L}$ & $<0.045$ & $<0.045$ & $<0.045$ & - & - & $<0.045$ & $<0.045$ \\
\hline Iron - Filtered & $\mathrm{mg} / \mathrm{L}$ & 0.5290 & 0.8062 & 0.8634 & - & - & 0.8601 & 0.0316 \\
\hline Lead - Filtered & $\mathrm{mg} / \mathrm{L}$ & 0.0007 & $<0.0005$ & $<0.0005$ & - & - & $<0.0005$ & 0.0006 \\
\hline Manganese - Filtered & $\mathrm{mg} / \mathrm{L}$ & 0.0470 & 0.0436 & 0.0397 & - & - & 0.0452 & 0.0529 \\
\hline Mercury - Filtered & $\mathrm{mg} / \mathrm{L}$ & $<0.0001$ & $<0.0001$ & $<0.0001$ & - & - & $<0.0001$ & $<0.0001$ \\
\hline Nickel - Filtered & $\mathrm{mg} / \mathrm{L}$ & $<0.040$ & $<0.040$ & $<0.040$ & - & - & $<0.040$ & $<0.040$ \\
\hline Silver - Filtered & $\mathrm{mg} / \mathrm{L}$ & $<0.001$ & $<0.001$ & $<0.001$ & - & - & $<0.001$ & $<0.001$ \\
\hline Thallium - Filtered & $\mathrm{mg} / \mathrm{L}$ & $<0.0015$ & $<0.0015$ & $<0.0015$ & - & - & $<0.0015$ & $<0.0015$ \\
\hline Vanadium - Filtered & $\mathrm{mg} / \mathrm{L}$ & $<0.055$ & $<0.055$ & $<0.055$ & - & - & $<0.055$ & $<0.055$ \\
\hline Zinc - Filtered & $\mathrm{mg} / \mathrm{L}$ & $<0.015$ & $<0.015$ & $<0.015$ & - & - & $<0.015$ & $<0.015$ \\
\hline Nitrate & $\mathrm{mg} / \mathrm{L}$ & - & 0.85 & 0.91 & - & - & - & - \\
\hline Phenols & $\mathrm{mg} / \mathrm{L}$ & $<0.015$ & - & - & $<0.020$ & $<0.020$ & $<0.015$ & $<0.020$ \\
\hline Hydrogen-3 & $\mathrm{nCi} / \mathrm{L}$ & $<0.1$ & - & - & $<0.1$ & $<0.1$ & $<0.1$ & $<0.1$ \\
\hline Total organic carbons & $\mathrm{mg} / \mathrm{L}$ & 4.3 & - & - & 7.2 & 11.3 & 6.2 & 3.4 \\
\hline Total organic carbons & $\mathrm{mg} / \mathrm{L}$ & 4.6 & - & - & 6.9 & 10.4 & 6.6 & 3.4 \\
\hline Total organic carbons & $\mathrm{mg} / \mathrm{L}$ & 4.2 & - & - & 7.4 & 8.4 & 6.6 & 4.8 \\
\hline Total organic carbons & $\mathrm{mg} / \mathrm{L}$ & 4.5 & - & - & 7.6 & 8.8 & 7.5 & 5.1 \\
\hline Total organic halogens & $\mathrm{mg} / \mathrm{L}$ & $<0.010$ & - & - & 0.019 & 0.015 & 0.013 & $<0.010$ \\
\hline Total organic halogens & $\mathrm{mg} / \mathrm{L}$ & $<0.010$ & - & - & 0.019 & 0.017 & 0.014 & $<0.010$ \\
\hline Acetone & $\mu \mathrm{g} / \mathrm{L}$ & 7 & - & - & 12 & 9 & - & - \\
\hline Methylene Chloride & $\mu \mathrm{g} / \mathrm{L}$ & 2 & - & - & 2 & 1 & 4 & 8 \\
\hline
\end{tabular}

A hyphen indicates that no analysis was performed. 
TABLE 6.37.

Groundwater Monitoring Results: Sanitary Landfill, Well 800201, 1995

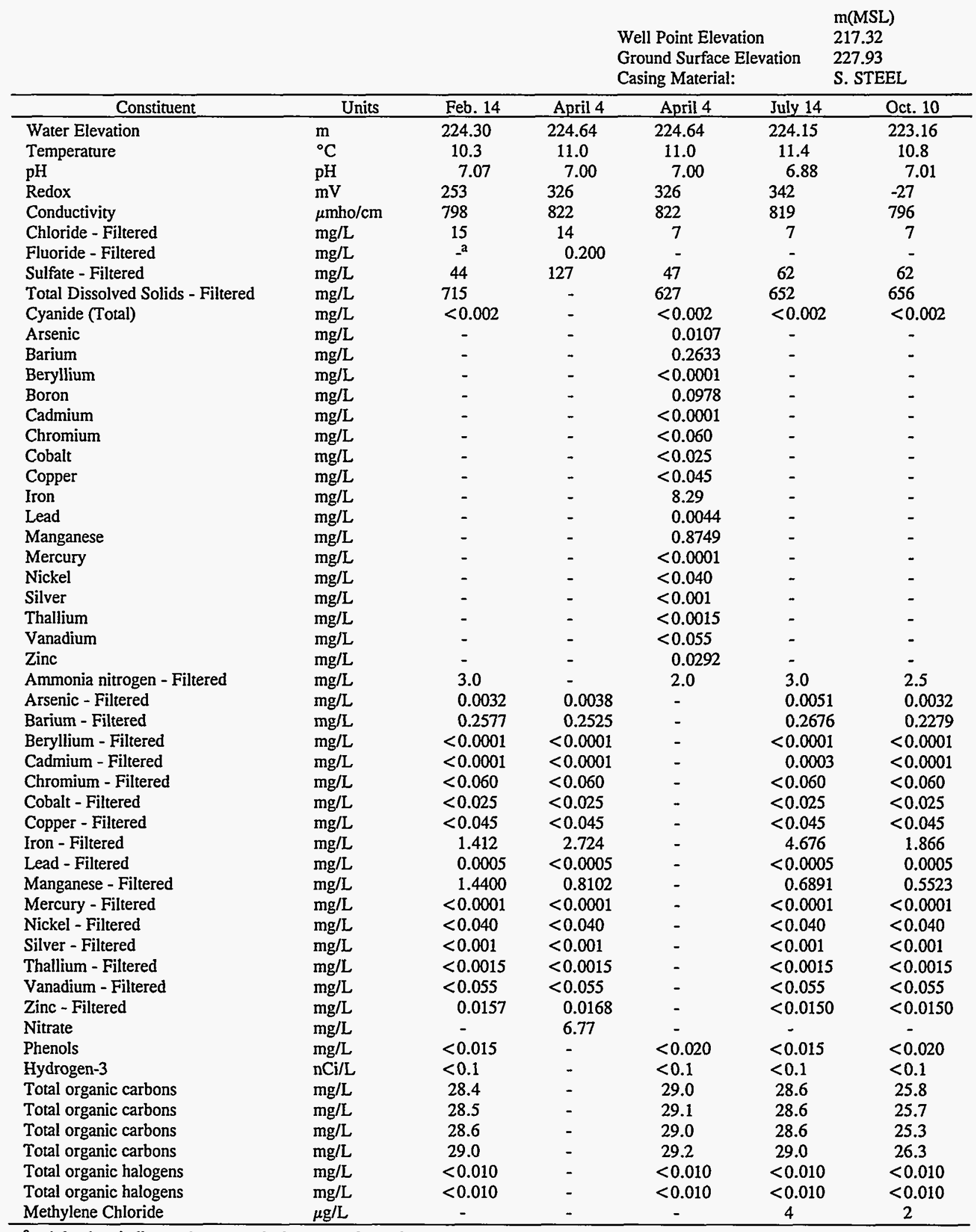

a A hyphen indicates that no analysis was performed. 
TABLE 6.38

Groundwater Monitoring Results: Sanitary Landfill, Well 800202, 1995

$\begin{array}{ll} & \mathrm{m}(\mathrm{MSL}) \\ \text { Well Point Elevation } & 209.70 \\ \text { Ground Surface Elevation } & 227.93 \\ \text { Casing Material: } & \text { S. STEEL }\end{array}$

\begin{tabular}{|c|c|c|c|c|c|c|}
\hline Constituent & Units & Feb. 28 & April 11 & April 11 & July 14 & Oct. 12 \\
\hline Water Elevation & $\mathrm{m}$ & 218.15 & 218.55 & 218.55 & 218.62 & 217.63 \\
\hline Temperature & ${ }^{\circ} \mathrm{C}$ & 10.4 & 10.4 & 10.4 & 11.1 & 11.4 \\
\hline $\mathrm{pH}$ & $\mathrm{pH}$ & 7.19 & 7.12 & 7.12 & 6.97 & 7.00 \\
\hline Redox & $\mathrm{mV}$ & -14 & 284 & 284 & 352 & -69 \\
\hline Conductivity & $\mu \mathrm{mho} / \mathrm{cm}$ & 757 & 752 & 752 & 761 & 763 \\
\hline Chloride - Filtered & $\mathrm{mg} / \mathrm{L}$ & 25 & 29 & 30 & 19 & 18 \\
\hline Fluoride - Filtered & $\mathrm{mg} / \mathrm{L}$ & $-^{a}$ & 0.196 & - & - & - \\
\hline Sulfate - Filtered & $\mathrm{mg} / \mathrm{L}$ & 53 & 52 & 64 & 73 & 71 \\
\hline Total Dissolved Solids - Filtered & $\mathrm{mg} / \mathrm{L}$ & 638 & - & 575 & 614 & 655 \\
\hline Cyanide (Total) & $\mathrm{mg} / \mathrm{L}$ & $<0.002$ & - & $<0.002$ & $<0.002$ & $<0.002$ \\
\hline Arsenic & $\mathrm{mg} / \mathrm{L}$ & - & - & 0.019 & - & - \\
\hline Barium & $\mathrm{mg} / \mathrm{L}$ & - & - & 0.1206 & - & - \\
\hline Beryllium & $\mathrm{mg} / \mathrm{L}$ & - & - & $<0.0001$ & - & - \\
\hline Boron & $\mathrm{mg} / \mathrm{L}$ & - & - & 0.1369 & - & - \\
\hline Cadmium & $\mathrm{mg} / \mathrm{L}$ & - & - & $<0.0001$ & - & - \\
\hline Chromium & $\mathrm{mg} / \mathrm{L}$ & - & - & $<0.060$ & - & - \\
\hline Cobalt & $\mathrm{mg} / \mathrm{L}$ & - & - & $<0.025$ & - & - \\
\hline Copper & $\mathrm{mg} / \mathrm{L}$ & - & - & $<0.045$ & - & - \\
\hline Iron & $\mathrm{mg} / \mathrm{L}$ & - & - & 1.571 & - & - \\
\hline Lead & $\mathrm{mg} / \mathrm{L}$ & - & - & 0.0007 & - & - \\
\hline Manganese & $\mathrm{mg} / \mathrm{L}$ & - & - & 0.3809 & - & - \\
\hline Mercury & $\mathrm{mg} / \mathrm{L}$ & - & - & $<0.0001$ & - & - \\
\hline Nickel & $\mathrm{mg} / \mathrm{L}$ & - & - & $<0.040$ & - & - \\
\hline Silver & $\mathrm{mg} / \mathrm{L}$ & - & - & $<0.001$ & - & - \\
\hline Thallium & $\mathrm{mg} / \mathrm{L}$ & - & - & $<0.0015$ & - & - \\
\hline Vanadium & $\mathrm{mg} / \mathrm{L}$ & - & - & $<0.055$ & - & - \\
\hline Zinc & $\mathrm{mg} / \mathrm{L}$ & - & - & $<0.015$ & - & - \\
\hline Ammonia nitrogen - Filtered & $\mathrm{mg} / \mathrm{L}$ & 1.5 & - & 1.0 & 1.0 & 1.0 \\
\hline Arsenic - Filtered & $\mathrm{mg} / \mathrm{L}$ & 0.0061 & 0.0208 & - & 0.0169 & 0.0153 \\
\hline Barium - Filtered & $\mathrm{mg} / \mathrm{L}$ & 0.1200 & 0.1116 & - & 0.1334 & 0.1078 \\
\hline Beryllium - Filtered & $\mathrm{mg} / \mathrm{L}$ & $<0.0001$ & $<0.0001$ & - & $<0.0001$ & $<0.0001$ \\
\hline Cadmium - Filtered & $\mathrm{mg} / \mathrm{L}$ & $<0.0001$ & $<0.0001$ & - & 0.0001 & $<0.0001$ \\
\hline Chromium - Filtered & $\mathrm{mg} / \mathrm{L}$ & $<0.060$ & $<0.060$ & - & $<0.060$ & $<0.060$ \\
\hline Cobalt - Filtered & $\mathrm{mg} / \mathrm{L}$ & $<0.025$ & $<0.025$ & - & $<0.025$ & $<0.025$ \\
\hline Copper - Filtered & $\mathrm{mg} / \mathrm{L}$ & $<0.045$ & $<0.045$ & - & $<0.045$ & $<0.045$ \\
\hline Iron - Filtered & $\mathrm{mg} / \mathrm{L}$ & 1.5300 & 1.2640 & - & 1.5630 & 0.6781 \\
\hline Lead - Filtered & $\mathrm{mg} / \mathrm{L}$ & 0.0006 & $<0.0005$ & - & $<0.0005$ & $<0.0005$ \\
\hline Manganese - Filtered & $\mathrm{mg} / \mathrm{L}$ & 0.4090 & 0.3257 & - & 0.3236 & 0.1567 \\
\hline Mercury - Filtered & $\mathrm{mg} / \mathrm{L}$ & $<0.0001$ & $<0.0001$ & - & $<0.0001$ & $<0.0001$ \\
\hline Nickel - Filtered & $\mathrm{mg} / \mathrm{L}$ & $<0.040$ & $<0.040$ & - & $<0.040$ & $<0.040$ \\
\hline Silver - Filtered & $\mathrm{mg} / \mathrm{L}$ & $<0.001$ & $<0.001$ & - & $<0.001$ & $<0.001$ \\
\hline Thallium - Filtered & $\mathrm{mg} / \mathrm{L}$ & $<0.0015$ & $<0.0015$ & - & $<0.0015$ & $<0.0015$ \\
\hline Vanadium - Filtered & $\mathrm{mg} / \mathrm{L}$ & $<0.055$ & $<0.055$ & - & $<0.055$ & $<0.055$ \\
\hline Zinc - Filtered & $\mathrm{mg} / \mathrm{L}$ & $<0.015$ & $<0.015$ & - & $<0.015$ & $<0.015$ \\
\hline Nitrate & $\mathrm{mg} / \mathrm{L}$ & - & $<0.50$ & - & - & - \\
\hline Phenols & $\mathrm{mg} / \mathrm{L}$ & $<0.015$ & - & $<0.020$ & $<0.015$ & $<0.020$ \\
\hline Hydrogen-3 & $\mathrm{nCi} / \mathrm{L}$ & $<0.1$ & - & $<0.1$ & $<0.1$ & $<0.1$ \\
\hline Total organic carbons & $\mathrm{mg} / \mathrm{L}$ & 11.6 & - & 16.0 & 13.1 & 16.9 \\
\hline Total organic carbons & $\mathrm{mg} / \mathrm{L}$ & 11.7 & - & 14.8 & 12.0 & 15.7 \\
\hline Total organic carbons & $\mathrm{mg} / \mathrm{L}$ & 11.1 & - & 15.1 & 12.6 & 16.3 \\
\hline Total organic carbons & $\mathrm{mg} / \mathrm{L}$ & 11.6 & - & 15.2 & 12.5 & 15.6 \\
\hline Total organic halogens & $\mathrm{mg} / \mathrm{L}$ & $<0.010$ & - & $<0.010$ & $<0.010$ & $<0.010$ \\
\hline Total organic halogens & $\mathrm{mg} / \mathrm{L}$ & $<0.010$ & - & $<0.010$ & $<0.010$ & $<0.010$ \\
\hline Acetone & $\mu \mathrm{g} / \mathrm{L}$ & - & - & 7 & 8 & - \\
\hline Methylene Chloride & $\mu \mathrm{g} / \mathrm{L}$ & 1 & - & - & 3 & 11 \\
\hline
\end{tabular}

a A hyphen indicates that no analysis was performed. 
TABLE 6.39

Groundwater Monitoring Results: Sanitary Landfill, Well 800203D, 1995

\begin{tabular}{|c|c|c|c|c|c|c|}
\hline \multirow[b]{2}{*}{ Constituent } & \multirow[b]{2}{*}{ Units } & \multirow[b]{2}{*}{ Feb. 28} & \multirow[b]{2}{*}{ April 11} & \multicolumn{2}{|c|}{$\begin{array}{l}\text { Well Point Elevation } \\
\text { Ground Surface Elevation } \\
\text { Casing Material: }\end{array}$} & \multirow{2}{*}{$\begin{array}{l}\text { m(MSL) } \\
189.59 \\
227.93 \\
\text { S. STEEL } \\
\text { Oct. } 12 \\
\end{array}$} \\
\hline & & & & April 11 & July 14 & \\
\hline Water Elevation & $\mathrm{m}$ & 193.05 & 193.05 & 193.05 . & 192.85 & 192.45 \\
\hline Temperature & ${ }^{\circ} \mathrm{C}$ & 11.9 & 11.6 & 11.6 & 11.9 & 11.7 \\
\hline $\mathrm{pH}$ & $\mathrm{pH}$ & 7.17 & 7.12 & 7.12 & 6.98 & 6.97 \\
\hline Redox & $\mathrm{mV}$ & 101 & 231 & 231 & 153 & -107 \\
\hline Conductivity & $\mu \mathrm{mho} / \mathrm{cm}$ & 1122 & 1168 & 1168 & 1003 & 909 \\
\hline Chloride - Filtered & $\mathrm{mg} / \mathrm{L}$ & 206 & 237 & 266 & 175 & 106 \\
\hline Fluoride - Filtered & $\mathrm{mg} / \mathrm{L}$ & $-{ }^{a}$ & 0.362 & - & - & - \\
\hline Sulfate - Filtered & $\mathrm{mg} / \mathrm{L}$ & 51 & 45 & 47 & 47 & 45 \\
\hline Total Dissolved Solids - Filtered & $\mathrm{mg} / \mathrm{L}$ & 813 & - & 787 & 712 & 661 \\
\hline Cyanide (Total) & $\mathrm{mg} / \mathrm{L}$ & $<0.002$ & - & $<0.002$ & $<0.002$ & $<0.002$ \\
\hline Arsenic & $\mathrm{mg} / \mathrm{L}$ & - & - & 0.0069 & - & - \\
\hline Barium & $\mathrm{mg} / \mathrm{L}$ & - & - & 0.1249 & - & - \\
\hline Beryllium & $\mathrm{mg} / \mathrm{L}$ & - & - & $<0.0001$ & - & - \\
\hline Boron & $\mathrm{mg} / \mathrm{L}$ & - & - & 0.2252 & - & - \\
\hline Cadmium & $\mathrm{mg} / \mathrm{L}$ & - & - & $<0.0001$ & - & - \\
\hline Chromium & $\mathrm{mg} / \mathrm{L}$ & - & - & $<0.060$ & - & - \\
\hline Cobalt & $\mathrm{mg} / \mathrm{L}$ & - & - & 0.0671 & - & - \\
\hline Copper & $\mathrm{mg} / \mathrm{L}$ & - & - & $<0.045$ & - & - \\
\hline Iron & $\mathrm{mg} / \mathrm{L}$ & - & - & 5.282 & - & - \\
\hline Lead & $\mathrm{mg} / \mathrm{L}$ & - & - & 0.0012 & - & - \\
\hline Manganese & $\mathrm{mg} / \mathrm{L}$ & - & - & 0.1015 & - & - \\
\hline Mercury & $\mathrm{mg} / \mathrm{L}$ & - & - & $<0.0001$ & - & - \\
\hline Nickel & $\mathrm{mg} / \mathrm{L}$ & - & - & $<0.040$ & - & - \\
\hline Silver & $\mathrm{mg} / \mathrm{L}$ & - & - & $<0.001$ & - & - \\
\hline Thallium & $\mathrm{mg} / \mathrm{L}$ & - & - & $<0.0015$ & - & - \\
\hline Vanadium & $\mathrm{mg} / \mathrm{L}$ & - & - & $<0.055$ & - & - \\
\hline Zinc & $\mathrm{mg} / \mathrm{L}$ & - & - & $<0.015$ & - & - \\
\hline Ammonia nitrogen - Filtered & $\mathrm{mg} / \mathrm{L}$ & 1.5 & - & 1.0 & 1.0 & 2.0 \\
\hline Arsenic - Filtered & $\mathrm{mg} / \mathrm{L}$ & 0.0060 & 0.0064 & - & 0.0116 & 0.0041 \\
\hline Barium - Filtered & $\mathrm{mg} / \mathrm{L}$ & 0.0937 & 0.1169 & - & 0.1375 & 0.1304 \\
\hline Beryllium - Filtered & $\mathrm{mg} / \mathrm{L}$ & $<0.0001$ & $<0.0001$ & - & $<0.0001$ & $<0.0001$ \\
\hline Cadmium - Filtered & $\mathrm{mg} / \mathrm{L}$ & $<0.0001$ & $<0.0001$ & - & $<0.0001$ & $<0.0001$ \\
\hline Chromium - Filtered & $\mathrm{mg} / \mathrm{L}$ & $<0.060$ & $<0.060$ & - & $<0.060$ & $<0.060$ \\
\hline Cobalt - Filtered & $\mathrm{mg} / \mathrm{L}$ & $<0.0250$ & $<0.025$ & - & $<0.025$ & $<0.025$ \\
\hline Copper - Filtered & $\mathrm{mg} / \mathrm{L}$ & $<0.045$ & $<0.0450$ & - & $<0.0450$ & $<0.0450$ \\
\hline Iron - Filtered & $\mathrm{mg} / \mathrm{L}$ & 2.619 & 4.589 & - & 8.030 & 2.797 \\
\hline Lead - Filtered & $\mathrm{mg} / \mathrm{L}$ & 0.0006 & $<0.0005$ & - & $<0.0005$ & $<0.0005$ \\
\hline Manganese - Filtered & $\mathrm{mg} / \mathrm{L}$ & 0.0930 & 0.0776 & - & 0.0868 & 0.0696 \\
\hline Mercury - Filtered & $\mathrm{mg} / \mathrm{L}$ & $<0.0001$ & $<0.0001$ & - & $<0.0001$ & $<0.0001$ \\
\hline Nickel - Filtered & $\mathrm{mg} / \mathrm{L}$ & $<0.040$ & $<0.040$ & - & $<0.040$ & $<0.040$ \\
\hline Silver - Filtered & $\mathrm{mg} / \mathrm{L}$ & $<0.001$ & $<0.001$ & - & $<0.001$ & $<0.001$ \\
\hline Thallium - Filtered & $\mathrm{mg} / \mathrm{L}$ & $<0.0015$ & $<0.0015$ & - & $<0.0015$ & $<0.0015$ \\
\hline Vanadium - Filtered & $\mathrm{mg} / \mathrm{L}$ & $<0.055$ & $<0.055$ & - & $<0.055$ & $<0.055$ \\
\hline Zinc - Filtered & $\mathrm{mg} / \mathrm{L}$ & $<0.015$ & $<0.015$ & - & $<0.015$ & $<0.015$ \\
\hline Nitrate & $\mathrm{mg} / \mathrm{L}$ & - & 1.04 & - & - & - \\
\hline Phenols & $\mathrm{mg} / \mathrm{L}$ & $<0.015$ & - & $<0.020$ & $<0.015$ & $<0.020$ \\
\hline Hydrogen-3 & $\mathrm{nCi} / \mathrm{L}$ & $<0.1$ & - & $<0.1$ & $<0.1$ & $<0.1$ \\
\hline Total organic carbons & $\mathrm{mg} / \mathrm{L}$ & 5.8 & - & 9.7 & 6.7 & 4.4 \\
\hline Total organic carbons & $\mathrm{mg} / \mathrm{L}$ & 5.7 & - & 5.9 & 6.6 & 4.9 \\
\hline Total organic carbons & $\mathrm{mg} / \mathrm{L}$ & 6.2 & - & 7.5 & 6.7 & 4.4 \\
\hline Total organic carbons & $\mathrm{mg} / \mathrm{L}$ & 5.6 & - & 5.9 & 6.8 & 4.4 \\
\hline Total organic halogens & $\mathrm{mg} / \mathrm{L}$ & 0.019 & - & 0.014 & 0.015 & $<0.010$ \\
\hline Total organic halogens & $\mathrm{mg} / \mathrm{L}$ & 0.017 & - & 0.015 & 0.015 & $<0.010$ \\
\hline Acetone & $\mu \mathrm{g} / \mathrm{L}$ & - & - & - & 66 & - \\
\hline Methylene Chloride & $\mu \mathrm{g} / \mathrm{L}$ & - & - & - & 2 & 4 \\
\hline
\end{tabular}

a A hyphen indicates that no analysis was performed. 


\section{GROUNDWATER PROTECTION}
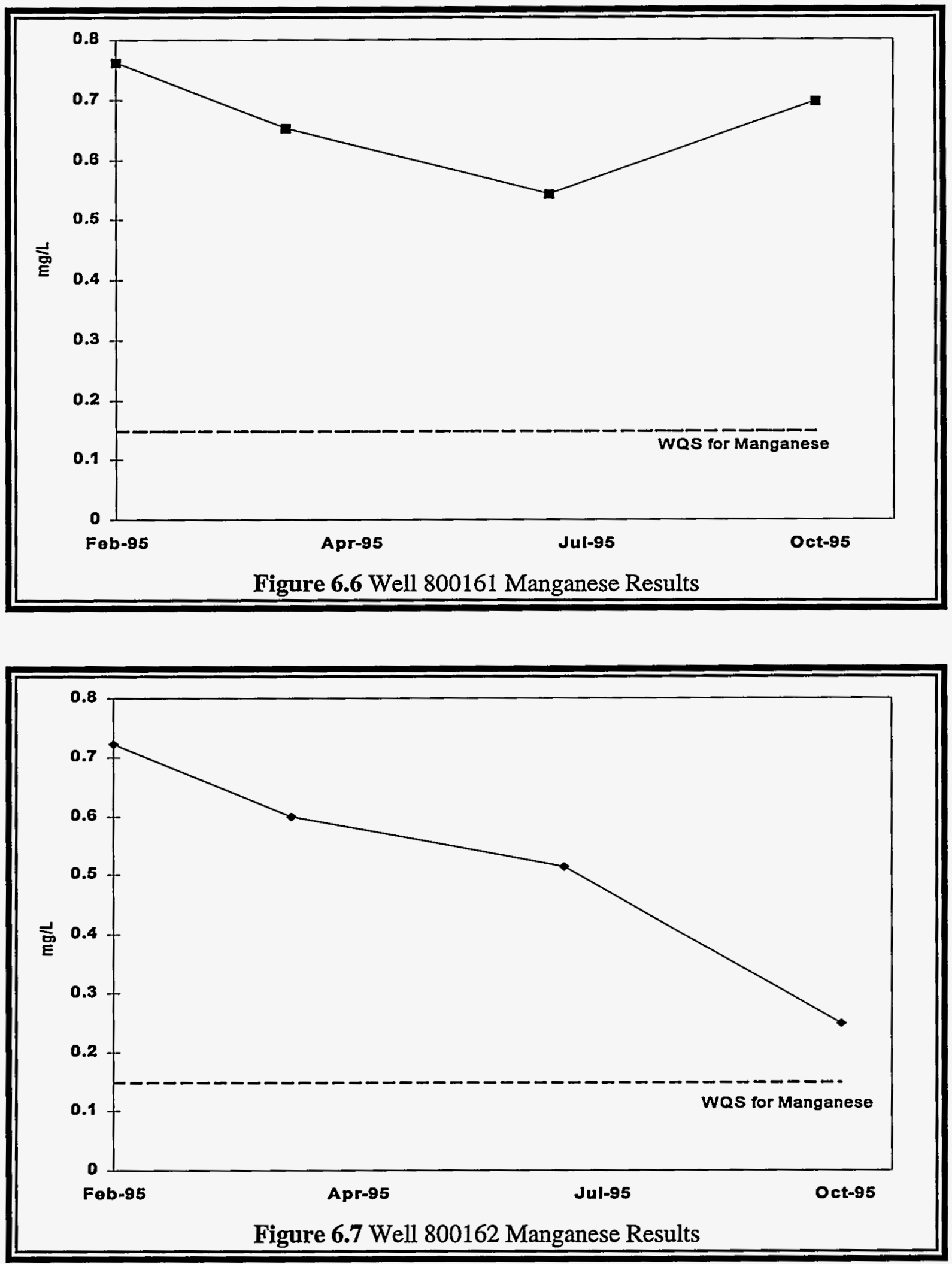

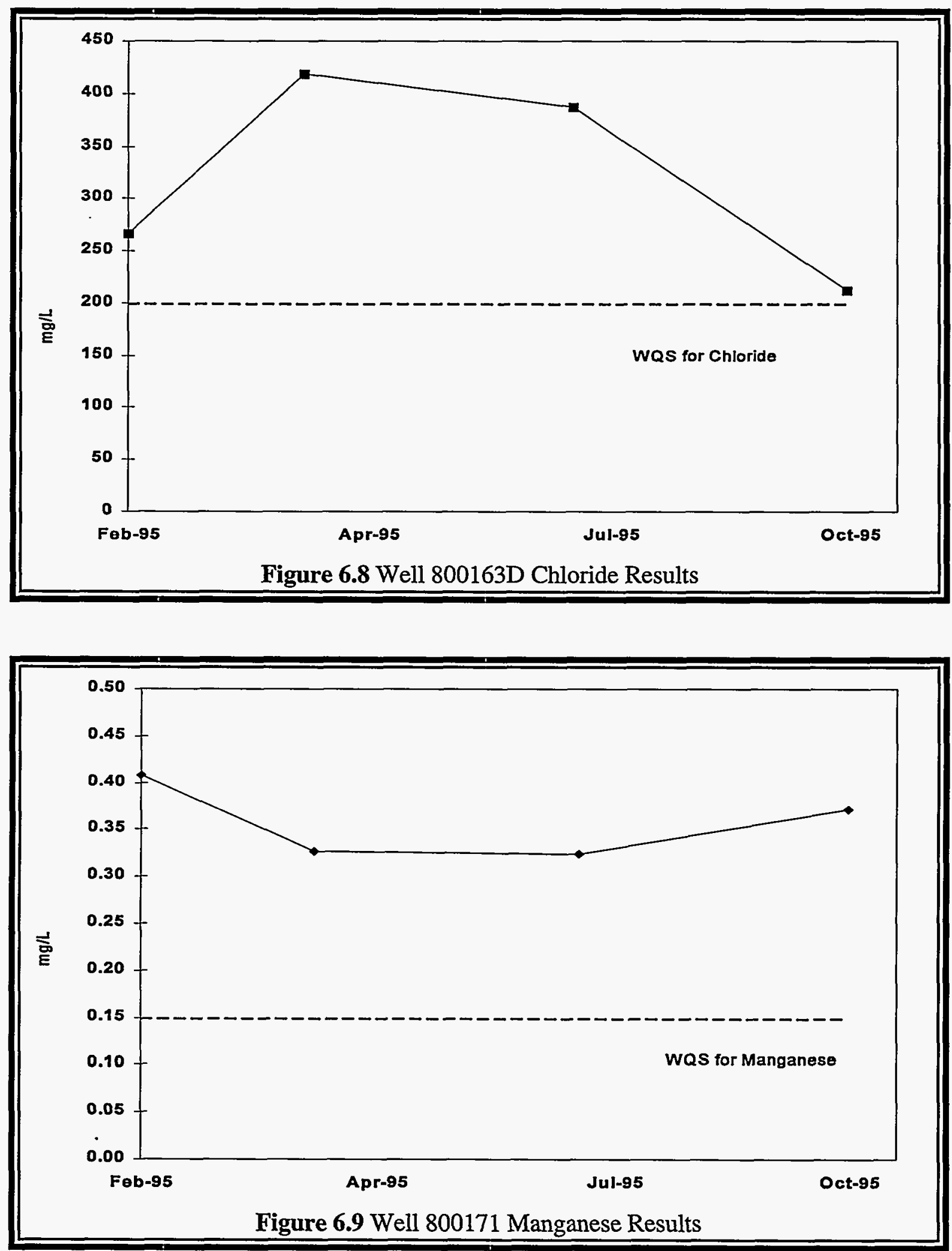


\section{GROUNDWATER PROTECTION}
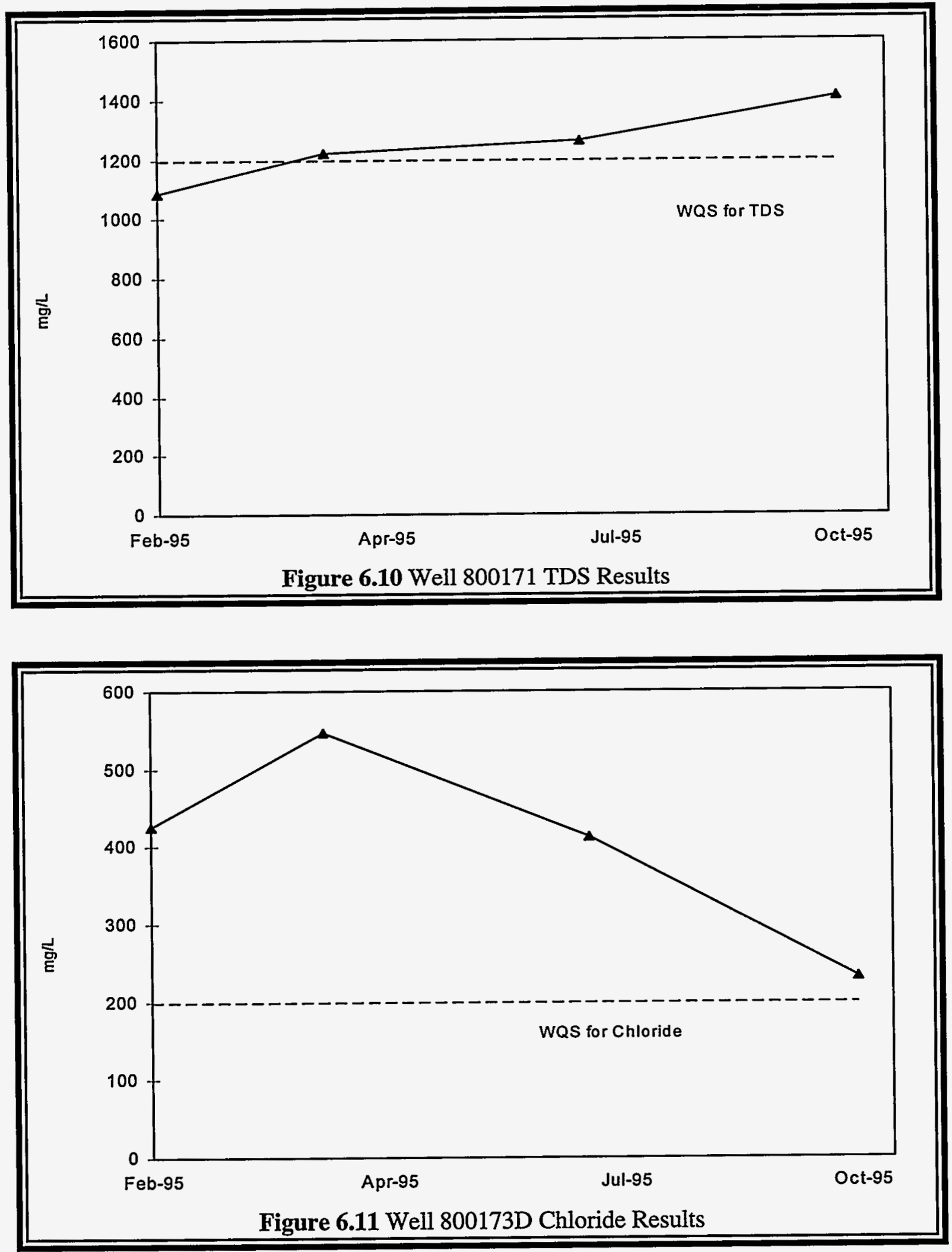

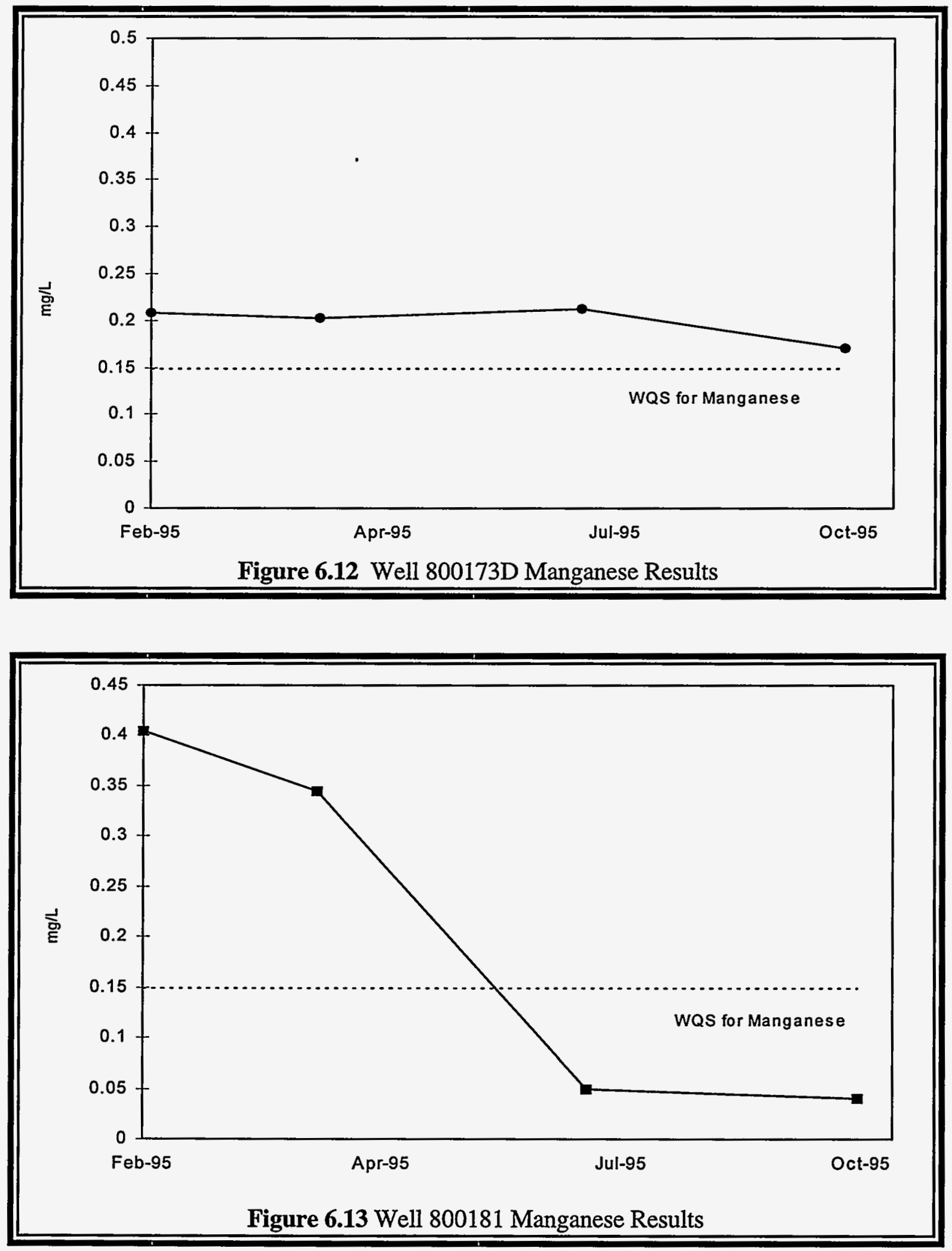

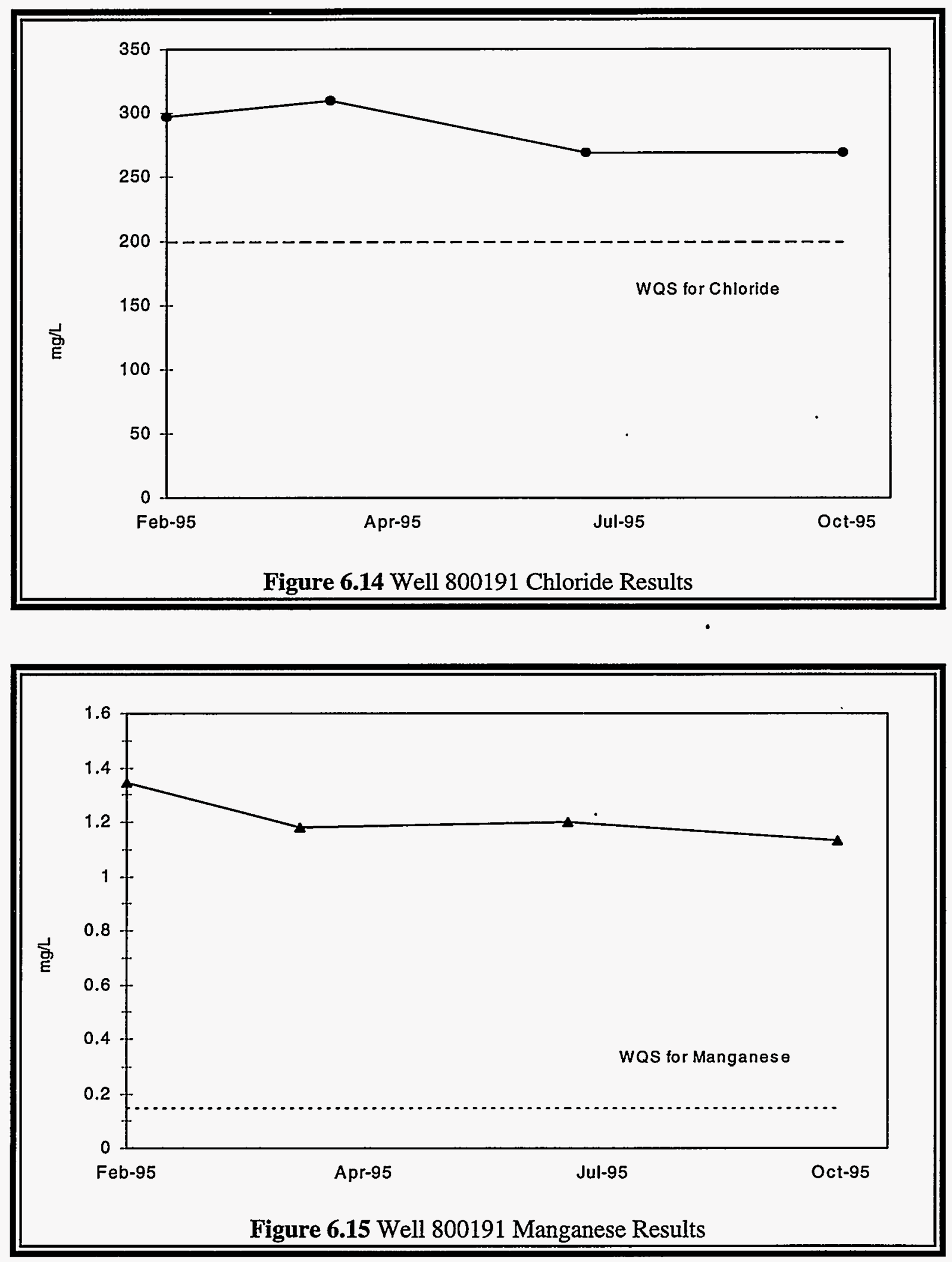

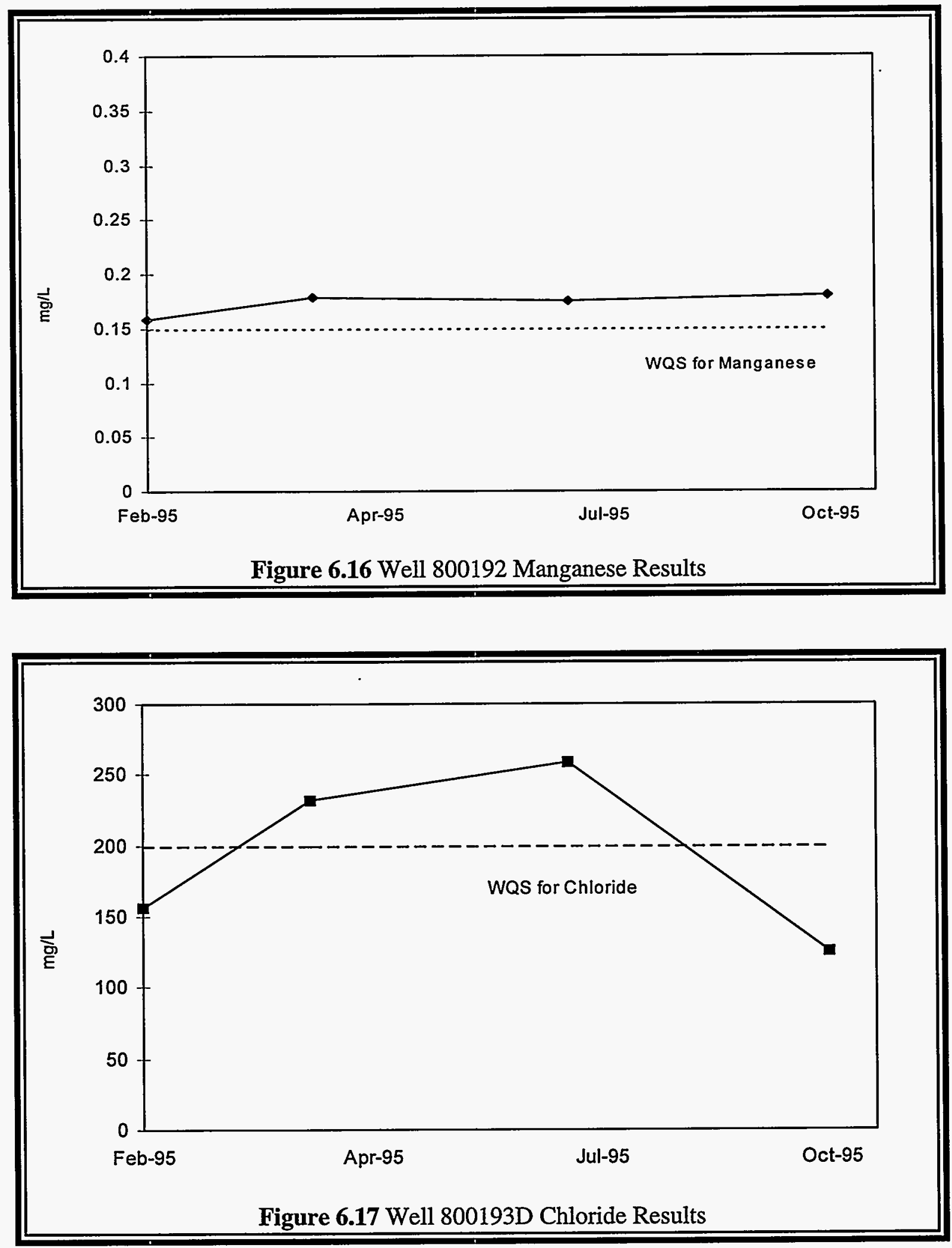


\section{GROUNDWATER PROTECTION}
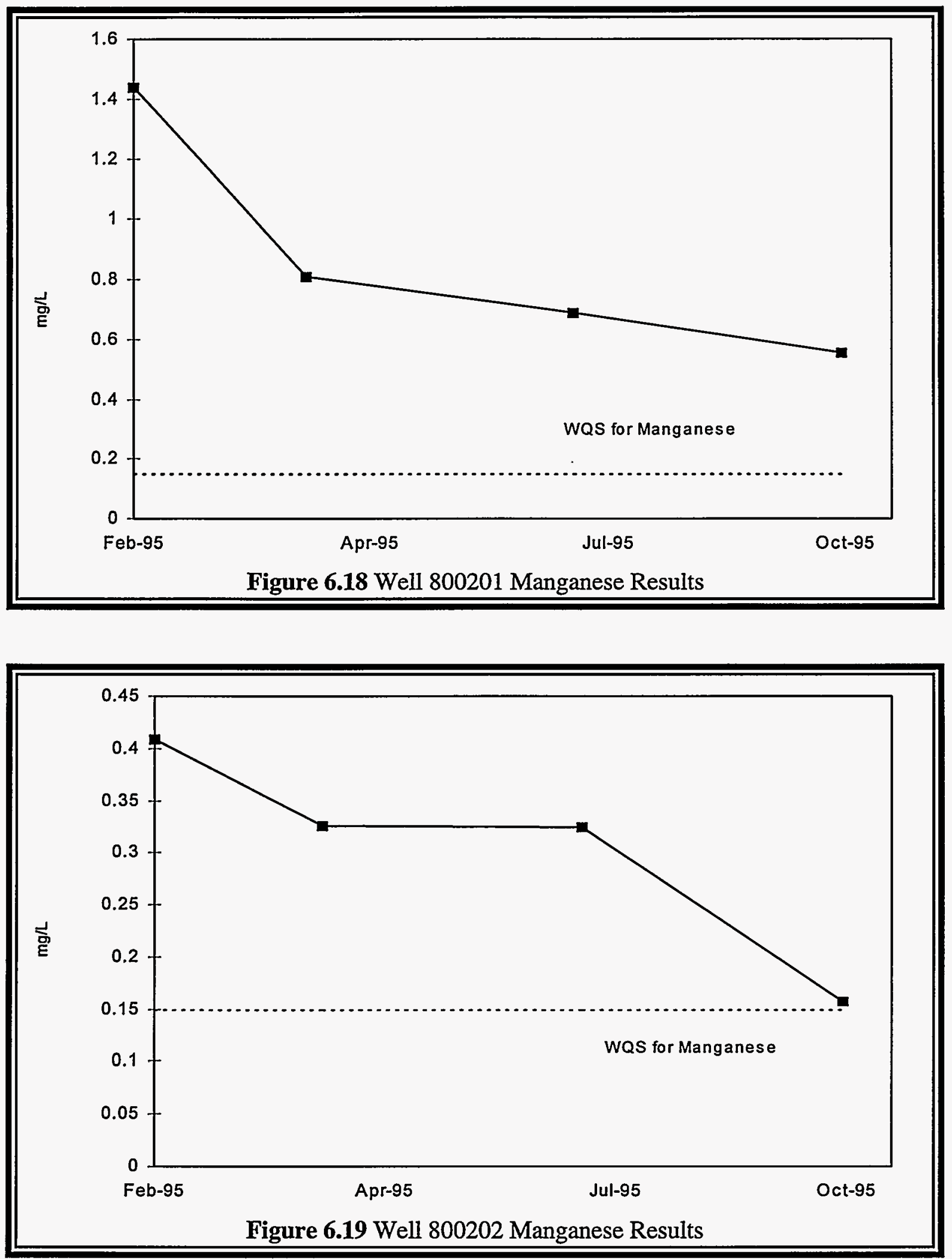


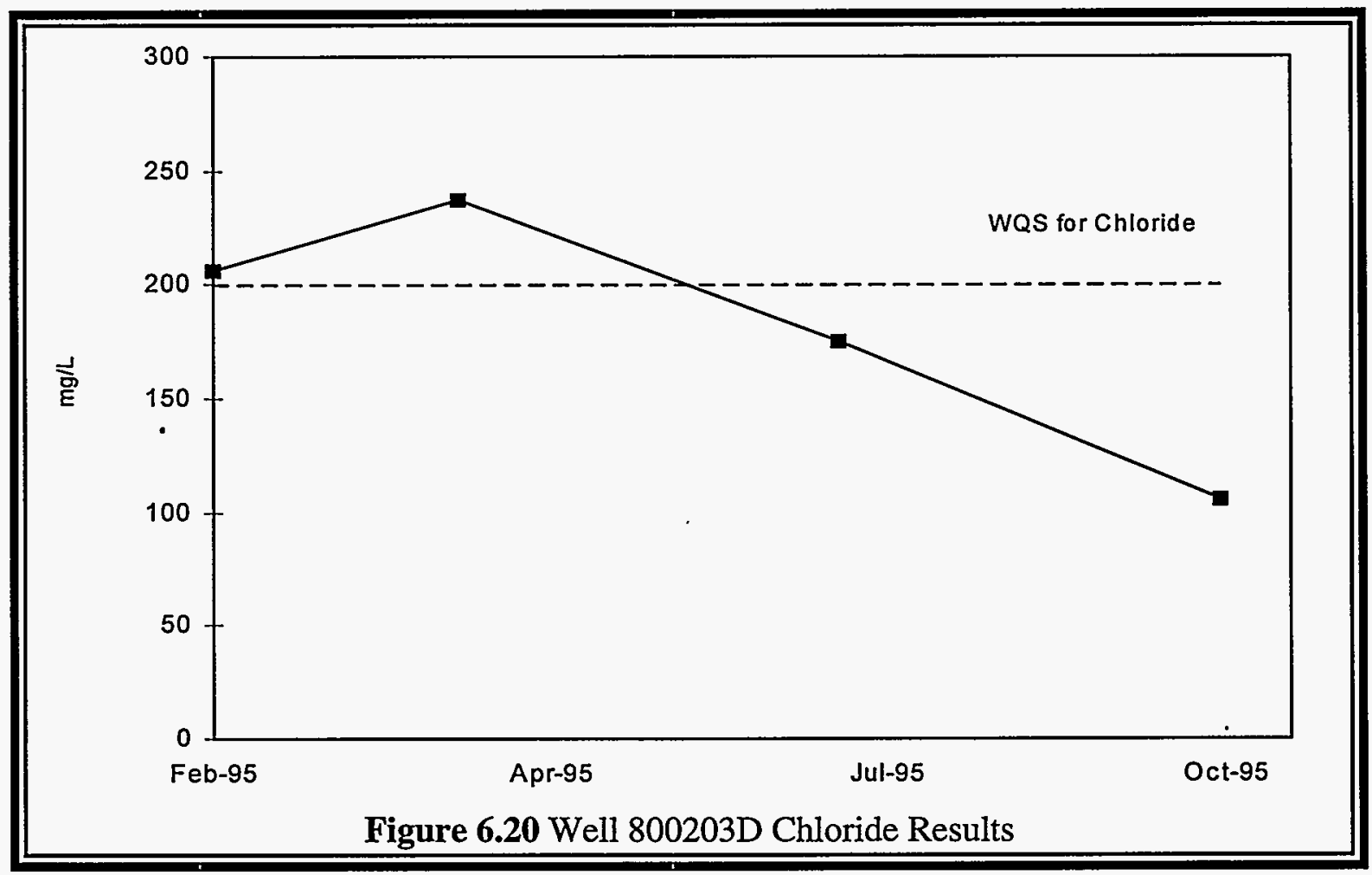

WQS for wells monitored as part of the IEPA-approved groundwater monitoring program for the sanitary landfill.

Inorganic Constituents. On April 24, 1992, and January 11, 1995, the IEPA issued supplemental permits to ANL-E that, in part, approved a groundwater monitoring program for the sanitary landfill. The program will be capable of identifying any releases from the facility and demonstrating compliance with the applicable groundwater quality standards. Under the January 1995 supplemental permit, IEPA chose 13 groundwater monitoring points (800161, 800162, 800163D, 800171, 800173D, 800181, 800183D, 800191, 800192, 800193D, 800201, $800202,800203 \mathrm{D}$ ) to be sampled on a quarterly basis commencing January 1995. Parameters to be monitored include field parameters, routine indicator parameters, inorganic parameters, and volatile organic parameters. Volatile organic parameters are to be monitored only during the second quarter of monitoring. Routine indicator parameters are field-filtered prior to analysis and are collected each quarter. Inorganic parameters are unfiltered prior to analysis and are collected only during the second quarter. 
ANL-E chose a conservative approach for evaluating the inorganic monitoring results by selecting as the standard of comparison the Illinois Groundwater Quality Standards for Class I: Potable Resource Groundwater, 35 IAC Section 620.410. The most common constituents at levels above the WQS (see Table 6.23) are chloride, iron, TDS, and manganese. This is consistent with results reported in prior years using the previous well monitoring network.

Wells 800163D, 800173D, 800191, 800193D, and 800203D consistently exceeded the WQS for chloride. Chloride levels ranged from $106 \mathrm{mg} / \mathrm{L}$ to $547 \mathrm{mg} / \mathrm{L}$ in these wells. The iron WQS was exceeded only once for a filtered sample at well 800203D. This appears to be an isolated result, and the cause is unknown. During the second quarter when unfiltered iron samples are required, the iron WQS was exceeded in wells 800173D, 800181, 800191, 800192, 800193D, 800201, and 800203D. The iron levels for these samples ranged from $5,280 \mathrm{mg} / \mathrm{L}$ to $24,300 \mathrm{mg} / \mathrm{L}$. The manganese WQS was consistently exceeded in wells $800161,800162,800171$, 800173D, 800181, 800191, 800192, 800201, and 800202.- Manganese levels in these wells ranged from $40 \mathrm{mg} / \mathrm{L}$ to $1,440 \mathrm{mg} / \mathrm{L}$. The total dissolved solid WQS was exceeded each quarter in well 800171 , and the levels ranged from $1,087 \mathrm{mg} / \mathrm{L}$ to $1,409 \mathrm{mg} / \mathrm{L}$. The chromium and nickel WQSs were exceeded during the second quarter in well 800181. Chromium and nickel are required to be monitored only during the second quarter.

Organic Constituents. No exceedances of the organic WQS were noted during 1995. Methylene chloride was the most consistent parameter detected during 1995; it was detected in each well at least two or more quarters. Levels were low and ranged from $1 \mu \mathrm{g} / \mathrm{L}$ to $12 \mu \mathrm{g} / \mathrm{L}$. Acetone was detected infrequently in wells 800162, 800163D, 800173D, 800183D, 800193D, 800202 , and $800203 \mathrm{D}$. Acetone levels ranged from $2 \mu \mathrm{g} / \mathrm{L}$ to $66 \mu \mathrm{g} / \mathrm{L}$. Acetone was also found in the blank samples during the first, third, and fourth quarters; low-level acetone results during these quarters may be indicative of laboratory contamination. Toluene was found in trace amounts in wells 800162 and $800163 \mathrm{D}$. Trace levels of 2-butanone were found in wells 800163D, 800173D, and 800183D. Chloroethane and cis-1,2-dichloroethene were detected at trace levels in well 800171 only one quarter, and trace levels of trichloroethene were detected for three quarters. No semivolatiles, PCBs, pesticides, and herbicides were detected in the 800 Area Landfill wells during 1995. 


\section{GROUNDWATER PROTECTION}

Radioactive Constituents. Samples collected from the 800 Area sanitary landfill monitoring wells were also analyzed for hydrogen-3. The results are shown in Tables 6.27 to 6.39. Although the disposal of radioactive materials was prohibited in the sanitary landfill, very low concentrations of hydrogen-3 were detected in wells 800161, 800171, and 800192, probably because of inadvertent disposal of radioactivity in ANL-E trash. However, the presence of hydrogen-3 as tritiated water allows information to be obtained on the subsurface water flow pathway in the sanitary landfill area. The data indicate that the principal direction of subsurface water flow is to the south-southeast, with a small component to the northwest. This is consistent with the estimated subsurface water flow based on water level measurements and general flow patterns in the area.

\subsection{CP-5 Reactor Area}

The CP-5 reactor is an inactive research reactor located in Building 330 (see Figure 1.1). CP-5 was a 5 MW research reactor that was used from 1954 until operations were ceased in 1977. In addition to the reactor vessel itself, the CP-5 complex contained several large cooling towers and an outdoor equipment yard used for storage of equipment and supplies. The reactor and associated yard area are in the process of being decommissioned. A single exploratory monitoring well was installed in 1989 in the yard immediately behind the reactor building, just outside the reactor fuel storage area of the complex. Two new wells were installed as part of a full characterization study of this site, which took place during 1993. The three wells were sampled quarterly in 1995 and analyzed for radionuclides, metals, VOCs, SVOCs, pesticides, herbicides, and PCBs. The results are shown in Tables 6.40 to 6.42. Table 6.43 characterizes all wells in this area (see Figure 6.21 for locations).

Well 330011 is installed in a relatively porous, saturated region of soil and as a result, recharges quickly. Purging the well by removing several well volumes of water does not lower the water level appreciably. The water has a higher conductivity than similar wells at other locations. The manganese WQS was exceeded each quarter, and levels ranged from $0.86 \mathrm{mg} / \mathrm{L}$ to $0.97 \mathrm{mg} / \mathrm{L}$. Low levels of barium and chloride were found, all well below the WQS. Manganese and barium 


\section{GROUNDWATER PROTECTION}

TABLE 6.40

Groundwater Monitoring Results: 300 Area, Well 330011, 1995

\begin{tabular}{|c|c|c|c|c|c|}
\hline & & & $\begin{array}{l}\text { Well Point } \\
\text { Ground Sur } \\
\text { Casing Mat }\end{array}$ & $\begin{array}{l}\text { ation } \\
\text { Elevation }\end{array}$ & $\begin{array}{l}\mathrm{m}(\mathrm{MSL}) \\
215.70 \\
222.56 \\
\text { Steel } \\
\end{array}$ \\
\hline Constituent & Units & March 9 & May 31 & Aug. 29 & Nov. 10 \\
\hline Water Elevation & $\mathrm{m}$ & 219.75 & 219.77 & 219.18 & 219.16 \\
\hline Temperature & ${ }^{\circ} \mathrm{C}$ & 8.9 & 13.9 & 18.1 & 18.9 \\
\hline $\mathrm{pH}$ & $\mathrm{pH}$ & 7.28 & 7.97 & 6.92 & 7.22 \\
\hline Redox & $\mathrm{mV}$ & 375 & 155 & 180 & 194 \\
\hline Conductivity & $\mu \mathrm{mho} / \mathrm{cm}$ & 1045 & 994 & 1340 & 1183 \\
\hline Chloride - Filtered & $\mathrm{mg} / \mathrm{L}$ & 76 & 62 & 178 & 116 \\
\hline Arsenic - Filtered & $\mathrm{mg} / \mathrm{L}$ & $<0.0025$ & $<0.0025$ & $<0.0025$ & $<0.0025$ \\
\hline Barium - Filtered & $\mathrm{mg} / \mathrm{L}$ & 0.0653 & 0.0674 & 0.0769 & 0.0706 \\
\hline Beryllium - Filtered & $\mathrm{mg} / \mathrm{L}$ & $<0.0001$ & $<0.0001$ & $<0.0001$ & $<0.0001$ \\
\hline Cadmium - Filtered & $\mathrm{mg} / \mathrm{L}$ & $<0.0001$ & $<0.0001$ & 0.0001 & $<0.0001$ \\
\hline Chromium - Filtered & $\mathrm{mg} / \mathrm{L}$ & $<0.060$ & $<0.060$ & $<0.060$ & $<0.060$ \\
\hline Cobalt - Filtered & $\mathrm{mg} / \mathrm{L}$ & $<0.025$ & $<0.025$ & $<0.025$ & $<0.025$ \\
\hline Copper - Filtered & $\mathrm{mg} / \mathrm{L}$ & $<0.045$ & $<0.045$ & $<0.045$ & $<0.045$ \\
\hline Iron - Filtered & $\mathrm{mg} / \mathrm{L}$ & $<0.025$ & $<0.025$ & $<0.025$ & $<0.025$ \\
\hline Lead - Filtered & $\mathrm{mg} / \mathrm{L}$ & $<0.0005$ & $<0.0005$ & $<0.0005$ & $<0.0005$ \\
\hline Manganese - Filtered & $\mathrm{mg} / \mathrm{L}$ & 0.8655 & 0.9225 & 0.9691 & 0.8624 \\
\hline Mercury - Filtered & $\mathrm{mg} / \mathrm{L}$ & $<0.0001$ & $<0.0001$ & $<0.0001$ & $<0.0001$ \\
\hline Nickel - Filtered & $\mathrm{mg} / \mathrm{L}$ & $<0.040$ & $<0.040$ & $<0.040$ & $<0.040$ \\
\hline Silver - Filtered & $\mathrm{mg} / \mathrm{L}$ & $<0.001$ & $<0.001$ & $<0.001$ & $<0.001$ \\
\hline Thallium - Filtered & $\mathrm{mg} / \mathrm{L}$ & $<0.0015$ & $<0.0015$ & $<0.0015$ & $<0.0015$ \\
\hline Vanadium - Filtered & $\mathrm{mg} / \mathrm{L}$ & $<0.055$ & $<0.055$ & $<0.055$ & $<0.055$ \\
\hline Zinc - Filtered & $\mathrm{mg} / \mathrm{L}$ & $<0.0150$ & $<0.0150$ & $<0.0150$ & 0.0316 \\
\hline Cesium-137 & $\mathrm{pCi} / \mathrm{L}$ & $<1.0$ & $<1.0$ & $<1.0$ & $<1.0$ \\
\hline Hydrogen-3 & $\mathrm{nCi} / \mathrm{L}$ & 7.785 & 4.370 & 9.189 & 5.139 \\
\hline Strontium-90 & $\mathrm{pCi} / \mathrm{L}$ & 1.18 & 0.98 & 1.43 & 1.57 \\
\hline Acetone & $\mu \mathrm{g} / \mathrm{L}$ & $-^{a}$ & 2 & - & 3 \\
\hline Dichlorofluoromethane & $\mu \mathrm{g} / \mathrm{L}$ & 4 & 2 & 4 & 3 \\
\hline Methylene Chloride & $\mu \mathrm{g} / \mathrm{L}$ & 6 & - & - & 2 \\
\hline Trichlorofluoromethane & $\mu \mathrm{g} / \mathrm{L}$ & 4 & 2 & 3 & 4 \\
\hline
\end{tabular}

a A hyphen indicates that the concentration is below the detection limit. 
TABLE 6.41

Groundwater Monitoring Results: 300 Area, Well 330021, 1995

\begin{tabular}{|c|c|c|c|c|c|}
\hline \multirow[b]{2}{*}{ Constituent } & \multirow[b]{2}{*}{ Units } & \multirow[b]{2}{*}{ March 9} & \multicolumn{2}{|c|}{$\begin{array}{l}\text { Well Point Elevation } \\
\text { Ground Surface Elevation } \\
\text { Casing Material: }\end{array}$} & \multirow{2}{*}{$\begin{array}{l}\mathrm{m}(\mathrm{MSL}) \\
215.88 \\
227.52 \\
\text { S. Steel } \\
\text { Nov. } 14 \\
\end{array}$} \\
\hline & & & May 31 & Aug. 29 & \\
\hline Water Elevation & $\mathrm{m}$ & 226.64 & 226.64 & 225.00 & 225.69 \\
\hline Temperature & ${ }^{\circ} \mathrm{C}$ & 7.9 & 9.5 & 12.5 & 12.8 \\
\hline $\mathrm{pH}$ & $\mathrm{pH}$ & 7.59 & 7.61 & 7.90 & 7.31 \\
\hline Redox & $\mathrm{mV}$ & 352 & 222 & 83 & 78 \\
\hline Conductivity & $\mu \mathrm{mho} / \mathrm{cm}$ & 544 & 566 & 641 & 573 \\
\hline Chloride - Filtered & $\mathrm{mg} / \mathrm{L}$ & 11 & 4 & 9 & 9 \\
\hline Arsenic- Filtered & $\mathrm{mg} / \mathrm{L}$ & $<0.0025$ & $<0.0025$ & $<0.0025$ & $<0.0025$ \\
\hline Barium - Filtered & $\mathrm{mg} / \mathrm{L}$ & 0.0263 & 0.0241 & 0.0246 & 0.0311 \\
\hline Beryllium - Filtered & $\mathrm{mg} / \mathrm{L}$ & $<0.0001$ & $<0.0001$ & $<0.0001$ & $<0.0001$ \\
\hline Cadmium - Filtered & $\mathrm{mg} / \mathrm{L}$ & $<0.0001$ & $<0.0001$ & $<0.0001$ & $<0.0001$ \\
\hline Chromium - Filtered & $\mathrm{mg} / \mathrm{L}$ & $<0.060$ & $<0.060$ & $<0.060$ & $<0.060$ \\
\hline Cobalt - Filtered & $\mathrm{mg} / \mathrm{L}$ & $<0.025$ & $<0.025$ & $<0.025$ & $<0.025$ \\
\hline Copper - Filtered & $\mathrm{mg} / \mathrm{L}$ & $<0.045$ & $<0.045$ & $<0.045$ & $<0.045$ \\
\hline Iron - Filtered & $\mathrm{mg} / \mathrm{L}$ & $<0.025$ & $<0.025$ & $<0.025$ & $<0.025$ \\
\hline Lead - Filtered & $\mathrm{mg} / \mathrm{L}$ & $<0.0005$ & $<0.0005$ & $<0.0005$ & $<0.0005$ \\
\hline Manganese - Filtered & $\mathrm{mg} / \mathrm{L}$ & 0.1217 & $<0.0200$ & 0.0228 & $<0.0200$ \\
\hline Mercury - Filtered & $\mathrm{mg} / \mathrm{L}$ & $<0.0001$ & $<0.0001$ & $<0.0001$ & $<0.0001$ \\
\hline Nickel - Filtered & $\mathrm{mg} / \mathrm{L}$ & 0.1501 & $<0.0400$ & $<0.0400$ & $<0.0400$ \\
\hline Silver - Filtered & $\mathrm{mg} / \mathrm{L}$ & $<0.001$ & $<0.001$ & $<0.001$ & $<0.001$ \\
\hline Thallium - Filtered & $\mathrm{mg} / \mathrm{L}$ & $<0.0015$ & $<0.0015$ & $<0.0015$ & $<0.0015$ \\
\hline Vanadium - Filtered & $\mathrm{mg} / \mathrm{L}$ & $<0.055$ & $<0.055$ & $<0.055$ & $<0.055$ \\
\hline Zinc - Filtered & $\mathrm{mg} / \mathrm{L}$ & $<0.015$ & $<0.015$ & $<0.015$ & $<0.015$ \\
\hline Cesium-137 & $\mathrm{pCi} / \mathrm{L}$ & 1.75 & $<1.0$ & $<1.0$ & $<1.0$ \\
\hline Hydrogen-3 & $\mathrm{nCi} / \mathrm{L}$ & 0.229 & 0.103 & 0.147 & 0.183 \\
\hline Strontium-90 & $\mathrm{pCi} / \mathrm{L}$ & $<0.25$ & $<0.25$ & $<0.25$ & $<0.25$ \\
\hline Acetone & $\mu \mathrm{g} / \mathrm{L}$ & $-^{\mathrm{a}}$ & - & - & 4 \\
\hline Methylene Chloride & $\mu \mathrm{g} / \mathrm{L}$ & 2 & - & - & 2 \\
\hline
\end{tabular}

a A hyphen indicates that the concentration is below the detection limit. 


\section{GROUNDWATER PROTECTION}

TABLE 6.42

Groundwater Monitoring Results: 300 Area, Well 330031, 1995

\begin{tabular}{|c|c|c|c|c|c|c|}
\hline \multirow[b]{2}{*}{ Constituent } & \multirow[b]{2}{*}{ Units } & \multirow[b]{2}{*}{ March 9} & \multicolumn{3}{|c|}{$\begin{array}{l}\text { Well Point Elevation } \\
\text { Ground Surface Elevation } \\
\text { Casing Material: }\end{array}$} & $\begin{array}{l}\mathrm{m}(\mathrm{MSL}) \\
220.97 \\
226.18 \\
\text { S. Steel }\end{array}$ \\
\hline & & & March 9 & May 31 & Aug. 29 & Nov. 14 \\
\hline Water Elevation & $\mathrm{m}$ & 225.88 & 225.88 & 225.94 & 224.90 & 226.03 \\
\hline Temperature & ${ }^{\circ} \mathrm{C}$ & 6.1 & 6.1 & 10.4 & 14.4 & 12.8 \\
\hline $\mathrm{pH}$ & $\mathrm{pH}$ & 7.50 & 7.50 & 7.20 & 7.46 & 7.21 \\
\hline Redox & $\mathrm{mV}$ & 364 & 364 & 199 & 160 & 40 \\
\hline Conductivity & $\mu \mathrm{mho} / \mathrm{cm}$ & 774 & 774 & 818 & 942 & 880 \\
\hline Chloride - Filtered & $\mathrm{mg} / \mathrm{L}$ & 52 & 51 & 54 & 56 & 73 \\
\hline Arsenic - Filtered & $\mathrm{mg} / \mathrm{L}$ & $<0.0025$ & $<0.0025$ & $<0.0025$ & $<0.0025$ & $<0.0025$ \\
\hline Barium - Filtered & $\mathrm{mg} / \mathrm{L}$ & 0.0281 & 0.0311 & 0.0364 & 0.0388 & 0.0397 \\
\hline Beryllium - Filtered & $\mathrm{mg} / \mathrm{L}$ & $<0.0001$ & $<0.0001$ & $<0.0001$ & $<0.0001$ & $<0.0001$ \\
\hline Cadmium - Filtered & $\mathrm{mg} / \mathrm{L}$ & $<0.0001$ & $<0.0001$ & $<0.0001$ & $<0.0001$ & $<0.0001$ \\
\hline Chromium - Filtered & $\mathrm{mg} / \mathrm{L}$ & $<0.060$ & $<0.060$ & $<0.060$ & $<0.060$ & $<0.060$ \\
\hline Cobalt - Filtered & $\mathrm{mg} / \mathrm{L}$ & $<0.025$ & $<0.025$ & $<0.025$ & $<0.025$ & $<0.025$ \\
\hline Copper - Filtered & $\mathrm{mg} / \mathrm{L}$ & $<0.045$ & $<0.045$ & $<0.045$ & $<0.045$ & $<0.045$ \\
\hline Iron - Filtered & $\mathrm{mg} / \mathrm{L}$ & $<0.025$ & $<0.025$ & $<0.025$ & $<0.025$ & $<0.025$ \\
\hline Lead - Filtered & $\mathrm{mg} / \mathrm{L}$ & $<0.0005$ & $<0.0005$ & $<0.0005$ & $<0.0005$ & $<0.0005$ \\
\hline Manganese - Filtered & $\mathrm{mg} / \mathrm{L}$ & $<0.0200$ & $<0.0200$ & $<0.0200$ & 0.0358 & 0.0410 \\
\hline Mercury - Filtered & $\mathrm{mg} / \mathrm{L}$ & $<0.0001$ & $<0.0001$ & $<0.0001$ & $<0.0001$ & $<0.0001$ \\
\hline Nickel - Filtered & $\mathrm{mg} / \mathrm{L}$ & $<0.0400$ & $<0.0400$ & $<0.0400$ & $<0.0400$ & 0.1608 \\
\hline Silver - Filtered & $\mathrm{mg} / \mathrm{L}$ & $<0.001$ & $<0.001$ & $<0.001$ & $<0.001$ & $<0.001$ \\
\hline Thallium - Filtered & $\mathrm{mg} / \mathrm{L}$ & $<0.0015$ & $<0.0015$ & $<0.0015$ & $<0.0015$ & $<0.0015$ \\
\hline Vanadium - Filtered & $\mathrm{mg} / \mathrm{L}$ & $<0.055$ & $<0.055$ & $<0.055$ & $<0.055$ & $<0.055$ \\
\hline Zinc - Filtered & $\mathrm{mg} / \mathrm{L}$ & $<0.015$ & $<0.015$ & $<0.015$ & $<0.015$ & $<0.015$ \\
\hline Cesium-137 & $\mathrm{pCi} / \mathrm{L}$ & $<1.0$ & $<1.0$ & $<1.0$ & $<1.0$ & $<1.0$ \\
\hline Hydrogen-3 & $\mathrm{nCi} / \mathrm{L}$ & 0.340 & 0.296 & 0.279 & 0.313 & 0.267 \\
\hline Strontium-90 & $\mathrm{pCi} / \mathrm{L}$ & $<0.25$ & $<0.25$ & $<0.25$ & $<0.25$ & $<0.25$ \\
\hline Acetone & $\mu \mathrm{g} / \mathrm{L}$ & 4 & 3 & 2 & $-{ }^{a}$ & 4 \\
\hline Methylene Chloride & $\mu \mathrm{g} / \mathrm{L}$ & 13 & 5 & - & - & 2 \\
\hline
\end{tabular}

a A hyphen indicates that the concentration is below the detection limit. 


\section{GROUNDWATER PROTECTION}

TABLE 6.43

Groundwater Monitoring Wells: 330 Area/CP-5

\begin{tabular}{lllccc}
\hline $\begin{array}{l}\text { ID } \\
\text { Number }\end{array}$ & $\begin{array}{c}\text { Well } \\
\text { Depth }^{\mathrm{a}}\end{array}$ & $\begin{array}{c}\text { Ground } \\
\text { Elevation }^{\mathrm{b}}\end{array}$ & $\begin{array}{c}\text { Monitoring } \\
\text { Zone }^{\mathrm{c}}\end{array}$ & $\begin{array}{c}\text { Well } \\
\text { Type }^{\mathrm{d}}\end{array}$ & $\begin{array}{c}\text { Date } \\
\text { Drilled }\end{array}$ \\
\hline 330011 & 20 & 745.5 & $10-20 / 736-726$ & $2 / \mathrm{PVC}$ & $8 / 89$ \\
330021 & 19 & 746.5 & $4-19 / 743-728$ & $2 / \mathrm{SS}$ & $9 / 93$ \\
330031 & 17.1 & 742.1 & $2-17 / 740-725$ & $2 / \mathrm{SS}$ & $9 / 93$ \\
\hline
\end{tabular}

${ }^{\text {a }}$ Feet below ground.

b Feet mean sea level.

c Depth/elevation.

d Inner diameter (in.)/well material (PVC = polyvinyl chloride, SS = stainless steel).

were detected each quarter in well 330021. Manganese was found two quarters in well 330031, and barium each quarter, all well below the WQS.

Similar to results in 1991, 1992, 1993, and 1994 collected from well 330011, each sample collected and analyzed in 1995 contained trichlorofluoromethane and dichlorofluoromethane ranging from $2 \mu \mathrm{g} / \mathrm{L}$ to $4 \mu \mathrm{g} / \mathrm{L}$. These levels are significantly lower than those reported in 1991 and 1992. Methylene chloride and acetone were noted at trace levels each quarter in each well.

The levels of hydrogen-3 ranged from 0.10 to $9.19 \mathrm{nCi} / \mathrm{L}$, and the levels of strontium-90 ranged from $<0.25$ to $1.6 \mathrm{pCi} / \mathrm{L}$ and were noted only in well 330011 . Cesium-137 ranged from $<1$ to $1.8 \mathrm{pCi} / \mathrm{L}$ and was noted only during the first quarter in well 330021 . CP-5 was a heavy water-moderated reactor. During its operational life, several incidents occurred that released small amounts of this heavy water containing high concentrations of hydrogen- 3 to the environment. In addition, the normal operation released significant amounts of water vapor containing hydrogen-3 from the main ventilation system that may have condensed and fallen to the ground in the form of precipitation. These activities are believed to be responsible for the residual amounts of hydrogen- 3 now found in the groundwater. The source of the strontium-90 is not known. 


\section{GROUNDWATER PROTECTION}
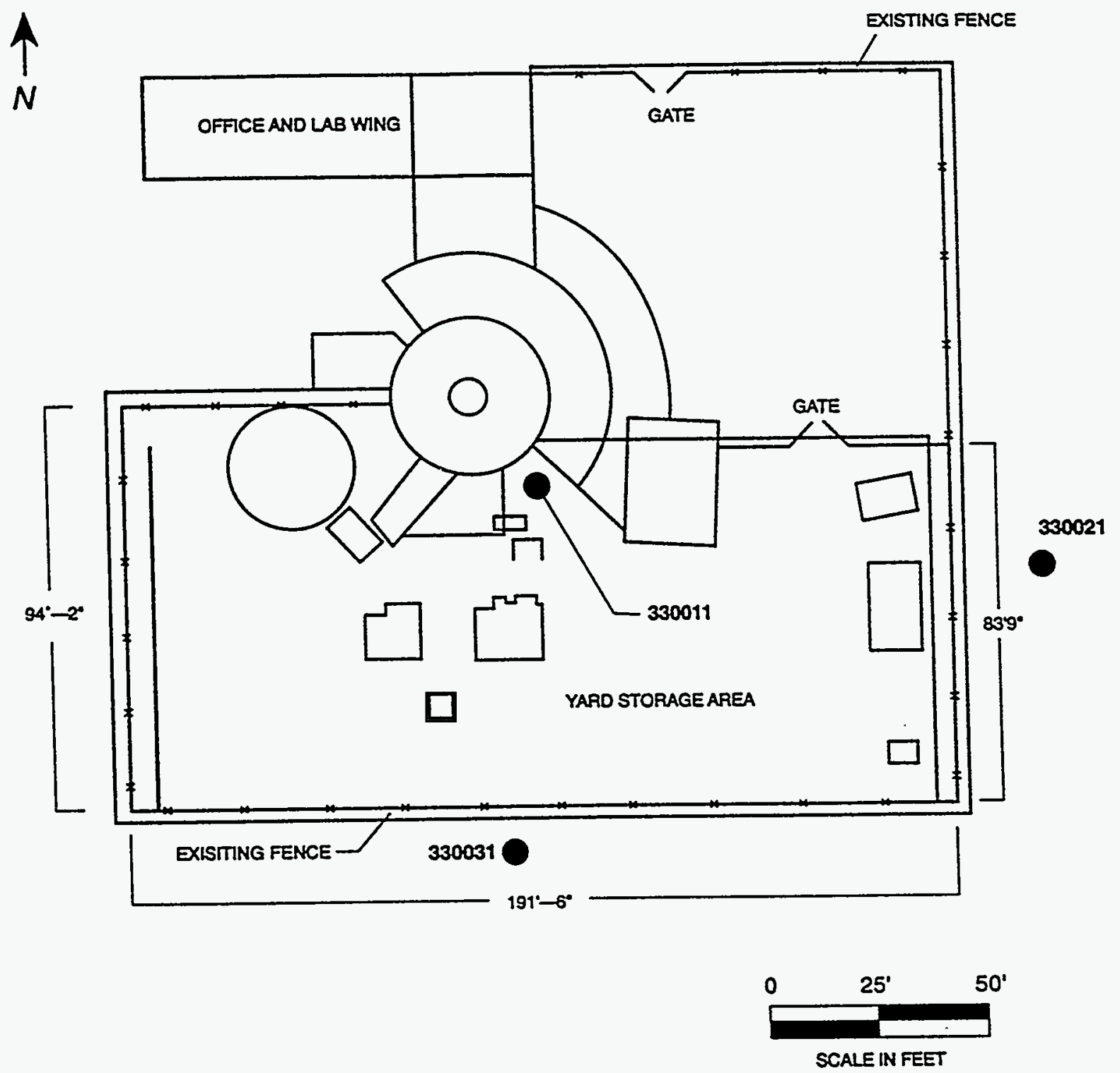

330040

MONITORING WELL LOCATION

Figure 6.21 Active Monitoring Wells in the CP-5 Reactor Area 


\subsection{Site Characterization Activities}

Historical information about waste disposal activities on the ANL-E site, as well as groundwater monitoring results, indicate that several sites are either currently releasing small amounts of hazardous materials to the environment or have the potential to do so in the future. Site characterization and remediation is currently in progress at locations where waste materials are known to have been managed or disposed of. To date, these projects have focused on the most significant sites, the 800 Area landfill and the 317/319 Areas. Significant progress was made on the RCRA Facility Investigation (RFI) in 1995. Characterization of these areas is expected to be completed in 1996.

\subsubsection{7/319/ENE Area Characterization}

\subsubsection{RCRA Facility Investigation}

Field activities for the RFI were conducted in the 317/319/ENE areas between December 1994 and September 1995. The field program resulted in the installation of 19 groundwater monitoring wells and the completion of 31 soil borings. A total of 83 soil samples and 30 groundwater samples were taken and submitted for chemical analysis. Thirty-nine soil samples were taken for geotechnical testing. Soil gas measurements and additional soil samples were taken during a shallow soil survey consisting of 90 split spoon probes.

In addition to the soil borings and well installation work, a sampling program for surface soil, surface water, and sediment was also completed. A total of 24 surface soil samples were collected from throughout the project area. Surface water and sediment samples were collected at 11 locations in four separate storm drainage ditches that remove storm water from the project area. The locations of the monitoring wells and soil borings are shown in Figure 6.2. 


\section{GROUNDWATER PROTECTION}

\subsubsection{Groundwater}

Water samples from the new monitoring wells that were capable of sampling were analyzed for common field parameters ( $\mathrm{pH}$, conductivity, and temperature), soluble metals, organic and inorganic halides, VOCs and SVOCs, and radiochemistry (gross alpha, gross beta, hydrogen-3, and gamma spectrometry). The analytical results from the samples collected indicate that, of the wells in the 317/319/ENE Area, the ground water from MW001S, which was adjacent to the reported position of the French Drain, contained the highest concentrations of chlorinated hydrocarbons, total organic halides, and chloride. Tritium levels were also slightly higher than in the other samples. Chlorinated and other VOCs were also detected in wells MW001I, MW003S, and MW006S. The groundwater chemistry of these wells is presented in Table 6.44. The complete set of results of the chemical analyses of all samples will be presented in the RFI report due in 1996.

The construction of additional monitoring wells is planned for 1996. One of the objectives of the 1996 drilling and well installation program is to establish background monitoring wells that will provide baseline groundwater chemistry against which the chemistry of the wells in the contaminated area can be compared.

\subsubsection{Soil Borings}

A program of shallow soil sampling and soil boring was conducted to determine the vertical and lateral extent of soil contamination in the area of the 317 French Drain, the 318 Compressed Gas Cylinder Area, and the Map Tube Vault. Split spoons were driven at about 80 locations within a surveyed grid pattern. The split spoon survey was conducted in an area approximately outlined by the positions of soil borings SB-A, SB-B, and SB-C.

The RFI investigation determined that in the 317 Area, soil contamination occurs throughout the area between SB-A, SB-B, and SB-C. The contamination is predominantly VOCs. The level of contamination generally decreases with depth and occurs down to between 6 to $12 \mathrm{~m}$ ( 20 to $40 \mathrm{ft}$ ) below ground surface in the vicinity of the 317 Area French Drain. 
TABLE 6.44

Groundwater Chemistry Summary: 317/319 Area, Characterization Wells

\begin{tabular}{|c|c|c|c|c|c|}
\hline Analyte & Units & MW001S & MW001I & MW003S & MW006S \\
\hline Temperature & ${ }^{\circ} \mathrm{C}$ & 10.5 & 10.5 & 9 & 8 \\
\hline $\mathrm{pH}$ & $\mathrm{pH}$ & 7.2 & 7.6 & 7.9 & 7.2 \\
\hline Redox & $\mathrm{mV}$ & $\mathrm{n} / \mathrm{a}$ & $\mathrm{n} / \mathrm{a}$ & $\mathrm{n} / \mathrm{a}$ & $\mathrm{n} / \mathrm{a}$ \\
\hline Conductivity & $\mu \mathrm{mho} / \mathrm{cm}$ & 1,500 & 900 & 550 & 1,300 \\
\hline Lead & $\mu \mathrm{g} / \mathrm{L}$ & 6.9 & 8.6 & 2.9 & 9.9 \\
\hline Nickel & $\mu \mathrm{g} / \mathrm{L}$ & $<10.0$ & $<10.0$ & $<10.0$ & 13.1 \\
\hline Silver & $\mu \mathrm{g} / \mathrm{L}$ & $<2.5$ & $<2.5$ & $<2.5$ & $<2.5$ \\
\hline Thallium & $\mu \mathrm{g} / \mathrm{L}$ & $<2.3$ & $<2.3$ & $<2.3$ & $<2.3$ \\
\hline Antimony & $\mu \mathrm{g} / \mathrm{L}$ & 37.2 & $<23.3$ & $<23.3$ & 29.3 \\
\hline Arsenic & $\mu \mathrm{g} / \mathrm{L}$ & 3.2 & $<2.0$ & $<2.0$ & 2.0 \\
\hline Barium & $\mu \mathrm{g} / \mathrm{L}$ & 181.0 & 102.0 & 46.0 & 36.0 \\
\hline Beryllium & $\mu \mathrm{g} / \mathrm{L}$ & $<0.3$ & 1.5 & 0.7 & $<0.3$ \\
\hline Cadmium & $\mu \mathrm{g} / \mathrm{L}$ & $<3.5$ & $<3.5$ & $<3.5$ & $<3.5$ \\
\hline Chromium & $\mu \mathrm{g} / \mathrm{L}$ & $<2.9$ & $<2.9$ & $<2.9$ & $<2.9$ \\
\hline Cobalt & $\mu \mathrm{g} / \mathrm{L}$ & $<4.0$ & $<4.0$ & $<4.0$ & $<4.0$ \\
\hline Copper & $\mu \mathrm{g} / \mathrm{L}$ & $<9.3$ & $<9.3$ & $<9.3$ & $<9.3$ \\
\hline Vanadium & $\mu \mathrm{g} / \mathrm{L}$ & 48.2 & 24.9 & 21.3 & 39.8 \\
\hline Zinc & $\mu \mathrm{g} / \mathrm{L}$ & 44.5 & 14.6 & 18.6 & 35.2 \\
\hline Selenium & $\mu \mathrm{g} / \mathrm{L}$ & 3.5 & $<2.1$ & $<2.1$ & $<2.1$ \\
\hline Alkalinity & $\mathrm{mg} / \mathrm{L}$ & 454 & 427 & 410 & 766 \\
\hline Nitrate, as $\mathrm{N}$ & $\mathrm{mg}-\mathrm{N} / \mathrm{L}$ & 0.03 & 0.04 & 0.22 & 0.10 \\
\hline Sulfate & $\mathrm{mg} / \mathrm{L}$ & 57.9 & 97.2 & 34.4 & 391 \\
\hline Chloride & $\mathrm{mg} / \mathrm{L}$ & 357 & 81.7 & 17.7 & 125 \\
\hline Carbon Tetrachloride & $\mu \mathrm{g} / \mathrm{L}$ & $<250$ & $<5$ & 70 & $<5$ \\
\hline Acetone & $\mu \mathrm{g} / \mathrm{L}$ & 440 & $<10$ & $<10$ & $<10$ \\
\hline Chloroform & $\mu \mathrm{g} / \mathrm{L}$ & 370 & $<5$ & 10 & $<5$ \\
\hline Benzene & $\mu \mathrm{g} / \mathrm{L}$ & 230 & 3 & $<5$ & $<5$ \\
\hline 1,1,1-Trichloroethane & $\mu \mathrm{g} / \mathrm{L}$ & 65,000 & 18 & $<5$ & $<5$ \\
\hline Vinyl Chloride & $\mu \mathrm{g} / \mathrm{L}$ & $<500$ & $<10$ & $<10$ & 63 \\
\hline Methylene Chloride & $\mu \mathrm{g} / \mathrm{L}$ & 150 & 8 & $<5$ & $<5$ \\
\hline Bromodichloromethane & $\mu \mathrm{g} / \mathrm{L}$ & $<250$ & $<5$ & $<5$ & $<5$ \\
\hline 1,1-Dichloroethane & $\mu \mathrm{g} / \mathrm{L}$ & 10,000 & 960 & $<5$ & 22 \\
\hline 1,1-Dichloroethane & $\mu \mathrm{g} / \mathrm{L}$ & 290 & $<5$ & $<5$ & $<5$ \\
\hline Trichlorofluoromethane & $\mu \mathrm{g} / \mathrm{L}$ & 50 & $<5$ & $<5$ & $<5$ \\
\hline Dichlorodifluoromethane & $\mu \mathrm{g} / \mathrm{L}$ & 68 & $<10$ & $<10$ & $<10$ \\
\hline Trichloroethene & $\mu \mathrm{g} / \mathrm{L}$ & 7,700 & $<5$ & 2 & 11 \\
\hline 1,2-Dichloroethane & $\mu \mathrm{g} / \mathrm{L}$ & 1,300 & 46 & $<5$ & 2 \\
\hline 4-Methyl-2-Pentanone & $\mu \mathrm{g} / \mathrm{L}$ & 230 & $<10$ & $<10$ & $<10$ \\
\hline Toluene & $\mu \mathrm{g} / \mathrm{L}$ & $<250$ & $<5$ & $<5$ & $<5$ \\
\hline Dibromochloromethane & $\mu \mathrm{g} / \mathrm{L}$ & $<250$ & $<5$ & $<5$ & $<5$ \\
\hline Tetrachloroethene & $\mu \mathrm{g} / \mathrm{L}$ & 27,000 & 3 & 14 & $<5$ \\
\hline 1,2-Dichlorethene (total) & $\mu \mathrm{g} / \mathrm{L}$ & 1,400 & 30 & $<5$ & 470 \\
\hline 1,4-Dioxane & $\mu \mathrm{g} / \mathrm{L}$ & 1,400 & 190 & $<11$ & $<10$ \\
\hline Gross Alpha, total & $\mathrm{pCi} / \mathrm{L}$ & 11 & 4 & 22 & 22 \\
\hline Gross Beta, total & $\mathrm{pCi} / \mathrm{L}$ & 13 & 3 & 20 & 14 \\
\hline Hydrogen-3 & $\mathrm{nCi} / \mathrm{L}$ & 3.1 & 0.411 & $<0.1$ & 0.19 \\
\hline
\end{tabular}




\section{GROUNDWATER PROTECTION}

\subsubsection{Surface Soil Sampling}

No appreciable concentrations of contaminants were detected in the surface soils of the 318 , 319, and ENE areas. Very low levels of PCBs were found in the 317, 319, and ENE areas.

\subsubsection{Surface Water and Sediment Sampling}

The surface water downstream of the 317 Area was found to contain very low levels of one VOC, as well as elevated levels of tritium. The tritium emanated from a leachate seep in the 319 Landfill Area. Stopping the release of the leachate from the landfill is the objective of an interim remedial action initiated and nearly completed in 1995 . One sediment sample contained low levels of PCBs. This sample was collected downstream of the 319 Landfill. No other waste samples contained elevated amounts of contaminants.

\subsubsection{South Vaults Decontamination and Demolition}

The D\&D of three unused concrete waste storage vaults is underway. These vaults were contaminated on the inside with low levels of radioactive materials as a result of past use of the vaults. This contamination was removed from one of the three vaults, and the vault was demolished. The D\&D of the remaining two vaults will occur in 1996. During the initial stages of the decontamination of these two vaults, it was discovered that the vault floor and underlying soils were contaminated by elevated levels of cesium-137 and strontium-90. Maximum measured concentrations in the South-Middle Vault were $8.66 \mathrm{pCi} / \mathrm{g}$ for strontium- 90 and $488.4 \mathrm{pCi} / \mathrm{g}$ for cesium-137. In the South-East Vault the maximum contaminant concentrations were $549.82 \mathrm{pCi} / \mathrm{g}$ for strontium-90 and $3.64 \mathrm{pCi} / \mathrm{g}$ for cesium-137. The contaminated soil will be removed when the vaults are demolished.

A surface soil survey was conducted to a distance of $6 \mathrm{~m}(20 \mathrm{ft})$ from the vaults. Localized contamination with cesium- 137 (maximum value of $47 \mathrm{pCi} / \mathrm{g}$ ) and cobalt-60 (maximum value of $11400 \mathrm{pCi} / \mathrm{g}$ ) was found and removed. 


\section{GROUNDWATER PROTECTION}

\subsubsection{Area Characterization}

The 800 Area RCRA RFI addresses 11 SWMUs, two environmental AOCs, and one area suspected of containing a former solid waste disposal area. The 800 Area RFI included a field program of soil boring, installation and sampling of ground water monitoring and leachate wells, surface water and sediment sampling, and geophysical and soil gas surveys.

Analysis of soil samples from the Waste Oil Storage Area detected the presence of SVOCs. The SVOCs detected are all common constituents of fuel and waste oil and include fluoranthene, pyrene, benzo[a]anthracene, chrysene, benzo[a]fluoranthene, and benzo[a]pyrene. Similar SVOCs were measured in the soil samples from the Waste Oil Satellite Accumulation Area, the area of the Waste Oil Spread on Roads, and the Scrap Metal Storage Area. The detection of VOCs, PCBs, pesticides, and inorganics in these areas was not at levels indicating a significant source of contamination but will be further examined in the next phase of the RFI field work.

Phase I sampling showed that several organic compounds exist in the soil near two removed USTs. Additional Phase II sampling is planned to further define the nature and extent of this contamination. Toluene, acetone, and PCB were detected in the soils in the Building 810 Paint and Solvent Disposal Area. No contamination was found in the groundwater.

In 1995, ANL-E completed the following RFI activities at the 800 Area Landfill: installation of nine new groundwater monitoring wells, installation of four leachate wells in the landfill, and collection of groundwater samples. Analytical results of surface water samples taken in the vicinity of the 800 Area Landfill, the French Drain (Northeast corner), wetland (West side), and leachate seeps indicate no contamination at the time of sampling. Wetland sediments taken at the same locations as surface water samples indicated low levels of pesticides, PCBs, and several SVOCs. A sediment sample taken upstream of the landfill contained low levels of a few organics. SVOCs were also detected. Pesticides were detected from the wetland areas west of the landfill in sediment samples; however, pesticides were also detected in the quality control duplicate sediment sample. PCBs were detected in one sediment sample. 
Analytical data from the three leachate wells sampled (one leachate well was dry) showed the presence of VOCs in all three wells (see Figure 6.5; LW02, LW-3, LW04). SVOCs were detected in samples from LW02 and LW03. PCBs were detected only in LW02. No pesticides were detected in any of the leachate wells. Elevated levels of tritium occurred in all the samples from the leachate wells.

Because the 800 Area Landfill and its leachate are a potential source of contamination for the wetland areas and because it is possible that there is a hydrologic connection between the landfill leachate, the groundwater, and the adjacent wetland, additional sampling and detailed water level mapping are planned as future RFI field activities in the 800 Area.

\subsubsection{Sitewide Hydrogeological Characterization Project}

This multiphase project will fully characterize the hydrogeology of the ANL-E site and support a sitewide RFI. The project is critical to defining the baseline hydrogeological conditions beneath ANL-E and the surrounding Forest Preserve, including the geological and hydrogeological properties of the uppermost aquifer system. This information will define the sitewide groundwater quality and flow regime and provide important baseline data for other, smaller scale, site characterization and remediation projects. It also will be an important resource for new construction project designs and environmental spill responses. The data will reveal whether ANL-E operations overall have impacted groundwater.

In 1995, 27 unusable wells were sealed in accordance with state and county health department regulations. Six usable wells were upgraded and incorporated into the sitewide monitoring well network.

The current funding plan calls for the Phase II field investigation to be completed over several years. Phase II will characterize the detailed hydrogeology of the larger portion of the ANL-E site and complete the major field component of the project. 


\section{QUALITY ASSURANCE}

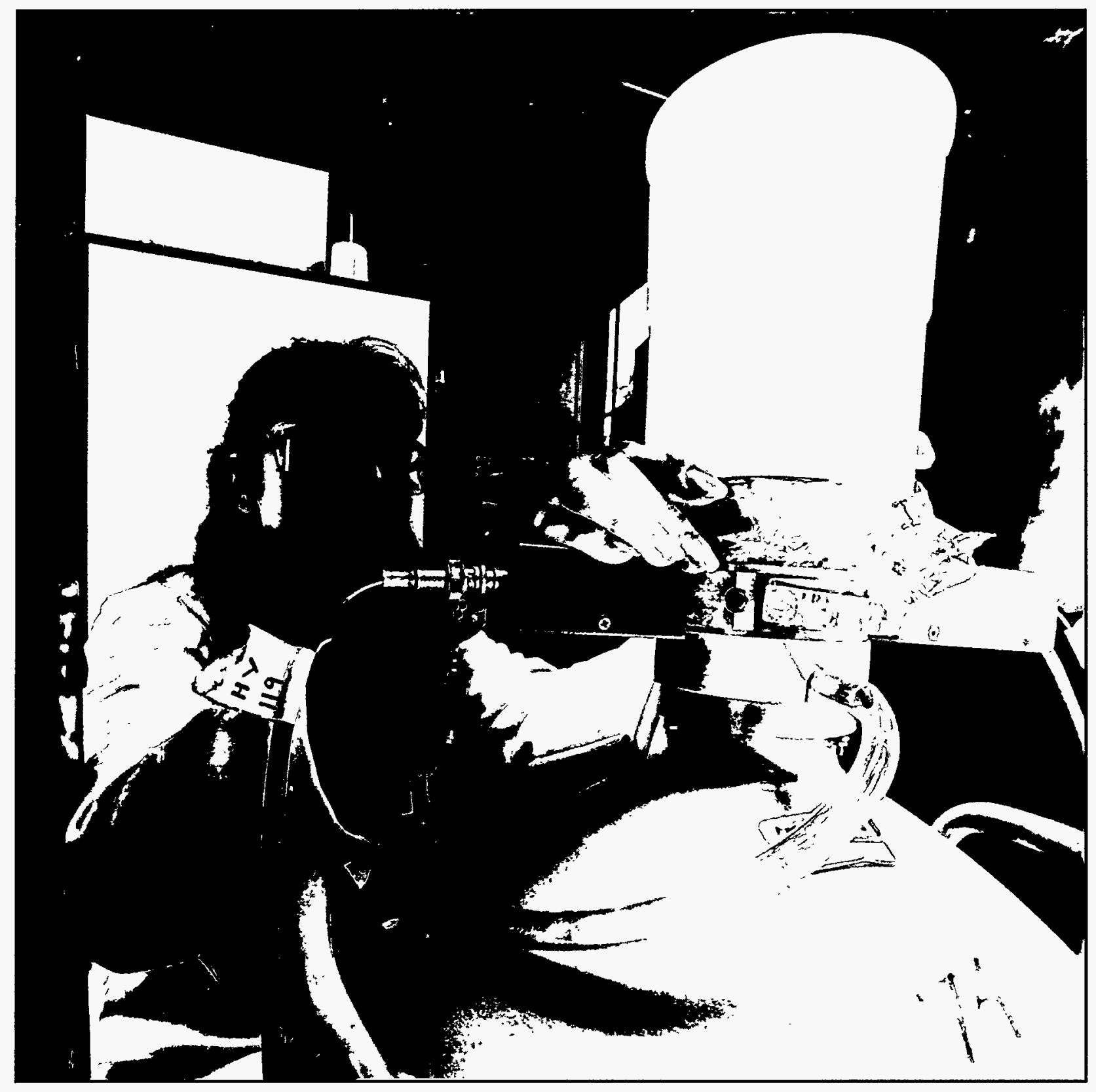


Quality Assurance (QA) plans exist for both radiological and nonradiological analyses. Both QA documents were prepared in accordance with DOE Order 5700.6C. The plans discuss who is responsible for QA and for auditing analyses. Both documents are supplemented by operating manuals.

\section{I. Radiochemical Analysis and Radioactivity Measurements}

All nuclear instrumentation is calibrated with standard sources obtained from or traceable to the NIST. The equipment is usually checked daily with secondary counting standards to ensure proper operation. Samples are periodically analyzed in duplicate or with the addition of known amounts of a radionuclide to check precision and accuracy. When a nuclide was not detected, the result is given as "less than" $(<)$ the detection limit by the analytical method used. The detection limits were chosen so that the measurement uncertainty at the $95 \%$ confidence level is equal to the measured value. The air and water detection limits for all radionuclides for which measurements were made are given in Table 7.1. The relative error in a result decreases with increasing concentration. At a concentration equal to twice the detection limit, the error is about $50 \%$ of the measured value and at 10 times the detection limit, the error is about $10 \%$.

Average values are usually accompanied by a plus-or-minus $( \pm)$ limit value. Unless otherwise stated, this value is the standard error at the $95 \%$ confidence level calculated from the standard deviation of the average. The \pm limit value is a measure of the range in the concentrations encountered at that location; it does not represent the conventional uncertainty in the average of repeated measurements on the same or identical samples. Since many of the variations observed in environmental radioactivity are not random but occur for specific reasons (e.g., seasonal variations), samples collected from the same location at different times are not replicates. The more random the variation in activity at a particular location, the closer the confidence limits will represent the actual distribution of values at that location. The averages and confidence limits should be interpreted with this in mind. When a plus-or-minus value accompanies an individual result in this report, it represents the statistical counting error at the $95 \%$ confidence level. 
TABLE 7.1

Detection Limits

\begin{tabular}{|c|c|c|}
\hline $\begin{array}{l}\text { Nuclide or } \\
\text { Activity }\end{array}$ & $\begin{array}{c}\text { Air } \\
\left(\mathrm{fCi} / \mathrm{m}^{3}\right)\end{array}$ & $\begin{array}{c}\text { Water } \\
(\mathrm{pCi} / \mathrm{L})\end{array}$ \\
\hline Americium-241 & $\AA^{a}$ & 0.001 \\
\hline Beryllium-7 & 5 & - \\
\hline Californium-249 & - & 0.001 \\
\hline Californium-252 & - & 0.001 \\
\hline Cesium-137 & 0.1 & 1 \\
\hline Curium-242 & - & 0.001 \\
\hline Curium-244 & - & 0.001 \\
\hline Hydrogen-3 & 100 & 100 \\
\hline Lead-210 & 1 & - \\
\hline Neptunium-237 & - & 0.001 \\
\hline Plutonium-238 & 0.0003 & 0.001 \\
\hline Plutonium-239 & 0.0003 & 0.001 \\
\hline Radium-226 & - & 0.1 \\
\hline Radium-228 & - & 0.1 \\
\hline Strontium-89 & 0.1 & 2 \\
\hline Strontium-90 & 0.01 & 0.25 \\
\hline Thorium-228 . & 0.001 & - \\
\hline Thorium-230 & 0.001 & - \\
\hline Thorium-232 & 0.001 & - \\
\hline Uranium-234 & 0.0003 & 0.01 \\
\hline Uranium-235 & 0.0003 & 0.01 \\
\hline Uranium-238 & 0.0003 & 0.01 \\
\hline Uranium - natural & 0.02 & 0.2 \\
\hline Alpha & 0.2 & 0.2 \\
\hline Beta & 0.5 & 1 \\
\hline
\end{tabular}

a A hyphen indicates that a value is not required. 
Participation continued in the DOE Environmental Measurements Laboratory Quality Assurance Program (DOE-EML-QAP), a semiannual distribution of four different sample matrices containing various combinations of radionuclides that are analyzed. Table 7.2 summarizes the results for 1995. In the table, the Environmental Measurements Laboratory (EML) value, which is the result of duplicate determinations by that laboratory, is compared with the average value obtained in the ANL-E laboratory. Information that will assist in judging the quality of the results includes the fact that typical uncertainties for ANL-E's analyses are 2 to $50 \%$, and that the uncertainties in the EML results are 1 to $30 \%$ (depending on the nuclide and the amount present). For most analyses for which the differences are large $(>20 \%)$, the concentrations were quite low and the differences were within the measurement uncertainties.

TABLE 7.2

Summary of DOE-EML-QAP Samples, 1995

\begin{tabular}{lcccc}
\hline & \multicolumn{4}{c}{ Percent Difference From EML Value } \\
\cline { 2 - 5 } Radionuclide & Air Filters & Soil & Vegetation & Water \\
\hline Hydrogen-3 & $\mathbf{A}^{\mathrm{a}}$ & - & - & $15(2)$ \\
Potassium-40 & - & $10(2)$ & $13(2)$ & - \\
Manganese-54 & $13(2)$ & - & - & $11(2)$ \\
Cobalt-57 & $22(2)$ & - & - & - \\
Cobalt-60 & $10(2)$ & - & $14(2)$ & $13(2)$ \\
Strontium-90 & $4(2)$ & $13(2)$ & $6(2)$ & $1(2)$ \\
Ruthenium-106 & $16(1)$ & - & - & - \\
Antimony-125 & $10(2)$ & - & - & - \\
Cesium-134 & $3(1)$ & - & - & $13(2)$ \\
Cesium-137 & $13(2)$ & $11(2)$ & $21(2)$ & $12(2)$ \\
Cerium-144 & $24(2)$ & - & - & $21(1)$ \\
Uranium-234 & $12(2)$ & $8(2)$ & - & $10(2)$ \\
Uranium-238 & $22(2)$ & $1(2)$ & - & $17(2)$ \\
Plutonium-238 & $2(2)$ & $3(2)$ & $9(1)$ & $2(2)$ \\
Plutonium-239 & $13(2)$ & $6(2)$ & $14(2)$ & $13(2)$ \\
Americium-241 & $4(2)$ & $20(2)$ & $12(2)$ & $5(2)$ \\
\hline & & & &
\end{tabular}

Note: The value in parentheses is the number of samples.

a A hyphen indicates that a sample is not required for analysis. 


\section{QUALITY ASSURANCE}

\subsection{Chemical Analysis}

The documentation for nonradiological analyses is contained in the ESH-DA Chemistry Laboratory Procedure Manual. All samples for NPDES and groundwater are collected and analyzed in accordance with EPA regulations found in 40 CFR Part $136,{ }^{26}$ EPA-600/4-84-017, 35 and SW-846. ${ }^{9}$

Standard Reference Materials (SRM), traceable to the NIST, exist for most inorganic analyses (see Table 7.3). These are replaced annually. Detection limits are determined with techniques listed in Report $S W-846^{9}$ and are listed in Table 7.4. In general, the detection limit is the measure of the variability of a standard material measurement at 5 to 10 times the instrument detection limit as measured over an extended time period. Recovery of inorganic metals, as determined by "spiking" unknown solutions, must be in the range of $75 \%$ to $125 \%$. The precision, as determined by analysis of duplicate samples, must be within $20 \%$. These measurements must be made on at least $10 \%$ of the samples. Comparison samples for organic constituents were formerly available from the EPA, but are now commercially available under the Cooperative Research and Development Agreement (CRADA) that exists between the EPA and commercial laboratories. In addition, standards are available that are certified by the American Association for Laboratory Accreditation, under a memorandum of understanding with the EPA. Many of these standards were used in this work. At least one standard mixture is analyzed each month; the results for 1995 are shown in Table 7.5 for VOCs and Table 7.6 for SVOCs. The recoveries listed are those required by the respective methods. 


\section{TABLE 7.3}

Reference Materials Used for Inorganic Analysis

\begin{tabular}{ll}
\hline Reference Material $^{\mathrm{a}}$ & Constituent \\
\hline HPS-10002-2 & Antimony \\
HPS-10003-1 & Arsenic \\
HPS-10004-1 & Barium \\
HPS-10005-1 & Beryllium \\
HPS-10008-1 & Cadmium \\
HPS-100012-1 & Chromium \\
HPS-100013-1 & Cobalt \\
HPS-100014-1 & Copper \\
HPS-100026-1 & Iron \\
HPS-100028-1 & Lead \\
HPS-100032-1 & Manganese \\
HPS-100033-1 & Mercury \\
HPS-100036-1 & Nickel \\
HPS-100049-1 & Selenium \\
HPS-100051-1 & Silver \\
HPS-100065-1 & Vanadium \\
HPS-100068-1 & Zinc \\
NIST-SRM 3181 & Sulfate \\
NIST-SRM 3182 & Chloride \\
NIST-SRM 3183 & Fluoride \\
\hline
\end{tabular}

a

HPS = High Purity Standards, Inc.; NIST-SRM = National

Institute of Standards and Technology - Standard Reference Materials. 
TABLE 7.4

Limit of Detection for Metal Analysis

\begin{tabular}{|c|c|c|}
\hline \multirow[b]{2}{*}{ Constituent } & \multicolumn{2}{|c|}{$\begin{array}{l}\text { Limits of Detection } \\
\mathrm{mg} / \mathrm{L}\end{array}$} \\
\hline & $\mathrm{AA}^{\mathrm{a}}$ & $\mathrm{ICP}^{\mathrm{b}}$ \\
\hline Antimony & 0.0025 & - \\
\hline Arsenic & 0.0025 & 0.110 \\
\hline Barium & - & 0.015 \\
\hline Beryllium & 0.00015 & 0.025 \\
\hline Boron & - & 0.080 \\
\hline Cadmium & 0.0001 & 0.040 \\
\hline Chromium & 0.020 & 0.060 \\
\hline Cobalt & - & 0.025 \\
\hline Copper & 0.010 & 0.045 \\
\hline Hexavalent Chromium ${ }^{c}$ & 0.006 & - \\
\hline Iron & 0.020 & 0.025 \\
\hline Lead & 0.0005 & 0.110 \\
\hline Manganese & 0.015 & 0.020 \\
\hline Mercury & 0.0001 & - \\
\hline Nickel & 0.020 & 0.040 \\
\hline Selenium & 0.0025 & 0.090 \\
\hline Silver & 0.0010 & 0.110 \\
\hline Thallium & 0.0015 & 0.145 \\
\hline Vanadium & - & 0.055 \\
\hline Zinc & 0.005 & 0.015 \\
\hline
\end{tabular}

a $\mathrm{AA}=$ Atomic Absorption Spectroscopy.

b ICP = Inductively Coupled Plasma - Atomic Emission Spectroscopy.

c Coulometric measurement. 
TABLE 7.5

Quality Check Sample Results: Volatile Analyses, 1995

\begin{tabular}{|c|c|c|}
\hline Compound & $\begin{array}{c}\text { Recovery }{ }^{\mathrm{a}} \\
(\%)\end{array}$ & $\begin{array}{c}\text { Quality Limits } \\
(\%)\end{array}$ \\
\hline Benzene & 111 & $73-126$ \\
\hline Bromobenzene & 96 & $76-133$ \\
\hline Bromodichloromethane & 90 & $101-138$ \\
\hline Bromoform & 87 & $57-156$ \\
\hline Butylbenzene & 94 & $71-125$ \\
\hline sec-Butylbenzene & 98 & $71-145$ \\
\hline t-Butylbenzene & 112 & 69-134 \\
\hline Carbon Tetrachloride & 96 & $86-118$ \\
\hline Chlorobenzene & 99 & $80-137$ \\
\hline Chloroform & 106 & $68-120$ \\
\hline o-Chlorotoluene & 103 & $81-146$ \\
\hline p-Chlorotoluene & 97 & $73-144$ \\
\hline 1,2-Dibromo-3-chloropropane & 93 & $36-154$ \\
\hline Dibromochloromethane & 84 & $68-130$ \\
\hline 1,2-Dibromoethane & 100 & $75-149$ \\
\hline Dibromomethane & 101 & $65-143$ \\
\hline 1,2-Dichlorobenzene & 112 & $59-174$ \\
\hline 1,3-Dichlorobenzene & 101 & $84-143$ \\
\hline 1,4-Dichlorobenzene & 99 & $58-172$ \\
\hline 1,1-Dichloroethane & 108 & $71-142$ \\
\hline 1,2-Dichloroethane & 100 & $70-134$ \\
\hline 1,1-Dichloroethene & 111 & $18-209$ \\
\hline cis-1,2-Dichloroethene & 87 & $85-124$ \\
\hline trans-1,2-Dichloroethene & 108 & $67-141$ \\
\hline 1,2-Dichloropropane & 99 & $19-179$ \\
\hline 1,3-Dichloropropane & 100 & $73-145$ \\
\hline 1,1-Dichloropropene & 87 & $71-133$ \\
\hline Ethyl Benzene & 106 & $84-130$ \\
\hline Isopropylbenzene & 100 & $70-144$ \\
\hline 4-Isopropyltoluene & 100 & $72-140$ \\
\hline Methylene Chloride & 121 & D-197 \\
\hline n-Propylbenzene & 128 & 78-139 \\
\hline $1,1,1,2$-Tetrachloroethane & 96 & $88-133$ \\
\hline Tetrachloroethene & 111 & $84-132$ \\
\hline Toluene & 94 & $81-130$ \\
\hline 1,1,1-Trichloroethane & 94 & $68-149$ \\
\hline 1,1,2-Trichloroethane & 89 & $70-133$ \\
\hline Trichloroethene & 99 & $91-135$ \\
\hline 1,2,3-Trichloropropane & 113 & $50-158$ \\
\hline 1,2,4-Trimethylbenzene & 105 & $80-144$ \\
\hline $1,3,5$-Trimethylbenzene & 97 & $76-142$ \\
\hline o-Xylene & 100 & $79-141$ \\
\hline $\mathrm{p}$-Xylene & 108 & $74-138$ \\
\hline
\end{tabular}

Note: $\mathrm{D}$ denotes the compound was detected.

${ }^{a}$ Average of two determinations. 
TABLE 7.6

Quality Check Sample Results:

Semivolatile Analyses, 1995

\begin{tabular}{|c|c|c|}
\hline Compound & $\begin{array}{c}\text { Recovery }^{\mathrm{a}} \\
(\%)\end{array}$ & $\begin{array}{c}\text { Quality Limits } \\
(\%)\end{array}$ \\
\hline 2-Fluorophenol ${ }^{b}$ & 57.2 & $21-100$ \\
\hline Phenol-d $5^{\mathrm{b}}$ & 49.3 & $10-94$ \\
\hline Phenol & 49.9 & $17-100$ \\
\hline 2-Chlorophenol & 92.5 & $36-120$ \\
\hline 1,4-Dichlorobenzene & 53.7 & $37-106$ \\
\hline n-Nitroso-n-Propyl Amine & 58.7 & $24-198$ \\
\hline Nitrobenzene-d $5^{\mathrm{b}}$ & 61.0 & $35-114$ \\
\hline 1,2,4-Trichlorobenzene & 62.2 & $57-129$ \\
\hline 4-Chloro-3-Methylphenol & 101.0 & $41-128$ \\
\hline 2-Fluorobiphenyl ${ }^{\mathrm{b}}$ & 82.2 & $43-116$ \\
\hline Acenaphthene & 88.8 & $47-145$ \\
\hline 2,4-Dinitrotoluene & 91.7 & $48-127$ \\
\hline 2,4,6-Tribromophenol ${ }^{\mathrm{b}}$ & 93.1 & $10-123$ \\
\hline Pentachlorophenol & 95.2 & $38-152$ \\
\hline Pyrene & 95.4 & $70-100$ \\
\hline Terphenyl-d14 ${ }^{\mathrm{b}}$ & 67.2 & $33-141$ \\
\hline
\end{tabular}

a Average of three determinations.

${ }^{\mathrm{b}}$ Required surrogates. 


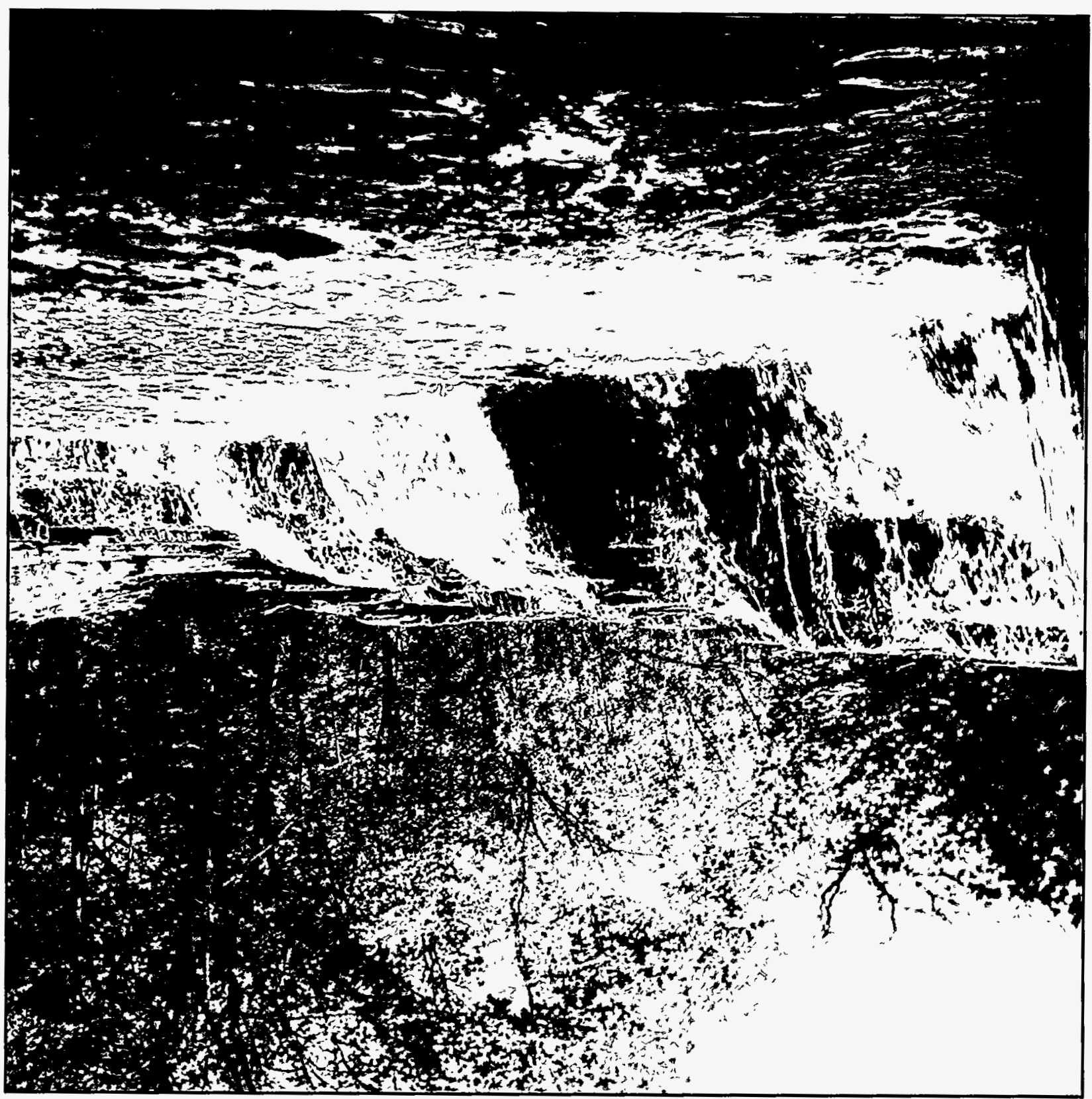




\subsection{References}

1. U.S. Department of Energy, 1988, "General Environmental Protection Program," DOE Order 5400.1, Nov. 9.

2. Moses, H., and M.A. Bogner, 1967, Fifteen-Year Climatological Summary, January 1, 1950 - December 31, 1964, ANL-7084, Argonne National Laboratory, Ill.

3. Moses H., and J.H. Willet, 1954, Five-Year Climatological Summary, July 1949 June 1954, ANL-5592, Argonne National Laboratory, Ill.

4. U.S. Department of Energy, 1995, Proposed Upgrade of Waste Storage Facilities at Argonne National Laboratory-East, Argonne, Illinois, DOE/EA-1073, Washington, D.C.

5. U.S. Department of Energy, 1995, Environmental Assessment: Management of Wildlife Causing Damage at Argonne National Laboratory-East, DuPage County, Illinois, DOEEA-1128, Washington, D.C.

6. U.S. Army Corps of Engineers, 1987, Corps of Engineers Wetlands Delineation Manual, Technical Report Y-87-1, Washington, D.C.

7. U.S. Department of Energy, 1988, "Radioactive Waste Management," DOE Order 5820.2A, Sept. 26.

8. Parks, B.S., 1992, User's Guide for CAP88-C, Version 1.0, EPA402-B-92-001, Office of Radiation Programs, U.S. Environmental Protection Agency, Las Vegas, Nev.

9. U.S. Environmental Protection Agency, 1986, Test Methods for Evaluating Solid Waste, 3rd ed., SW-846, Washington, D.C. 
10. U.S. Department of Energy, 1991, Environmental Regulatory Guide for Radiological Effluent Monitoring and Environmental Surveillance, DOE/EH-0173T, Washington, D.C.

11. U.S. Department of Energy, 1990, "Radiation Protection of the Public and the Environment," DOE Order 5400.5, Feb. 8.

12. International Commission on Radiological Protection, 1977, Recommendations of the International Commission on Radiological Protection, ICRP Publication 26, Annals of the ICRP, 1(2), Pergamon Press, New York, N.Y.

13. International Commission on Radiological Protection, 1979-1982, Limits for Intakes of Radionuclides by Workers, ICRP Publication 30, Part 1 (and Supplement), Part 2 (and Supplement), Part 3 (and Supplements A and B), and Index, Annals of the ICRP, Pergamon Press, New York, N.Y.

14. U.S. Department of Energy, 1988, Internal Dose Conversion Factors for Calculation of Dose to the Public, DOE/EH-0071, Washington, D.C.

15. Larsen, R.J., 1993, "Global Decrease of Beryllium-7 in Surface Air," Journal of Environmental Radioactivity 18:85-87.

16. American Society for Testing and Materials, 1989, 1989 Annual Book of ASTM Standards, Vol. 12.01, "Sampling Surface Soil for Radionuclides, C-998-83," ASTM, West Conshocken, Pa.

17. American Society for Testing and Materials, 1989, 1989 Annual Book of ASTM Standards, Vol. 12.01, "Soil Sample Preparation for the Determination of Radionuclide, C-999-83," ASTM, West Conshocken, Pa.

18. Bennett, B.G, 1978, Environmental Aspects of Americium, DOE/EML-348, U.S. Department of Energy, Washington, D.C. 
19. Golchert, N.W., and R.G. Kolzow, 1995, Argonne National Laboratory-East Site Environmental Report for Calendar Year 1994, ANL 95/8, Argonne National Laboratory, Argonne, Ill.

20. U.S. Environmental Protection Agency, 1990, "National Standards for Hazardous Air Emissions: Standards for Radionuclides," Code of Federal Regulations, title 40, part 61, subpart $\mathrm{H}$.

21. National Council on Radiation Protection and Measurements, 1987, Ionizing Radiation Exposure of the Population of the United States, NCRP Report No. 93, Washington, D.C.

22. International Commission on Radiological Protection, 1975, Reference Man: Anatomical, Physiological, and Metabolic Characteristics, ICRP Publication 23, Pergamon Press, New York, N.Y.

23. U.S. Environmental Protection Agency, 1993, "National Primary Drinking Water Regulations," Code of Federal Regulations, title 40, part 141.

24. State of Illinois, Rules and Regulations, 1985, Title 35, Environmental Protection, Subtitle C, Water Pollution, chapter 1.

25. U.S. Environmental Protection Agency, 1984, "EPA Administered Permit Program : The National Pollutant Discharge Elimination System," Code of Federal Regulations, title 40, part 122.

26. U.S. Environmental Protection Agency, 1986, "Test Procedures for the Analysis of Pollutants under the Clean Water Act," Code of Federal Regulations, title 40, part 136.

27. State of Illinois, Rules and Regulations, 1991, Title 35, Environmental Protection, Subtitle C, Part 304, Jan. 22. 
28. State of Illinois, Rules and Regulations, 1990, Title 35, Environmental Protection, Subtitle C, Part 302.

29. State of Illinois, Rules and Regulations, 1991, Title 35, Groundwater Quality Standards, Subtitle F, Part 620.

30. State of Illinois, Illinois Administrative Code, 1991, Title 77, Drinking Water System Code, Part 900.

31. U.S. Environmental Protection Agency, 1986, RCRA Ground-Water Monitoring Technical Enforcement Guidance Document, OSWER-9950.1, Office of Solid Waste and Emergency Response, Washington, D.C.

32. Soil Testing Services, 1980, Application for Permit to Develop and/or Operate a Solid Waste Management Site, STS Job. No. 14236, prepared by Soil Testing Services, Northbrook, Ill., for Argonne National Laboratory, Argonne, Ill.

33. U.S. Environmental Protection Agency, 1984, Methods for Chemical Analysis of Water and Wastes, EPA-600/4-84-017, Washington, D.C. 


\subsection{Acknowledgments}

We are indebted to the ANL-E-ESH Health Physics Section, which provided most of the radioactive gaseous effluent data. The ESH Dosimetry and Analytical Support Section provided analytical support and the sections on sample analysis techniques. Sample collection and field measurements were conducted by Michael Cole, Noel Feeney, Robert Piorkowski, and Keith Trychta of the EMO Monitoring and Surveillance Group. - Most of the data tables and figures were prepared by Edyta Betlej and Michael Skwarek, who are parallel co-op students within EMO under the direction of Dolores M. Ray. The dedicated effort of Rita M. Beaver (EMO), who typed and prepared some of the manuscript and performed other tasks needed to complete the report, is greatly appreciated. Editorial and document preparation services were provided by Pat Hollopeter and Kerri Schroeder of ANL-E's Information and Publishing Division. 


\subsection{Distribution for $96 / 3$}

Internal:

S.I. Baker

G. L. Barrett

L. E. Boing

G. A. Borland

R. W. Cannon

M. C. Cole

R. F. Coley

A. J. Dvorak

D.E. Eastman

N. Feeney

N. W. Golchert (50)

G. E. Griffin

B. A. Harvey

W. H. Hannum

M. A. Kamiya

R. G. Kolzow (5)

G. A. Kulma

W. D. Luck

J. A. Mathiesen
L.P. Moos

G. D. Mosho

D. M. Nelson

R. A. Pagel

B. G. Pierce

R. E. Piorkowski

S. D. Rabidou

D. M. Ray

M. J. Robinet

J. Sedlet

M. A. Sodaro

V. C. Stamoudis

R. E. Swale

R. J. Teunis

J. R. Thuot

K. W. Trychta

G. H. Wittman

R. A. Wynveen

TIS File

\section{External:}

DOE OSTI for distribution per UC-607 (154)

ANL-E Library, (2)

ANL-W, AW-IS

DOE-HQ Assistant Secretary for Environment, Safety and Health, EH-1 (2) 
DOE-HQ, Ross Natoli, Office of Environmental Policy and Assistance, EH-41 (3)

DOE-HQ, Caryle Miller, Office of Energy Research; ER-7

DOE-HQ Office of Energy Research, ER-8.2 (3)

C. J. Langenfeld, DOE-CH

P. M. Neeson, DOE-CH, ESHD (6)

G. Walach, DOE-CH, GLD

T. S. Crawford, DOE-ARG (8)

David Antonacchi, Illinois Department of Public Health, Springfield, Illinois

Robert H. Gray, Pantex Plant, Amarillo, Texas

Dave Brekke, Sandia National Laboratories, Livermore, California

Sandra Bron, Illinois Environmental Protection Agency, Springfield, Illinois

Daniel G. Carfagno, Mound Laboratory, Miamisburg, Ohio

William Griffing, Fermi National Accelerator Laboratory, Batavia, Illinois

Larry Eastep, Illinois Environmental Protection Agency, Springfield, Illinois

Rebecca Failor, Lawrence Livermore National Laboratory, Livermore, California

Fred Ferate, Nevada Test Site, Las Vegas, Nevada

Isabel M. Fisenne, DOE-EML, New York, New York

Wayne R. Hansen, Los Alamos National Laboratory, Los Alamos, New Mexico

Robert Harrach, Lawrence Livermore National Laboratory, Livermore, California

James D. Heffner, Westinghouse Savannah River Company, Aiken, South Carolina

Diana L. Hoff, DOE Idaho Operations Office, Idaho Falls, Idaho

Hue-Su Hwang, Sandia National Laboratories, Albuquerque, New Mexico

Illinois Department of Nuclear Safety, Springfield, Illinois

William Isherwood, Lawrence Livermore National Laboratory, Livermore, California

Dennis Leuhring, DuPage County (IL) Health Department, Westmont, Illinois

Robert P. Miltenberger, Brookhaven National Laboratory, Upton, New York

John B. Murphy, Oak Ridge National Laboratory, Oak Ridge, Tennessee

Michael Murphy, U.S. Environmental Protection Agency, Region 5, Chicago, Illinois

J. R. Naidu, Brookhaven National Laboratory, Upton, New York

J. O'Connor, Illinois Department of Public Health, West Chicago, Illinois

Ron Pauer, Lawrence Berkeley Laboratory, Berkeley, California 
C. Lyle Roberts, West Valley Demonstration Project, West Valley, New York

Kenneth Rogers, Water Compliance, Illinois Environmental Protection Agency, Springfield, Illinois

Lars Soholt, Los Alamos National Laboratory, Los Alamos, New Mexico

Robert Stanton, DuPage County Forest Preserve District, Glen Ellyn, Illinois

David H. Stoltenberg, U. S. Environmental Protection Agency, Region 5, Chicago, Illinois

Matthew Wertman, Illinois Environmental Protection Agency, Maywood, Illinois

Rodger Dirkes, Battelle-Pacific Northwest Laboratories, Richland, Washington

\&.S. GPO 1996: 545-499 